\title{
المكي والمدني في القرآن دراسة تأصيلية ودراسة نقدية لنزول السور والآيات المستثناة من كل سورة من أول سورة الفاتحة حتى آخر سورة المائدة
}

\author{
الدكثور

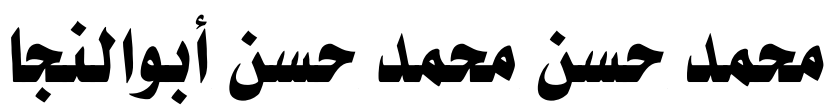 \\ ملدرس التثسير وعلوم الثرآن بكلية الدبراسات الإسلامية

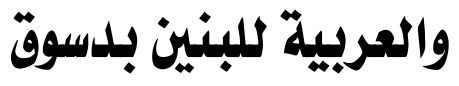




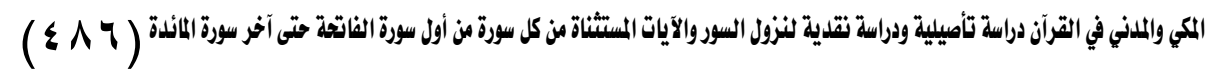


ملخص البحث

في هذا البحث و الذي هو بعنوان : "المكي و المدني في القرآن دراسة تأصيلية ودراسة نقدية لنزول السور والآيات المستثناة من كل

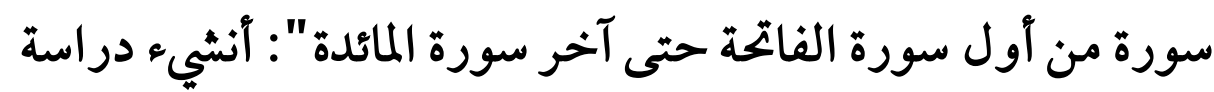

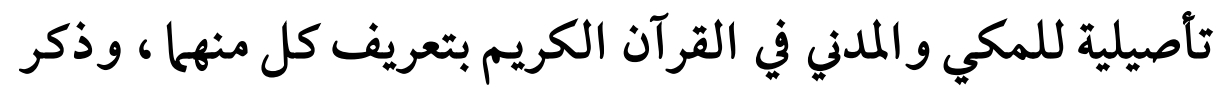
فوائد دراسته ، والطرق التي يعرف بها المكي والمدني ، وذكر الروايات

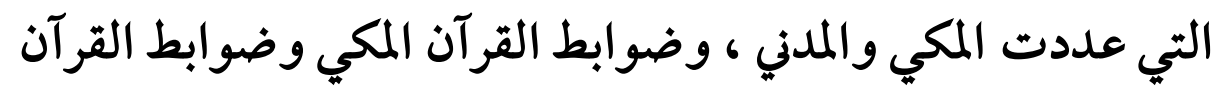

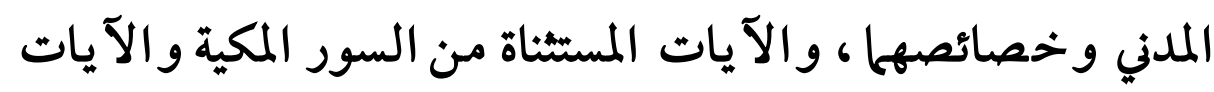
المستثناة من السور المدنية ، ثم أجيب عن سؤال مهم وهو : هل تكرو

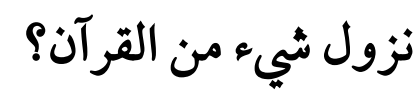
ثم يأتي الغرض من الأصلي من هذا البحث و هو در اسة مكان

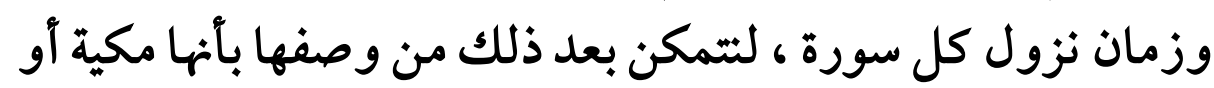

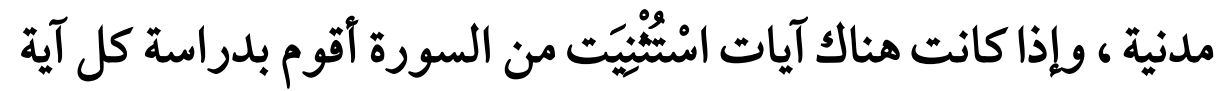

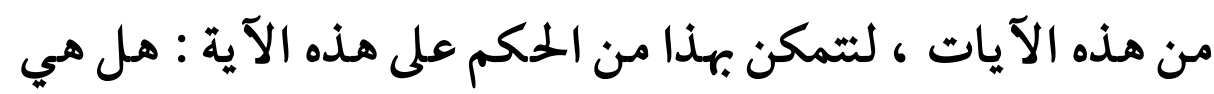
كسورتها ـ مكية أو مدنية ـ آم لا؟ لها؟

والله هو الموفق والمادي إلى سواء السبيل الباحث

د : محمد حسن محمد حسن أبو النجا مدرس التفسير وعلوم القرآن بكلية الدراسات الإسلامية والعربية للبنين بدسوق 


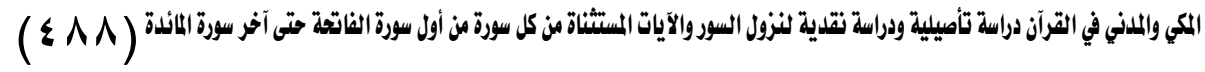

\section{Research Summary}

In this research, which is entitled: "Makki and Madani in the Koran a thorough study and critical study of the descent of the wall and the verses excluded from each of the first Surat Al-Fatihah until the last Surat Al-Maida": Which is known as Makki and Madani, and mentioned the narrations that enumerated Makki and Madani, and the controls of the Makkah Koran and the controls of the Koran and their characteristics, and verses excluded from the fence Makki and verses excluded from the civil wall, and then answer the important question is: Is repeating something from the Koran?

Then comes the original purpose of this research is to study the place and time of the descent of each surah, so we can then describe it as Makiya or civil, and if there are verses excluded from the Sura I study each of these verses, to be able to judge this verse: Fractions Makiya or civil or not?

God is the conciliator and the Mahdi to the path researcher

D: Mohamed Hassan Mohamed Hassan Aboulnja Lecturer of Interpretation and Sciences of the Koran at the Faculty of Islamic Studies and Arabic for boys in Disoq 


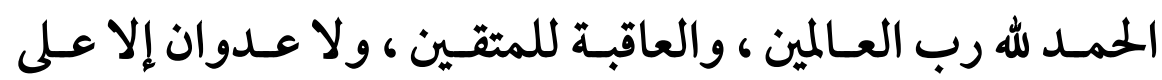

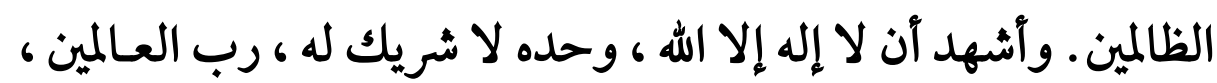

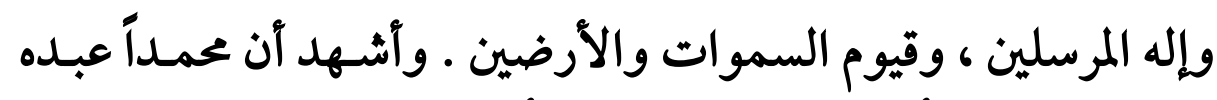

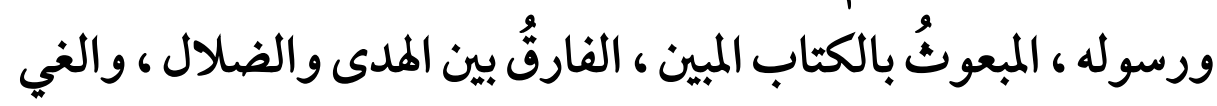
والرشاد ، والشك واليقين .

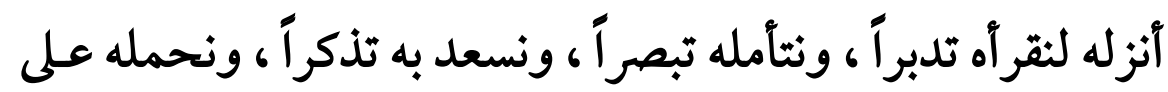
أحسن وجوهه ومعانيه ، ونصدق به ، ونجتهد في إقامة أوامره ونواهيه.

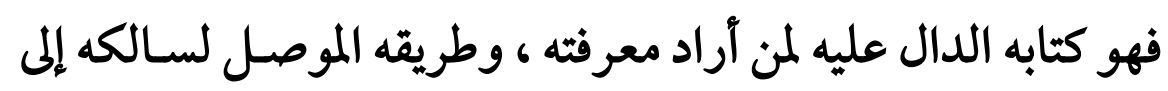

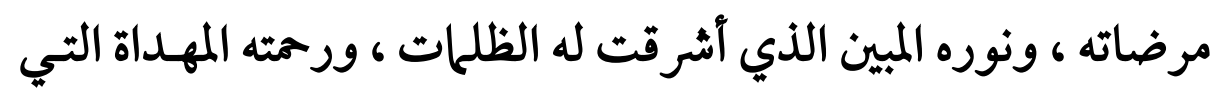

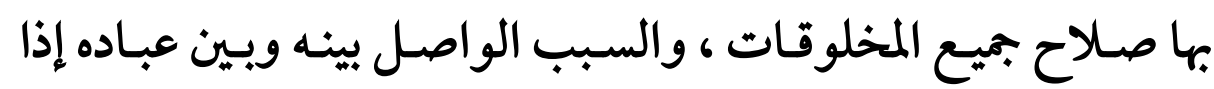

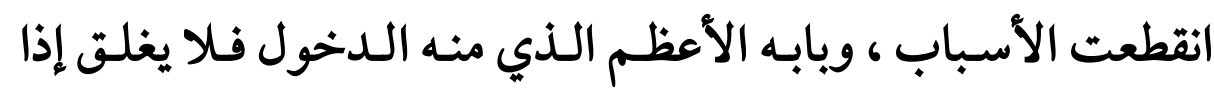

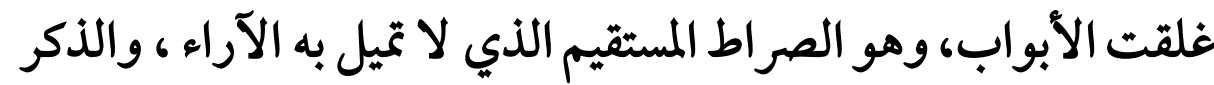

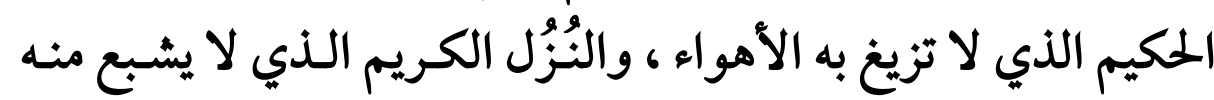

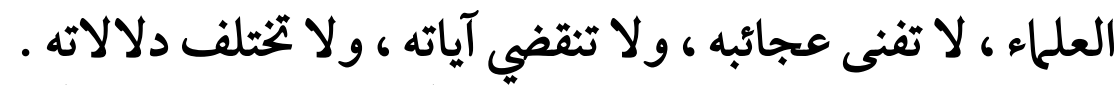

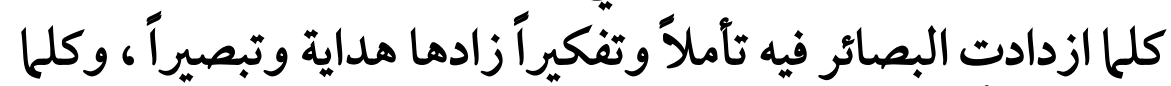

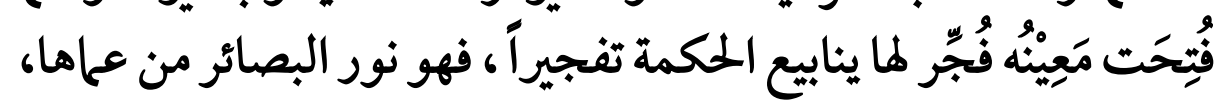

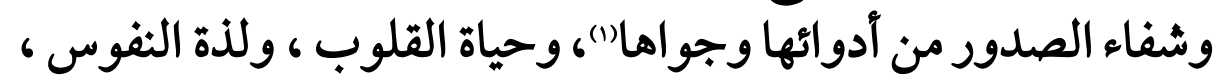

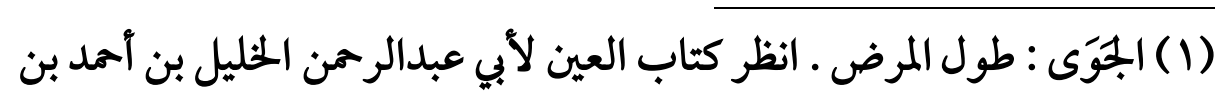

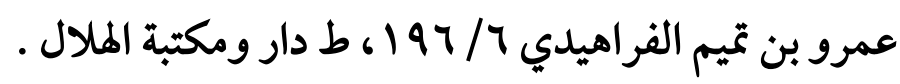




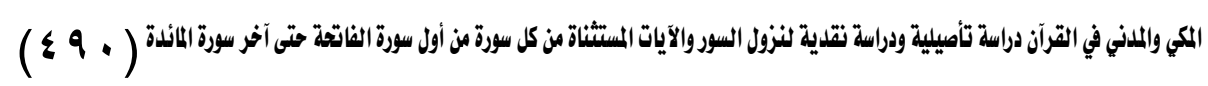
وشفاء الصدور ، وحادي الأرواح إلى بلاد الأفراح ، والمنادي بالمسـاء

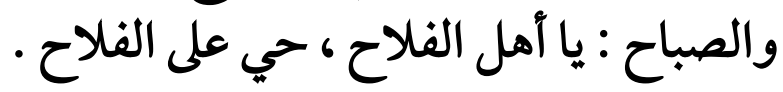

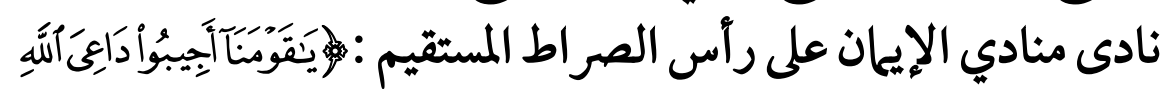

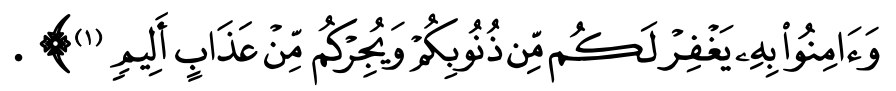

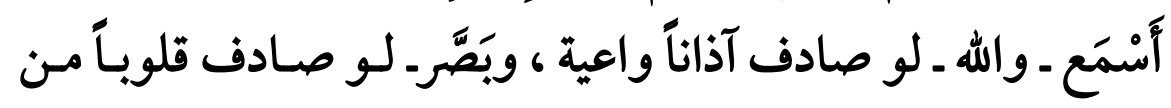
الفساد خالية . وبعد.....، فمن الجلدير بالإنسان أن ينفق ساعات عمره ـ بل آنفاسه

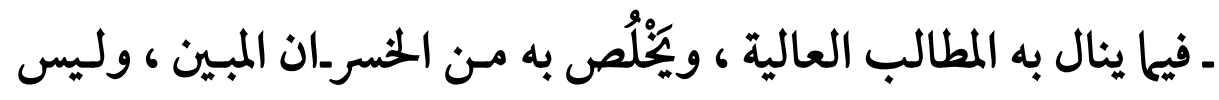

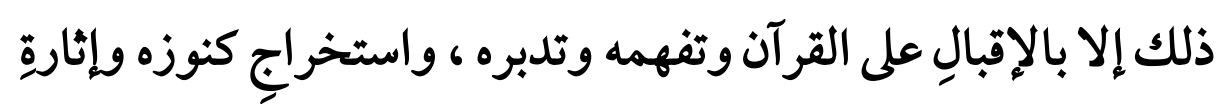

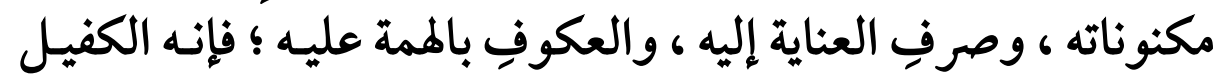

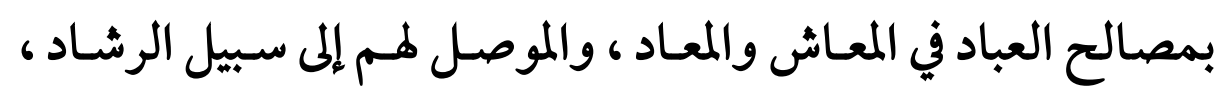

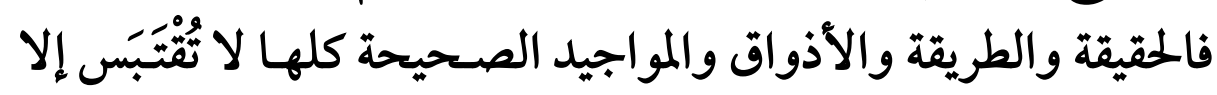

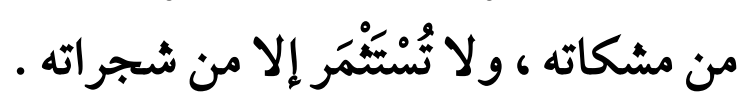

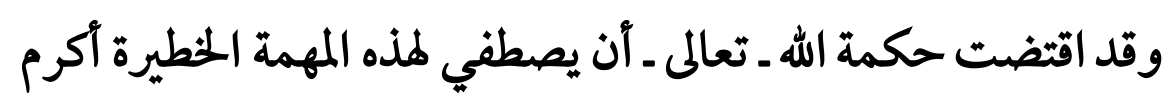

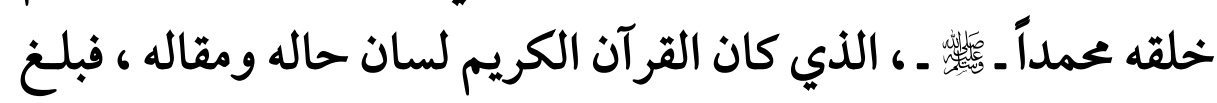

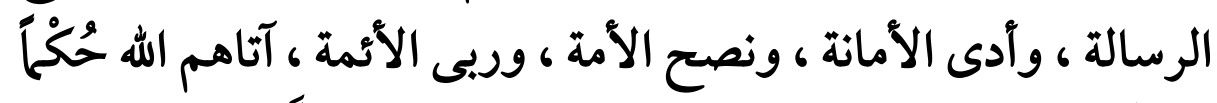

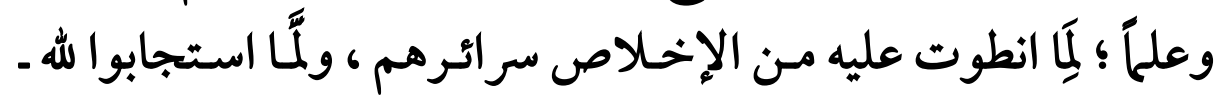

$$
\text { (1) (1) سورة الأحقاف (r) . }
$$


(ะ91)

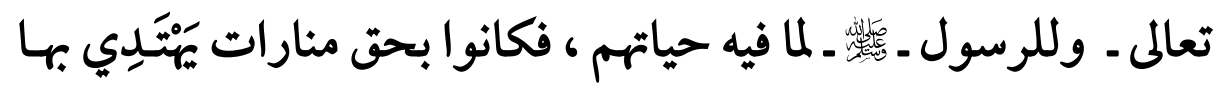

$$
\text { من قصد المداية ، وابتغى الرشاد . مالمان. }
$$

$$
\text { وكانت مدة تلك الرسالة الخاتمة على فترتين : }
$$

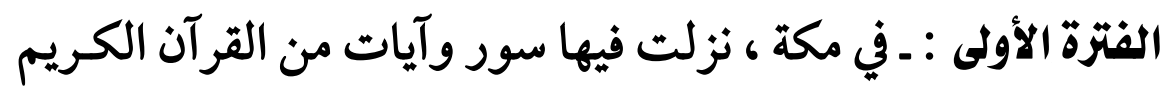

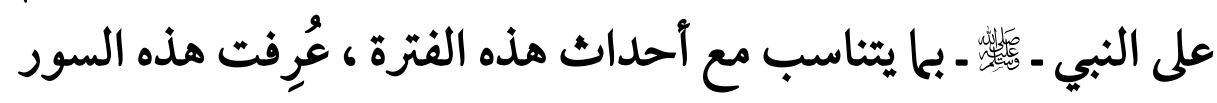

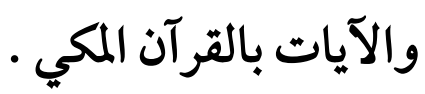

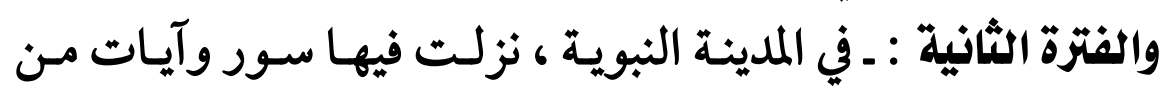

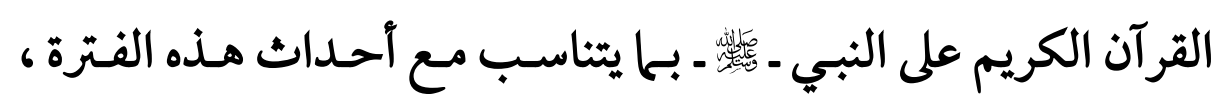
عُرِفت هذه السور والآيات بالقرآن المدني . ومن ثم أصبح من علوم القرآن التي عُني بها العلماء قديحاً وحـديثاً

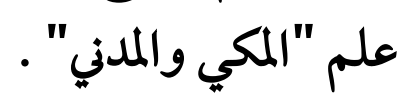

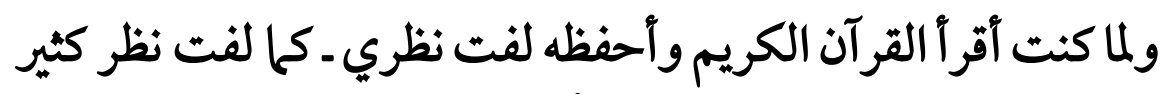

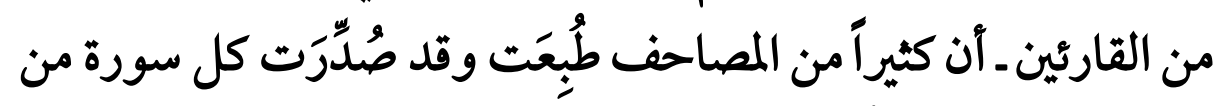

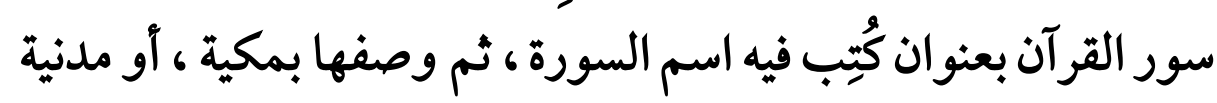

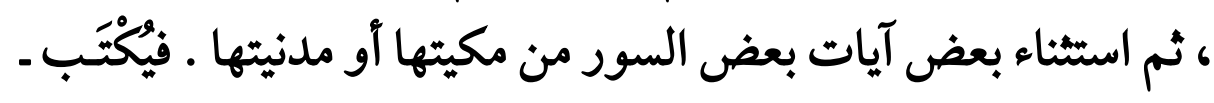

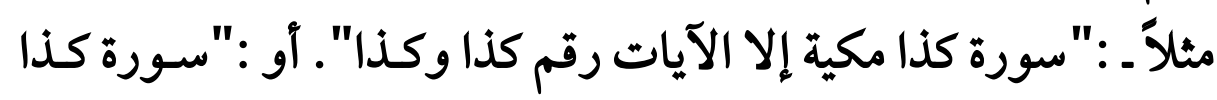

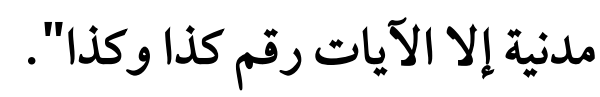

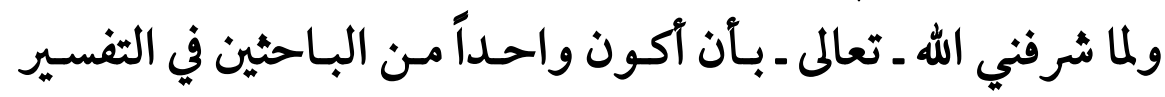

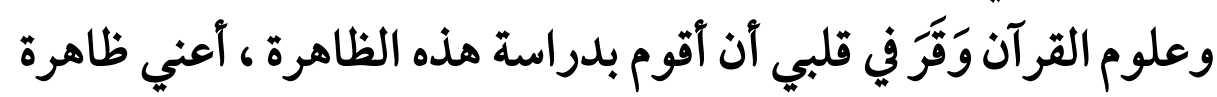




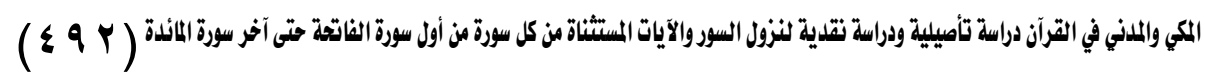
الملكي والمدني من سور القرآن وآياته ، مع التركيز وشدة العناية بالآيات المستثناة من كل سورة .

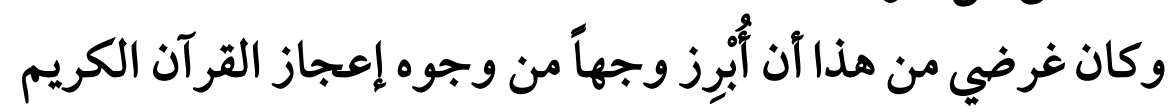

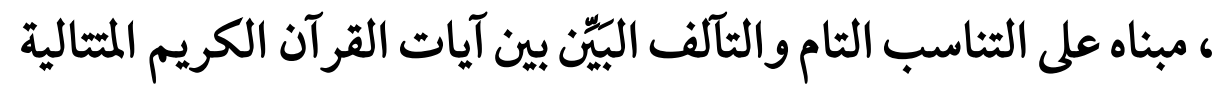
، مع أن بعض هذه الآيات مكي والآيات التي تليها مدنية ، أو العكس.

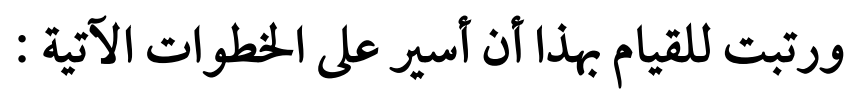

$$
\text { أولاً : إنبات مكية أو مدنية السورة . }
$$

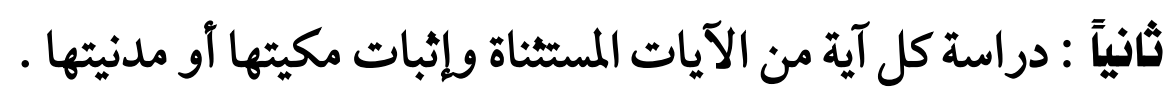

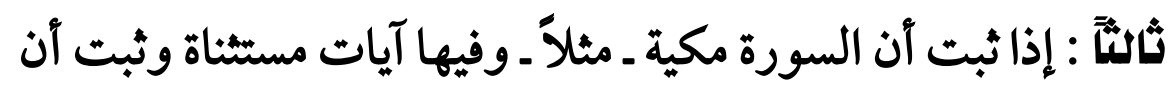

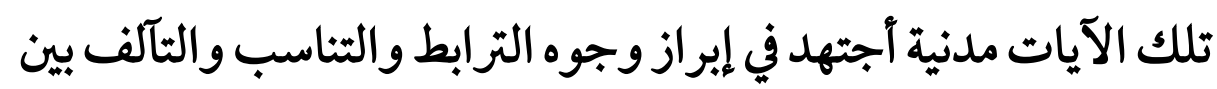

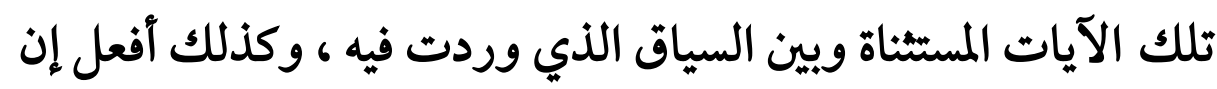
كانت السورة مدنية وفيها آيات مكية . لكن لما بدأت البحث والدراسة ، واتبعت الضوابط العلمية للبحث البه

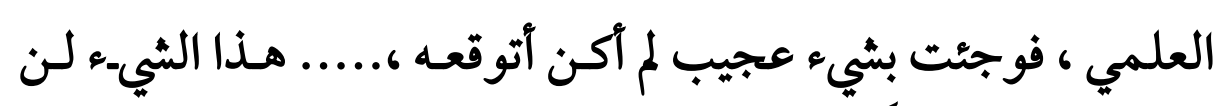

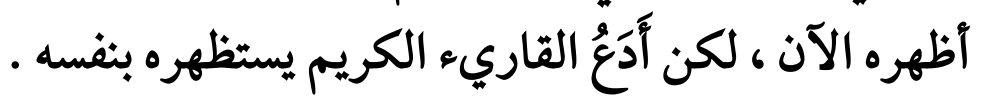

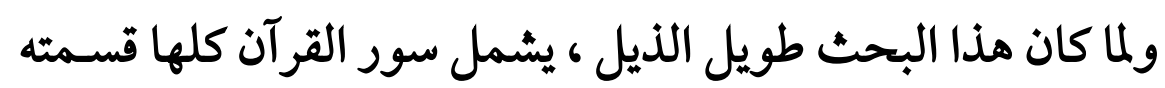

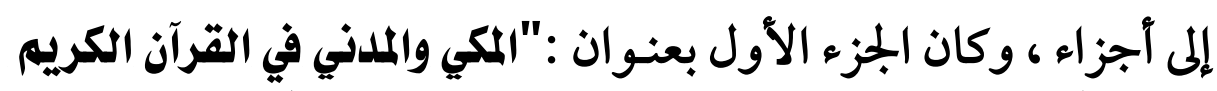

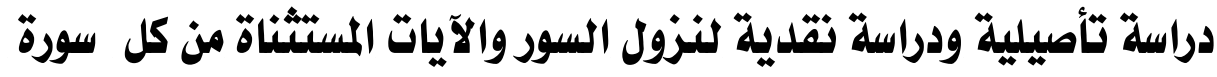
من أول سورة الفاتخة حتى آخر سورة المائدة": وأسير في هذا البحث على وفق الخطوات الآتية : 
( $(94)$

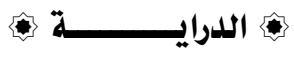

أولاً : أعقد دراسة تأصيلية للمكي والمدني في القرآن الكريم ، أذكر

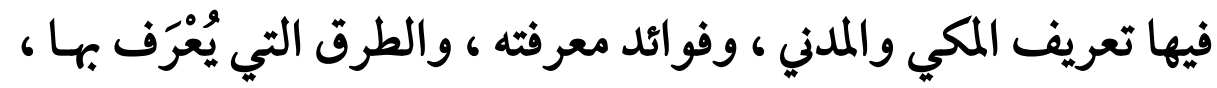

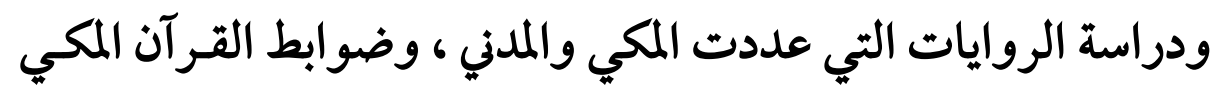
وضوابط القرآن المدني وخصائصها ، ثم دراسة ظاهرة الآيات المستثناة

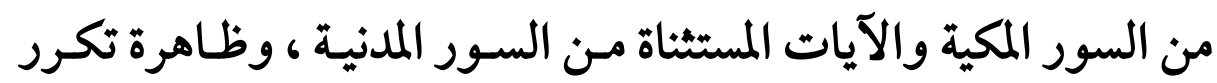
نزول شيء من القرآن الكريم •

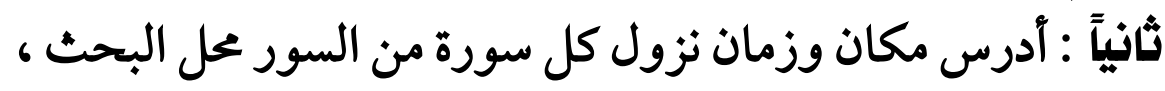

لنتمكن - بعد ذلك ـ من وصفها بأنها مكية أو مدنية .

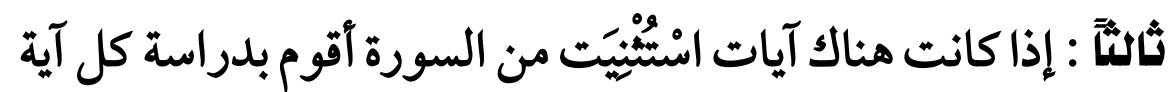

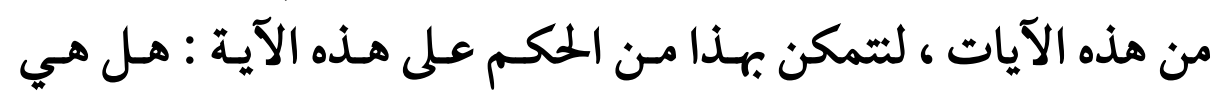

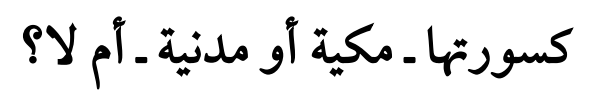

وعملي في هذا أن أنشيء لكل سورة فصلاً أجعله باسم السورة ، ثم مأم أقسم هذا الفصل إلى مبحثين :

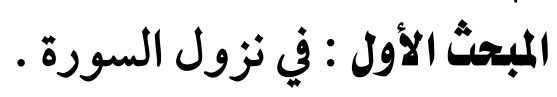

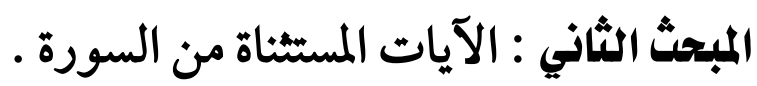
ثم أبحث كل آية في مطلب مستقل .

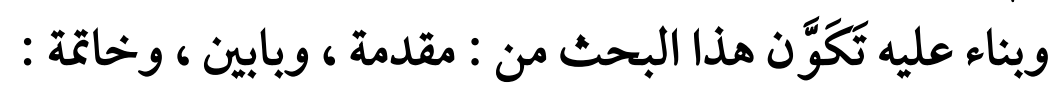

أما المقدمة : فـأذكر فيها الـدافع لهذا البحـث ، والمنهج المتبـع فيه ،

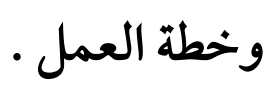




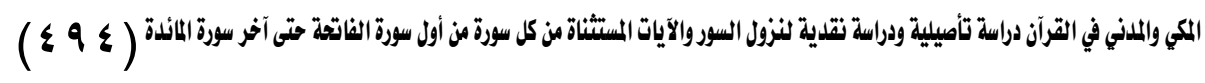

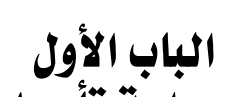

المكي والملني في القرآن الكريم دراسة تأصيلية

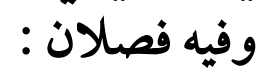

الفصل الأول : ـ تعريف المكي والمدني وفوائد معرفته .

$$
\text { وفيه مبحثان : }
$$

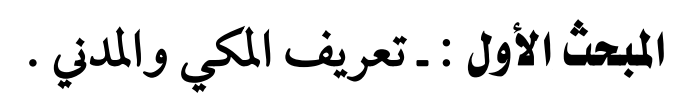

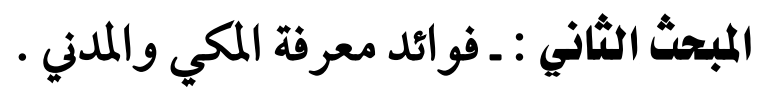

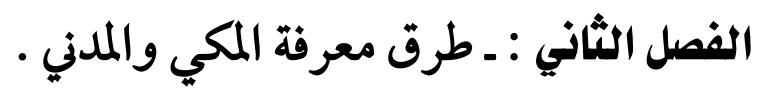

$$
\text { وفيه أربعة مباحث : }
$$

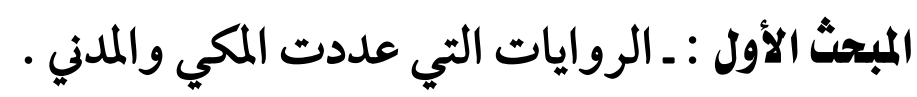

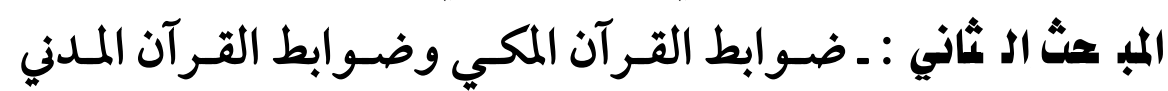

$$
\text { وخصائصها . }
$$

المبحث الثالث : ـ الآيات المستثناة من السور المكية والآيات المستثيثاة

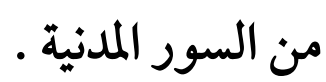

$$
\begin{aligned}
& \text { المبحث الرابع : ـ هل تكرر نزول شئ ـ من المرآن }
\end{aligned}
$$

$$
\begin{aligned}
& \text { نزول السور والآيات من أول سورة الثابَّة حثيى آخر سورة المائدة }
\end{aligned}
$$

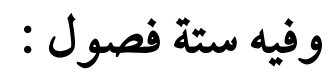

$$
\begin{aligned}
& \text { الفصل الأول : ـ سورة الفاتحة . فمول. } \\
& \text { وفيه مبحث واحد وهو : نزول سورة الفاتحة . }
\end{aligned}
$$


$(\leqslant 90)$

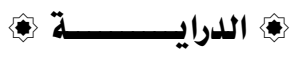

الفصل الثاني : ـ سورة البقرة ـ وفيه مبحثان :

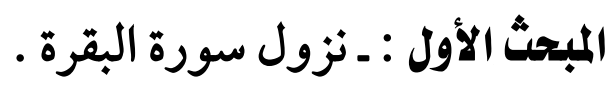

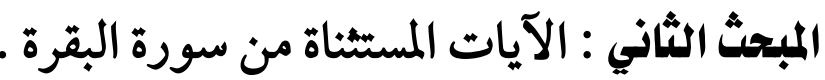

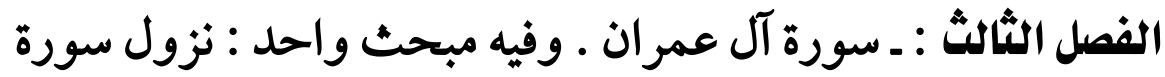

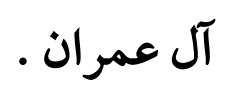

الفصل الرابع : ـ سورة النساء ـ وفيه مبحثان :

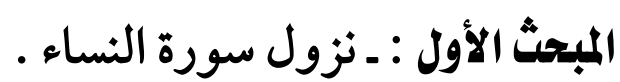

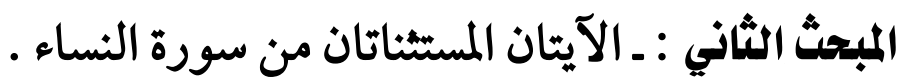

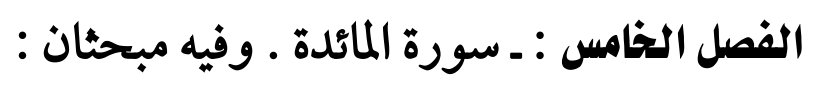

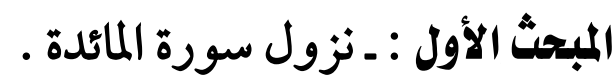

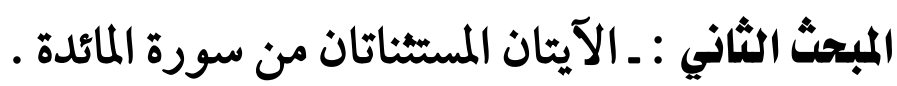

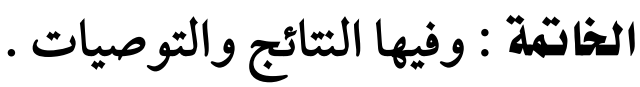

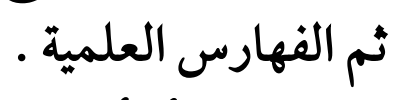

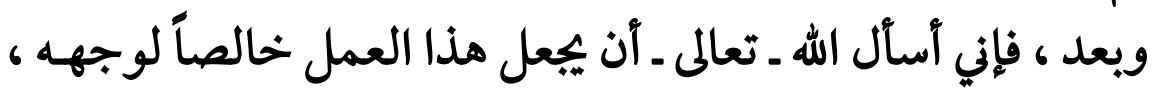

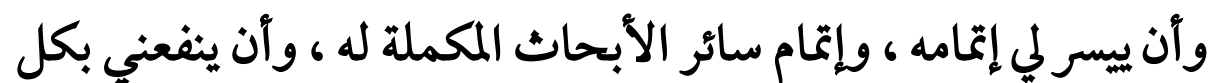

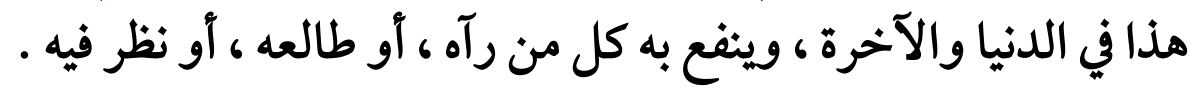

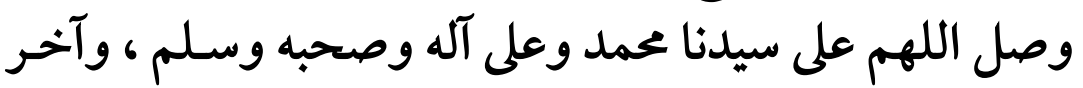

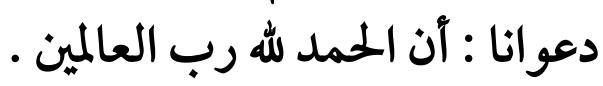




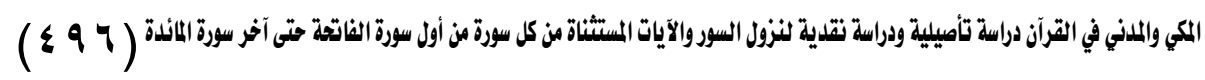

$$
\text { المكي والمدني في القرآن الكريم دراسّة تأصيلية }
$$

الفصل الأول : ـ تعريف المكي والمدني وفوائد معرفته .

$$
\text { وفيه مبحثان : }
$$

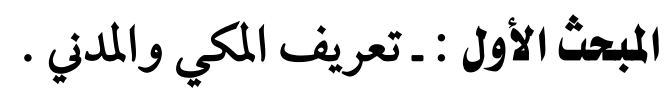

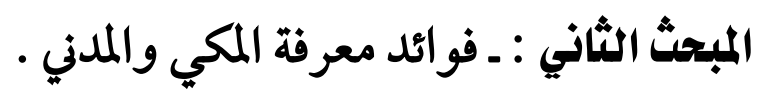

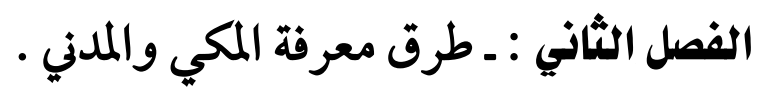

$$
\text { وفيه أربعة مباحث : }
$$

المبحث الأول : ـ الروايات التي عددت المث : المكي والمدني .

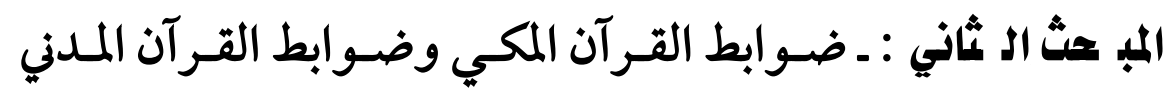

$$
\text { وخصائصها . }
$$

المبحث الثالث : ـ الآيات المستئاة من السور المكية والآيات المستيثناة

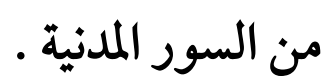

$$
\begin{aligned}
& \text { المبحث الرابع : ـ هل تكرر نزول ثنيء من القرآن؟ }
\end{aligned}
$$




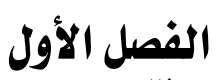

\section{تصريف المكي والملدني وفوائد معرفته}

\section{المبحث الأول}

\section{تعريف المكي والملدني}

المكي في اللغة : كل ما نُسِب إلى مكة ، وهي آم القرى ، وهي آثرف

$$
\text { بقاع الأرض (1). }
$$

والمدني في اللغة : كل ما نُسِب إلى المدينة ، وهي نسبة غلبت على مدينة

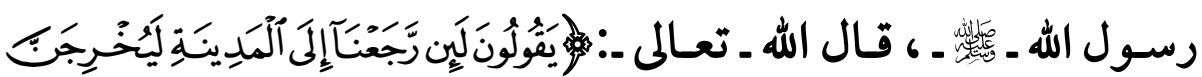

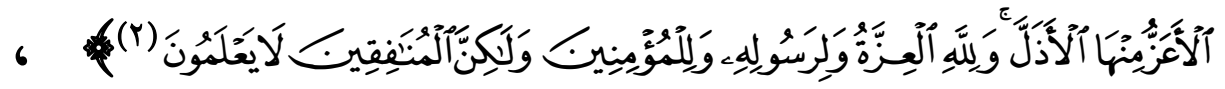

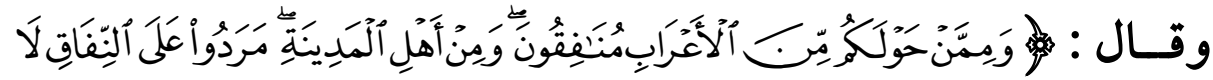

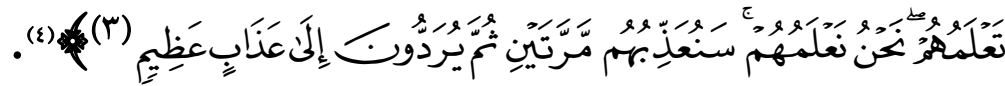
أما المكي والمدني في الاصطلاح فللعلماء فيه ثلاثة الجاهات :

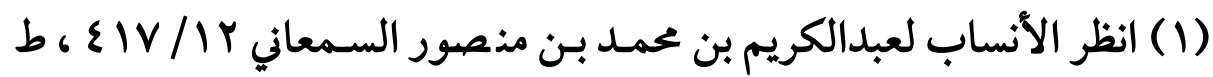

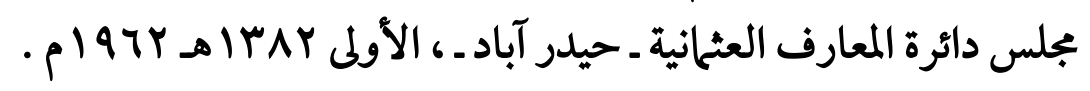

$$
\begin{aligned}
& \text { (Y) سورة المنافقون (N) (Y) . (Y) } \\
& \text { (Y) سورة التوبة (1) (1) . }
\end{aligned}
$$

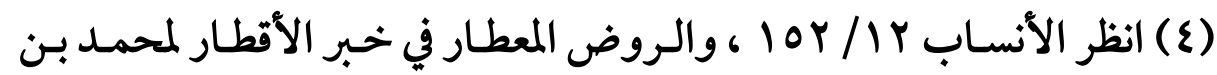

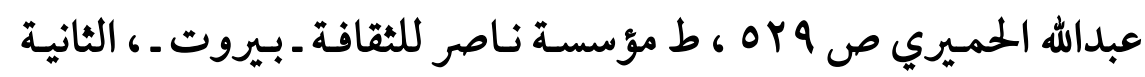




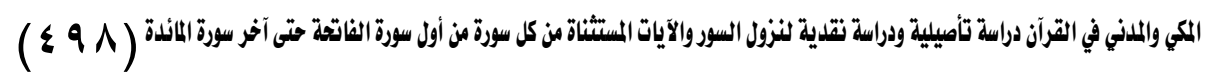
الاتجاه الأول : أن المكي : ما وقع خطاباً لأهل مكة ، والمدني : ما وقع

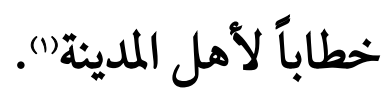

وهذا التعريف لوحظ فيه المخاطبون ، وفُسِّر بهذا قول عبـدالله بـن

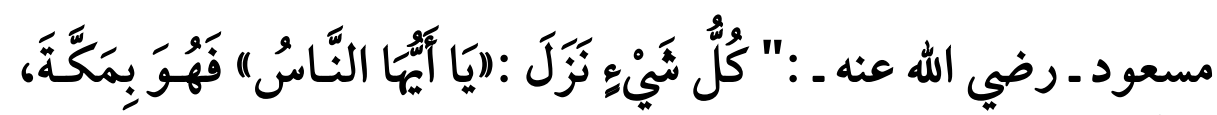

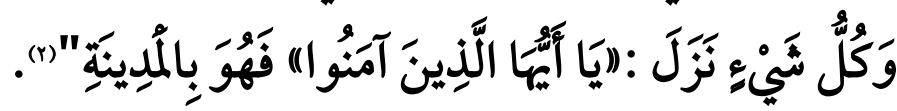
وذلك لأن الكفر كان غالباً على أهـل مكـة فخوطبوا بـ بـ : (يـا آيها الناس) ، وإن كان غيرهم داخلاً فيهم • ولأن الإيجان كان غالباً على آهل

(1) انظر البرهان في علوم القرآن لبدر الدين محمد بن عبد الله بن بهادر الزركثيي

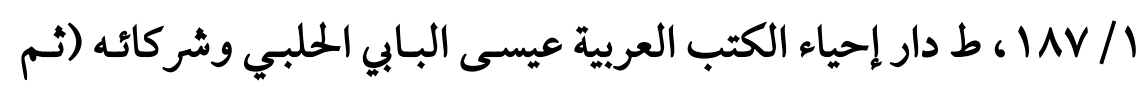

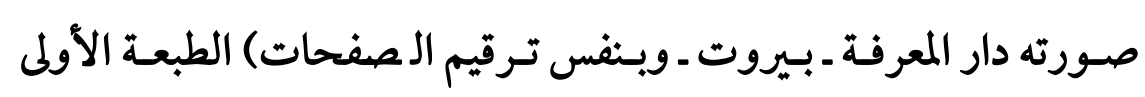

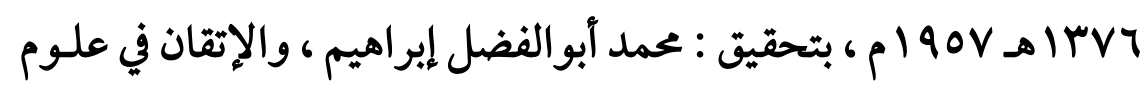
القرآن لجلال الدين عبدالرحمن بـن أبي بكر السيوطي / / ب ، ط الميئة

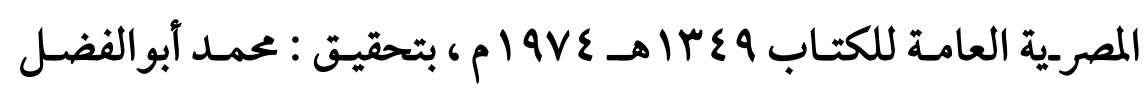
إبراهيم • (1)

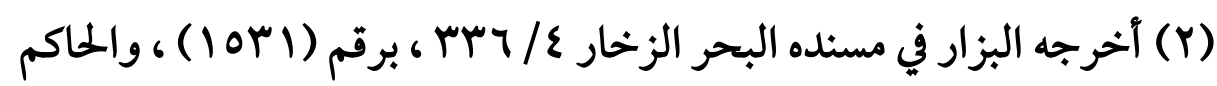

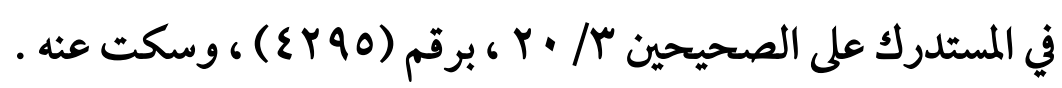


المدينة فخوطبوا بـ : (يا آيها الذين آمنوا) ، وإن كان غيرهم داخلاً فيهم -

$$
\text { آيضاً.-. }
$$

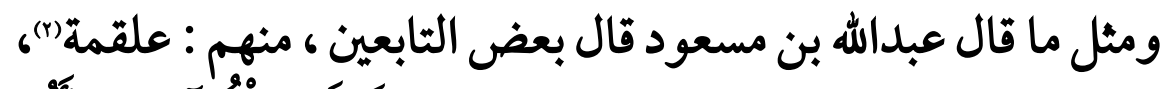

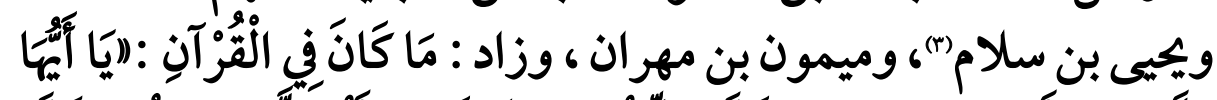

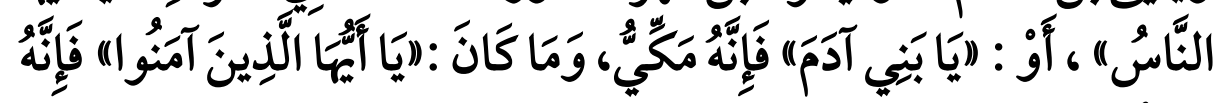
مَدَنِيٌّ

وقد توجه النقد ضد هذا الاتجاه من وجوه ثلاثة :

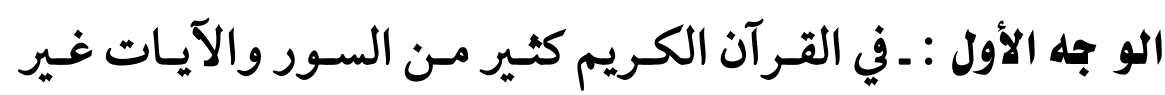

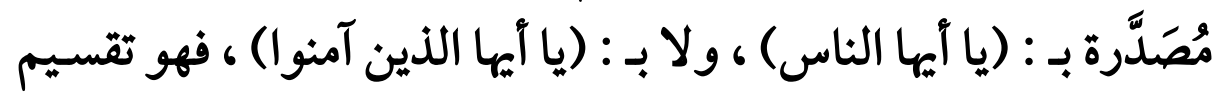

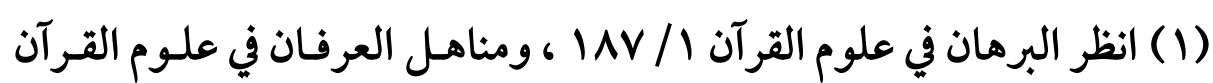

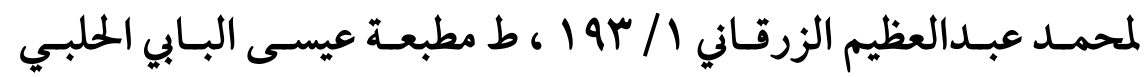

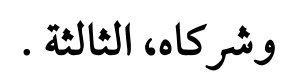

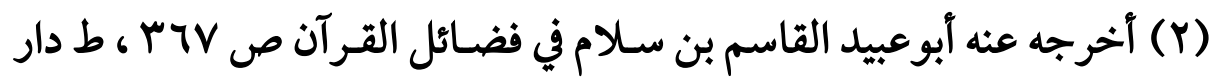

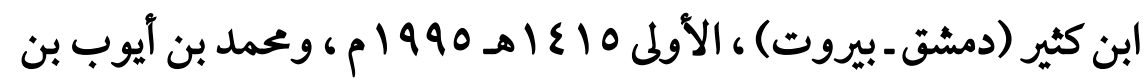

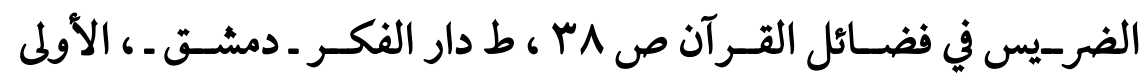

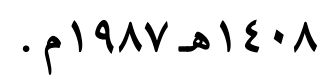

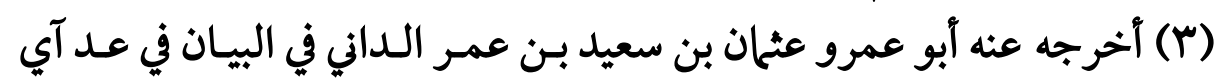

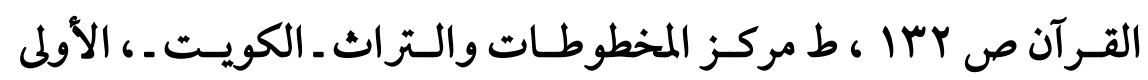

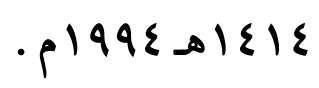

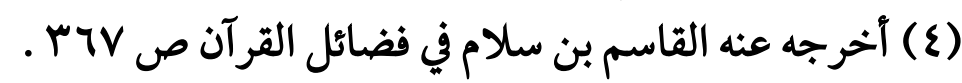




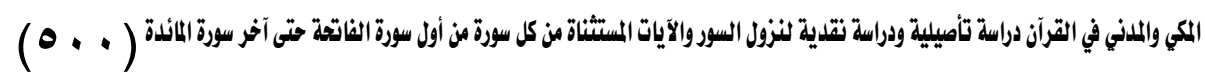

$$
\text { غير حاصر (1)، ولا ضابط (r)(r). }
$$

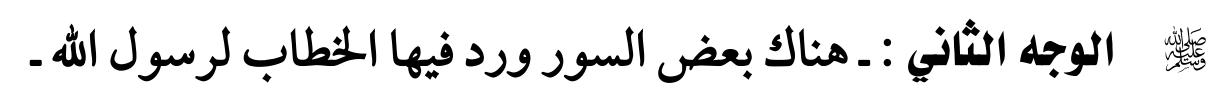

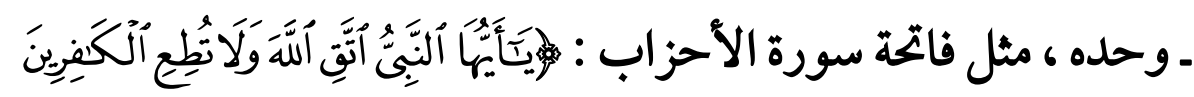

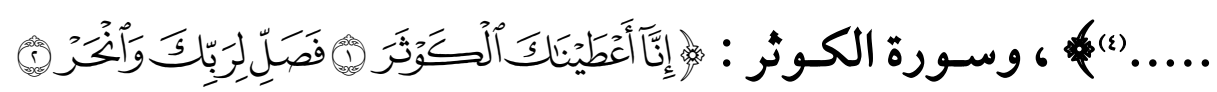

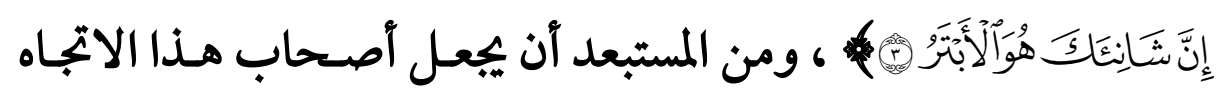

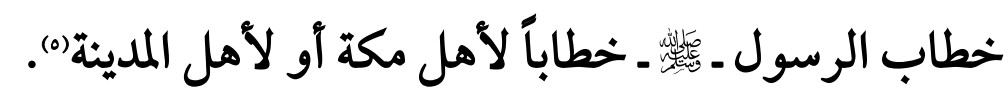

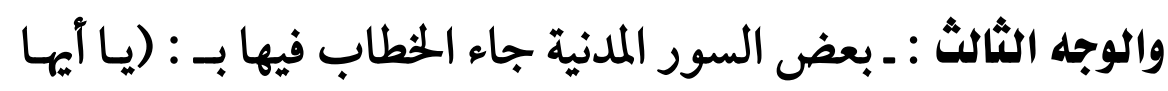

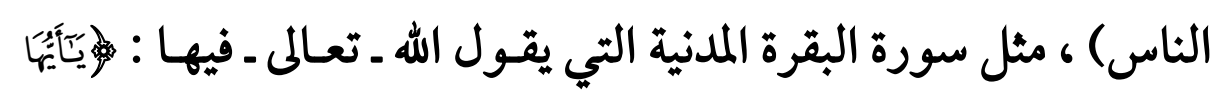

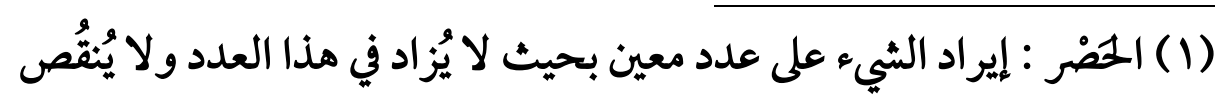

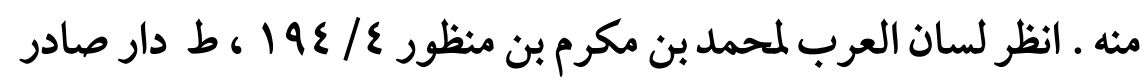

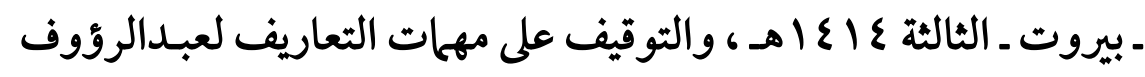

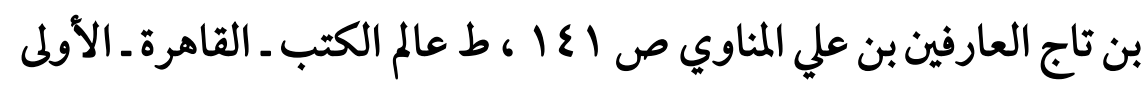

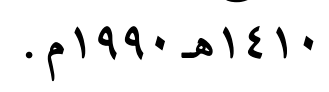

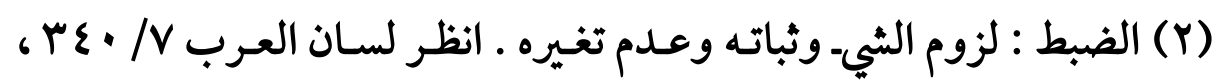

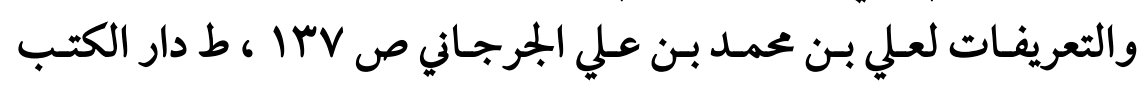

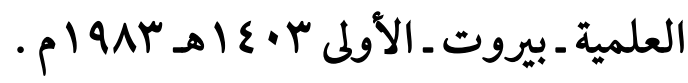

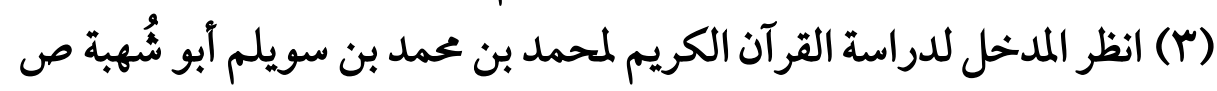

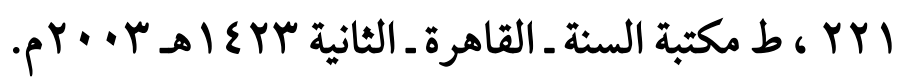

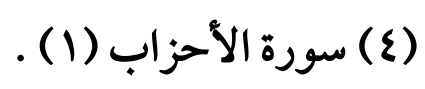

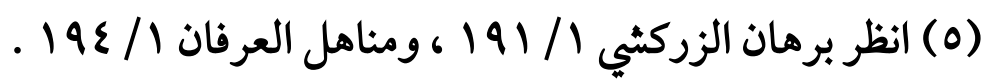




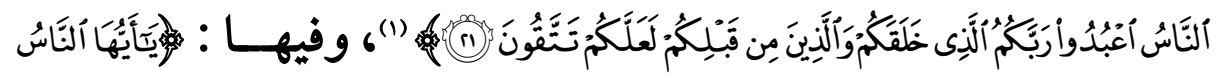

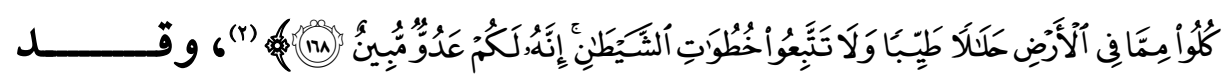

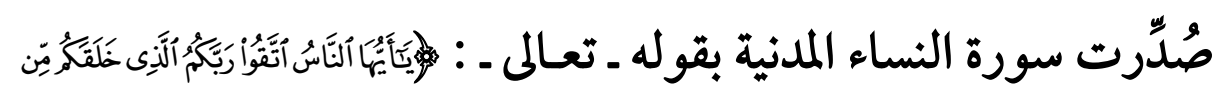

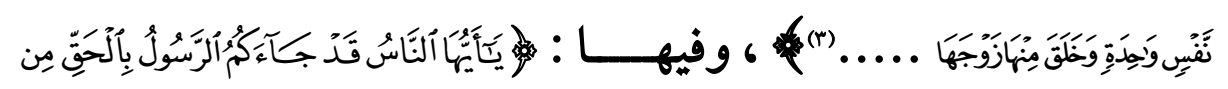

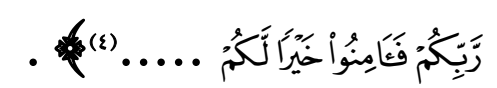
وبعض السور المكية جاء الحطاب فيها بـ : (يا آيها الذين آمنوا) ، مثل هئل

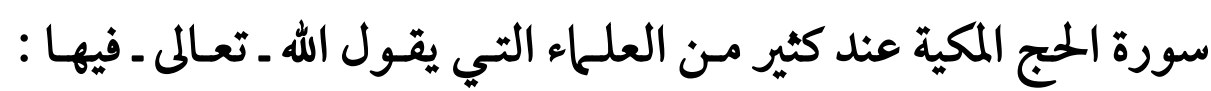

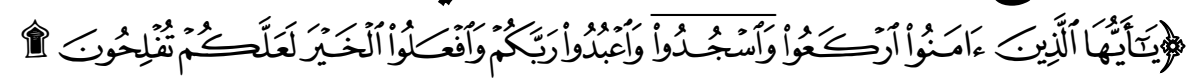

$$
\begin{aligned}
& \text { (1) سورة البقرة (YI) . (Y) } \\
& \text { (Y) سورة البقرة (Y) (IT) . } \\
& \text { (r) سورة النسا (1) (1) } \\
& \text { ( ) سورة النساء ( ) (IV) (1V) } \\
& \text { (0) سورة الحج (VV) (1) (1) (1) }
\end{aligned}
$$

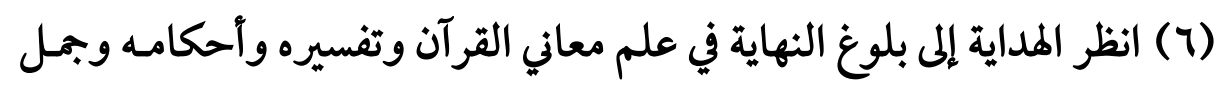

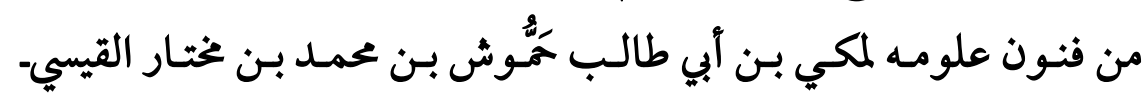

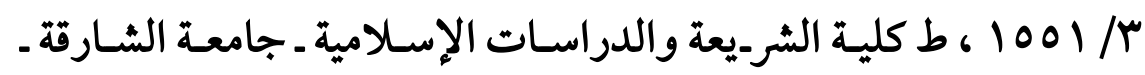

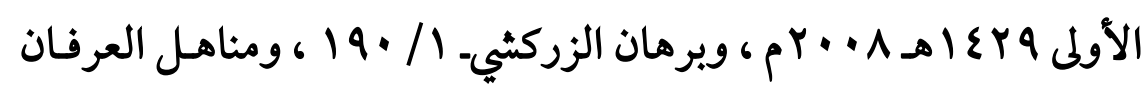




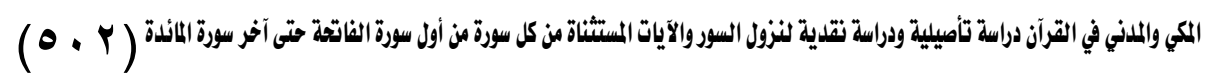
ولم يستبعد بعض العلم)ء أن يكون المقصود من هذا القول الحمل على المالى

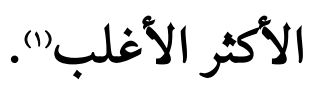

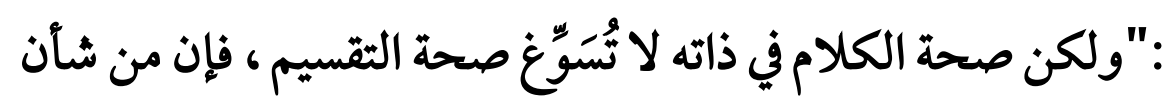

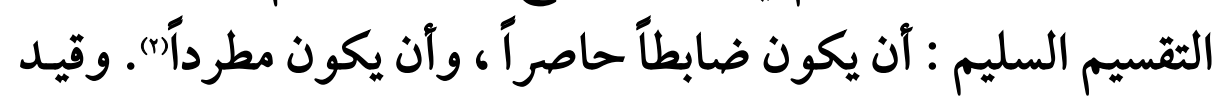

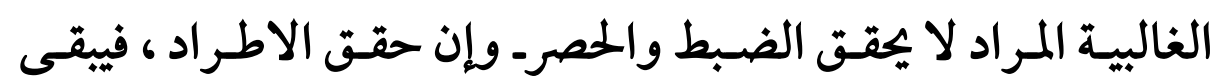

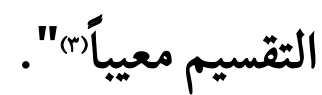
الاتجاه الثاني : ـ أن المكي : ما نزل من القرآن بمكة ولو بعد المجرة،

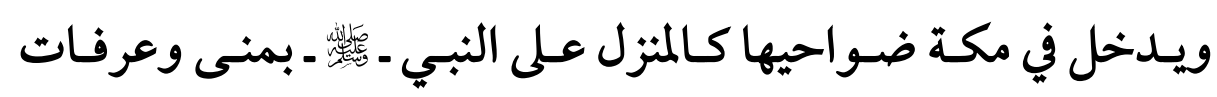
والحديبية .

والمدني : ما نزل بالمدينة ، ويدخل في المدينة ضواحيها ـ أيضًا ـ كالمنزل

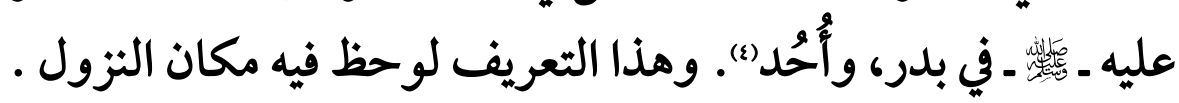

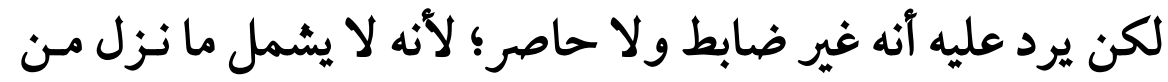

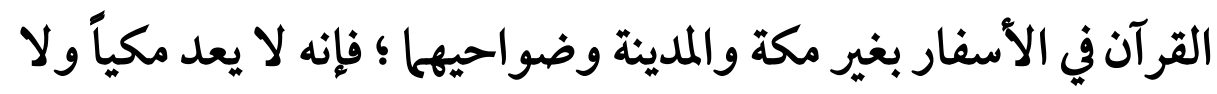

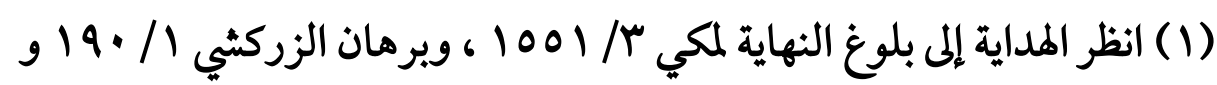

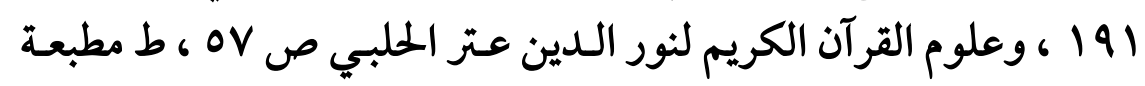

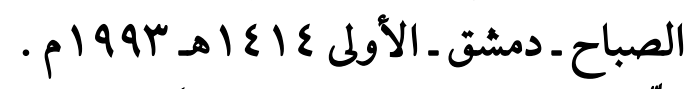

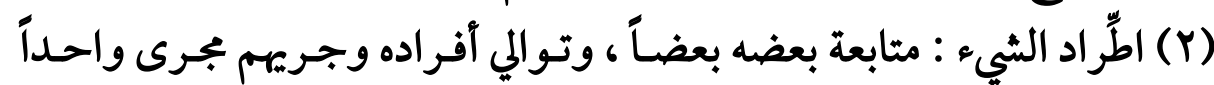

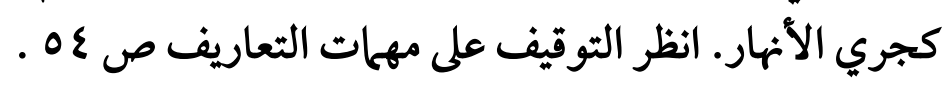

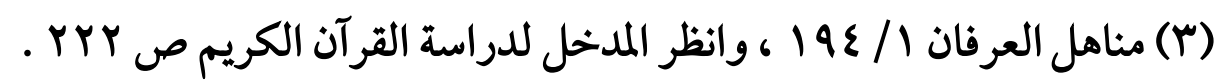

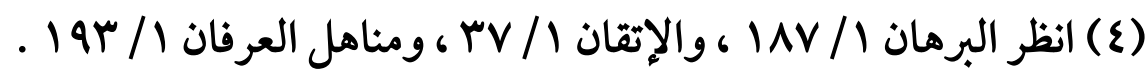


$(0 \cdot r)$

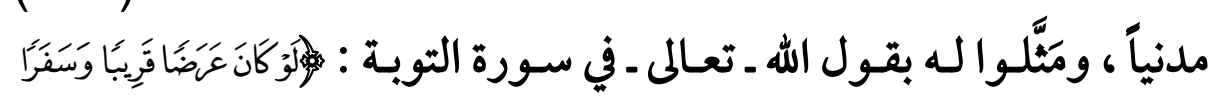

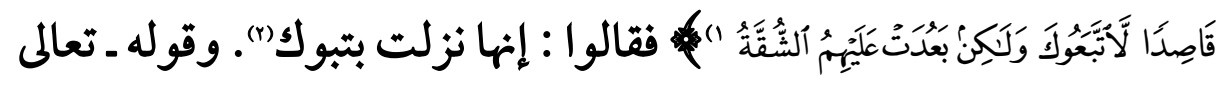

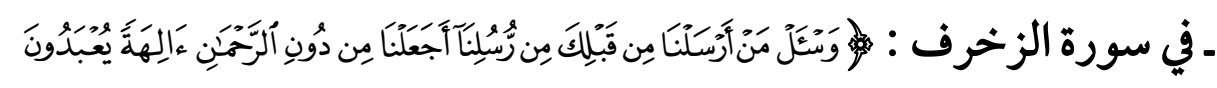

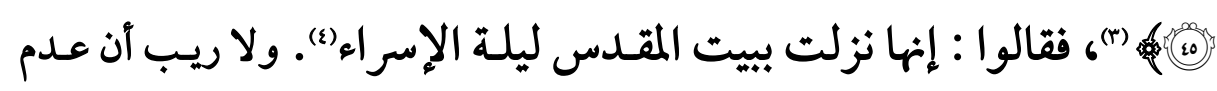

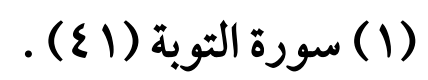

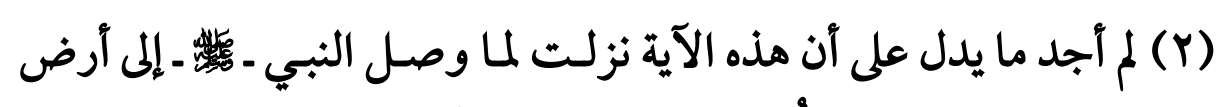

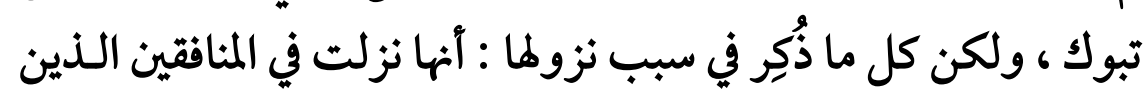

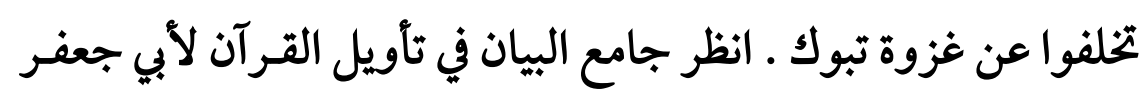

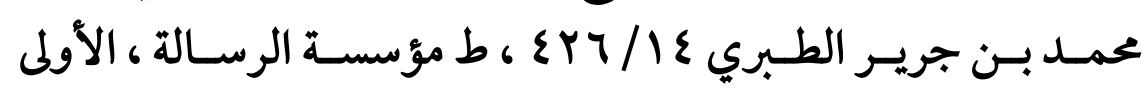

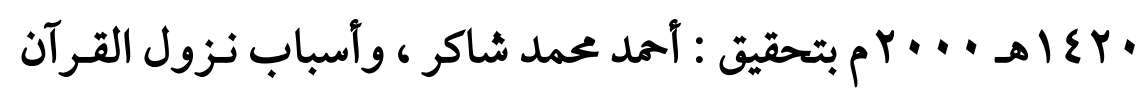

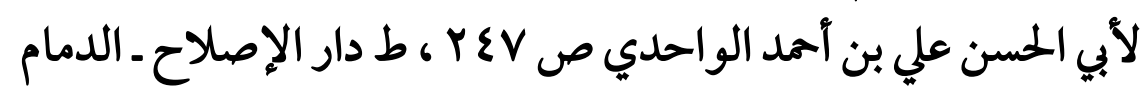

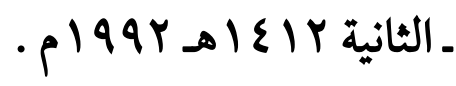

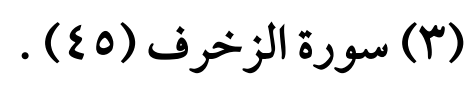

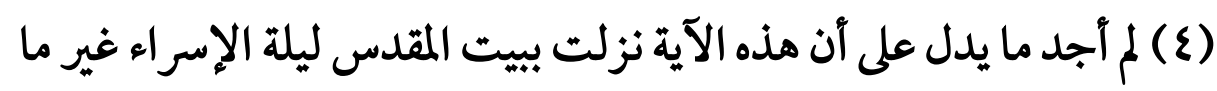

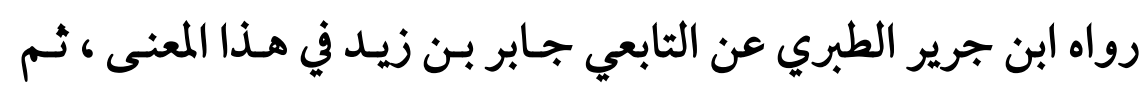

$$
\text { رجح الطبري خلافه . }
$$

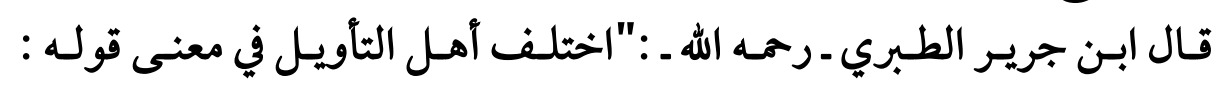

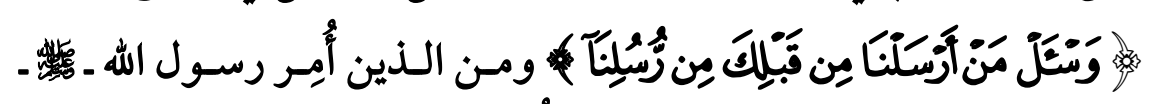

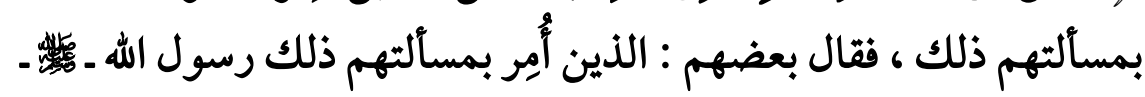

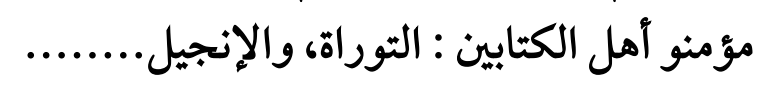




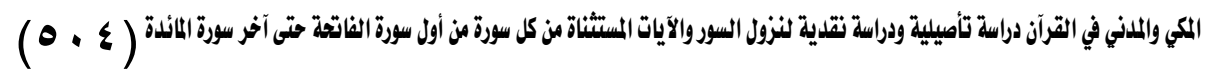
الضبط في التقسيم يترك واسطة لا تدخل فيلا يـذكر مـن الأقسـام ، وذلك ولك

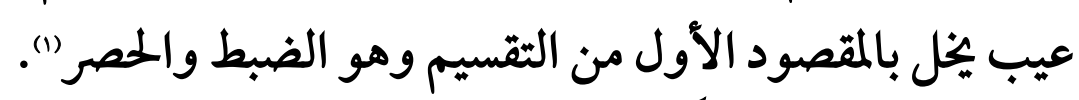

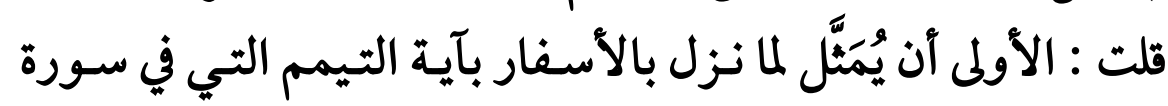

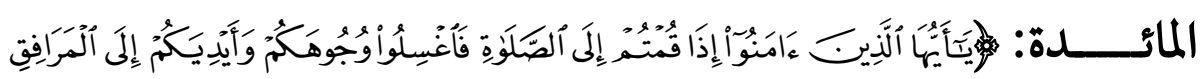

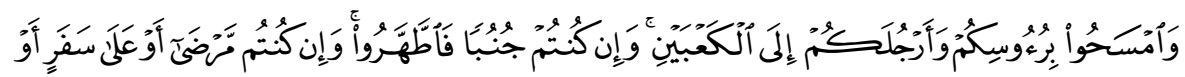

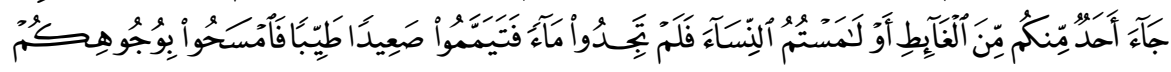

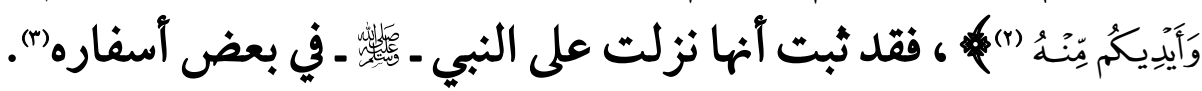

وقال آخرون : بل الذي أُمِر بمسألثهم ذلك الأنبياء الذين جُمِعـوا له ليلة

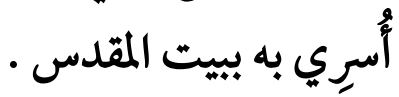

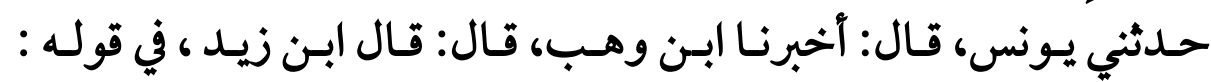

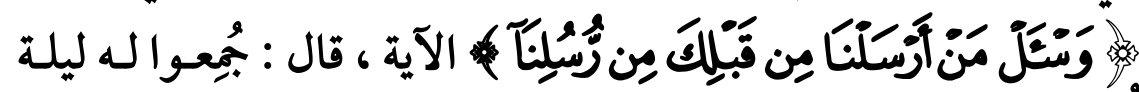

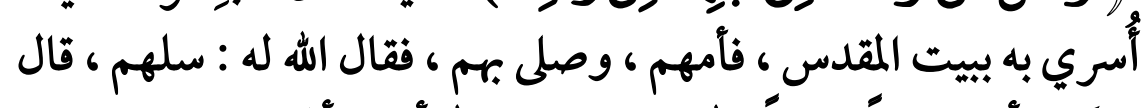

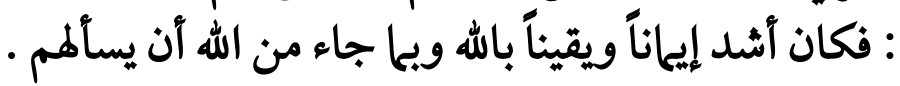

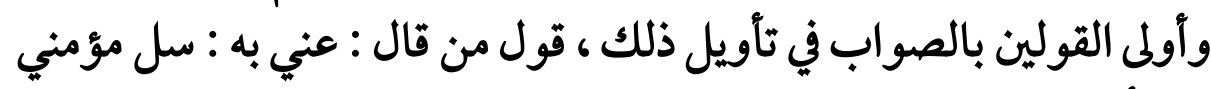

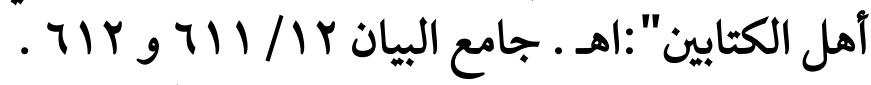

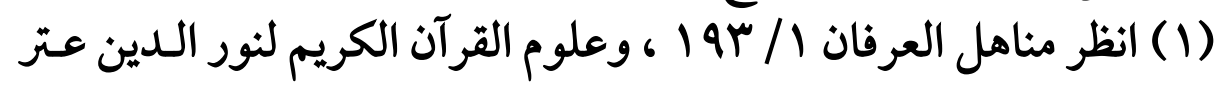

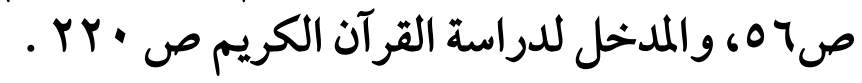

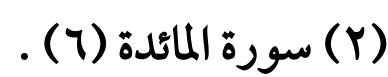

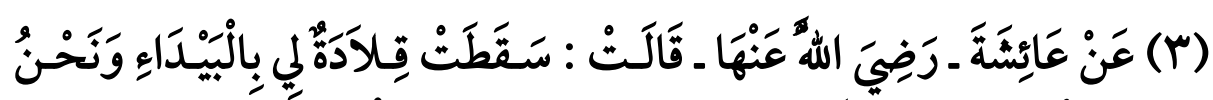

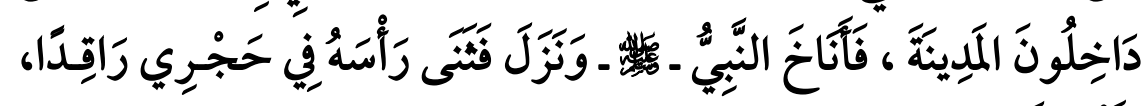

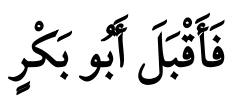


$(0 \cdot 0)$

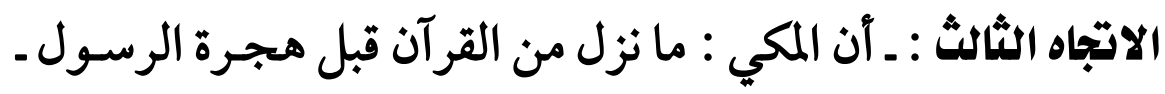

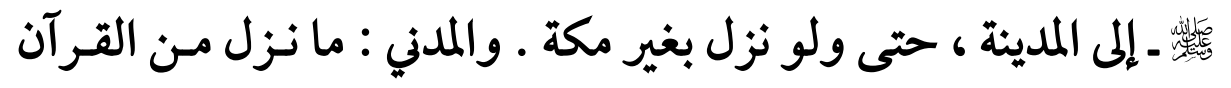

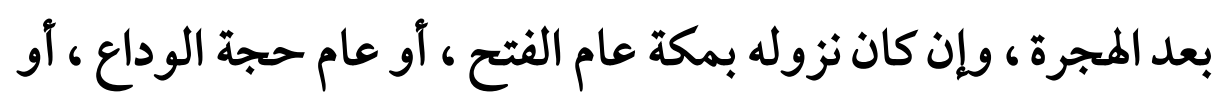

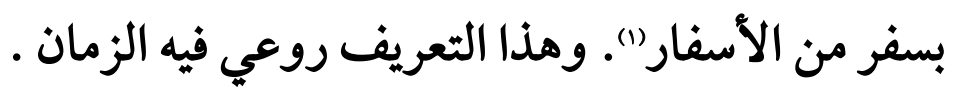

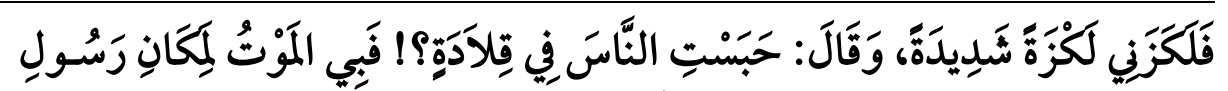

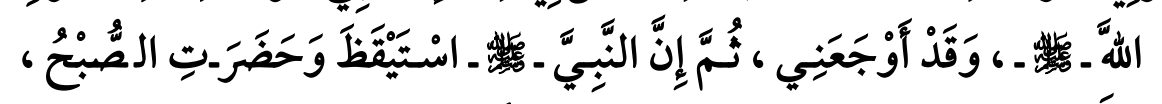

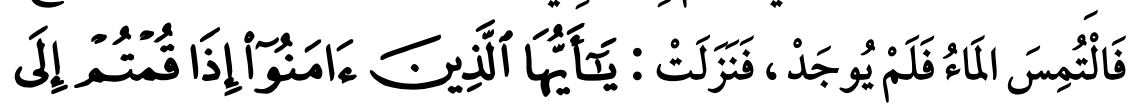

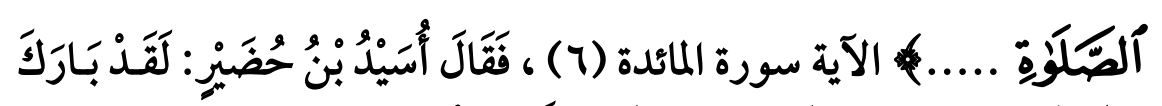

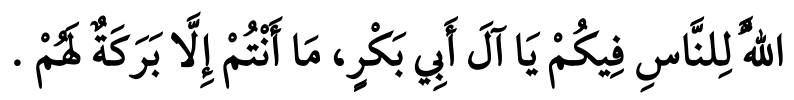

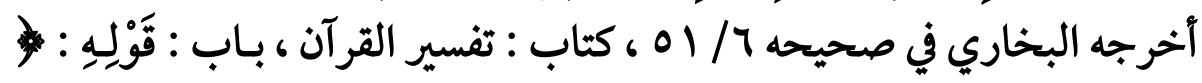

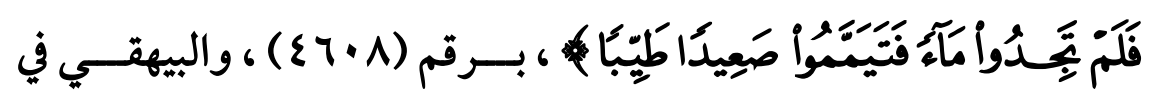

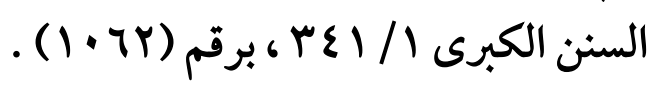

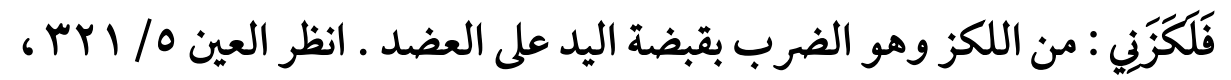

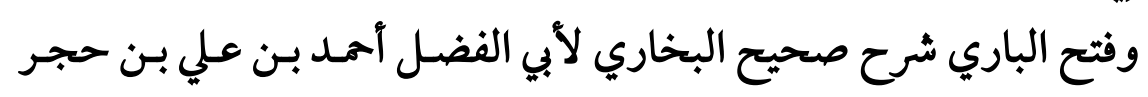

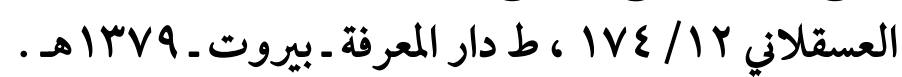

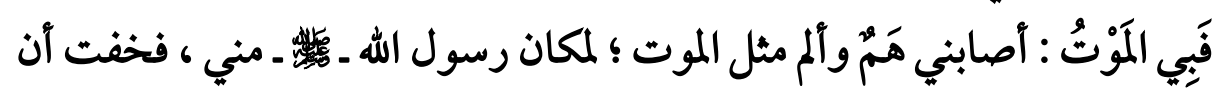

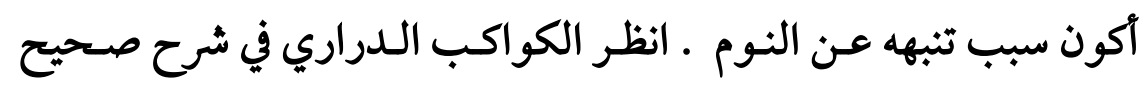

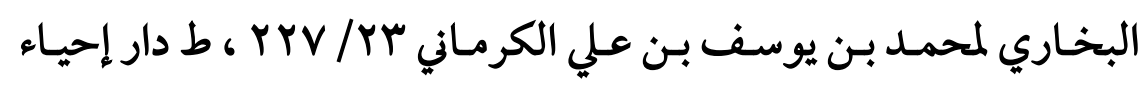

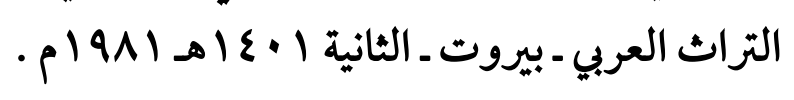

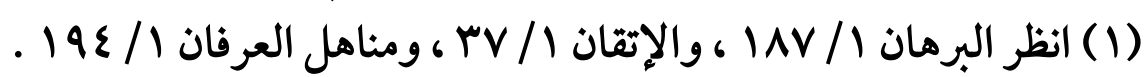




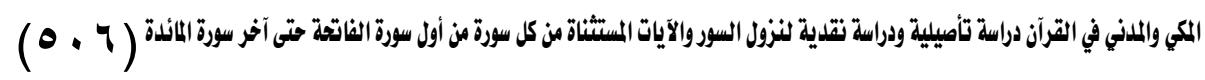
وهو الراجح ، والأقرب إلى القبول ، من وجهين :

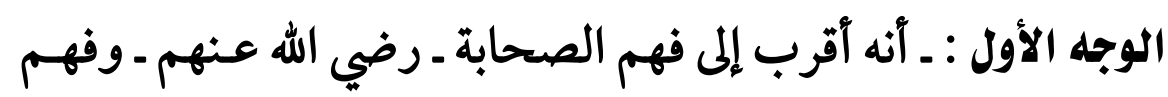

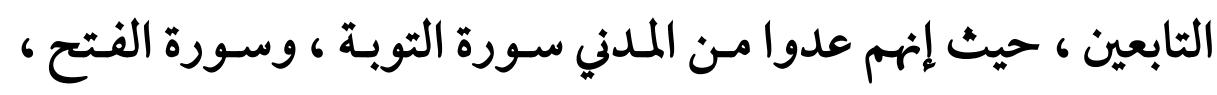

وسورة المنافقون")

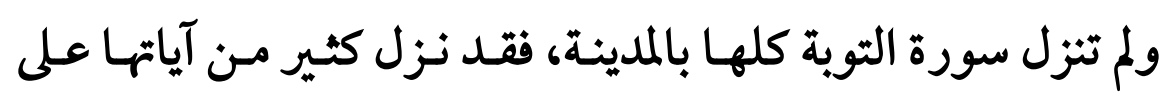

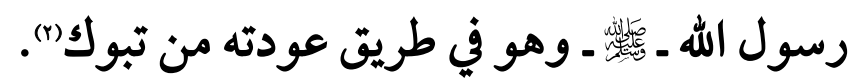

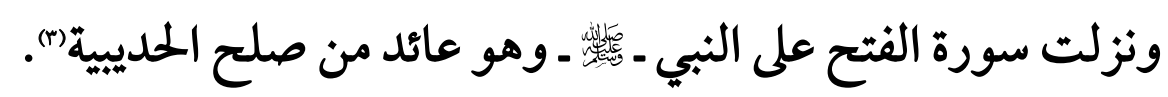

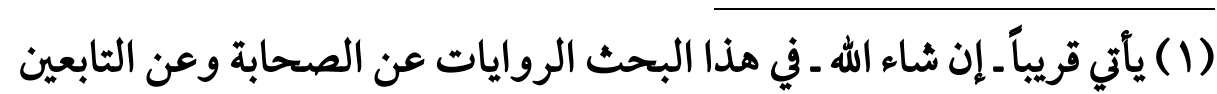

$$
\text { في عَدِّ السور المكية وعَدِّ السور المدنية. }
$$

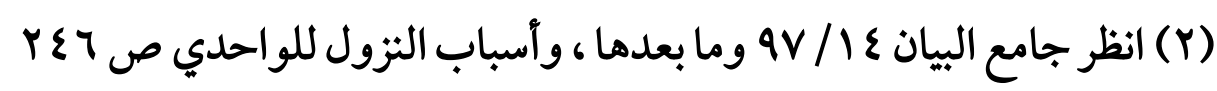

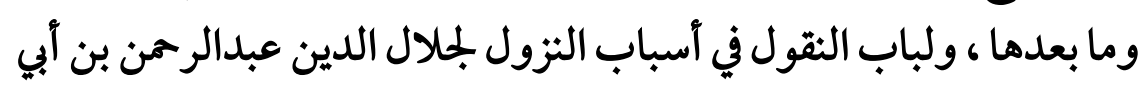

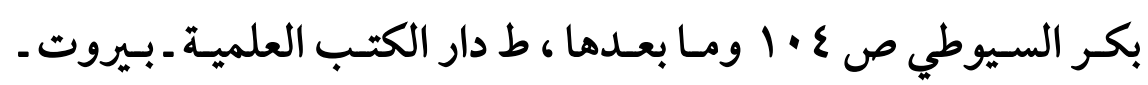

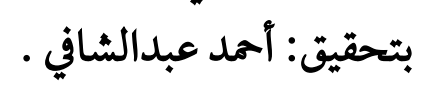

وتبوك : موضع بين وادي القرى والشام ـ انظر معجم البلدان لياقوت بن عبدالله

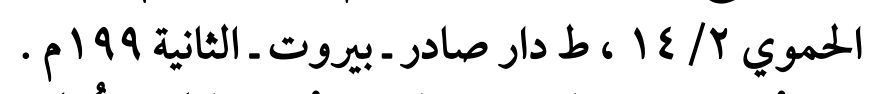

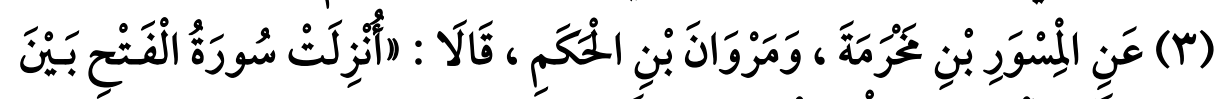

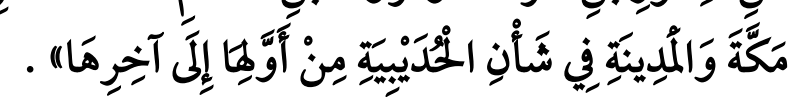

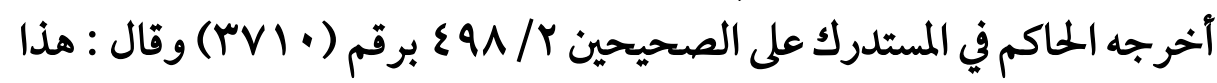
حديث صحيح على شرط مسلم ولم يخرجاه ـ و ووافقه الذهبي . 
$(0 \cdot v)$

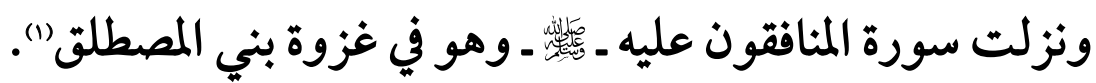

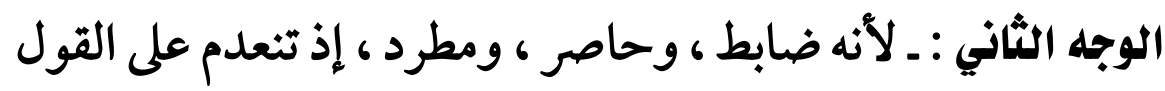
به الواسطة ، ولا يرد عليه ما ينقضه ، والاعتهاد عليه يقضي على معظم

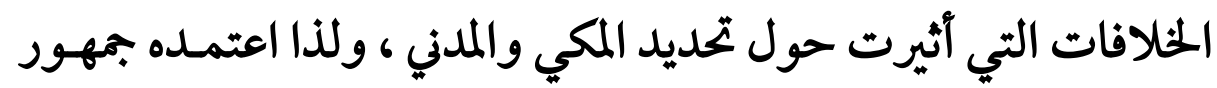

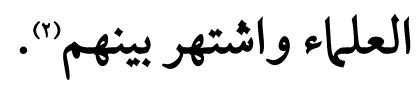

والححَيبيَّة : قرية متوسطة ، بينها وبين مكة مسيرة يوم ، وبينها وبين المدينة مسيرة

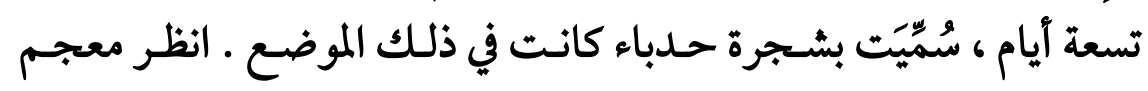

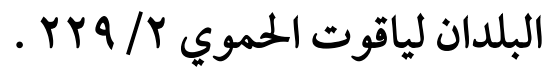

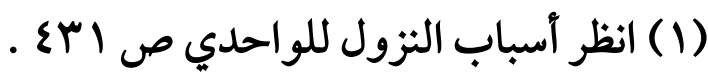

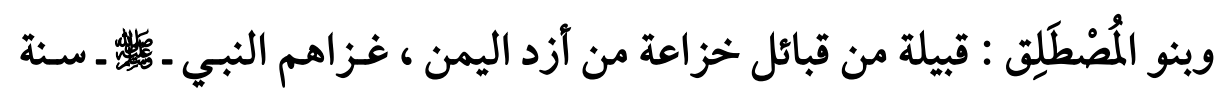

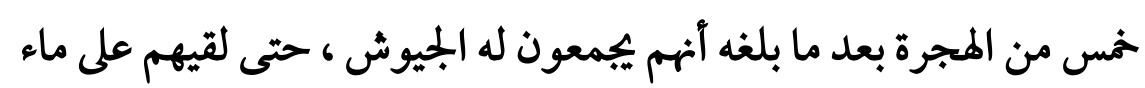

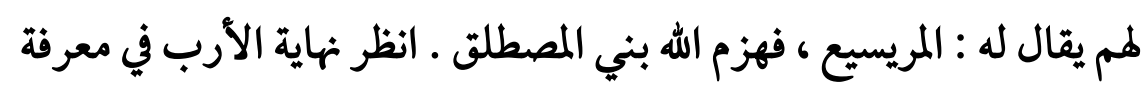

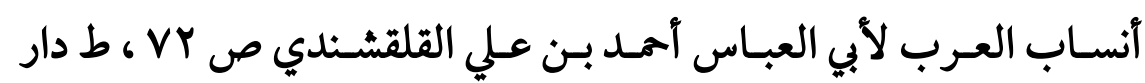

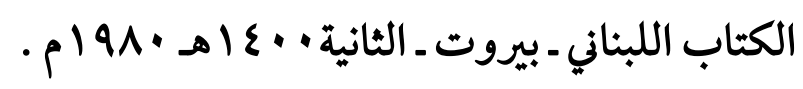

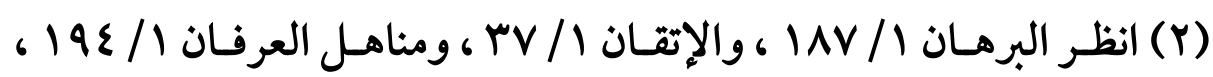

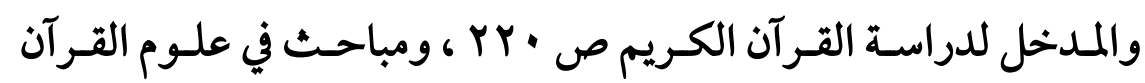

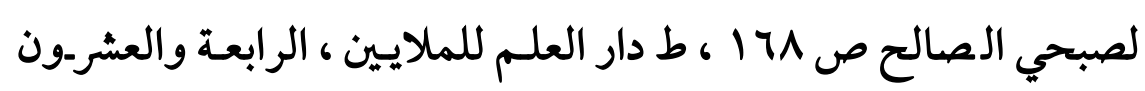




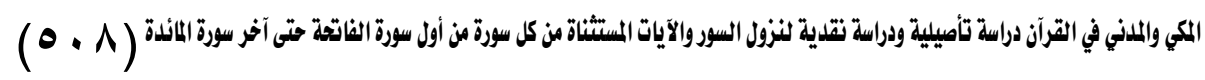

قال ابن عطية ـ رحمه الله ـ :"كل ما نزل من القرآن بعد هجرة النبي -

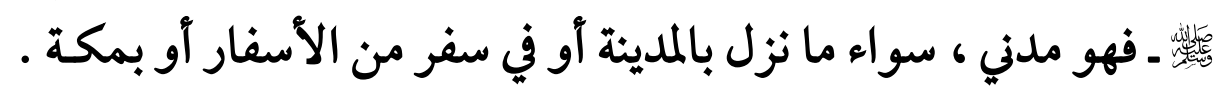

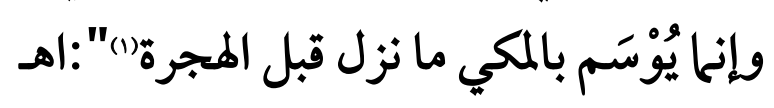

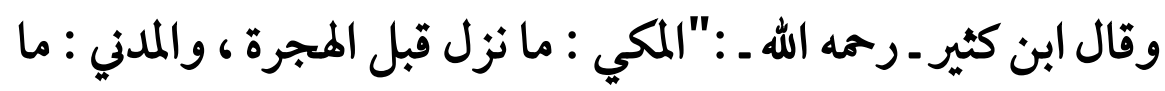

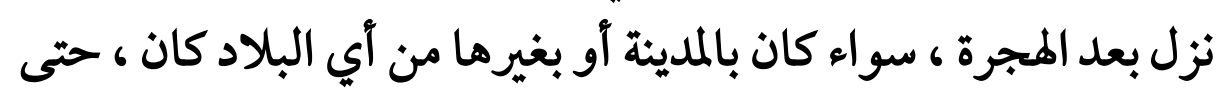

$$
\text { ولو كان بمكة آو عرفة (r)":اهـ }
$$

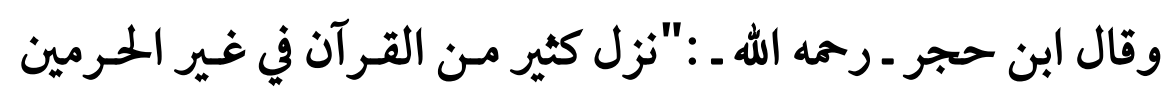

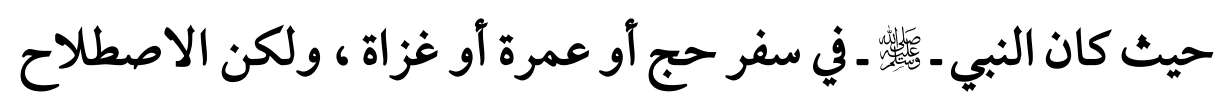

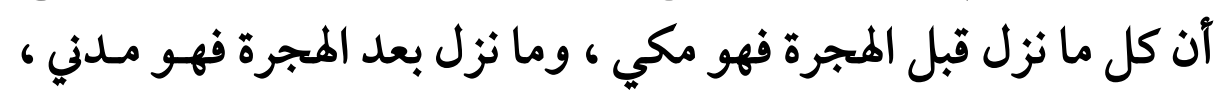

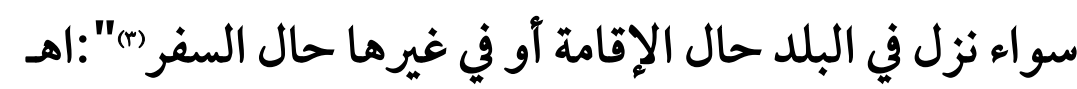

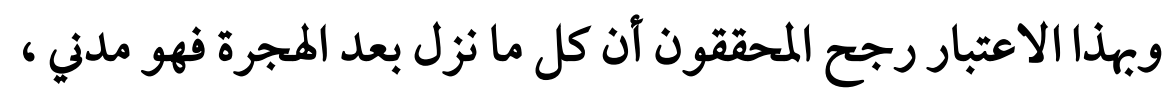

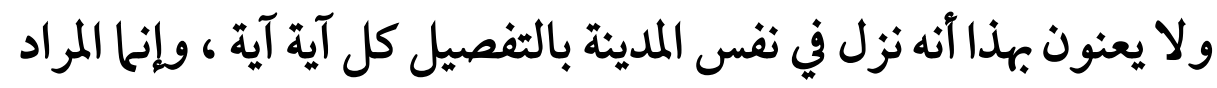
أنه نزل في الزمن الذي كانت المدينة فيه هي عاصـمة الإسـلام ، وكـان

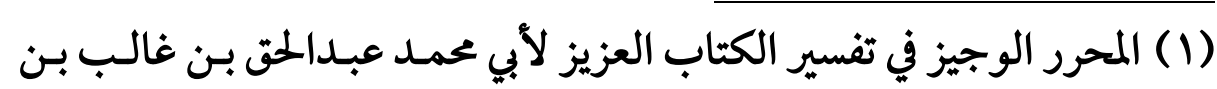

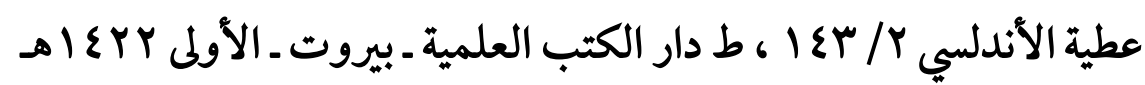

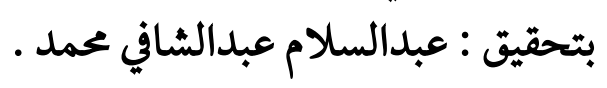

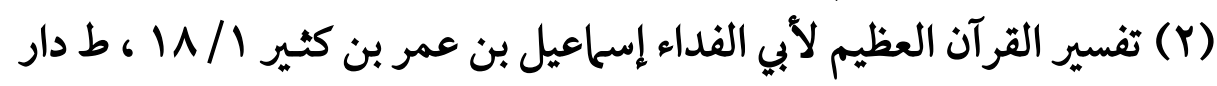

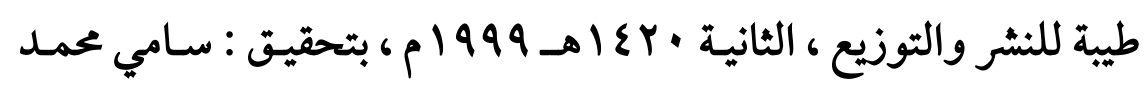

(r) فتح الباري شرح صحيح البخاري 9 / ه . 
للمسلمين فيه قوة تمنعهم ونظام يجمع شملهم ، وعلى هذا يكون حكم

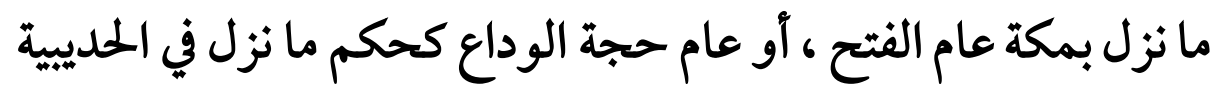

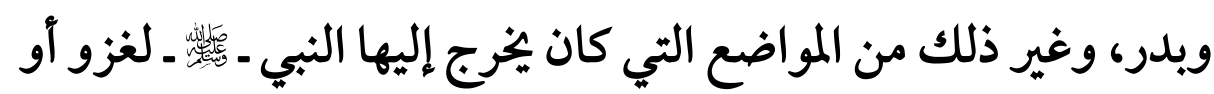
غيره على عزم العود إلى المدينة")

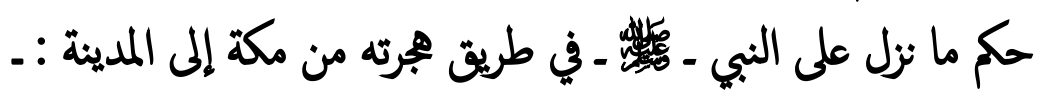

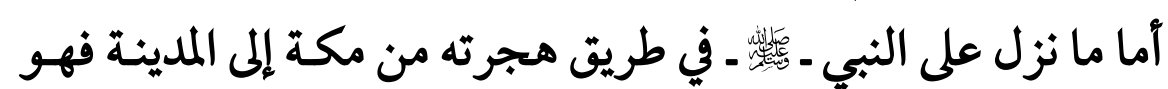

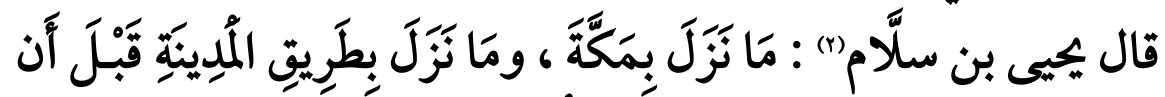

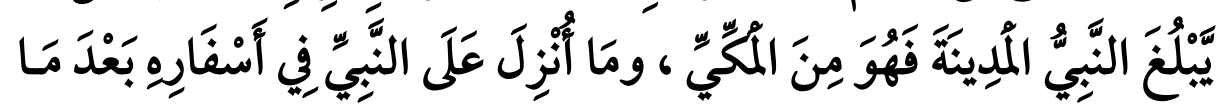

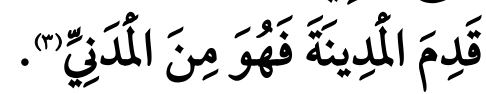

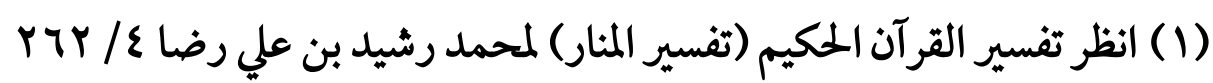
، ط الميئة المصرية العامة للكتاب • 199 19.

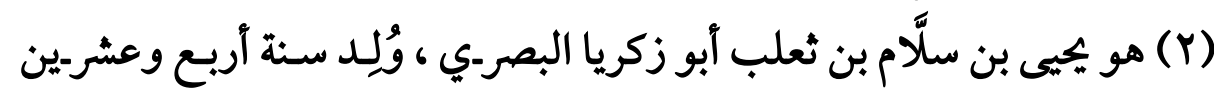

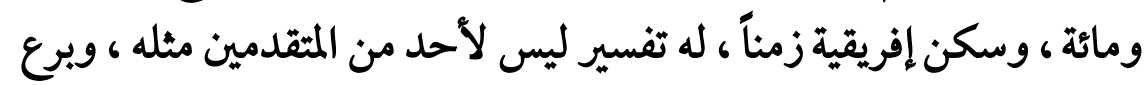

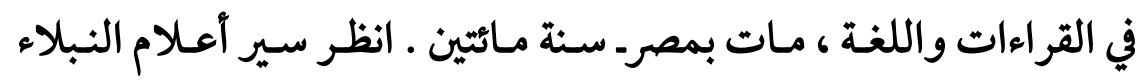

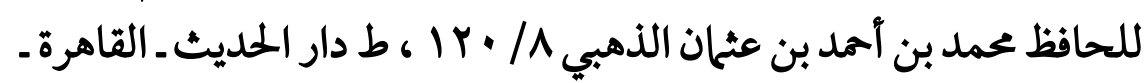

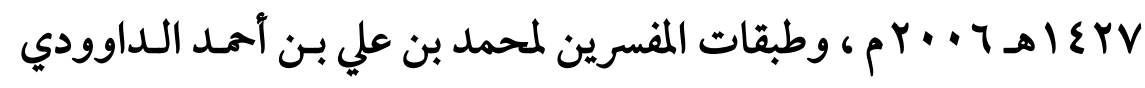
أ

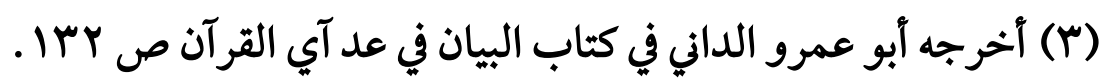




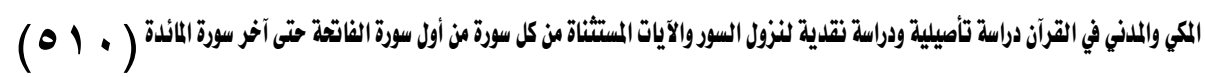

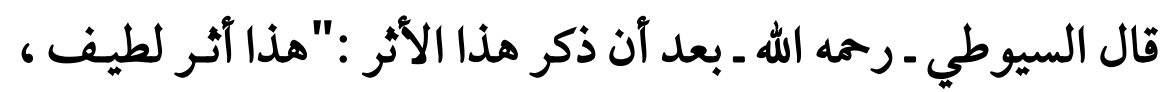

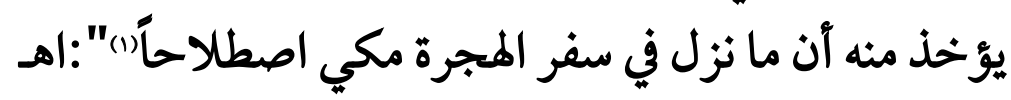

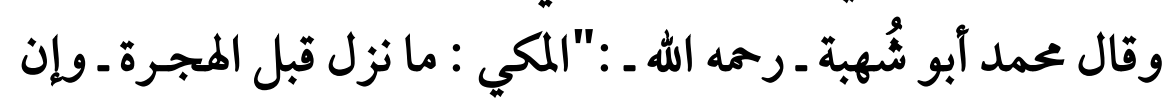

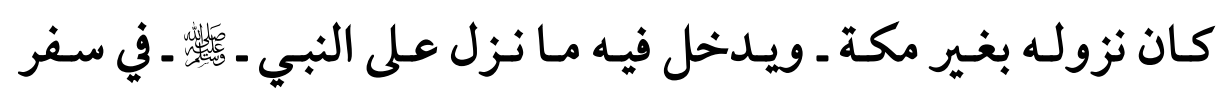

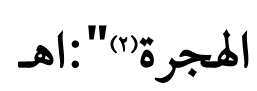

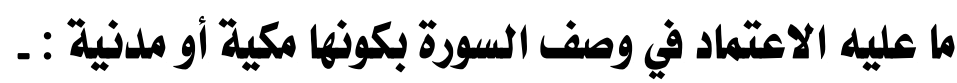

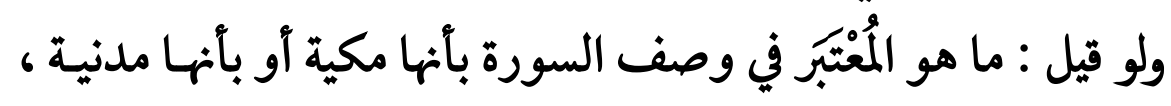
هل لأن الآيات المفتتحة بها مكية أو مدنية ، آم العبرة بالغالب من آياتها

قلت : قد ورد ما يدل على آن العبرة في هذا بنزول فاتحة السورة ، فقد

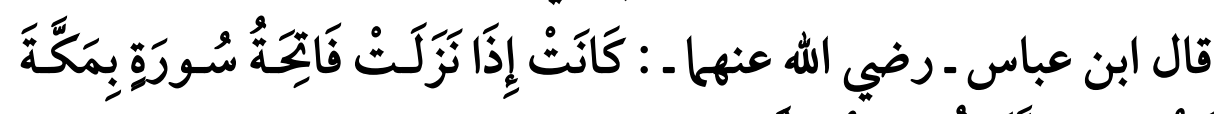

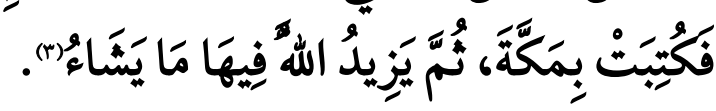

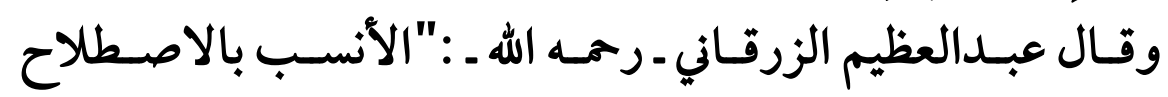

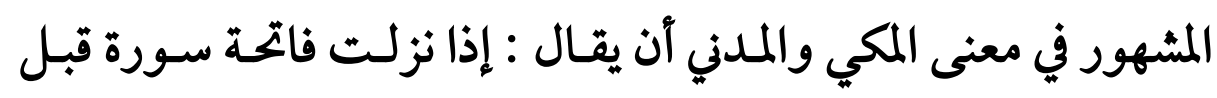

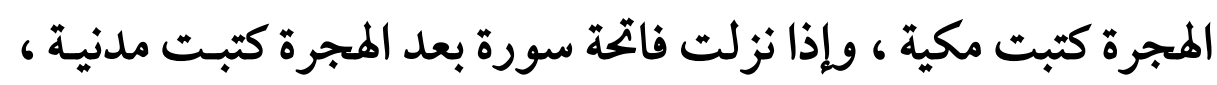

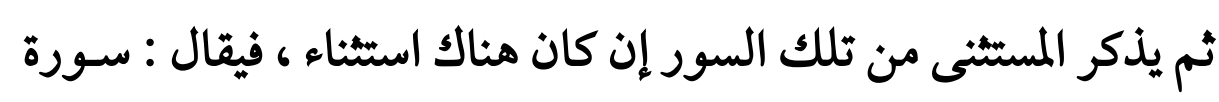

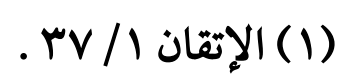

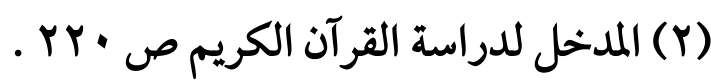

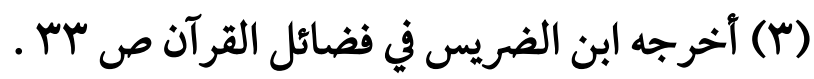


كذا مكية إلا آية كذا فإنها مدنية ، آو سورة كذا مدنية إلا آية كذا فإنها

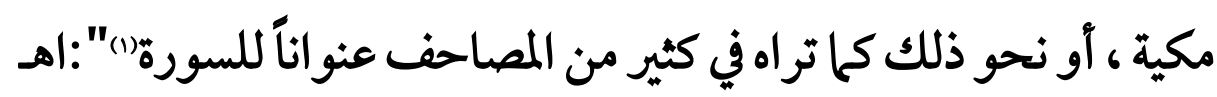

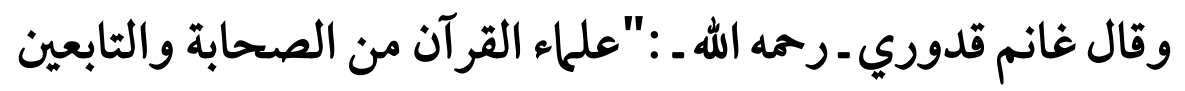

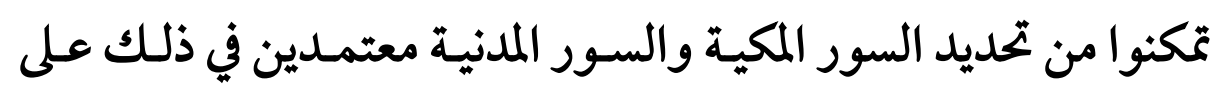

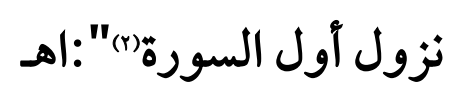

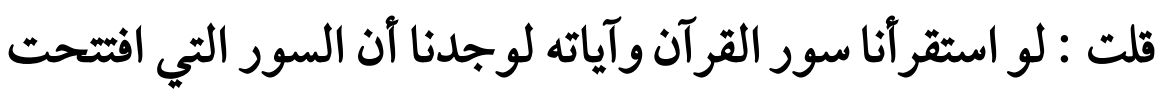

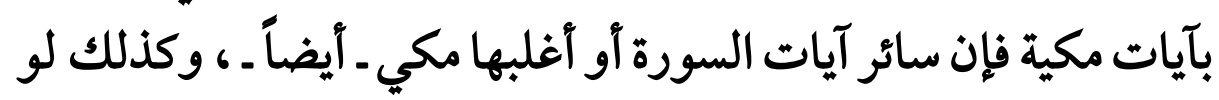

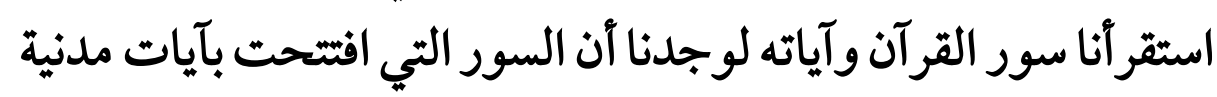

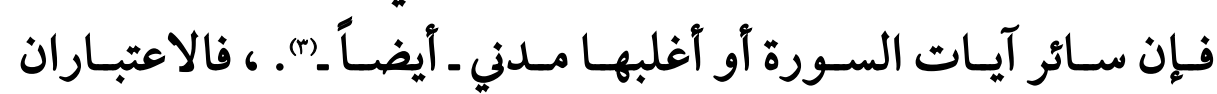

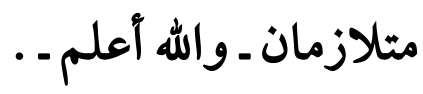

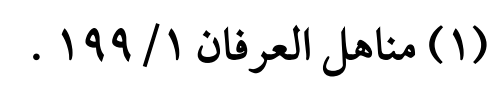

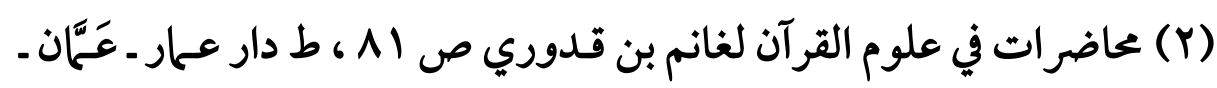

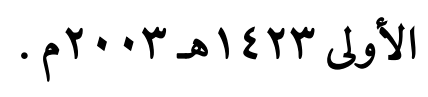

(r) قيل : إن الإحدى عشرة آية الأولى من سورة العنكبوت مدنية ، وسائر آيات

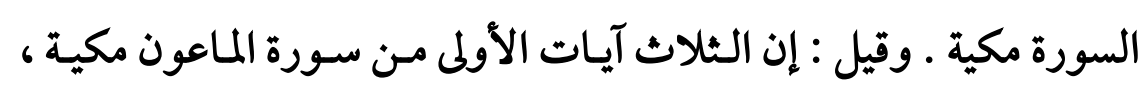

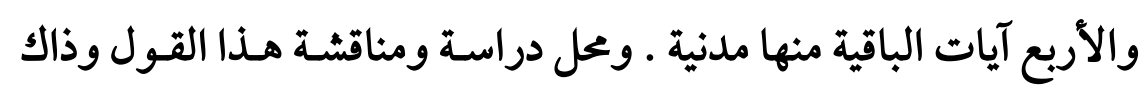
يكون في بحث لاحق ـ إن شاء الله .. . 


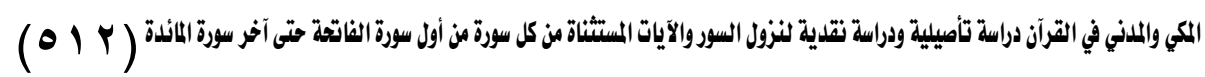

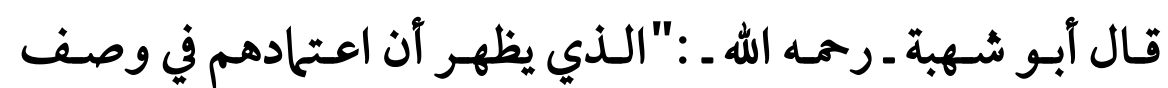

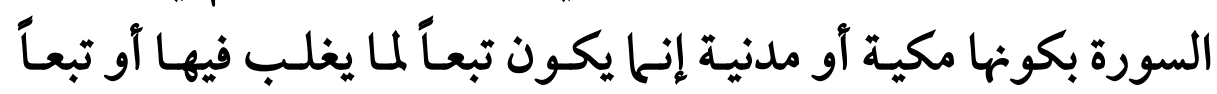

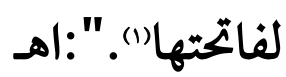

تنبييه : قـد يستمر نزول السـورة فتنزل في آثناء مـدة نزولها سـور

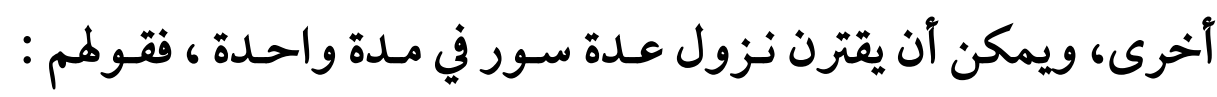

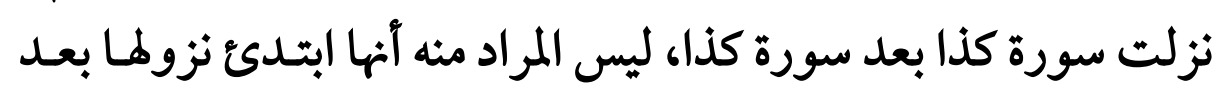

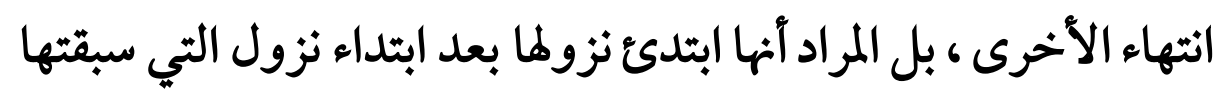
(r) فسورة البقرة ـ مثلاًا ـ أول سورة أنزلت بالمدينة ، كحا حكاه غير واحد من أهل العلم"(r)، بل حكى بعضهم الإجماع على ذلك ، كما قال ابن كثير

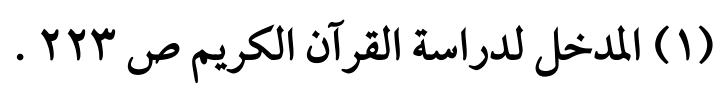

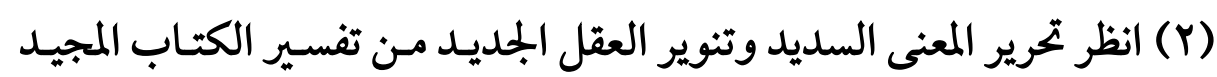

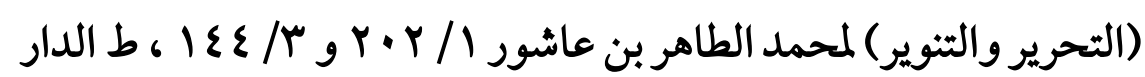

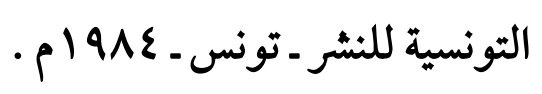

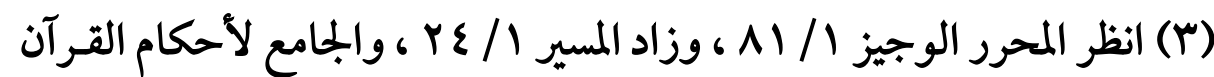

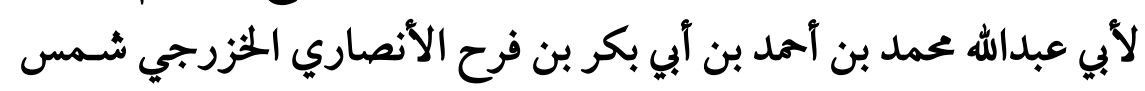

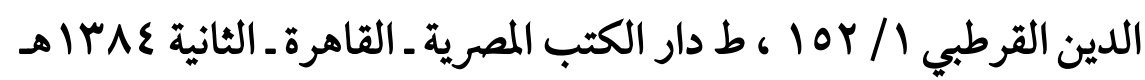


ـ ـ رهمه الله ـ :"البقرة جميعها مدنية بلا خلاف ، وهي من أوائل ما نزل

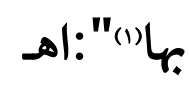

وقال ابن حجر :"اتفقوا على أنها ـأي سورة البقرة ـ مدنية وأنها أول

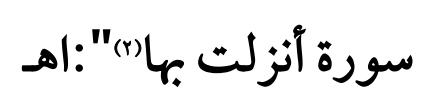

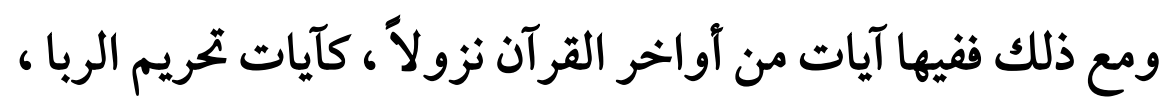

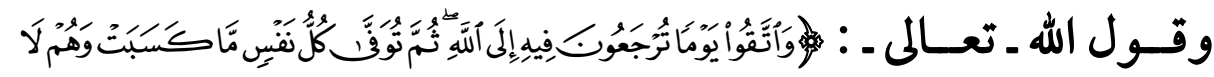

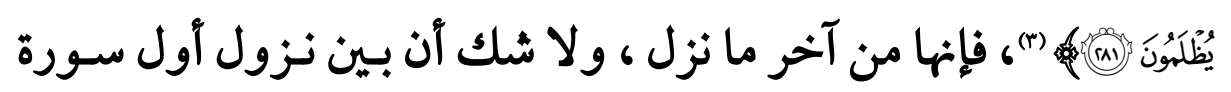
البقرة ونزول تلك الآيات نزلت سور وآيات أخرى (").

$$
\begin{aligned}
& \text { (1) تفسير القرآن العظيم / آ آ . }
\end{aligned}
$$

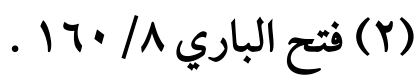

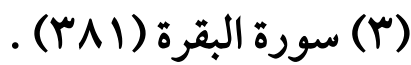

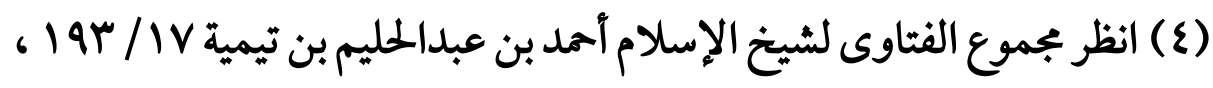

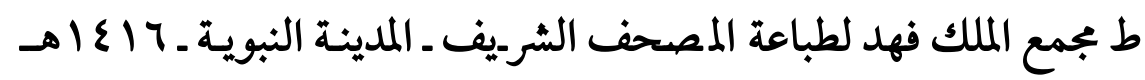

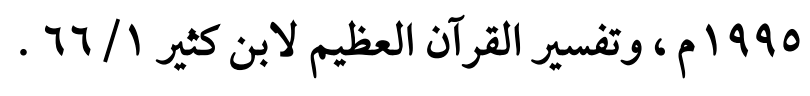




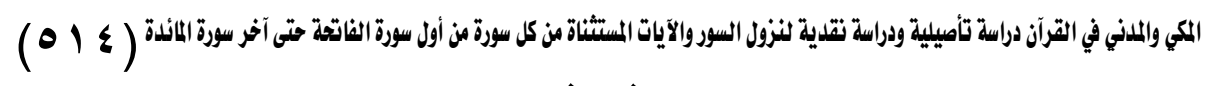

$$
\text { فوائل معرفة المكي والملاني الثاذي }
$$

$$
\text { اللعلم بالمكي والمدني فوائد أهمها ما يلي : }
$$

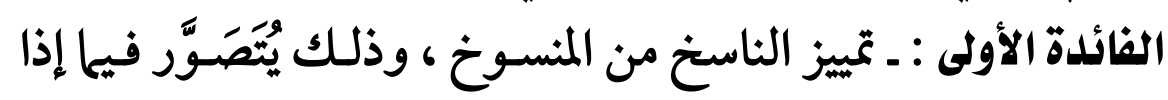

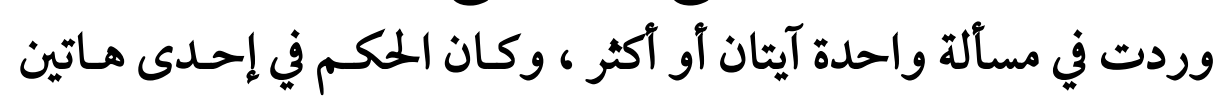

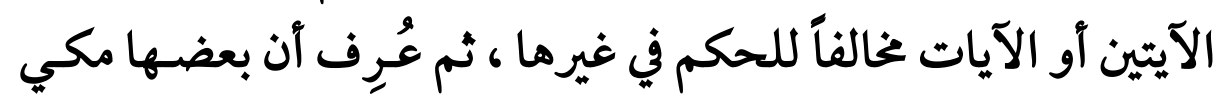

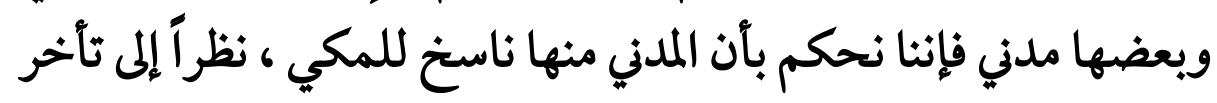

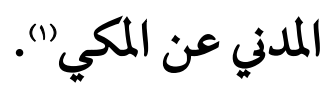
قال القرطبي ـ رحمه الله ـ :"ينبغي له ـ يعني للمفسر ـ أن يعرف المكي

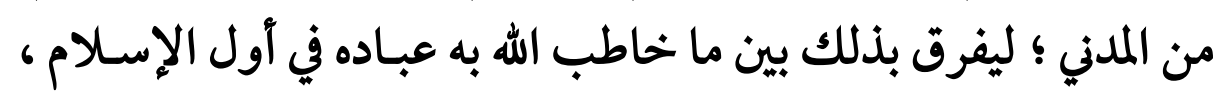

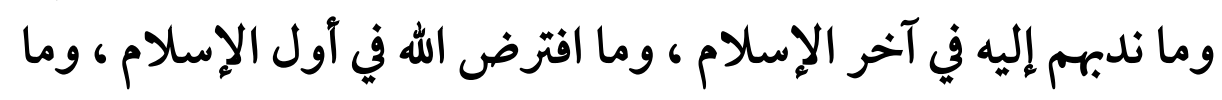

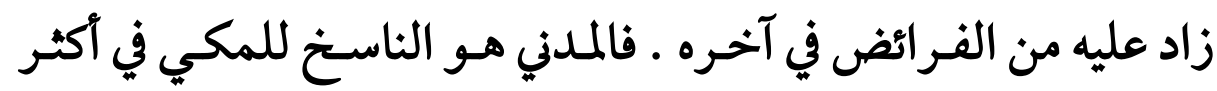

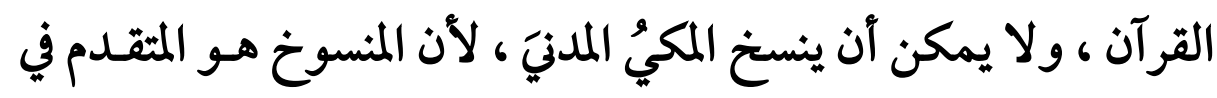

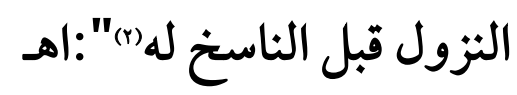

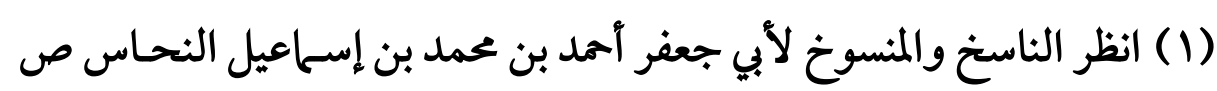

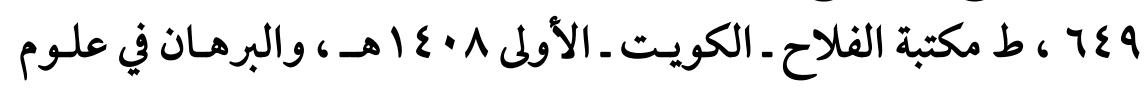

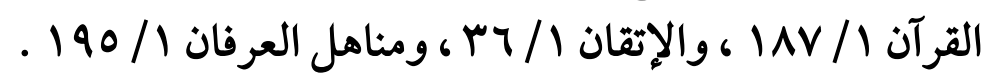

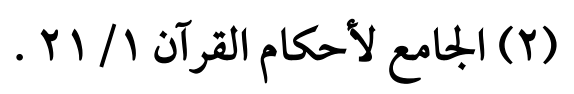


$(010)$

الفائلة الثانية : ـ الاستعانة بمعرفة المكي والمدني في تفسير القرآن

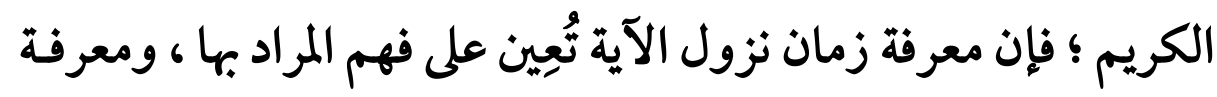

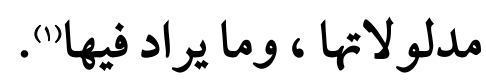

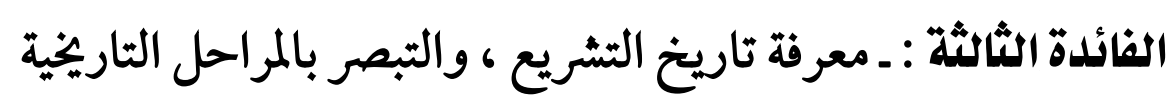
التي سار عليها ديننا السامي ، والوقوف على سنة الله في التدرج بالآمة

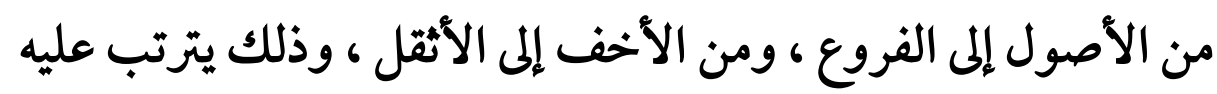

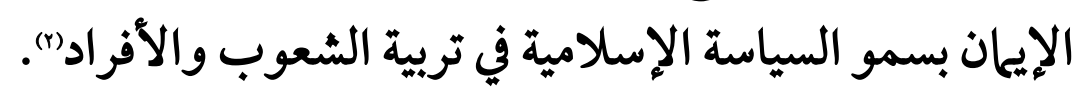

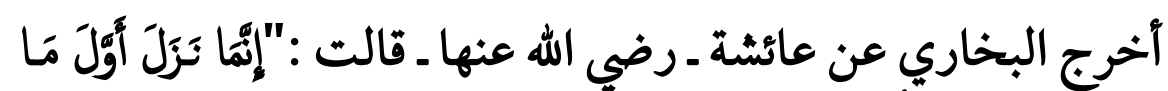

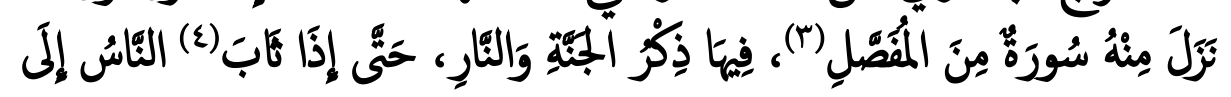

(1) انظر مباحث في علوم القرآن لمناع بـن خليل القطان ص ه ه ، ، ط مكتبة

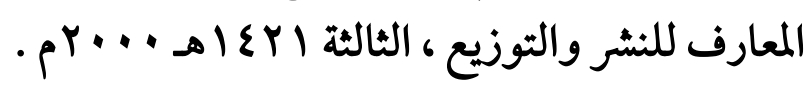

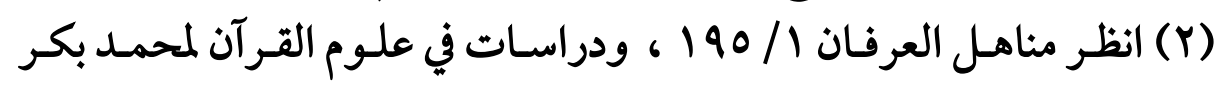

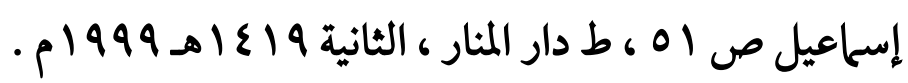

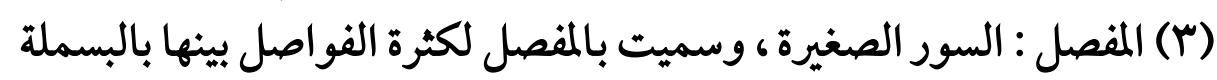

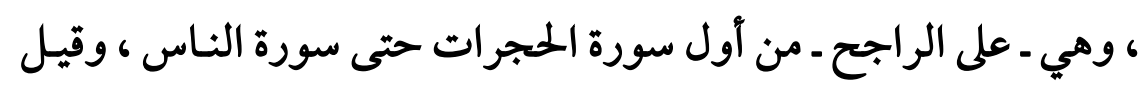

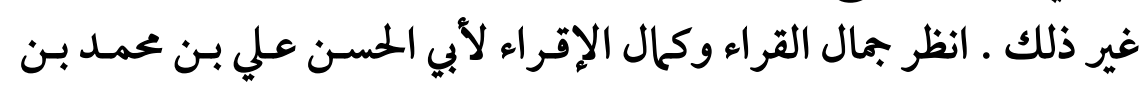

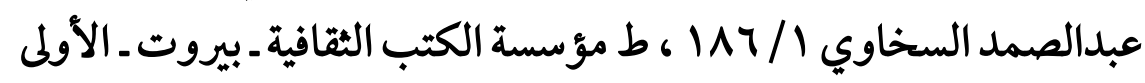

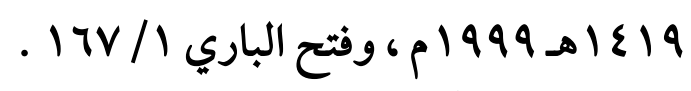

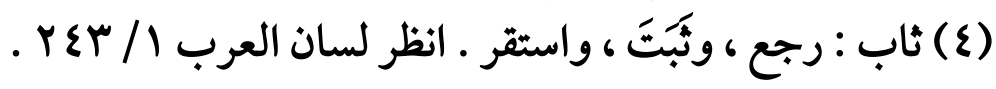




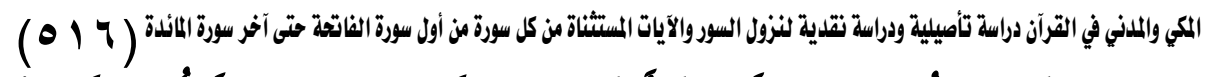

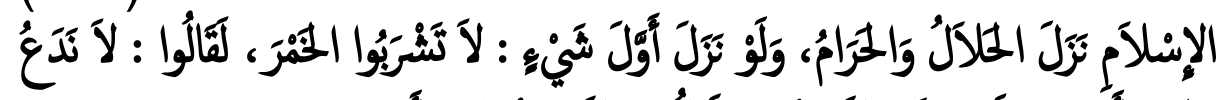

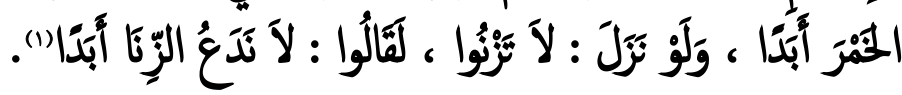

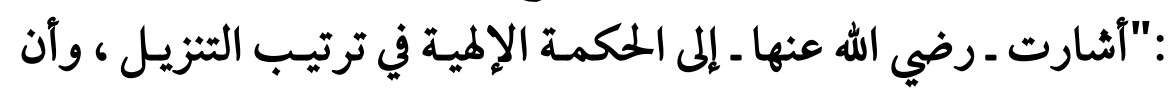

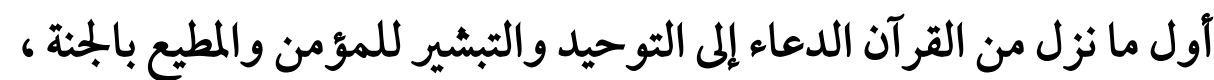

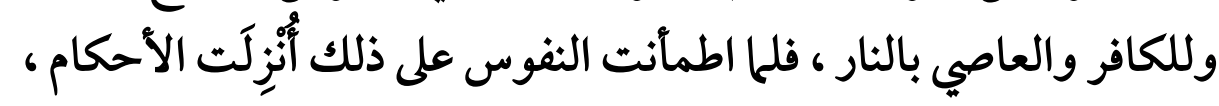

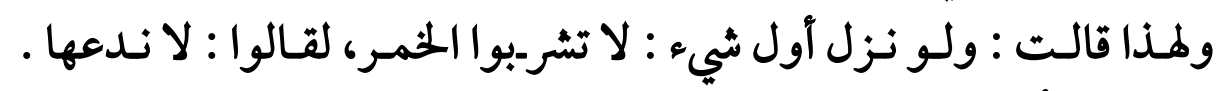

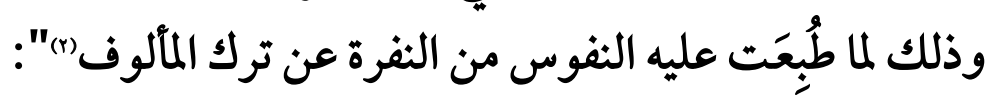

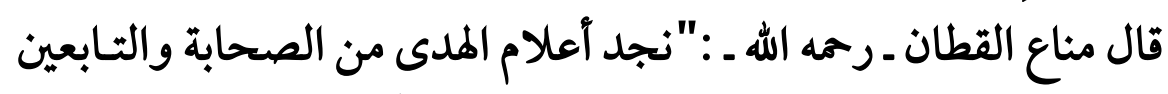

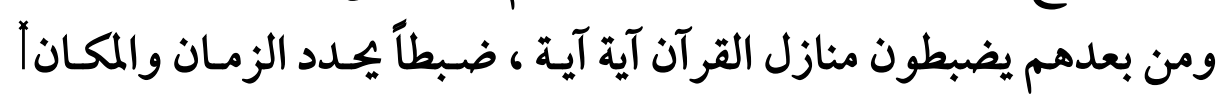

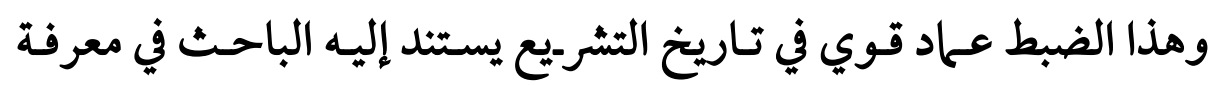

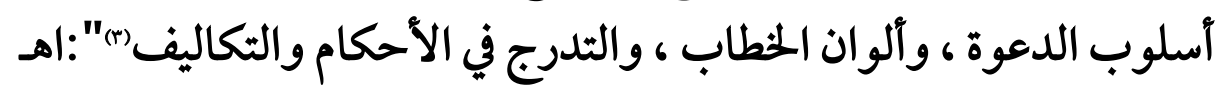

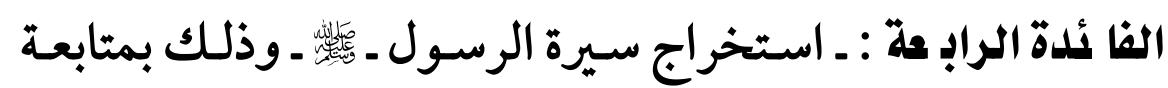

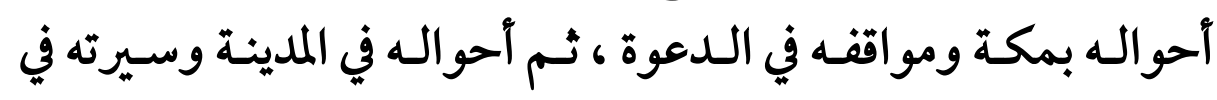
الدعوة إلى الله فيها . الهو ومواله

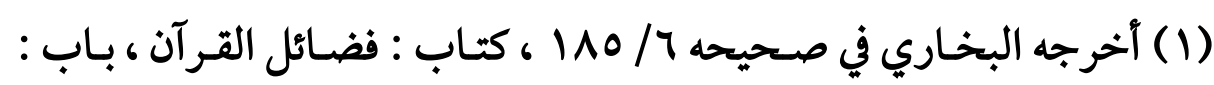

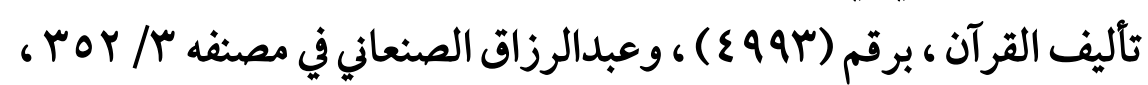

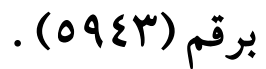

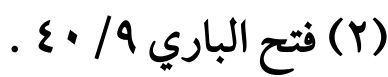

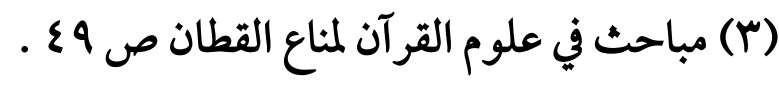


(oiv)

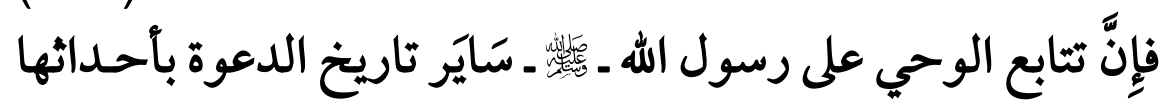

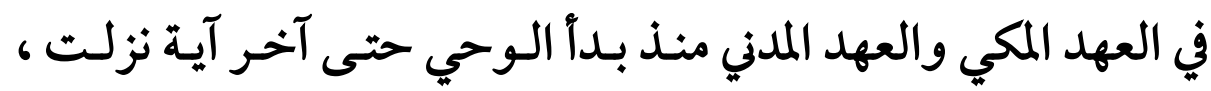

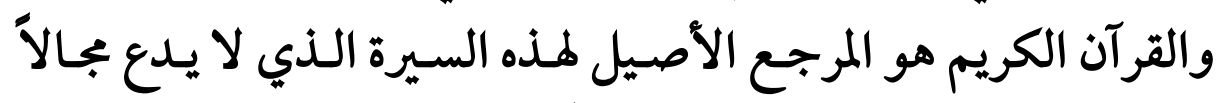

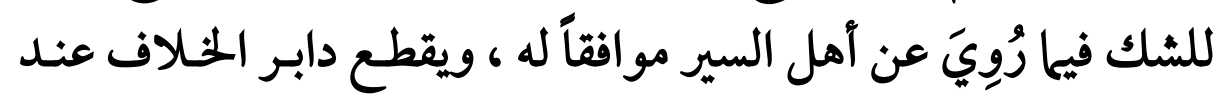

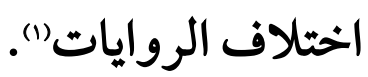

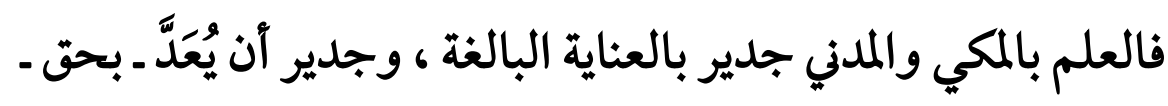

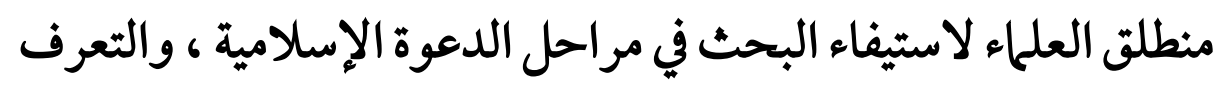

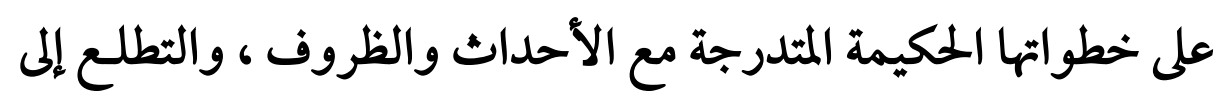

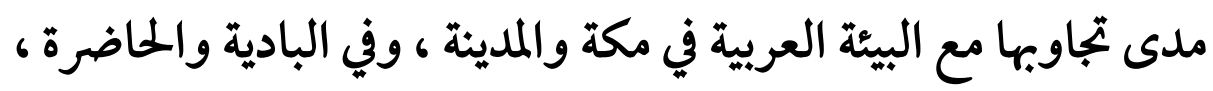

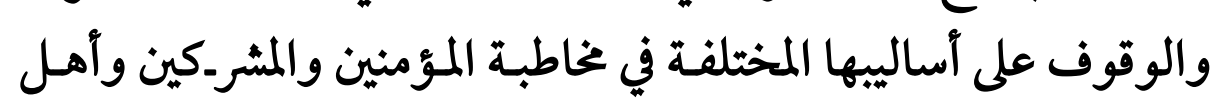

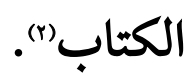

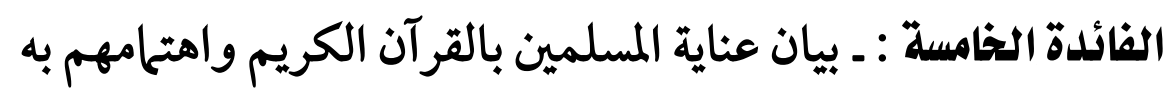

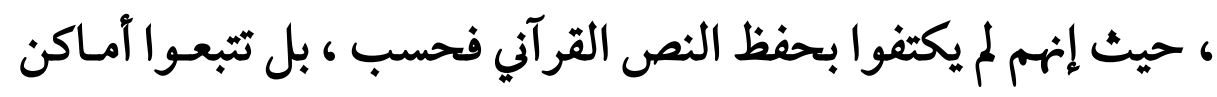

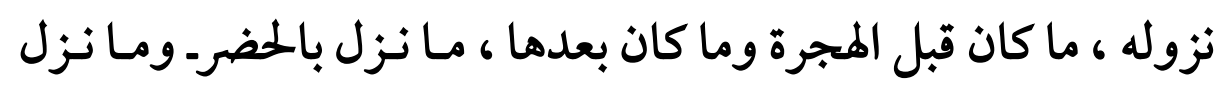

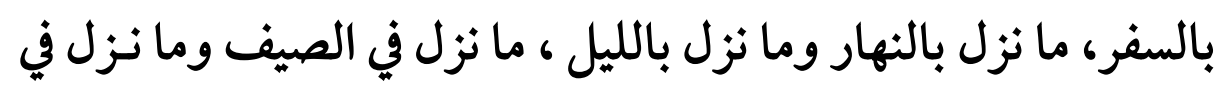

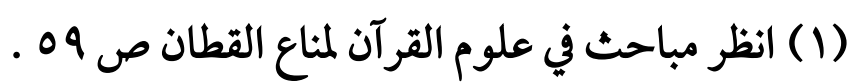

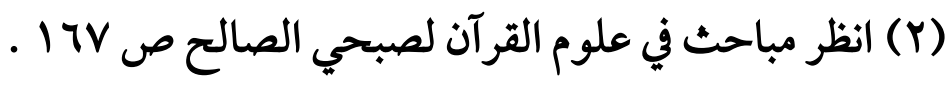




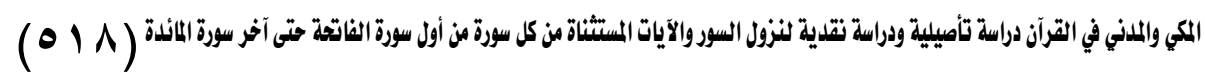

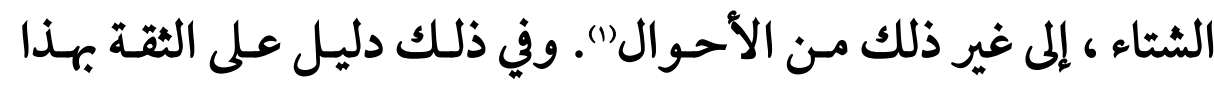

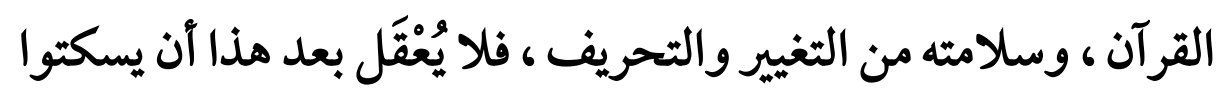
ويتركوا أحداً يمسه بسوء ويعبث به به وهم المتحمسون لحر استه واسته وحمايته

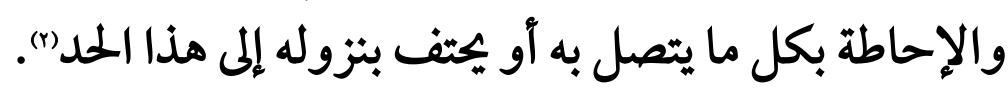

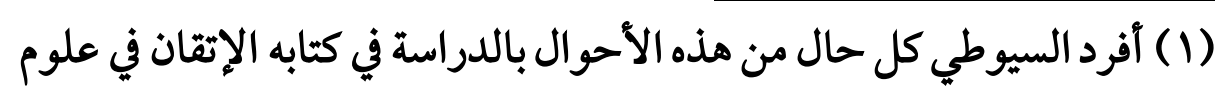

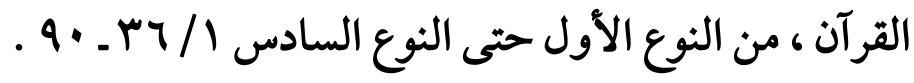

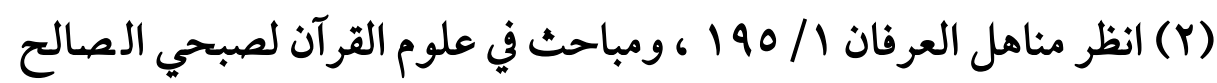

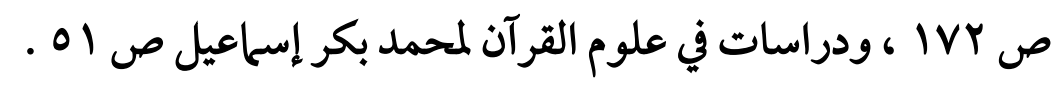


$(019)$

\section{الفصل الثاني - مقاني \\ طرق معرفة المكي والملدني}

$$
\text { لمعرفة المكي والمدني طريقان : }
$$

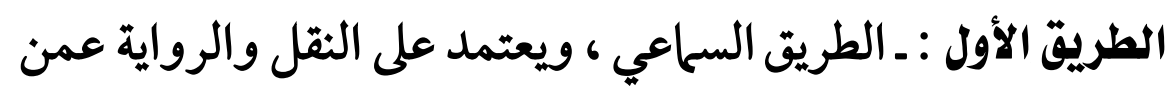

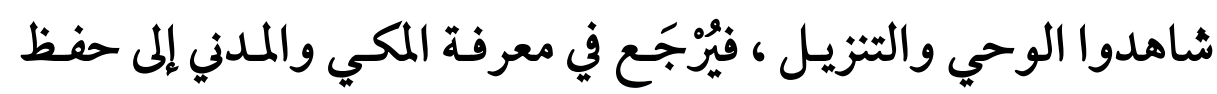

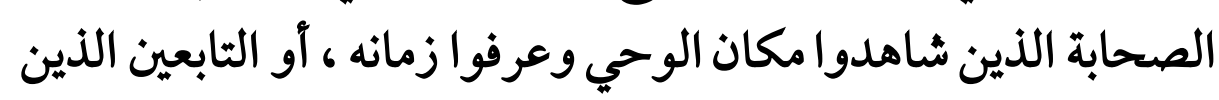
سمعوا وصف ذلك وتفصيله من الصحابة).

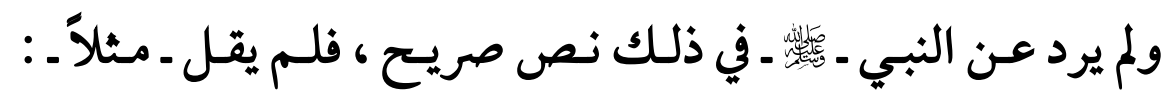

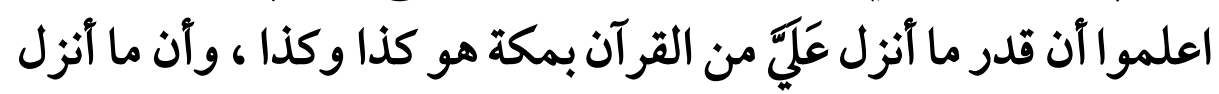

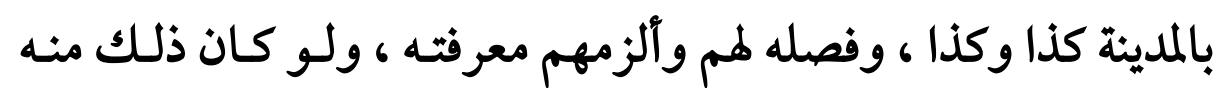

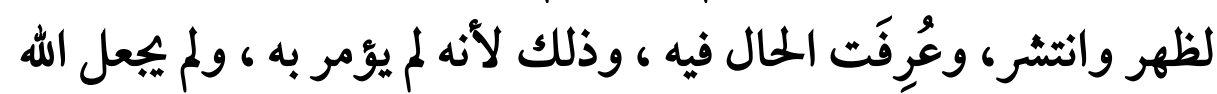

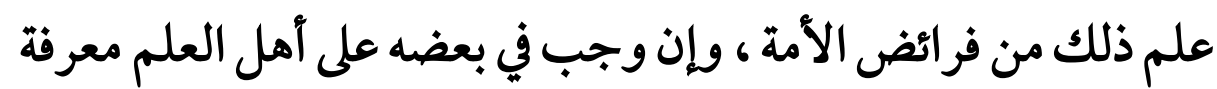

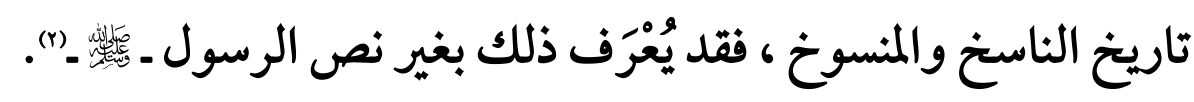

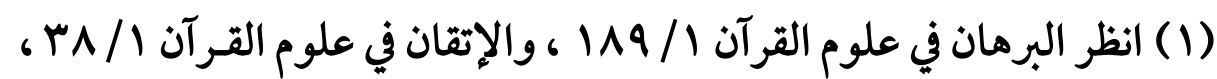

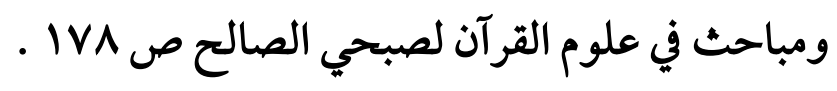

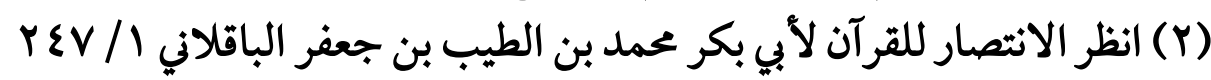

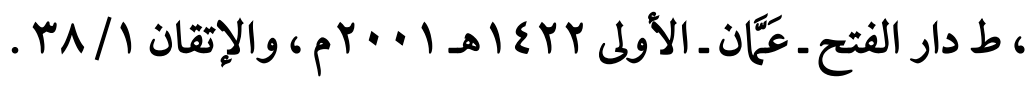




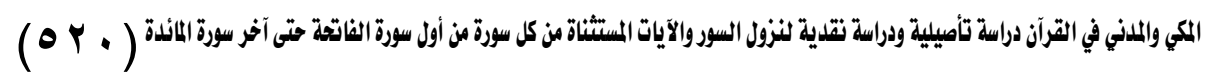

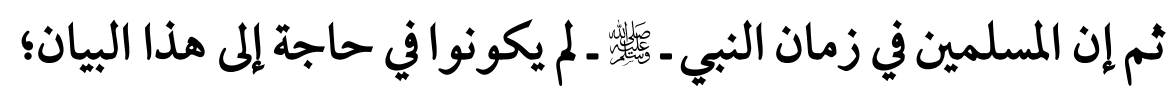
لأنهم يشاهدون الوحي والتزيل ، ويشهدون مكانه وزمانه وأسباب

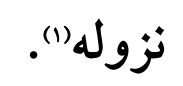

ولا ريب أن كثيراً من الصحابة كانوا على علم كامل بالمكي والمدني ،

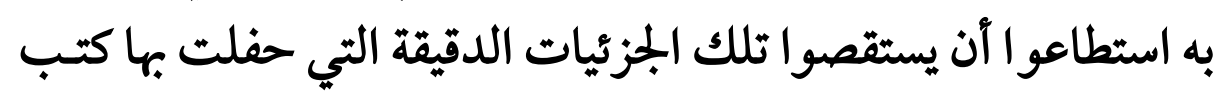

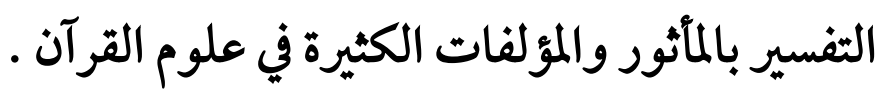

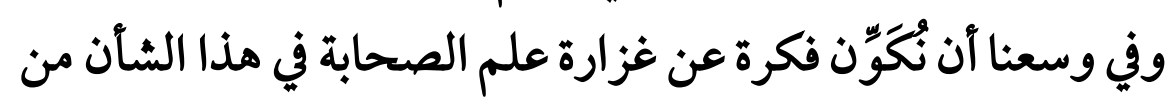

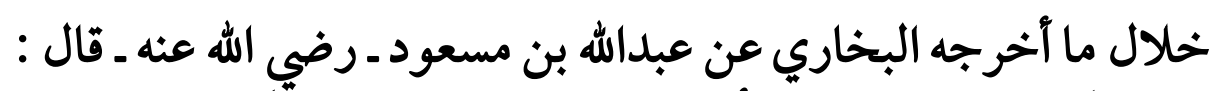

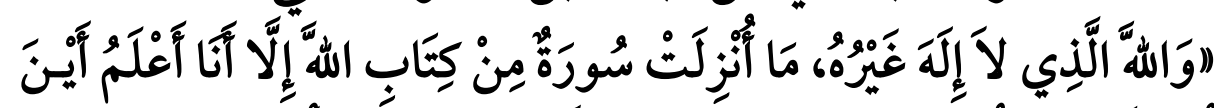

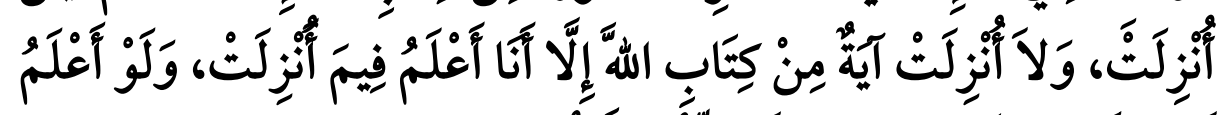

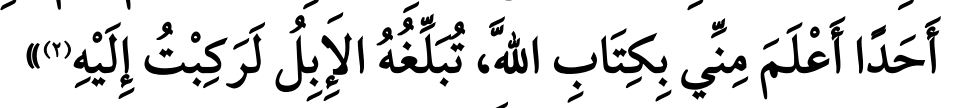

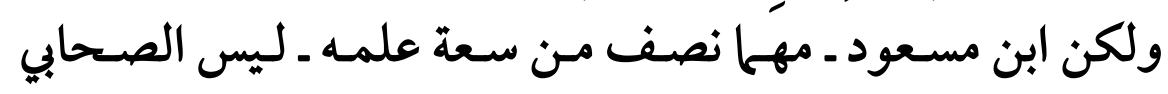

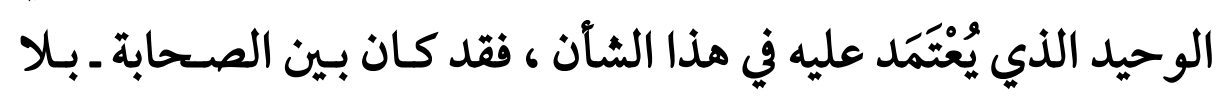

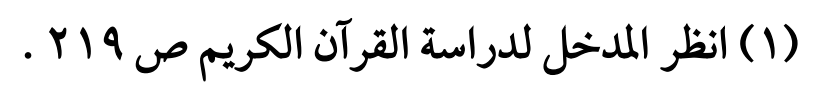

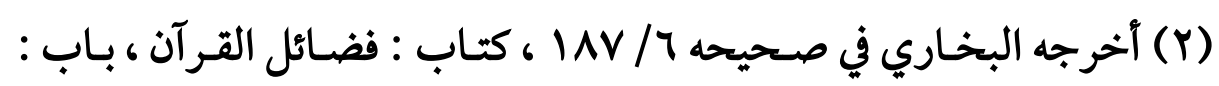

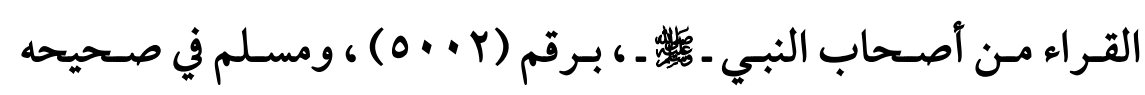

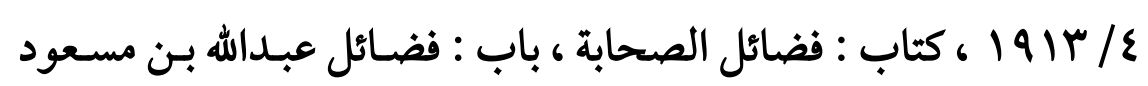

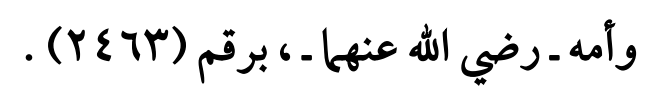


ريب ـ من أتيح له أن يشهد ما شهد ابن مسعود ، وربـا رآى بعضهـم أكثر مما رآه(1).

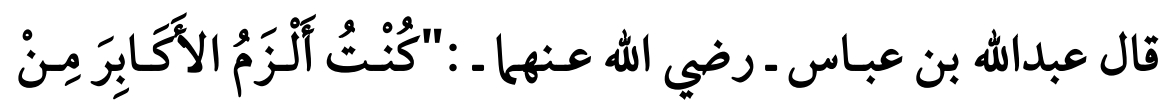

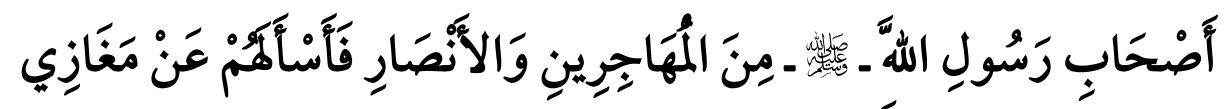

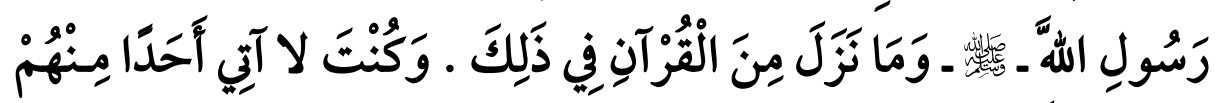

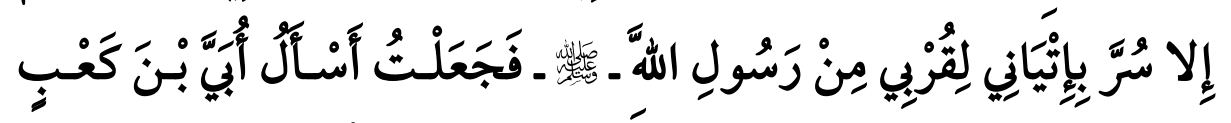

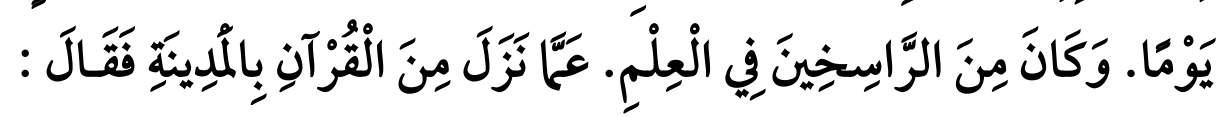

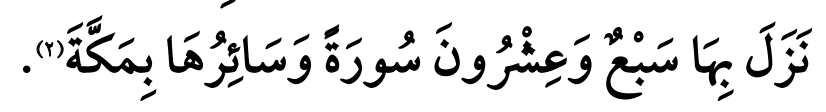

الطريق الثاني : ـ الطريق القياسي الاجتهادي ، ويستند إلى خصائص المكي وخصائص المدني ، فإذا وُجِدَ في السورة خصائص القرآن المكي

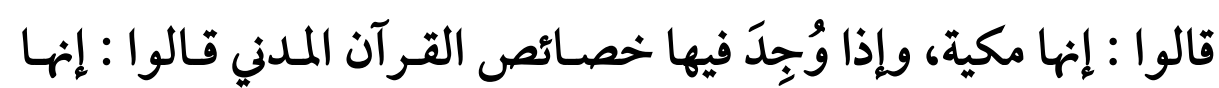

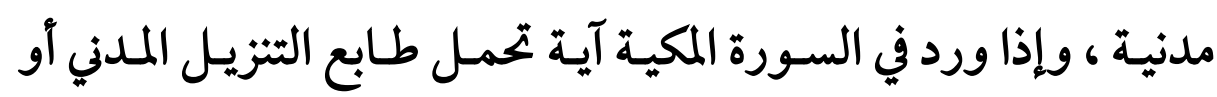
تتضمن شيئًا من حوادثه قالوا : إنها مدنية ، وإذا ورد في السورة المدنية

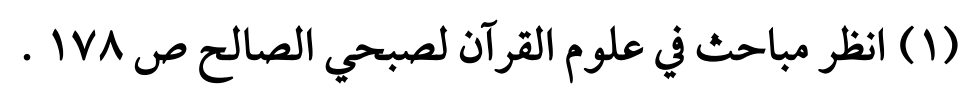

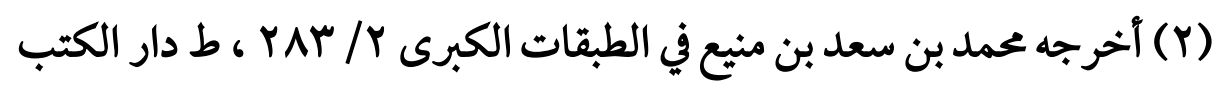

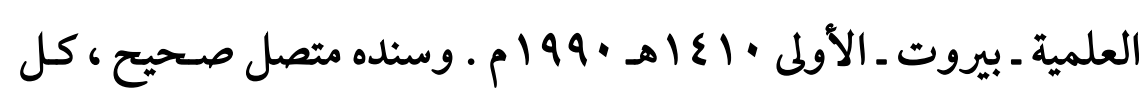

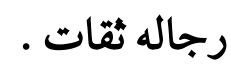




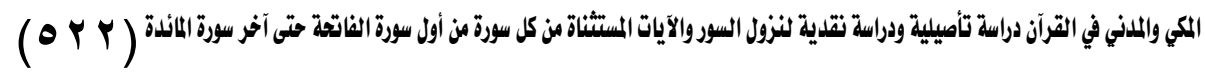

آية تحمل طابع التنزيل المكي أو تتضمن شيئا مـن حوادثه قالوا : إنها

مكية")

ولا شك أن السماعي يعتمد على النقل ، والقياسي يعتمد على العقل آ المعال

والنقل والعقل هما طريقا المعرفة السليمة والتحقيق العلمي .

ومن ثم نستطيع دراسة هذين الطريقين من خلال مبحثين :

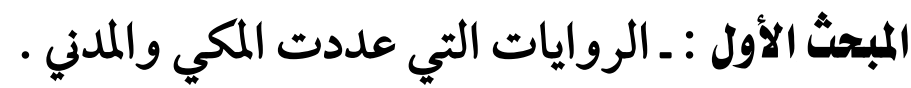

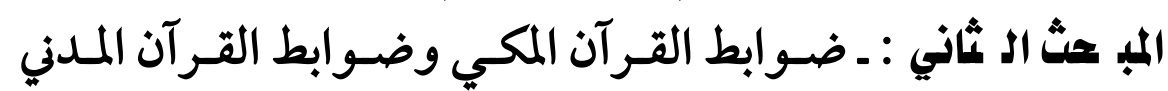

وخصائصها .

ومن خلال هذين المبحثين نستطيع ـ بفضل الله ـ معرفة السور المكية ،

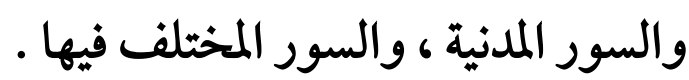

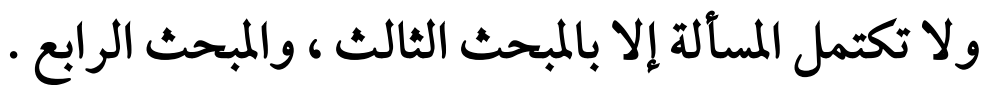

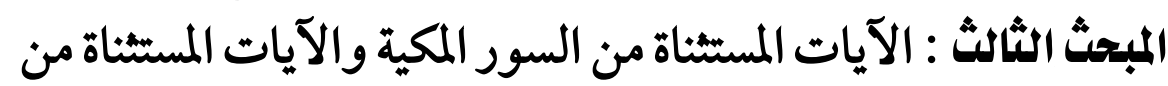

السور الملنية .

المبحث الرابع : هل تكرر نزول ثبيء من القرآن؟

(1) انظر البرهان / / 19 ، والإتقان / /9 / ، ، ومباحث في علوم القرآن لمناع بن

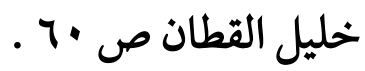


$(\Delta r r)$

\section{المبحث الأول \\ الروايات التي عددت المكي والملدني}

قد وردت بجموعة من الروايـات عن الصحابة والتابعين حسدت

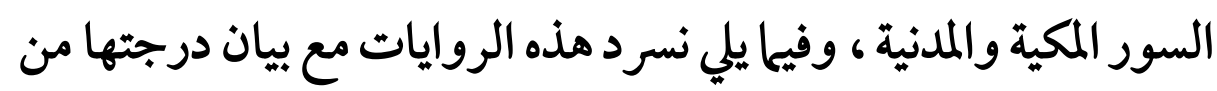
حيث الصحة والضعف ـ ثم نذكر على ضوتئا السور المثفق علي مكيتها أو مدنيتها والسور المختلف فيها .

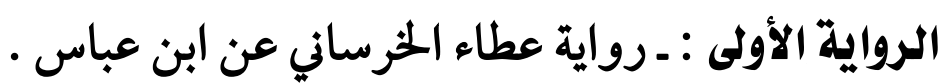

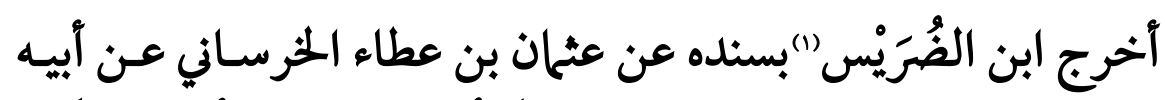

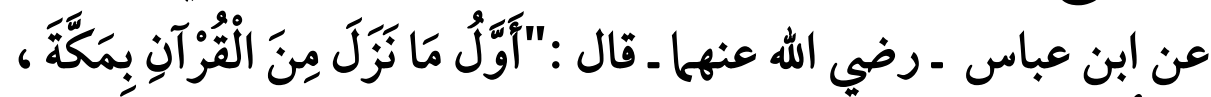

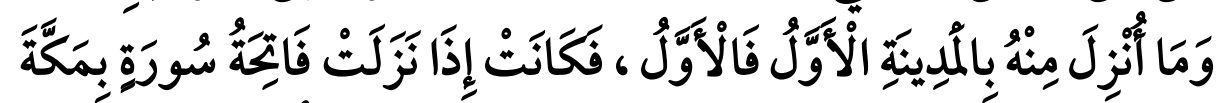

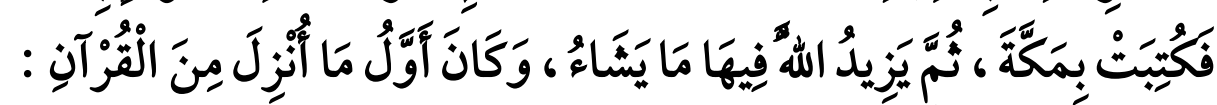

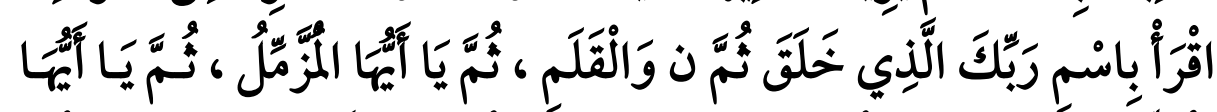

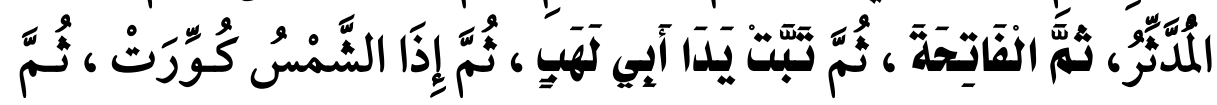

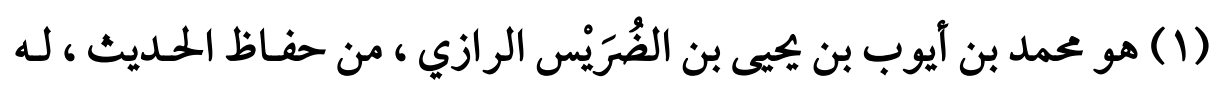

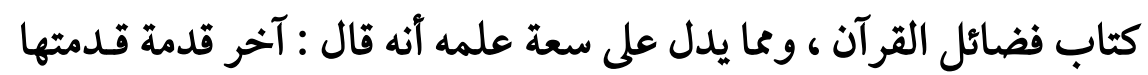

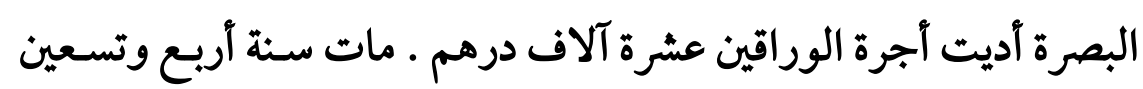

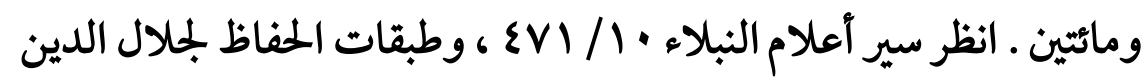

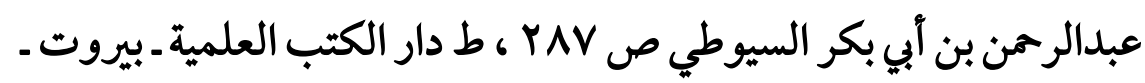

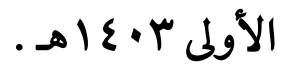




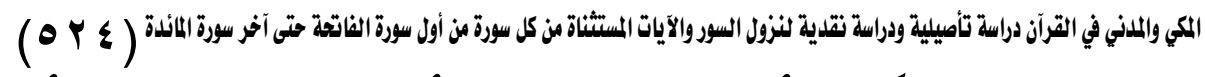

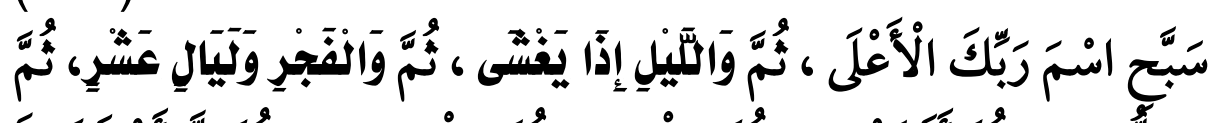

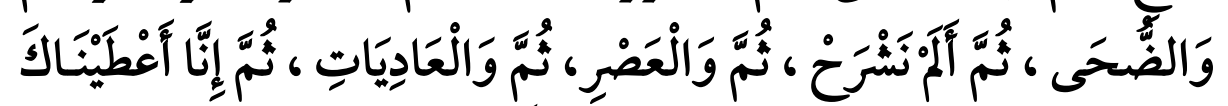

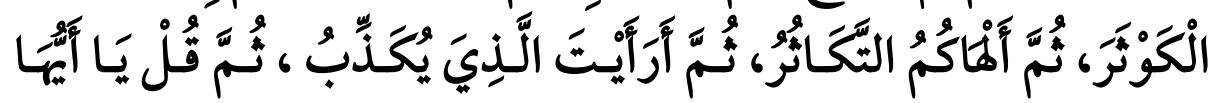

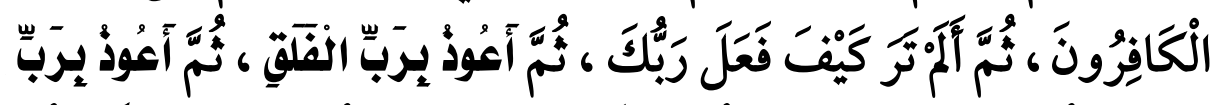

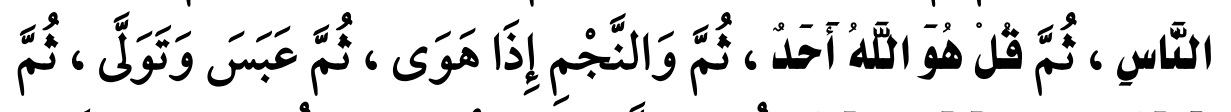

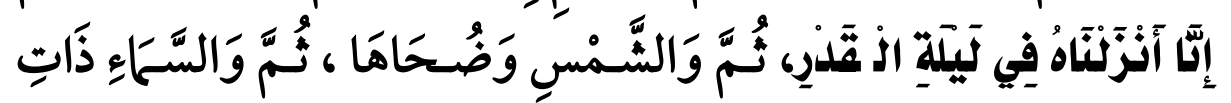

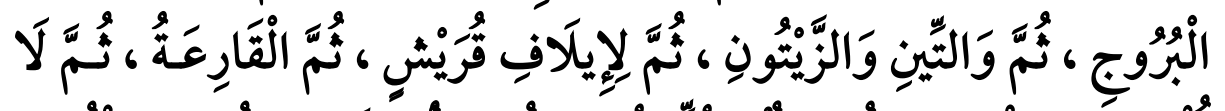

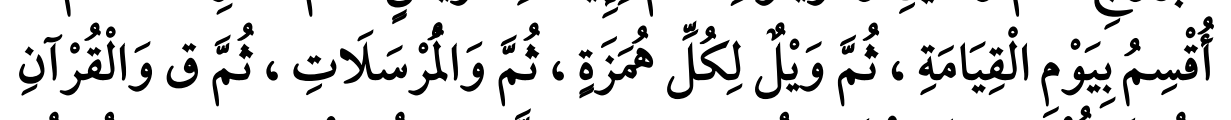

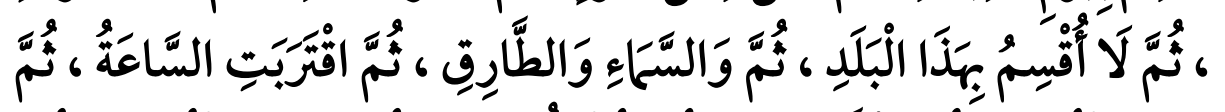

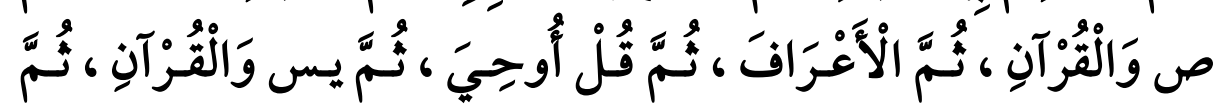

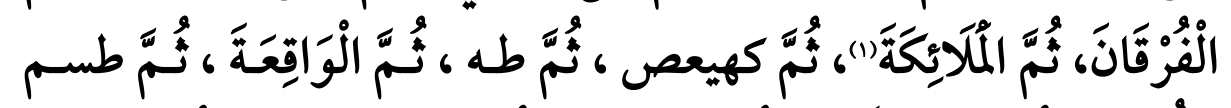

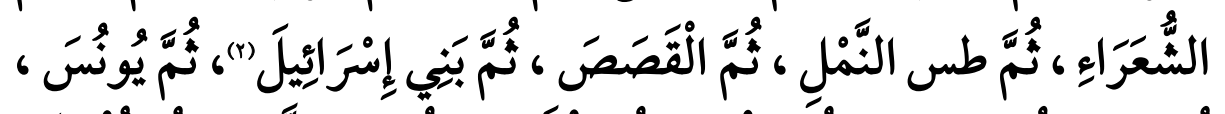

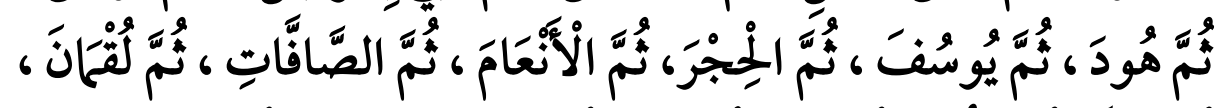

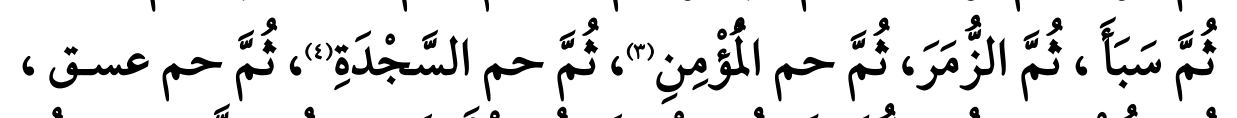

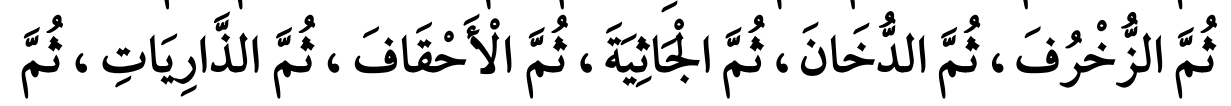

$$
\begin{aligned}
& \text { (1) يعني سورة العنكبوت . } \\
& \text { (Y) يعني سورة الإسراء . (Y) }
\end{aligned}
$$

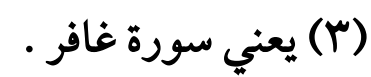

$$
\begin{aligned}
& \text { (ع) يعني سورة فصلت . يعني سورة . }
\end{aligned}
$$


(oro)

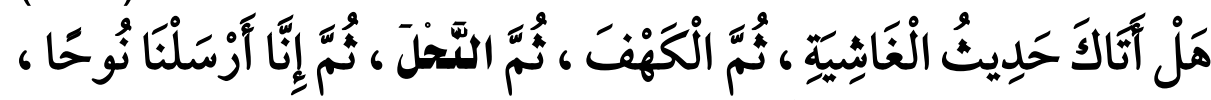

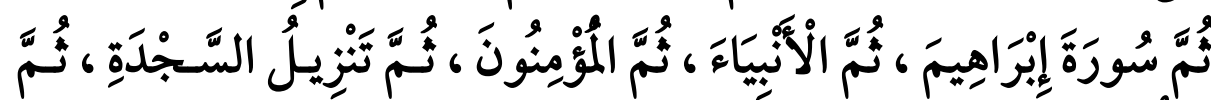

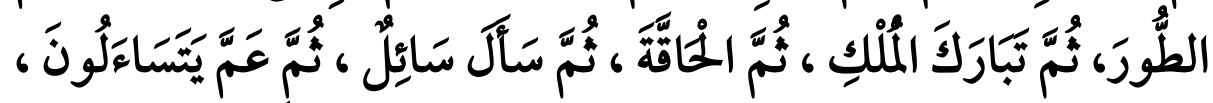

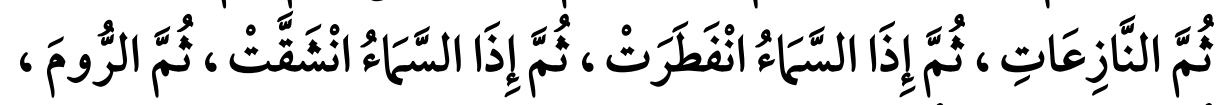

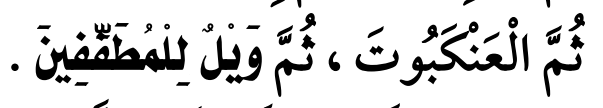

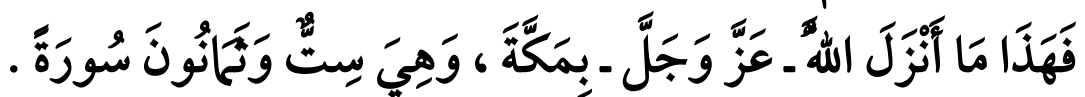

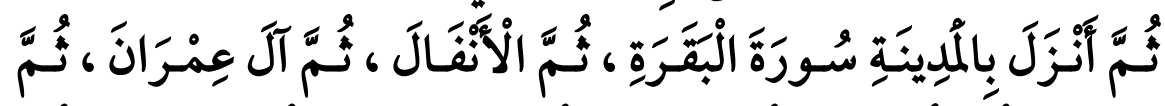

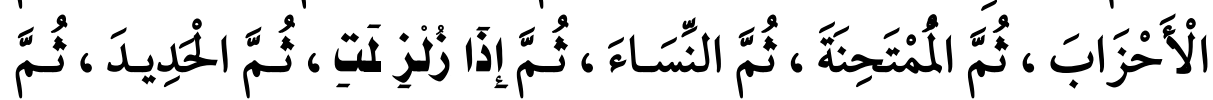

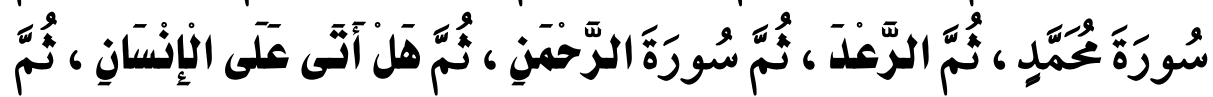

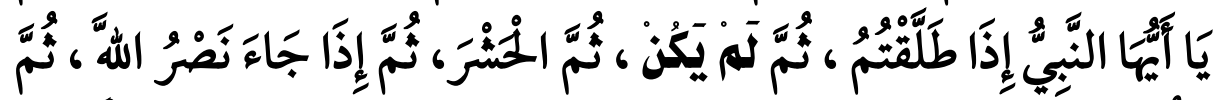

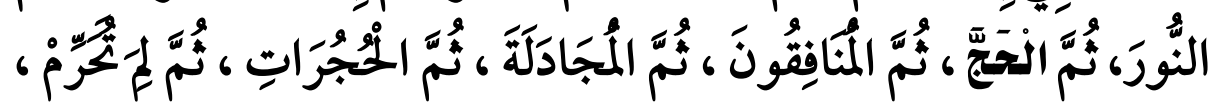

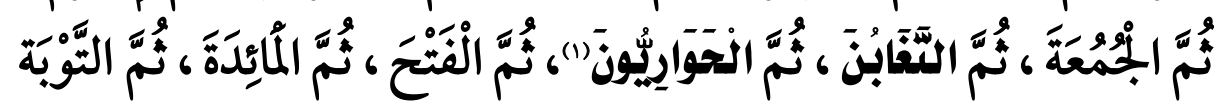

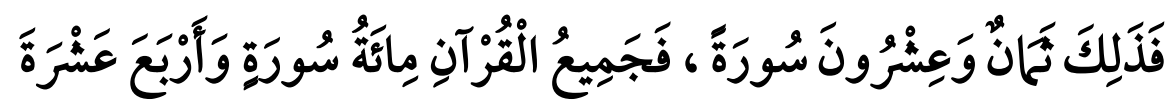

$$
\text { سُورَةَّم"ه". }
$$

$$
\text { (1) يعني سورة الصف . (1) }
$$

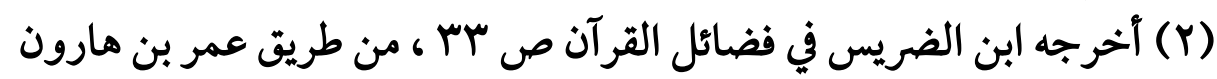

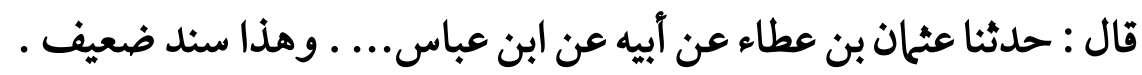

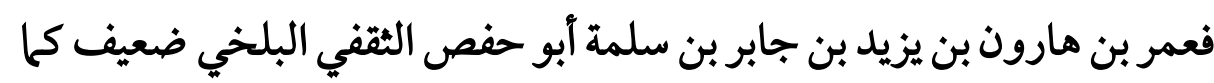

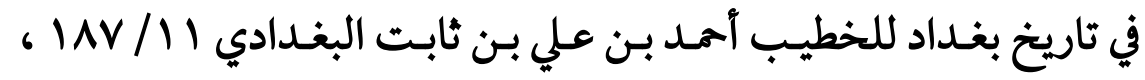




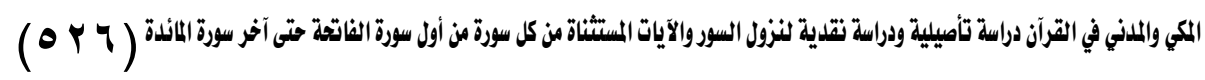

الرواية الثانية : ـ رواية عكرمة ، والحسن بن أبي الحسن البصري .

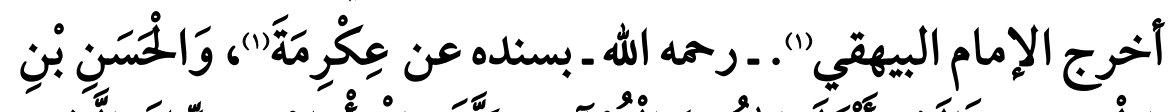

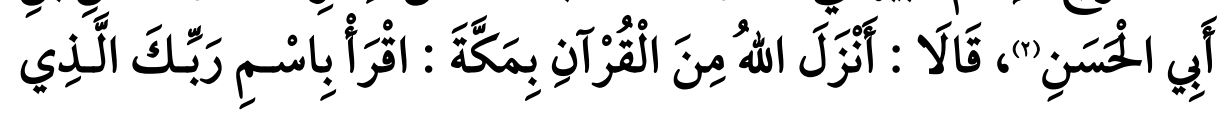

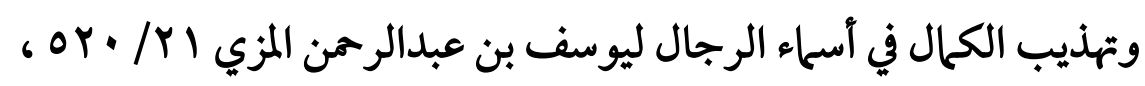

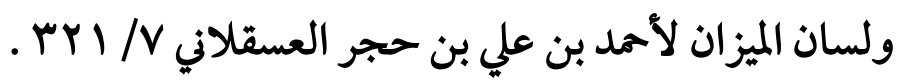

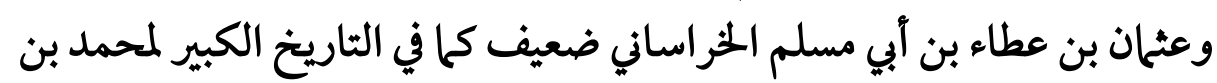

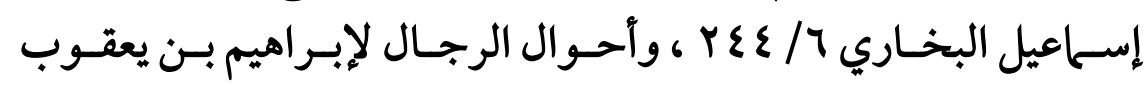

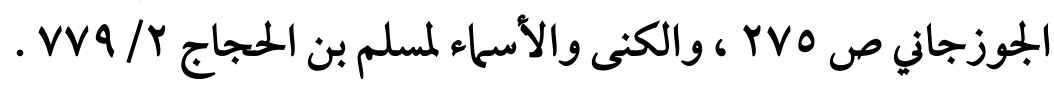

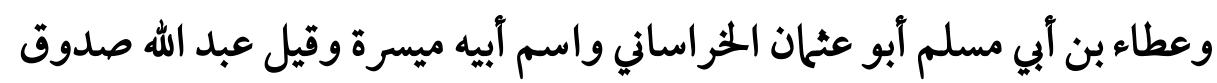

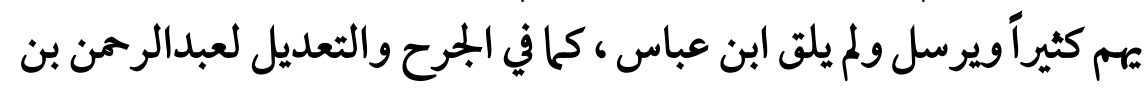

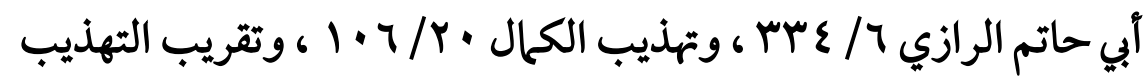

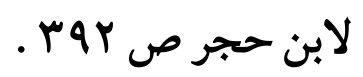

وقد ذكر ابن الضريس في فضائله ص هب مب رواية أخرى بنفس السند ولكن عن

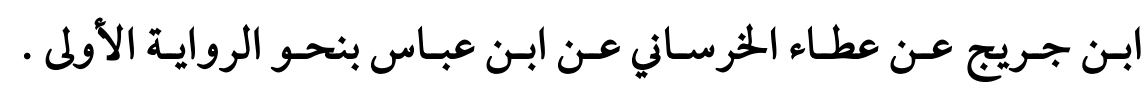

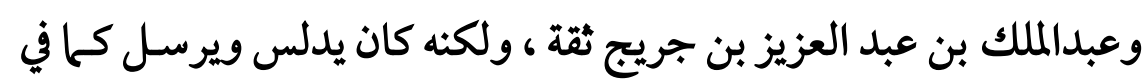

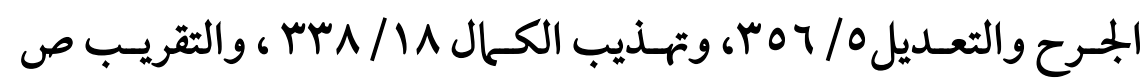
זדr.

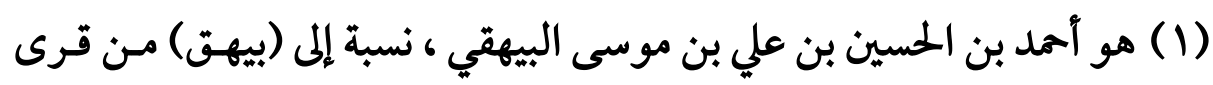

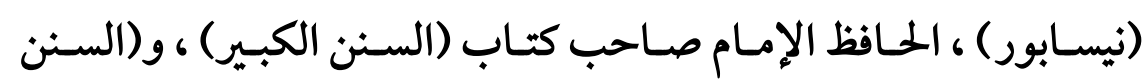

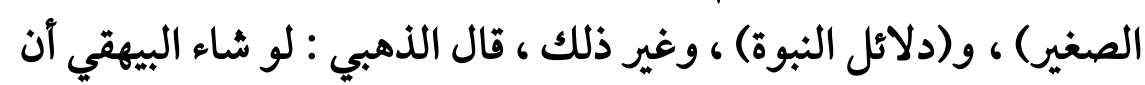

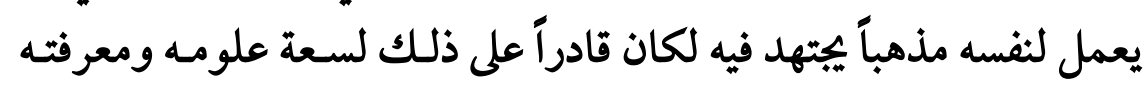


(orv)

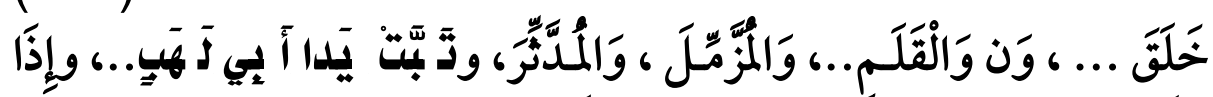

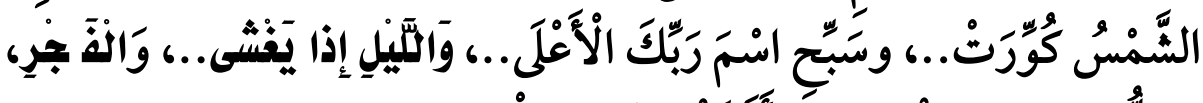

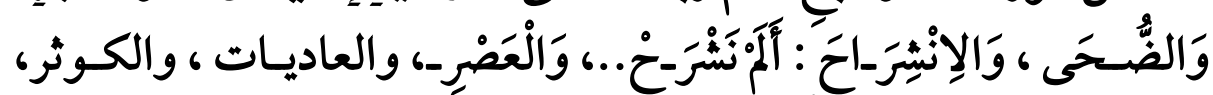

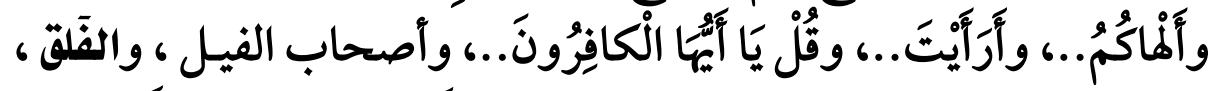

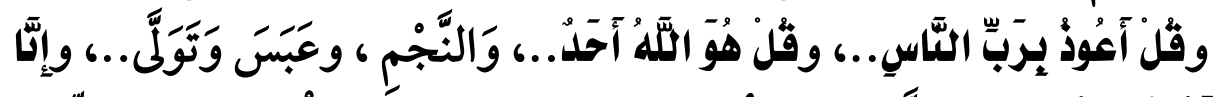

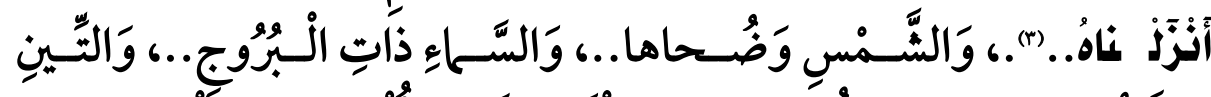

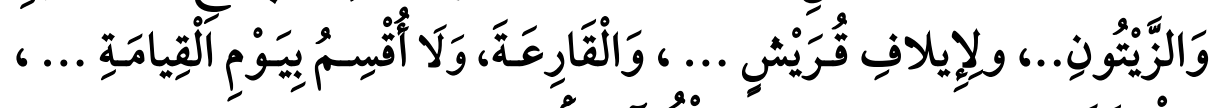

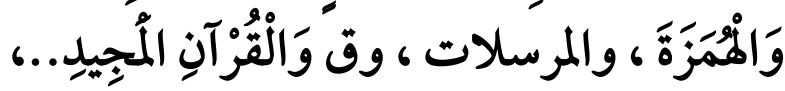

بالاختلاف ـ مات سنة ثجان وخمسين وأربع|ئة ـ انظر وفيات الأعيان وأنباء

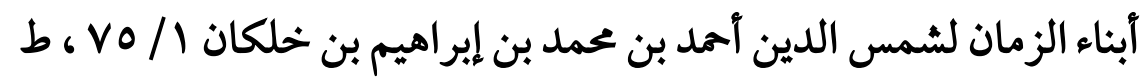

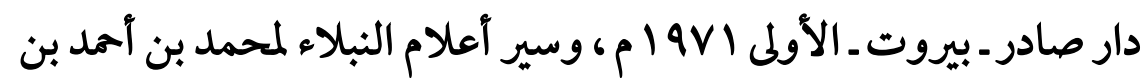

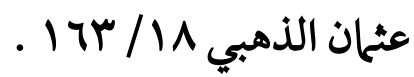
(1) هو عكرمة بن عبد الله مولى عبد الله بن عباس ، أصله مـن البربر مـن أهـل

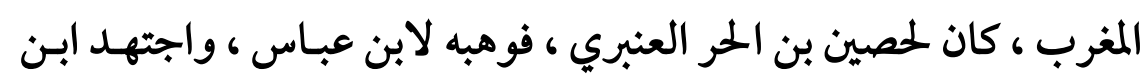

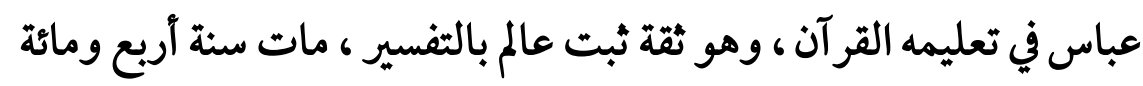

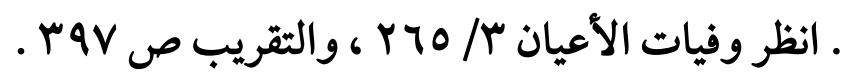

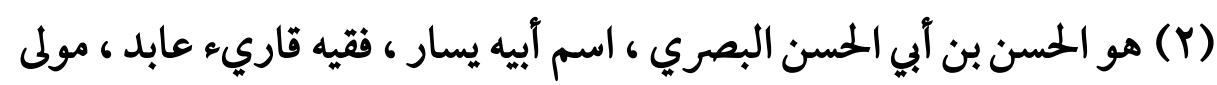

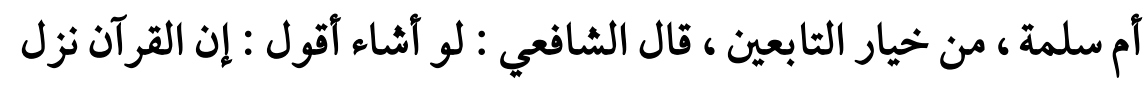

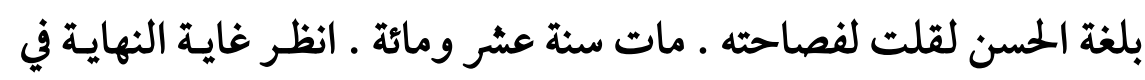

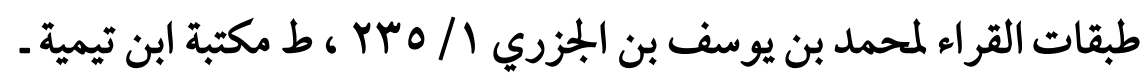

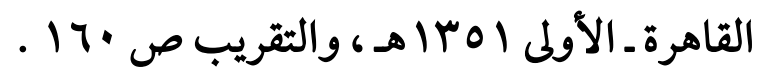

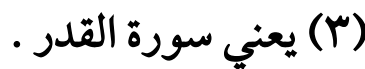




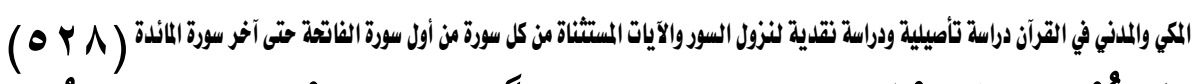

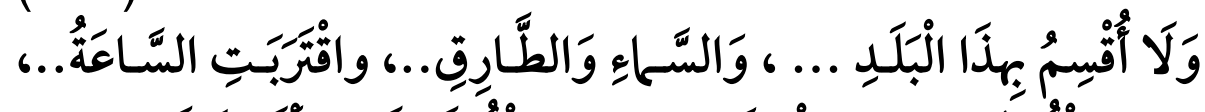

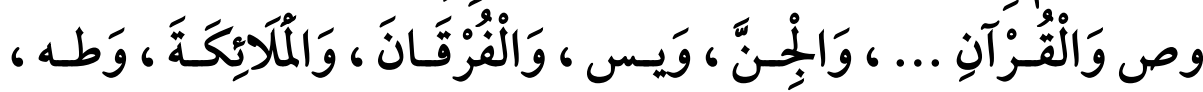

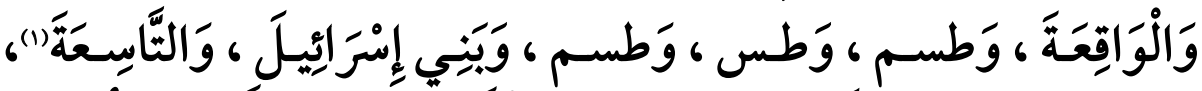

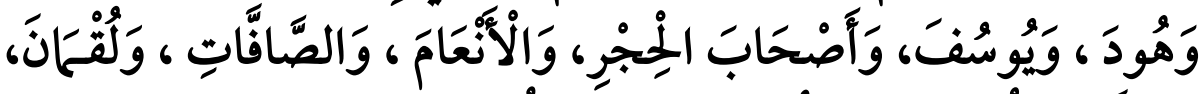

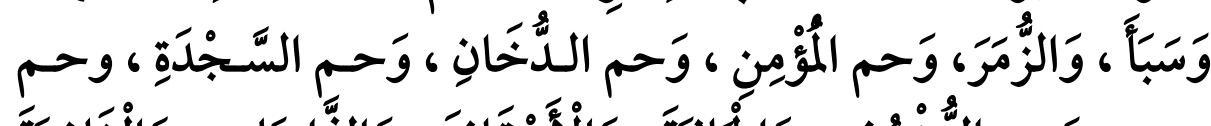

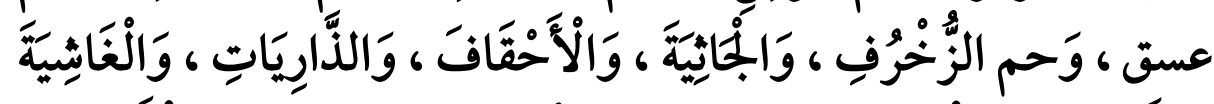

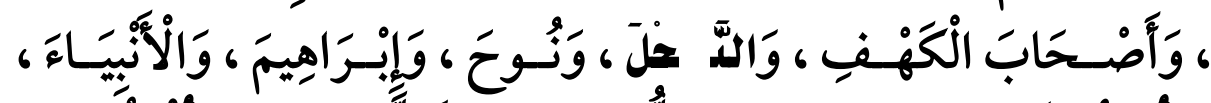

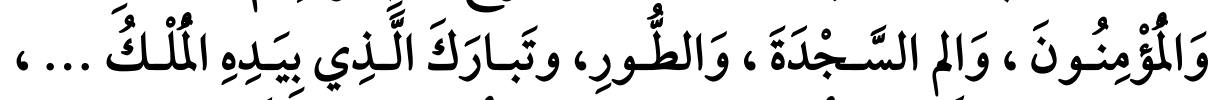

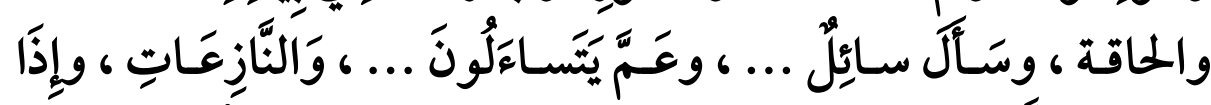

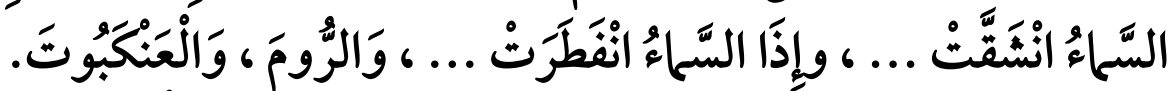

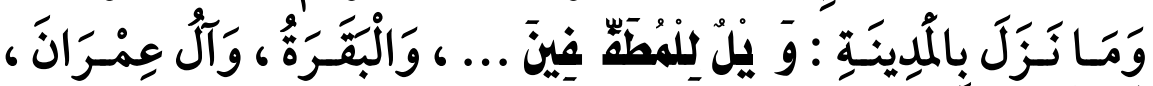

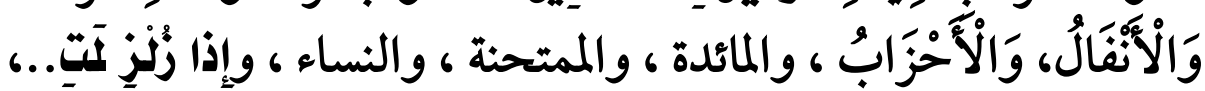

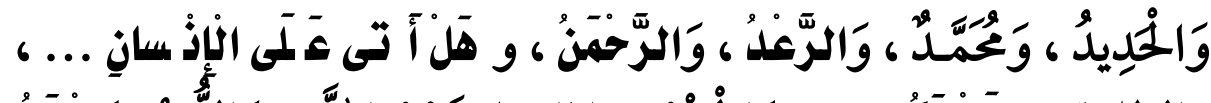

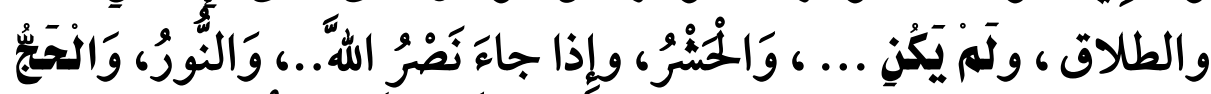

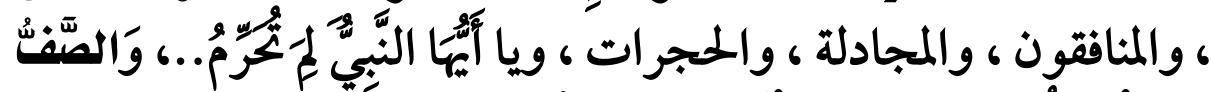

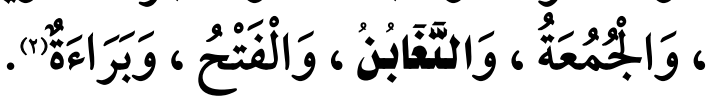

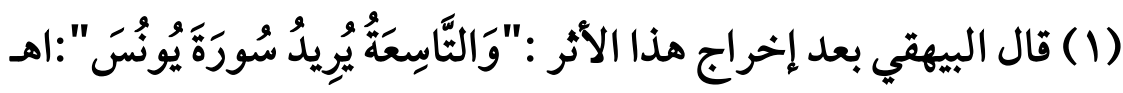

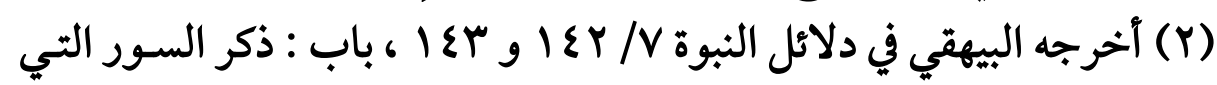
نزلت بمكة والتي نزلت بالمدينة ، من طريق علي بن الحسين بن واقد ، عـن

أبيه ، قال : حدثنا يزيد النحوي عن عكرمة ، والحسن بن آبي الحسن • 
(or9)

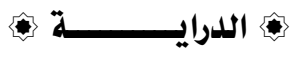

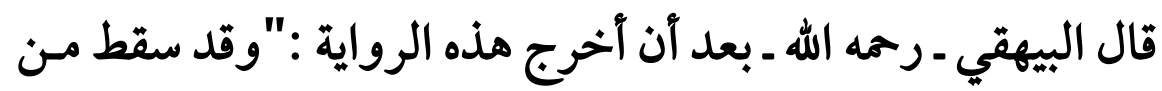

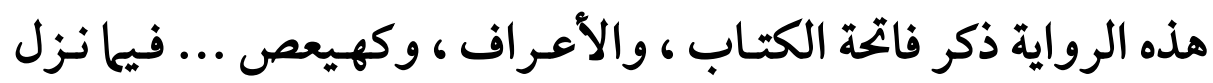
بمكة":اهـ

ثم آخرج البيهقي رواية آخرى لتشـهد للروايـة الأولى ، وفيها ذِكْرُ التر السور التي سقطت منها في ذكر ما نزل بمكة ـ ـ وهي الرواية الثالثة التي لئي أذكرها الآن . الرواية الثالثة : ـ رواية خُصَيْف عن مجاهد عن ابن عباس .

وعلي بن الحسين بن واقد مولى عبد الله بن عامر بن كريز، كنيته أبو الحسن ، مـن

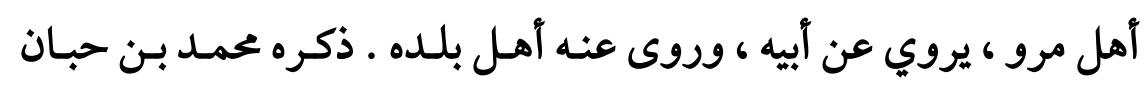

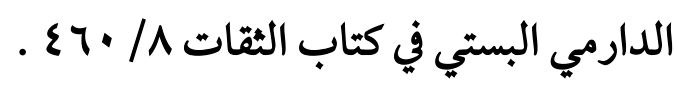

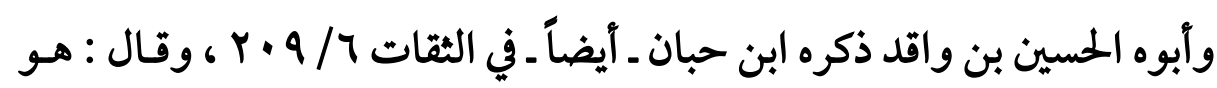

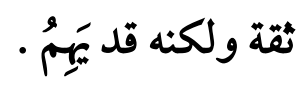

ويزيد النحوي هو يزيد بن ابى سعيد النحوي أبو الحسن مولى قريش ، ثقة كما في

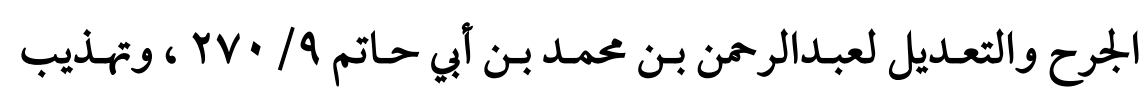

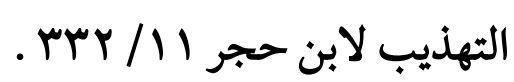

فالأثر آقل درجاته أنه حسـن إلى عكرمة والحسـن البصري ، لا سيـا والروايـة

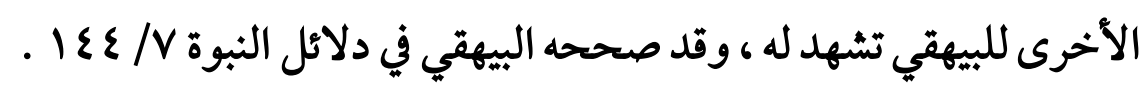




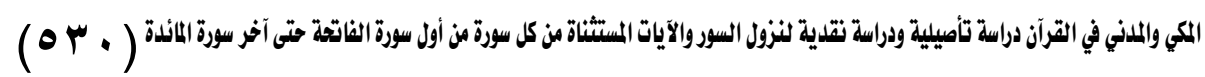

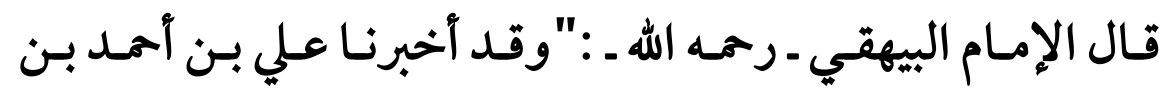

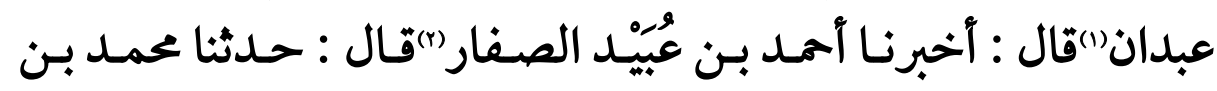

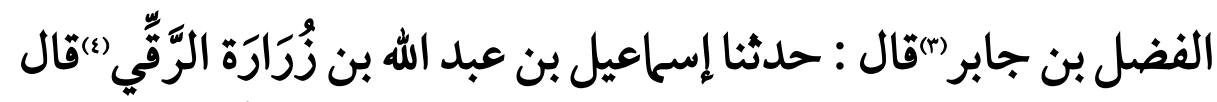

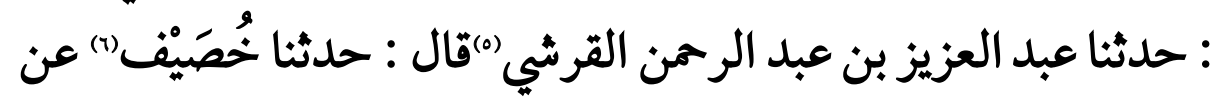

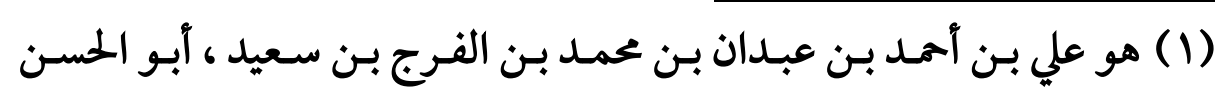

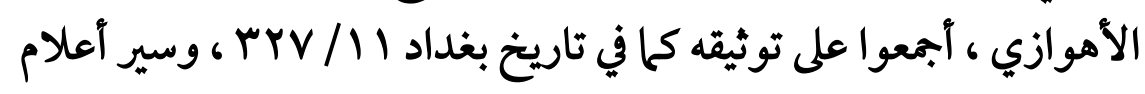

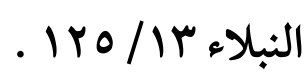

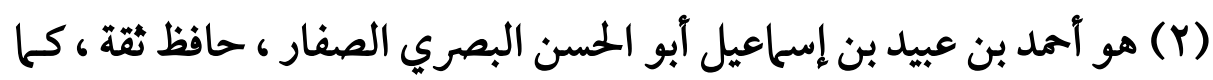

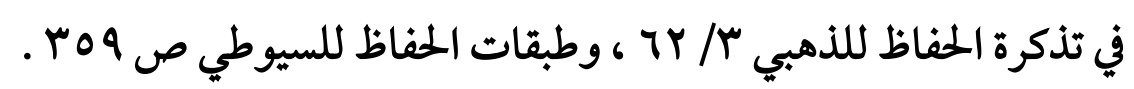

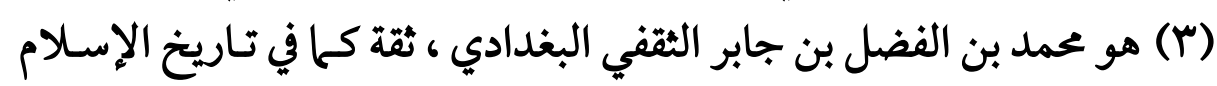

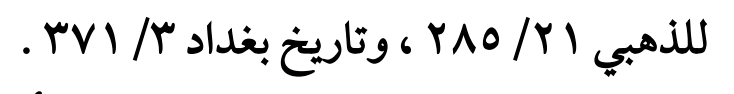

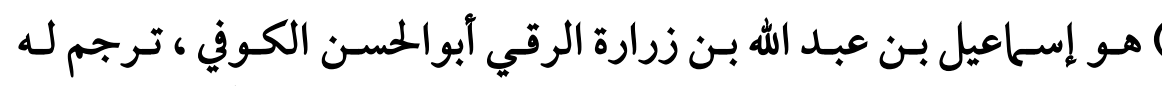
(₹)

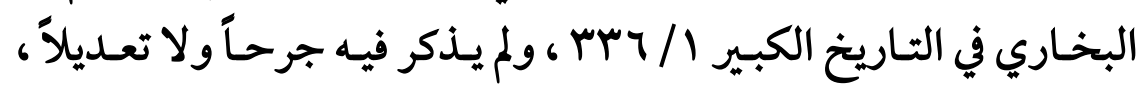

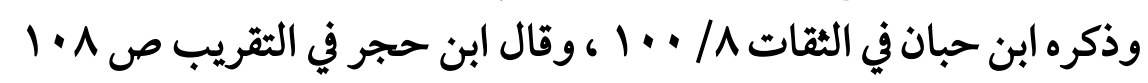

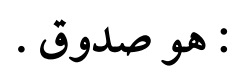

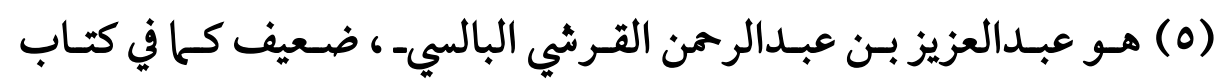

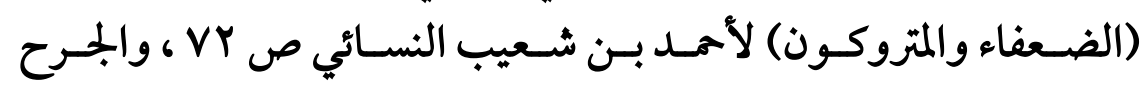

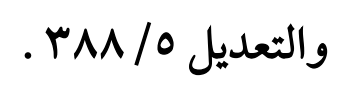

(7) هو خُصَيْف بن عبدالرحمن الجزري أبوعون مولى لعثمان بن عفان أو لمعاوية

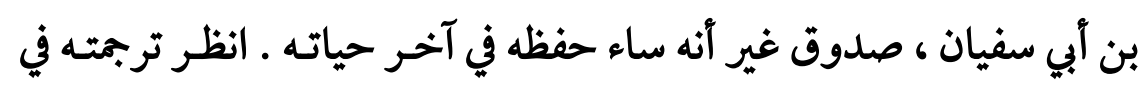

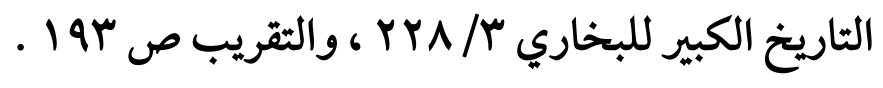


(orl)

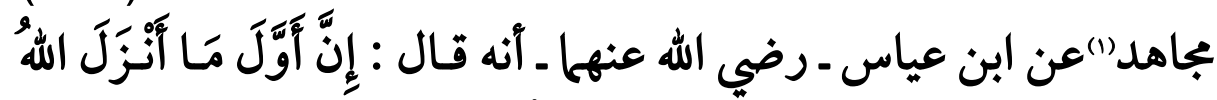

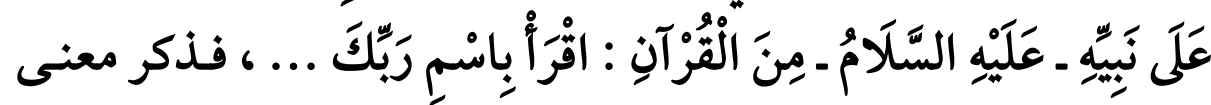

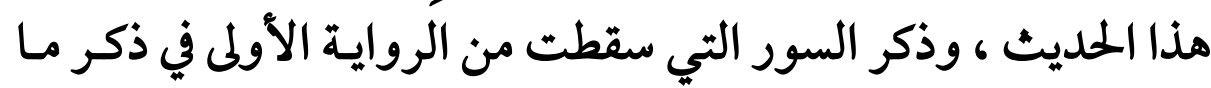

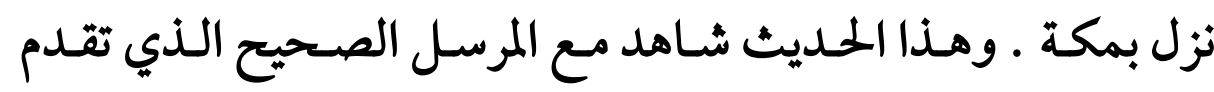
ذكره(r)":اهـ

$$
\text { الرواية الرابعة : ـ رواية جابر بن زيد . }
$$

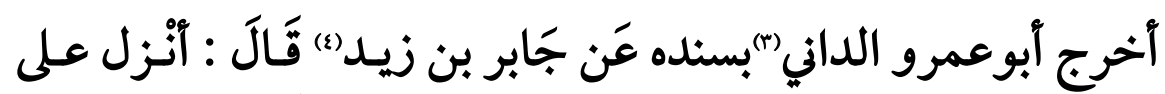

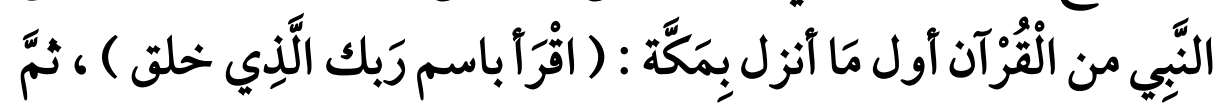

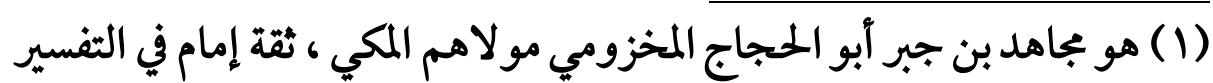

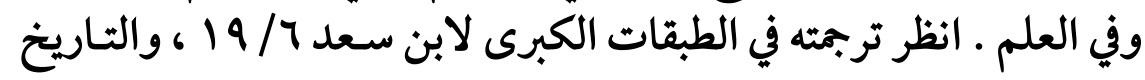

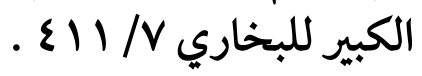

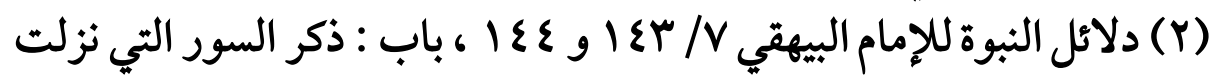

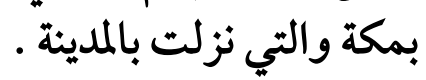

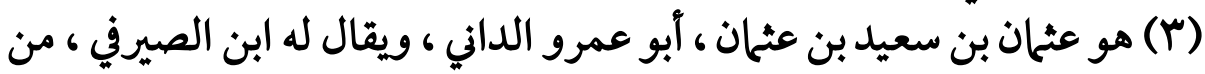

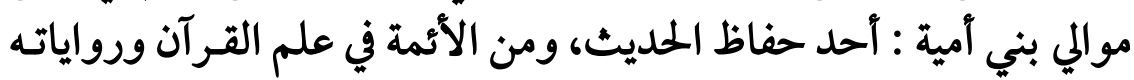

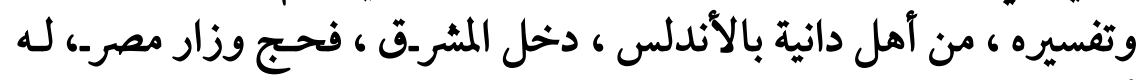

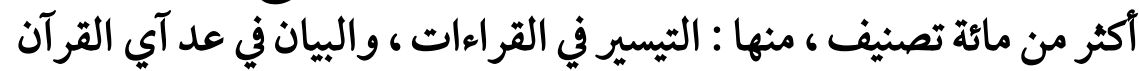

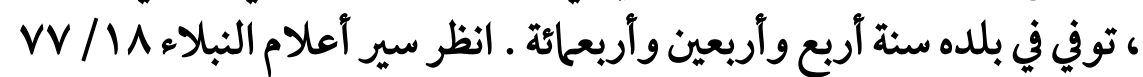

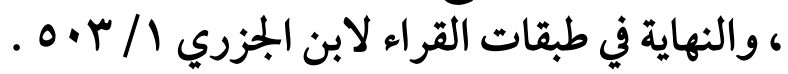

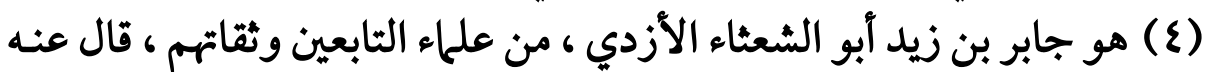

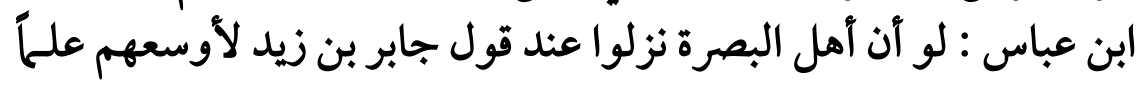




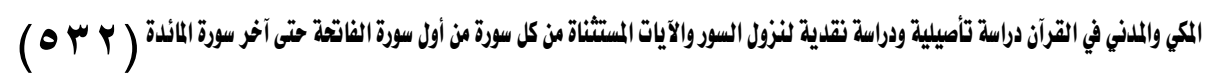

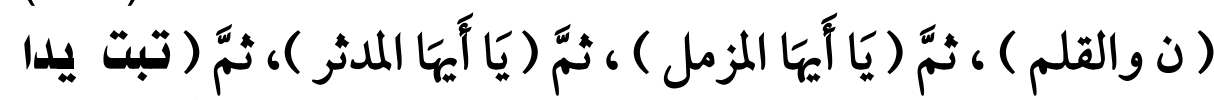

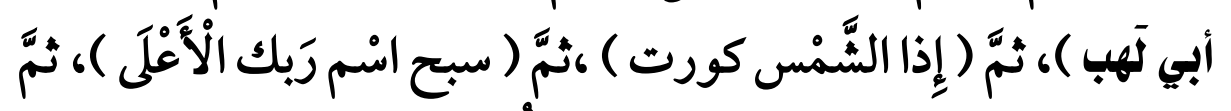

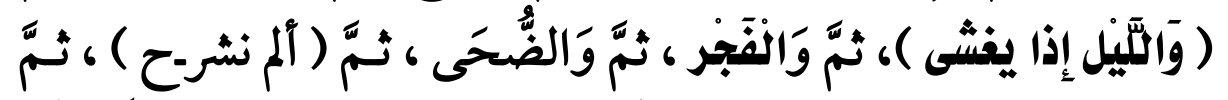

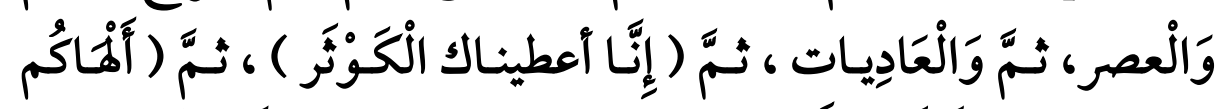

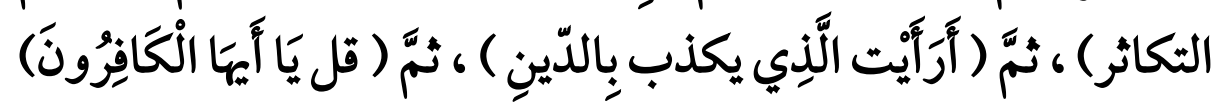

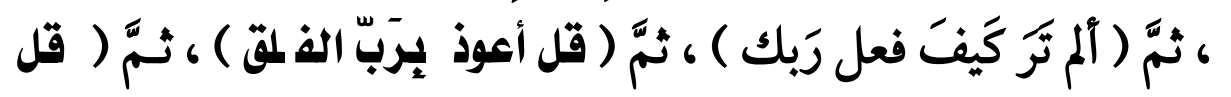

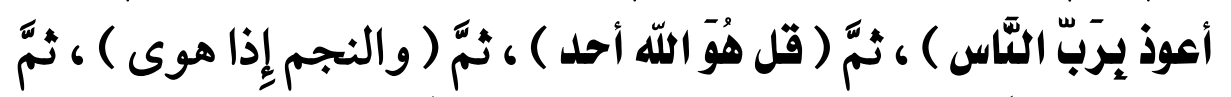

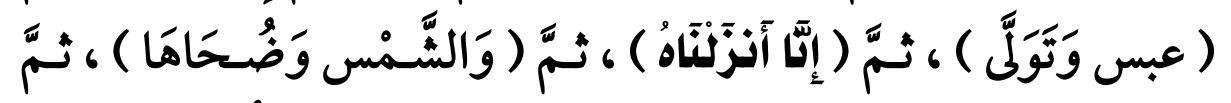

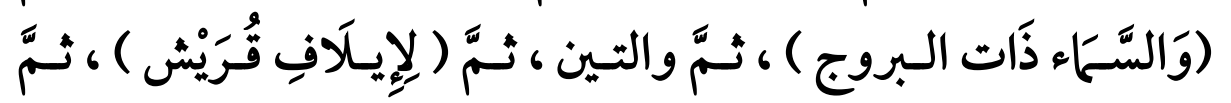

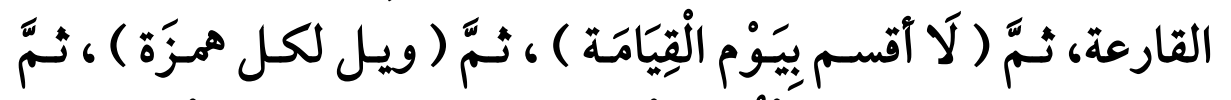

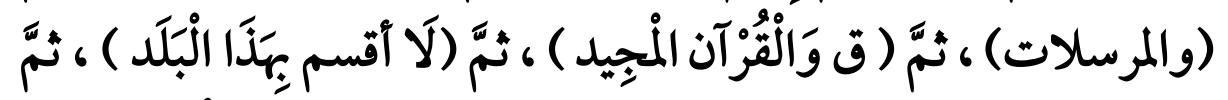

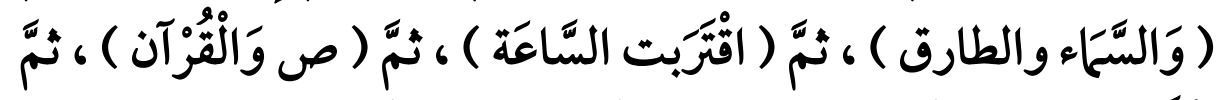

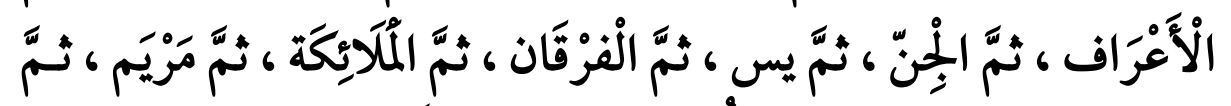

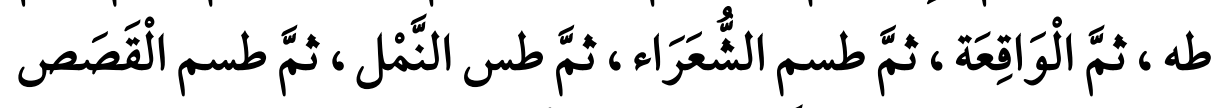

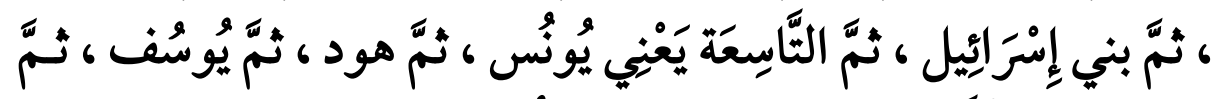

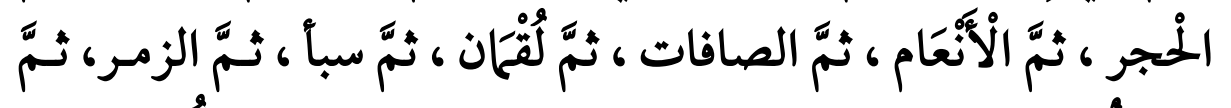

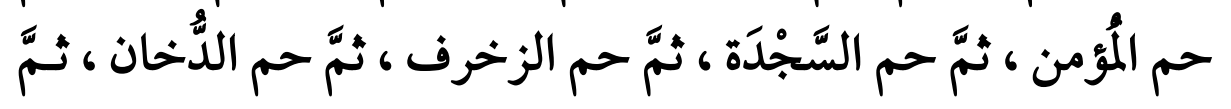

عا في كتاب الله ، مات سنة ثلاث وتسعين ـ انظر التاريخ الكبير للبخاري

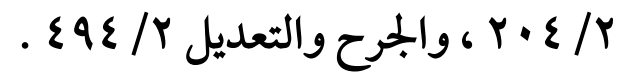


(Orr)

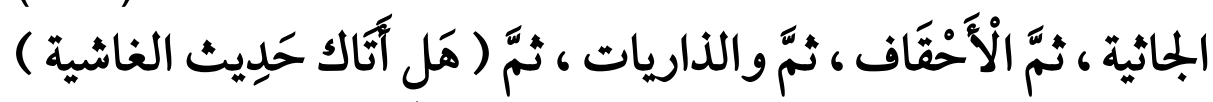

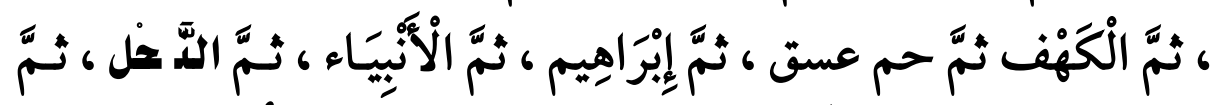

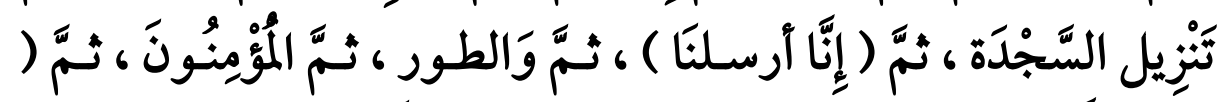

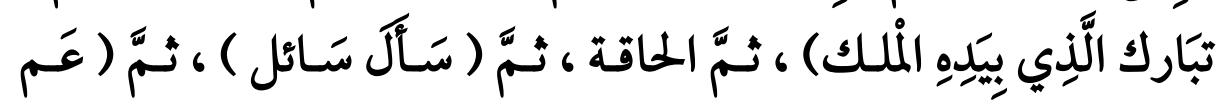

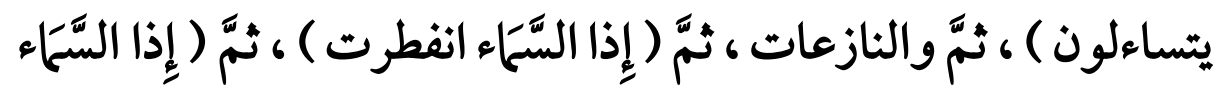

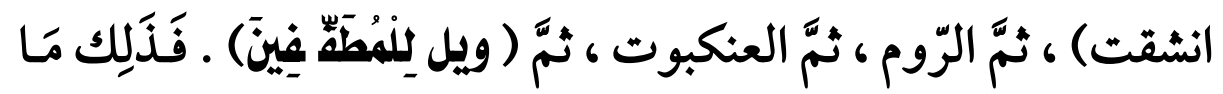
أنزل عَلَيْهِه بِمَكَّة .

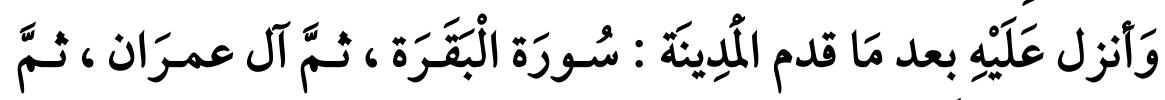

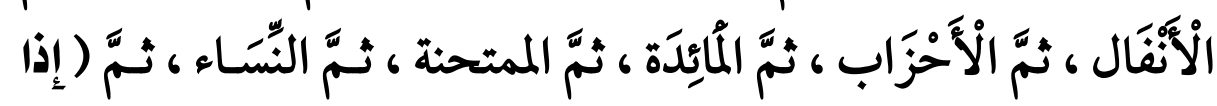

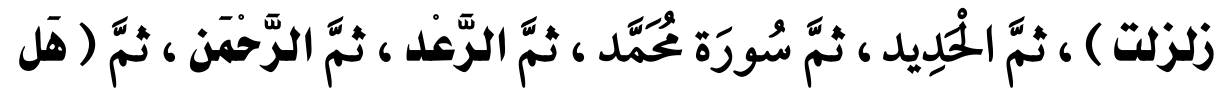

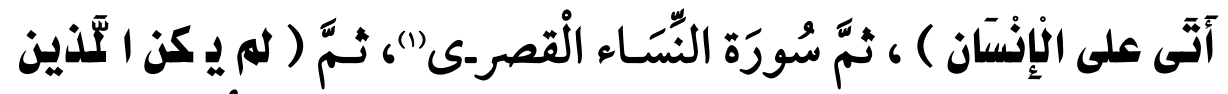

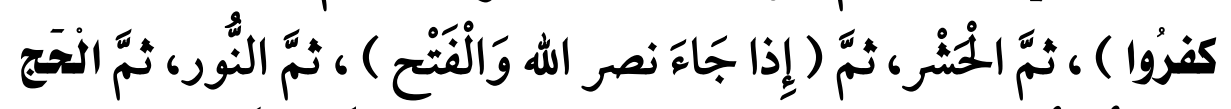

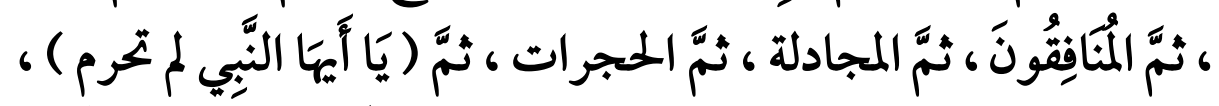

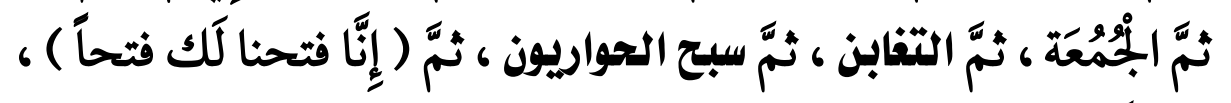

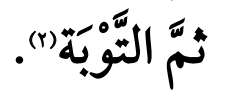

(1) سورة النساء القصرى هي سورة الطلاق .

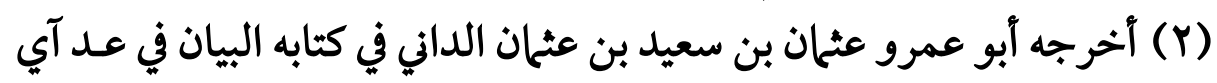

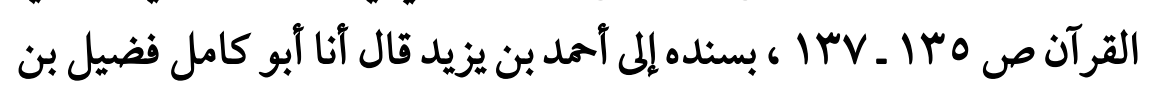

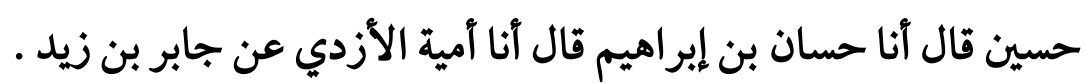




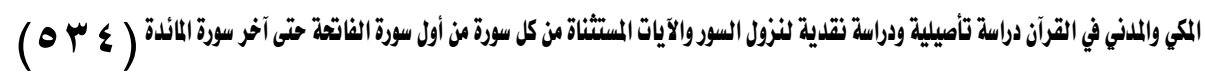
قلت : لم تذكر هذه الرواية سورة الفاتحة .

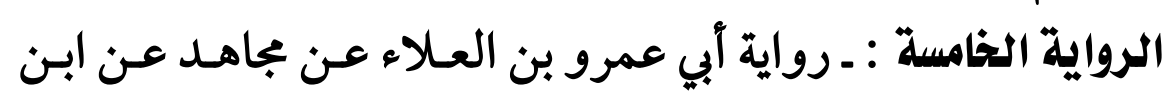
عباس - مبر أخرج الإمام أبو جعفر النحاس (1)في كتابه الناسخ والمنسوخ بسنده في صدر سورة الأنعام ، ثم آخرج بنفس السـند في صـدر كل سـورة بعـد الإند

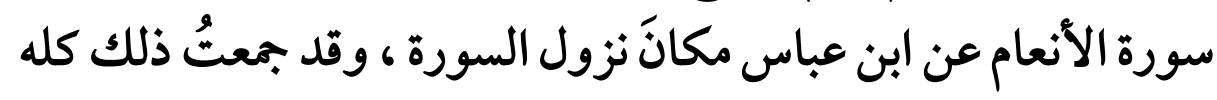
في سياق واحد على النحو الآتي :

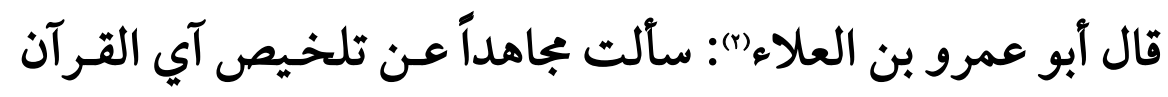

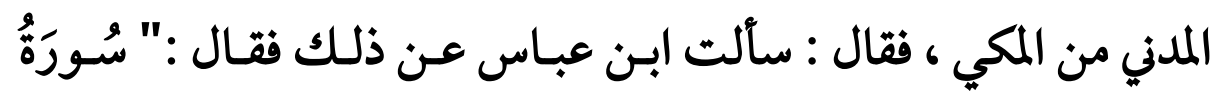

والسند موصول ، وكل رجاله ثقات إلا أحمد بن يزيد الحُلواني المقريء صاحب

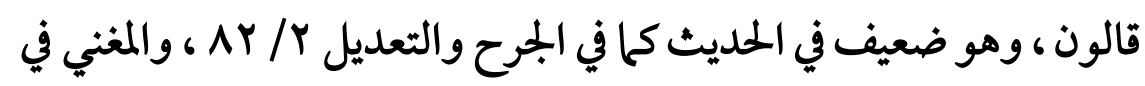

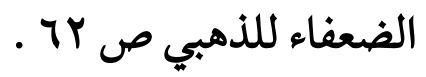

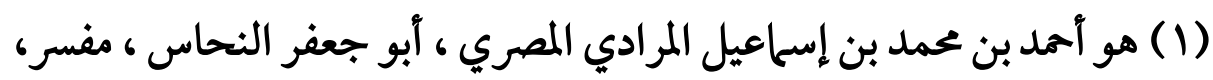

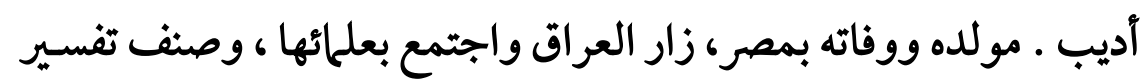

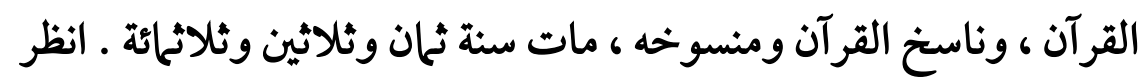

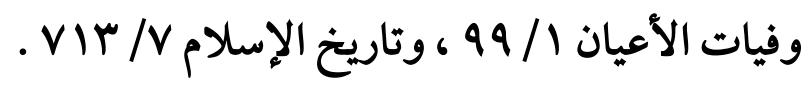

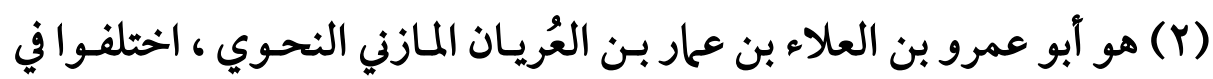

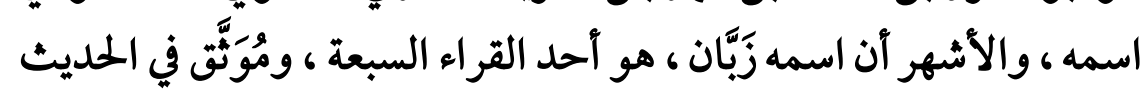

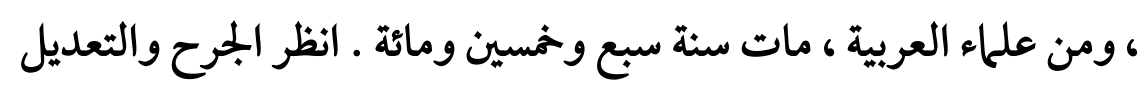

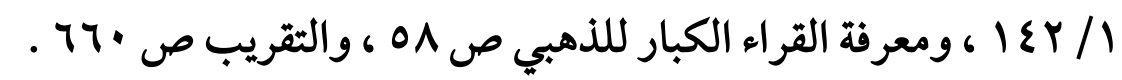




\section{(oro)}

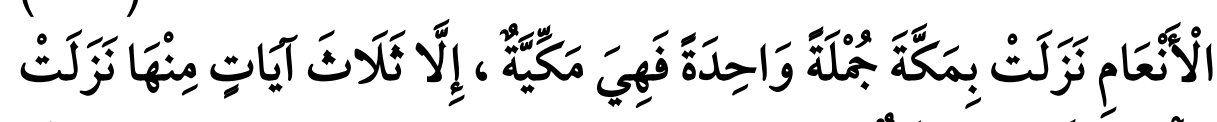

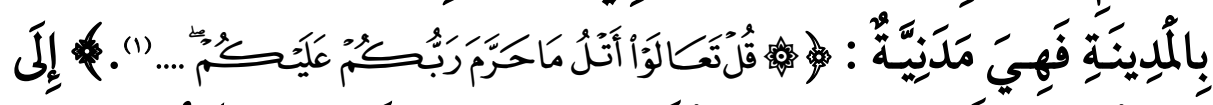

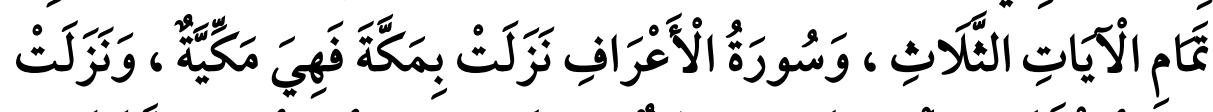

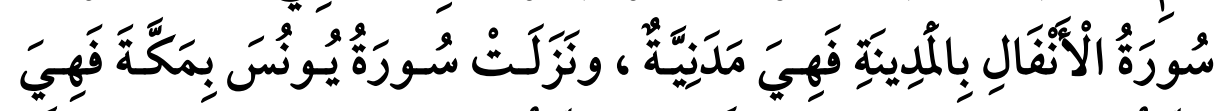

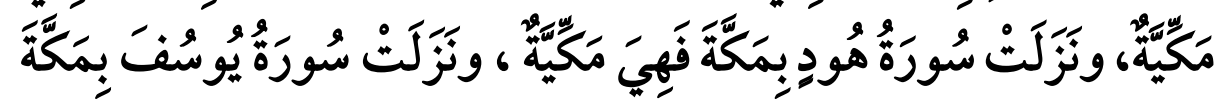

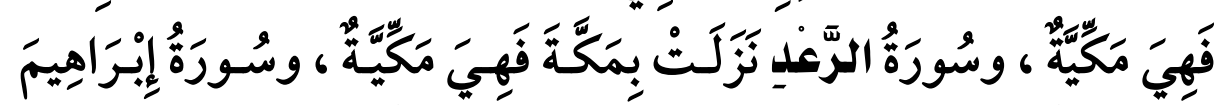

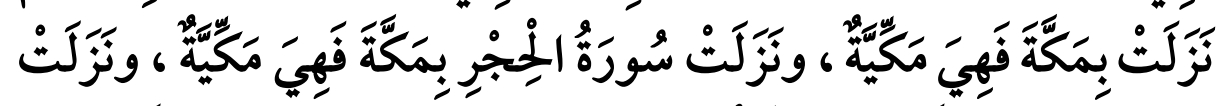

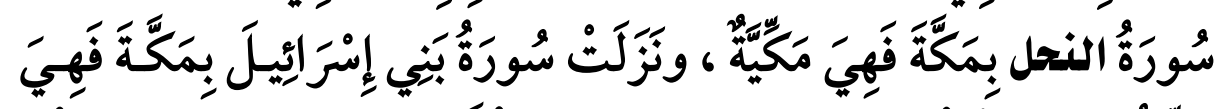

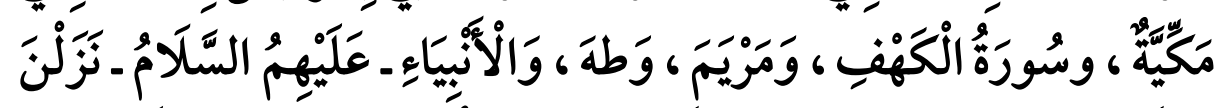

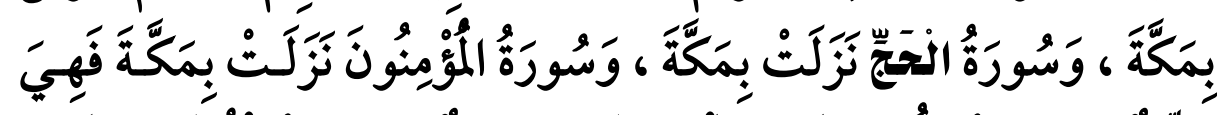

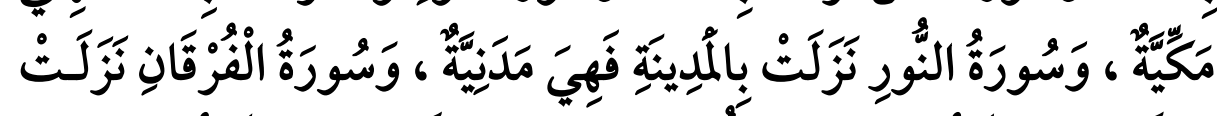

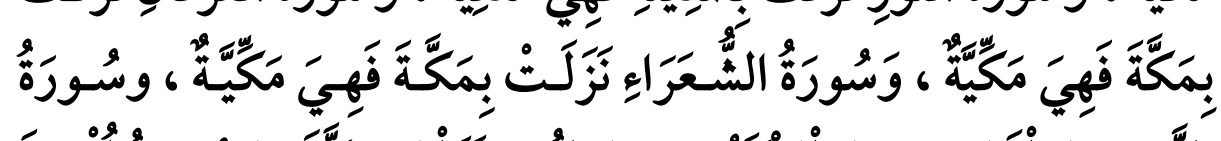

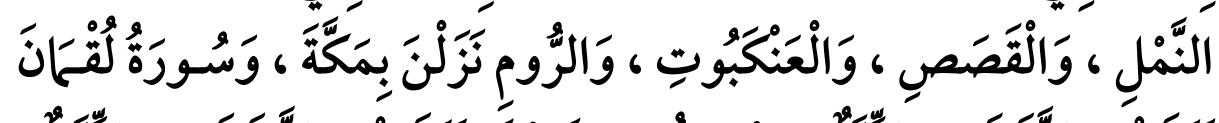

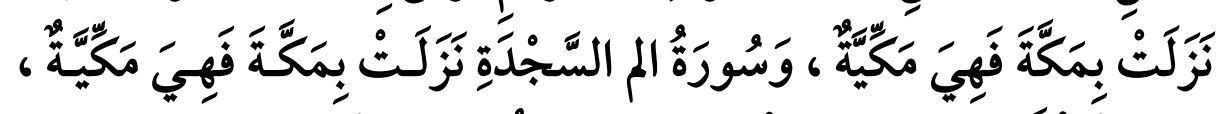

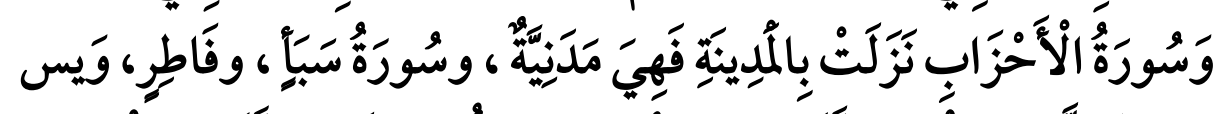

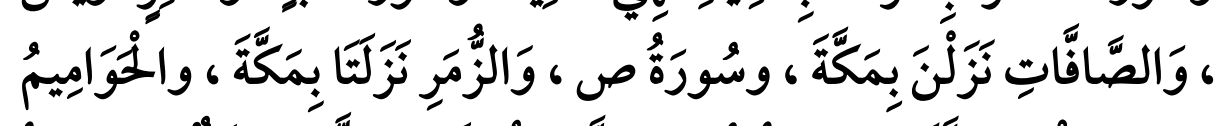

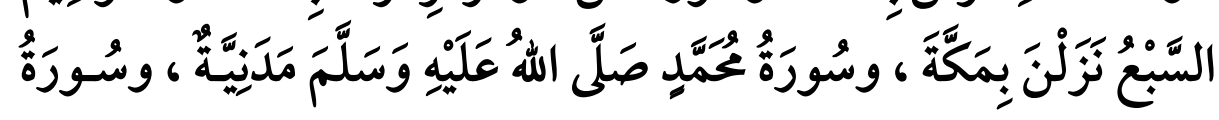

$$
\text { (1) سورة الأنعام (101 ـ 10r). }
$$




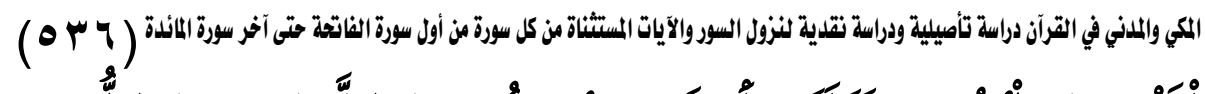

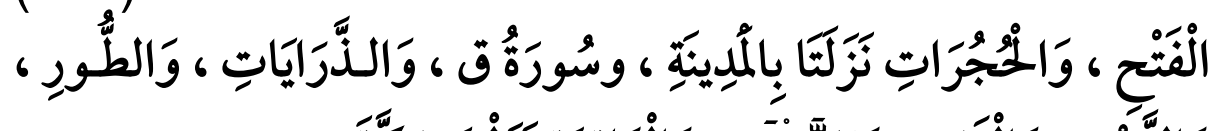

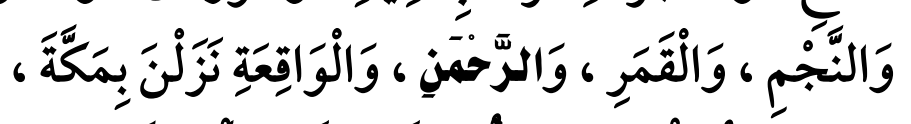

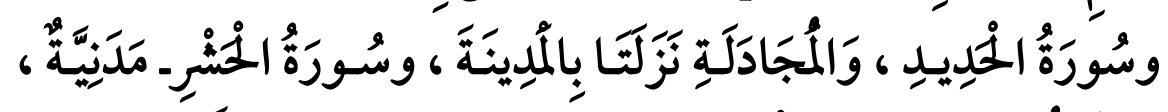

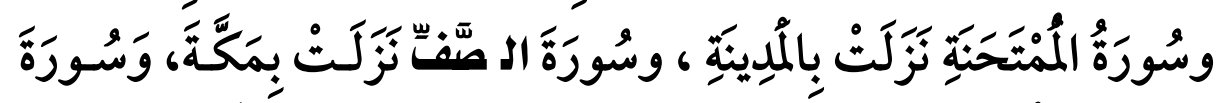

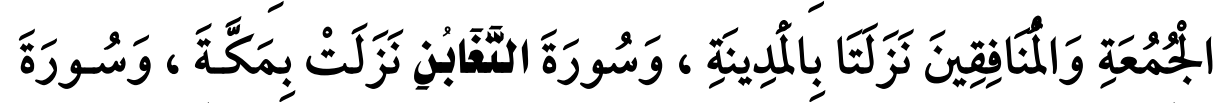

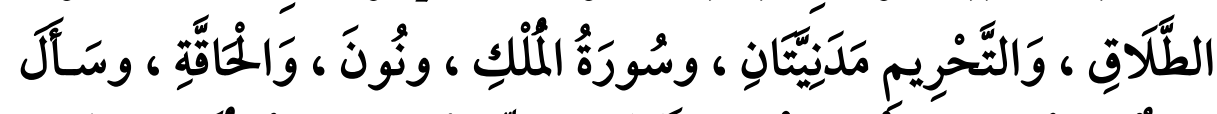

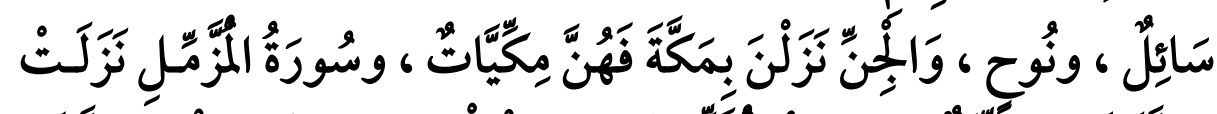

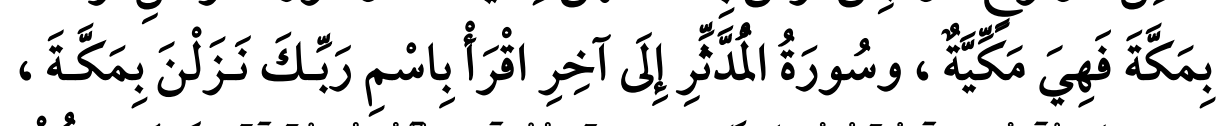

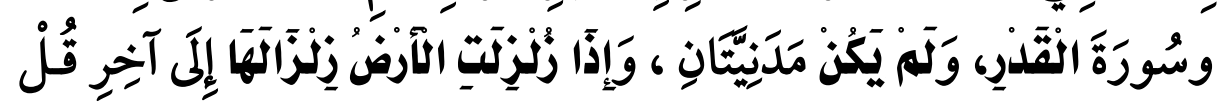

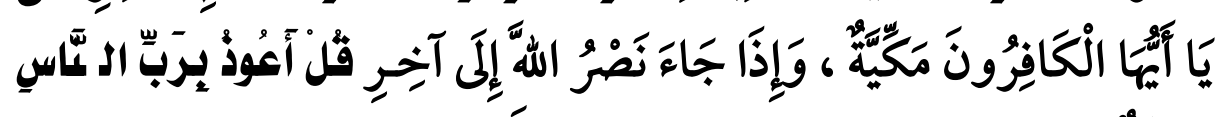

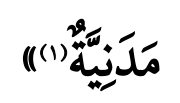

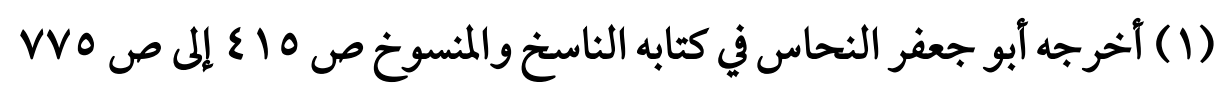

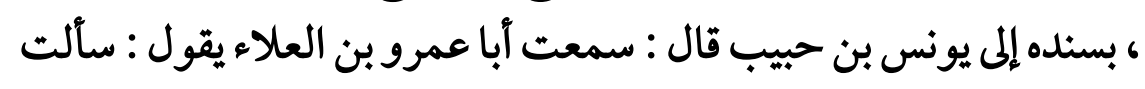

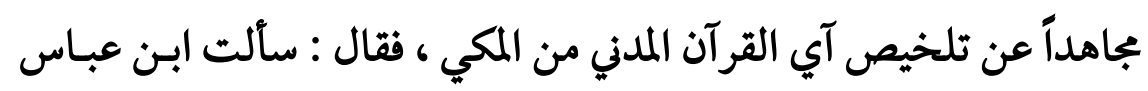
عن ذلك فقال........إلى آخره .

وهو سند موصول ، كل رجاله ثقات إلا يونس بن حبيب أبا عبدالرحمن الضَّبِّي

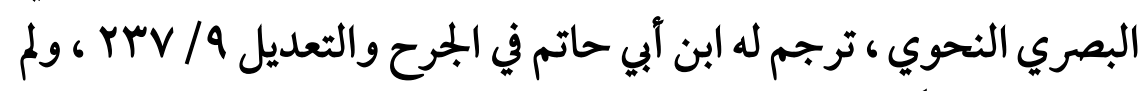

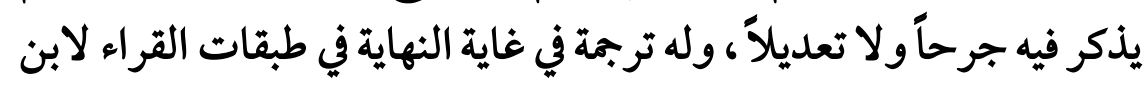

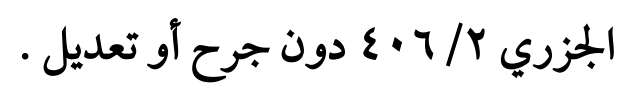


(orv)

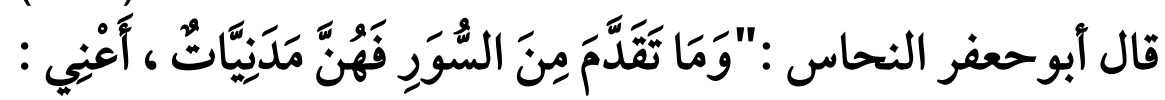

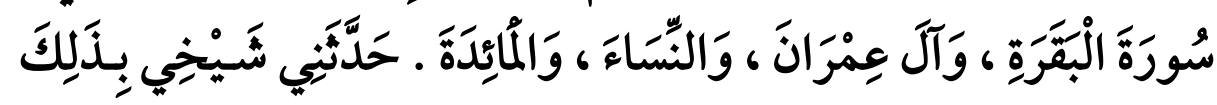

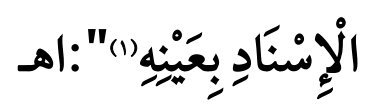

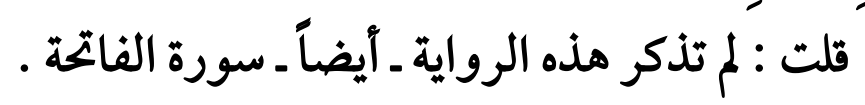

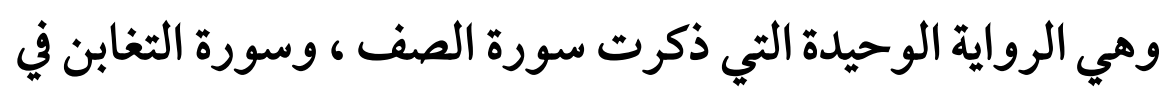

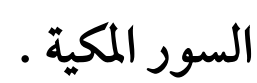

وهي الرواية الوحيدة التي ذكرت سورة المسد ، وسورة الفلق ،

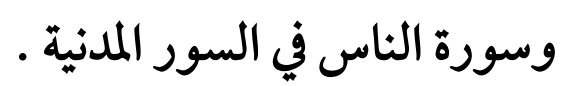

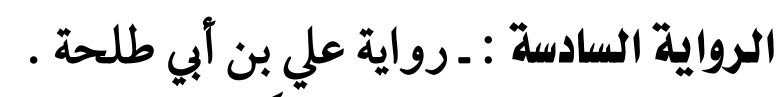

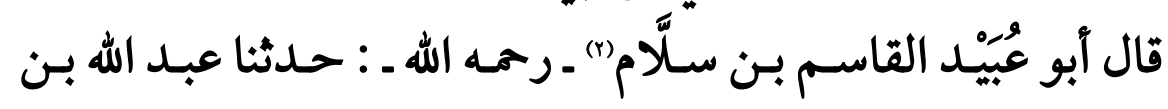

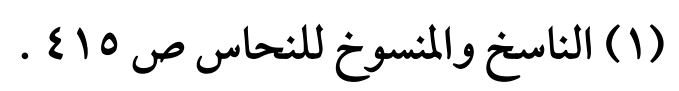

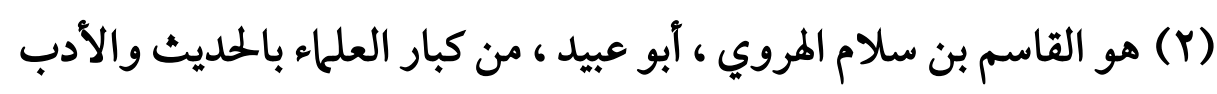

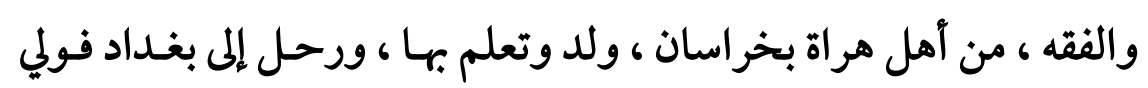

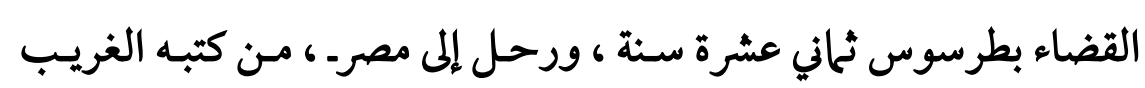

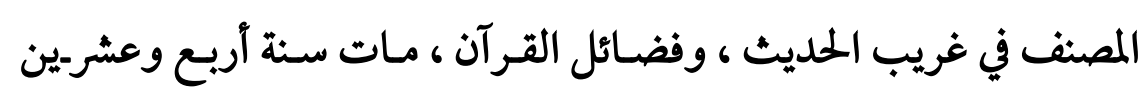

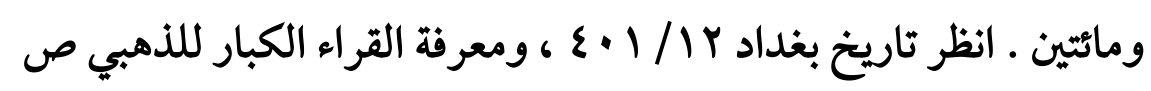
$.1 \cdot 1$ 


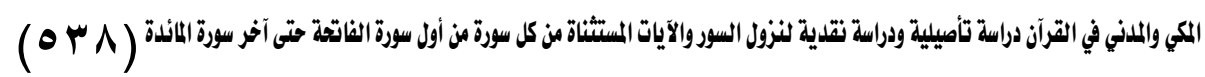

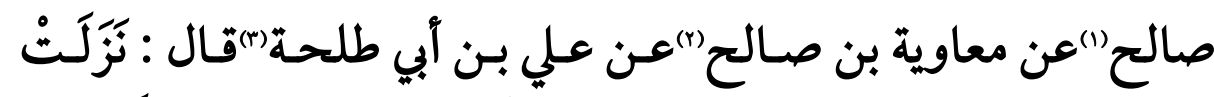

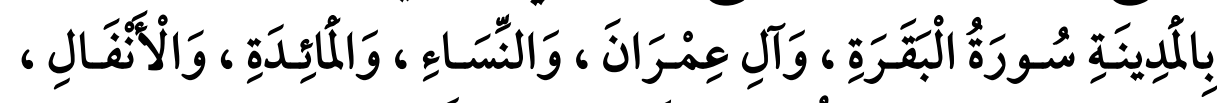

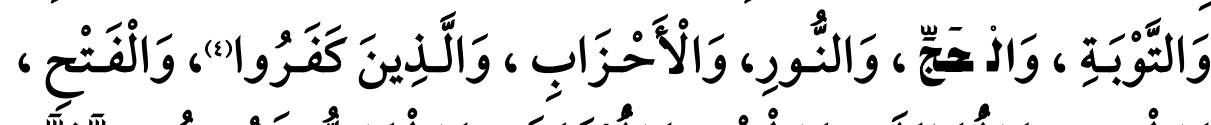

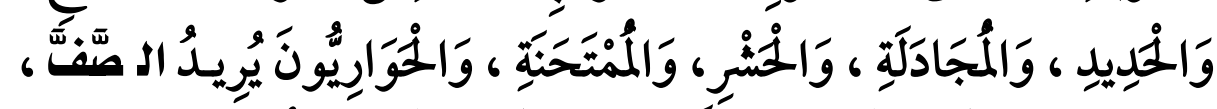

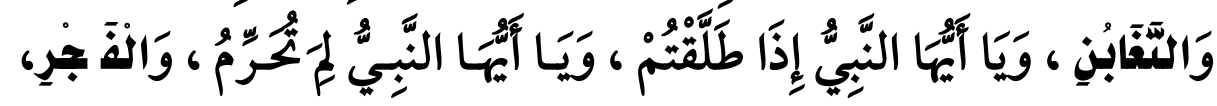

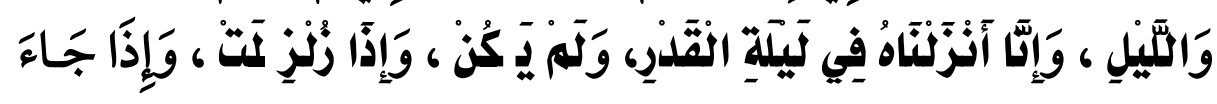

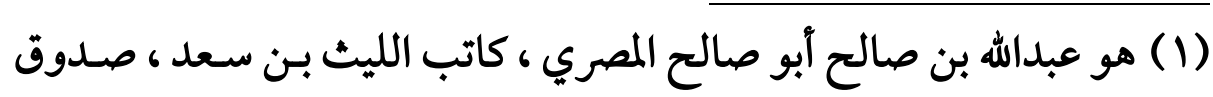

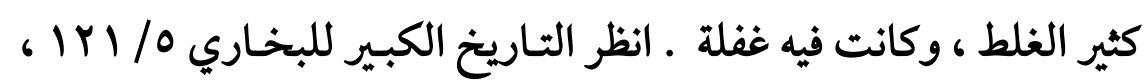

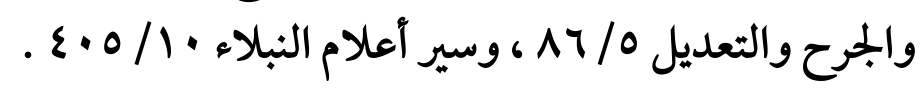

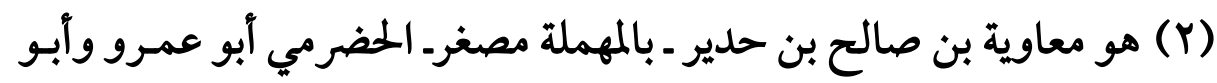

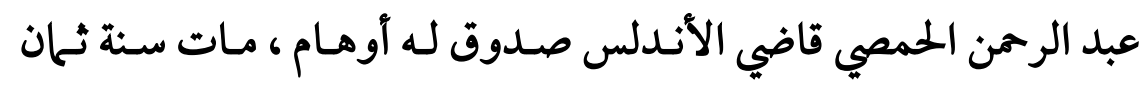

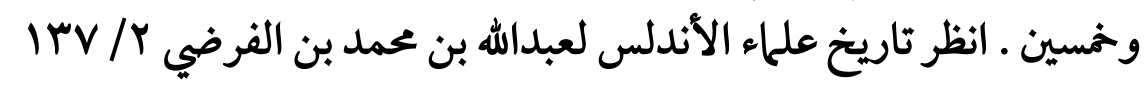

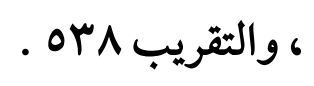

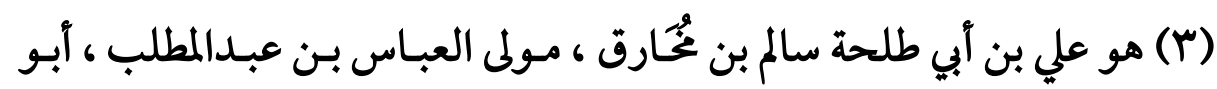

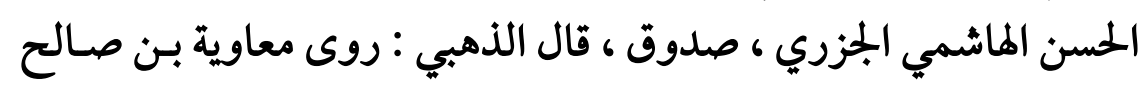

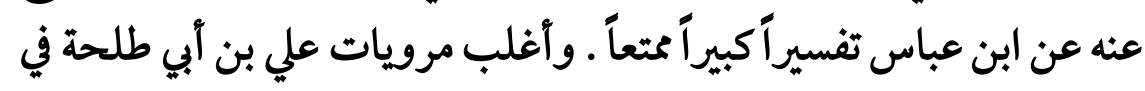

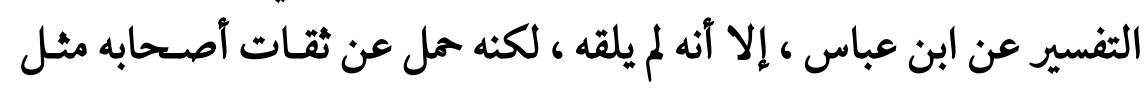

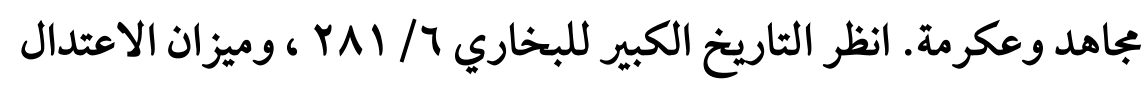

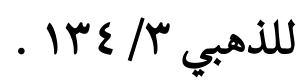

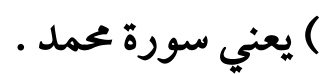




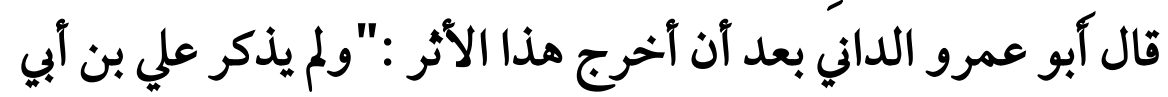

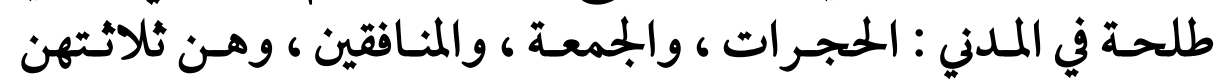

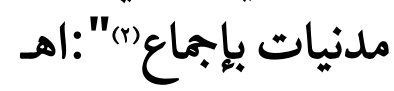

قلت : هذه هي الرواية الوحيدة التي ذكرت سورة الفجر، وسـورة

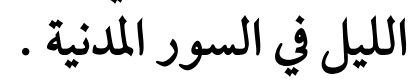

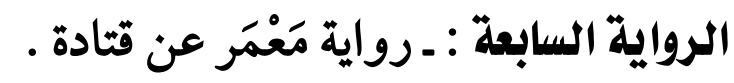

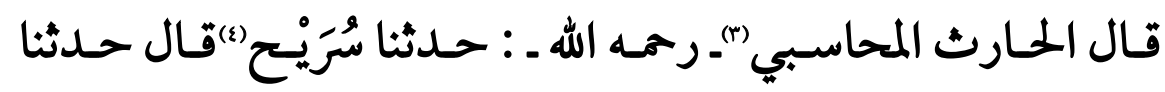

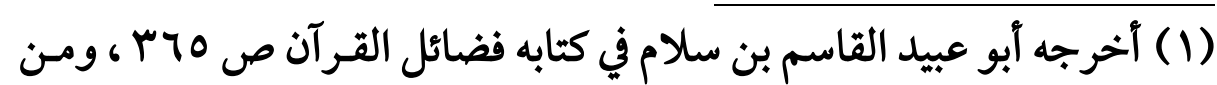

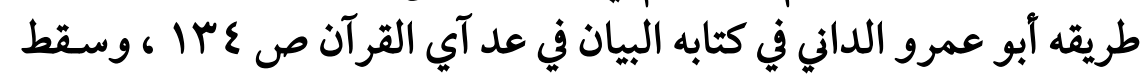

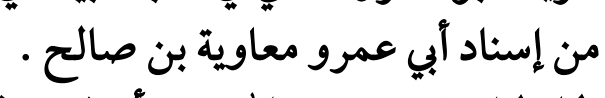

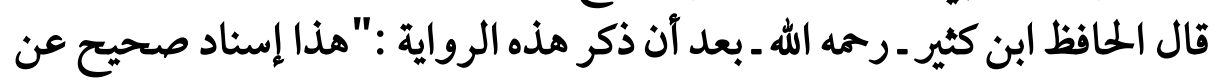

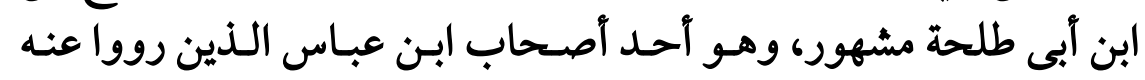

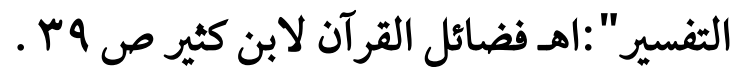

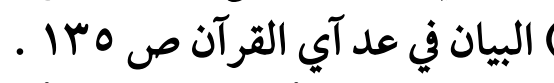
(Y)

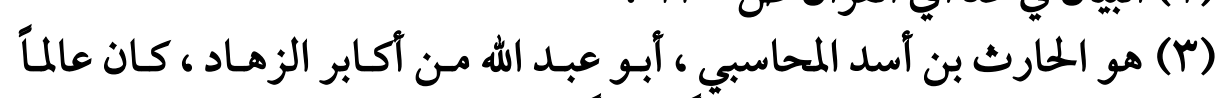

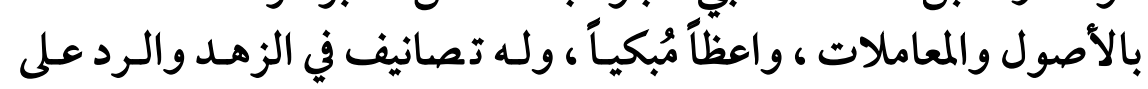

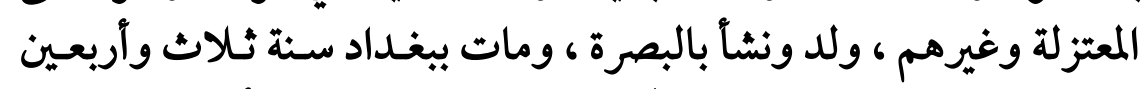

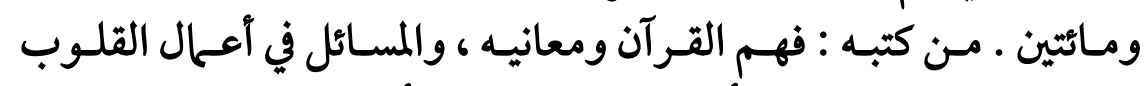

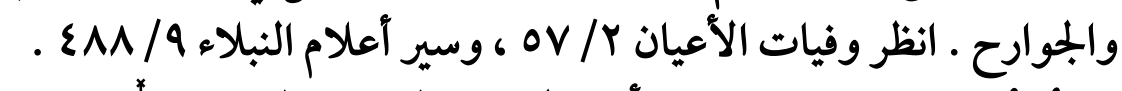

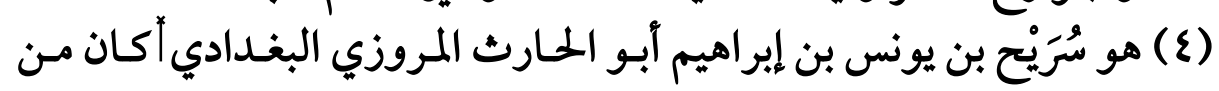

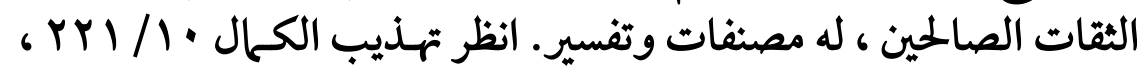

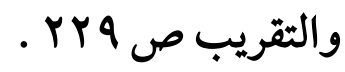




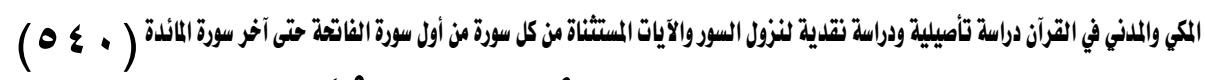

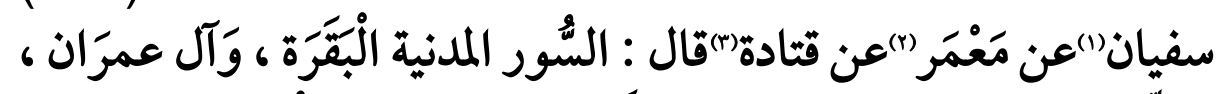

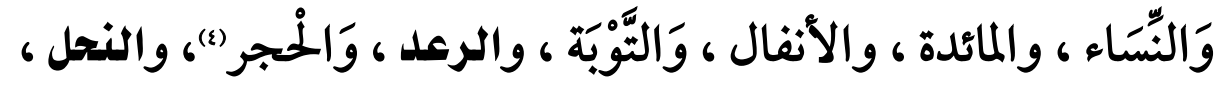

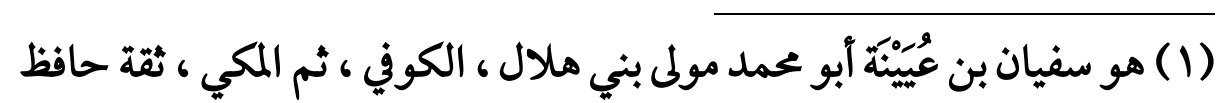

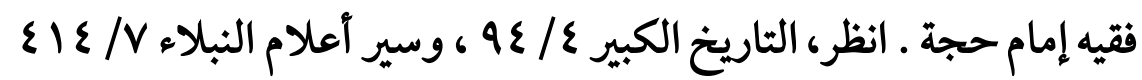

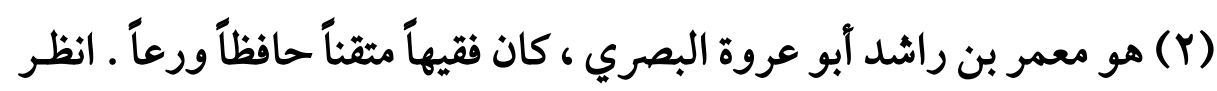

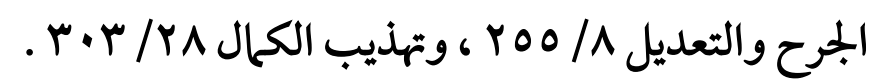

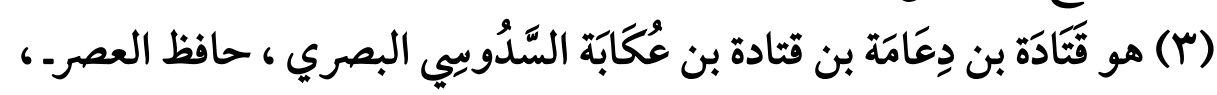

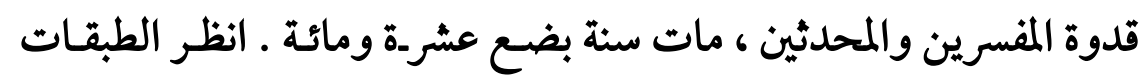

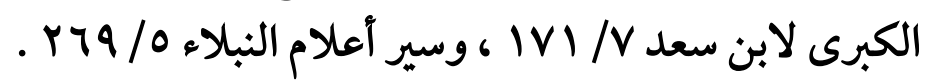

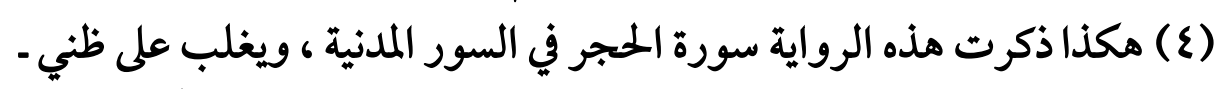

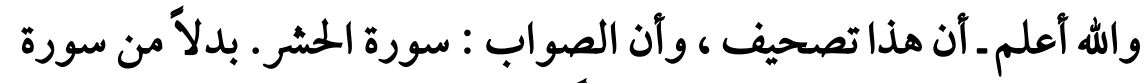

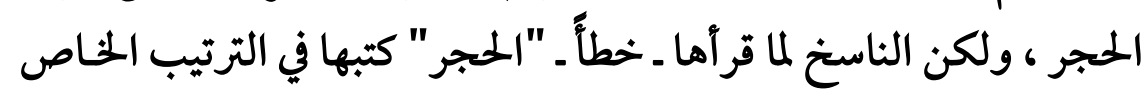

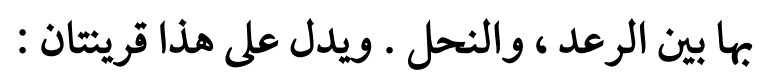

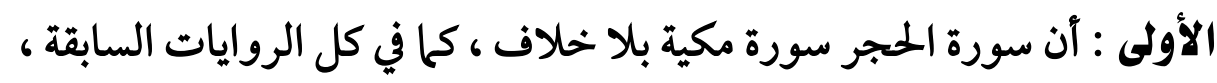

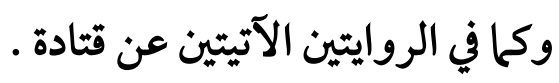

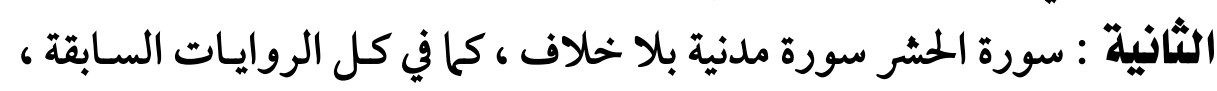

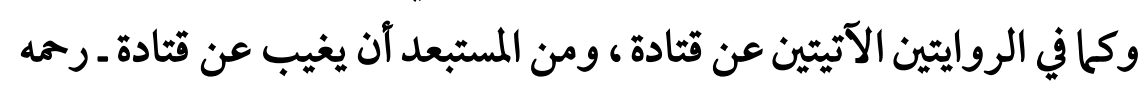

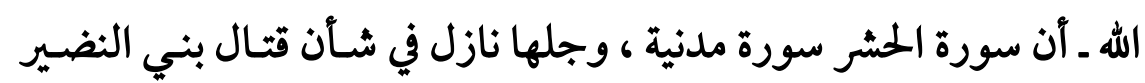

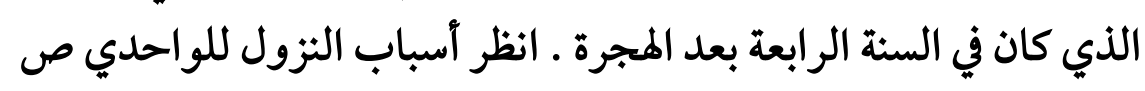

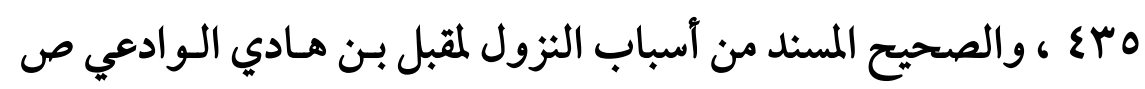

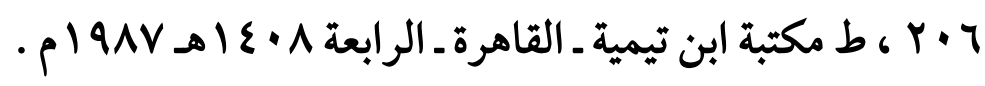


$(0 \leq 1)$

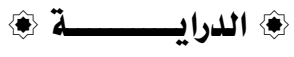

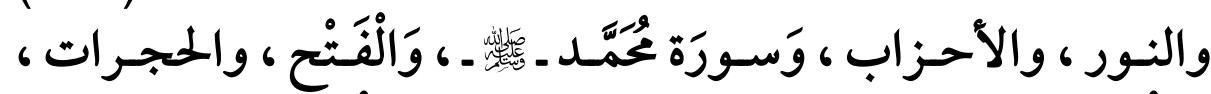

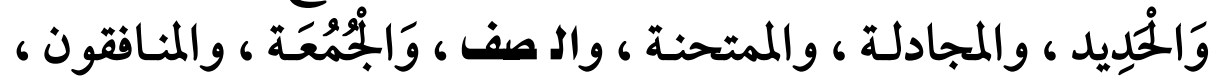

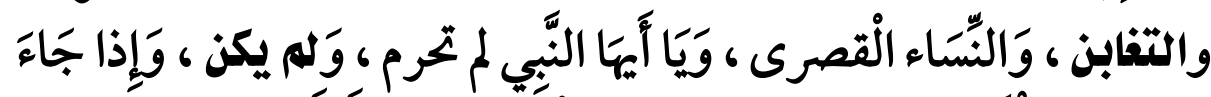

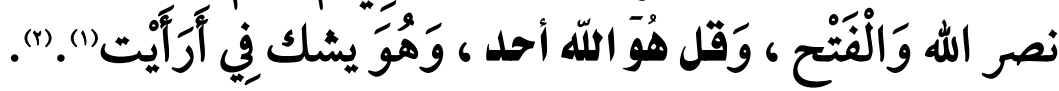

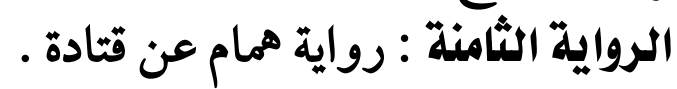

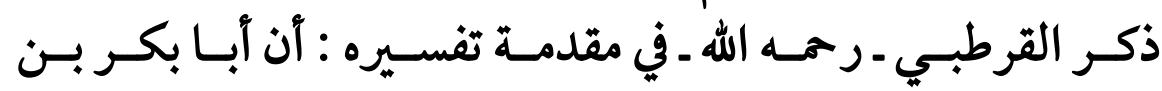

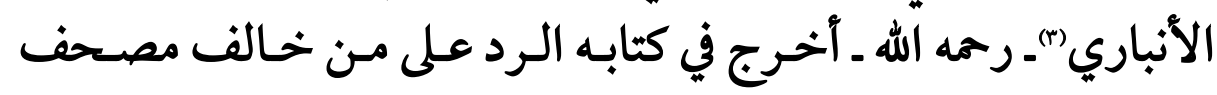

وبناء عليه لابد آن تُذْكَر سورة الحجر في السور المكية ، وتُذْكَرَ سورة الحشر- في

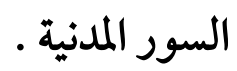

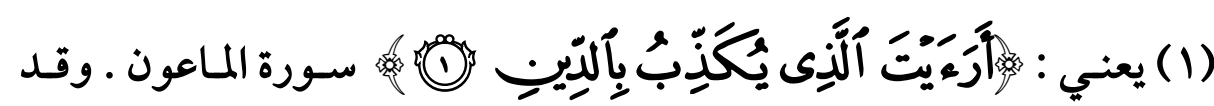

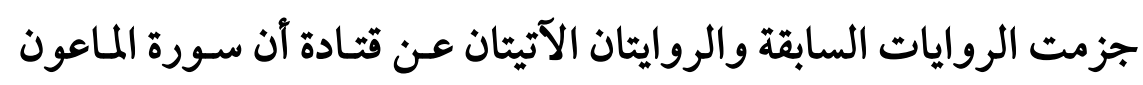

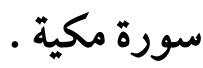
(Y) آخرجه الحارث المحاسبي في كتابه فهم القرآن ومعانيه ص ه 90 ، ب بسند صحيح إلى قتادة .

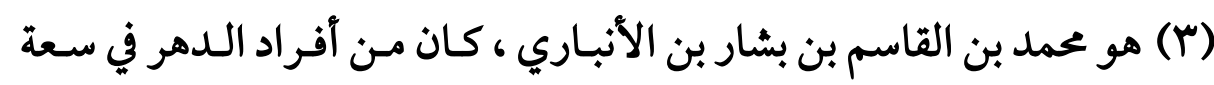

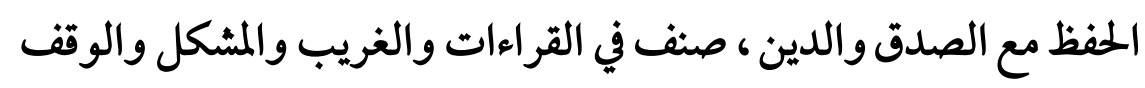

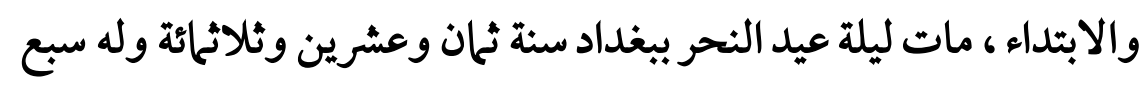

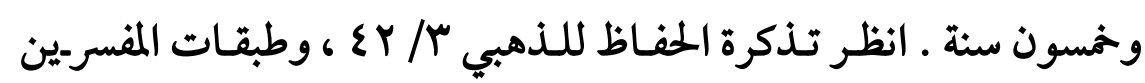

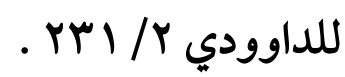




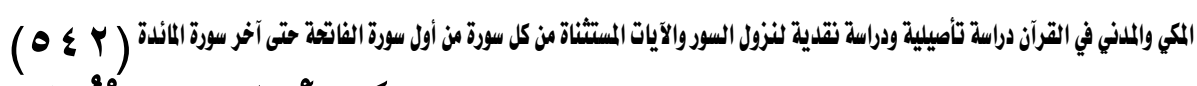

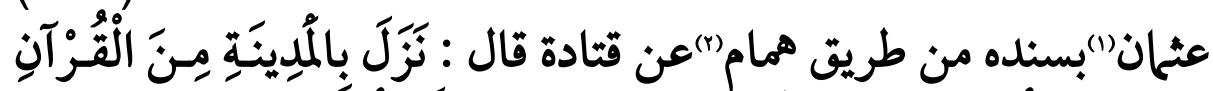

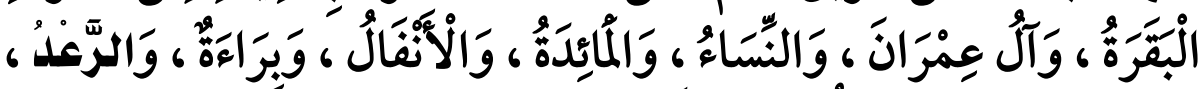

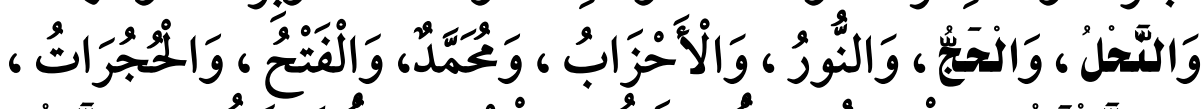

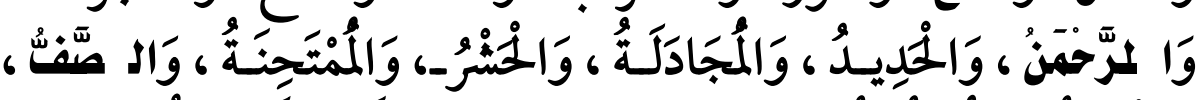

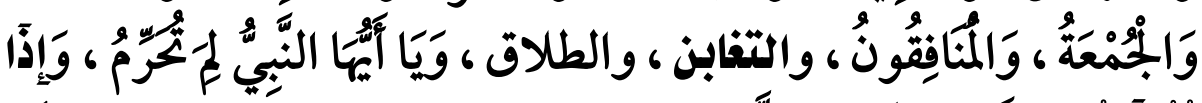

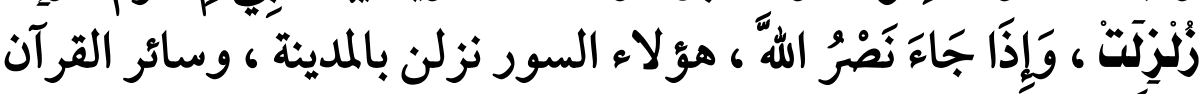

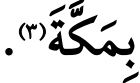

قلت : لم تذكر هذه الرواية سورة البينة في السور المدنية ، وعليه فهي

الرواية الوحيدة التي جعلت سورة البينة مكية .

الرواية التاسعة : . روية سعيد عن قتادة .

(1) كتاب الرد على من خالف مصحف عثمان ذكره محمد بن إسحاق بن النديم

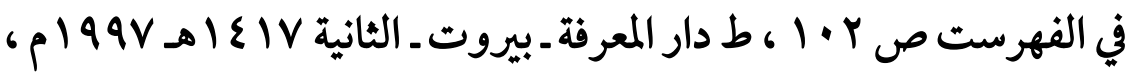
وإسماعيل بن محمد الباباني في إيضاح المكنون في الذيل على كشـف الظنون ץ/

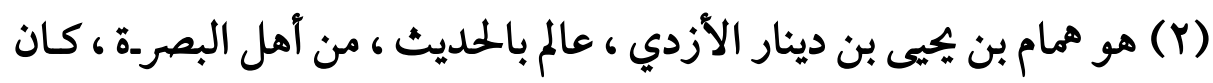

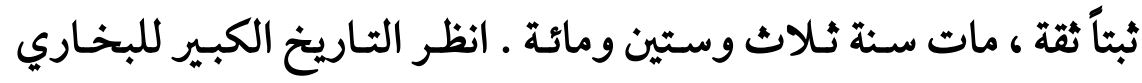

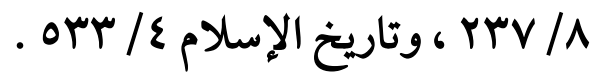

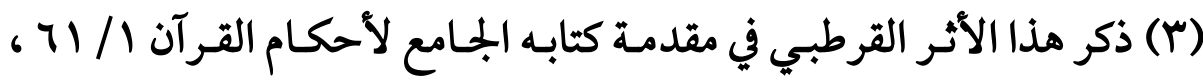

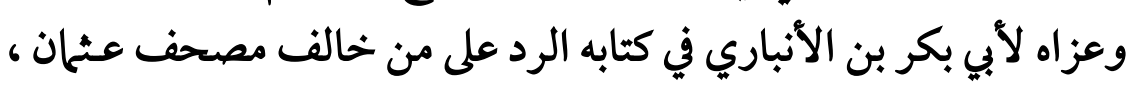
وذكر سند ابن الأنباري ، وهو سند صحيح موصول إلى قتادة . 
$(0 \leq r)$

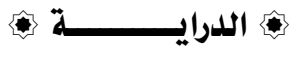

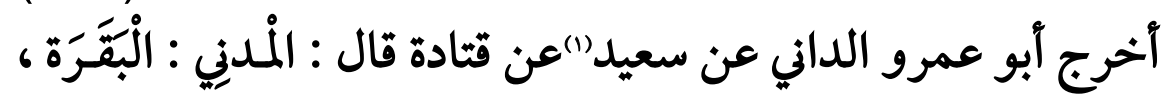

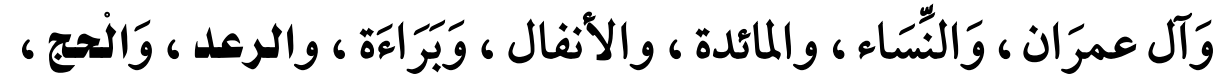

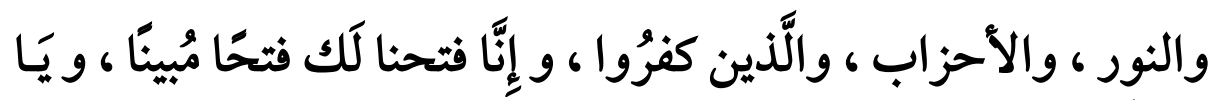

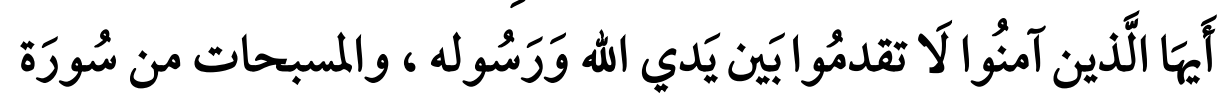

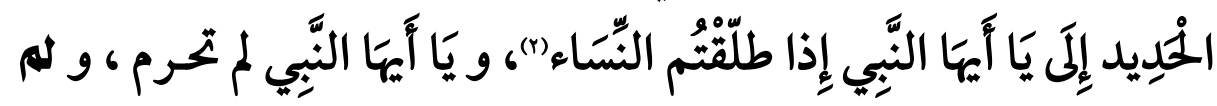

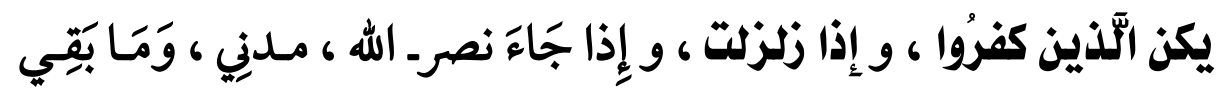

شواهد من هذه الروايات . ماته

إن الناظر في هذه الروايات يستطيع آن يقيم منها شواهد مداه بارزة تكون

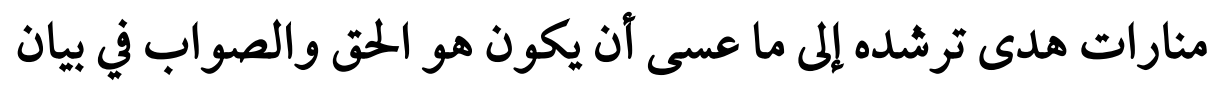

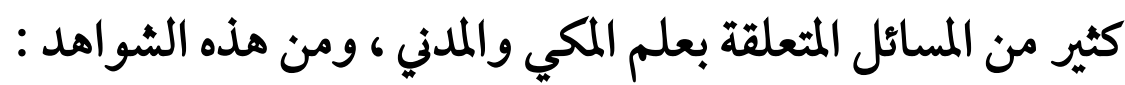

(1) هو سعيد بن أبي عَرُوبَة مِهْرَان اليشكري أبو النضر البصري ثقـة حـافظ لـه

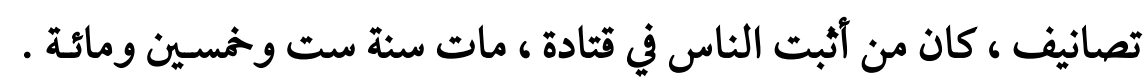

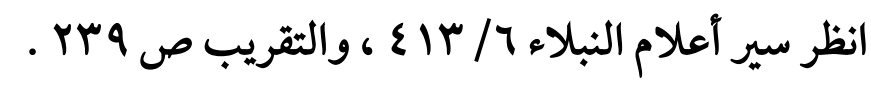

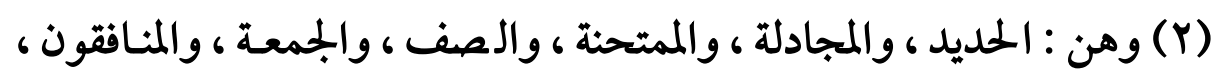

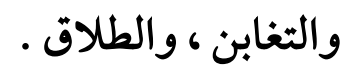

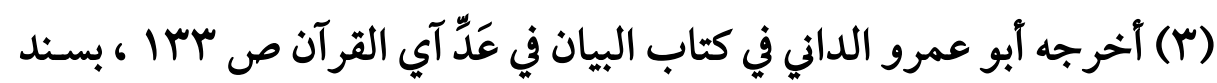
صحيح إلى قتادة . 


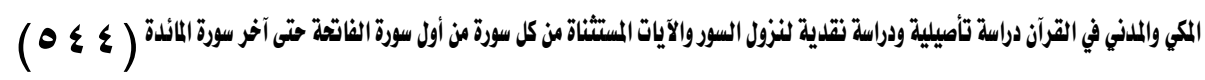

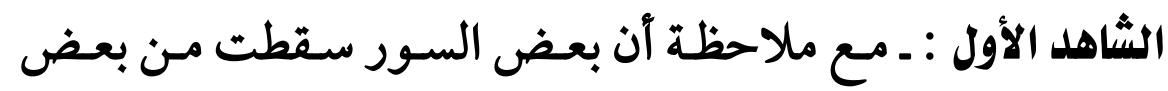

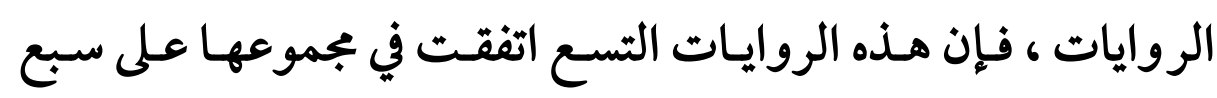
وسبعين سورة أنها سور مكية ، وهذه السور المتفق على مكيتها هي :

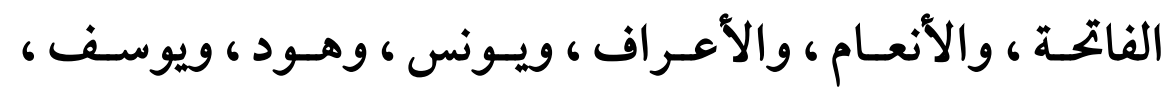

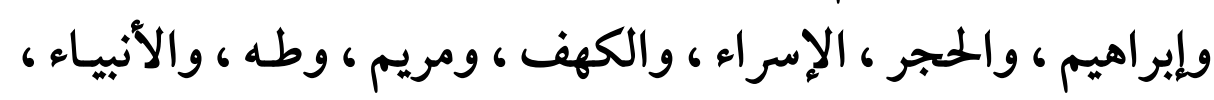

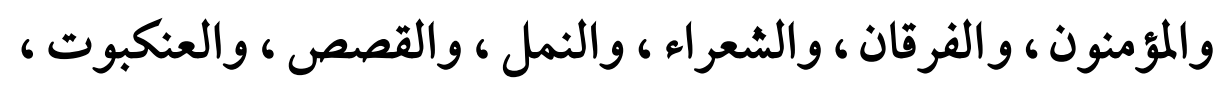

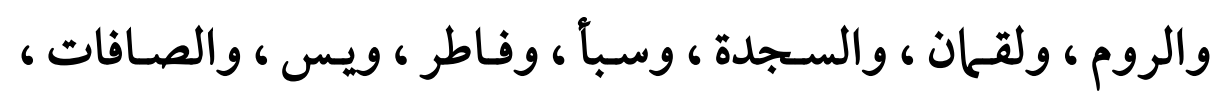

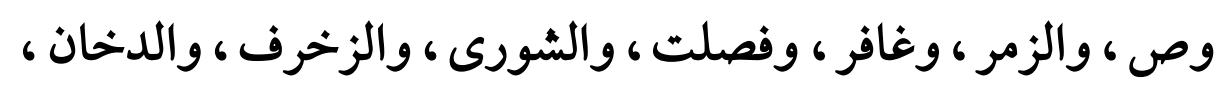

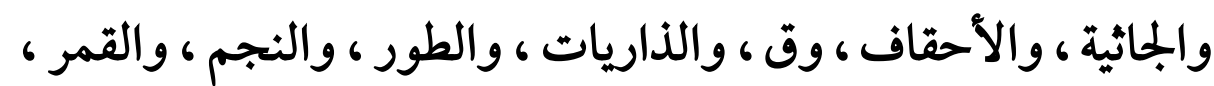

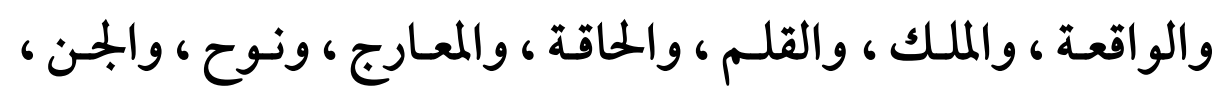

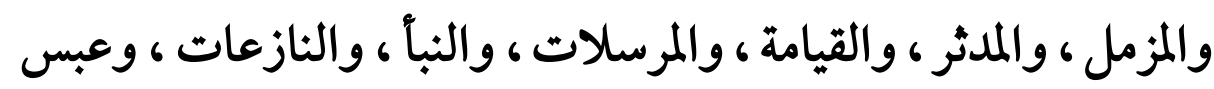

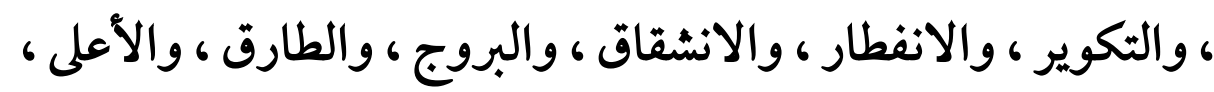

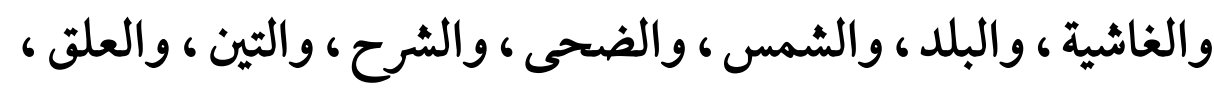

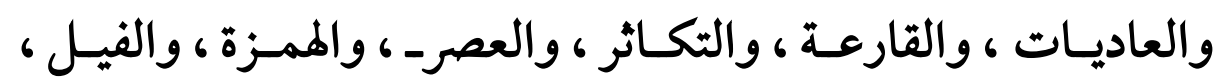

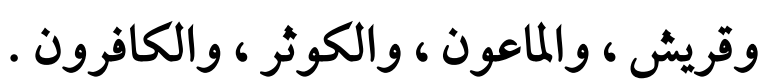

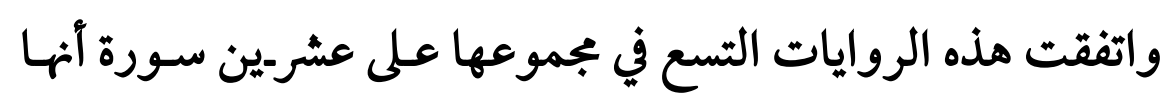
سور مدنية ، وهذه السور المتفق على مدنيتها هي :

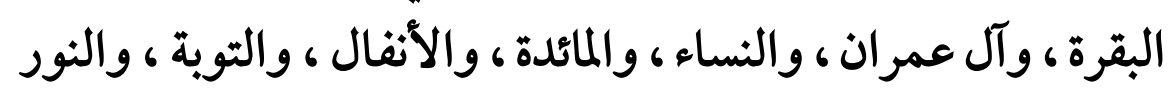

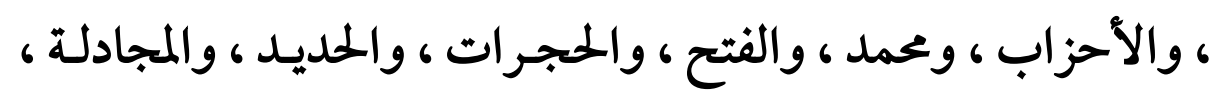


والحشر ، والممتحنة ، والجمعـة ، والمنافقون ، والطلاق ، والتحريم ،

والنصر.

واختلفت هذه الروايات التسع في سبع عشرة سورة وهي :

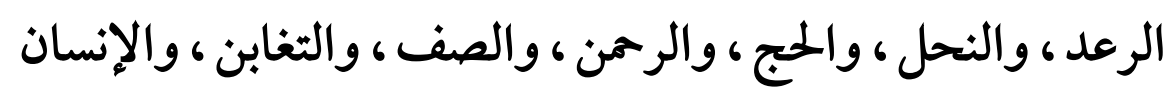

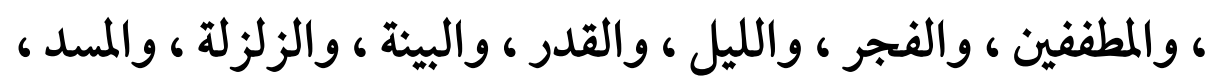
والإخلاص ، والفلق ، والناس .

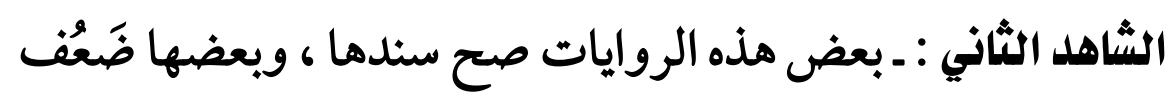
سندها .

فما صح منها آو ضعف واتفق في الحكم على بعض السور آنها مكية ، أو مدنية فهو حجة في نفسه ، وثبت به آن هذه السور مكية ، آو مدنية ،

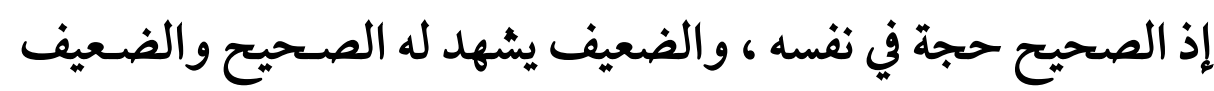
الآخر . إد الصحت. وما ضعف منها ، فإن اتفق في بعض السور مع الروايات الصحيحة

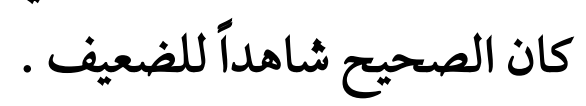
وإن اختلفت الروايات الضعيفة مع الصحيحة فالحجة للصحيحة .

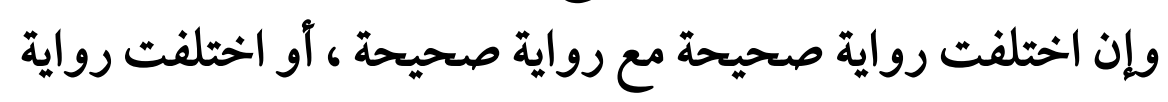

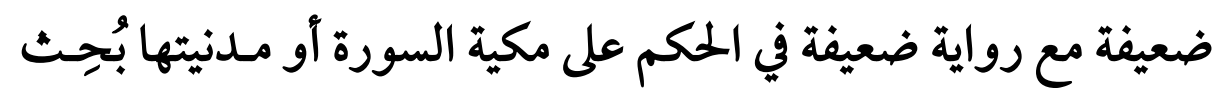
عن مرجح آخر. 


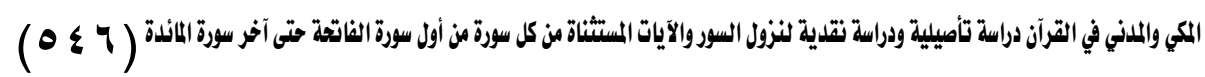
الشاهد الثالث : قَدَّمْتُ الروايات الأربـع الأولى في الذكر لأن فيها

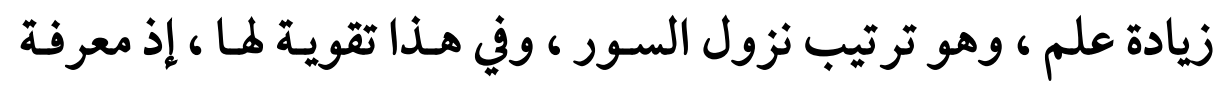

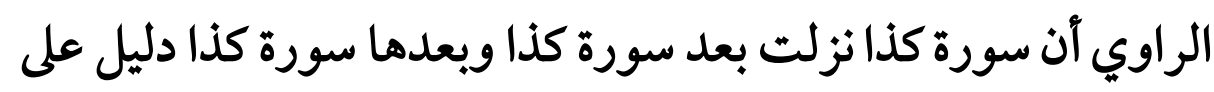

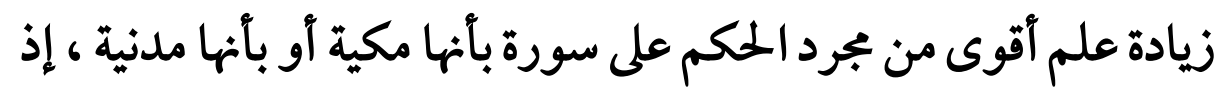

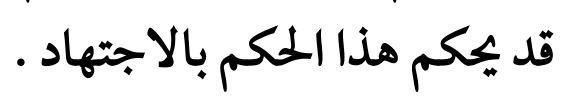




\section{المبحث الثاني}

ضوابط القرآن المكي وضوابط القرآن الملدني وخصائصهما

تقرر فيا سبق أن مرد العلم بالمكي والمدني إلى طريقين :

ا ـ سلاعي : وهو النقل والرواية ، والروايات في هذا المجال لم ترد

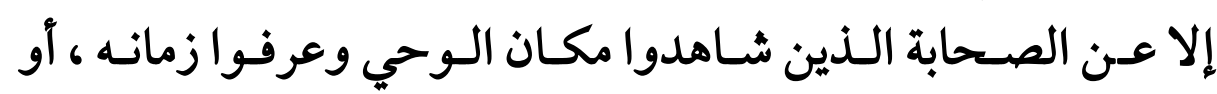

التابعين الذين سمعوا وصف ذلك وتفصيله من الصحابة ـ أما رسول

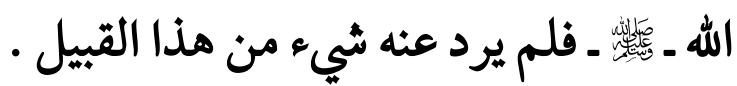

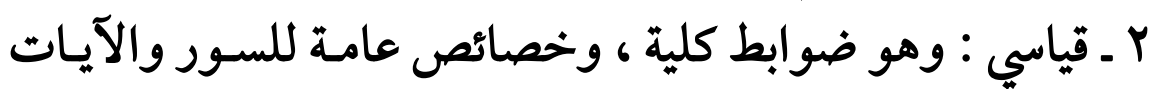

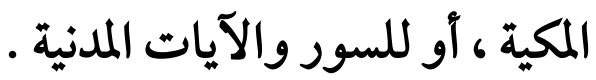

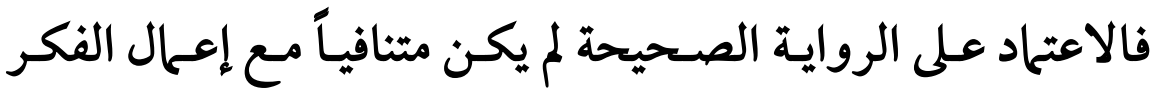

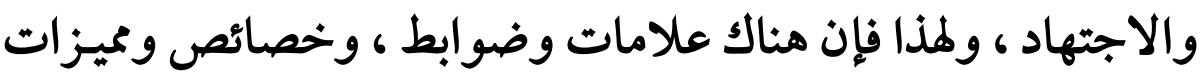

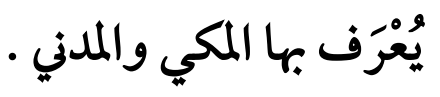

ونعني بالضوابط أموراً تتعلق بالألفاظ والآسلوب .

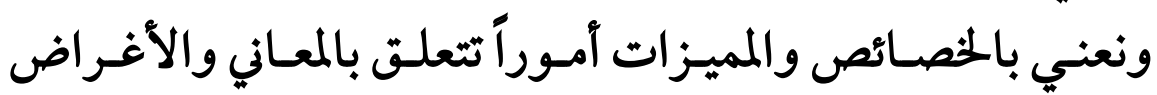

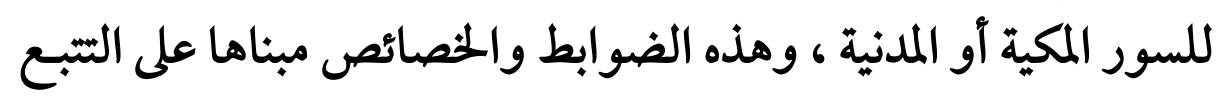

والاستقر اء للسور والآيات(1).

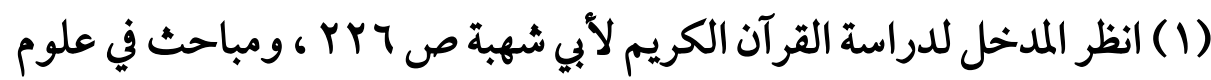

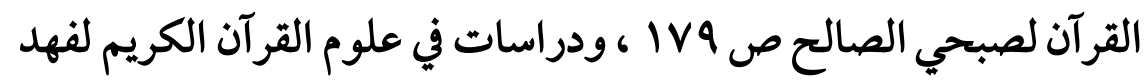

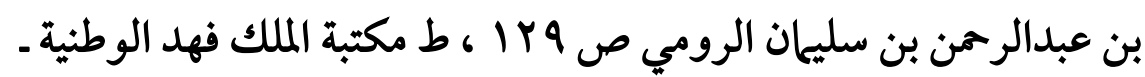

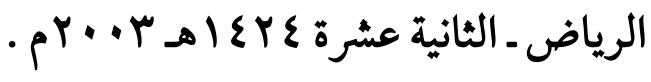




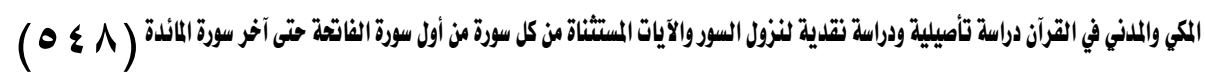
فقد استقر آ العلم)ء السور المكية ، والسور المدنية ، واستنبطوا ضوابط قياسية لكل من المكي والمدني ، واستنبطوا ـ كذلك ـ خصائص تميزت بهاء المبها

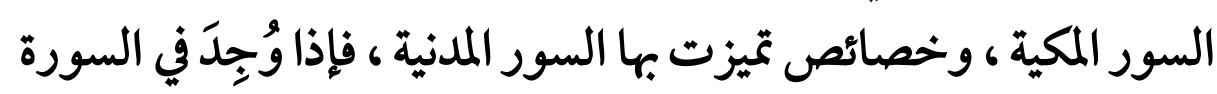

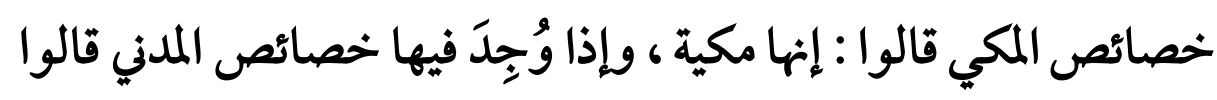

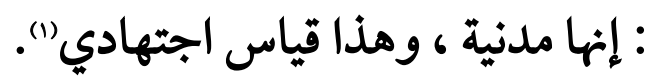

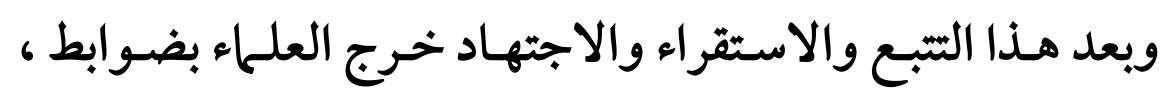
وبخصائص ميزة للسور المكية وللسور المدنية .

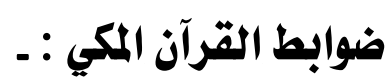
1 : ـ ـكل سورة فيها : (يا آيها النساس) وليس فيها : (يـآيها الذين

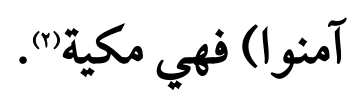
وإنها وضعوا هذا القيد ، أعني قولهم : وليس فيها : (يـآيها الذين

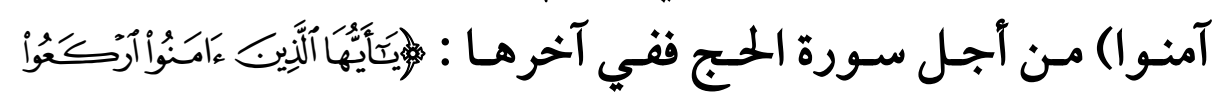

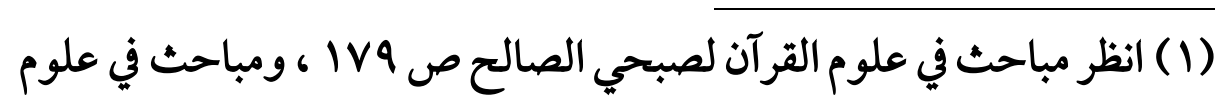

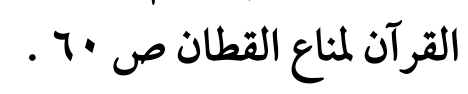

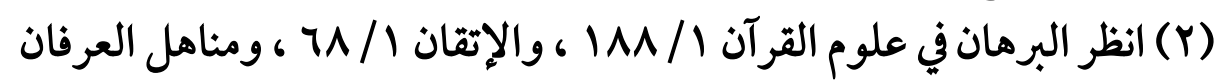

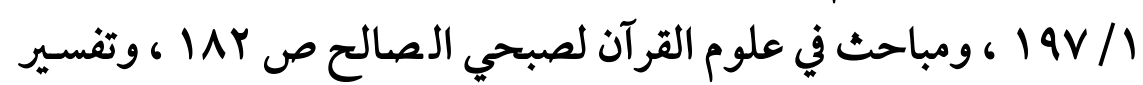

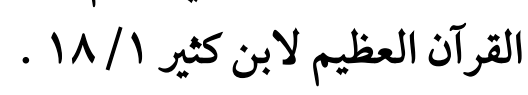




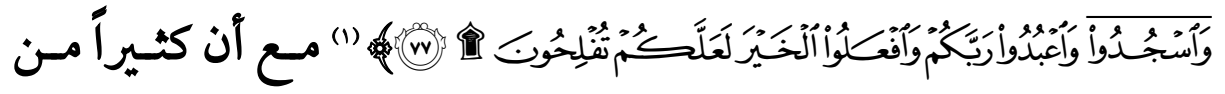
العلم)ء يرون أنها مكية (r)

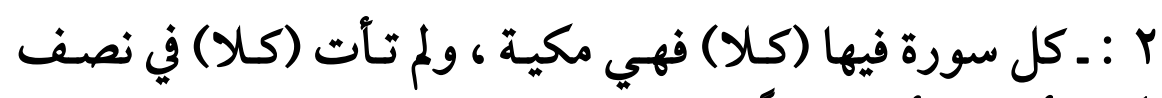

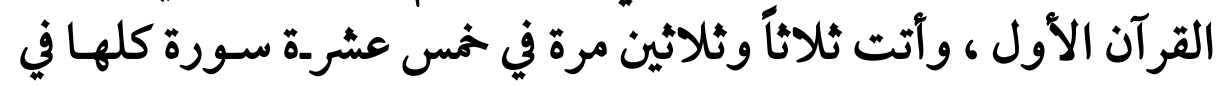

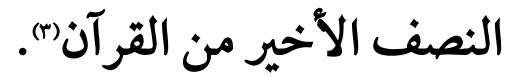

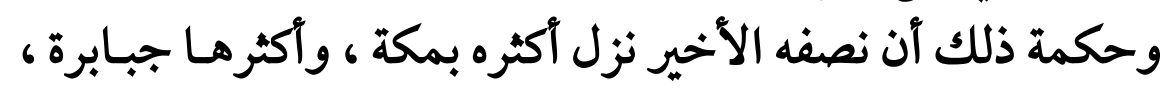

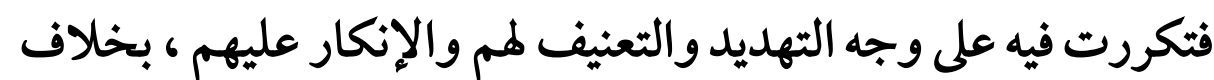

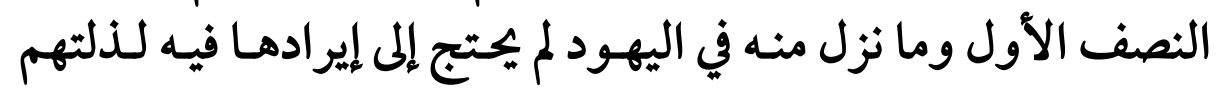
ץ : ـ كل سورة في أولما حروف التهجي فهي مكية سـوى سورة

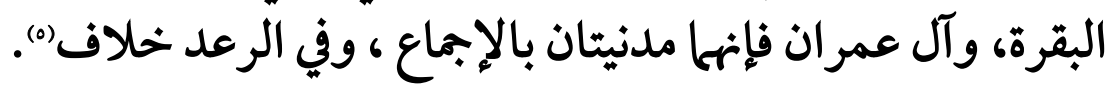

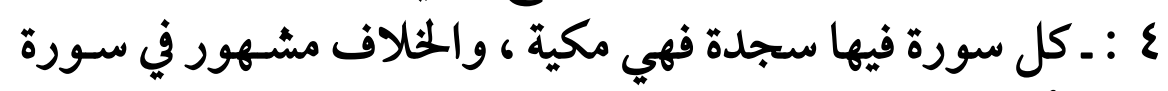
الحج مع أن فيها سجدتين آن

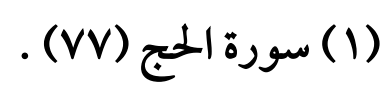

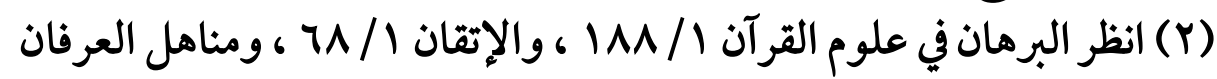

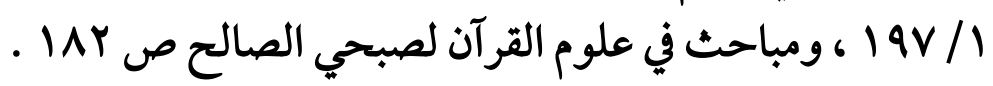

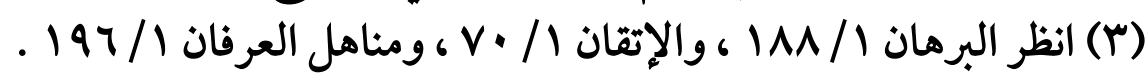

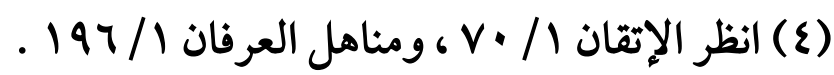

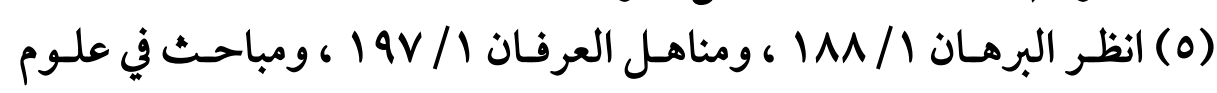

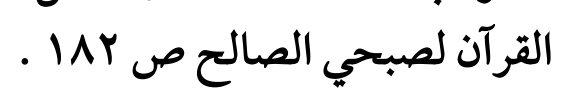

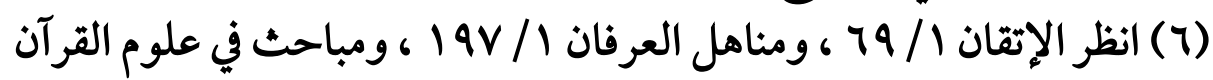

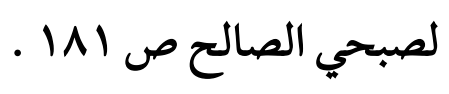




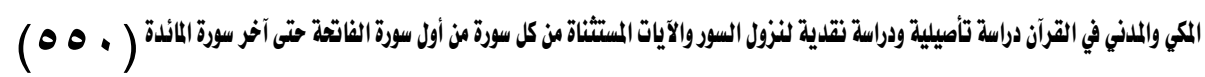

ه : ـقِصَر الآيـات والسـور ، وإيجازهـا وحرارة تعبيرهـا وتجانسها

الصوتي" (1).

وقِقَر معظم آيات القرآن المكي وسوره ـ ولا سيها آوائل ما نزل ــله

فائدتان :

الفائدة الأولى : ـ وهي فائدة ترجع إلى كفار مكة ، وأكثر أهلها يومئذ

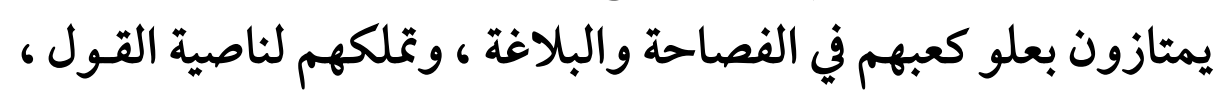

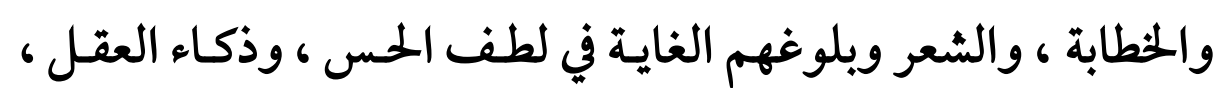

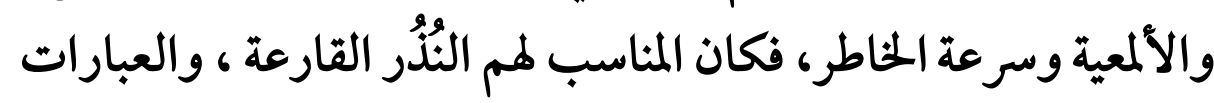

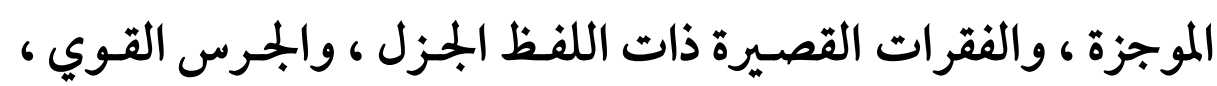
والمعنى الفحل فتصخ الآذان وتستولي على المشاعر وتعقل ألسنتهم عن ون

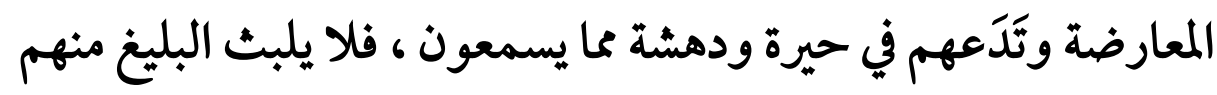

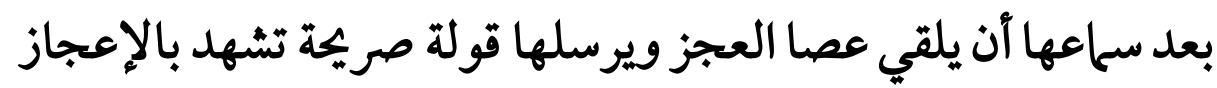

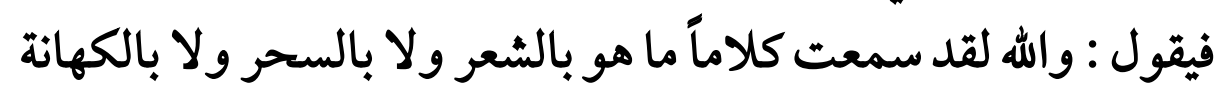

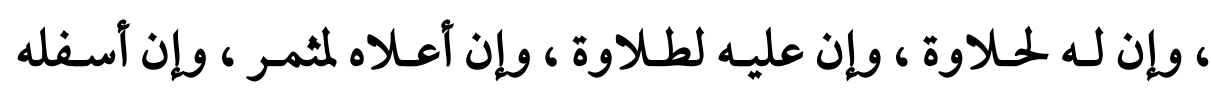
لمغدق ، وما هو بقول بشر، وإنه ليعلو ولا يُعْلى ، وإنه ليحطم ما تحته (r).

(1) انظر المدخل لدراسة القرآن الكريم ص وY Y ، ومباحثث في علوم القرآن

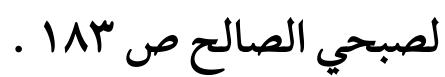

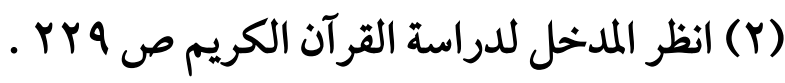


(001)

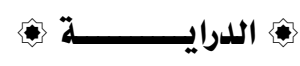

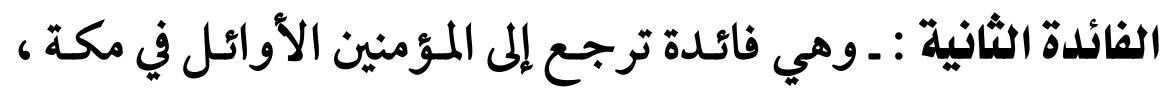

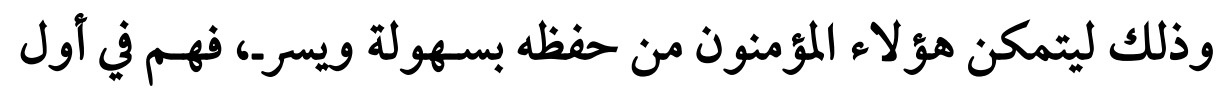

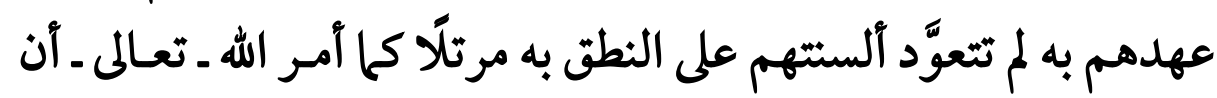

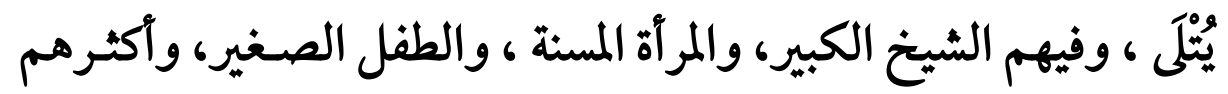

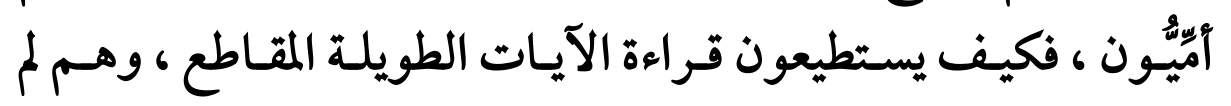

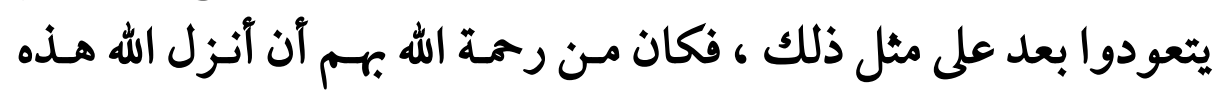
السور القصيرة في آيتها ومقاطعها ليتمكنوا من حفظها وتلاونتها في يسر

ونشاط"). (").

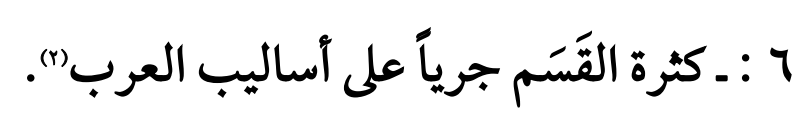

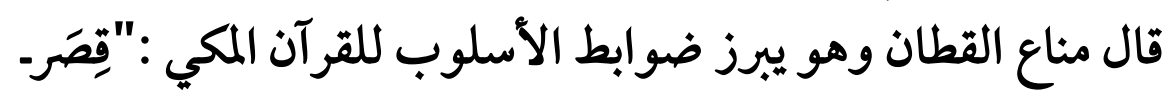

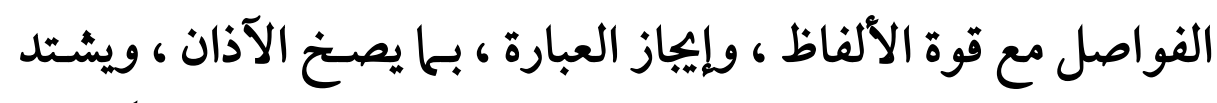

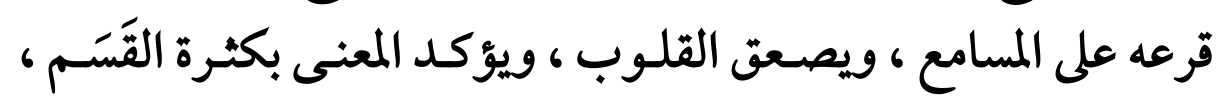

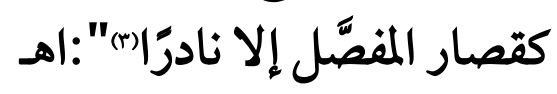

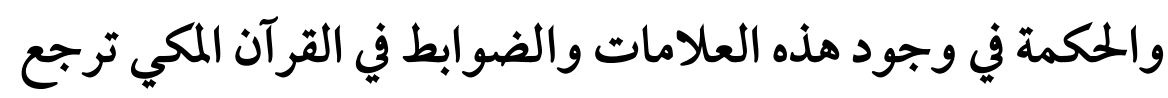

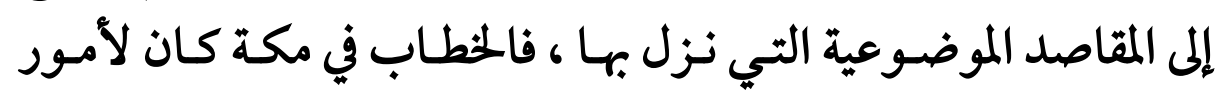

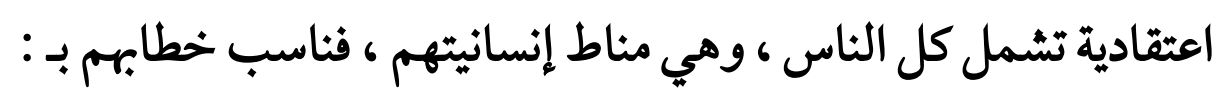

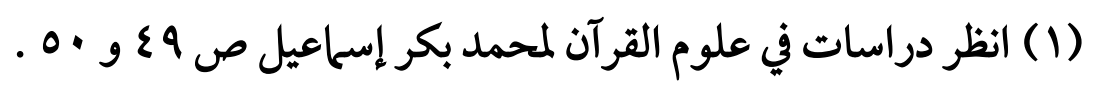

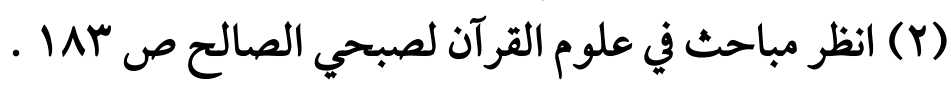

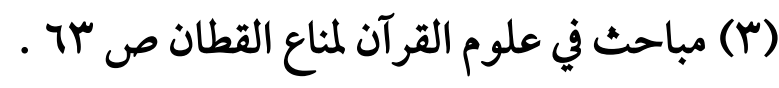




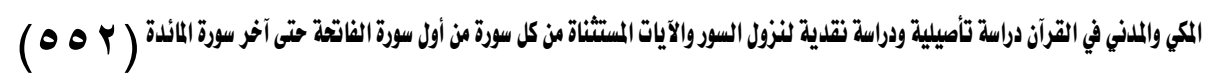

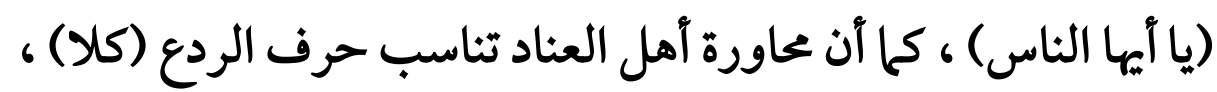

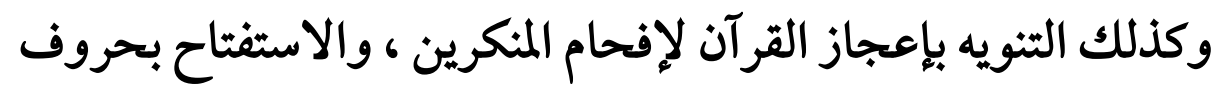

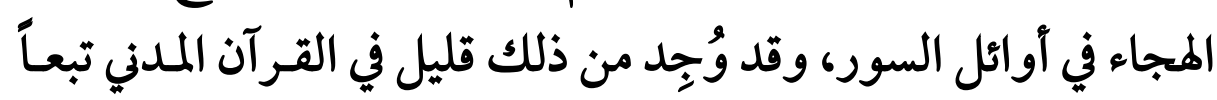

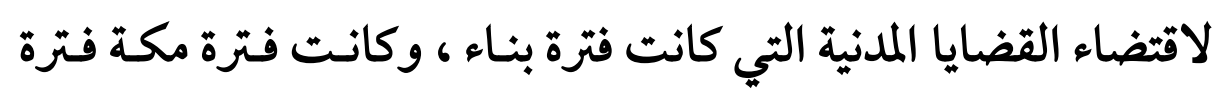
تأسيس (1).

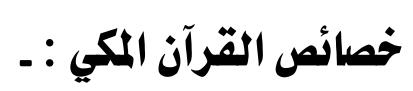

قد امتاز القرآن المكي غير ما تقدم من الضوابط الهُ بأمور كثرت فيه ،

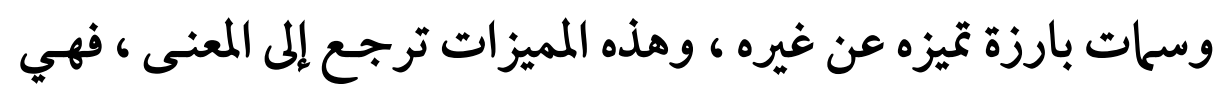

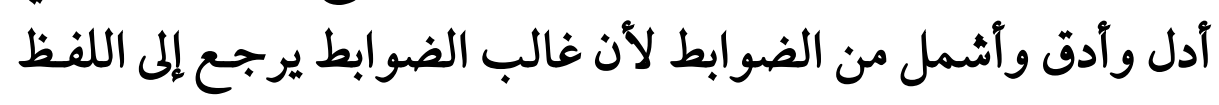

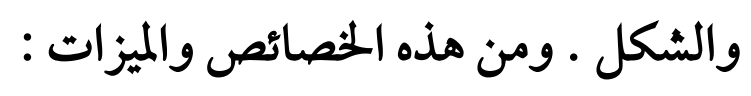

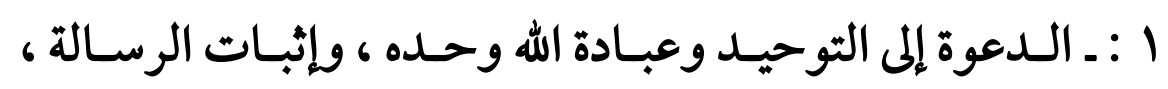

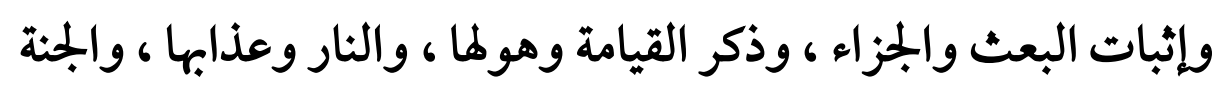

ونعيمها ، ومجادلة المشركين بالبراهين العقلية ، والآيات الكونية) و(r).

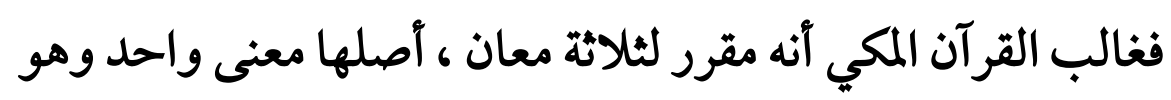

$$
\text { الدعاء إلى عبادة الله ـ تعالى ـ : }
$$

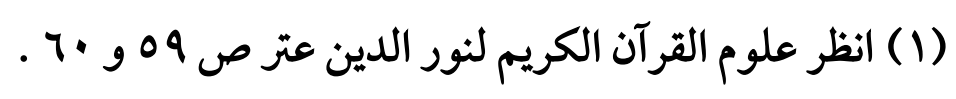

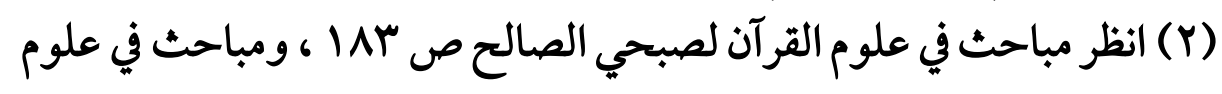

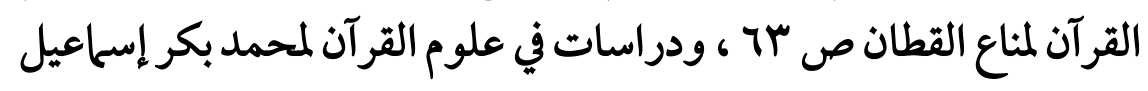


أحدها : تقرير الوحدانية لله الواحد الحق ، غير آنه يأتي على وجوه ؛ كنفي

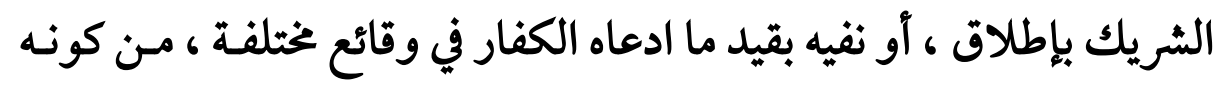

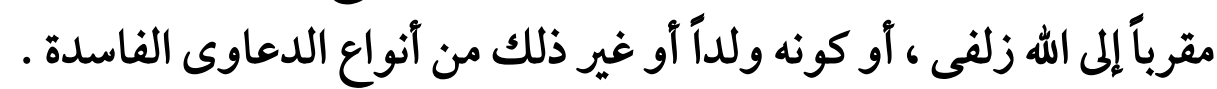

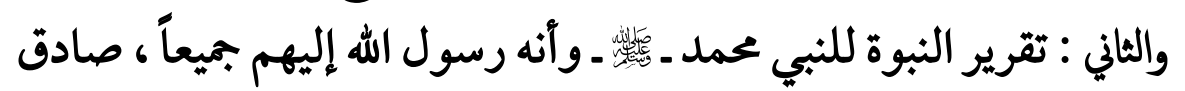

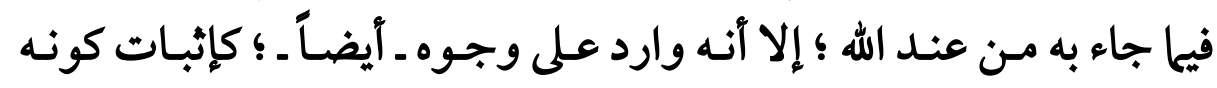

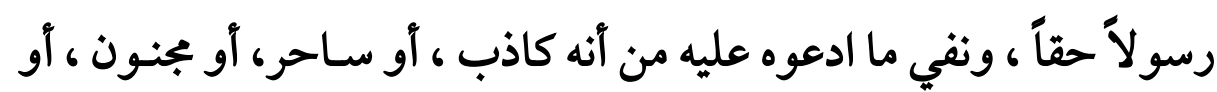

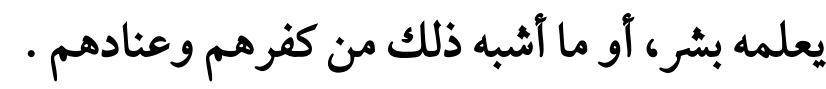

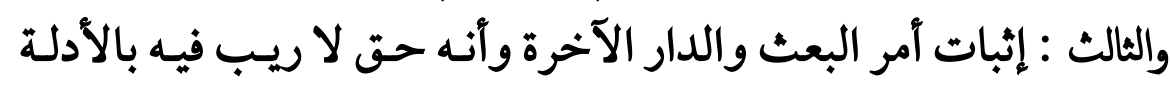

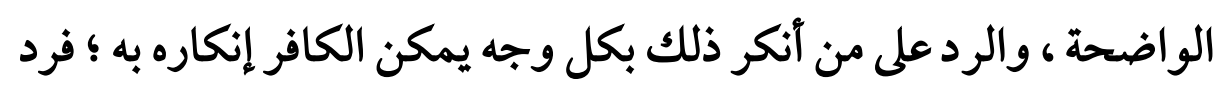

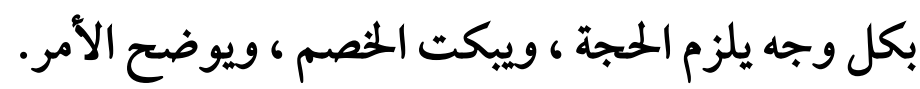

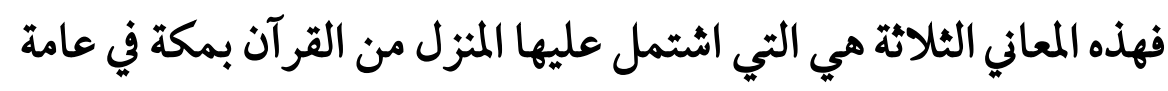

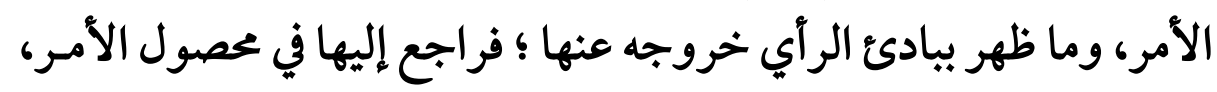

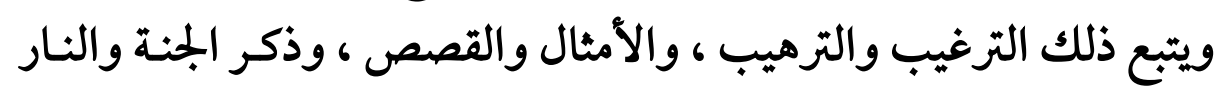
ووصف يوم القيامة وأشباه ذلك والث

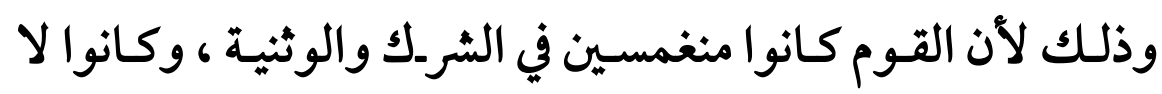
يقرون بالنبوات ، ولا بالبعث وما بعده ، ويقولون : إن هي إلا حياتنا

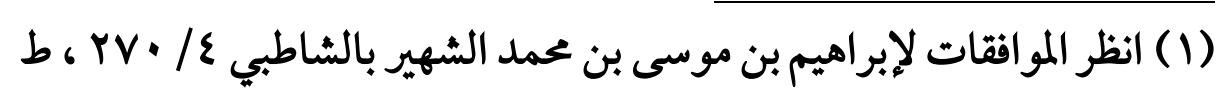

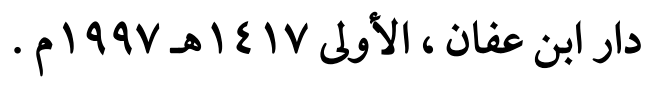




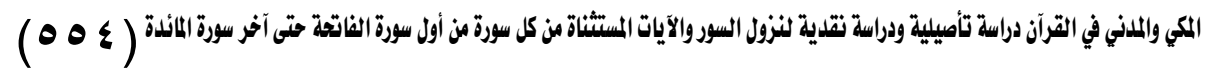
الدنيا نموت ونحيا وما نحن بمبعوثين ، فكان اللائق بحالمم دعوتهم

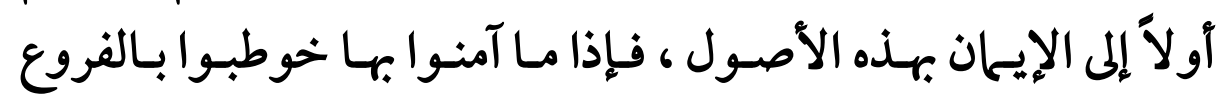
والتشريعات التفصيلية").

ولا يعني ذلك أن القرآن المدني يخلو من الحديث الحيث عن العقيدة ، وإنما

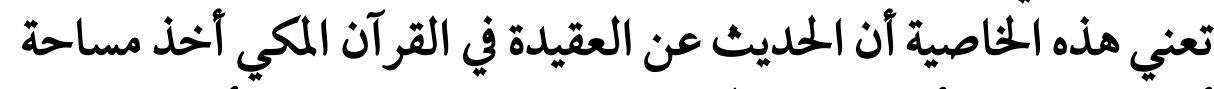

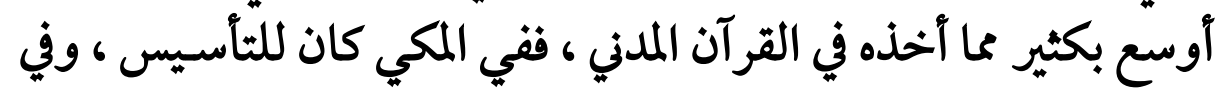

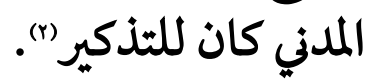

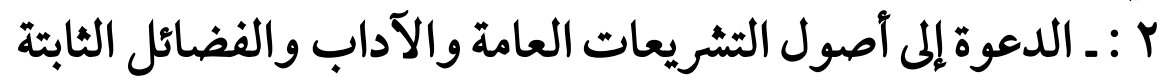

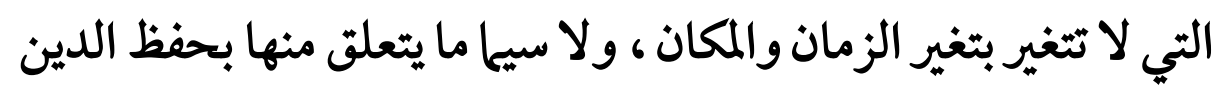

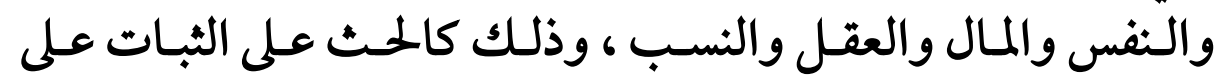

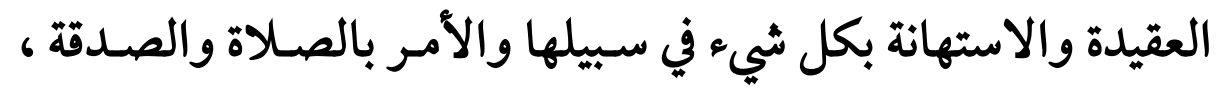

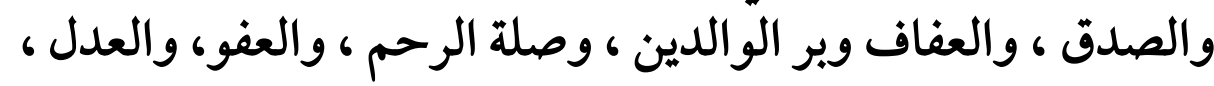

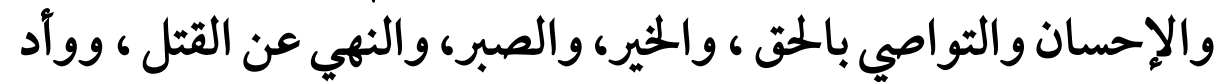

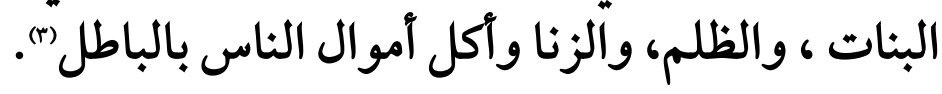

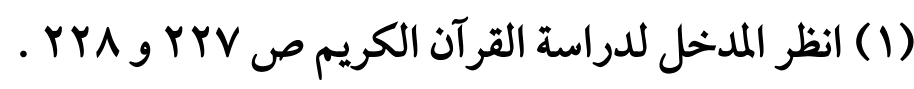

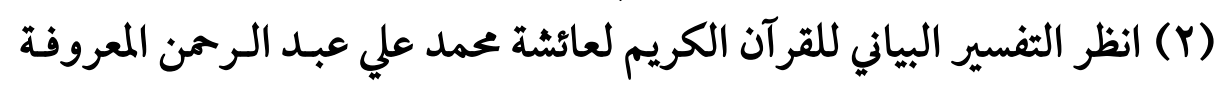

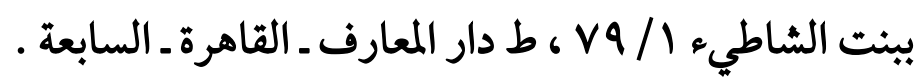

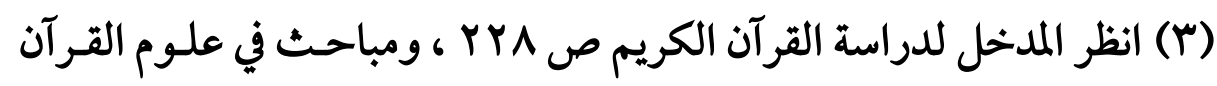

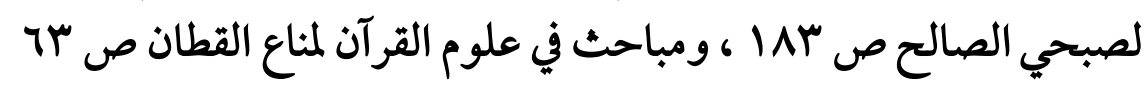

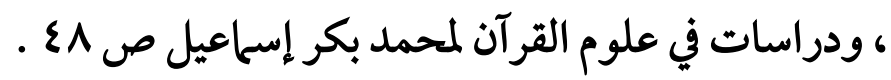


(000)

r : ـ ـ ولتبيت هذه الأصول والمعتقدات الصحيحة في قلوب الناس

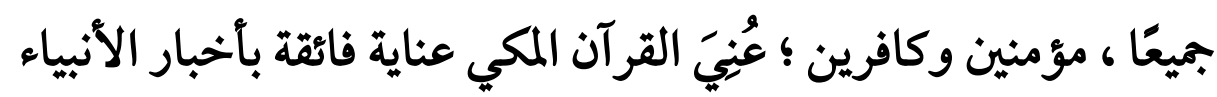

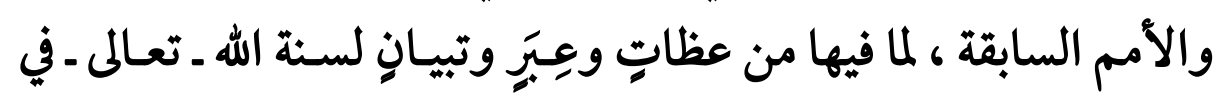

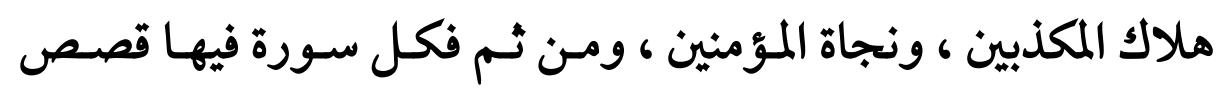

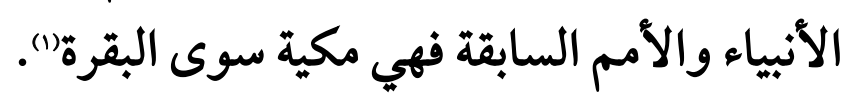

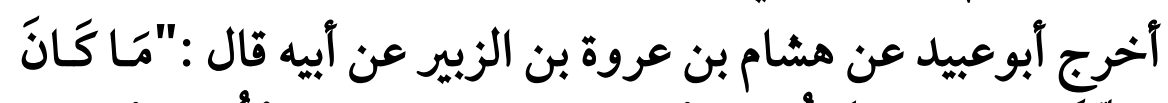

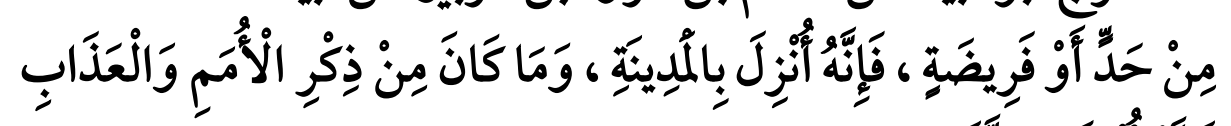

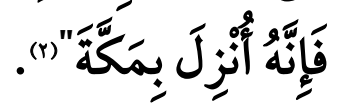

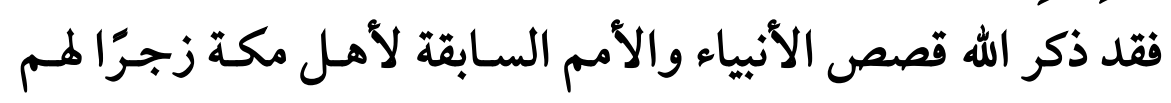

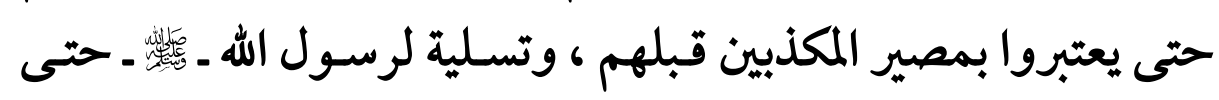

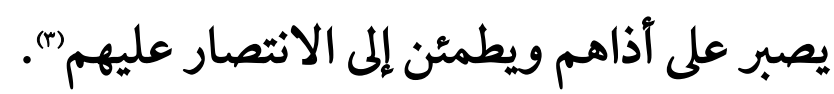

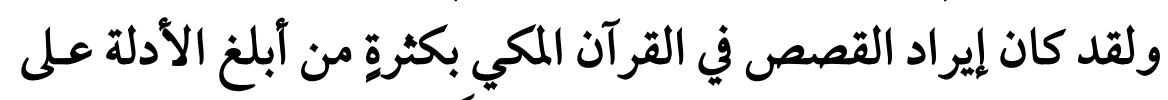

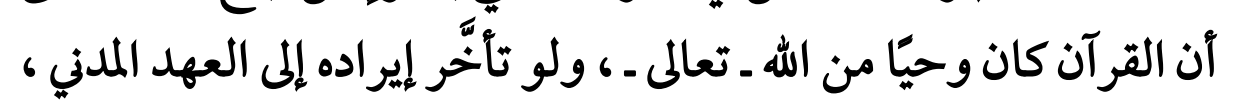

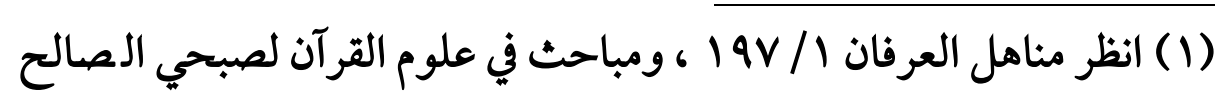

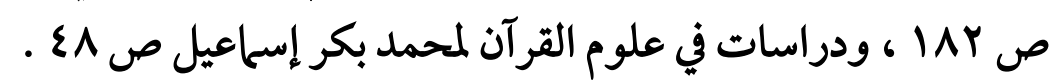

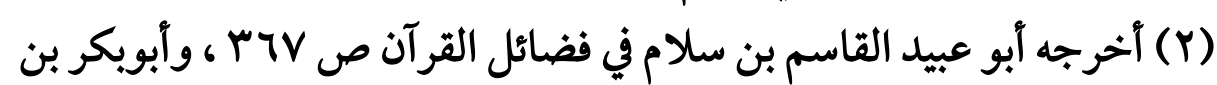

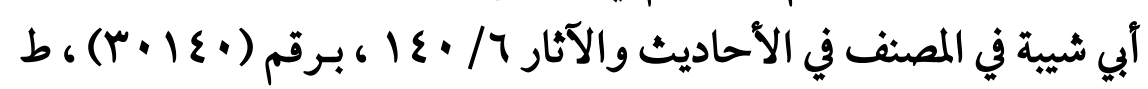

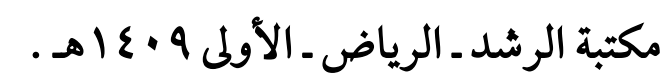

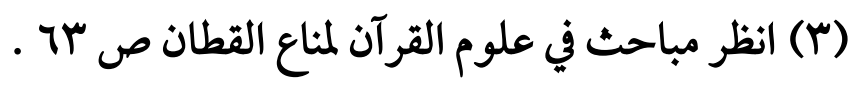




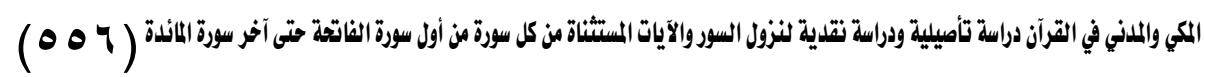

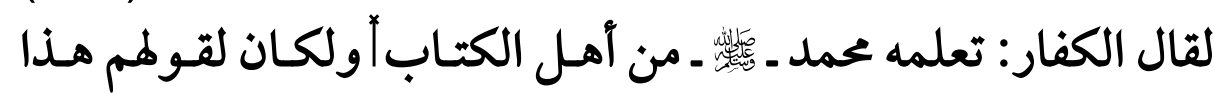

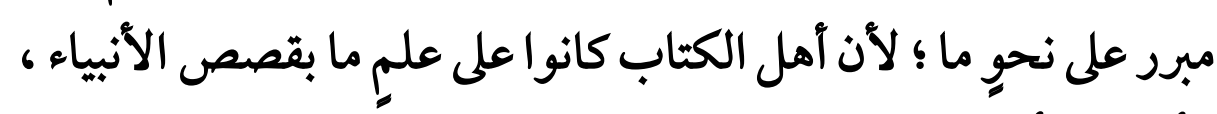

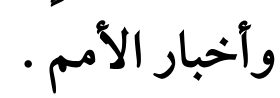

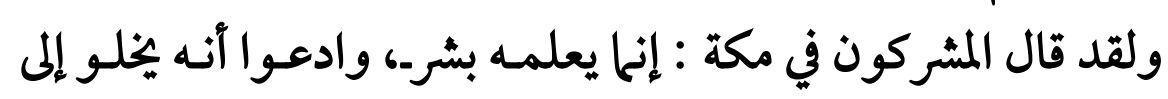

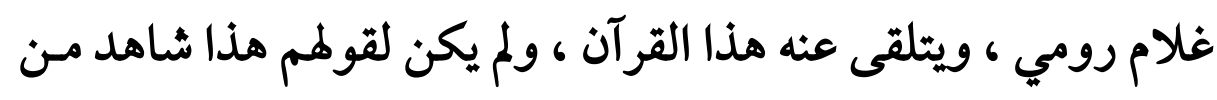

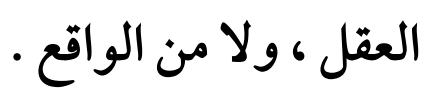

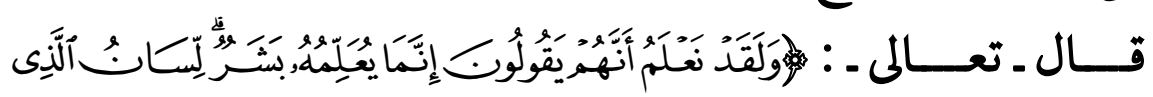

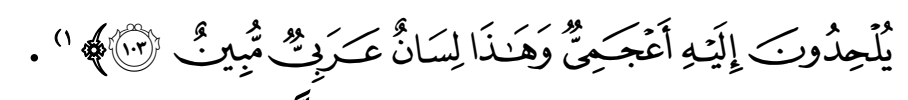

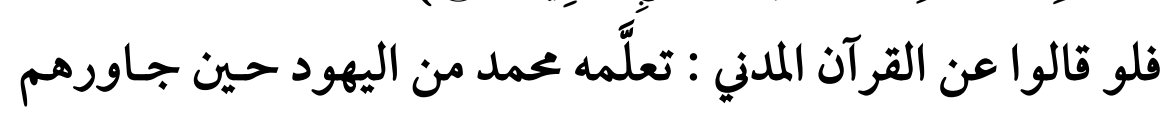

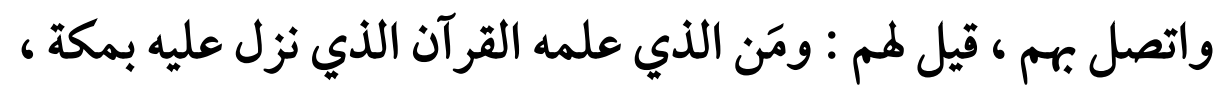

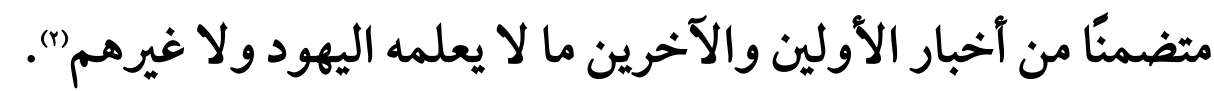

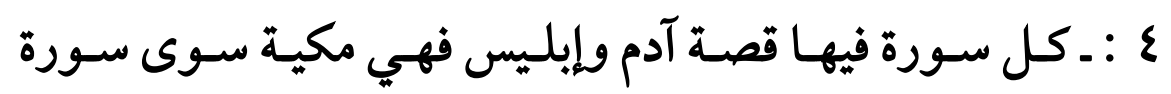

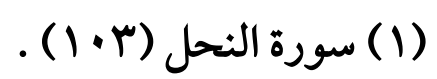

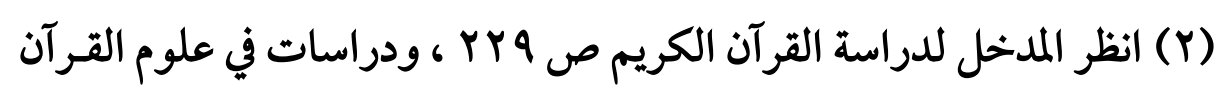

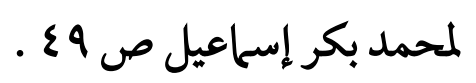

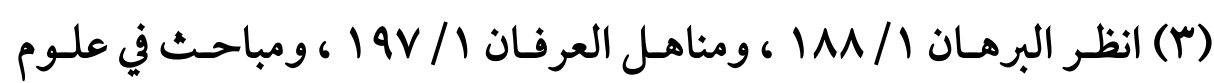

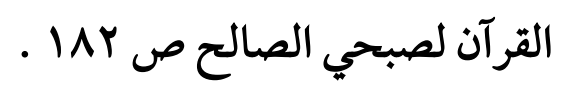


$(\Delta \Delta V)$

قال مناع القطان ـ بجملاً الطابع العام للقرآن المكي ـ :"فحيـث كان القوم في جاهلية تُعْمِى وتُصِسم ، يعبدون الأوثنان ، ويشر.كون بـالله 6

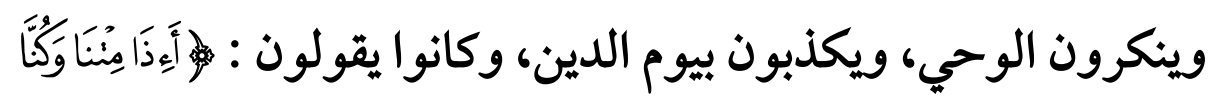

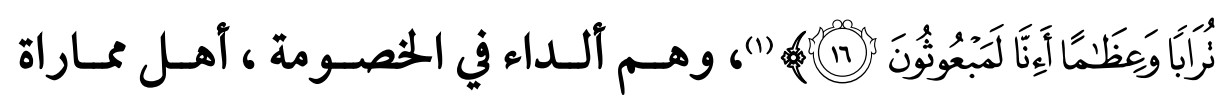
وبلاجة في القول عن فصـاحة وبيـان ؛ حيـث كـان القـوم كذلك نزل الوحي المكي قوارع زاجرة ، وشهبًا منذرة ، وحججَا قاطعة ، يحطم وثنيتهم في العقيدة ، ويدعوهم إلى توحيد الألوهية والربوبية ، ويهتك

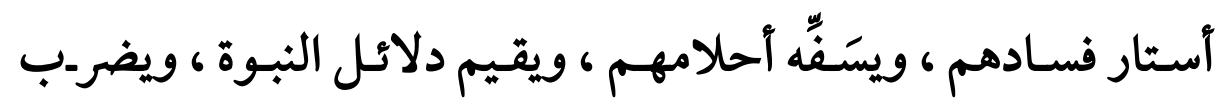

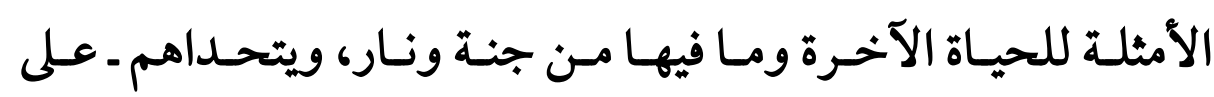
فصاحتهم ـ بأن يأتوا بمثل القـرآن ، ويسـوق إليهم قصص المكذبين

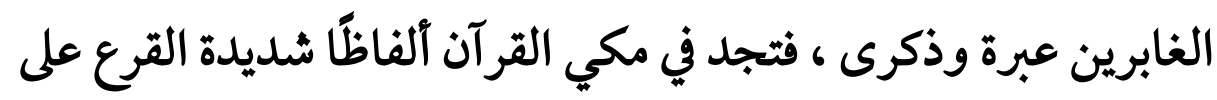

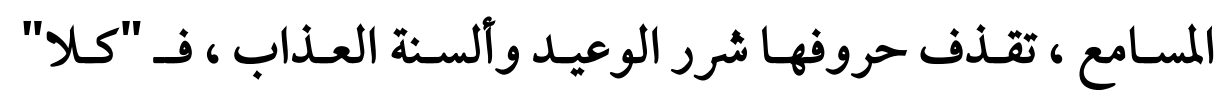
الرادعة الزاجرة ، والصاخة والقارعة ، والغاشية والواقعـة ، وألفـاظ المجـاء في فواتح السـور، وآيـات التحـدي في ثناياهـا ، ومصـير الأمـم السابقة ، وإقامة الأدلة الكونية ، والبراهين العقلية(r)":اهـ

$$
\text { (1) (1) سورة الصافات (17) ماحث (1) . }
$$

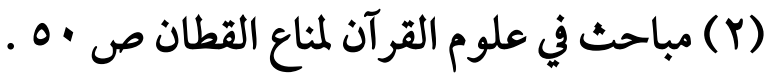




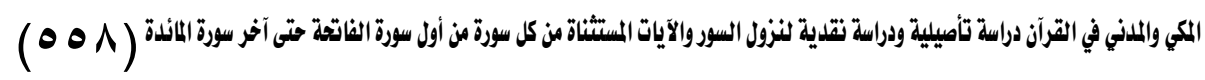
ضوابط القرآن الملدني : .

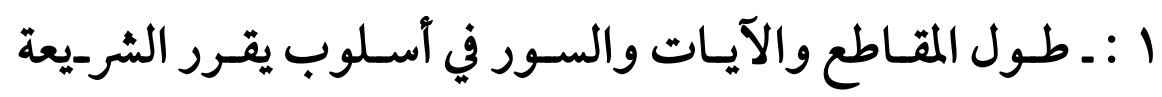
ويوضح أهدافها ومراميها") وهذا يصور الخطى الحكيمة المثدرجة التي كان يخطوها الإسـام فئي

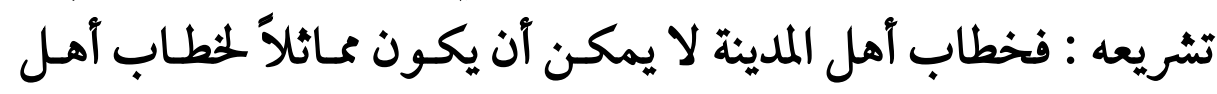

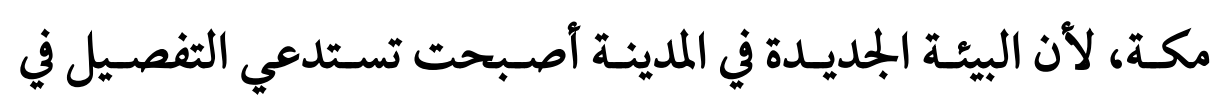

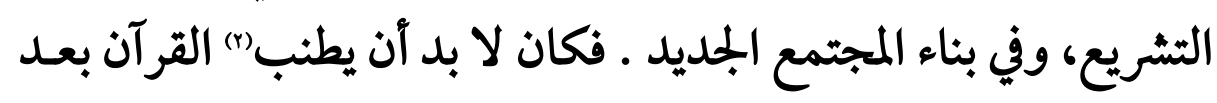

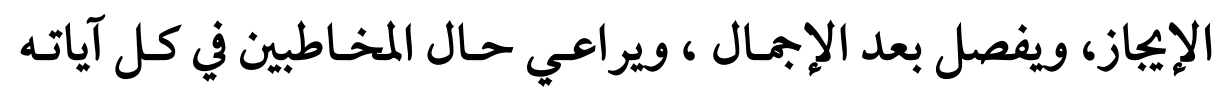

$$
\text { وسوره") }
$$

أضف إلى ذلك أن أهل المدينة لم يكونوا في درجة أهل مكة في البلاغة

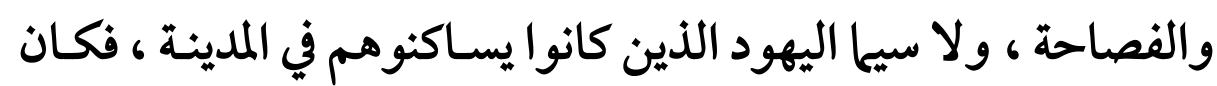

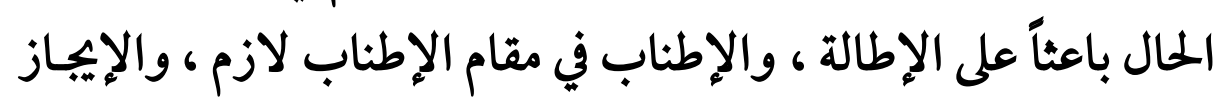

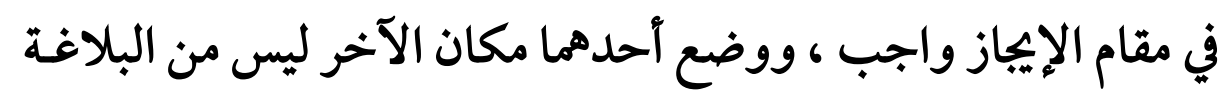

(1) انظر مباحث في علوم القرآن لصبحي الصالح ص س 1 I ، ومباحث في علوم

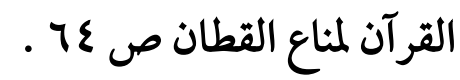

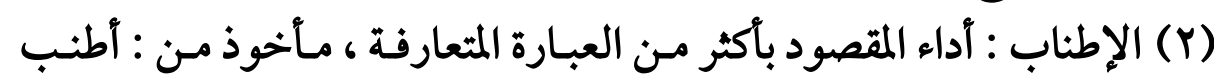

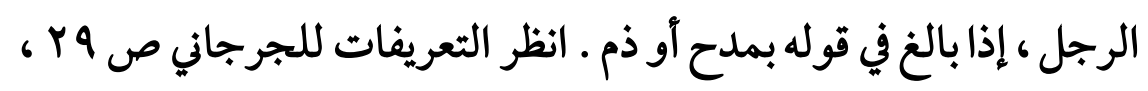

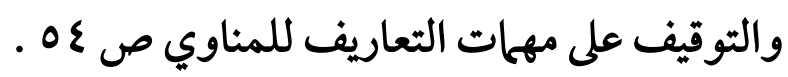

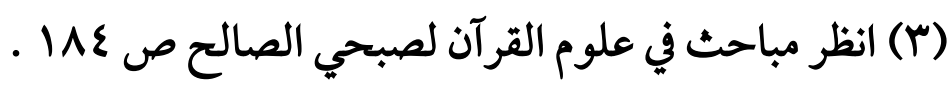


في شيء ، وقد سلك القرآن كلتا الطريقتين مـع كونه في أعلى درجات

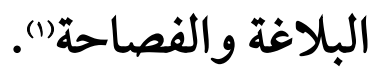

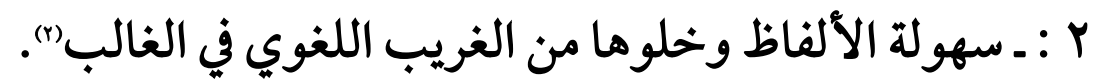

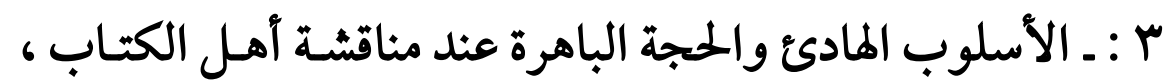

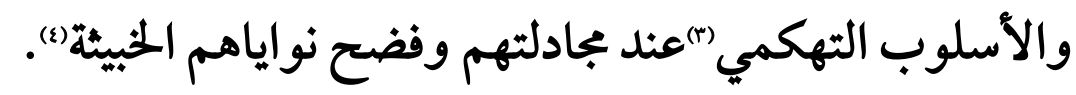
خصائص القرآن المدني : - مئل ا : ـ ذكر الفرائض والثشريعات الماتئ : الثفصيلية والألحكام العملية في العبادات والمعاملات والأحوال الشخصية).

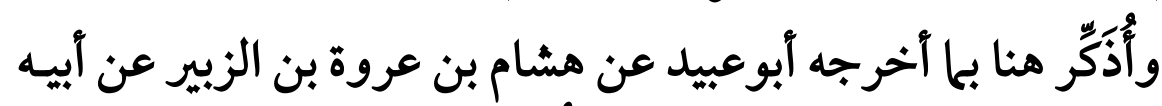

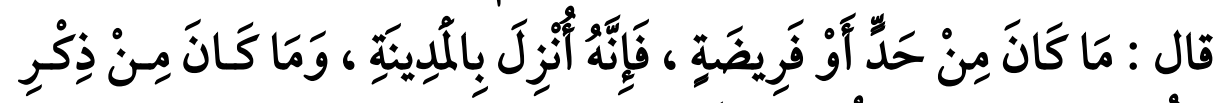

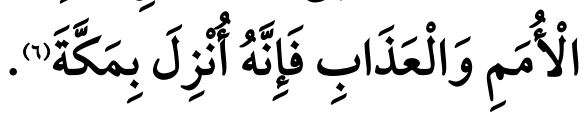

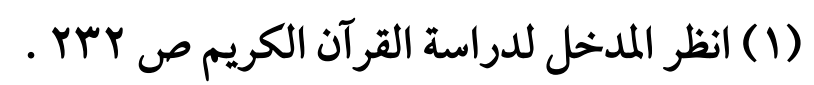

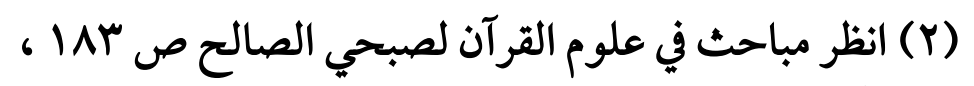

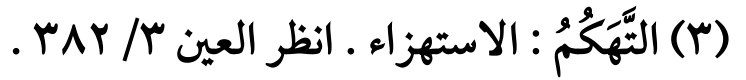

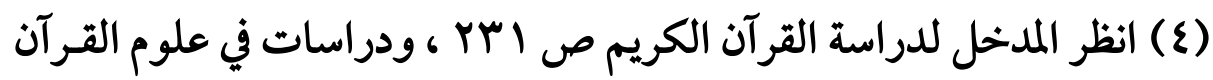

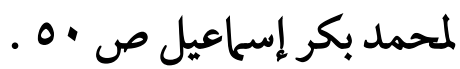

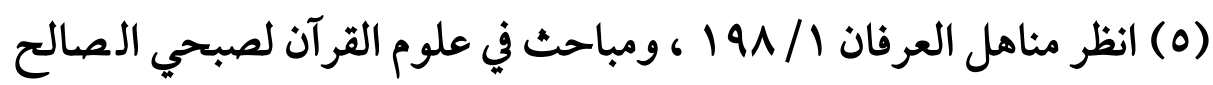

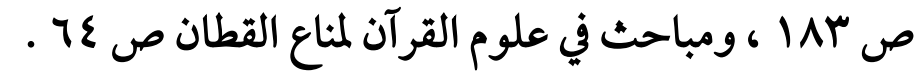

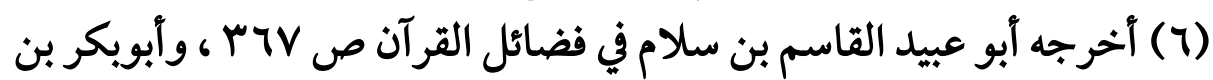

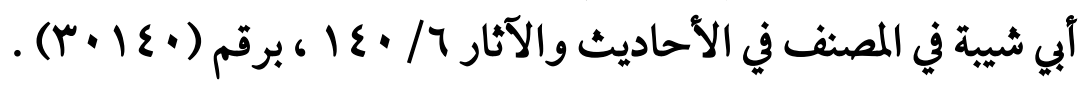




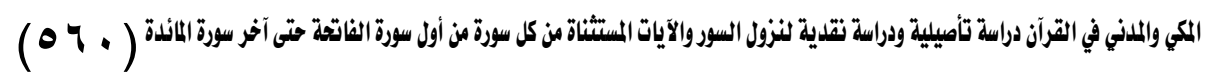
وذلك لأن حياة المسلمين في المدينة بدأت في الاستقرار ، وأصبح لهم كيان ودولة وسلطان ، ومن شأن الجماعة التي لما رابطة تربطها أن تكون

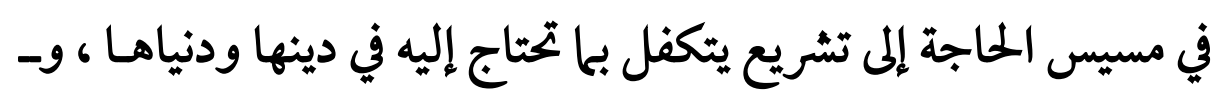

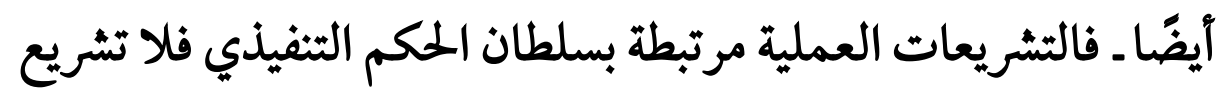

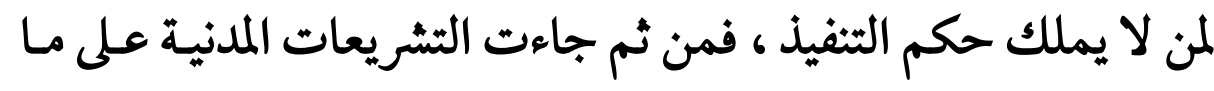
ذكرنا')

قال شيخ الإسلام ابن تيمية :"أما السور المدنية ففيها الخطاب لمن

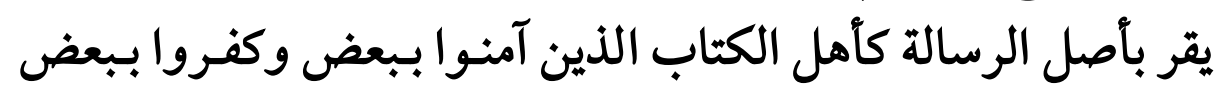

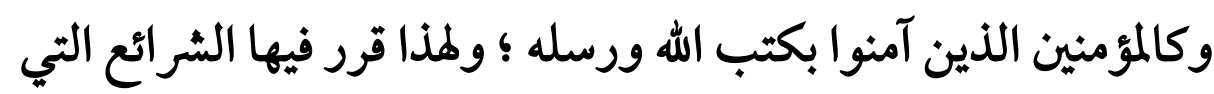

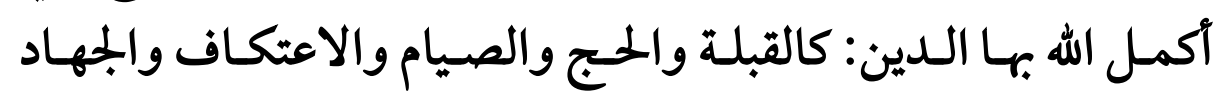

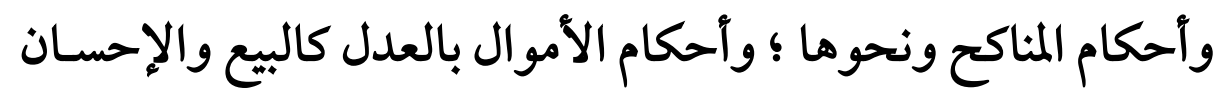

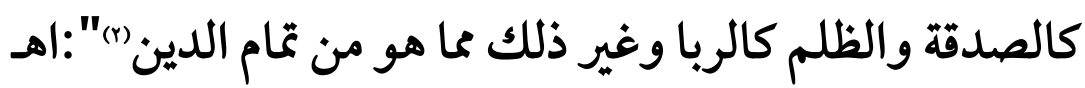

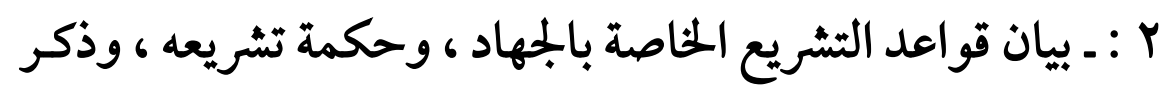
الأحكام المتعلقة بالحروب والغزوات والمدئ والمعاهدات والصـلح والغنائم

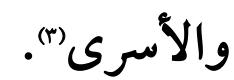

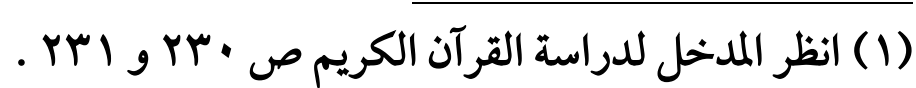

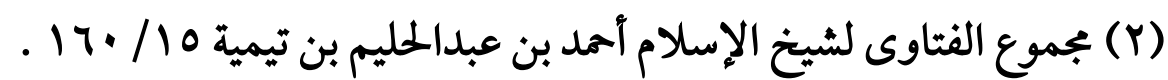

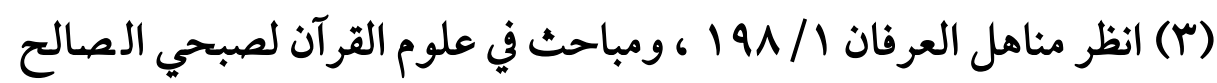

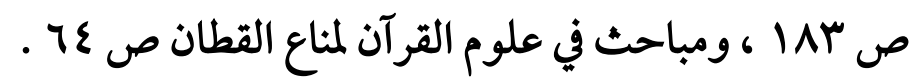


(071)

ץ : ـ دعـوة أهـل الكتـاب إلى الإسـلام ، ومناقشـتهم في عقائـدهم

الباطلة، وبيان ضلالفم فيها")

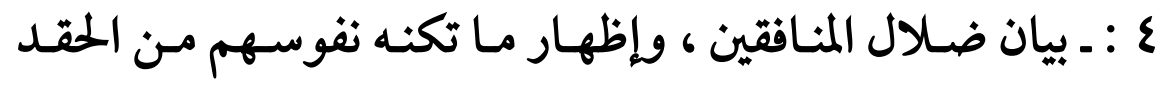

والعداوة على الإسلام والمسلمين (r).

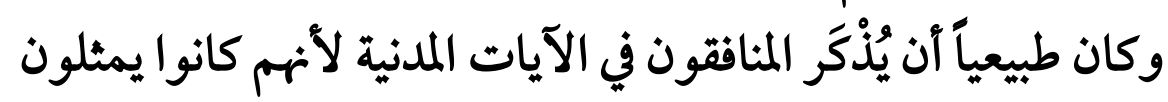

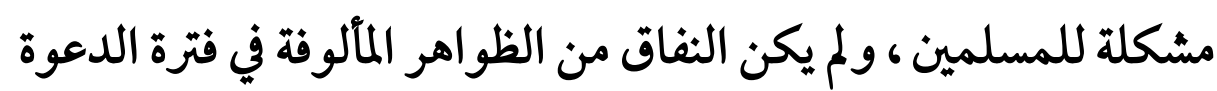

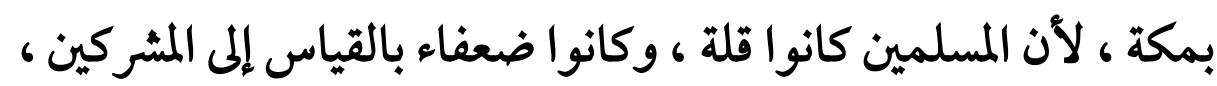

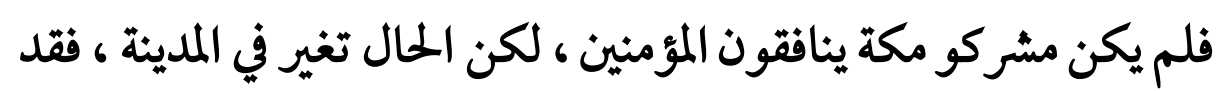

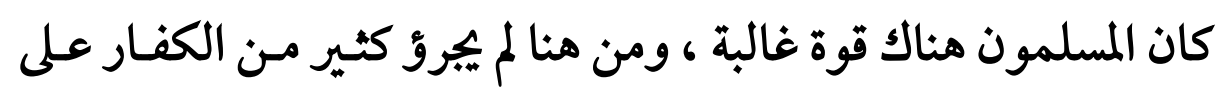
معارضتهم معارضة صريحة ، فلجئو إلى النفاق (r).

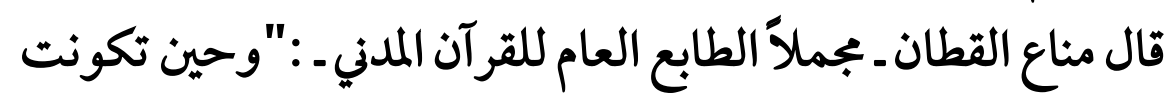
الجماعة المؤمنة بالله وملائكته وكتبه ورسله واليوم الآخر وبالقدر خيره

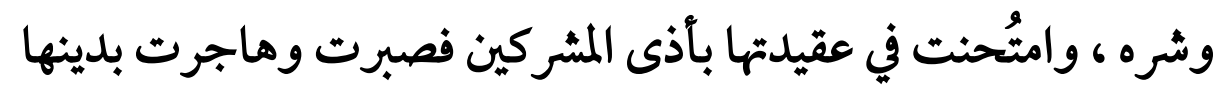

(1) انظر مباحث في علوم القرآن لصبحي الصالح ص س ا I ، ومباحث في علوم

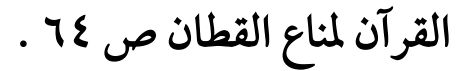

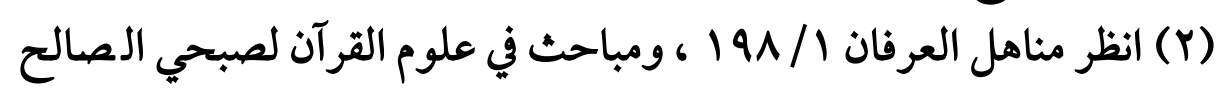

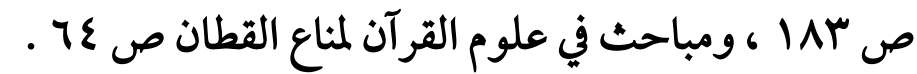

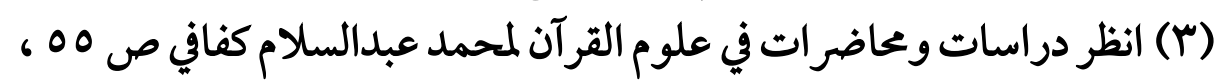

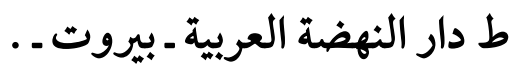




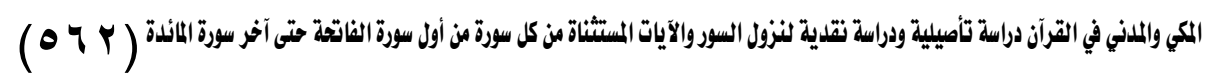

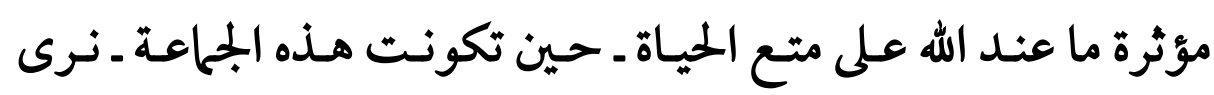

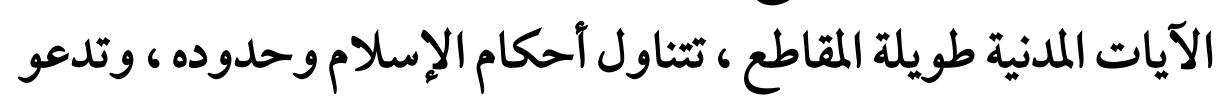
إلى الجمهاد والاستشهاد في سبيل الله ، وتفصل أصول التشريع ، وتضـع

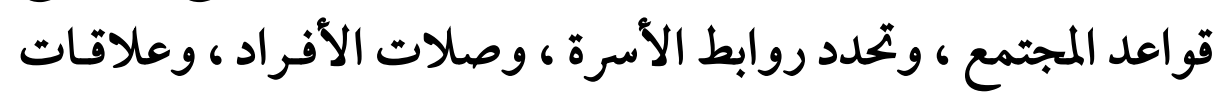
الدول والأمم ، كما تفضح المنافقين وتكشف دخيلتهم ، وتبـادل آهـل

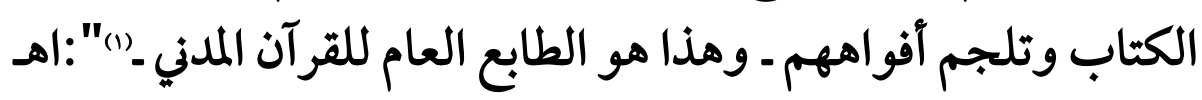

(1) مباحث في علوم القرآن لمناع القطان ص • ه . 
$(07 r)$

\section{المبحث الثالث}

الآيات المستثناة من السور المكية والآيات المستثثاة من السور المداثية

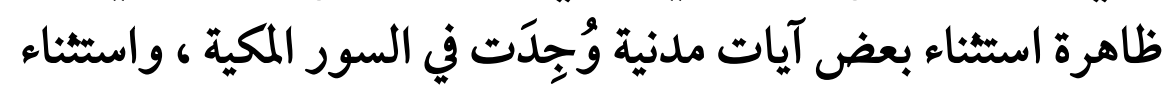

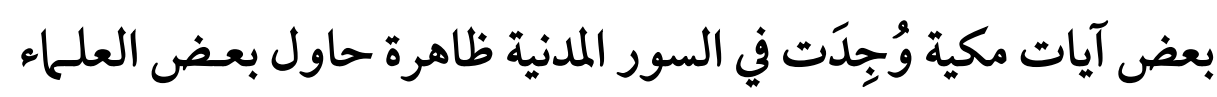
تقريرها ، حتى اشتهرت وانتشرت تلك الاستثناءات في كتب التفسير

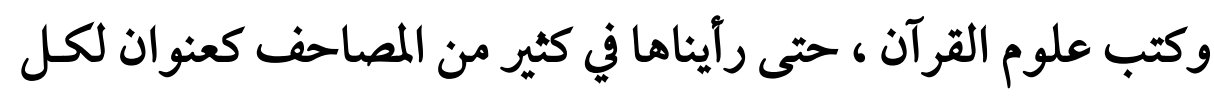
سورة . - مات.

قال البيهقي :"في بعض السور التي نزلت بمكة آيات نزلت بالمدينة ،

$$
\text { فألحقت بهاب(1)":اهـ }
$$

وقال الزرقاني ـ رحمه الله ـ :"وصف السورة بأنها مكية أو مدنية يكون

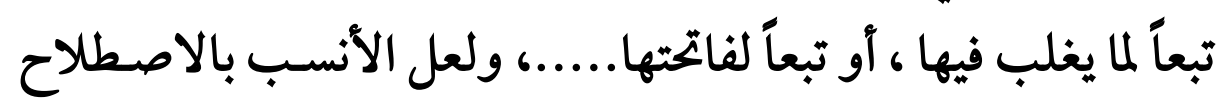

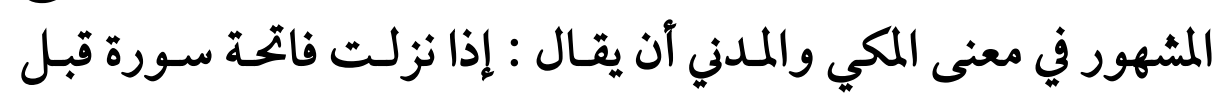

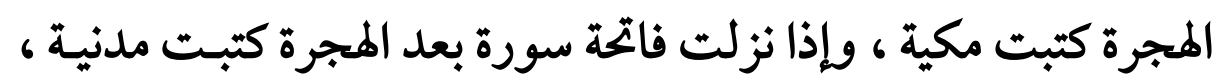

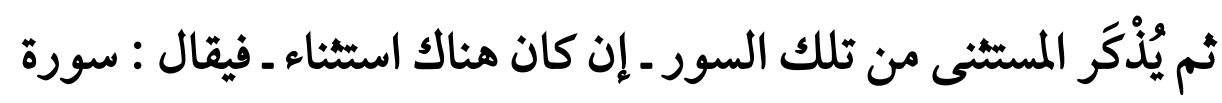

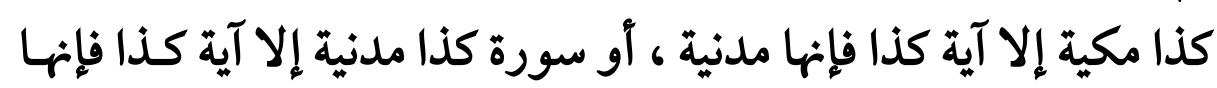

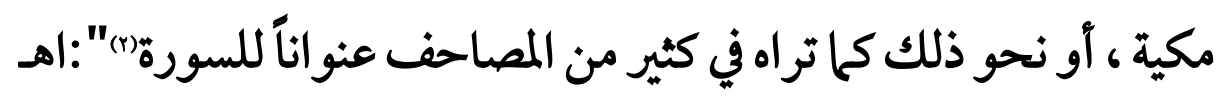

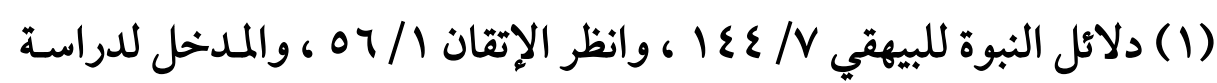

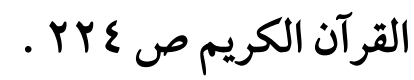
(Y) مناهل العرفان في علوم القرآن / / 199 ، و وانظر علوم القرآن الكريم لنور

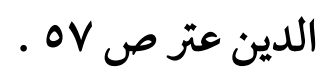




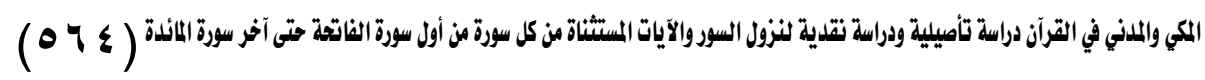
وقال مناع القطان :"لايُقصد بوصف السورة بأنها مكية أو مدنية

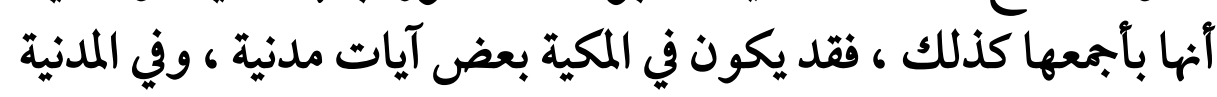

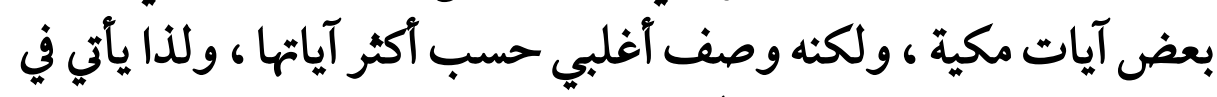

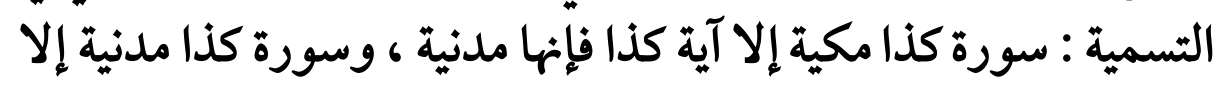

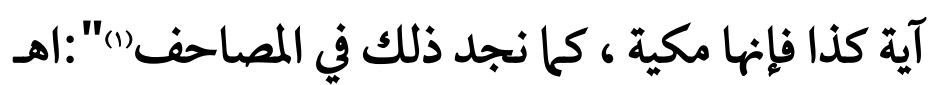

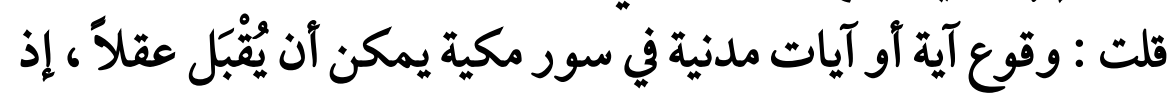

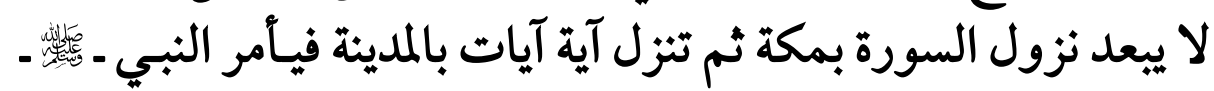

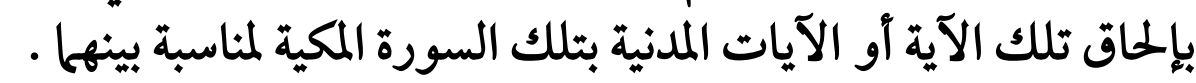

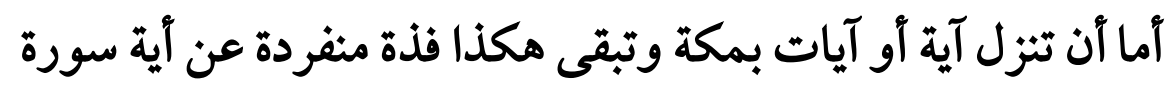

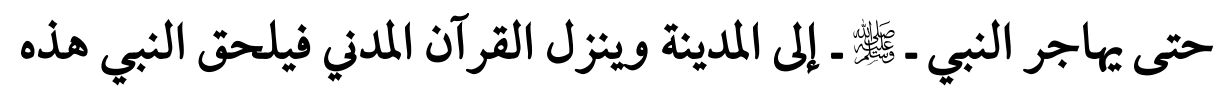

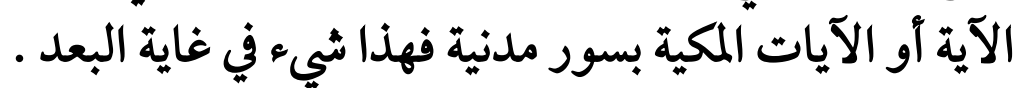

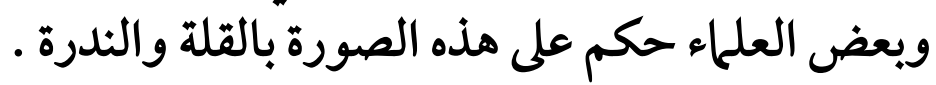

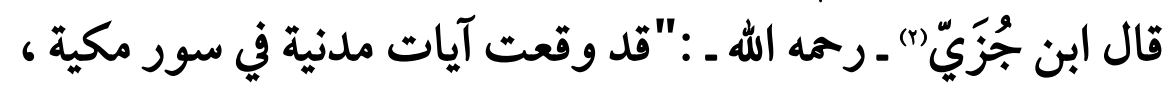

(1) مباحث في علوم القرآن لمناع القطان ص عه ، و وانظر المقدمات الأساسية في

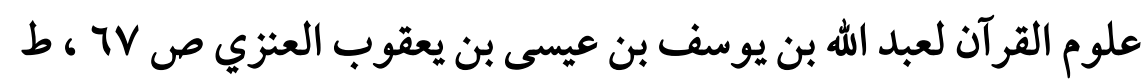

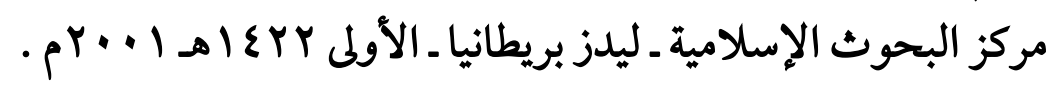

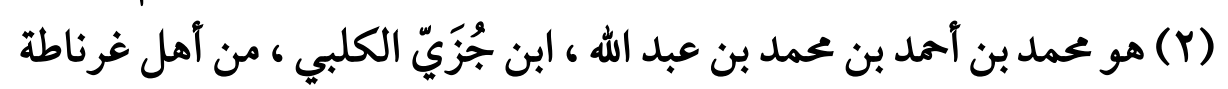

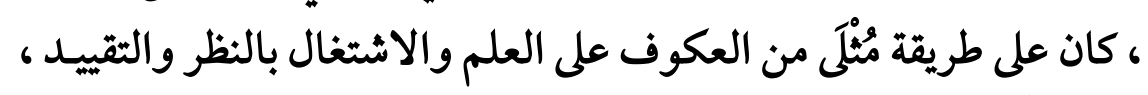

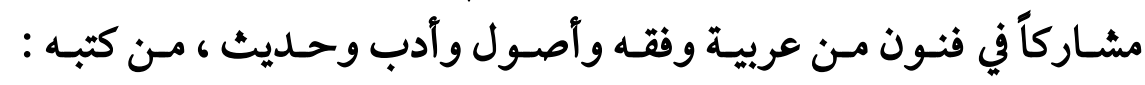

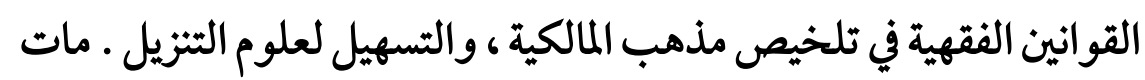

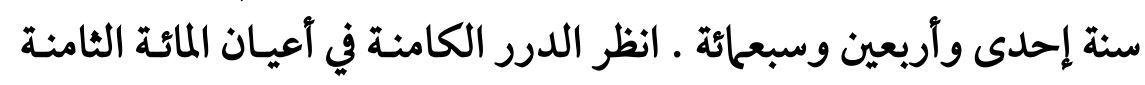


(040)

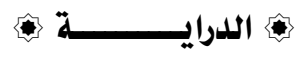

كـا وقعـت آيـات مكيـة في سـور مدنيـة ، وذلـك قليـل ، مختلـف في

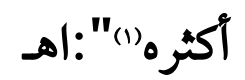

وقال ابن حجر :"قد اعتنى بعض الأئمة بييان مـا نزل مـن الآيـات

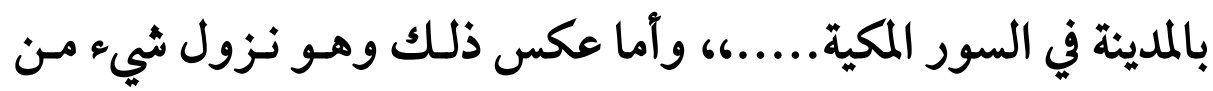

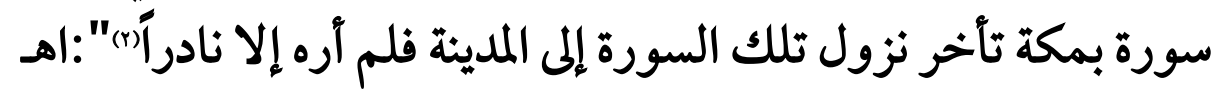
وهذا البحث كفيل ـ بفضل الله ـ بدراسة ذلك وتحقيقه والتدقيق فيه

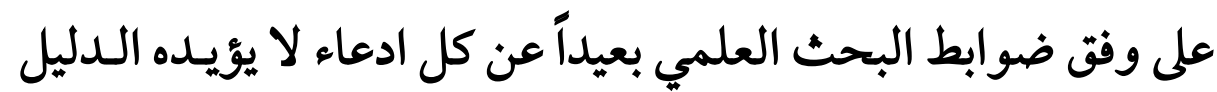

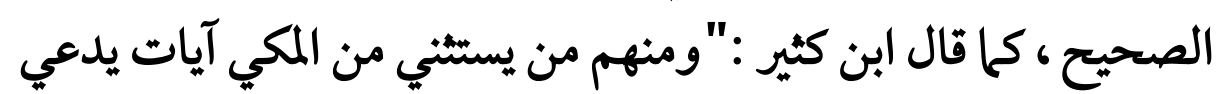

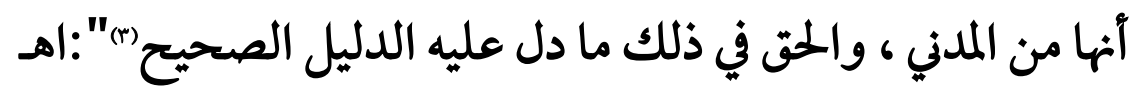
فالأصل في السورة المكية أن تكون كل آياتها مكية ، ولا يُقْبَل القول

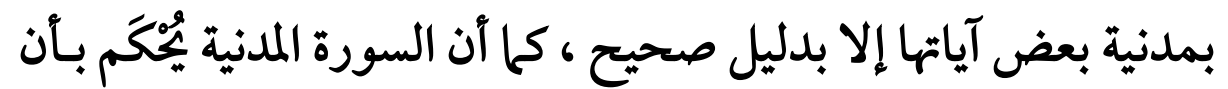

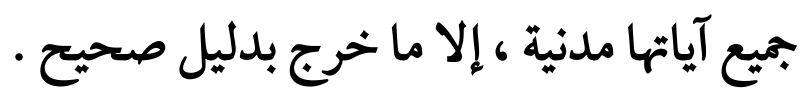

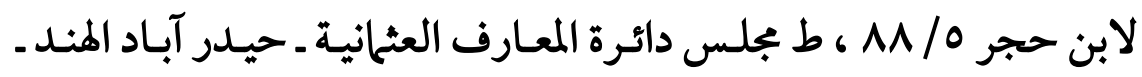

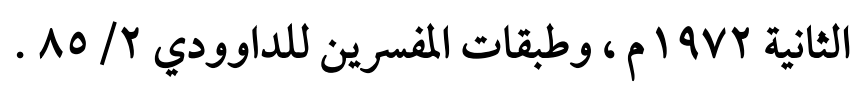

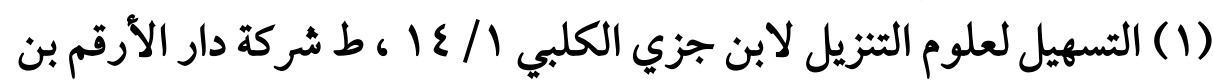

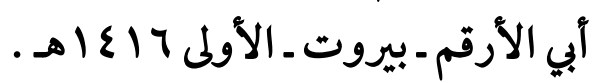

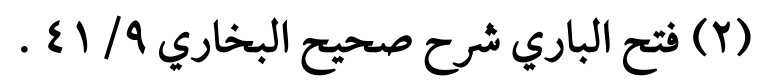

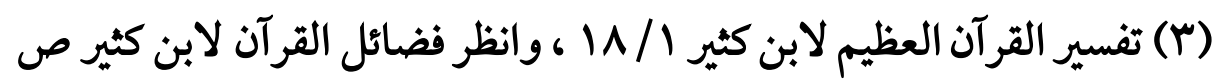




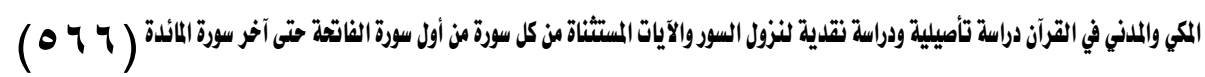
قال السيوطي :"قال ابن الحصار (1) : وكل نوع من المكي والمدني منه

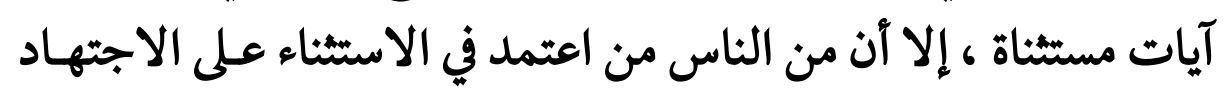

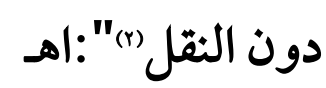

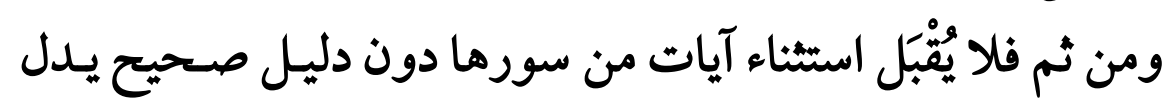

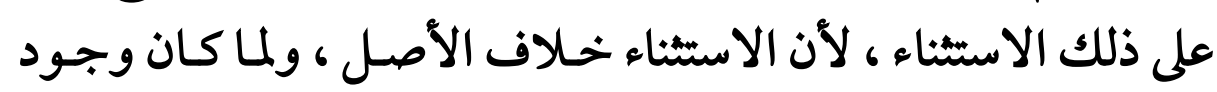

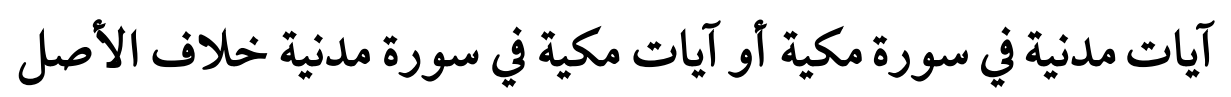

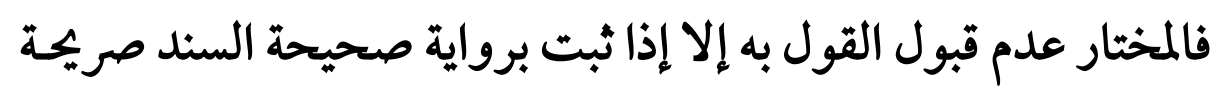

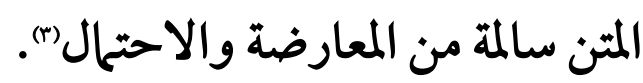

(1) هو علي بن محمد بن الحصار الحزرجي ، له كتاب في الناسخ والمنسوخ ، نقل

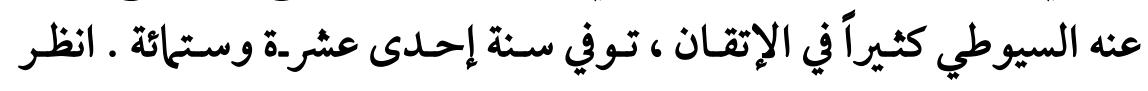

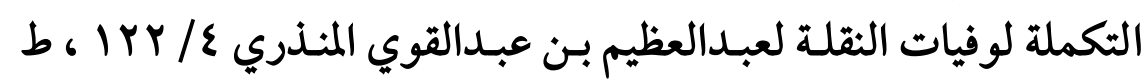

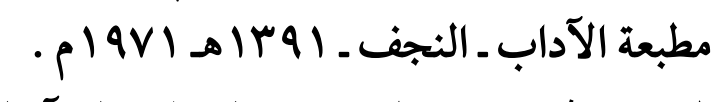

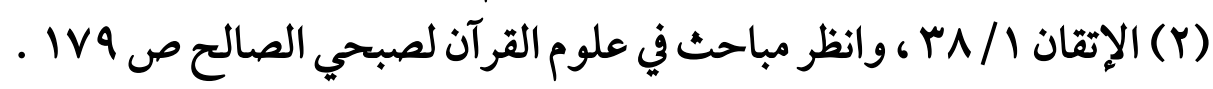

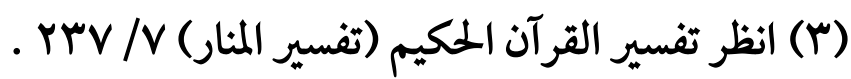




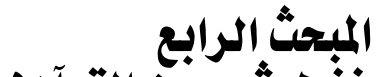

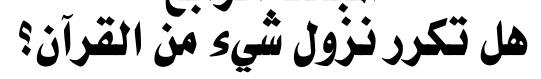

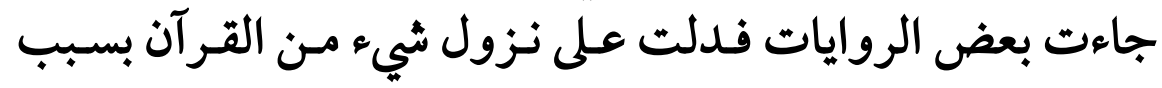

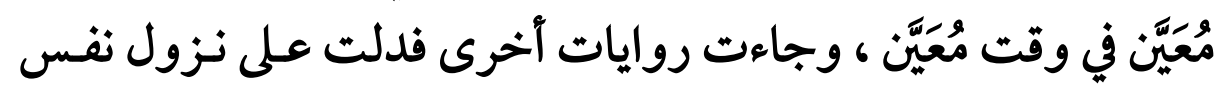

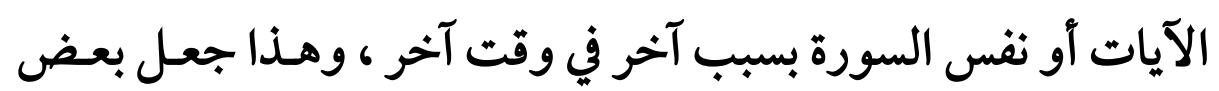

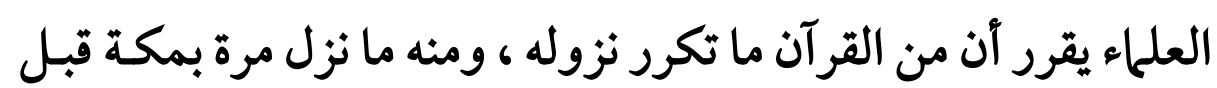

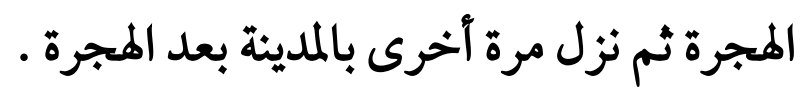

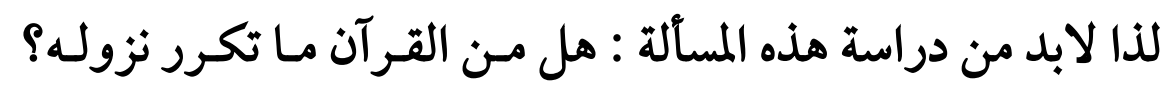

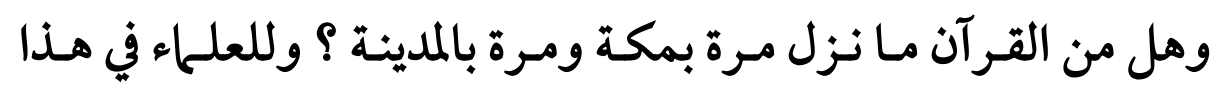

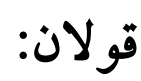

القول الأول : ـ من القرآن ما تكرر نزوله فنزل مرتين ، ومنه مـانزل

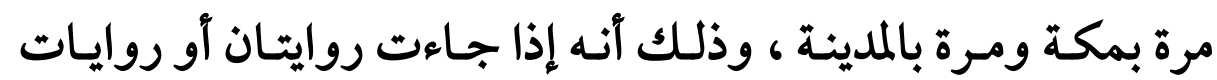

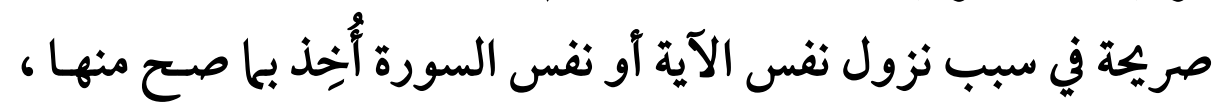
فإن استووا في الصحة وتقارب الزمان في الأحسداث التي كانت سبت فيباً

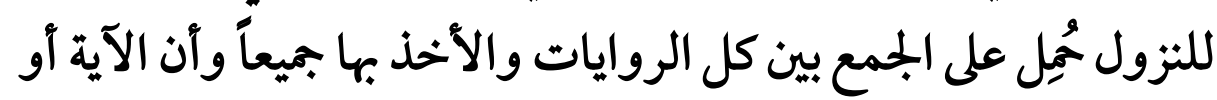

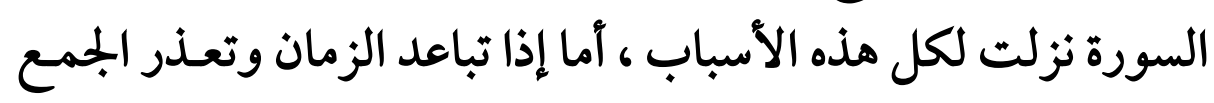

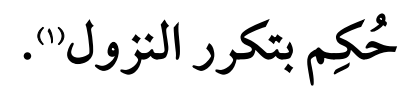

(1) انظر البرهان في علوم القرآن / / 9 ، ، والإتقان / / • با ، ومناهل العرفان

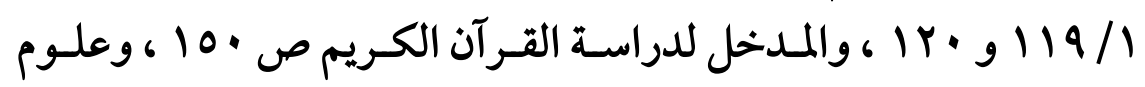

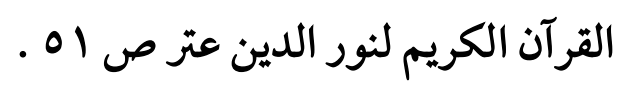




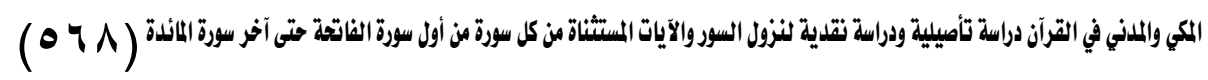

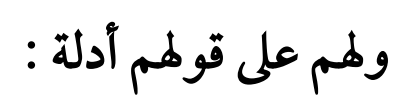

الدليل الأول : ـ وجود أمثلة من القرآن تدل على هذا ماد ، مثل سورة الفاتحة

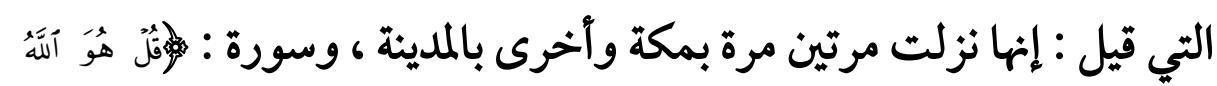

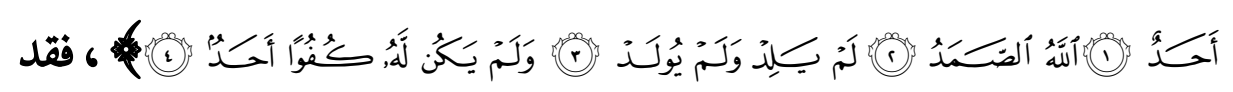

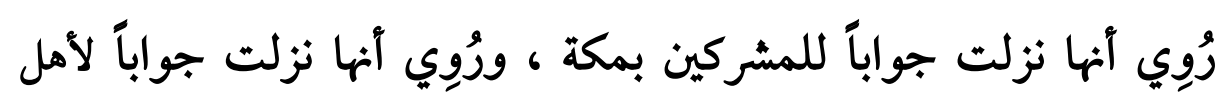

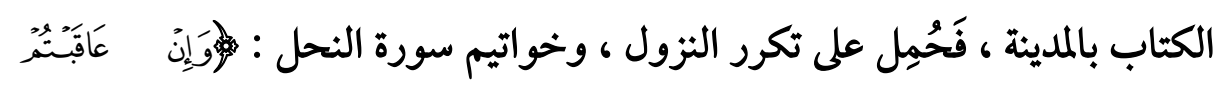

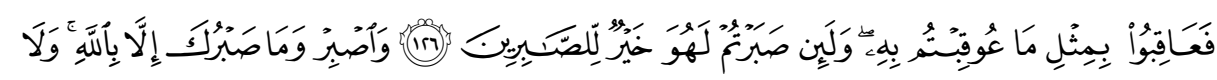

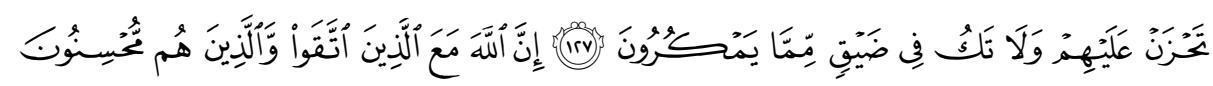

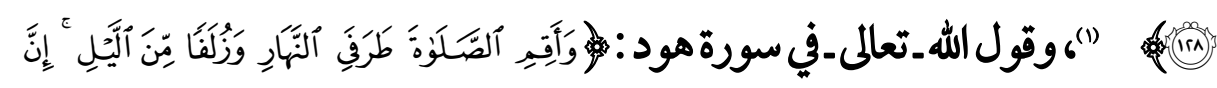

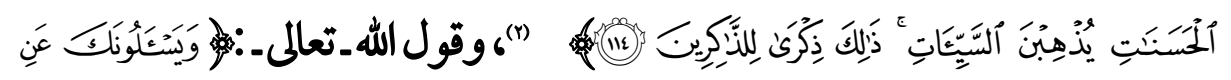

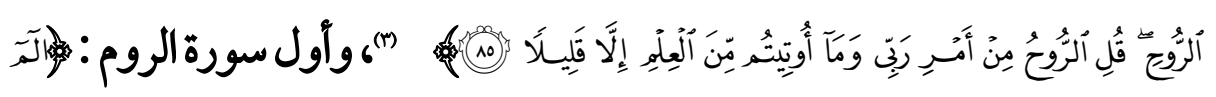

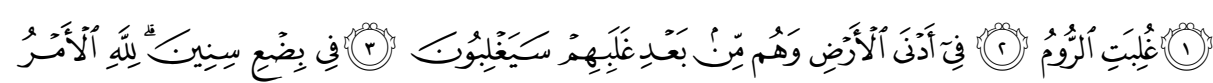

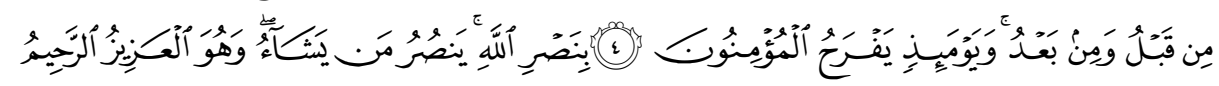
(1) (घ) 0

$$
\begin{aligned}
& \text { (1) سورة النحل (TY _ IY (I) ). }
\end{aligned}
$$

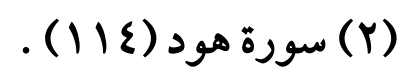

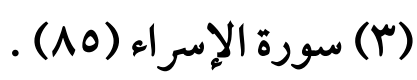

$$
\begin{aligned}
& \text { (צ) سورة الروم (1 ـ (0). }
\end{aligned}
$$


(079)

وقد أجيب عن هذه الأمثلة بأنها مبنية على روايات ضعيفة لا يصح

الاستدلال بها ، وهذا هو الأكثر والأغلب ، ومنه وما صنح منها وأوهم تكرر

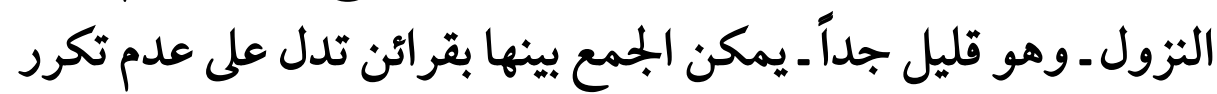

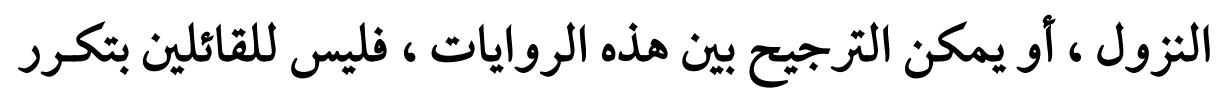
النزول مثال واحد صحيح يسلم عند البحث والمناظرة ، مع آن آن الأمثلة لئل

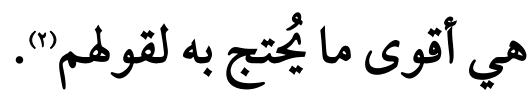

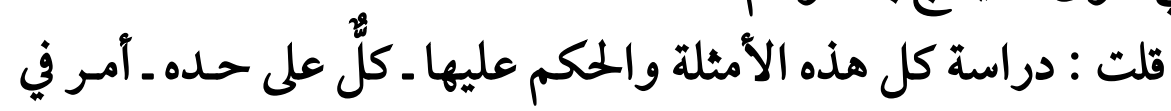

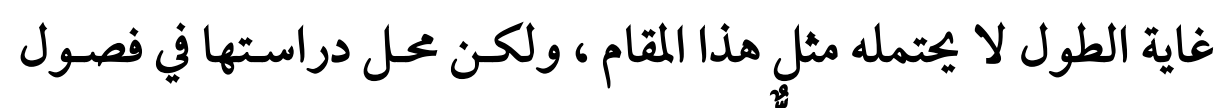

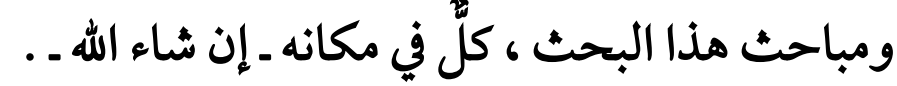

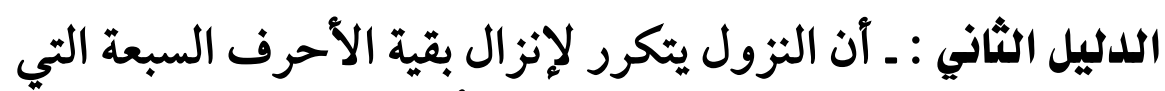

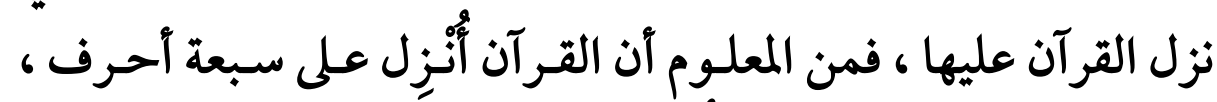

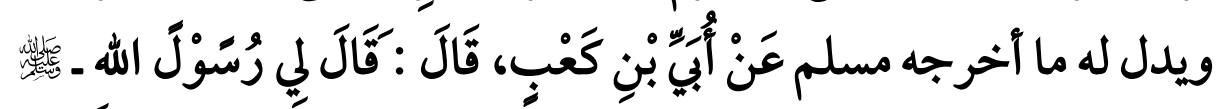

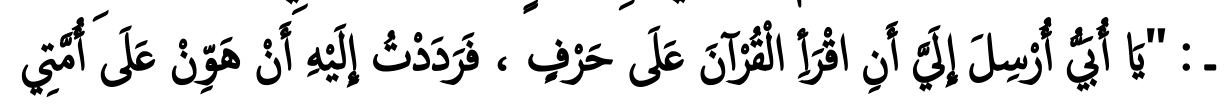

(1) انظر البرهان / / ه و • ب ، والإتقان / / • با ، والمدخل لدراسة القرآن

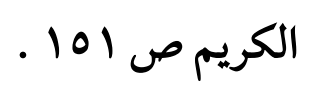

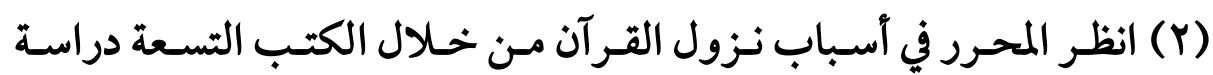

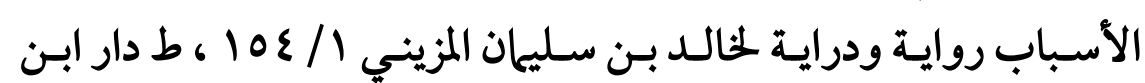

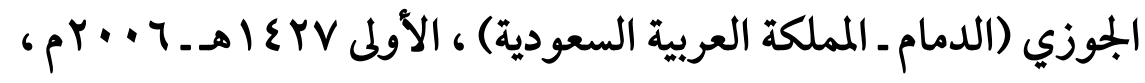

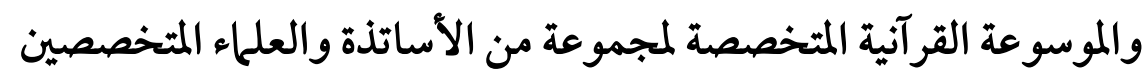
ص r ج ، ط وزارة الأوقاف المصرية ـ القاهرة ـ . 


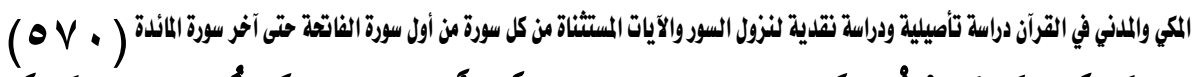

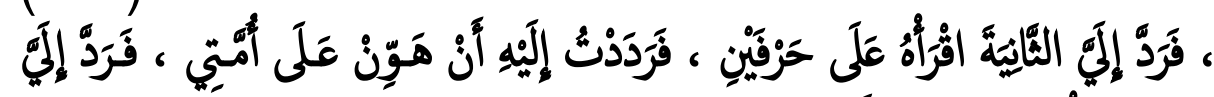

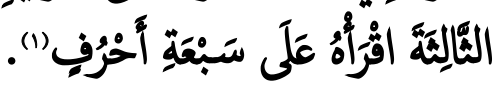
فهذا الحديث يدل على أن القرآن لم ينزل من أول وهلة بله بل مـرة بعـد

$$
\text { أخرى (r) }
$$

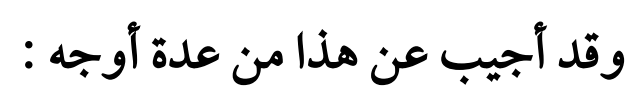

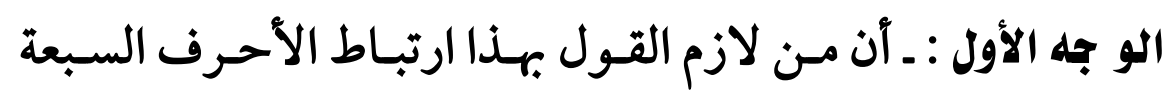

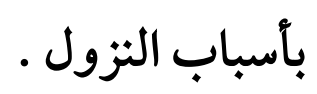

والواقع أن الأحرف السبعة غير مرتبطة بأسباب النزول ، فالغرض

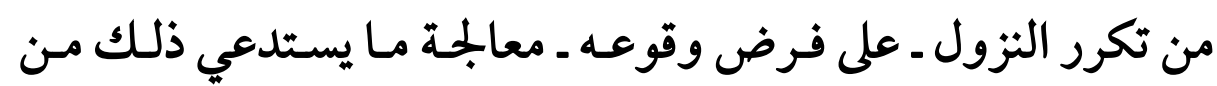

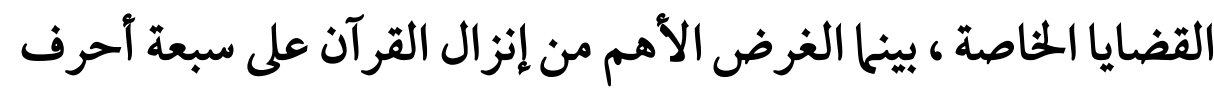

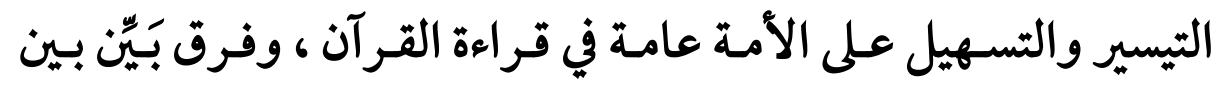

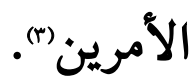

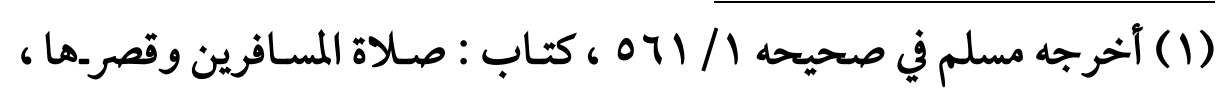

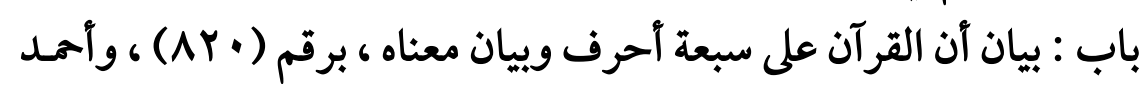

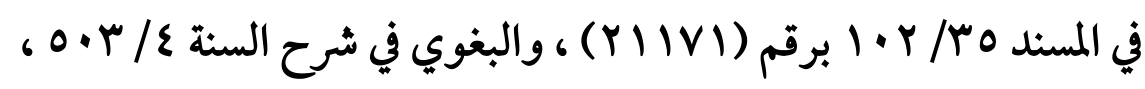

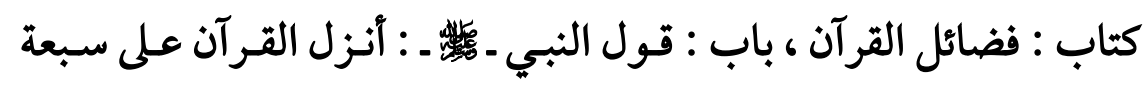

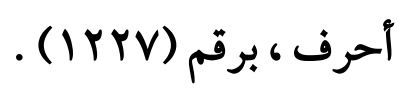

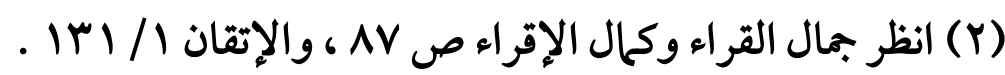

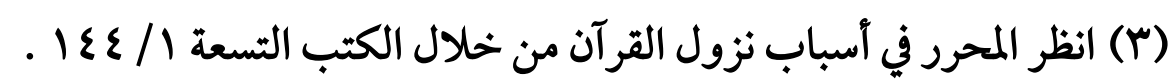


(ovi)

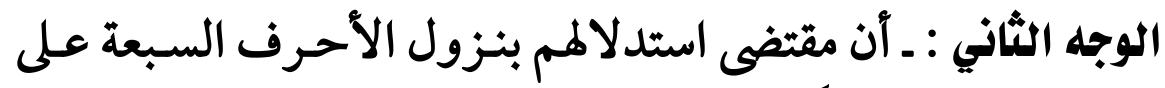

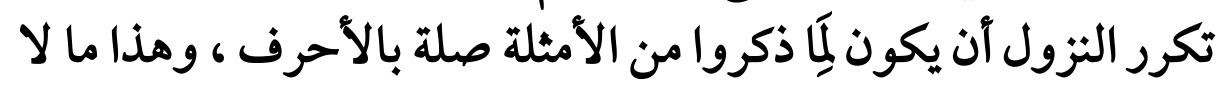

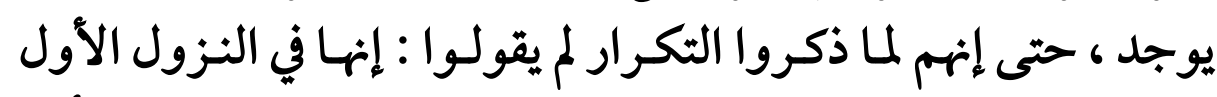

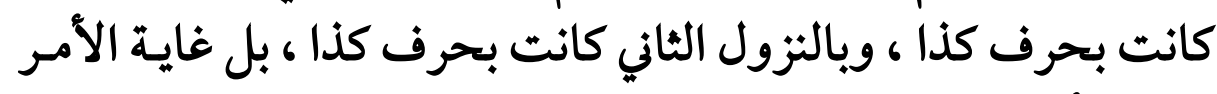

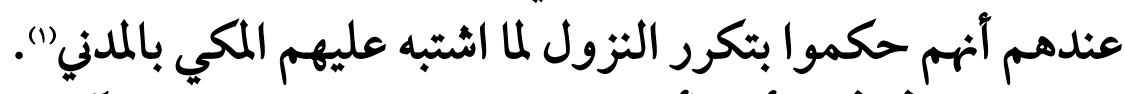

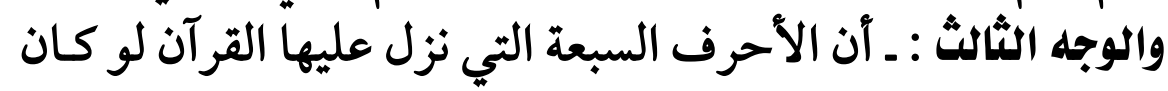

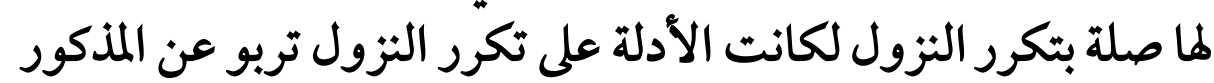

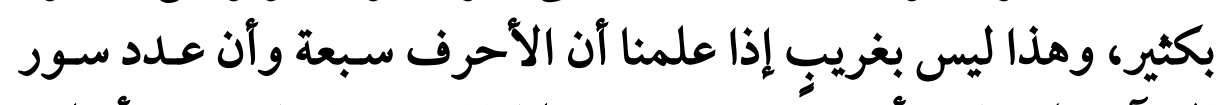

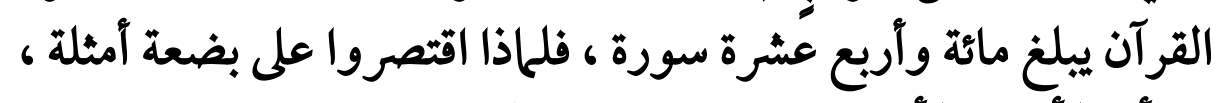

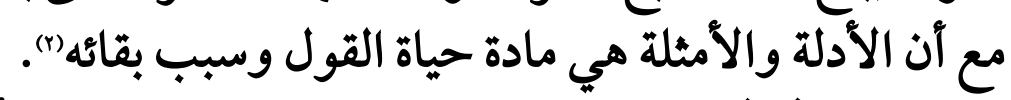

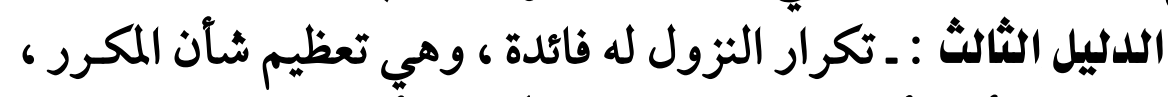

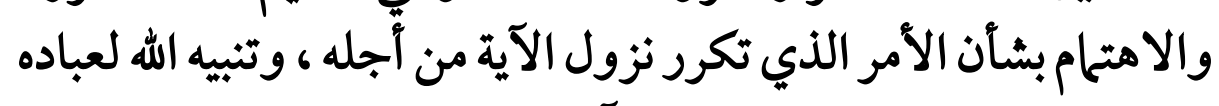

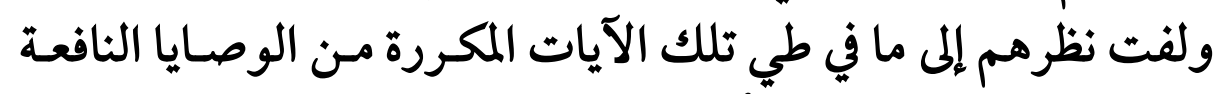

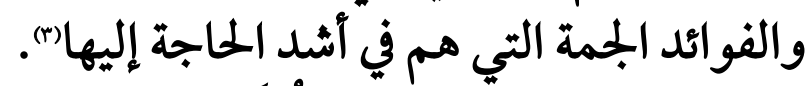

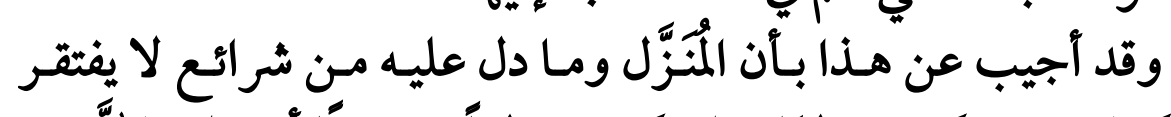

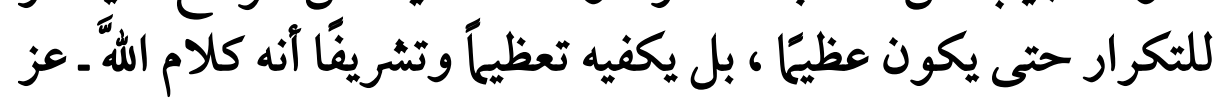
وجل - لمبرات

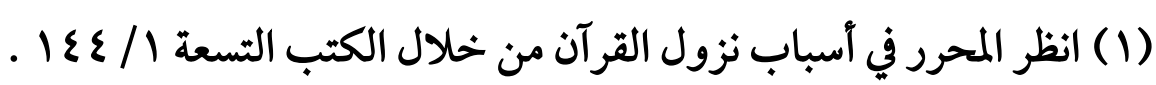

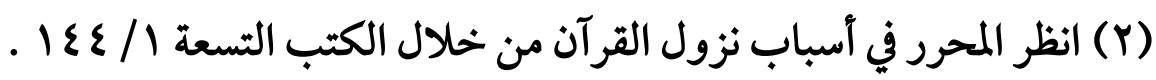

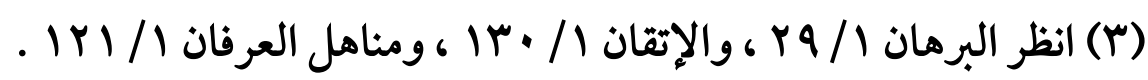

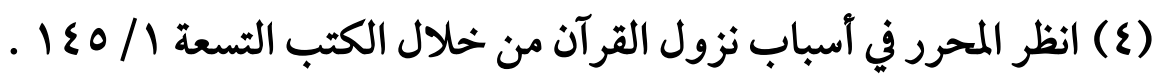




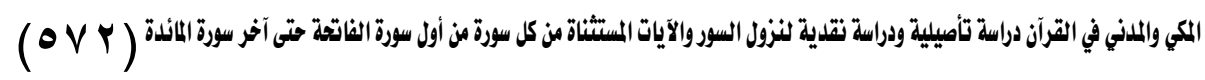
قلت : لو كان تكرار النزول مرتبطاً بتعظيم السورة أو الآيـة لكانـت

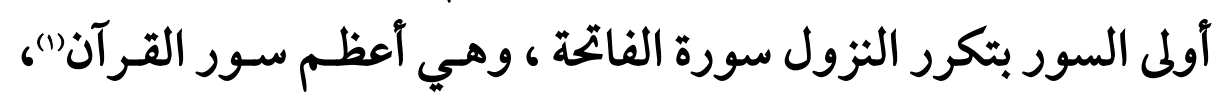

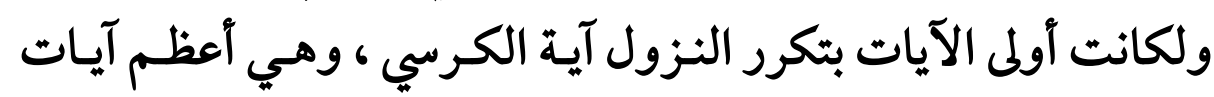

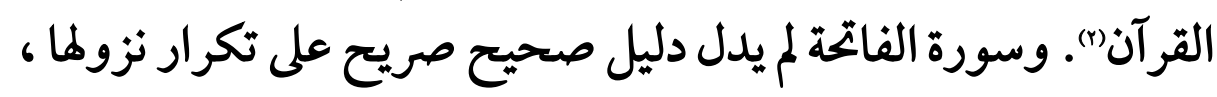

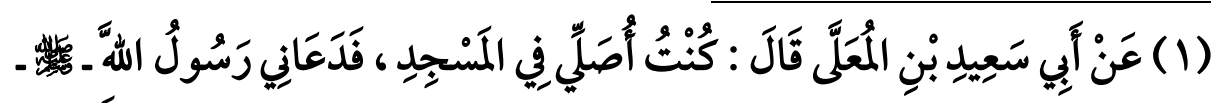

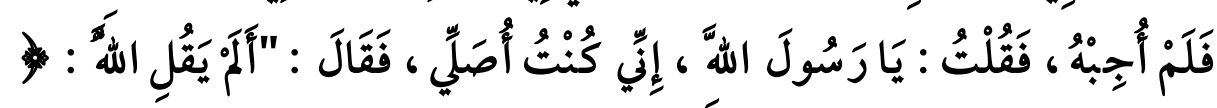

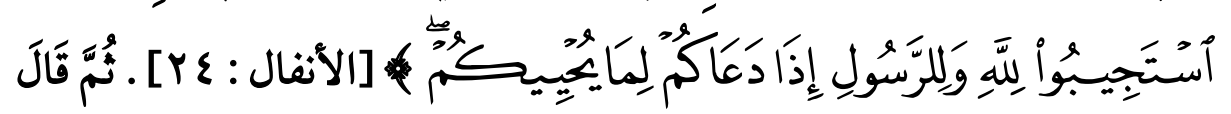

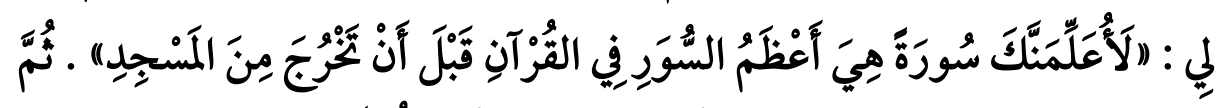

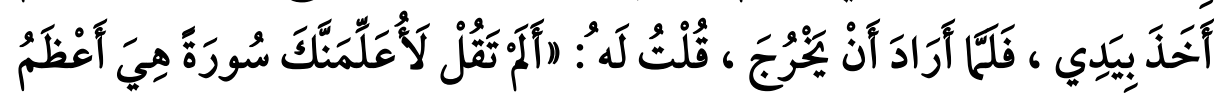

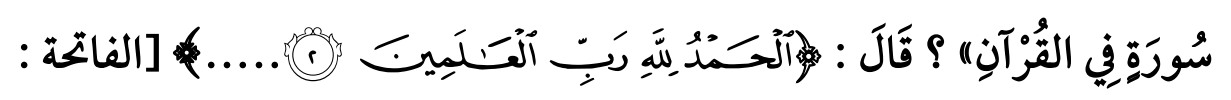

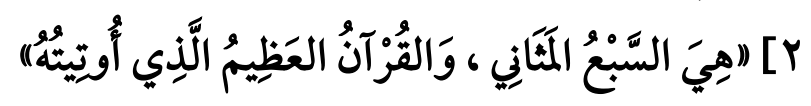

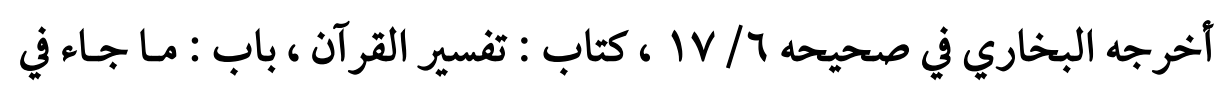

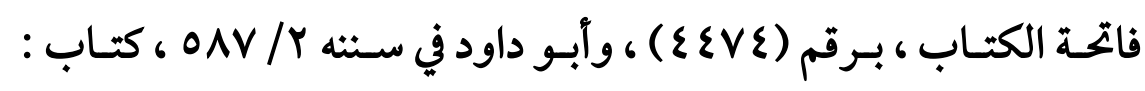

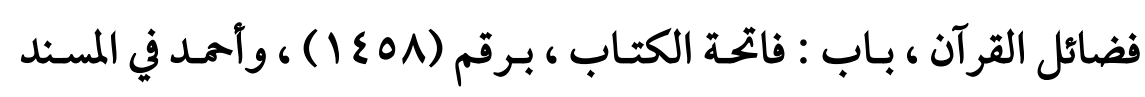

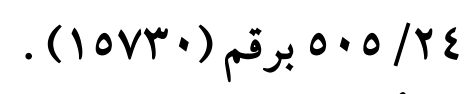

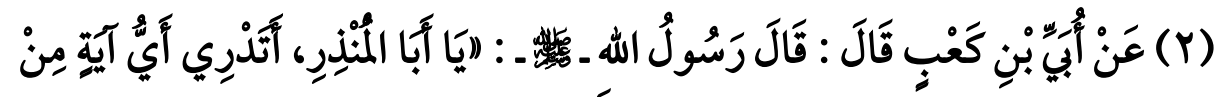

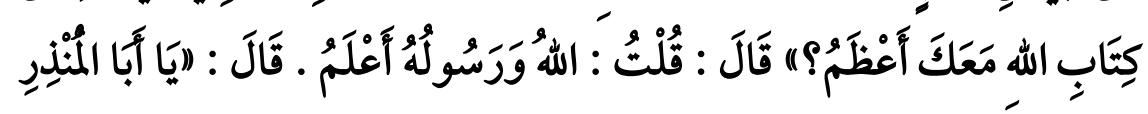

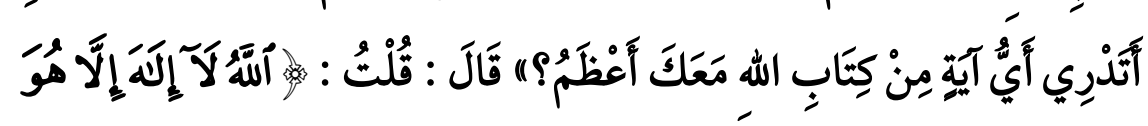


(OVT)

وادعى تكرار نزولما قليل من أهل العلم"). وآية الكربي لم يدل دليل

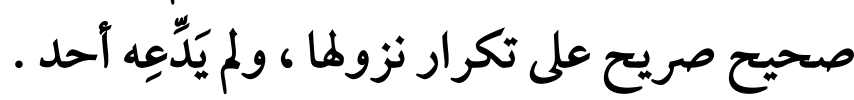

الدليل الرابع : ـ تكرار النزول له فائدة ، وهي التذكية التهير بالآية عند

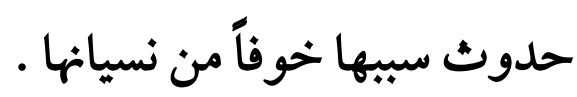

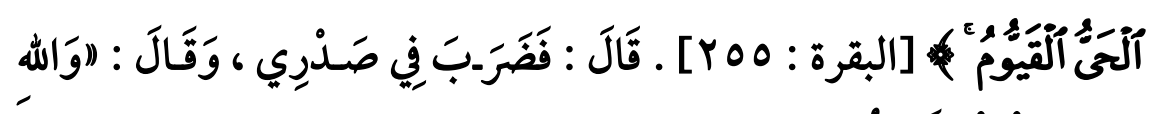

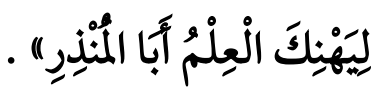

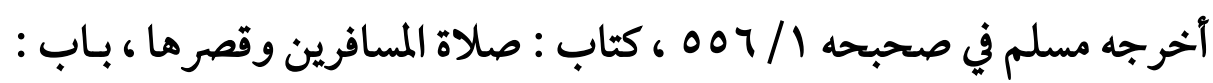

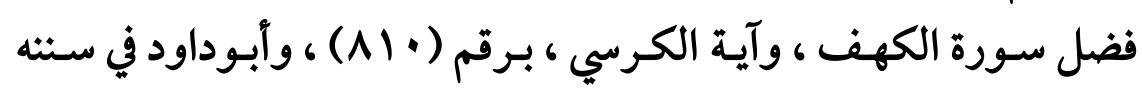

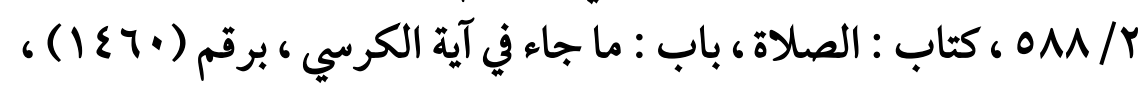

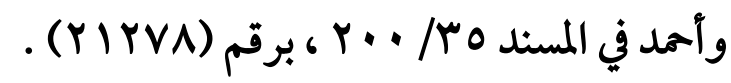

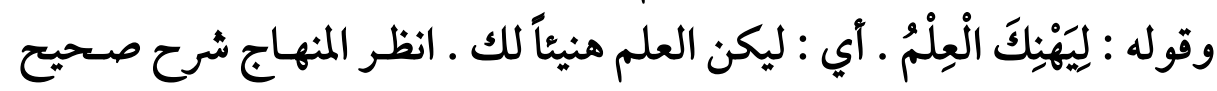

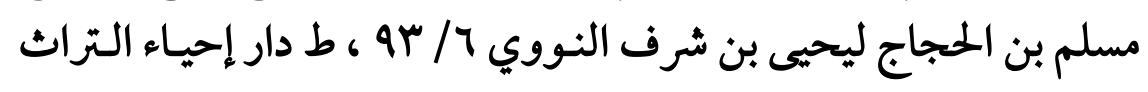

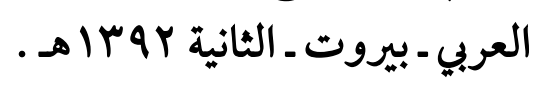

(1) حكى القول بتكراد نزول سورة الفاتحة ولم ينسبه إلى قائله الثعلبي في

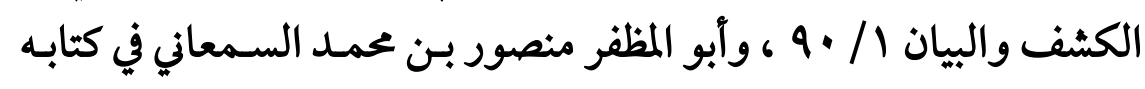

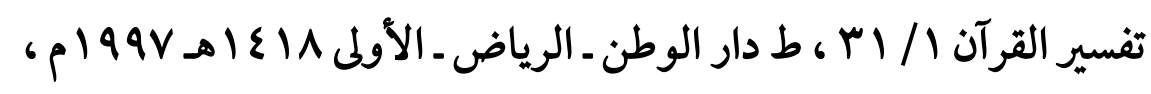

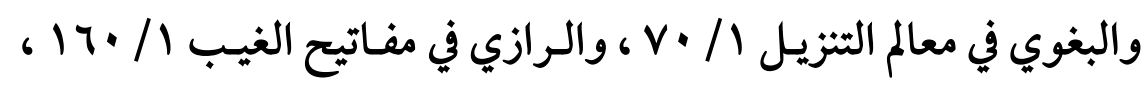
والقرطبي في الجامع لأحكام القرآن / / / 11 ، والآلوسي في في روح المعاني

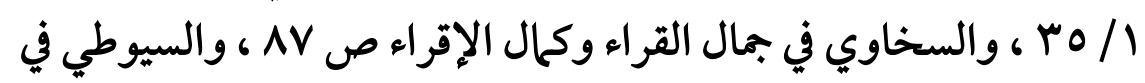

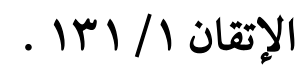




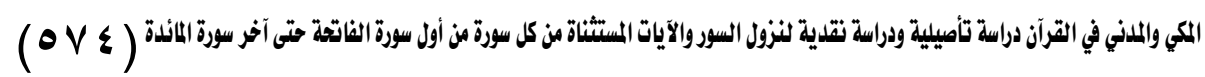
قال الزركشي ـ رحمه الله ـ :"قد ينزل الشيء مـرتين ، تعظيحاً لشـأنه ،

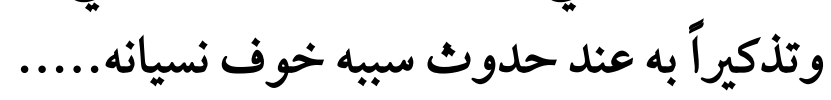

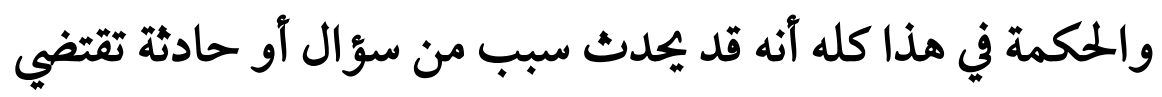

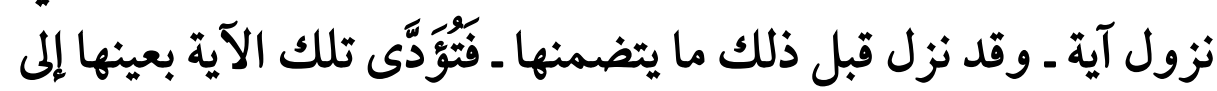

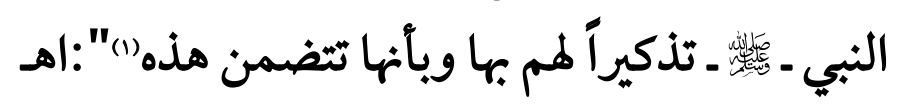

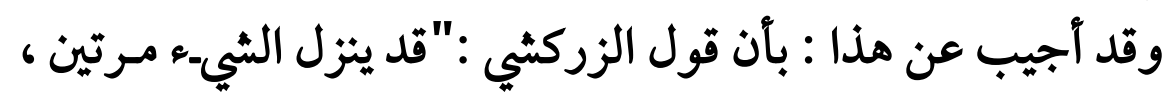

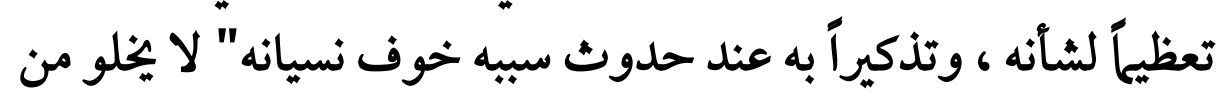
أمرين :

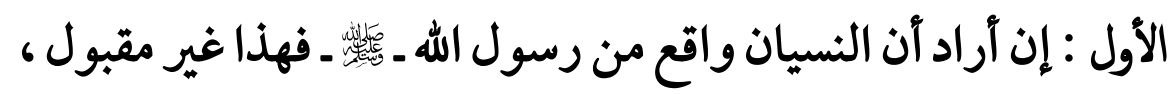

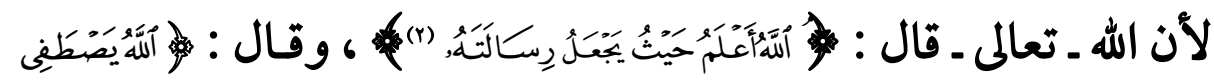

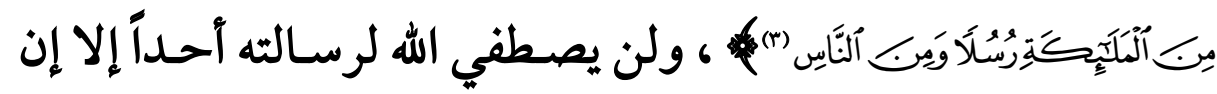

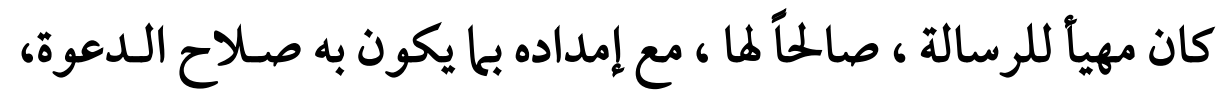

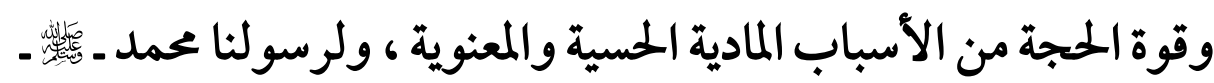

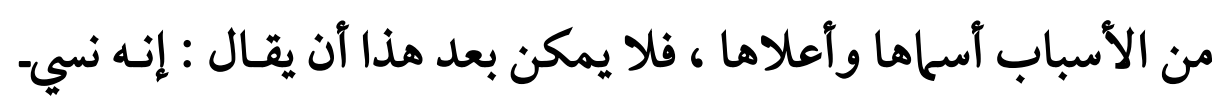

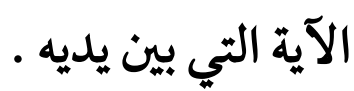

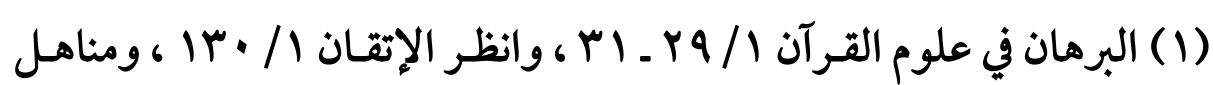

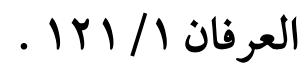

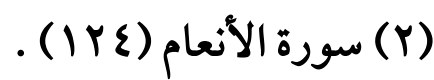

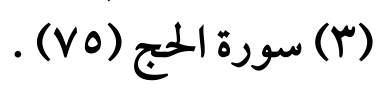


(ovo)

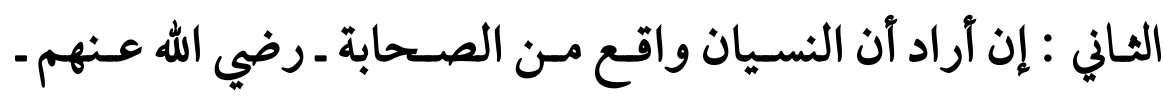

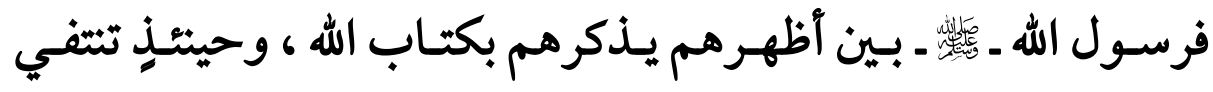

الحاجة للتكرار (1).

القول الثاني : ـ إنه لم يتكرر نزول شيء لإن من القرآن آن ، ولا معنى للإنزال

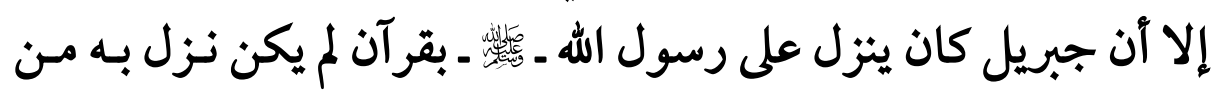

$$
\text { قبل فيُقْرِيُه إياه }
$$

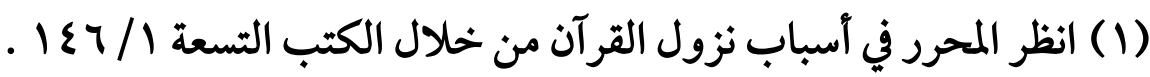
(Y) انظر التبيان لبعض المباحث المتعلقة بالقرآن على طريق الإتقان لطاهر

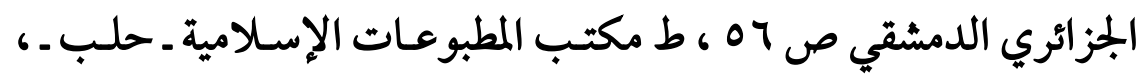

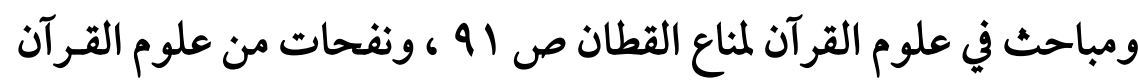

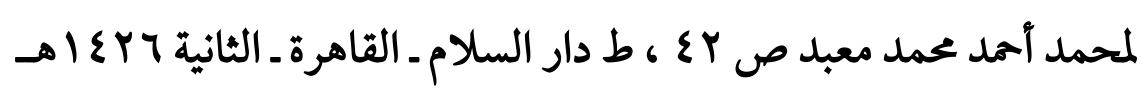

$$
\text { . }
$$

وانظر عناية القـاضي وكفاية الراضي على تفسير البيضاوي المشهور بحاشية

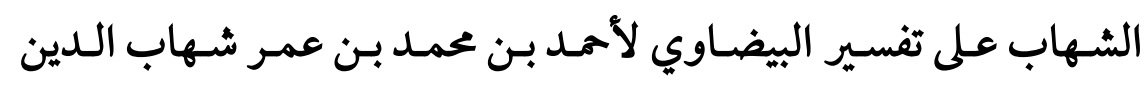

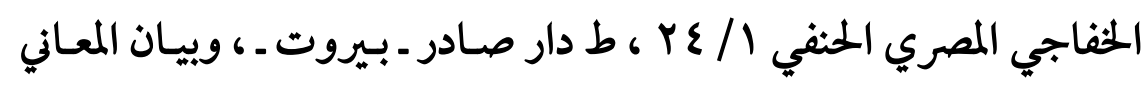
وهو تفسير مرتب على حسب ترتيب النزول تأليف : السيد عبد القادر مُلَّلاً

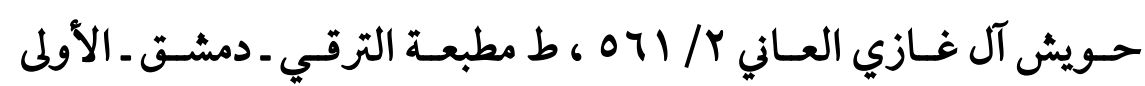

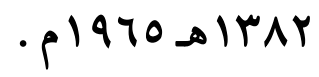




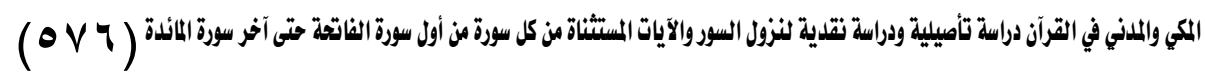

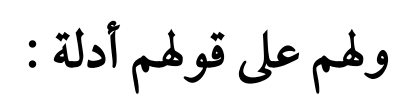

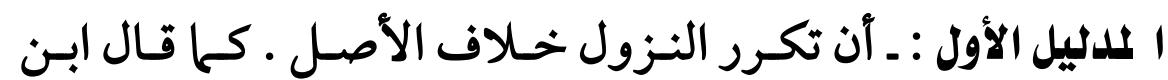

$$
\text { حجر:"الأصل عدم تكرر النزول(1)":اهـ }
$$

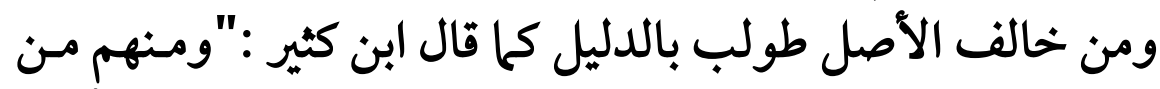

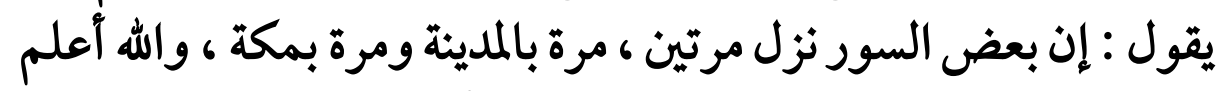

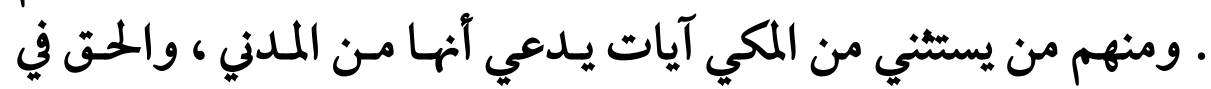

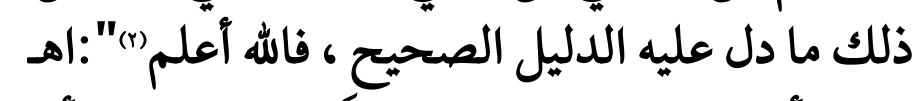

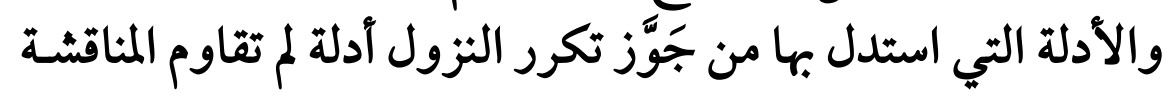

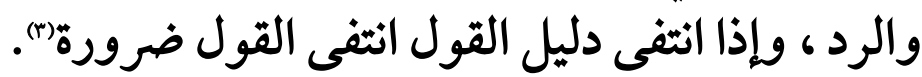

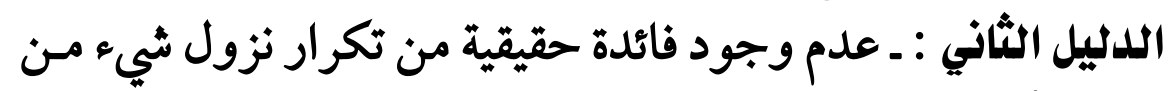

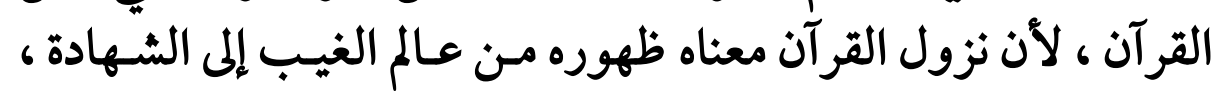

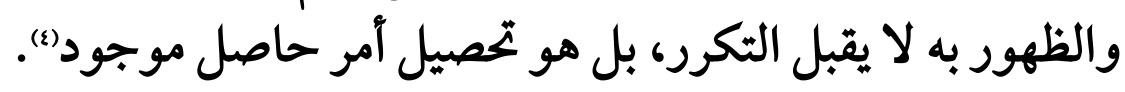

(1) فتح الباري 1 / ^•0 ، ، وانظر الأحاديث المشكلة الواردة في تفسير القرآن

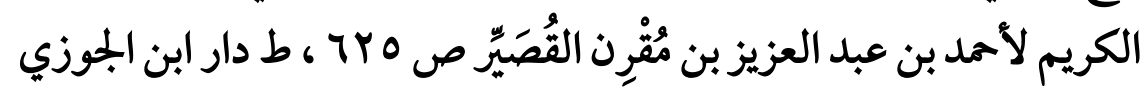

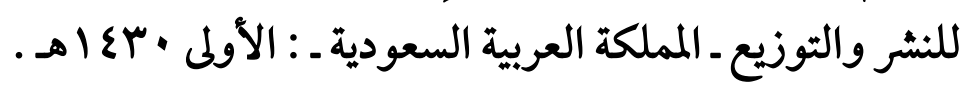

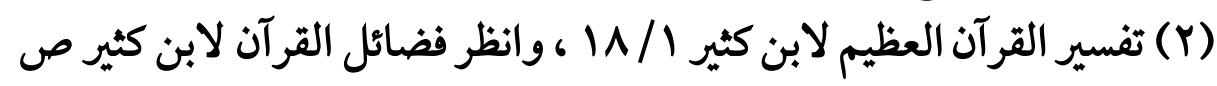
. r

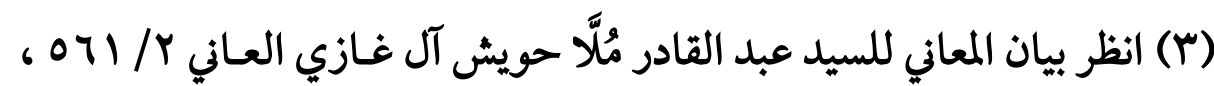

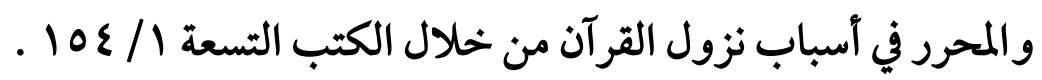

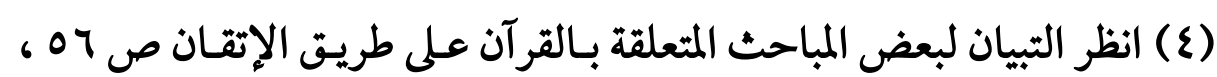

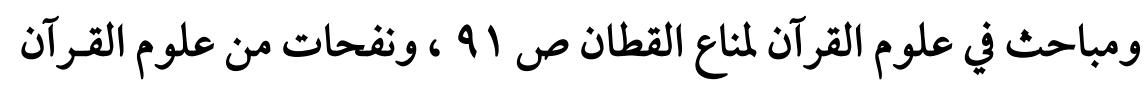




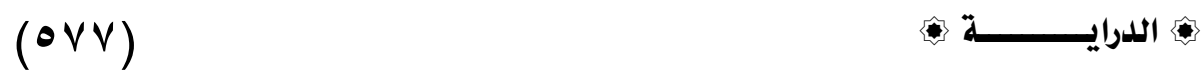

الدليل الثالث : ـ أن القول بتكرار النزول يلزم منه ما لا يستطيع أحد

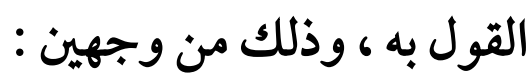

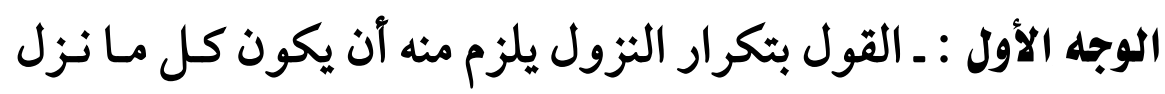

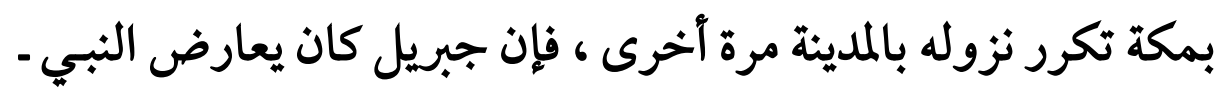

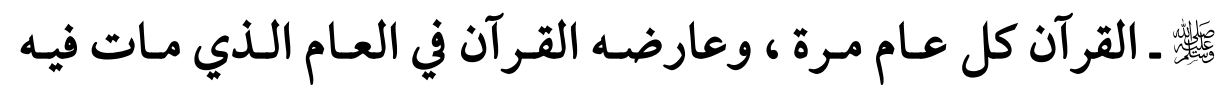
مرتين(1)(1).

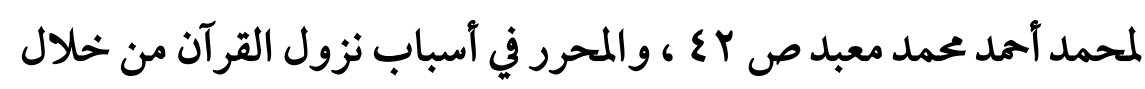

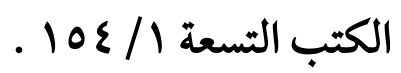

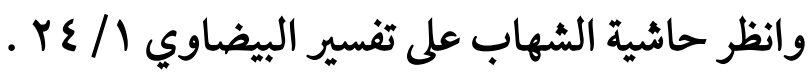

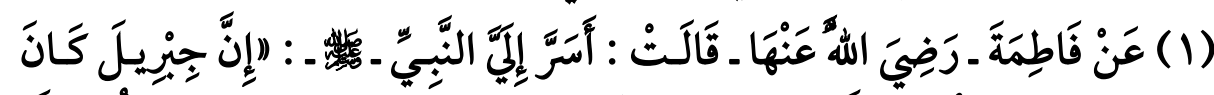

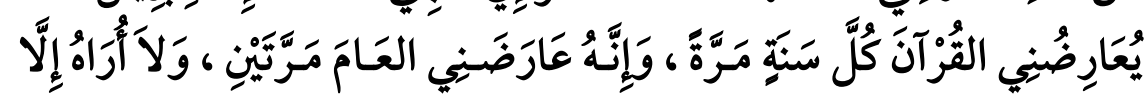

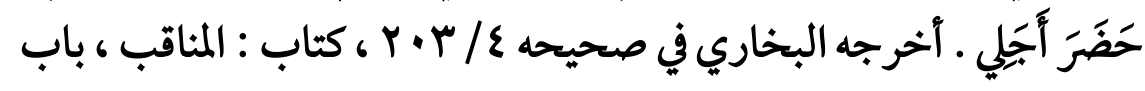

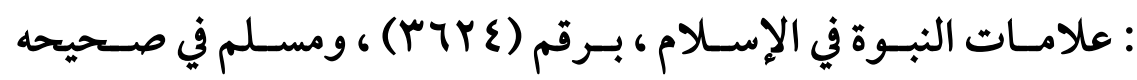

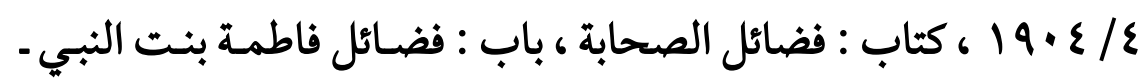

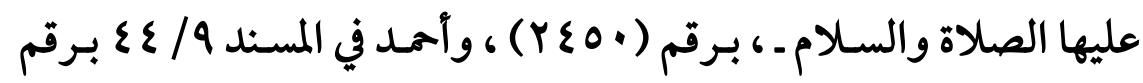
. ( $($ T\&|r)

قال ابن حجر في الفتح / / / ع : "المعارضة : مفاعلة من الجانبين ، كأن كلاً منها|

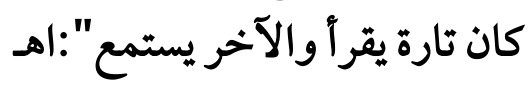
(Y) انظر التبيان لبعض المباحث المتعلقة بالقرآن على طريق الإتقان ص 07 هـ 


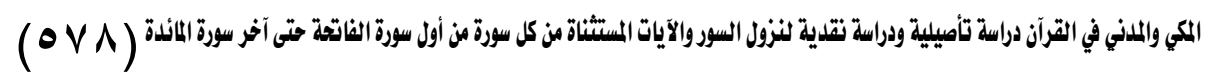
والوجه الثاني : ـ أن كل ما نزل مرتين لزم آن يثبت في القرآن مرتين ، كما هو الحال في الآيات والقصص المكررة").

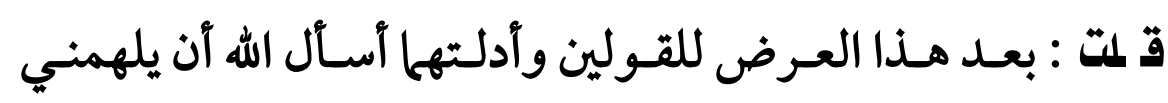

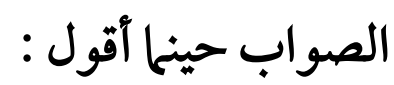
إذا جاءت روايتان أو روايات صريحة في سبب نزول نفس الآيـة آو

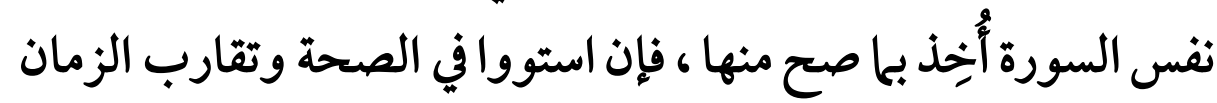

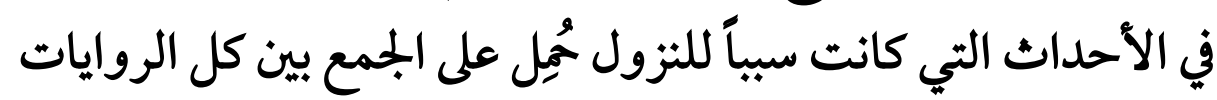

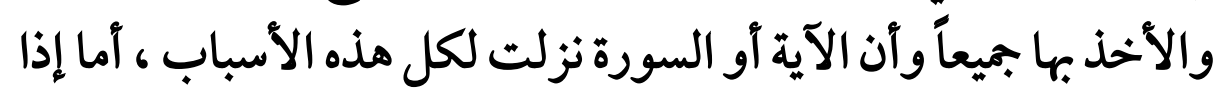

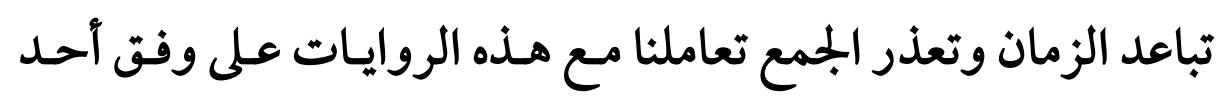

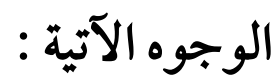

الوجه الأور : ـ الترجيح بين الروايـات ، كـا قال منـاع القطان مـا

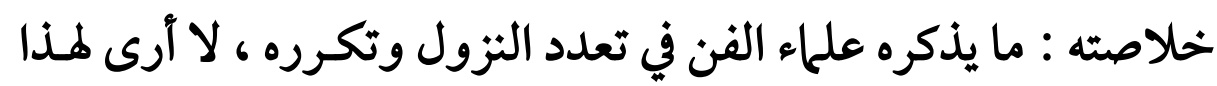

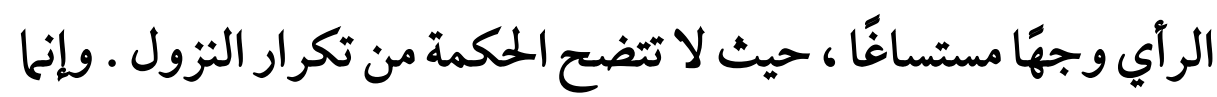

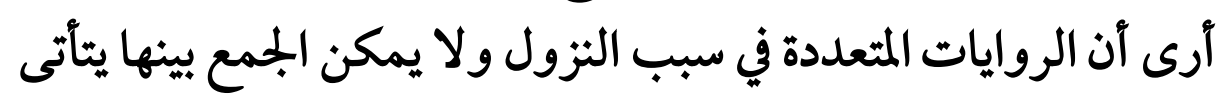
فيها الترجيح · فان

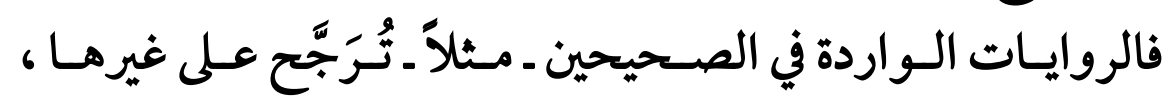
وحسبك برواية الشيخين قوة ـ وكذلك يُنظرَ في سائر الروايات ، فإنها

(1) انظر بيان المعاني للسيد عبد القادر مُلَّل حويش آل غازي العاني / / ع | ـ ـ 
(ov9)

ليست في درجة سواء ـ والأخذ بأرجحها أولى من القول بتعدد النزول

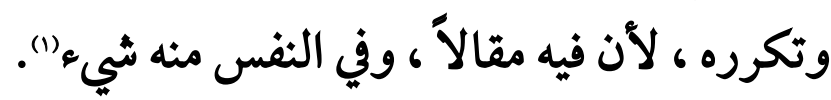

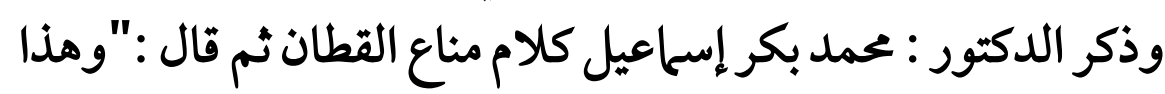

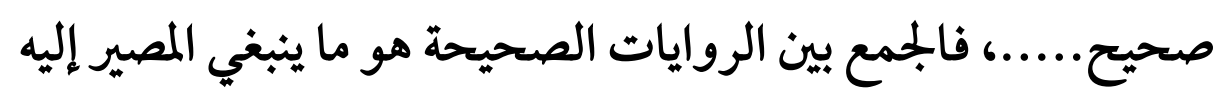

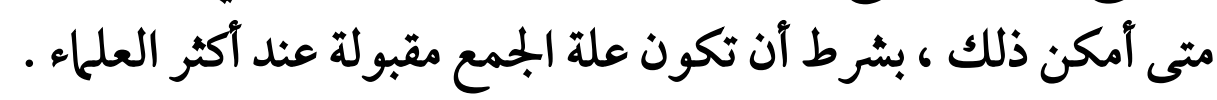

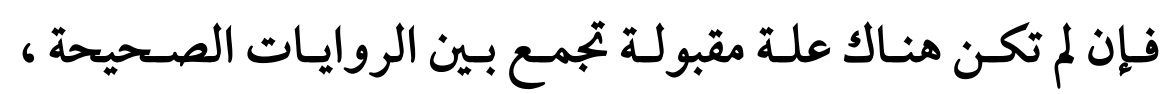

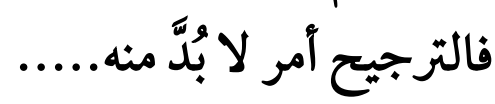

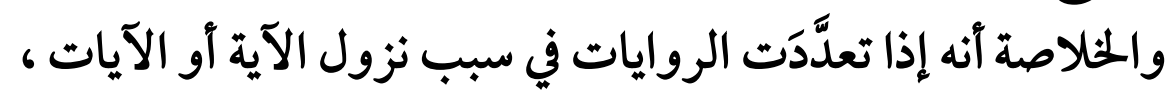

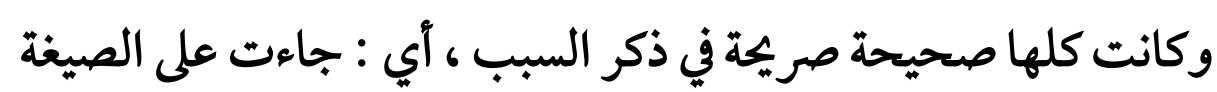

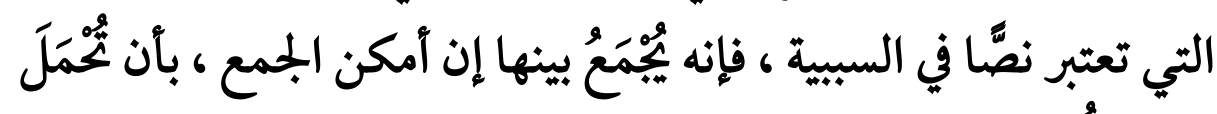

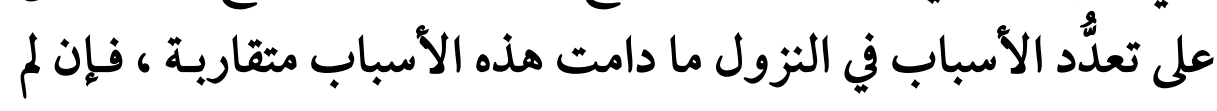

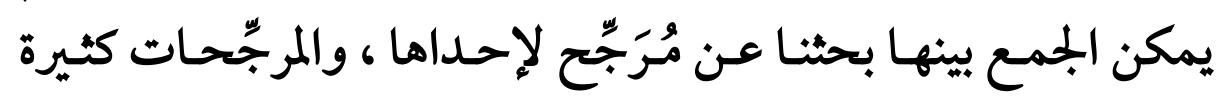

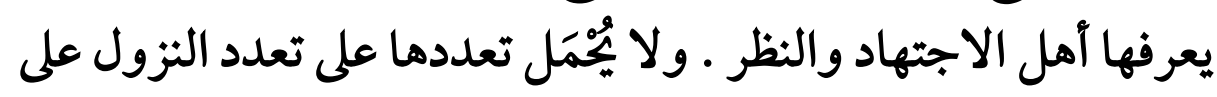

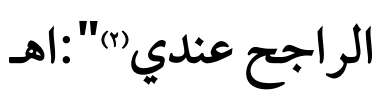

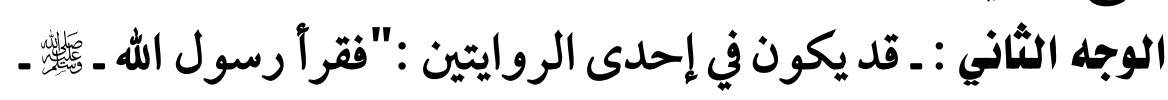
كذا": فيغلط الراوي فيقول : فنزل كذا ـ فيظن أن ذلك سبب للنزول الرول ،

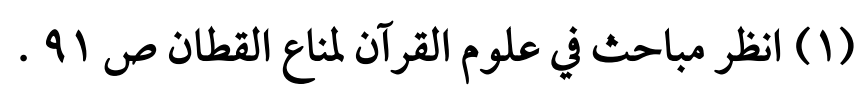

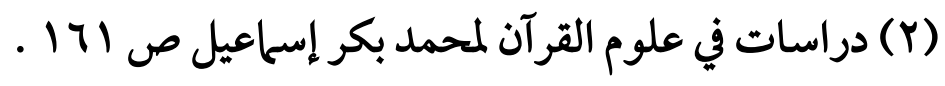




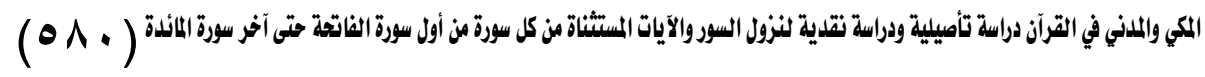
وليس كذلك ، فينبغي التنبـه لـذلك ، وتحريـر لفظ الروايـة ، ويـذلك

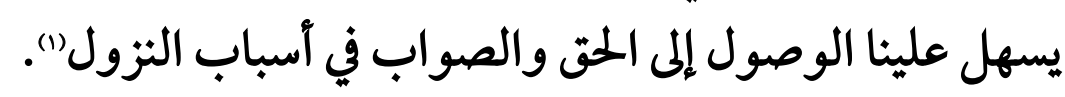

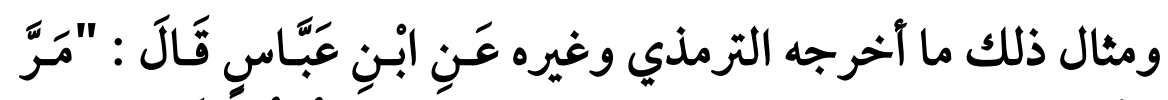

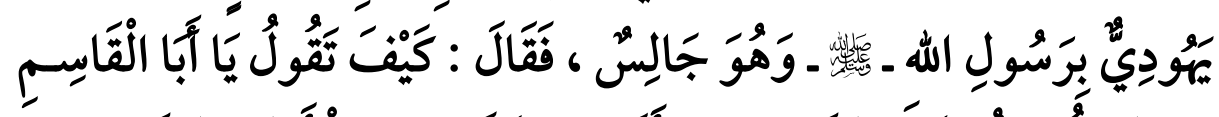

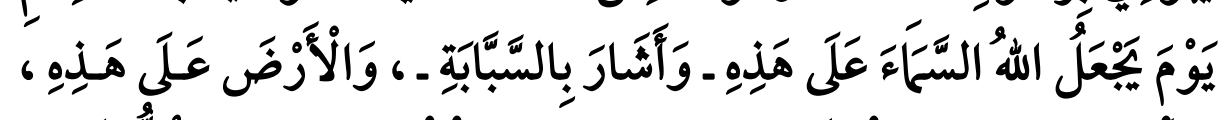

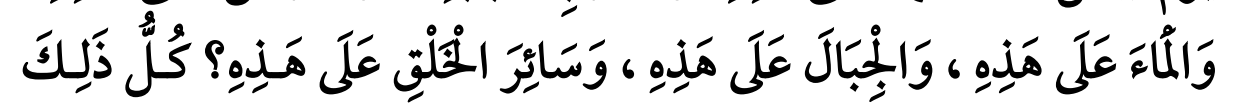

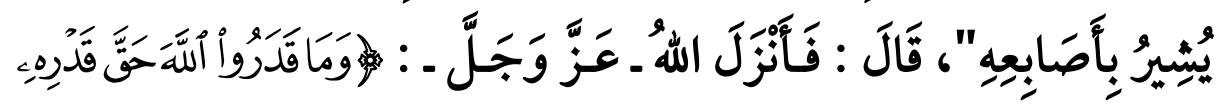
(r)

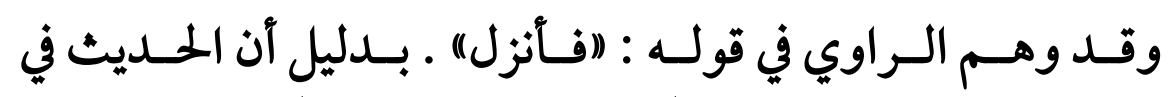

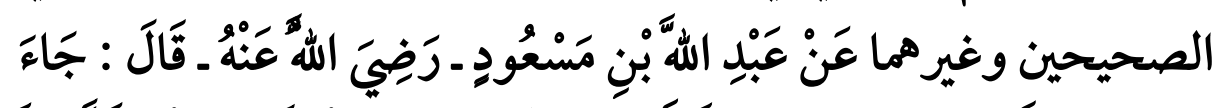

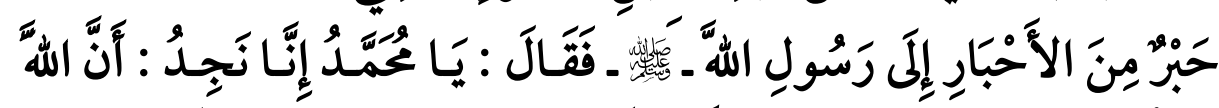

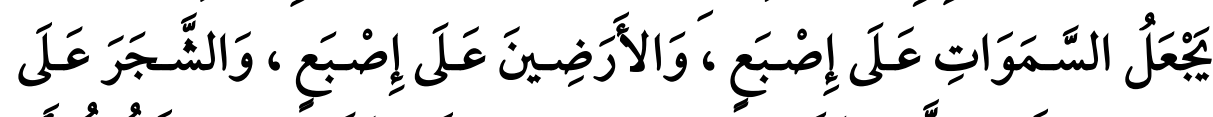

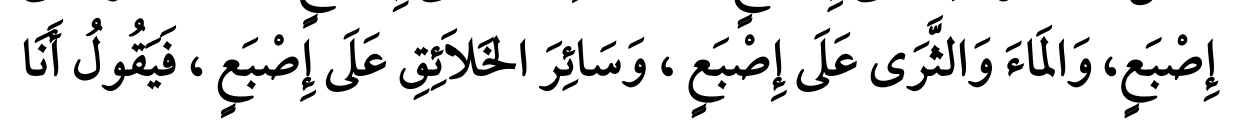

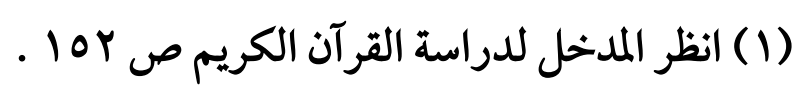

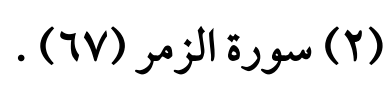

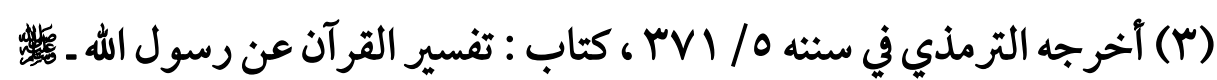

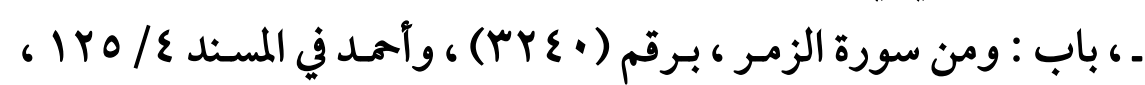

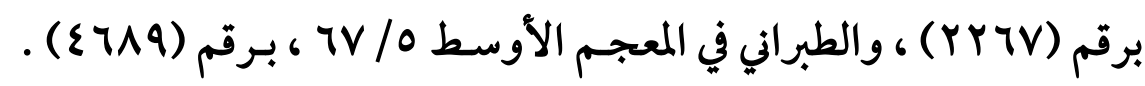

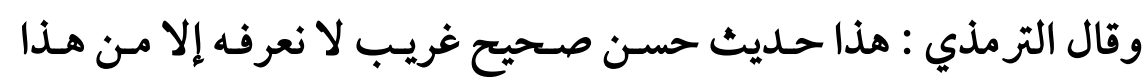


$(\circ \wedge 1)$

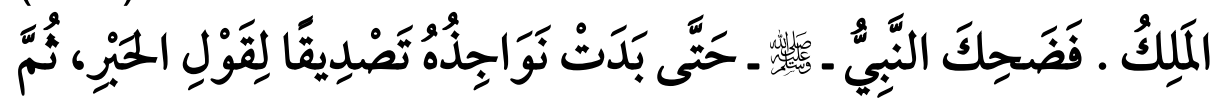

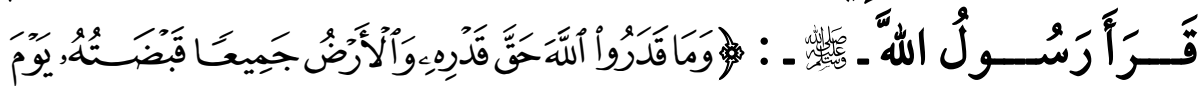

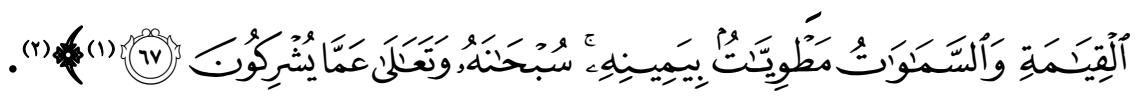

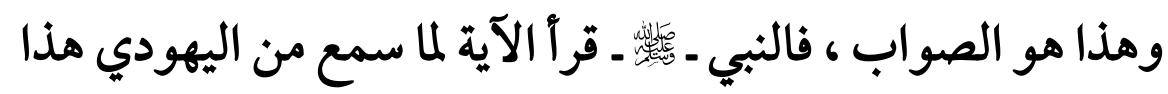

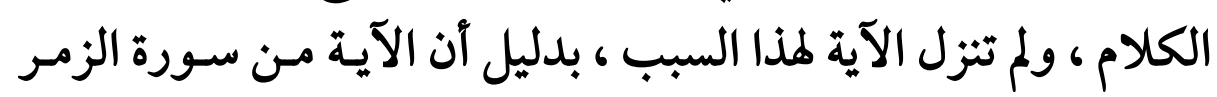

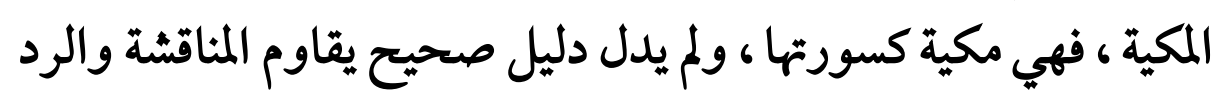
على أنها نزلت بالمدينة (r).

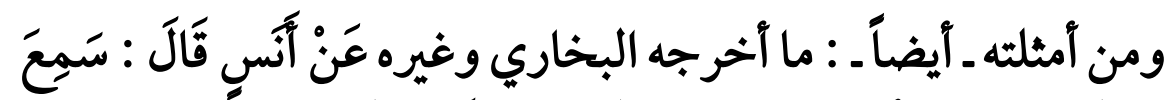

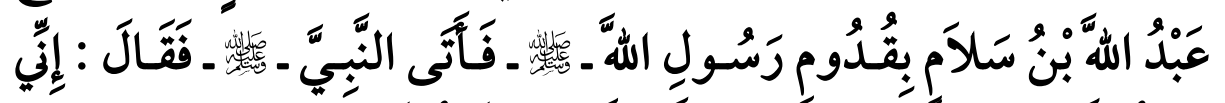

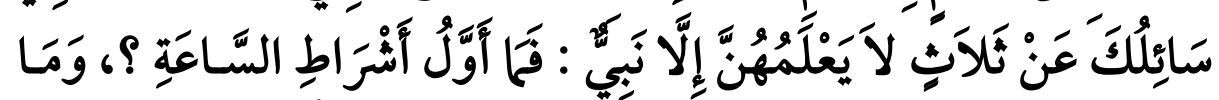

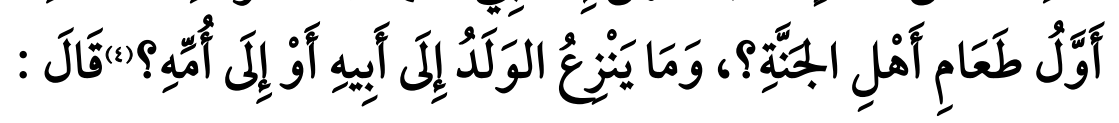

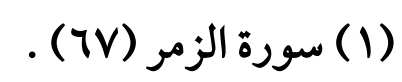

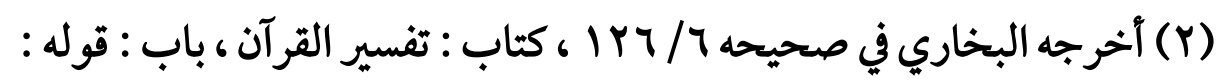

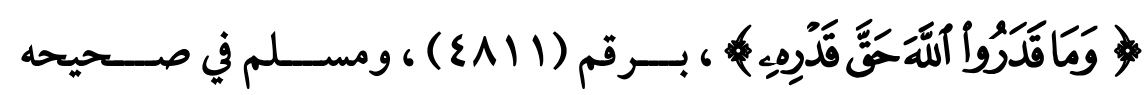

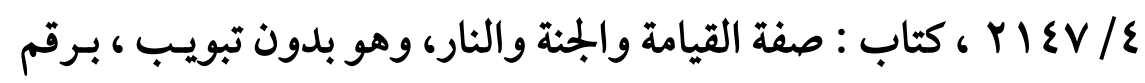

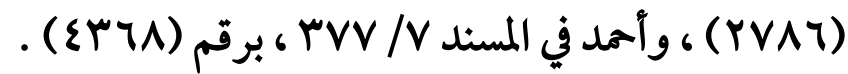

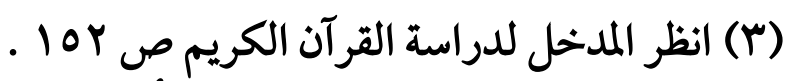

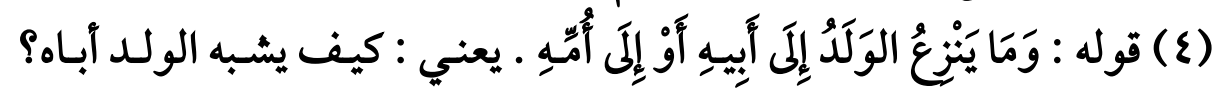

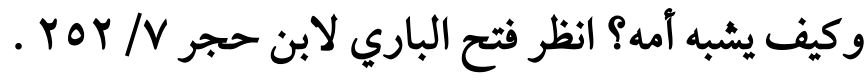




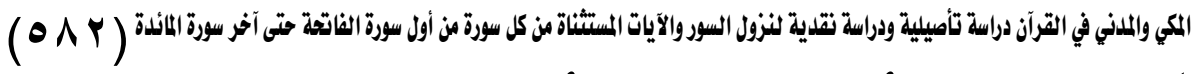

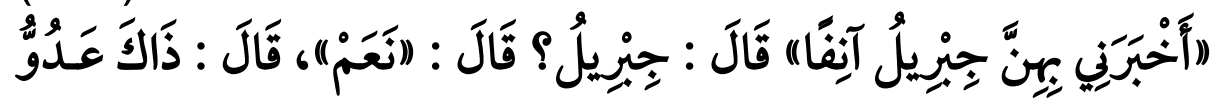

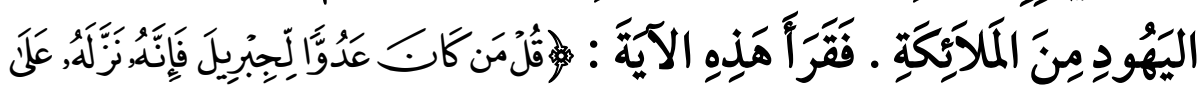

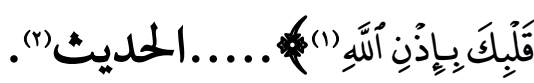

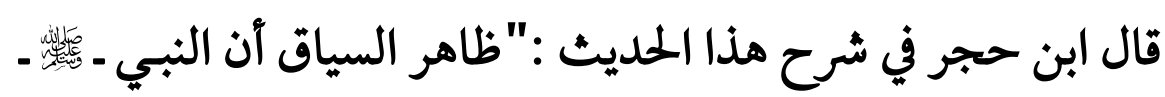

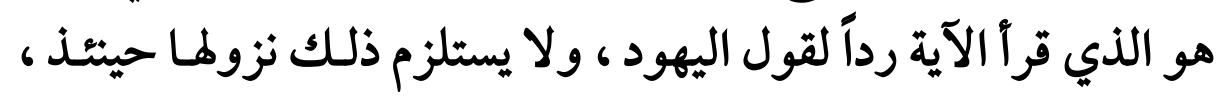
وهذا هو المعتمد ، فقد صح في سبب نزول الآية قصة غير قصة عبد الله

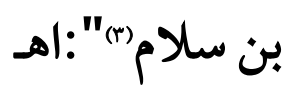

وهكذا يتبين لنا أن (افتلا كذا)) آو ((فقر أ كذا) لا تـدل على آن الآية نزلت حينئذ ، ويكون ذكرها عقب القصة إما للاستشهاد كها في المثال

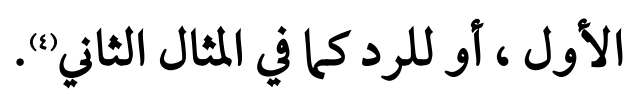

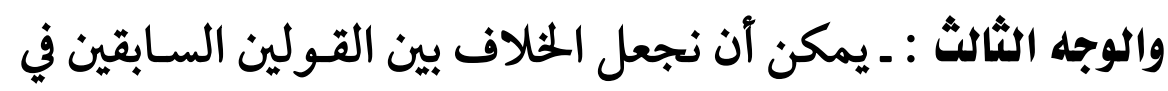

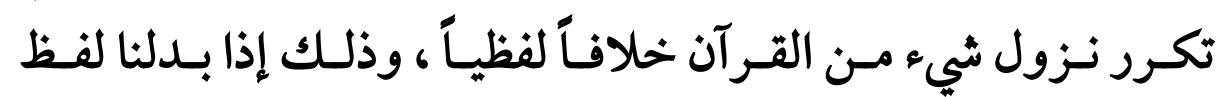

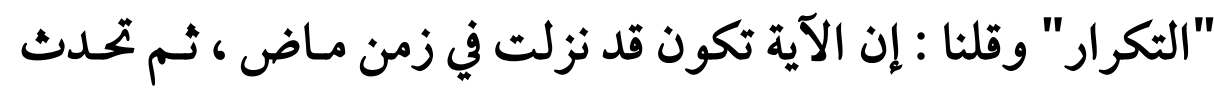

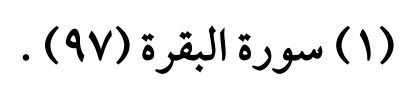

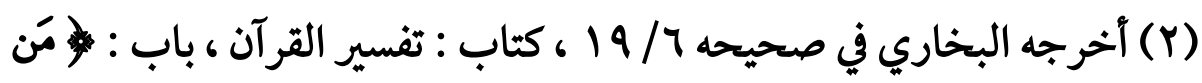

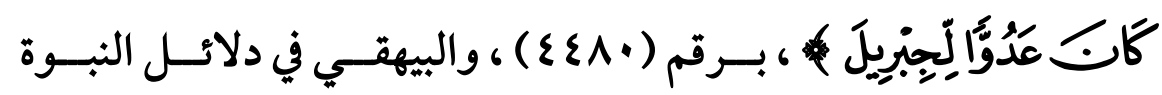


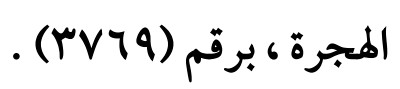

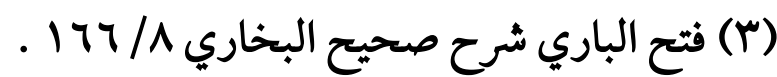

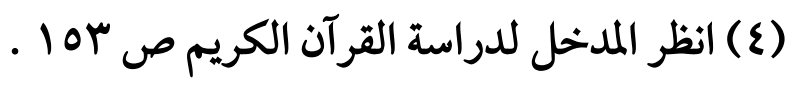


واقعة تشتمل الآية على حكمها ، فينزل جبريل فيقرأ الآية على النبي -

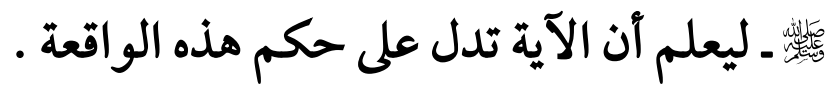

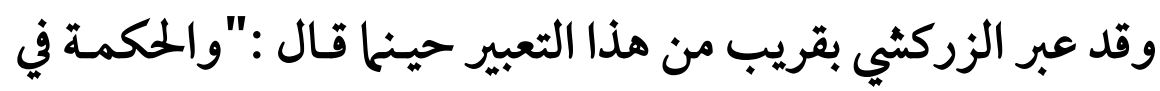

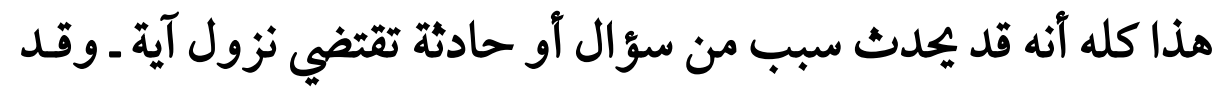

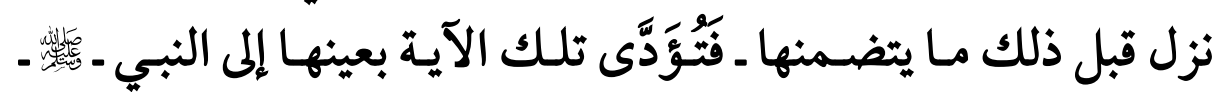

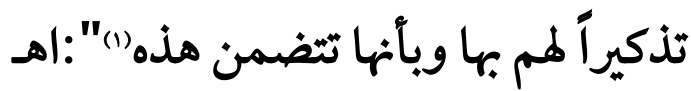

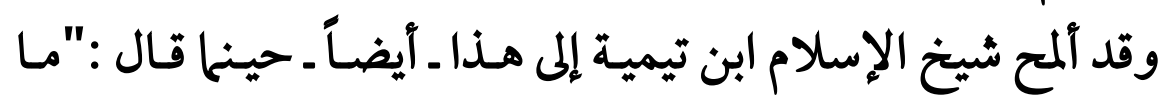

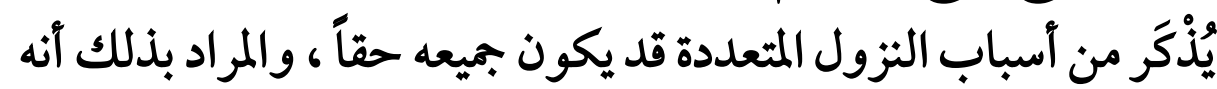

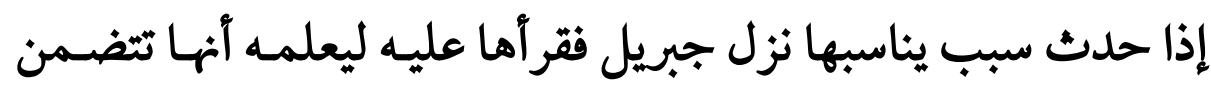
جواب ذلك السبب ، وإن كان الرسول يحفظها قبل ذلك(r)":اهـ

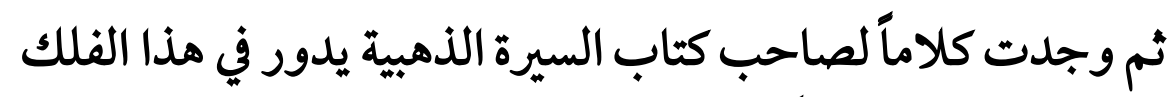

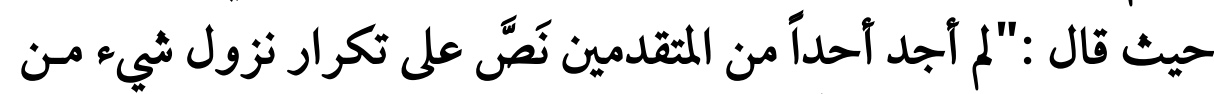

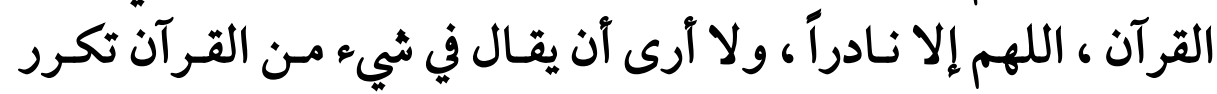

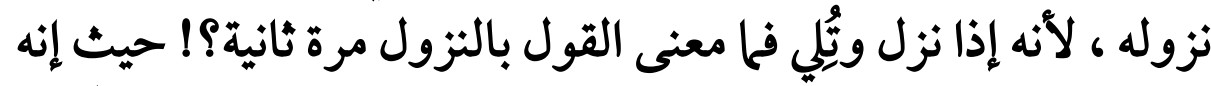

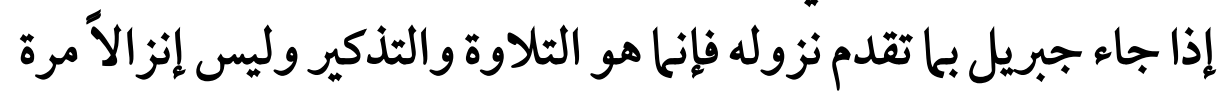

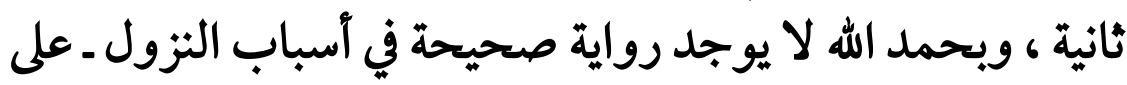




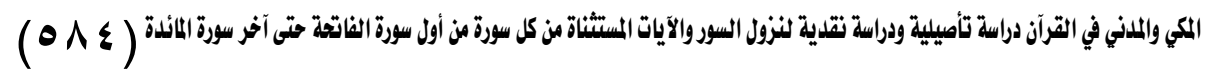
الرغم من التبع الشديد ـ تجعلنا نقول بتعدد النزول ، وما ورد مما يقال

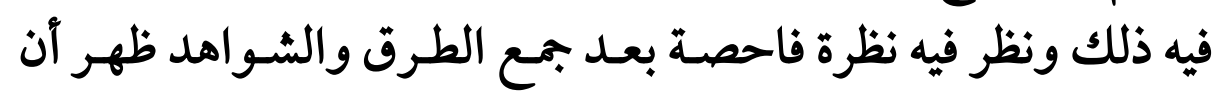

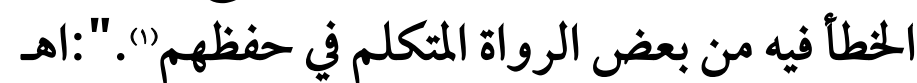

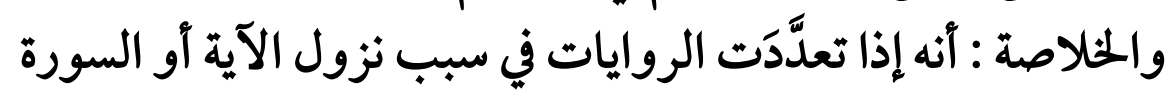

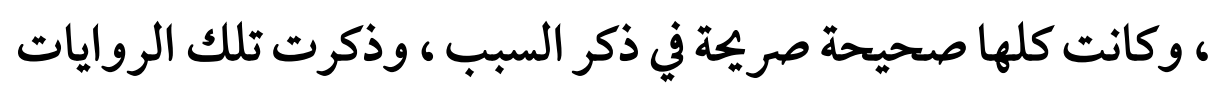

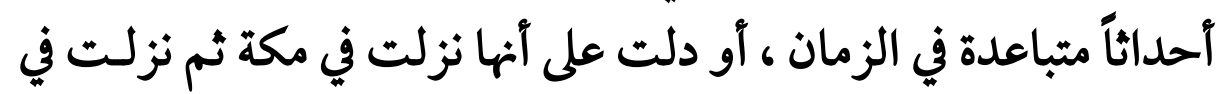

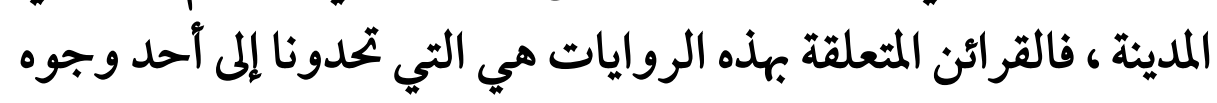
ثلاثة :

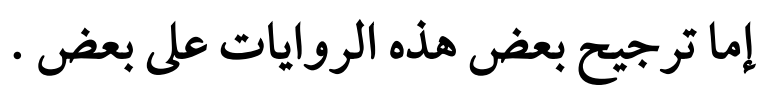

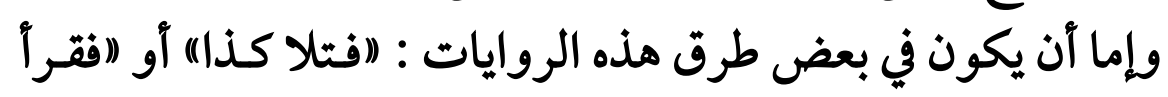

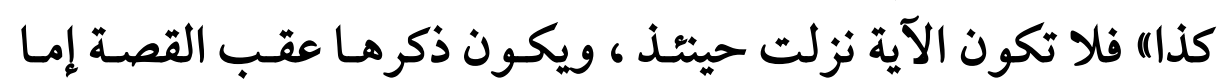

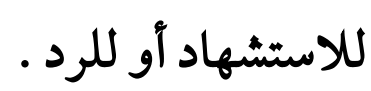

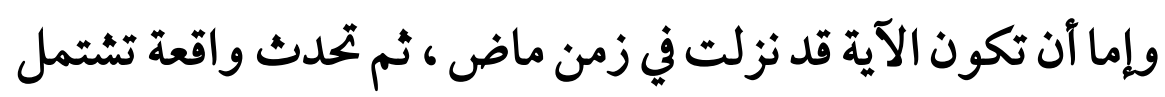

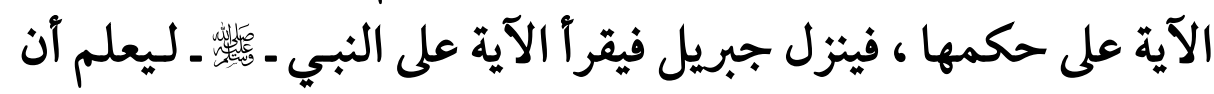
الآية تدل على حكم هذه الواقعة .

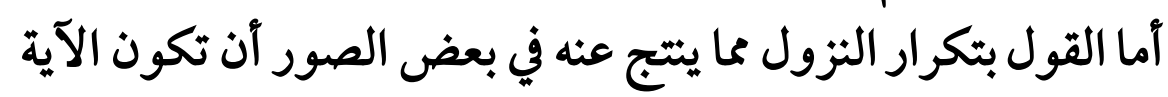

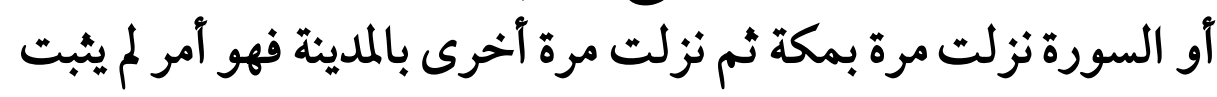

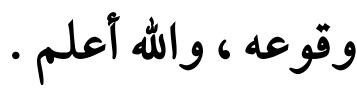

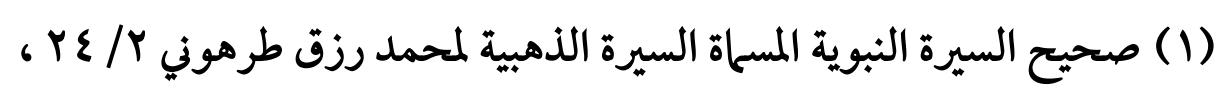

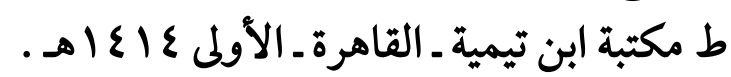


$(\bullet \wedge \bullet)$

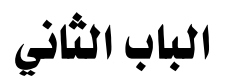

$$
\begin{aligned}
& \text { نزول السوروالآيات } \\
& \text { مز أول سورة الفاتحة حتى آخر سورة المائدة }
\end{aligned}
$$

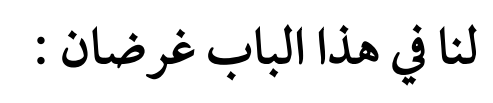

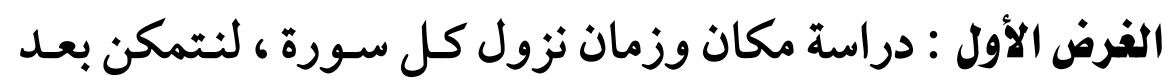

$$
\text { ذلك من وصفها بأنها مكية أو مدنية . }
$$

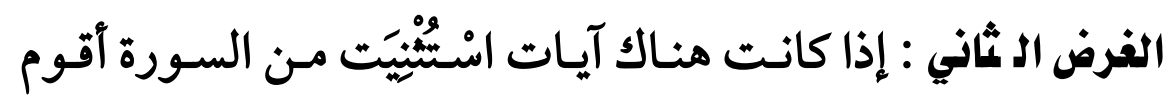

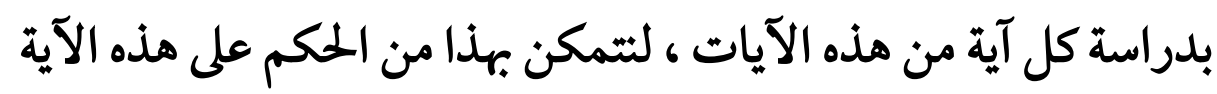

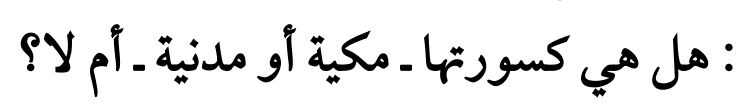

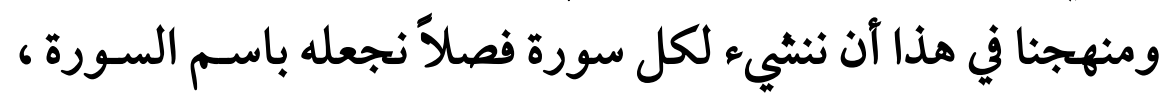

$$
\text { ثم نقسم هذا الفصل إلى مبحثين : المبحث الأول : في نزول السورة الميثيث }
$$

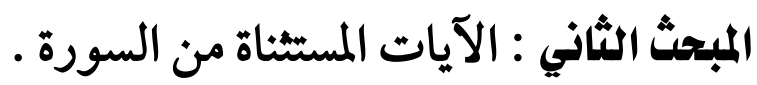

ثم نبحث كل آية في مطلب مستقل . 
المي والملني في القرآن دراسة تأصيلية وادراسة تقدية لنزول السور والآيات الستثناة من كل سورة من أول سورة الفاتثة حتى آخر سورة المائدة ( 7 م ه )

$$
\text { سورة الفصل الأول }
$$

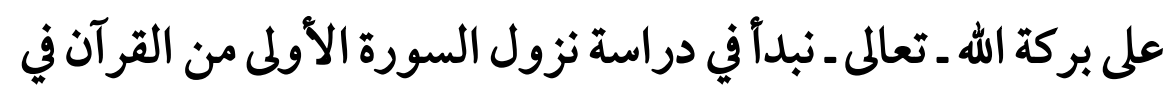

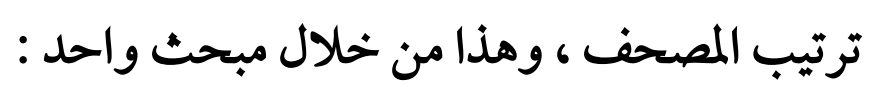

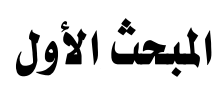

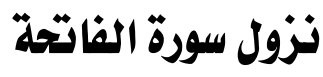

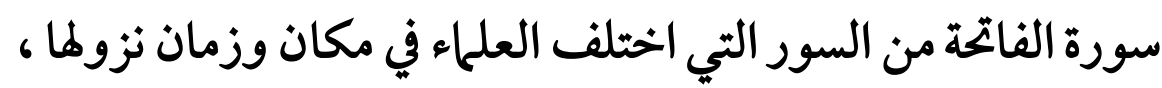

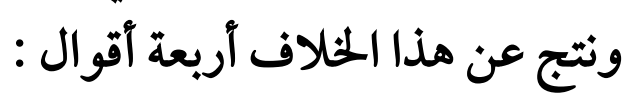

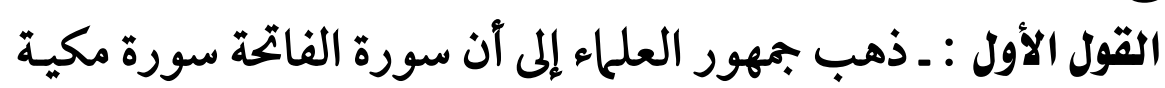

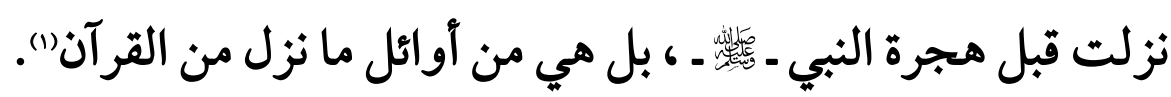

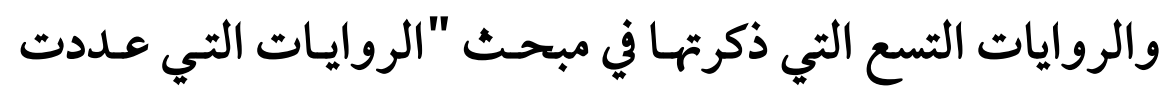

(1) انظر الكثف والبيان عن تفسير القرآن لأمد بن محمد بن إيراهيم الثعلبي

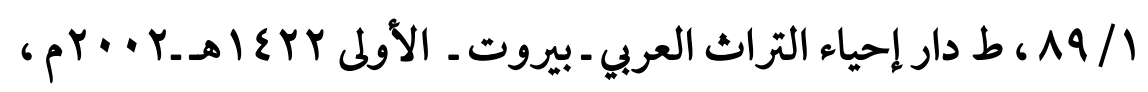

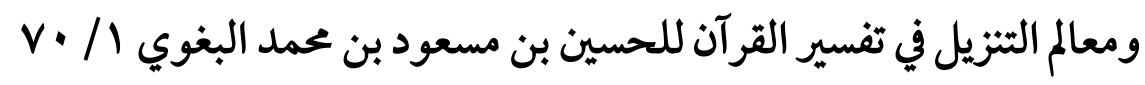

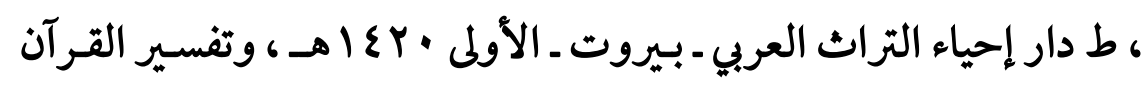

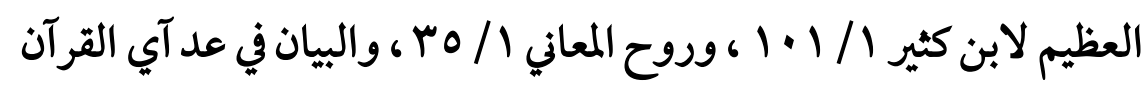

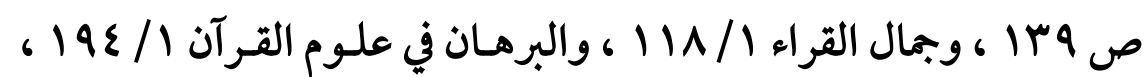

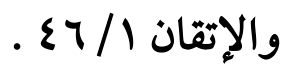


(OAv)

المكي والمدني"(1) سقطت سورة الفاتحة من ثناث منها ، وجـاء في روايـة

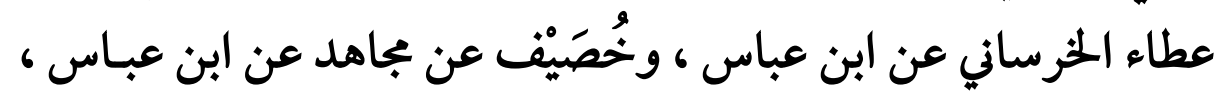

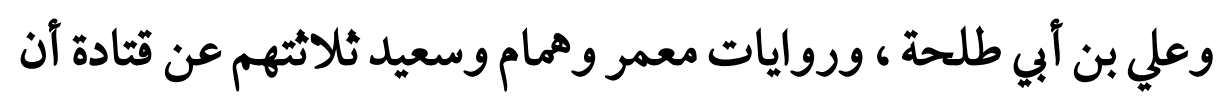
سورة الفاتحة مكية . وقد دل على هذا القول جملة أدلة :

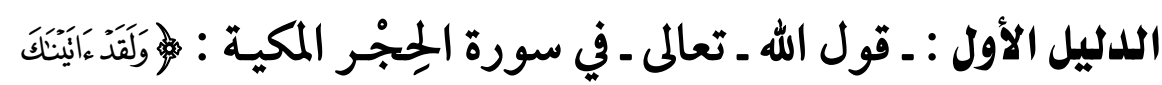

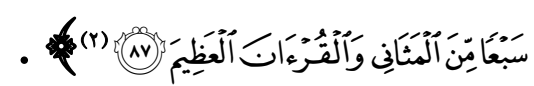

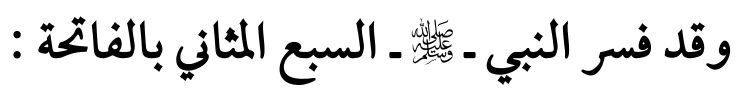

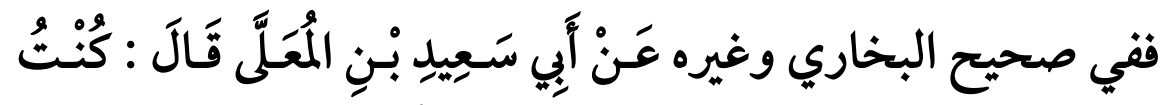

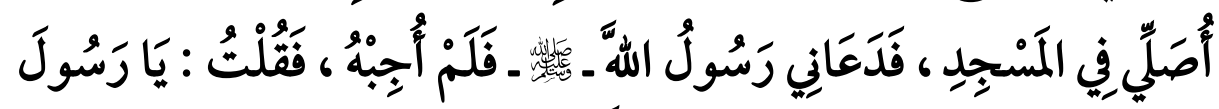

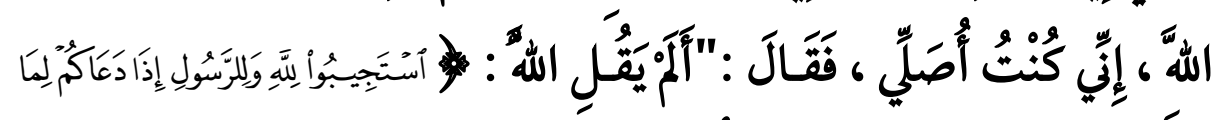

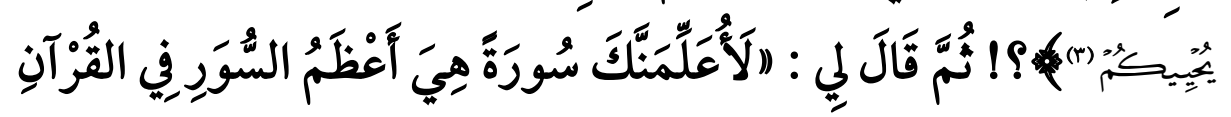

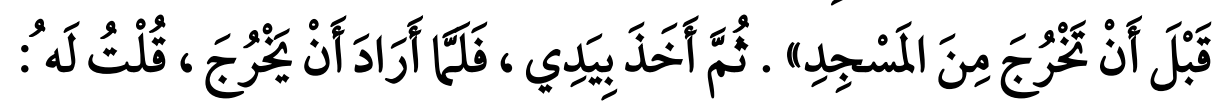

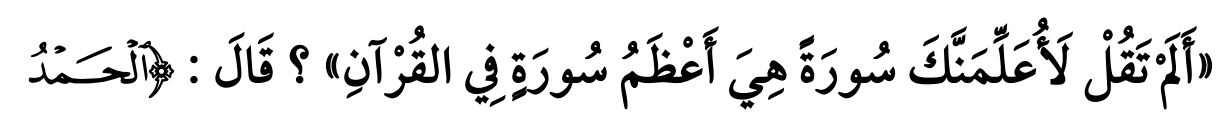

(1) انظر من ص r r إلى ص Or من هذا البحث .

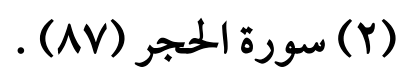

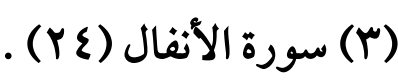




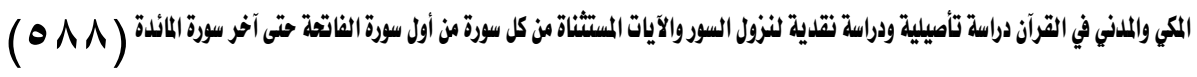

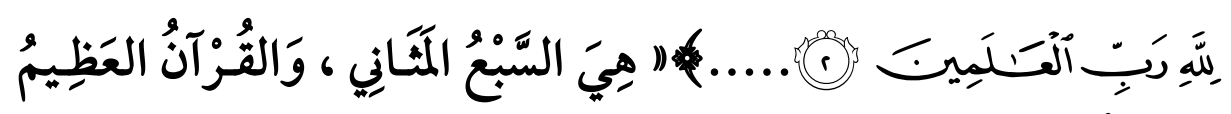

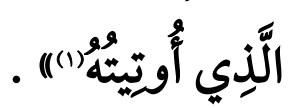

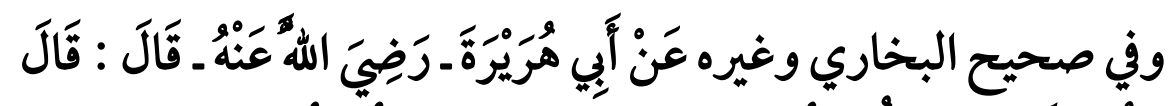

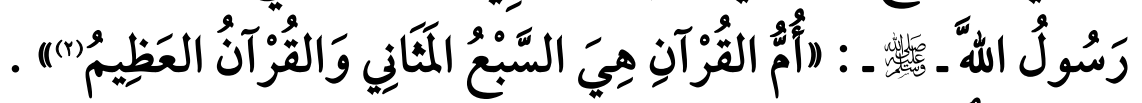

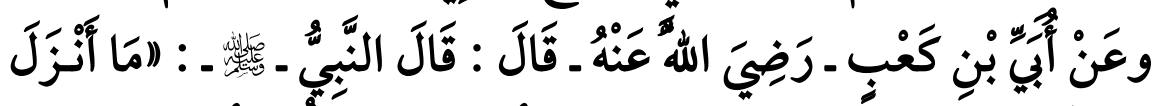

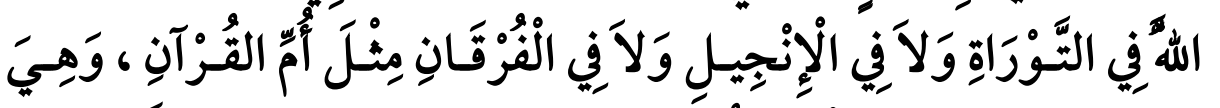

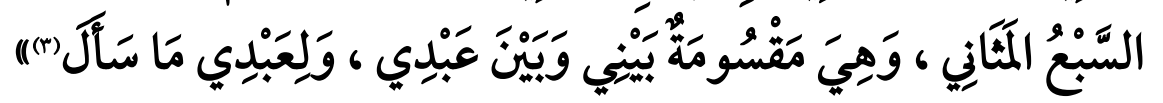

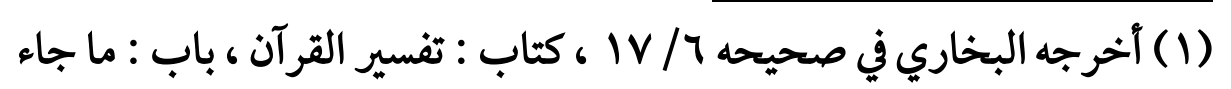

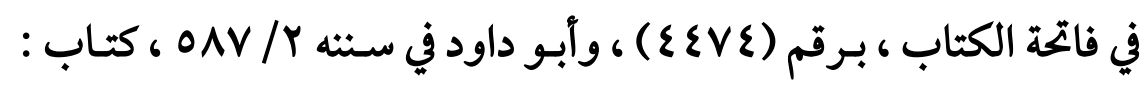

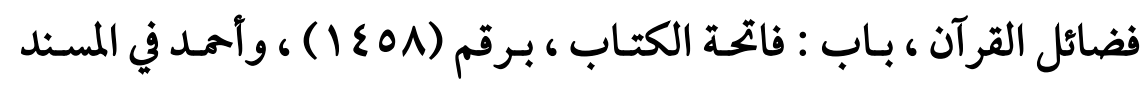

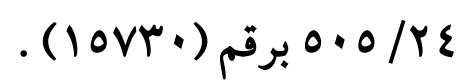

(Y) أخرجه البخاري في صحيحه T/ 1 1 ، كتاب : تفسير القرآن ، باب : قوله :

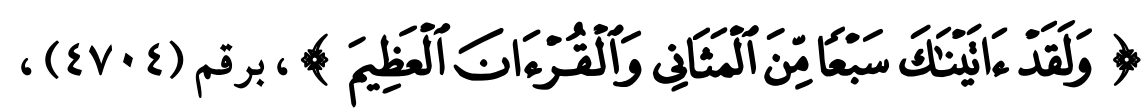

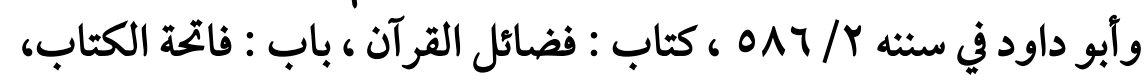

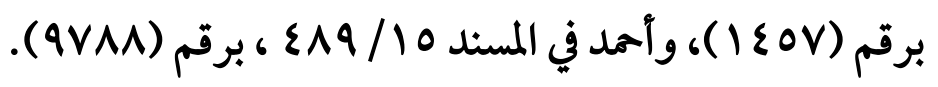

跣

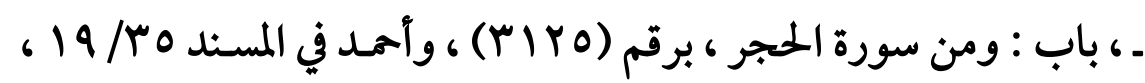

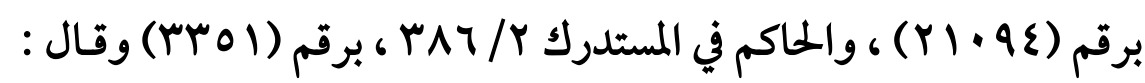
هذا حديث صحيح الإسناد على شرط مسلم ولم يخرجاه ـ وصححه محمد 
$(\bullet \wedge 9)$

وسورة الحجر مكية بلا خحلاف ، وقد امتن الله في آية من آياتها على

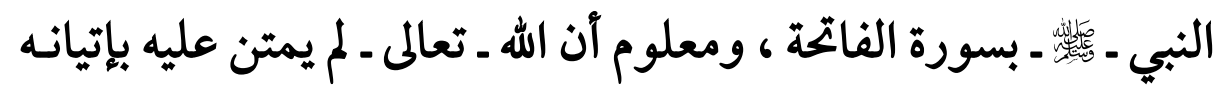

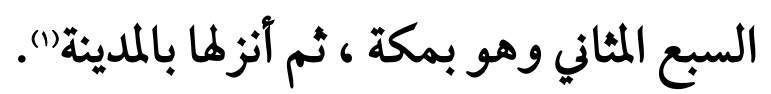

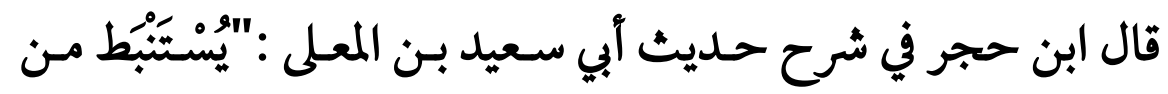

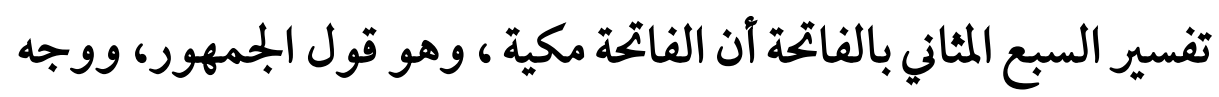

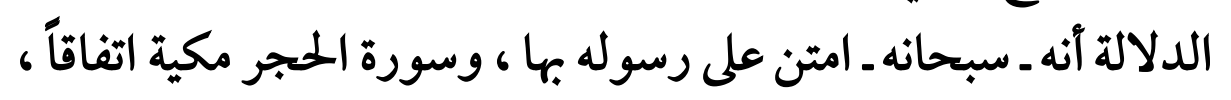

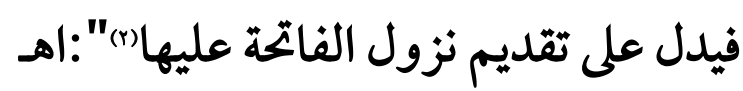

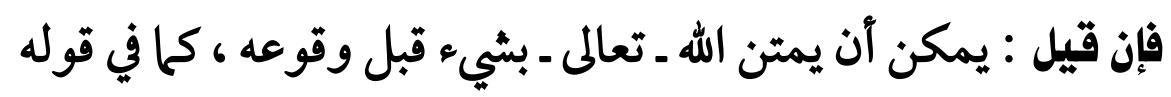

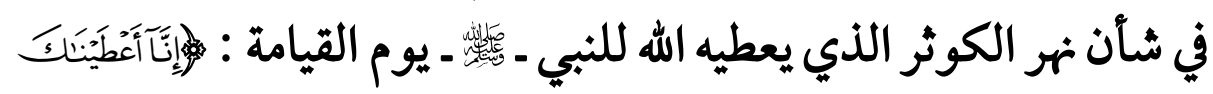

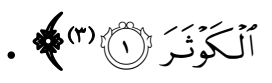

قيل : القرائن هي التي تدل على الامتنان بالشيء قبل إيتائه ، وهـو

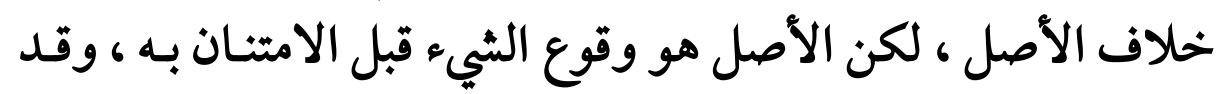

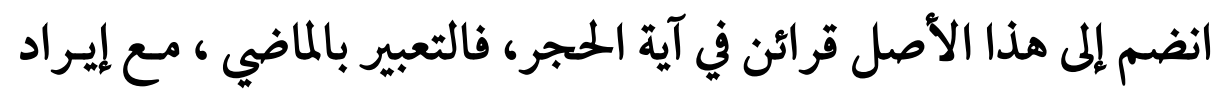

ناصر الدين الألباني في صحيح الجامع الصغير وزياداته / / ع 9 ، ، برقم

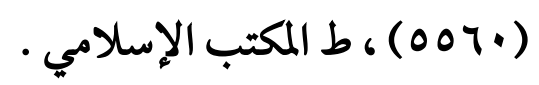

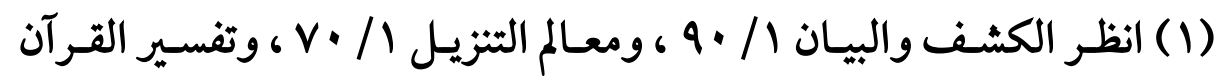

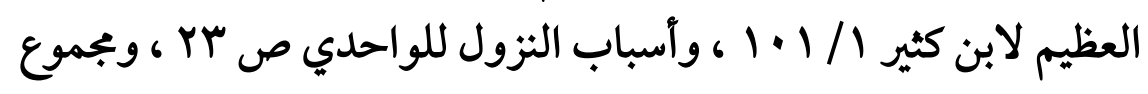

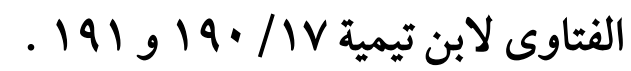

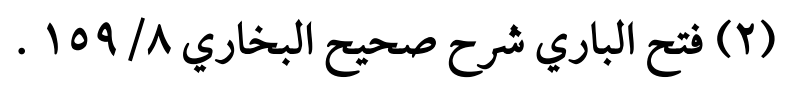

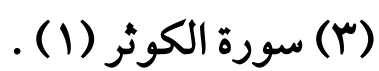




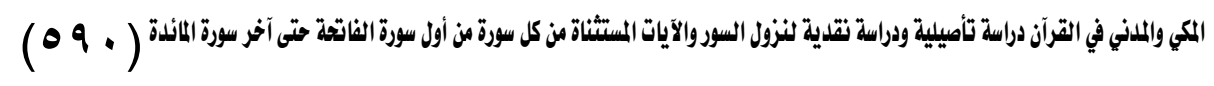
اللام التي للقسـم ، وكلمـة ((قـد) ، وورود الكـلام في معـرض المنـة ، والأصل في هذا سبق الوقوع).

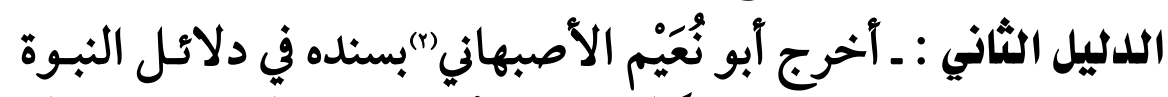

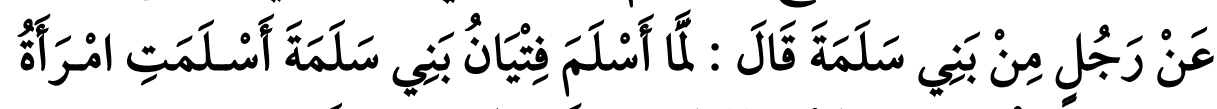

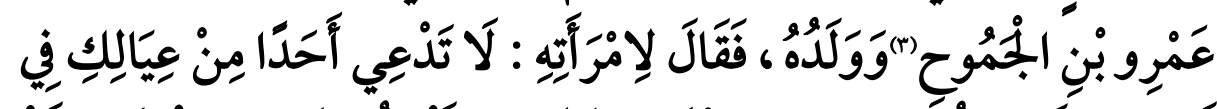

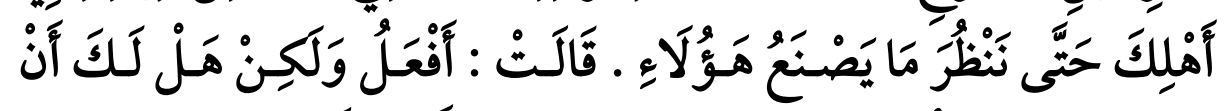

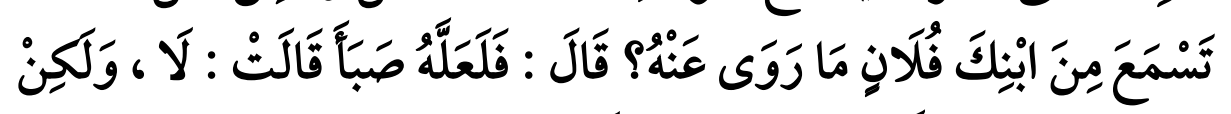

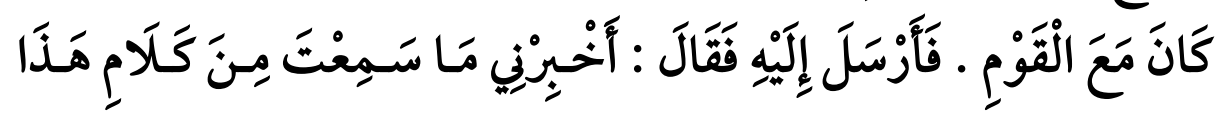

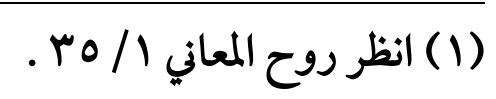

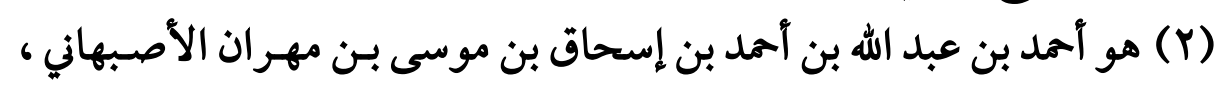

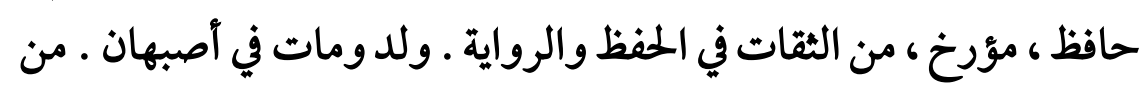

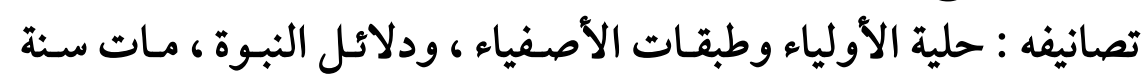

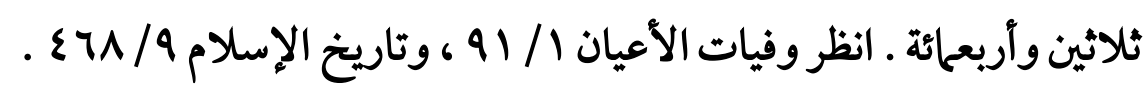

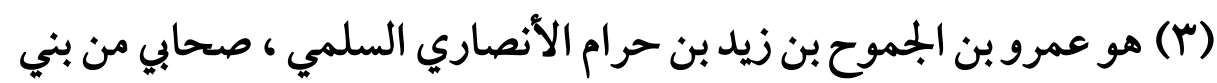

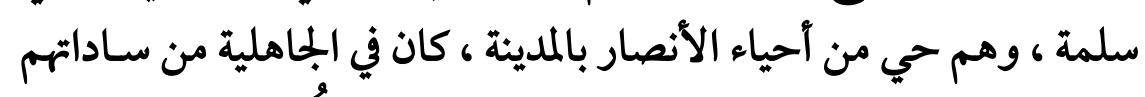

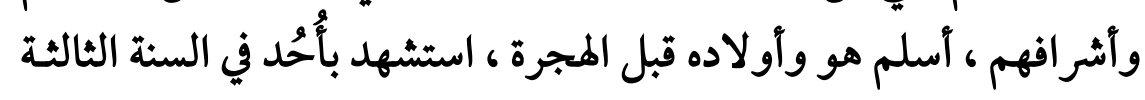

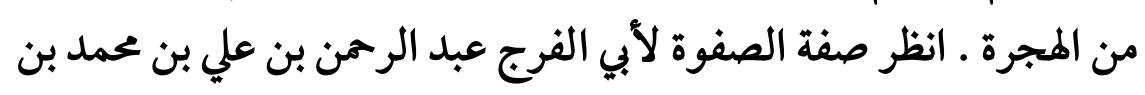

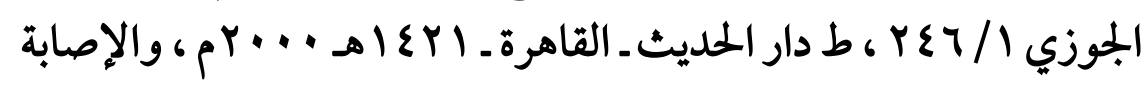

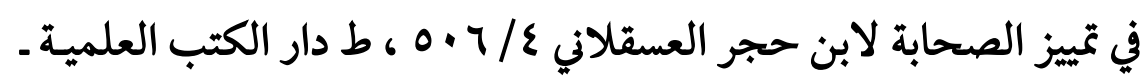
بيروت ـ الأولى 1 اع أهـ الهـ 
(091)

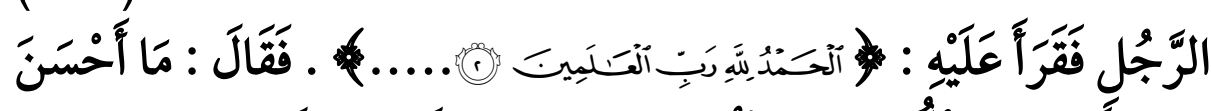

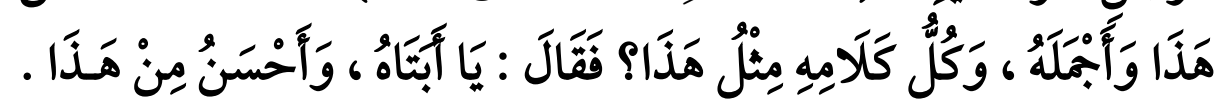

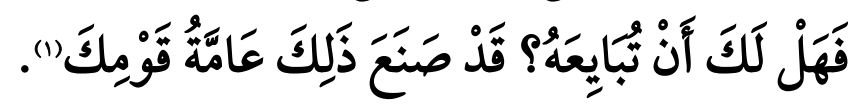

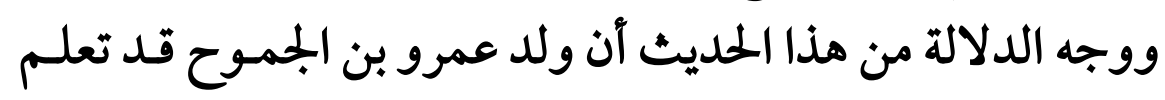

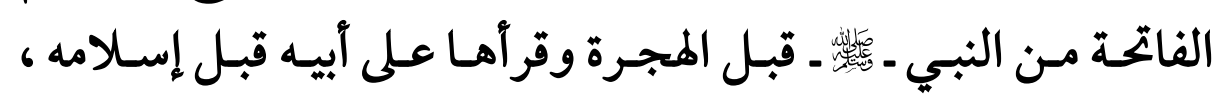

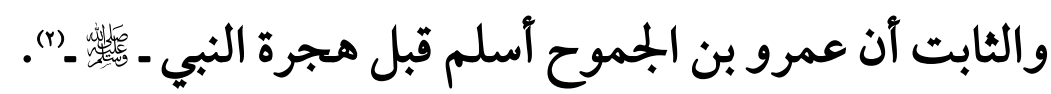

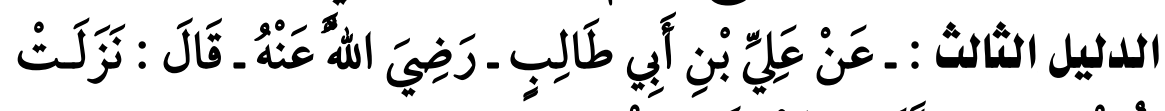

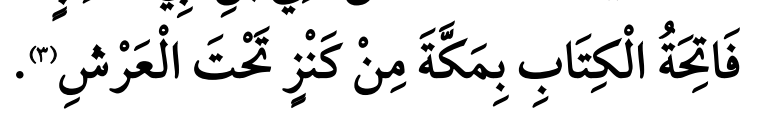

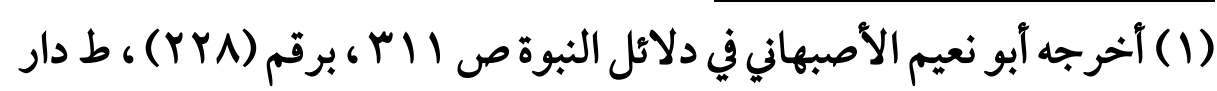

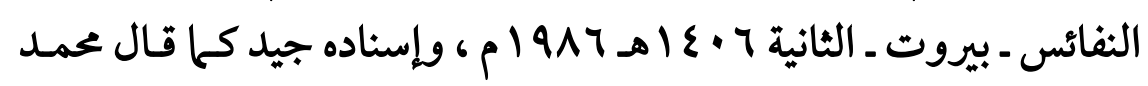

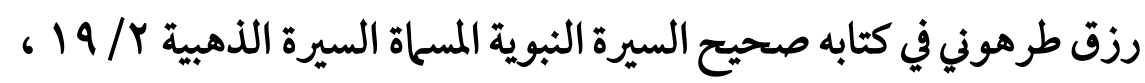

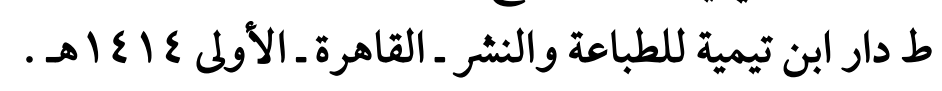

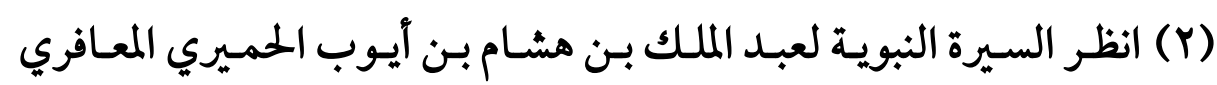

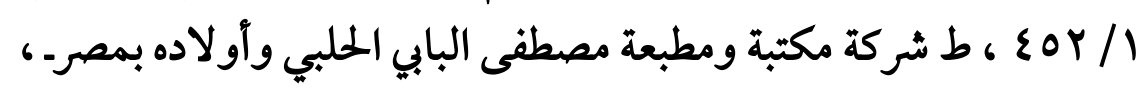

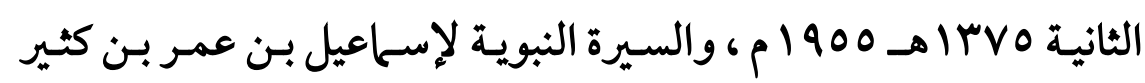

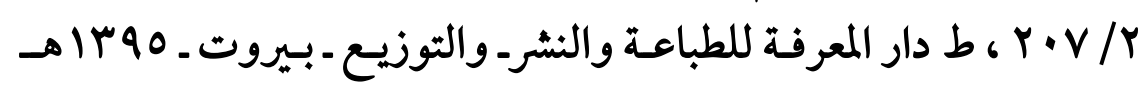

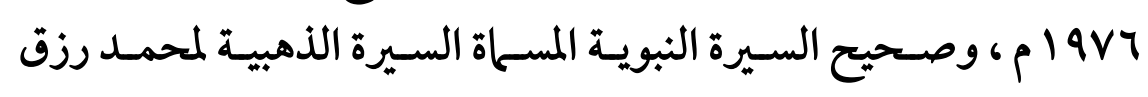

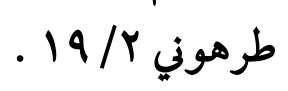

(r) أخرجه الثعلبي في الكشف والبيان / / 19 ، و ومن طريقه الواحدي في أسباب

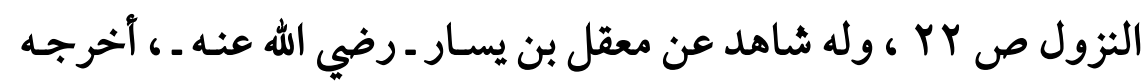

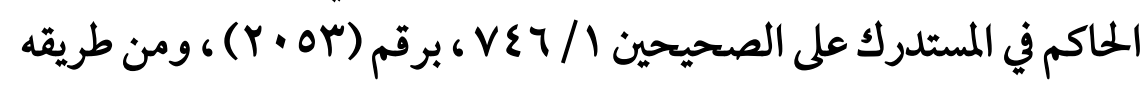




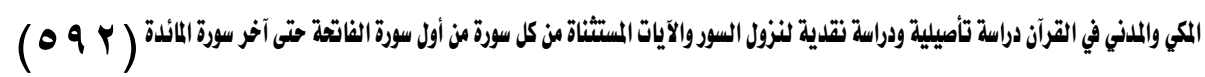
الدليل الرابع : ـ ما قرره بعض العلماء من أن سورة الفاتحة هي آول

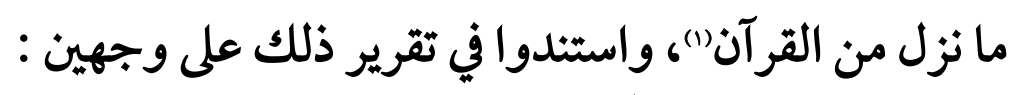

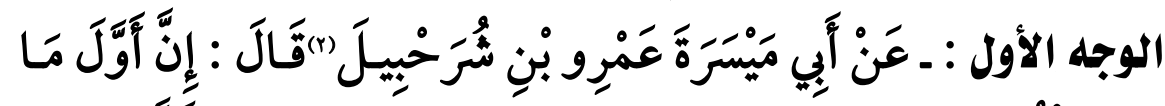

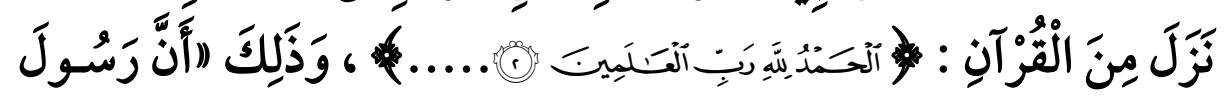

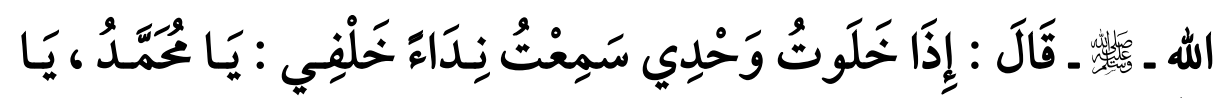

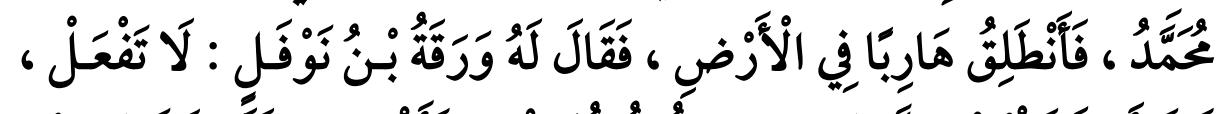

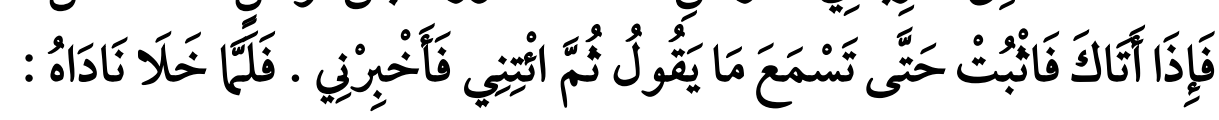

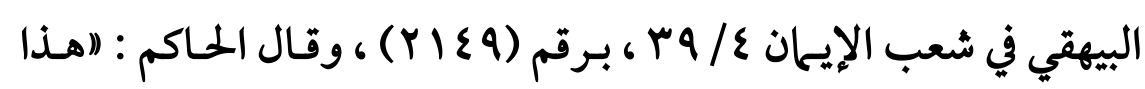

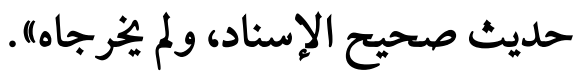

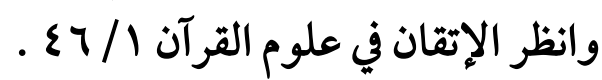

(1) انظر الكشف والبيان للثعلبي / / 19 ، والإيضاح في القراءات لأحمد بن أبي

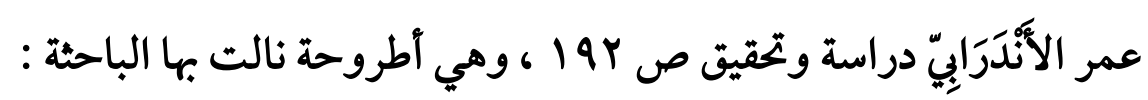
منى عدنان غني درجة الدكتوراة في كلية التربية للبنات في جامعة تكريت ـ

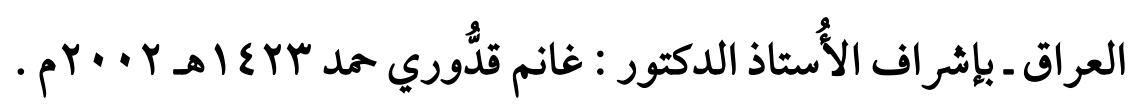
(Y) هو عمرو بن شرحبيل أبو ميسرة الممداني ثم الوادعي ، من أكابر التابعين

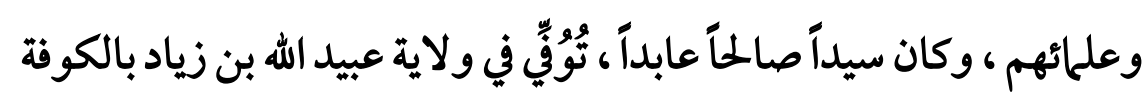

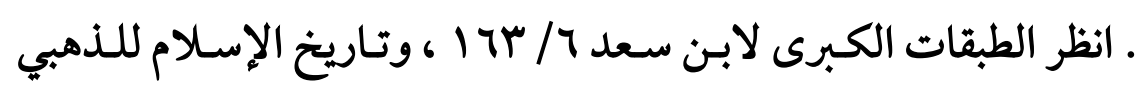


(०9

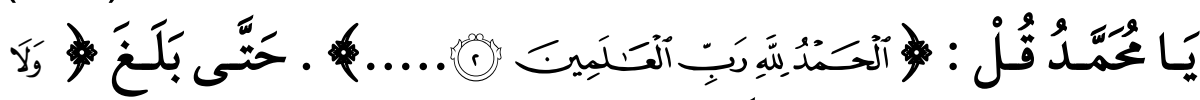

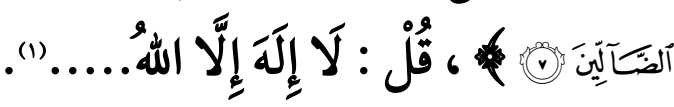

قلت : الثابت أن صدر سورة العلق هو أول ما نزل مـن القرآلن على آلى

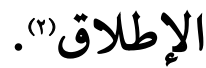

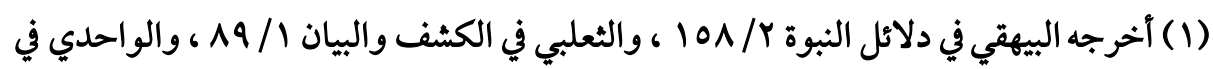

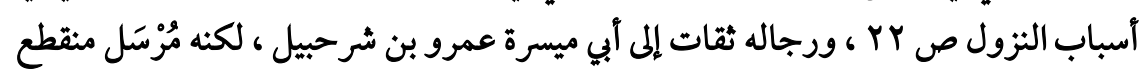

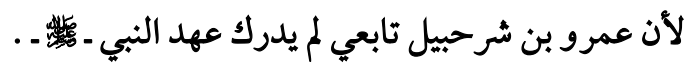

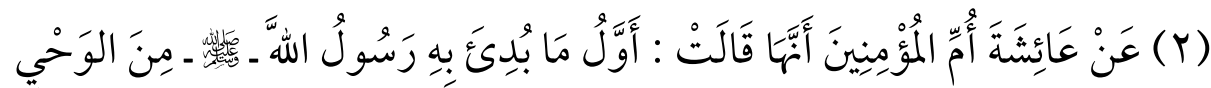

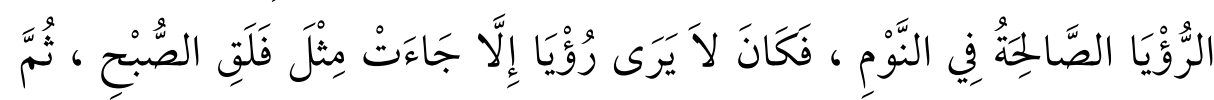

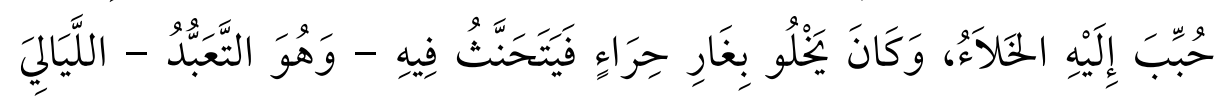

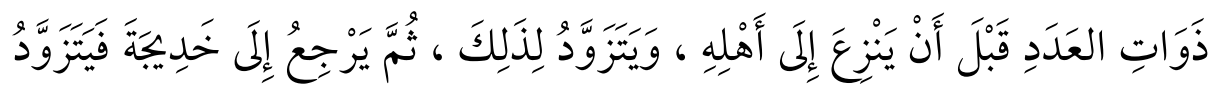

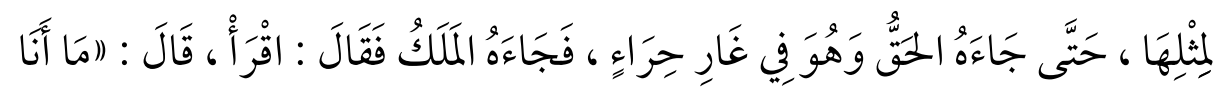

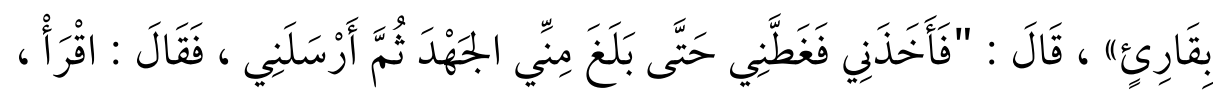

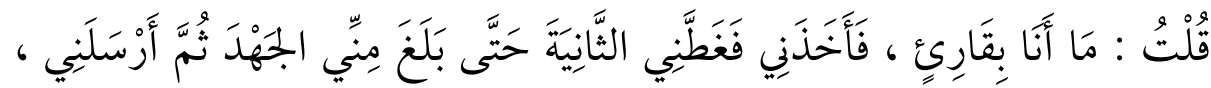

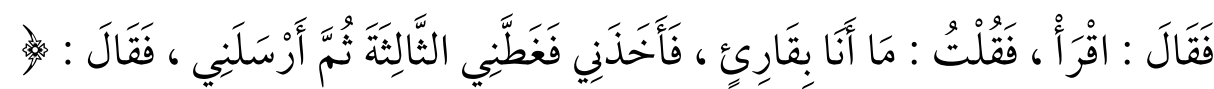

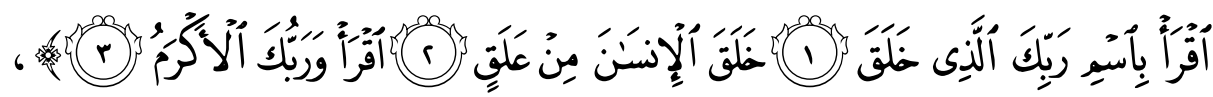

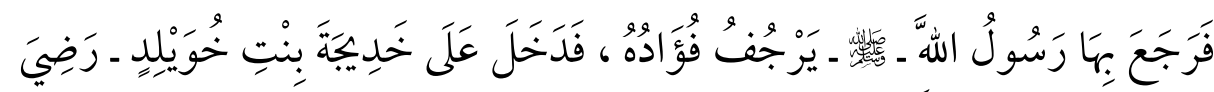

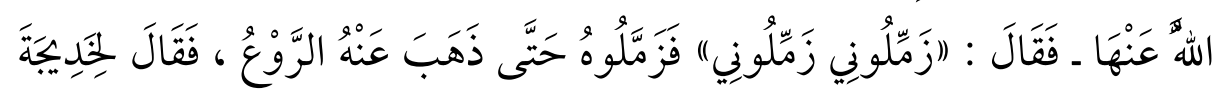




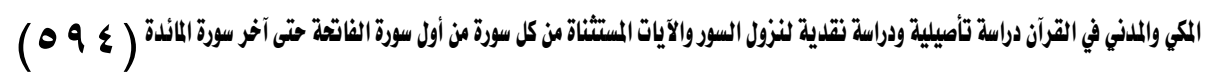
ولكن يكفي في حديث أبي ميسرة هذا آنه يدل على أن سورة الفاتحة

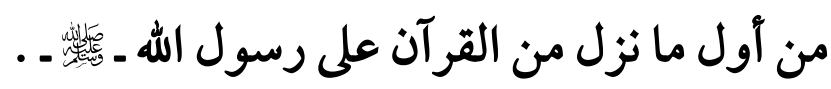

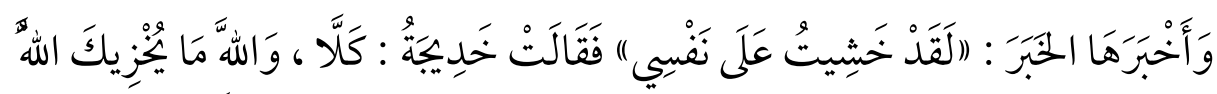

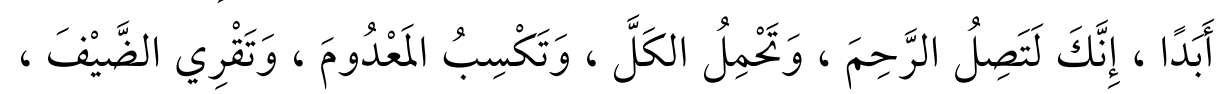

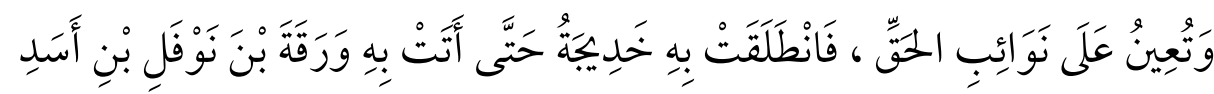

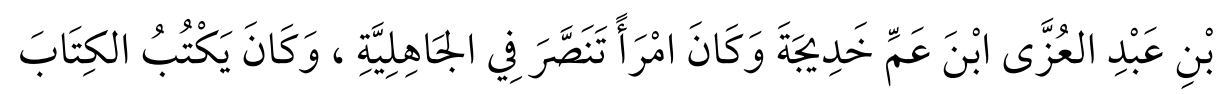

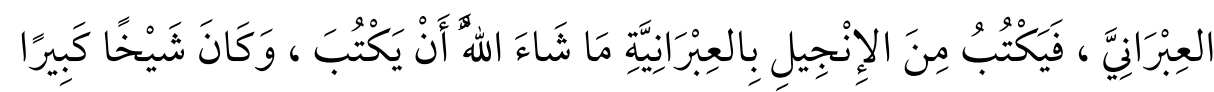

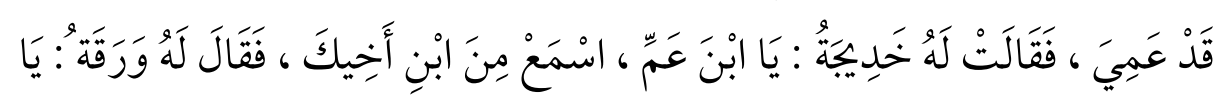

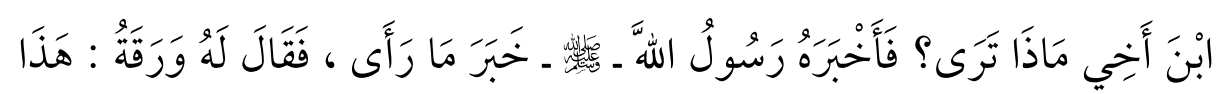

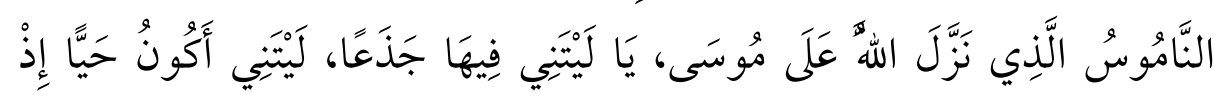

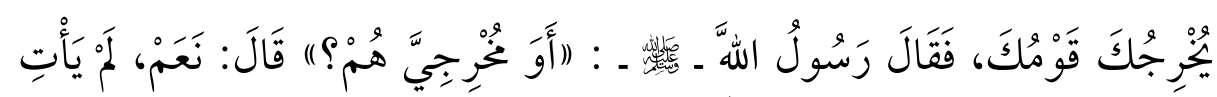

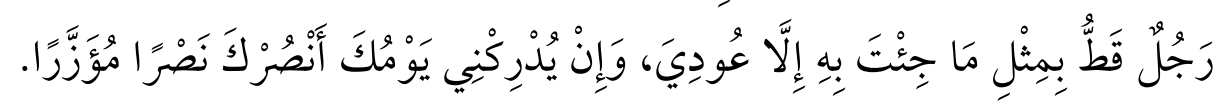

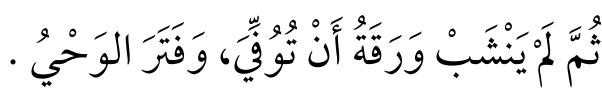

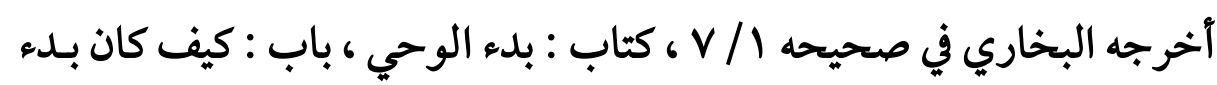

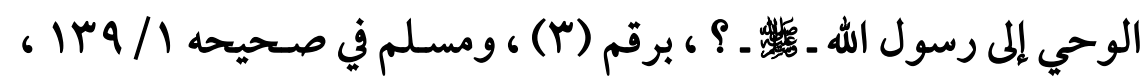

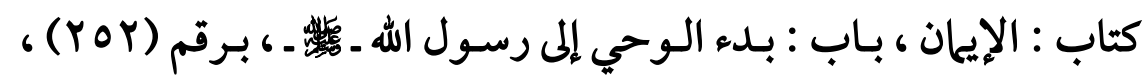

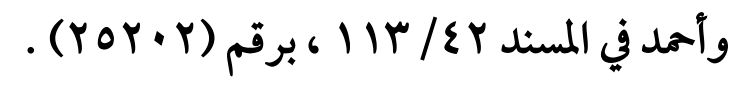

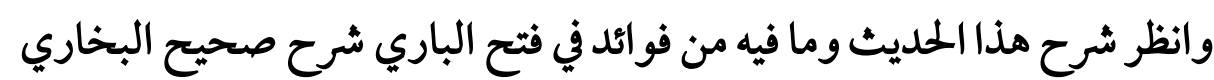

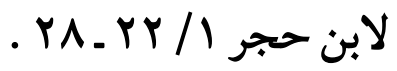


$(\bullet 90)$

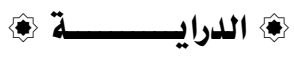

قال البيهقي بعد أن أخرجه :"هذا منقطع ، فإن كان محفوظاً فيحتمل

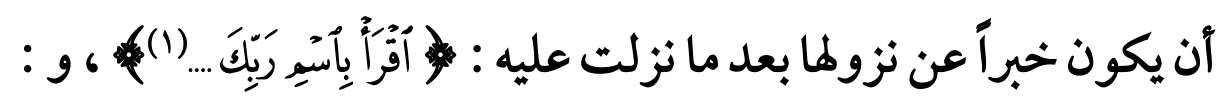

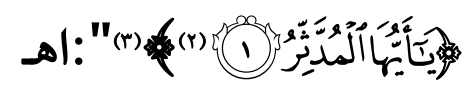

وقال ابن حجر في الفتـح :"هـو مُرْسَل ، وإن كـان رجاله ثقــات ،

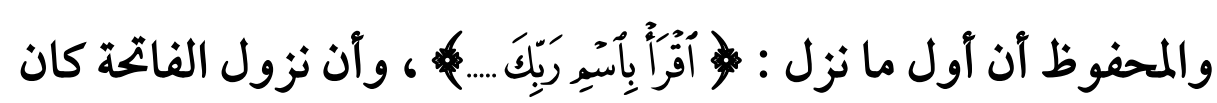
بعد ذلك(\&)":اهـ

وقال في العُجَاب :"هو مُرَسَل ، ورجاله ثُقات ، فإن ثُبت مُمِل على أن ذلك كان بعد قصة غار حراء ، ولعله كان بعد فترة الوحي (0)":اهـ وقال محمد رأفت سعيد :"لا يُفْهَم من قول الإمام البيهقي ـ رحمه الله ـ أنها السورة الثالثة ، ولكن يعني آن بداية التنزيل كان في الآيات الأولى لئ.

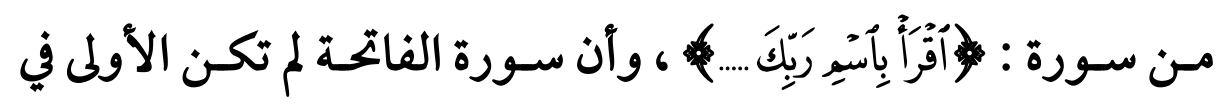

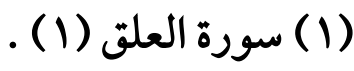

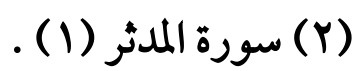

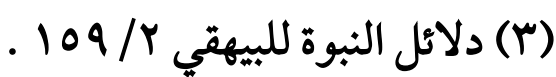

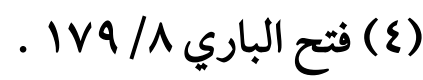

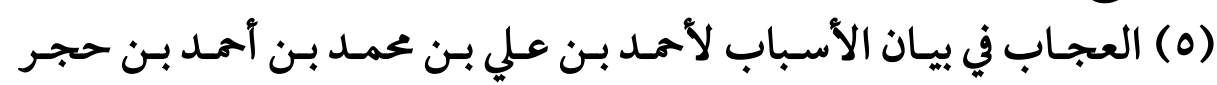

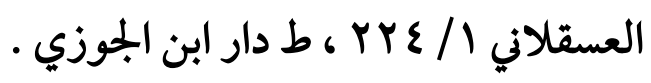




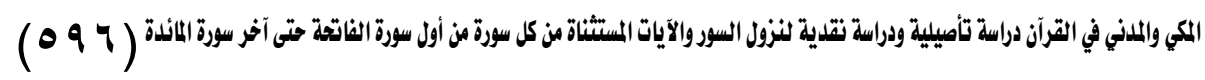

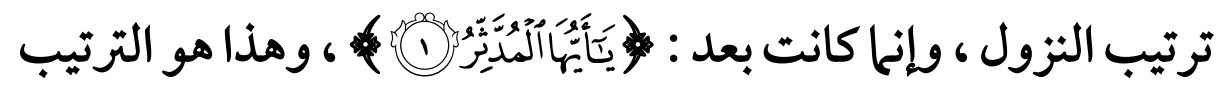

$$
\text { الراجح")" (1) - اهـ }
$$

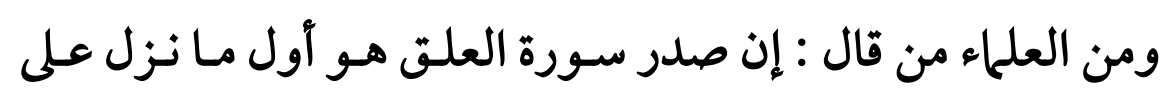

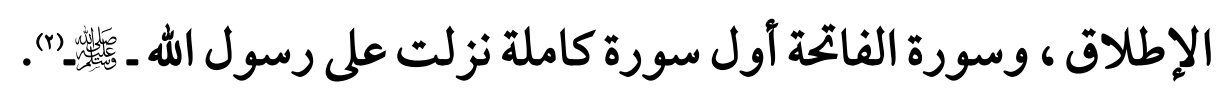

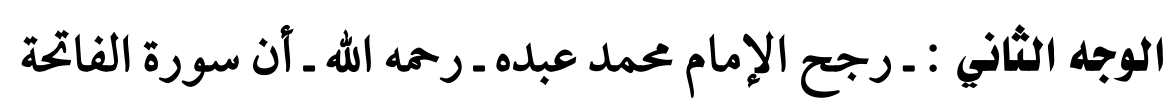

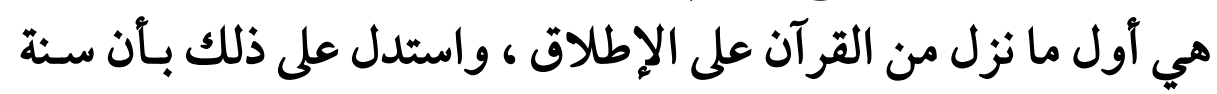

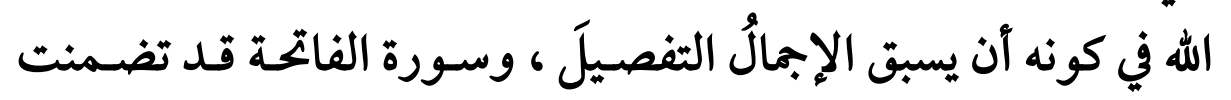

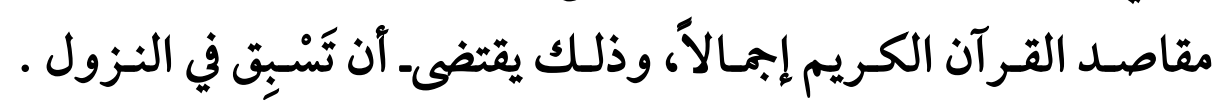

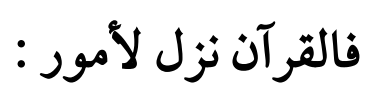

أحدها : التوحيد لأن الناس كانوا لأنوا وثنيين .

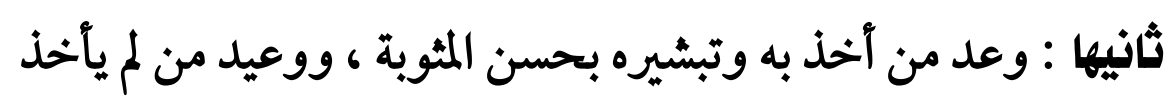

به وإنذاره بسوء العقوبة .

ثاثثها : العبادة التي تحيي التوحيد في القلوب وتثبته في النفوس.

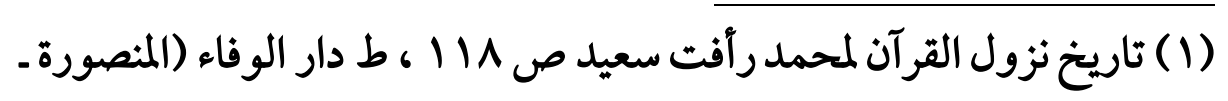

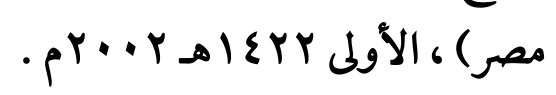

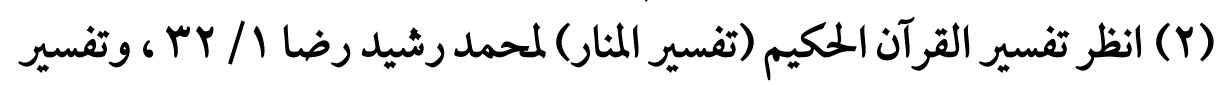

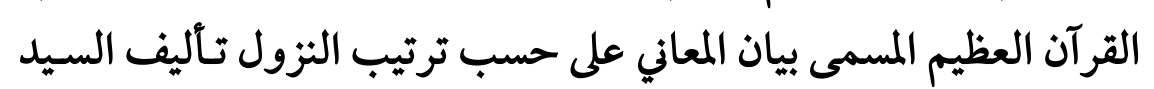

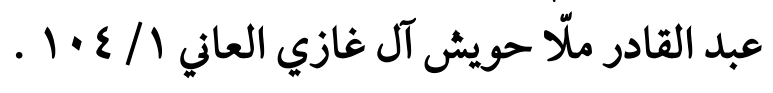


(o9v)

رابعها : بيان سييل السعادة وكيفية السير فيه الموصل إلى نعم الدنيا

والآخرة.

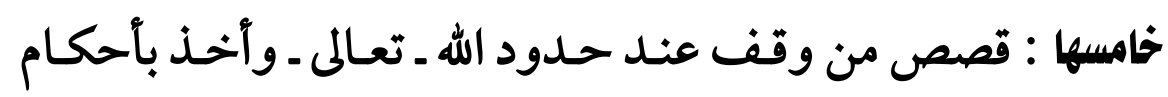

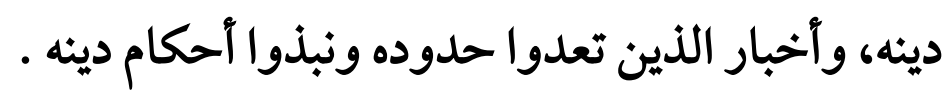
هذه هي الأمور التي احتوى عليها القرآن ، وفيها حياة الناس وسعادتهم الدنيوية والأخروية ، والفاتحة مشتملة عليها إنمالاً:

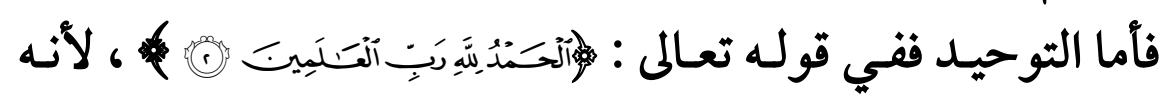

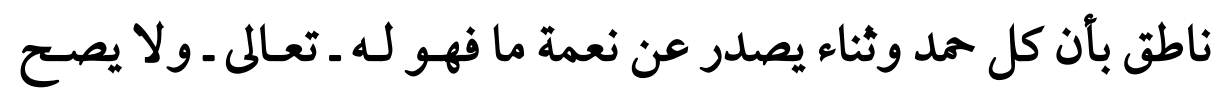

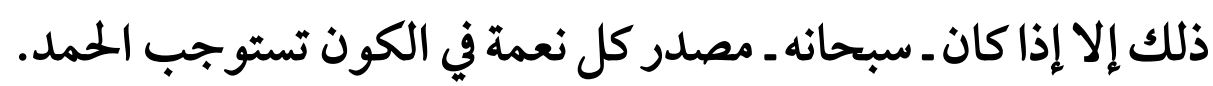

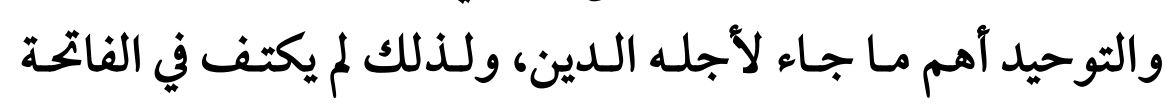

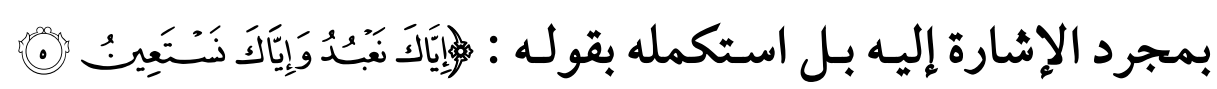

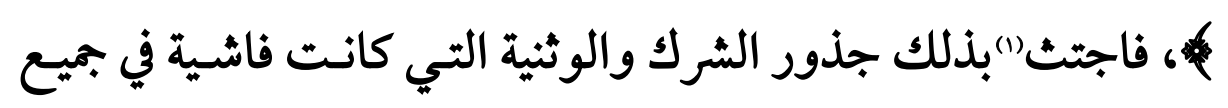
الأمم.

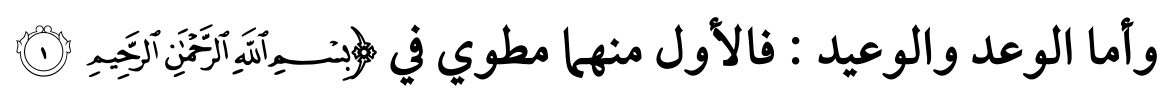

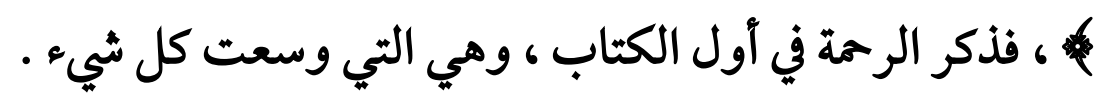

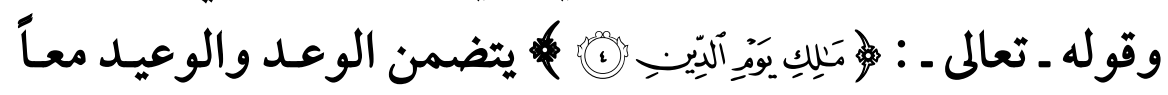

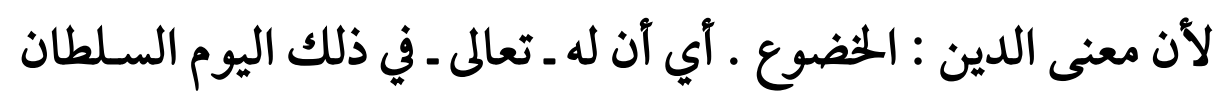
المطلق ، فالعالم كله يكون خاضعاً لعظمته ظاهراً وباطناً يرجو رهمته الئه

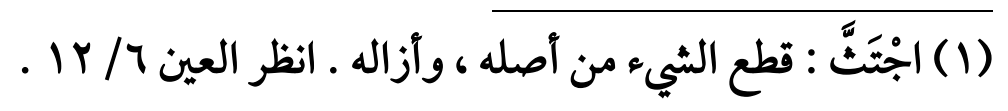




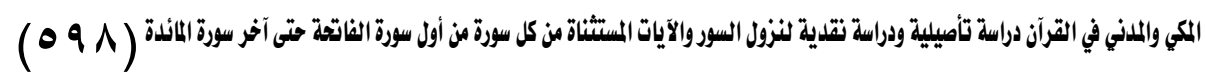
ويخشى عذابه ، وهذا يتضمن الوعد والوعيد ـ أو معنى الدين : الجزاء ،

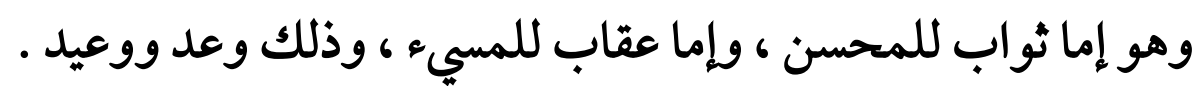

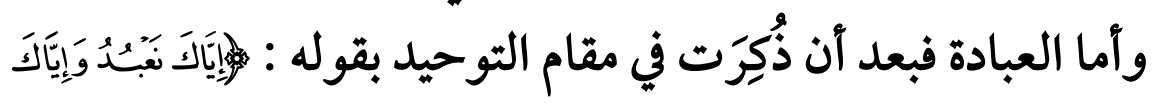

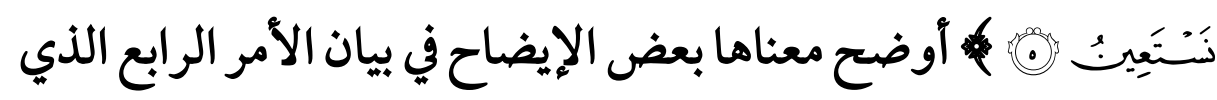

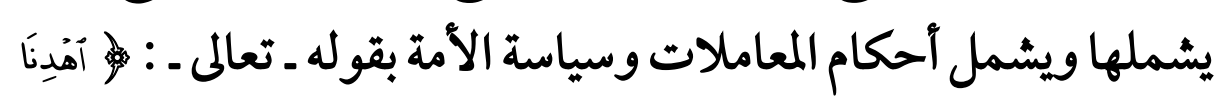

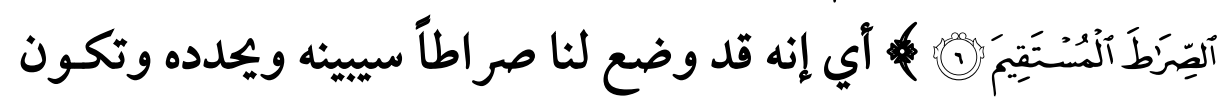

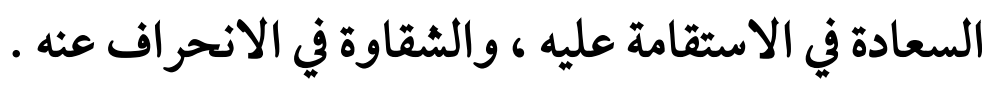

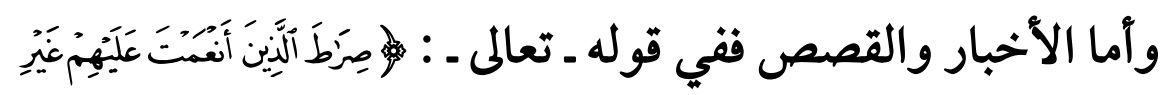

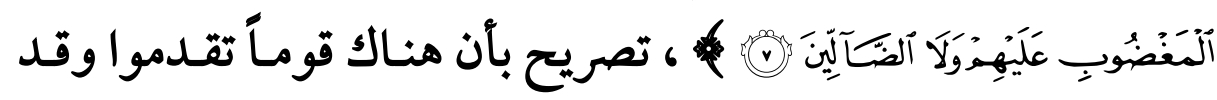

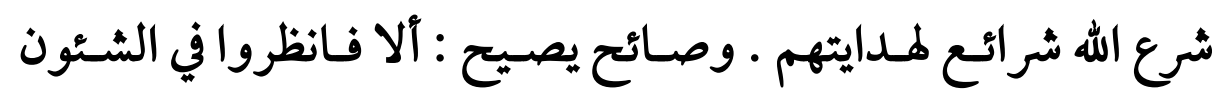
العامة التي كانوا عليها واعتبروا بها .

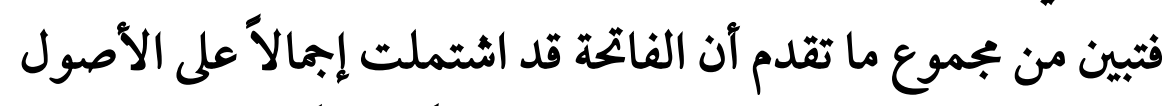

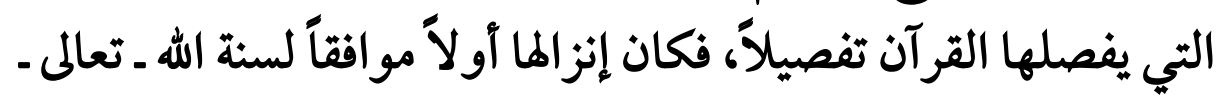

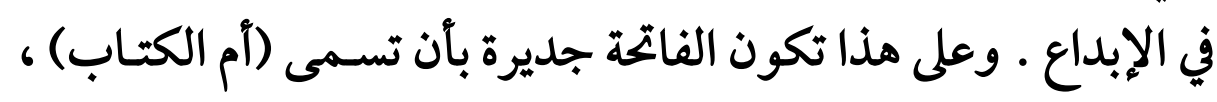

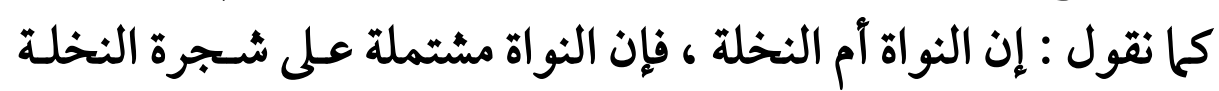

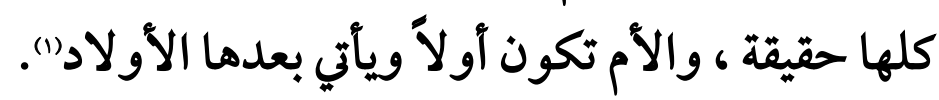

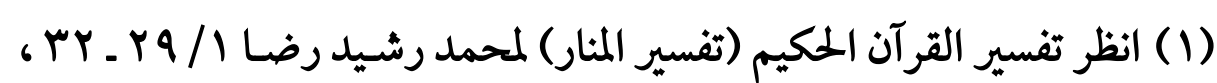
باختصار . 
وقد نقل هذا التوجيه عن الإمام محمد عبده تلميذه محمد رشيد رضا

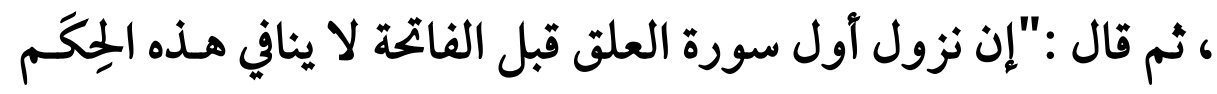

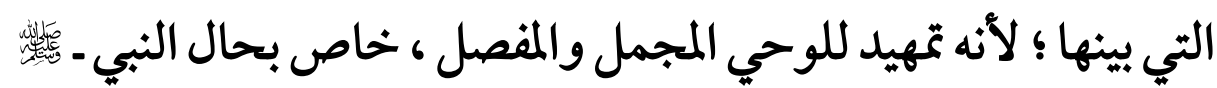
ـ ـ وإعلام له بأنه يكون ـ وهو أمي ـ قارئاً بعناية الله ـ تعالى ـ ومخرجياً

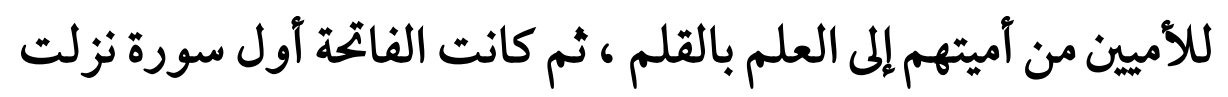

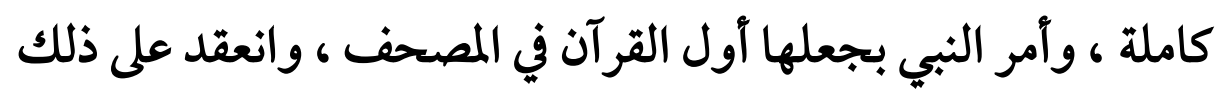

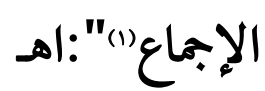

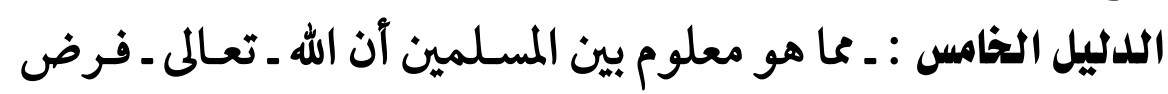

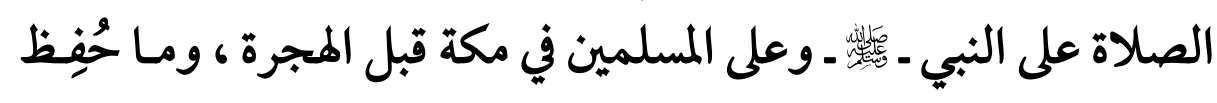

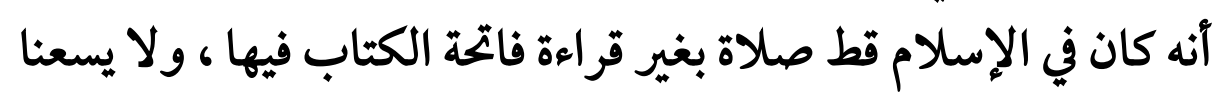

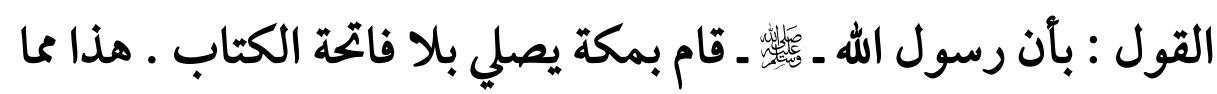
لا تقبله العقول ().

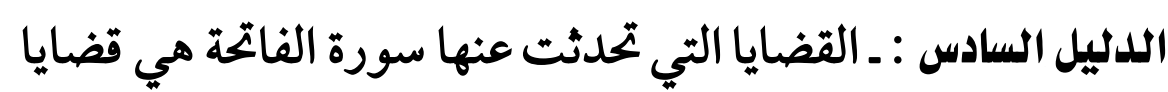

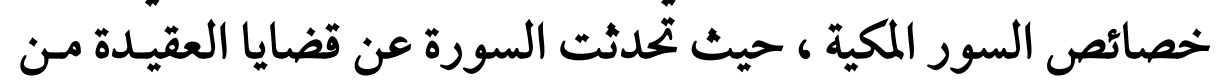

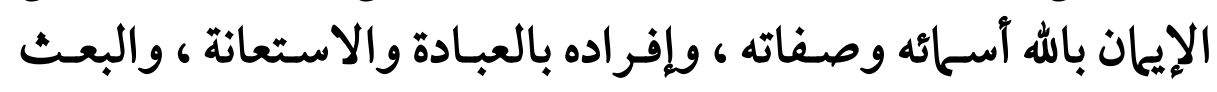

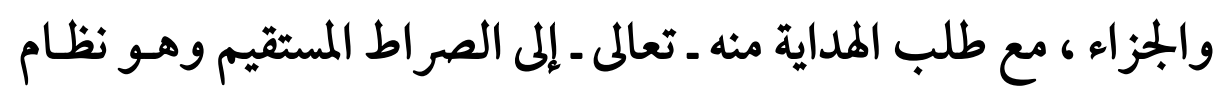

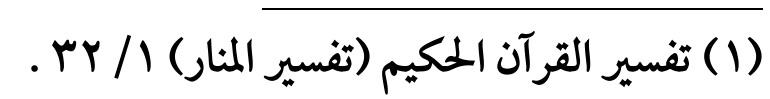

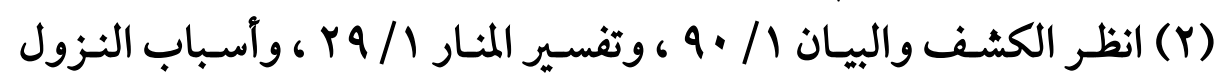

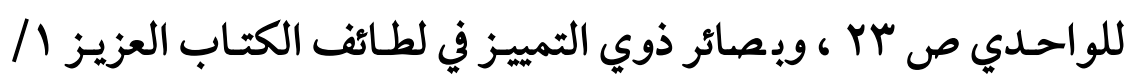

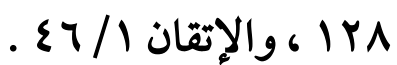




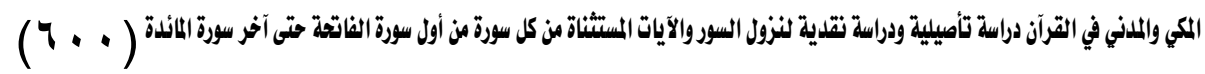

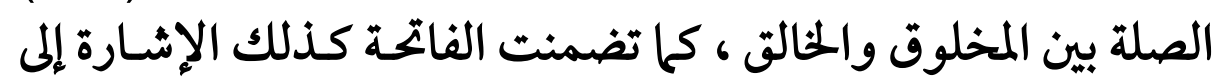

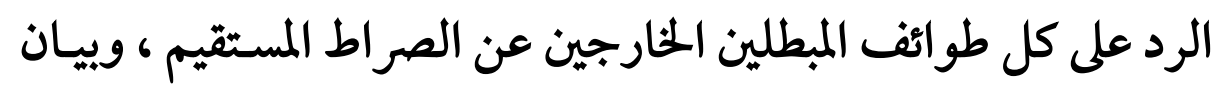

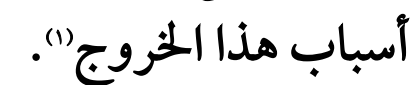

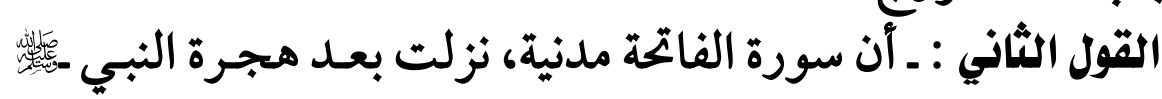

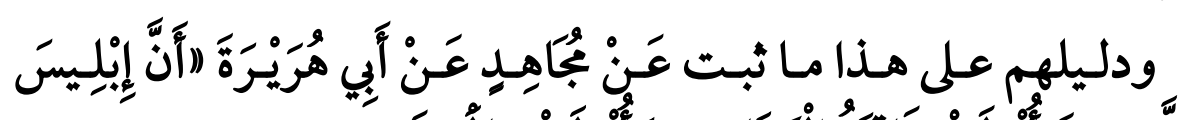

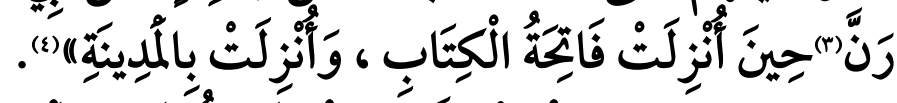

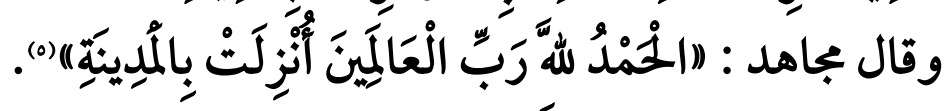

(1) انظر مصاعد النظر للإِشراف على مقاصد السور لإبراهيم بن عمر البقاعي

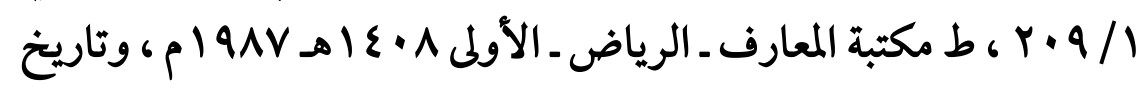

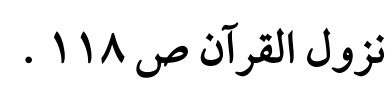

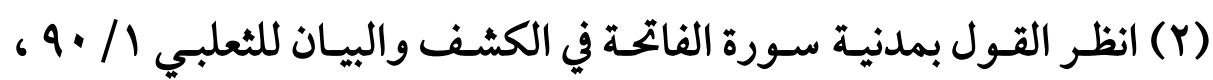

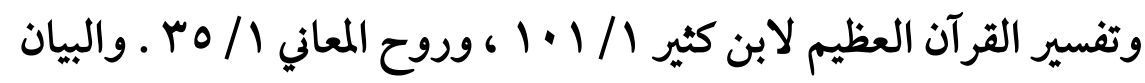

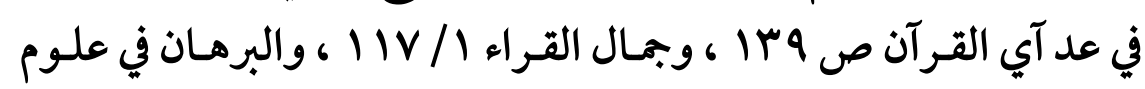

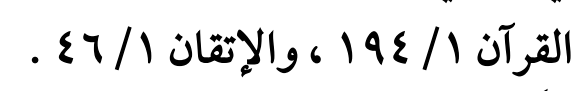

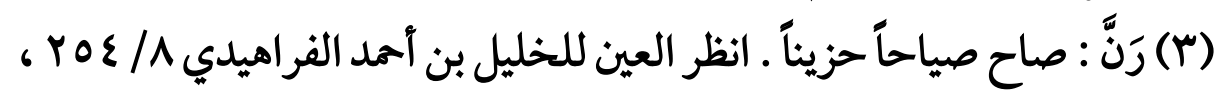

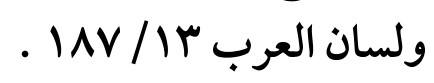

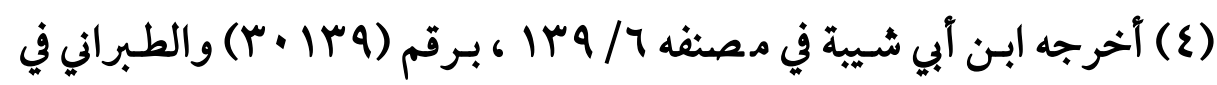

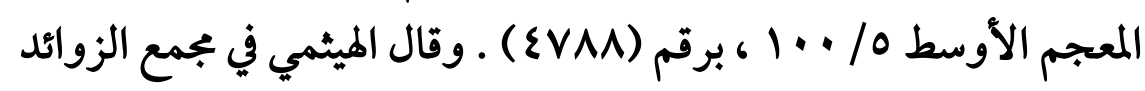

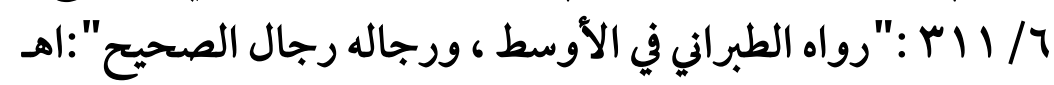

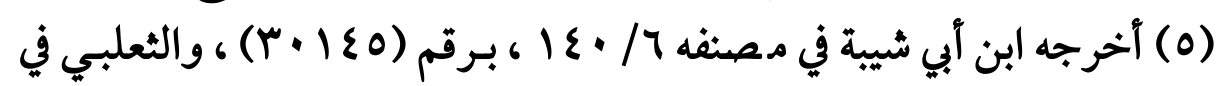

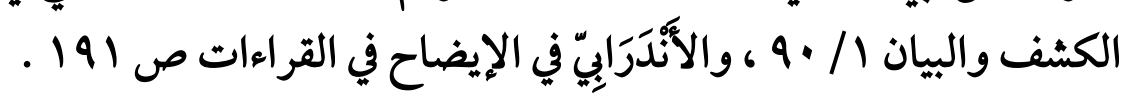


$(7 \cdot 1)$

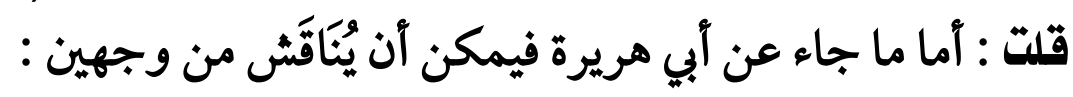

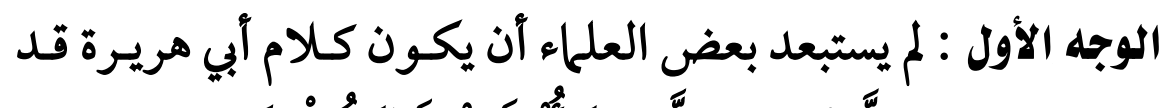

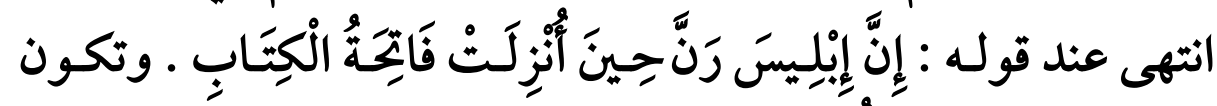

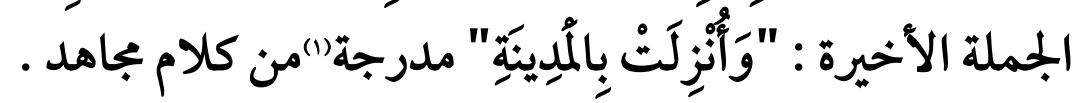

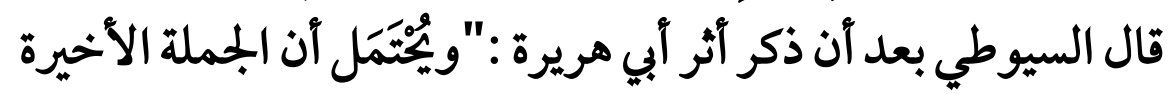
مدرجة من قول بجاهد (r)":اهـ

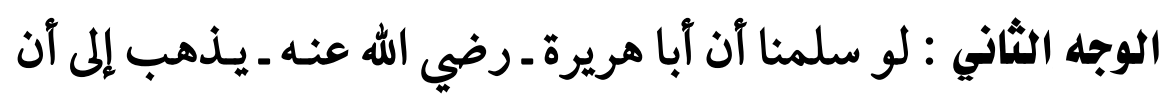

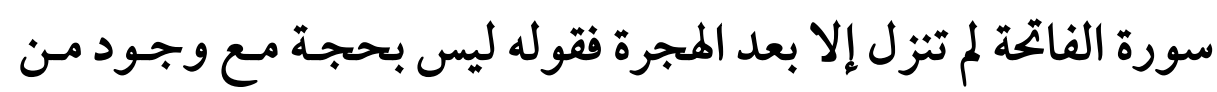

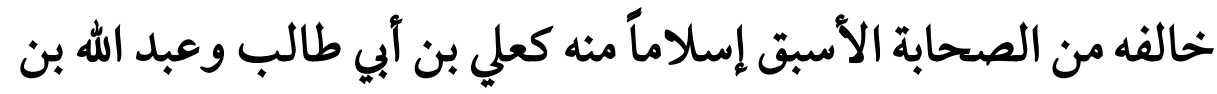

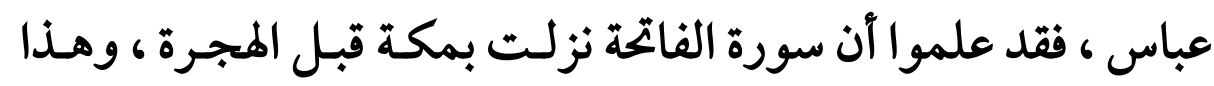

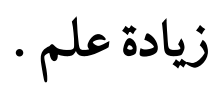

قال ابن تيمية :"وكذلك قول من قال : الفاتحة لم تنزل إلا بالمدينة

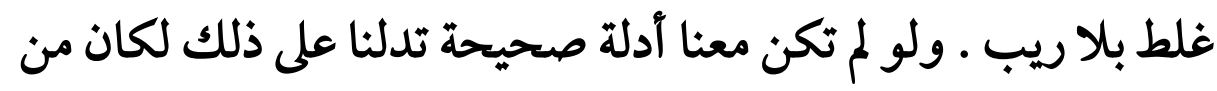
قال إنها مكية معه زيادة علم (r)" :اهـ

(1) (1) الحديث المُدْرج هو : ما كان فيه زيادة ليست منه ، في الإسناد أو المتن ـ انظر

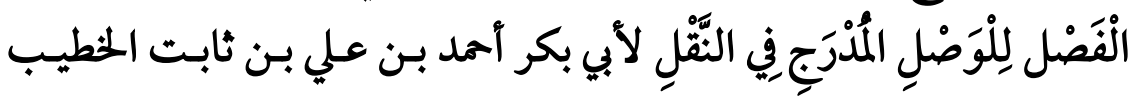

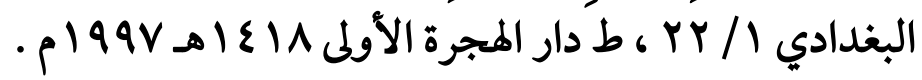

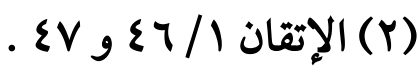

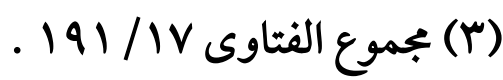




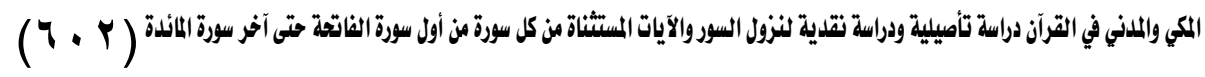
وأما ما جاء عن بجاهد فقد نقل غير واحد من العلماء قول الحسين بن

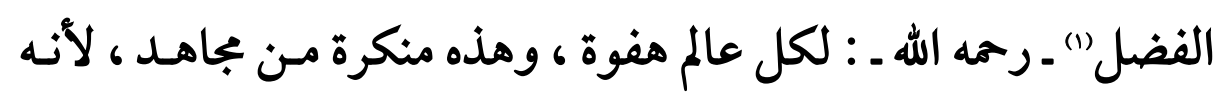
تفرد بها ، والعلم)ء على خلافه (r).

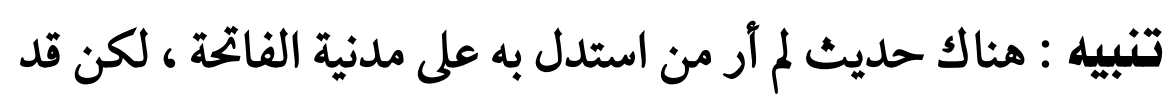

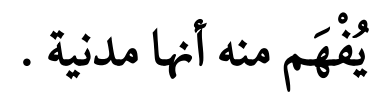

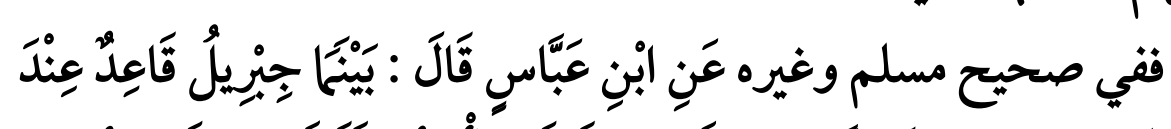

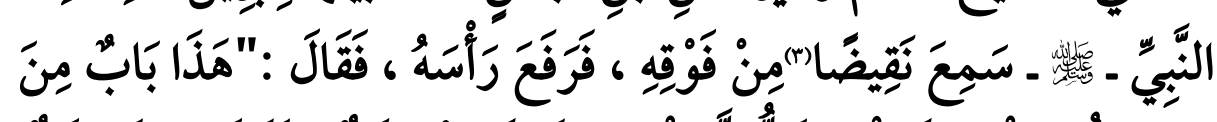

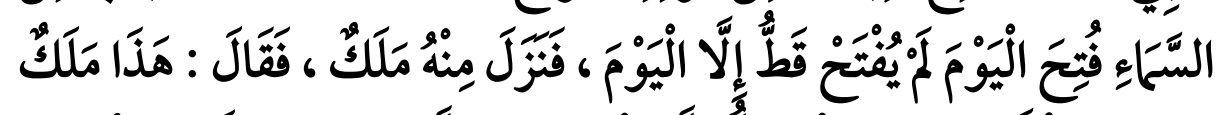

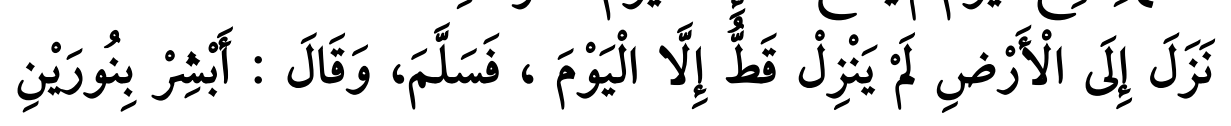

(1) هو الحسين بن الفضل بن عمير البجلي ، مفسر معمر، كان رأساً في تفسير

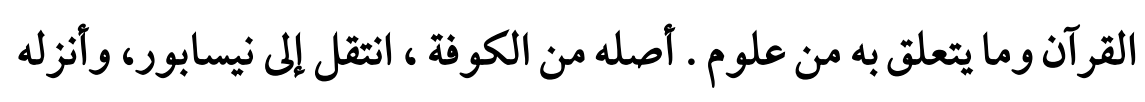

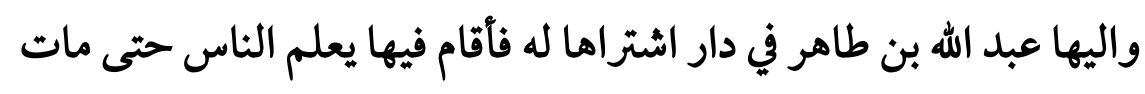

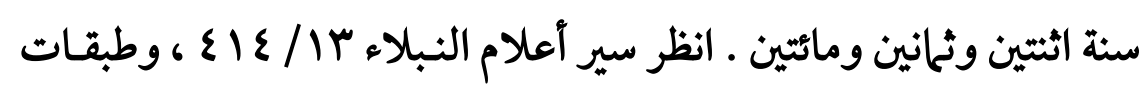

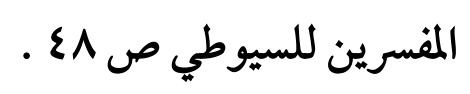

(Y) انظر الكشـف والبيان / / • 9 ، وروح المعاني / / هب ، وأسباب النزول

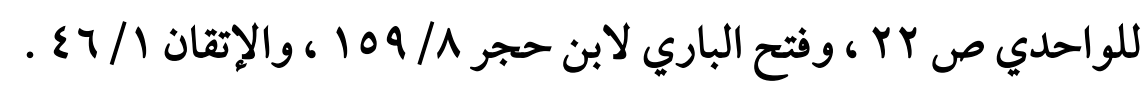

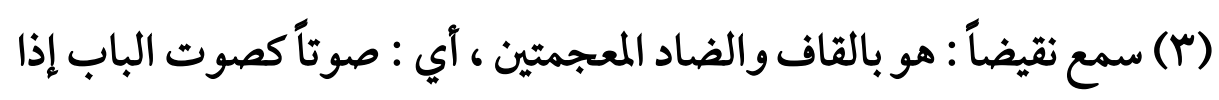

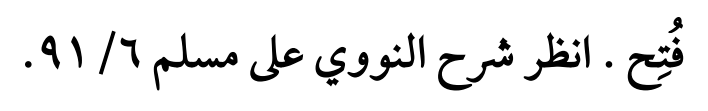


$(\tau \cdot r)$

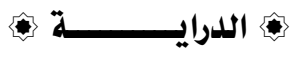

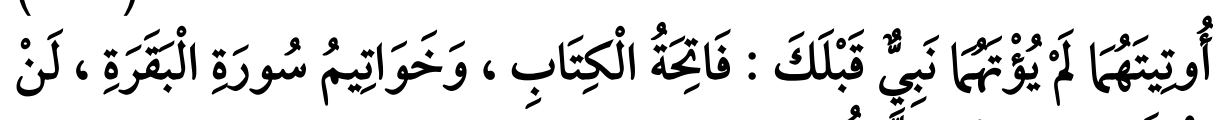

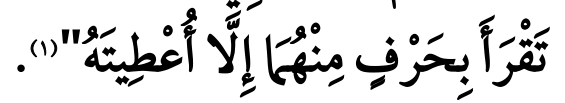

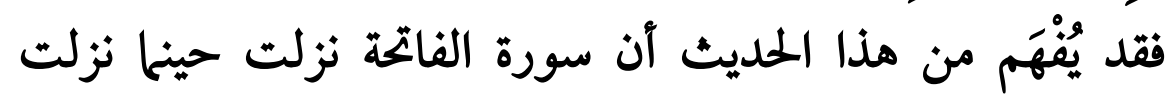

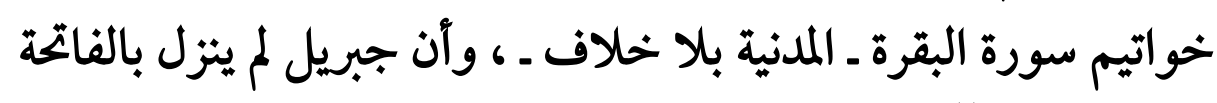

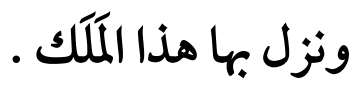

وقد أجاب القرطبي عن الإشكال فقال :"هذا الحديث يدل على آنها مدنية ، وأن جبريل لم ينزل بها ، وليس كذلك ، بل نزل بها جبريل ـ عليه

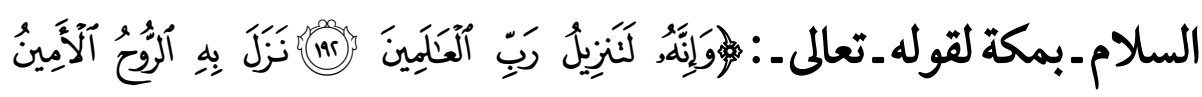

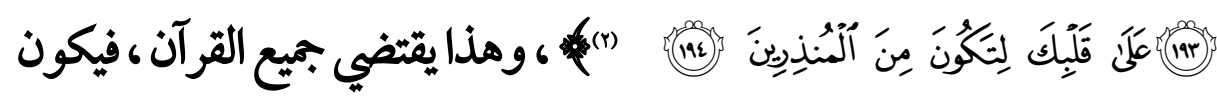
جبريل ـ عليه السلام ـ نزل بتلاوتها بمكة ، ونزل الملك بفضلها وثوابها بالمدينة ، فتتفق الآثار (r)":اهـ

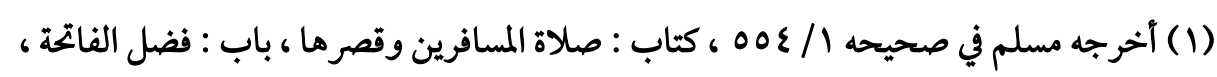

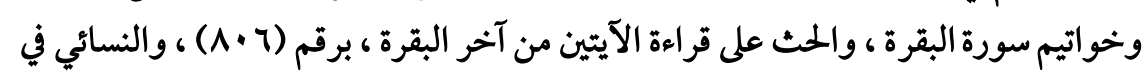

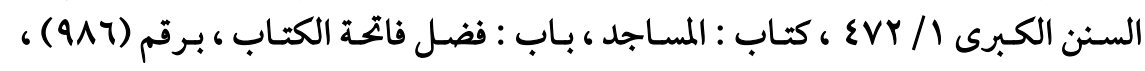

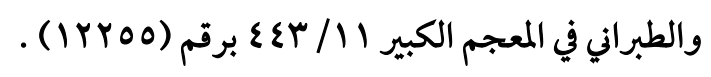

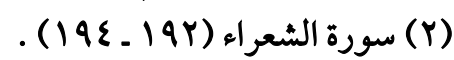

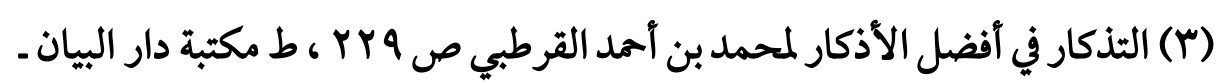

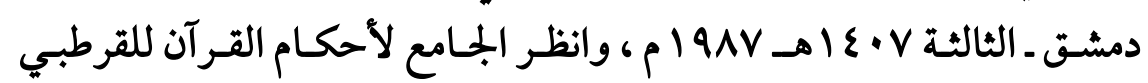




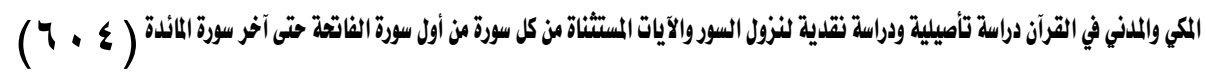

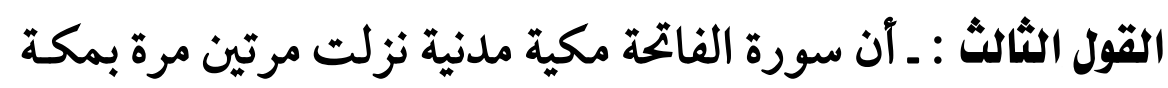

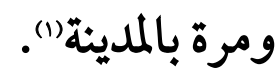

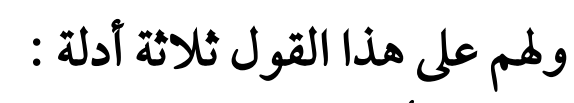

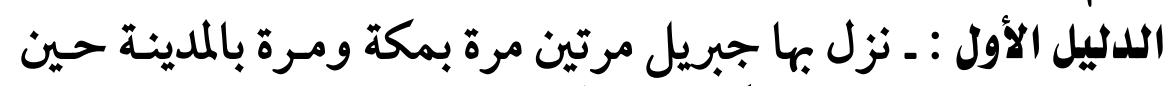

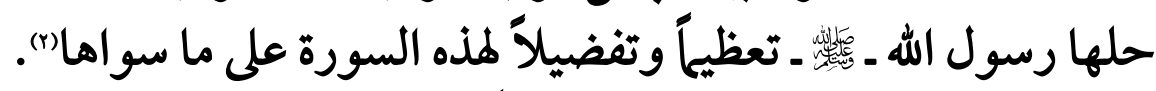

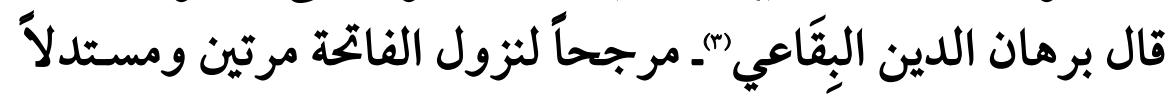

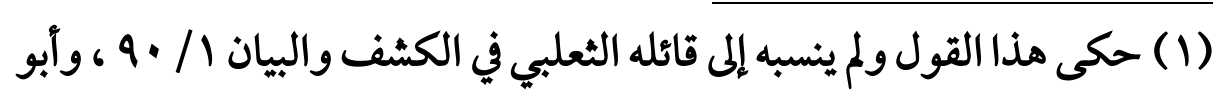

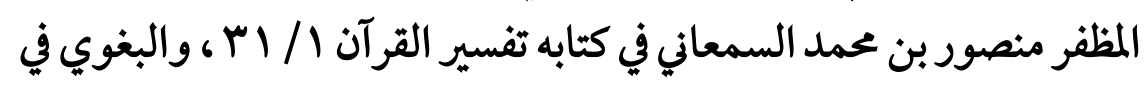

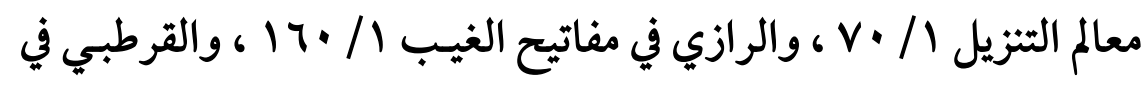

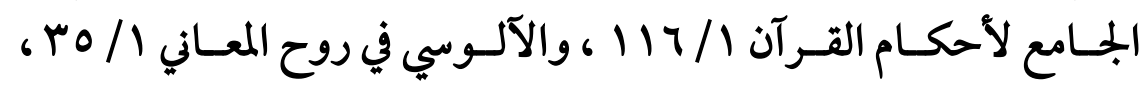

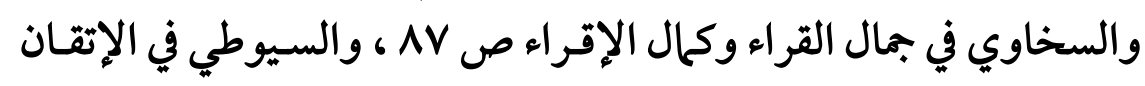

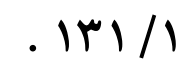

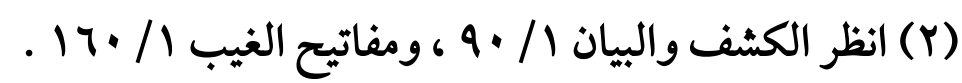

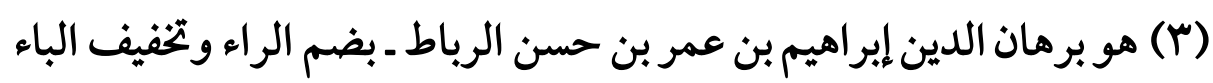

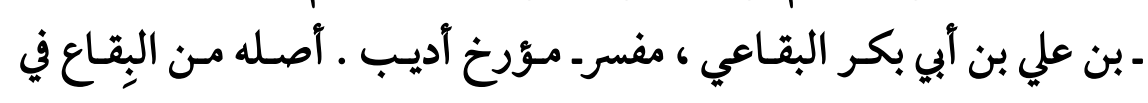

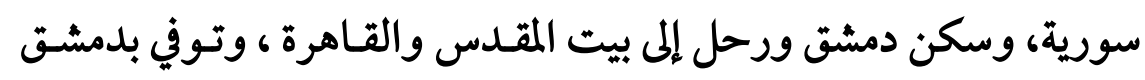

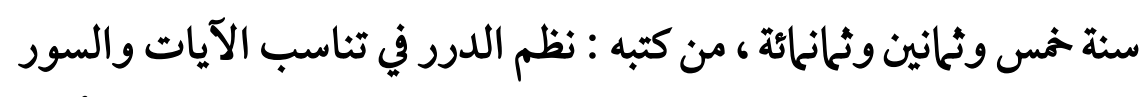

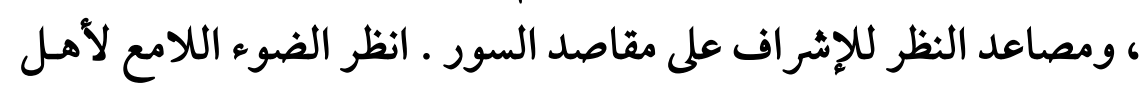

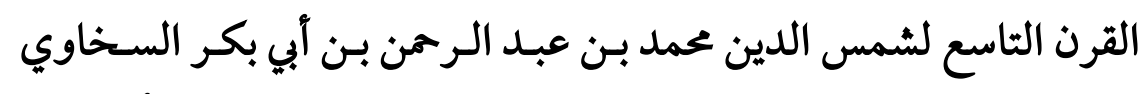

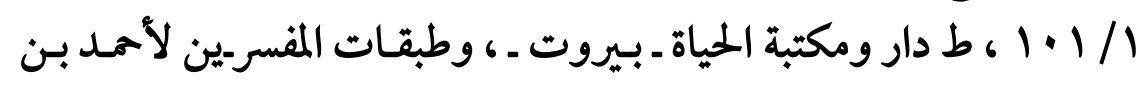


$(7 \cdot 0)$

على ذلك ـ :"وعندي أنها نزلت مرتين ، في كل من البلدين مـرة ، فيإن

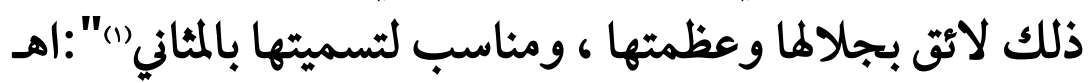

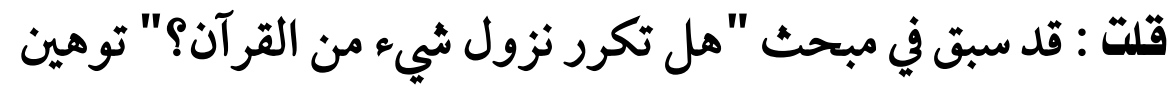
ما قاله بعض العللهاء مـن تكـرار نزول بعض مئ آيـات وسـور القرآن ، وتوهين أدلتهم ، التي منها آن من القرآن ما يتكرر نزوله تعظيهاً لهأنه (r).

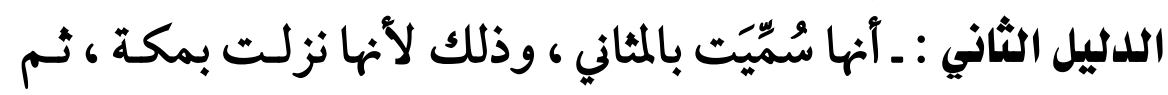

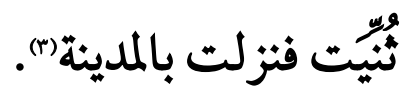

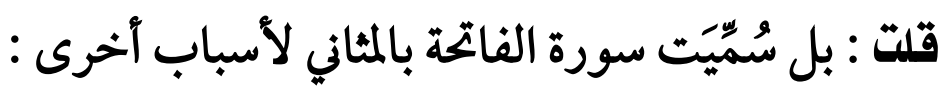

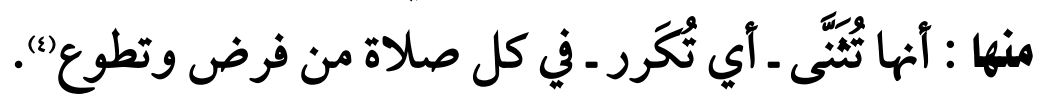

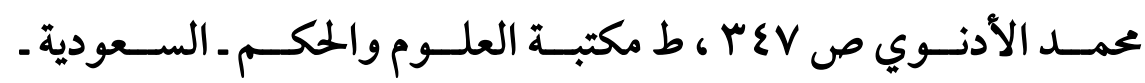

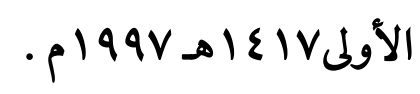

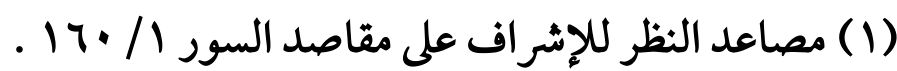

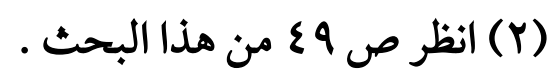

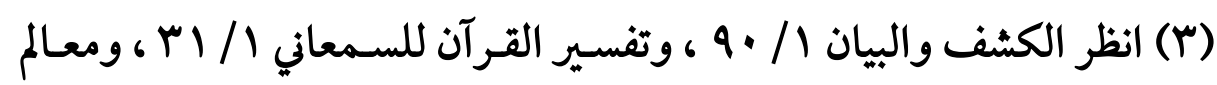

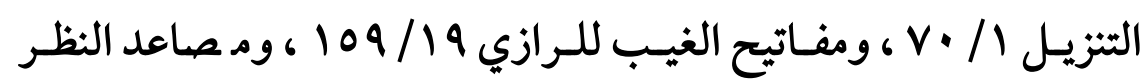

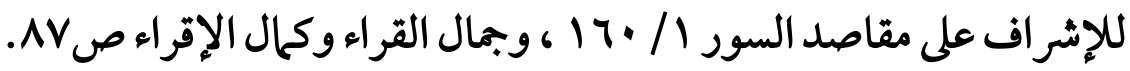

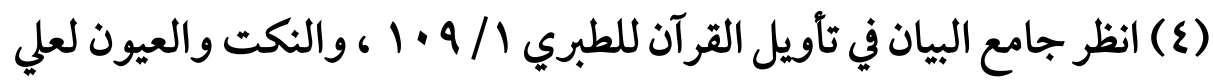

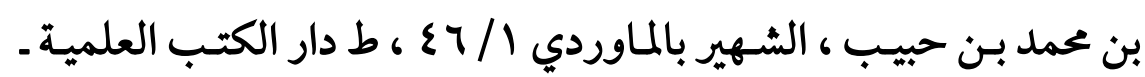

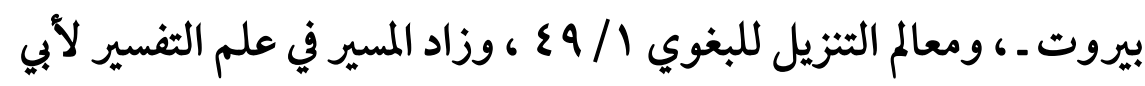

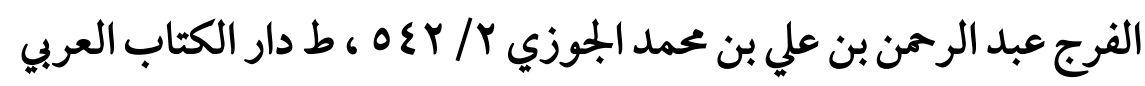

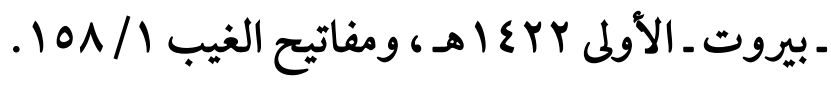




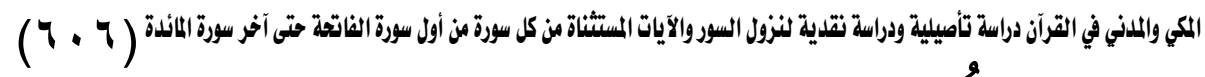
ومنها : أنها أثني بها على الله ـ تعالى ـ ، لأن فيها محد الله وتوحيده وذِكر ملكته (1).

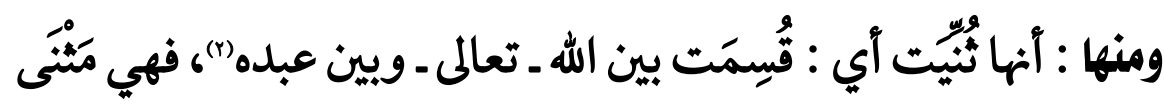

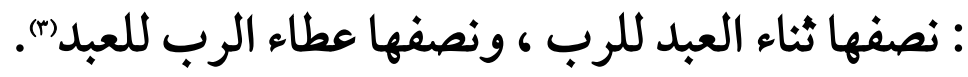

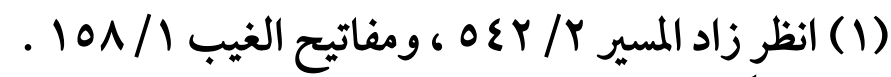

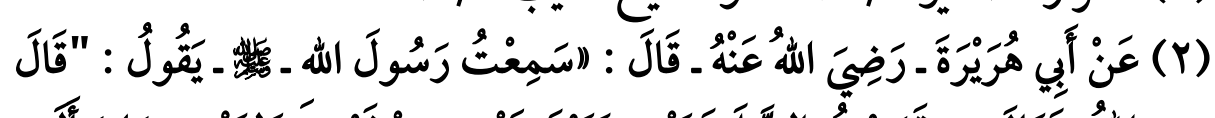

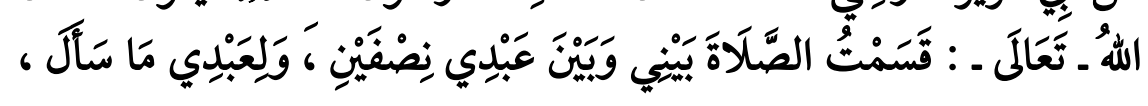

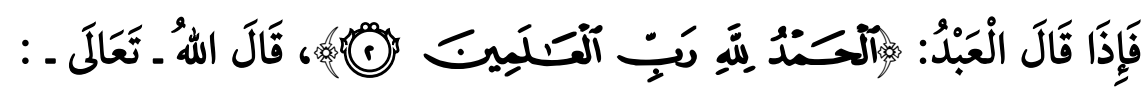

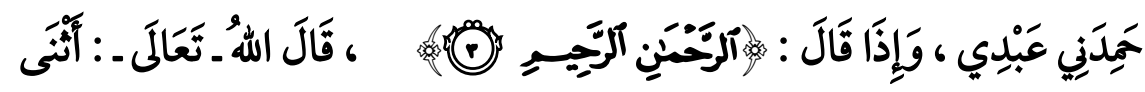

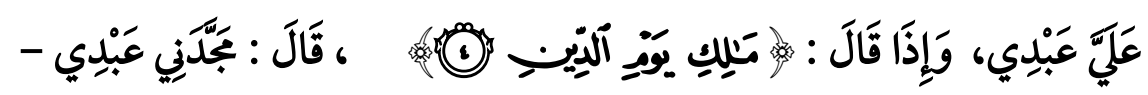

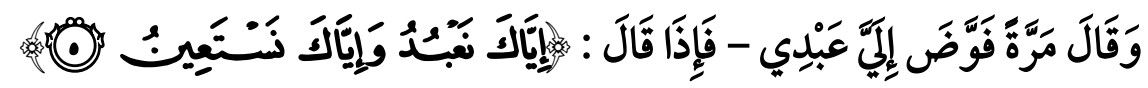

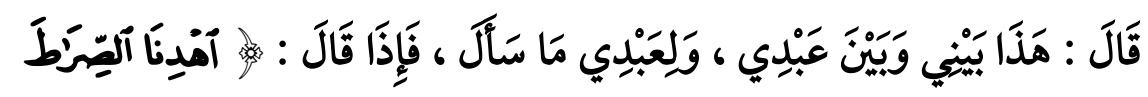

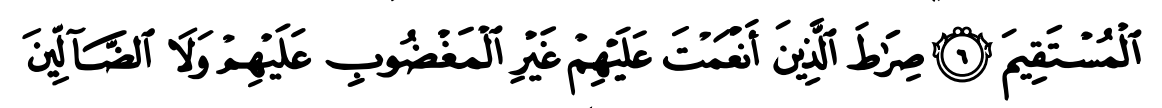

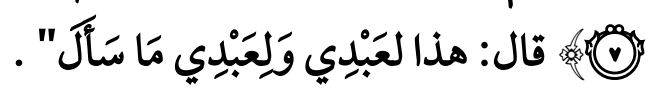

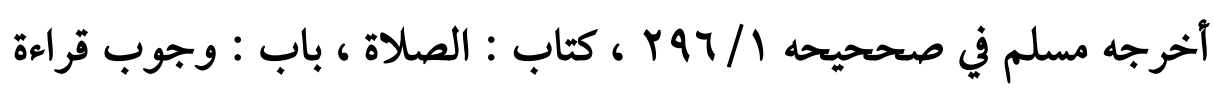

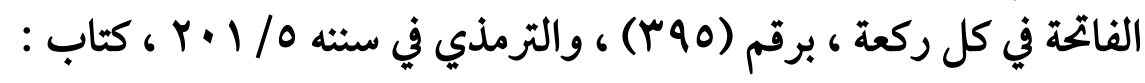

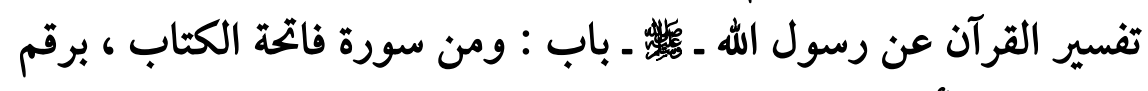

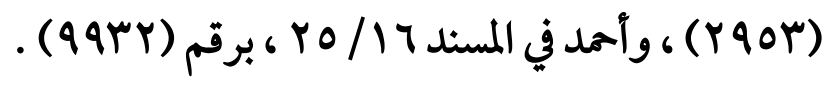

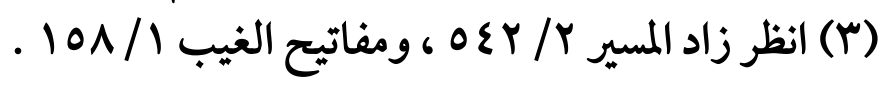




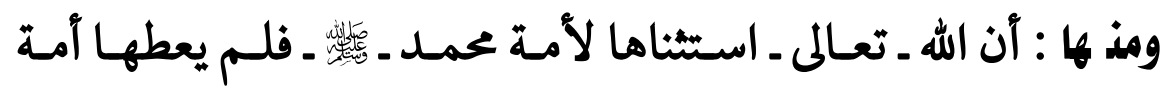

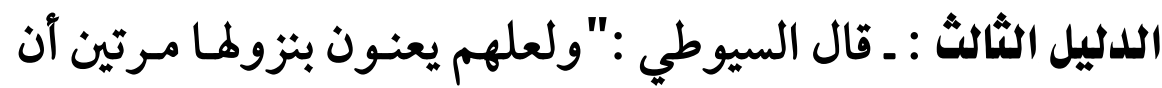

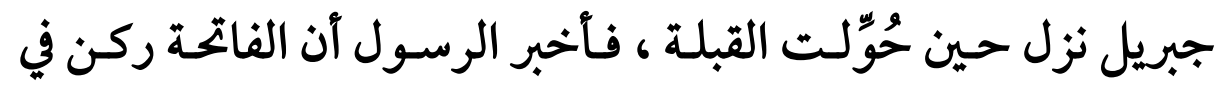

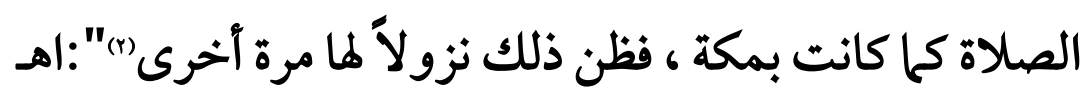

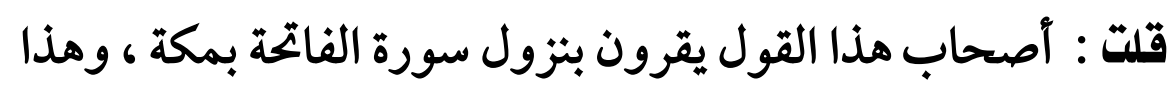

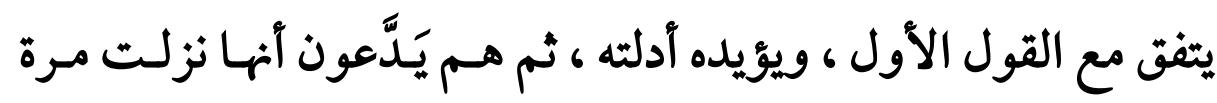

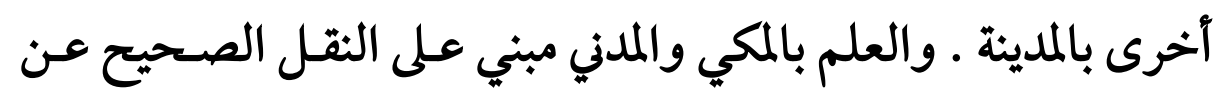

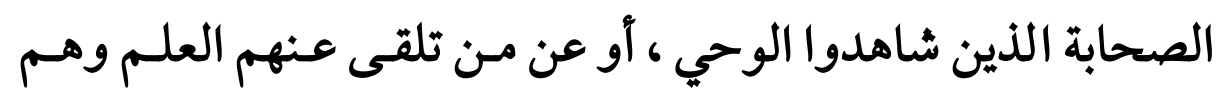

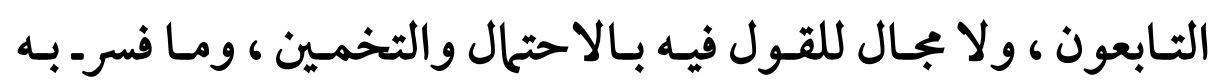

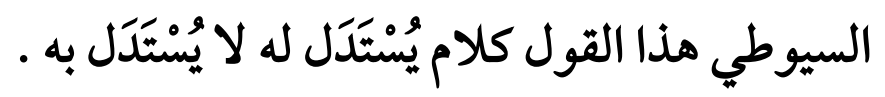

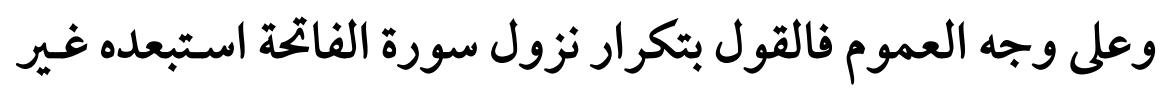

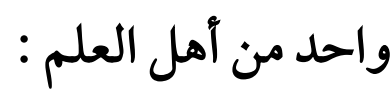

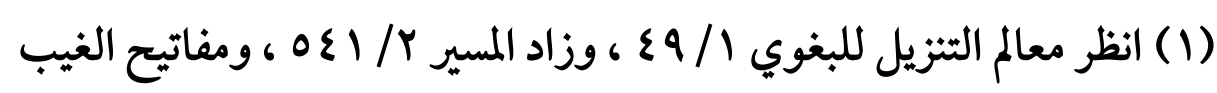
. 101/1

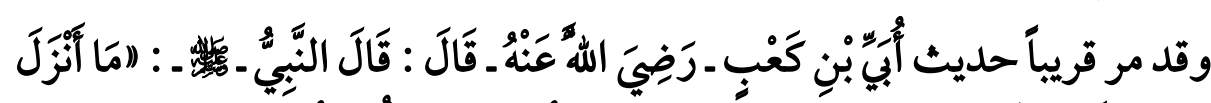

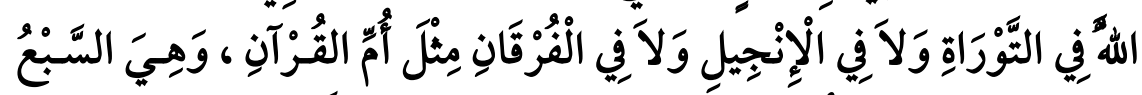

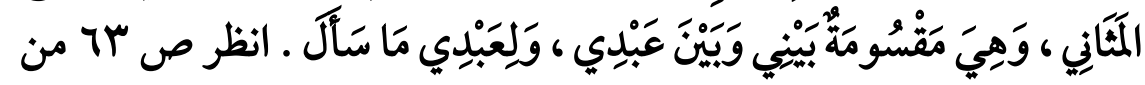

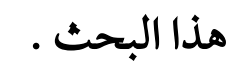

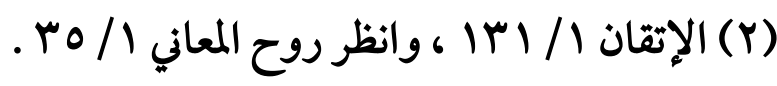




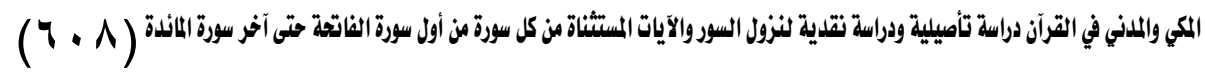

قال السمعاني"):"قيل : نزلت ـ يعني الفاتحة ـ مرتين مرة بمكة ، ومرة

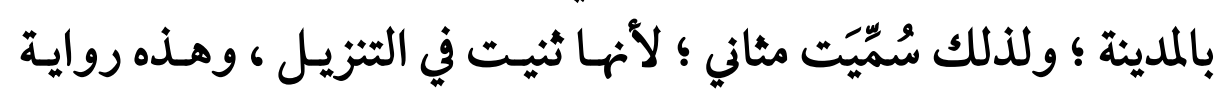
غريبة(r)":اهـ

وقال القرطبي :"قيل : إنها مكية مدنية ، نزل بها جبريل مرتين ـ وما

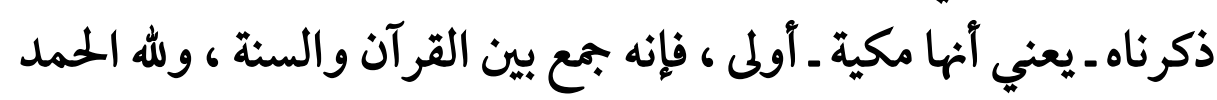

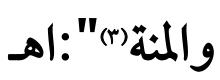

وقال الطاهر بن عاشُور :"قيل : سُمِيَّت المثاني لأنها ثُنِيِّت في النزول

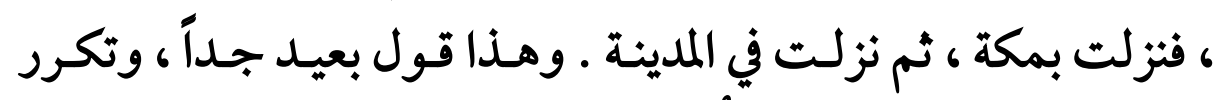

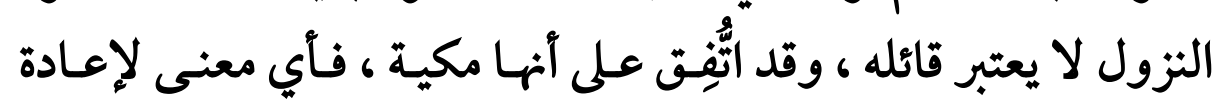

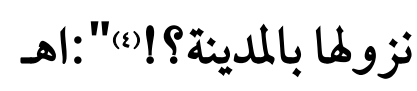

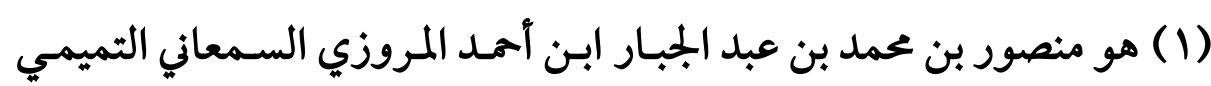

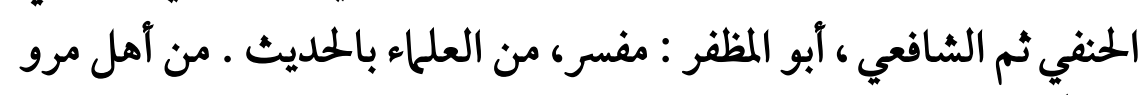

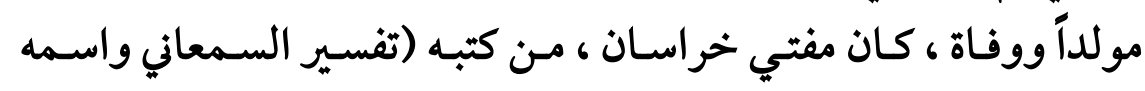

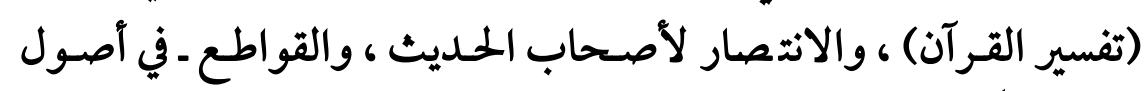

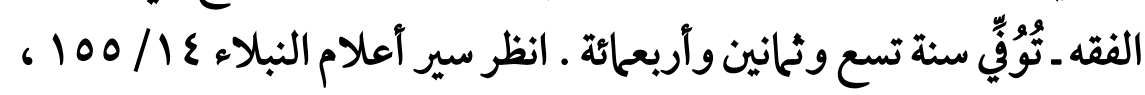

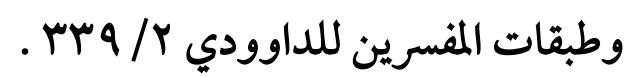

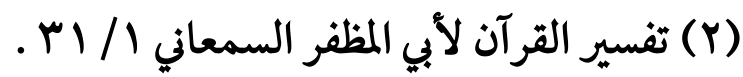

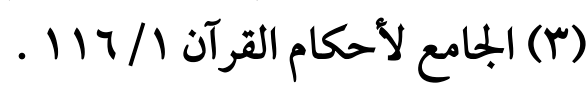

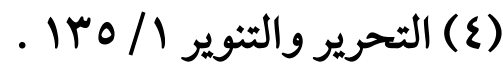


$(7.9)$

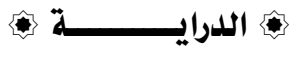

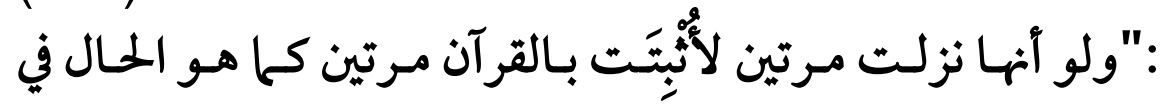

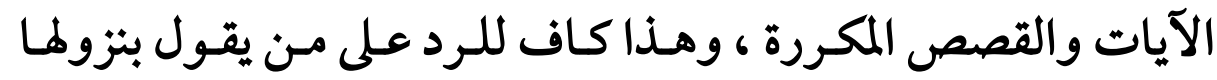
مرتين، فتدبر (1)":

القول الرابع : ـ أن سـورة الفاتحة نصففها نزل بمكـة ونصفها نزل

$$
\text { بالمديثة) (r) }
$$

قال السيوطي :"تقدم قول أن نصفها نزل بالمدينة ، والظاهر أنه

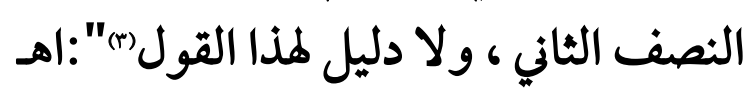

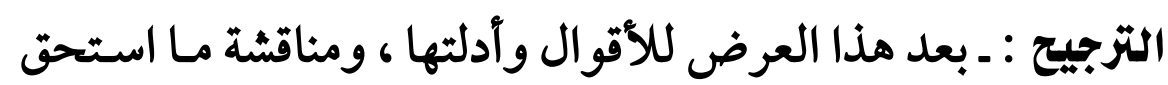

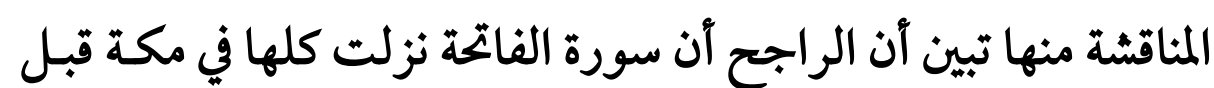

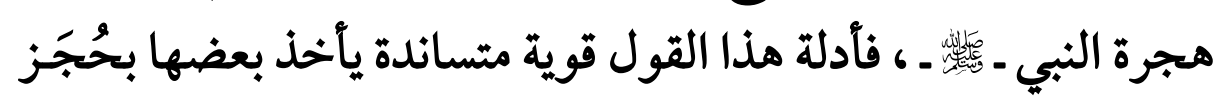

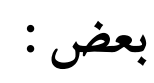

(1) تفسير بيان المعاني المرتب على حسب ترتيب النزول للسيد عبدالقادر مـلّا

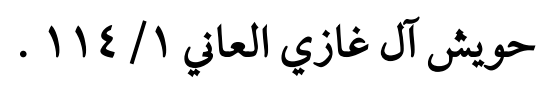

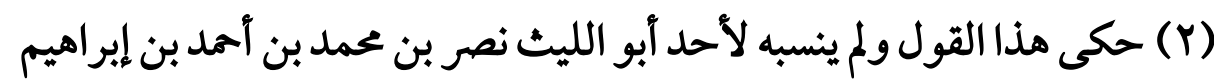

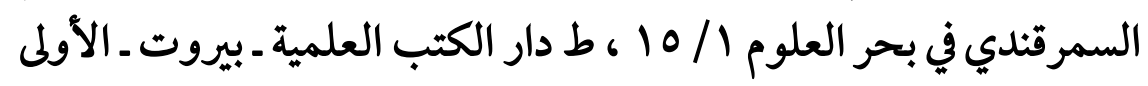

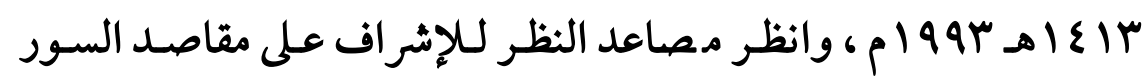

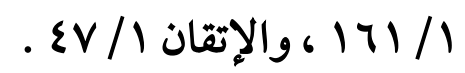

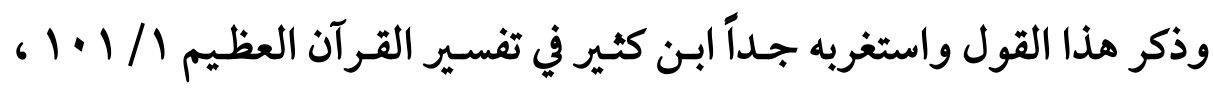

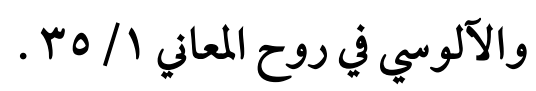




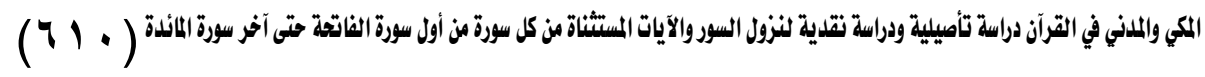
فقد امتن الله على نبيه بسورة الفاتحة في آيـة مكية هي قوله : وَوََلَقَد

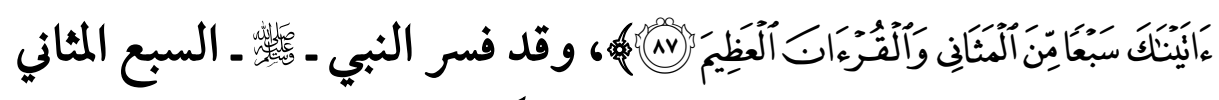
بالفاتحة ، وكفى بتفسير رسول الله تفسيراً . وثبت أن ولد عمرو بن الجموح قد تعلم الفاتحة قبل المجرة ، وقئ وقرأها

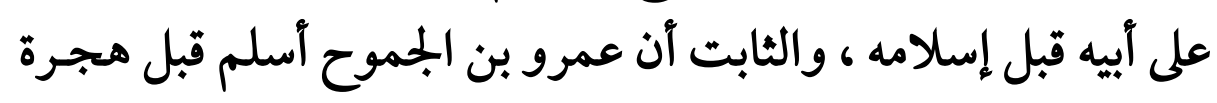

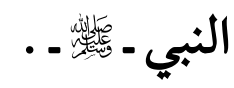
وشهد علي بن أبي طالب ـ رضي الله عنه ـ أنها نزلت بمكة .

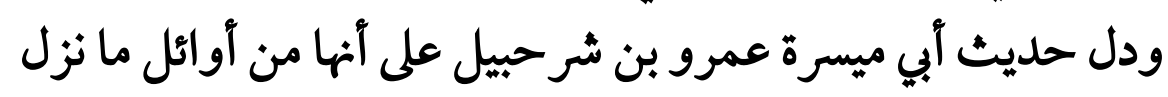

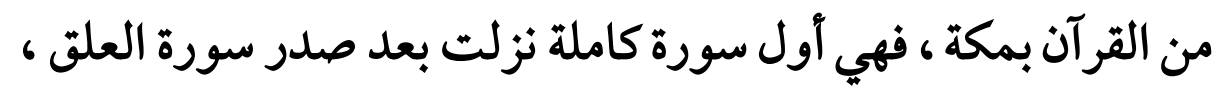

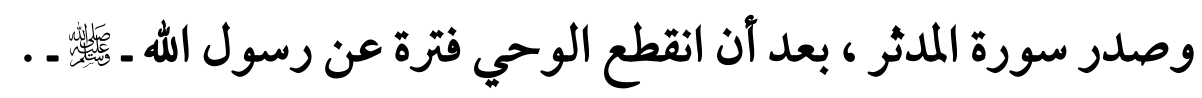

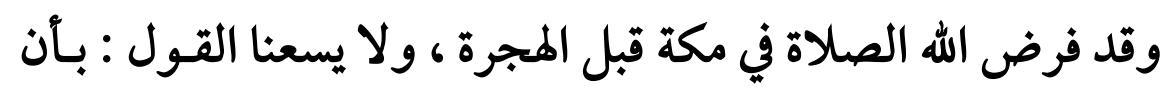

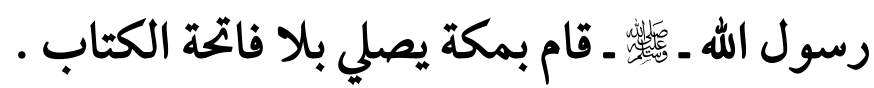

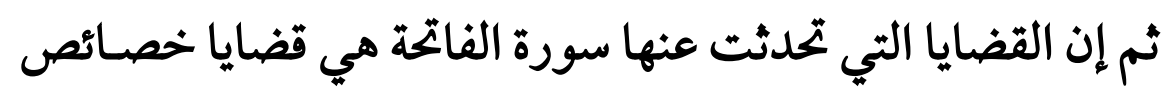
السور المكية . أما الأقوال الأخرى فأدلتها لم تسلم من المناقشة والرد ـ والله أعلم . 
(711)

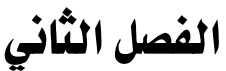

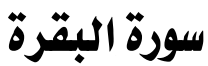

أدرس سورة البقرة من خلال مبحثين :

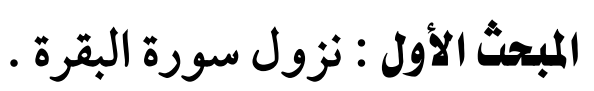

المبحث الثاني : الآيات المستثناة من سورة البحول البقرة .

المبحث الأول

\section{نزول سورة البقرة}

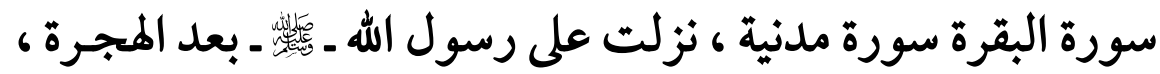

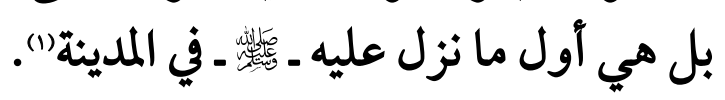

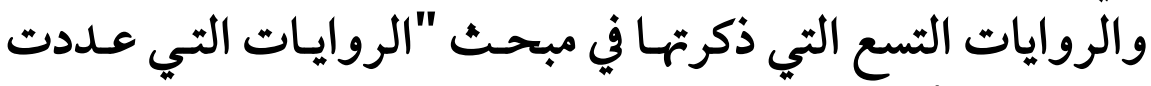

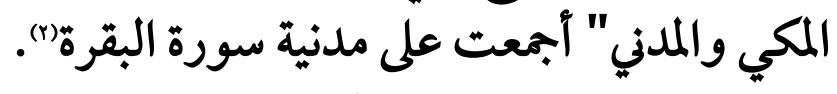

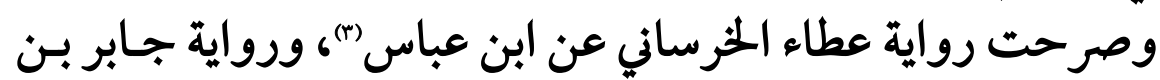

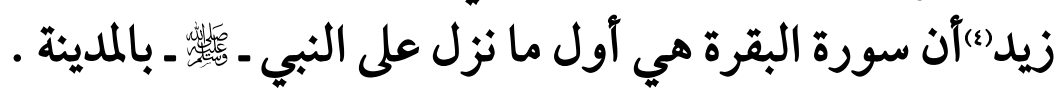

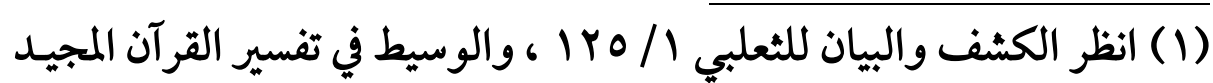

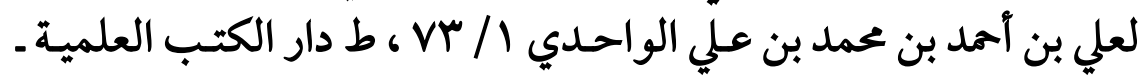

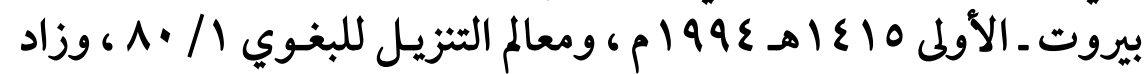

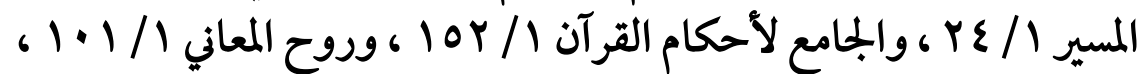

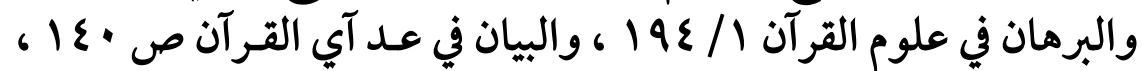

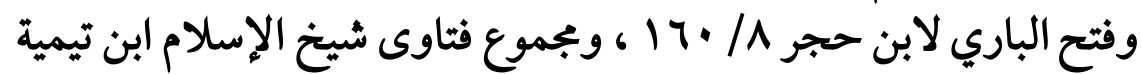

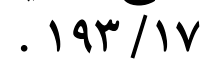

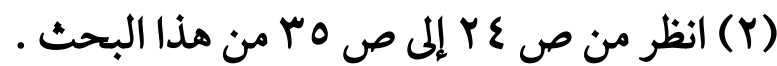

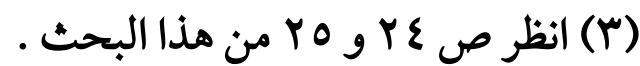

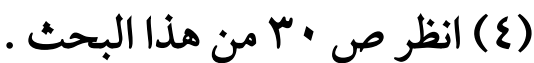




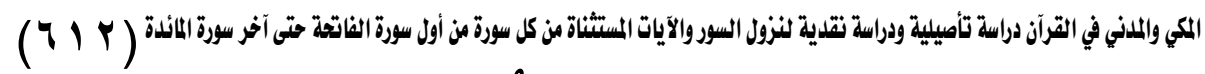

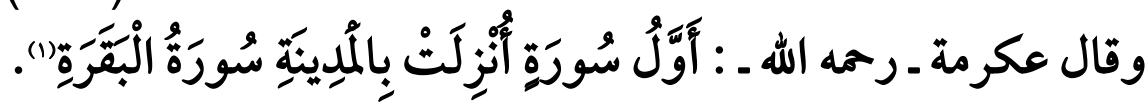
ويمكن أن نستدل على مدنية سورة البقرة بأربعة أدلة :

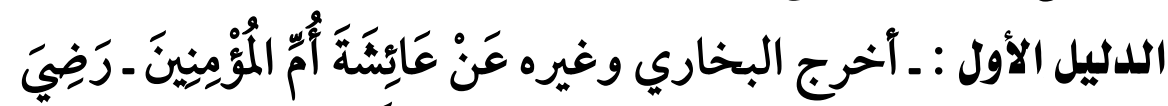

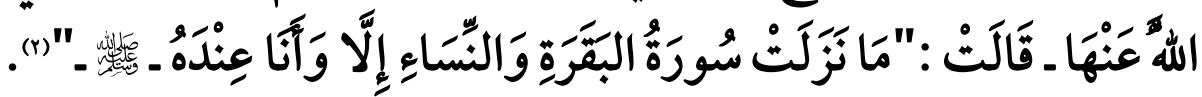

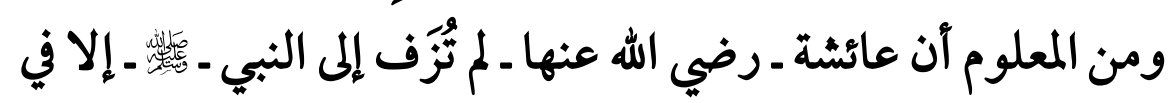

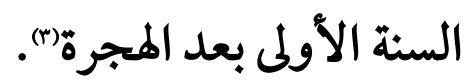
قال ابن حجر في الفتح :"أثارت بقولما : "وأنا عنده" أي : بالمدينة، لأن دخولها عليه إنها كان بعد المجرة اتفاقاً (ء)":اهـ

(1) أخرجه الثعلبي في الكشف والبيان / / مبا ، والواحدي في أسباب النزول ص ع r . . .

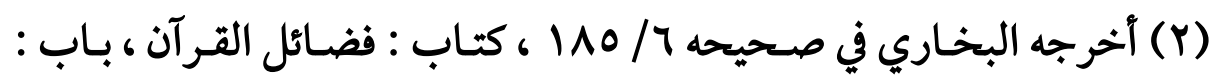

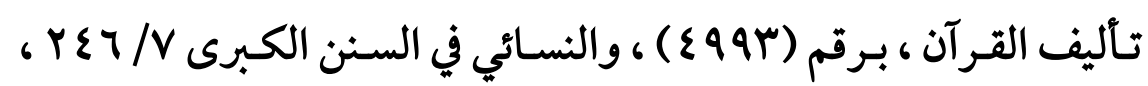

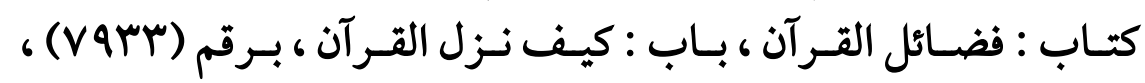

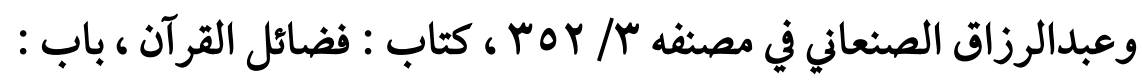

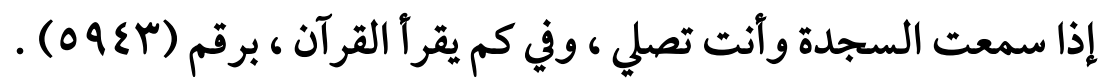

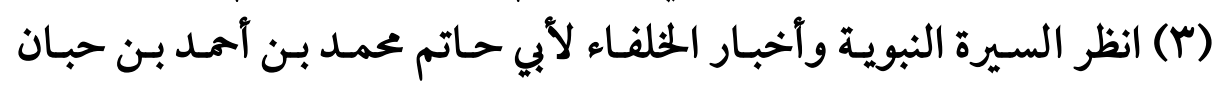

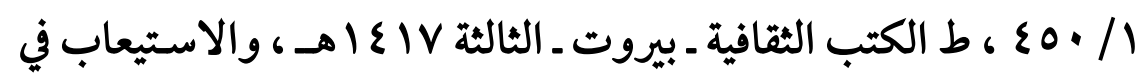

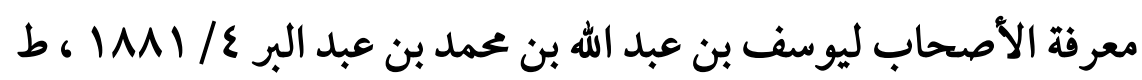

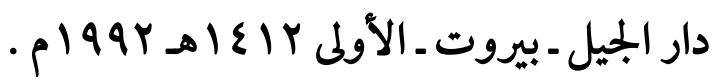

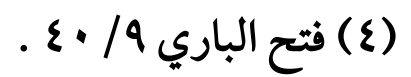




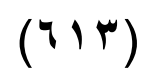

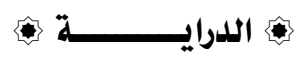

الدليل الثاني : ـ ماصح من أسباب نزول كثير من آيات سورة البقرة

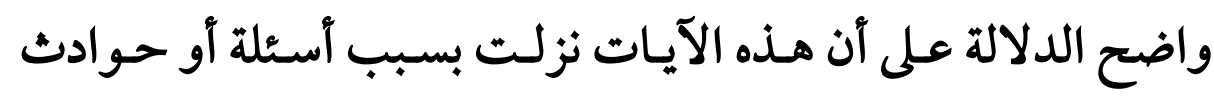

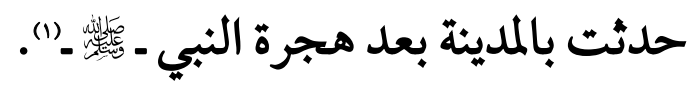

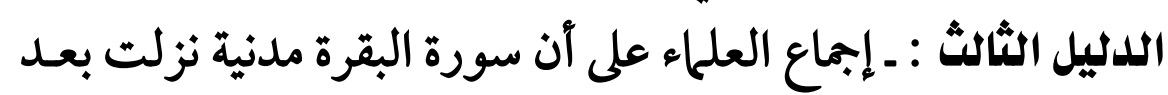

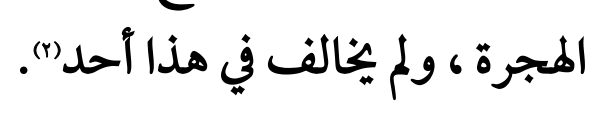

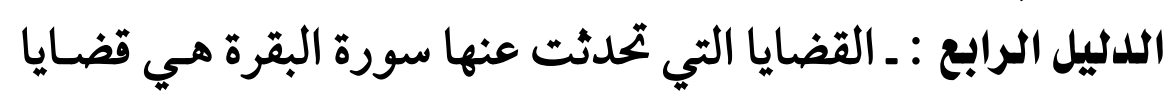

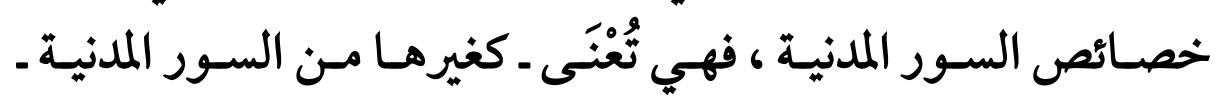

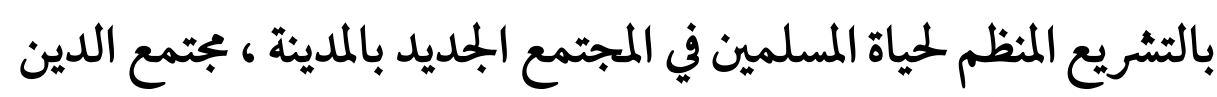

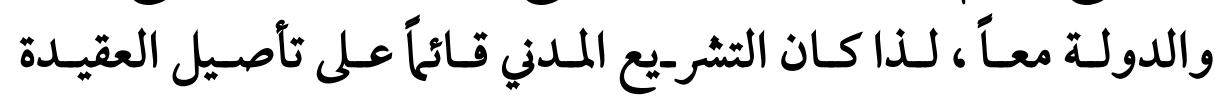

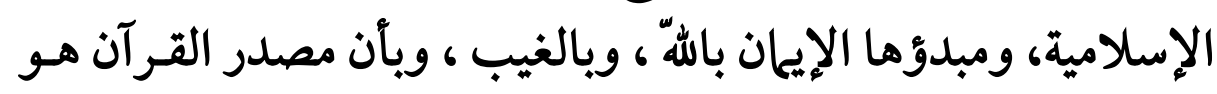
اللهّ ـ عز وجل ـ والاعتقاد الجازم بها أنزل اللّّ على رسوله وباله وعلى الأنبياء

(1) انظر أسباب نزول كثير من آيات سورة البقرة في أسباب النزول للواحدي

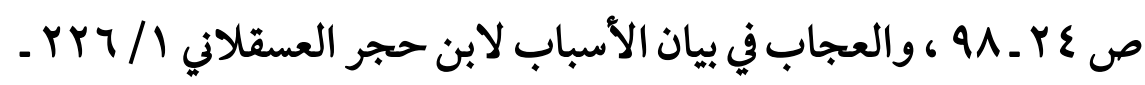

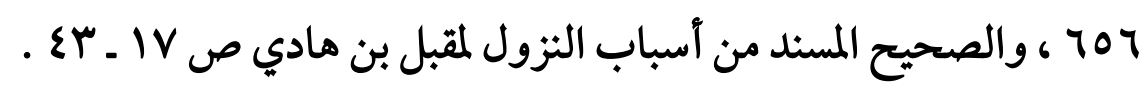

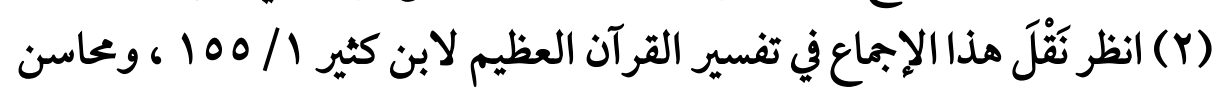

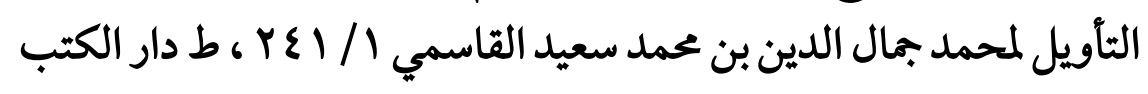

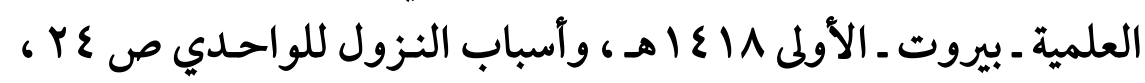

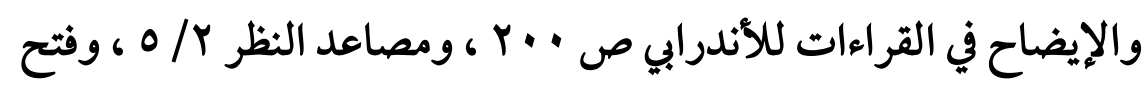

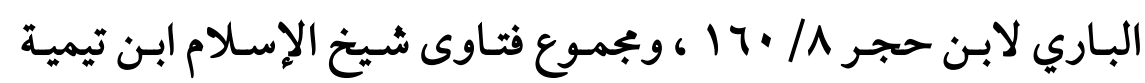




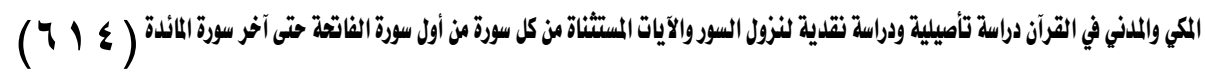
السابقين ، وبأن العمل الصالح ترجمان ذلك الإيهان ، ويتمثل العمل العانل

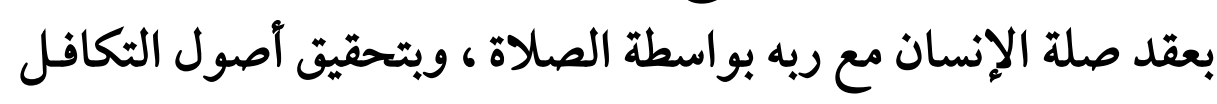
الاجتحاعي بواسطة الإنفاق في سبيل اللهّ.

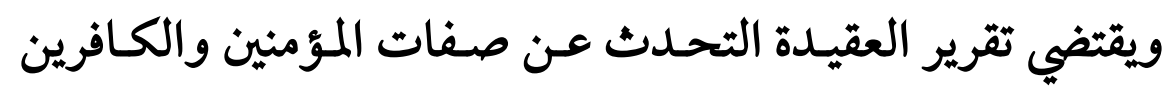

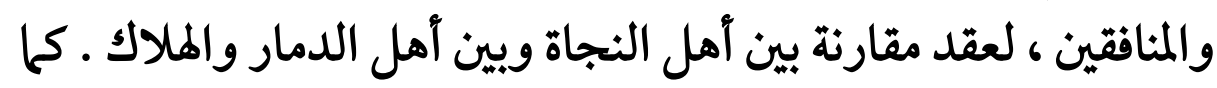

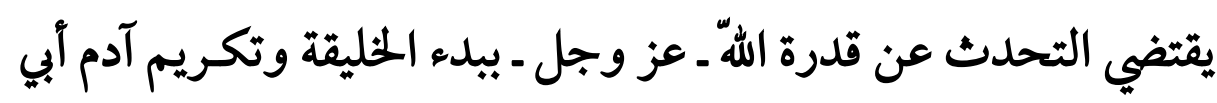

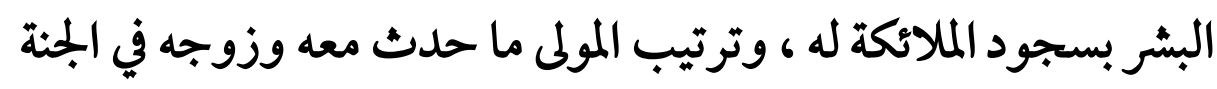

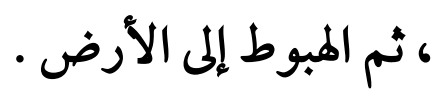

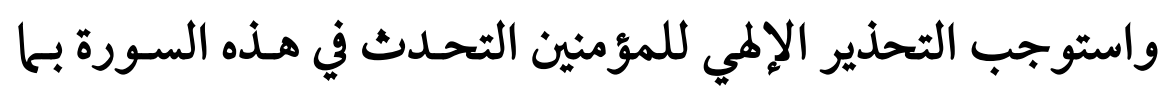

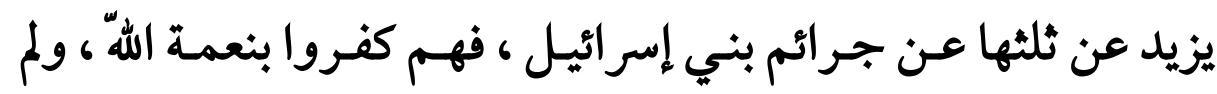

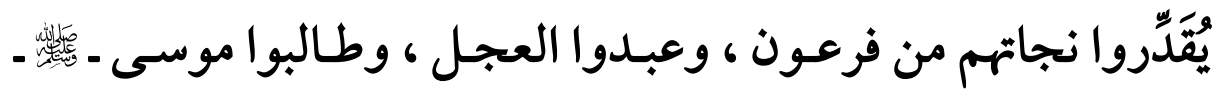

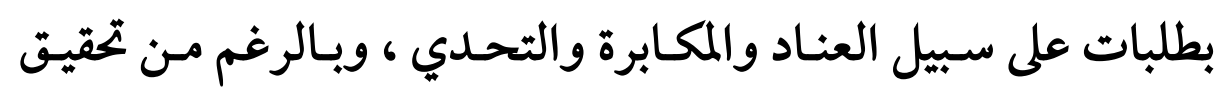

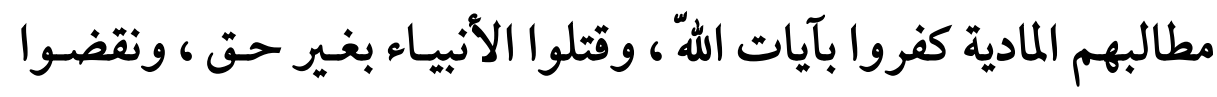

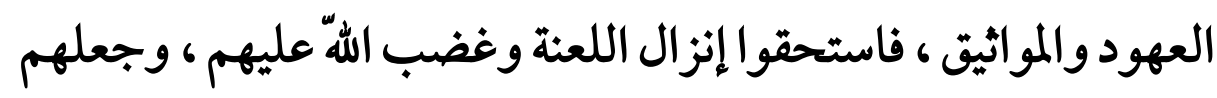

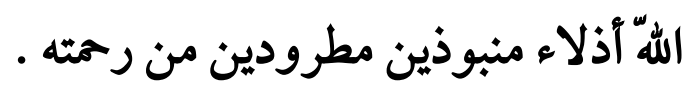

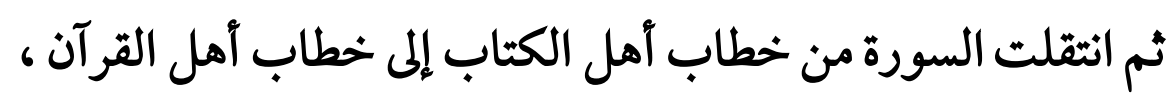

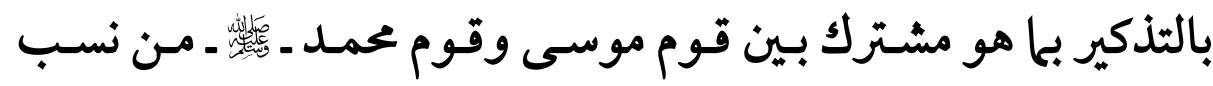

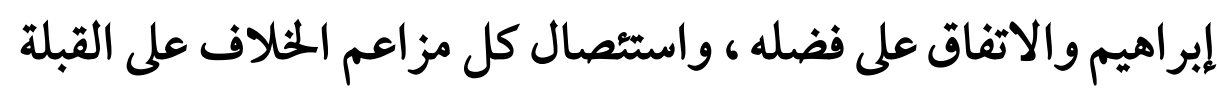

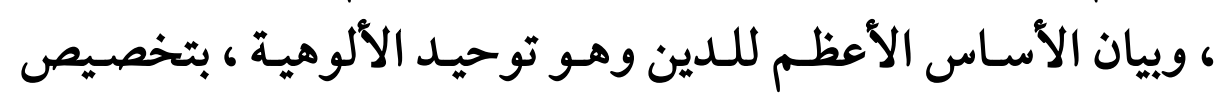


الخالق بالعبودية ، وشكر الإله على ما أنعم به من إباحة الاستمتاع بطيبات الرزق وإباحة المحرّمات حال الضرورة، وبيان أصول البر.

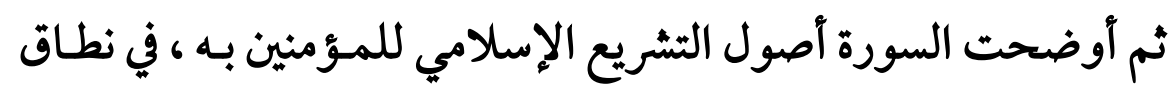

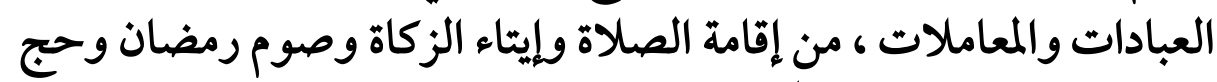

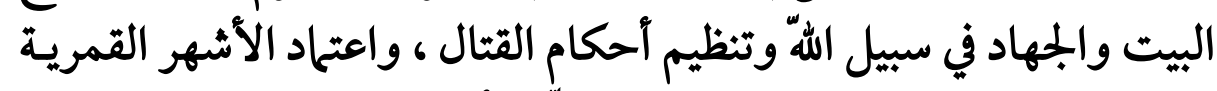

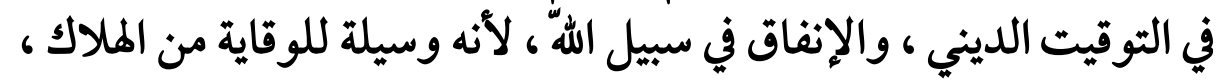

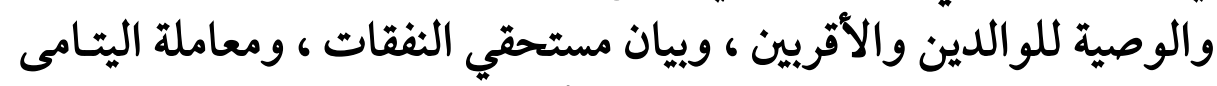

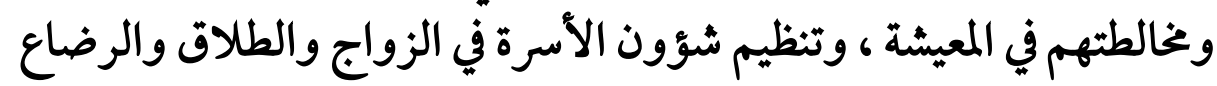

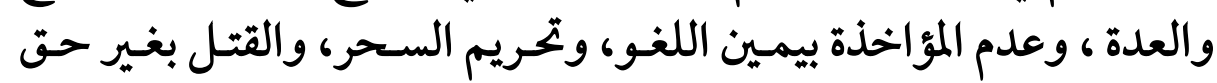

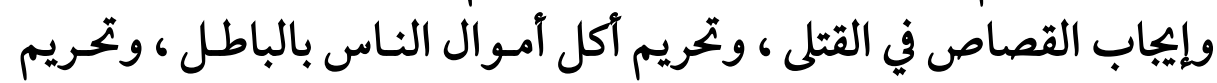

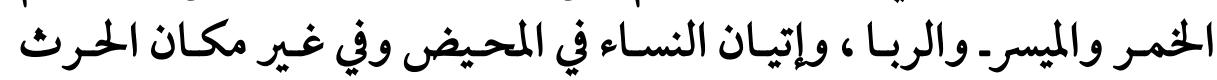

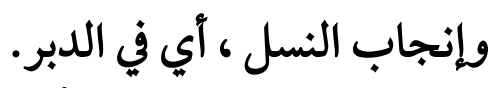

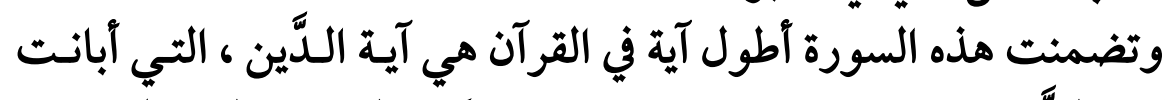

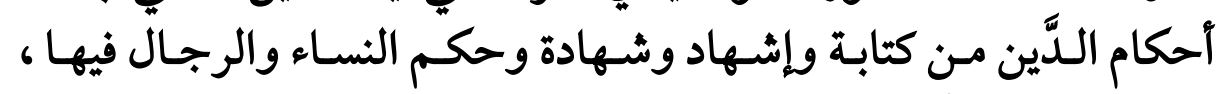

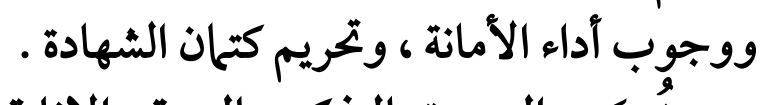

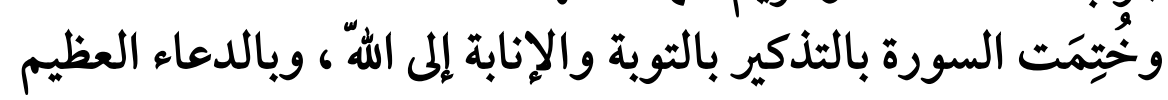

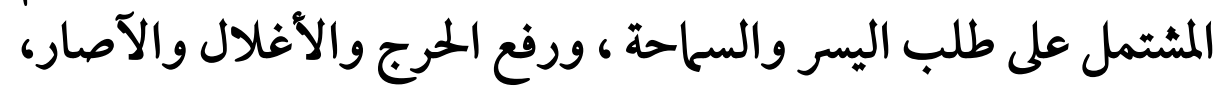
وطلب النصرة على الكفار (1)

(1) انظر مصاعد النظر للإشراف على مقاصد السور / / 9 ، والثفسير المنير في

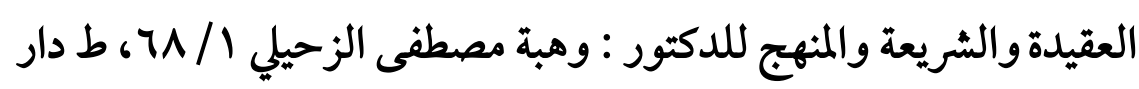

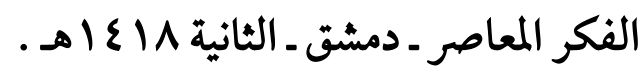




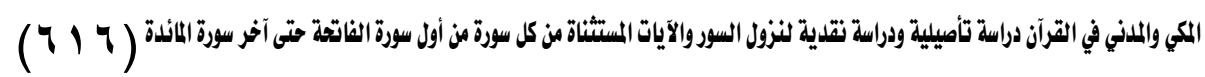
وما قرره غير واحد من أهل العلم من أن سورة البقرة هي أول مـا

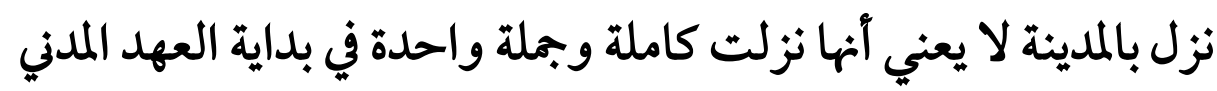

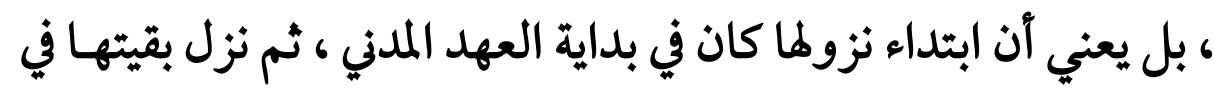

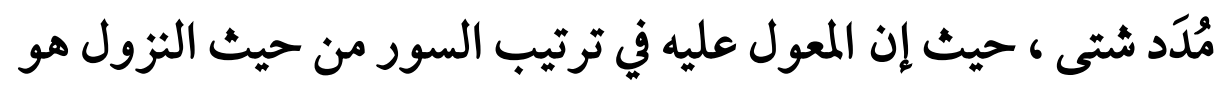

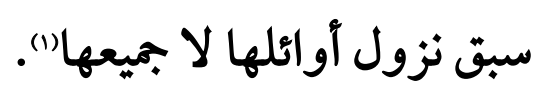

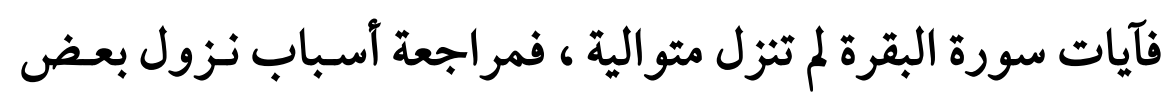

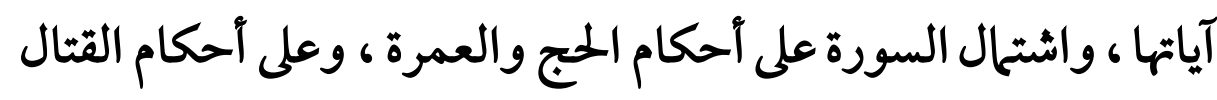

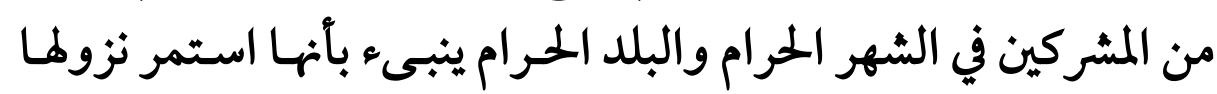

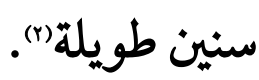

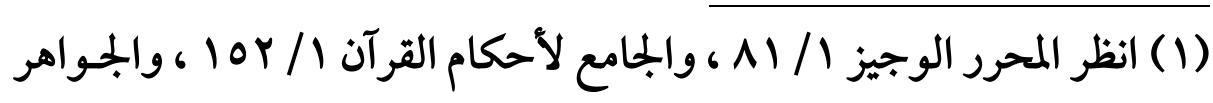

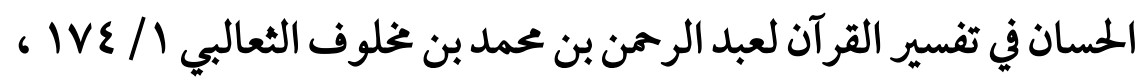

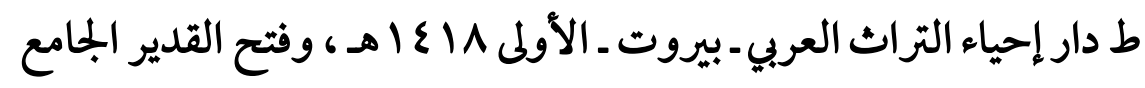

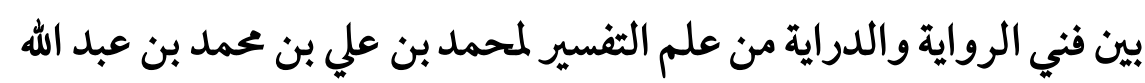

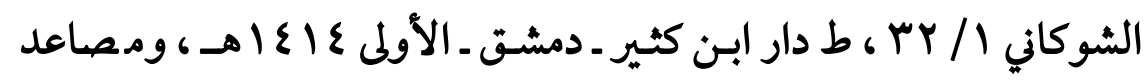

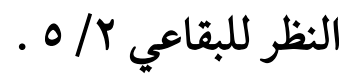

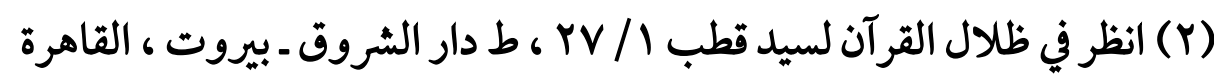

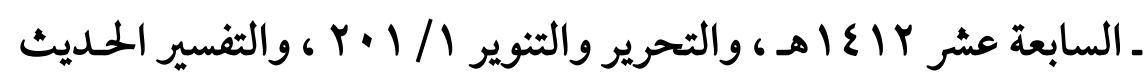

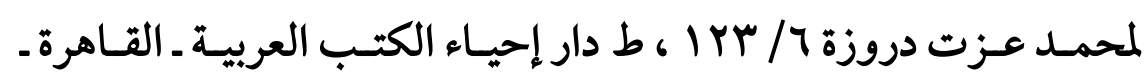


$(71 \mathrm{~V})$

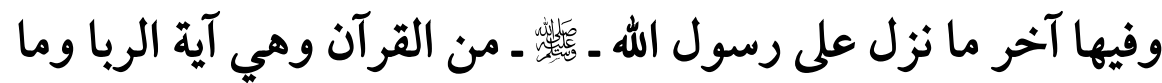

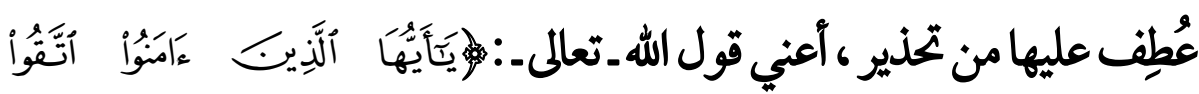

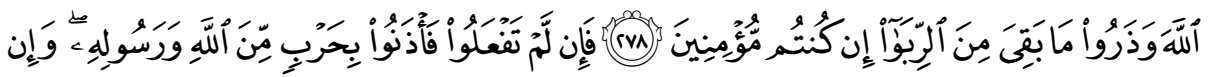

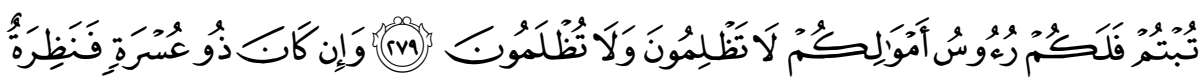

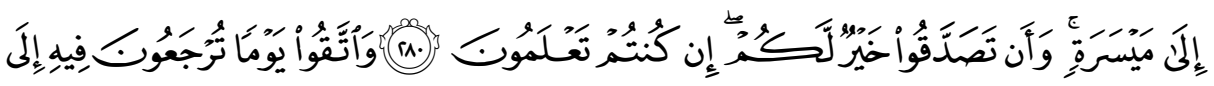

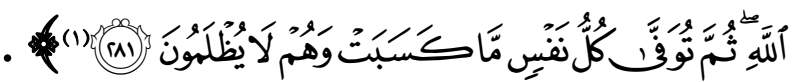

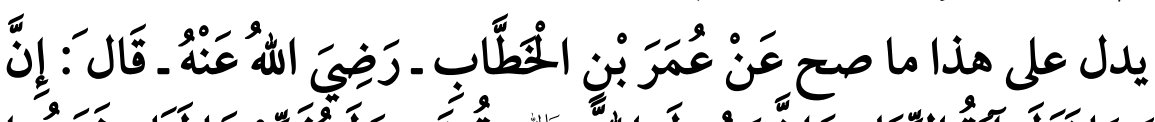

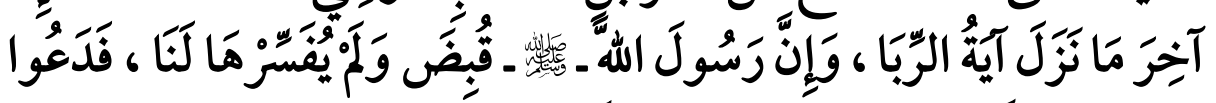

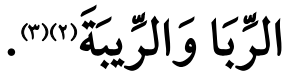

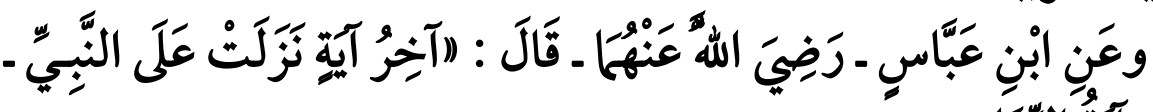

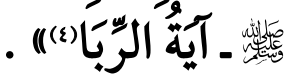

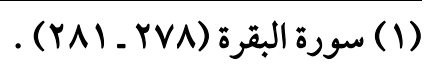

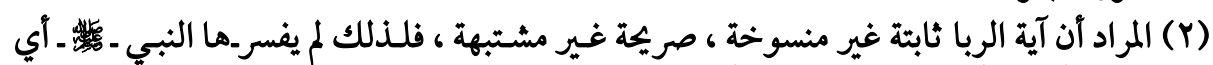

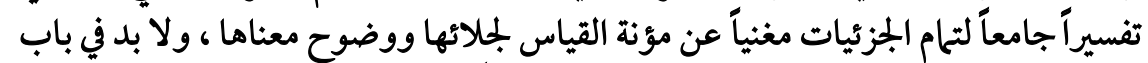

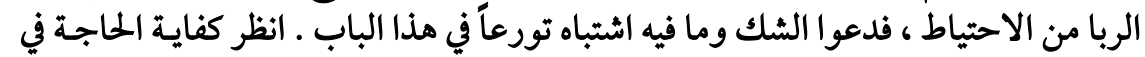

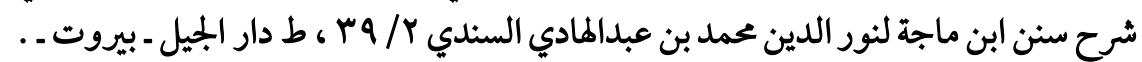

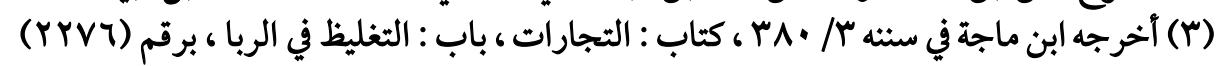

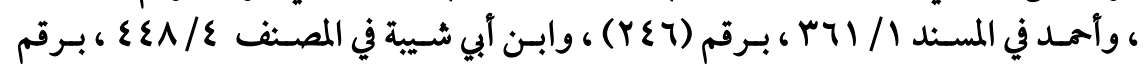

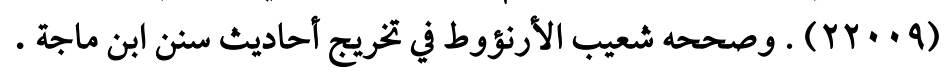

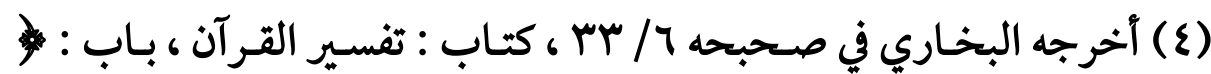

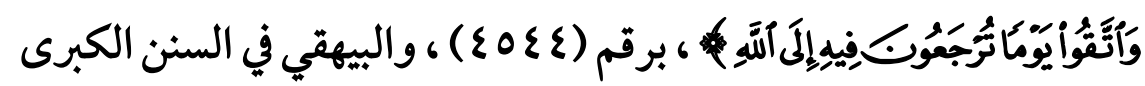




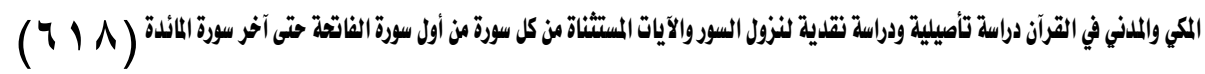

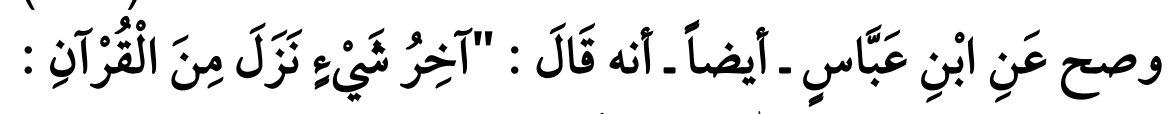

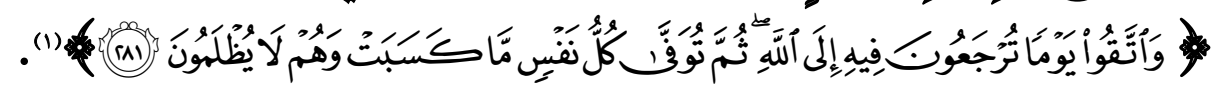

ولا يوجد تناقض بين قولي ابن عبـاس ، وطريـق الجمــع بـين هـذين

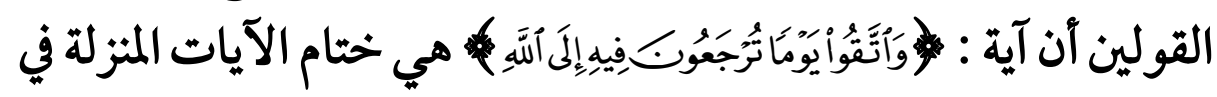

الربا ، إذ هي معطوفة عليهن ، فالسياق كله هو آخر ما نزل من القرآن .

وقد أشار إلى هذا البخخاري ـ رحمه الله ـ حيث تُوجَم في كتاب الثفسير

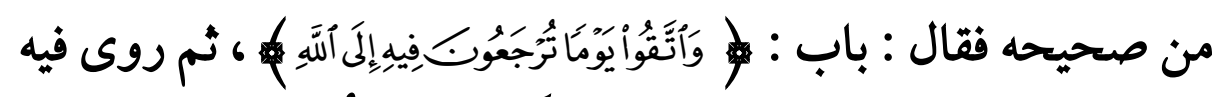

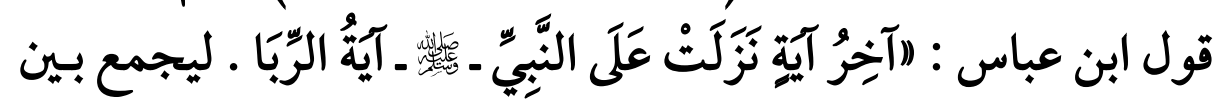
قولي ابن عباس في المسألة)

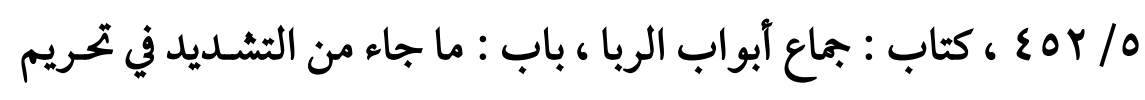

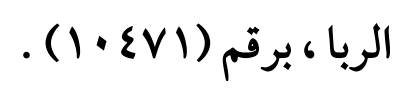

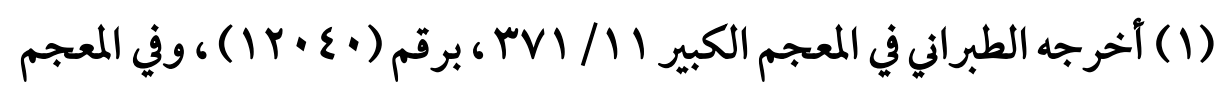

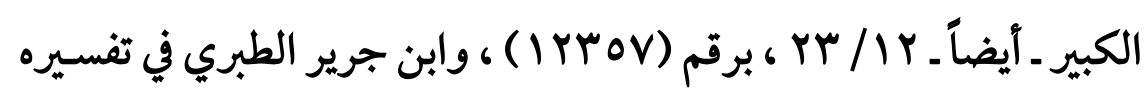

7/ • ع ، وابن المنذر قي تفســره / / ع7 ، وقال الميثمي في بجمـع الزوائد

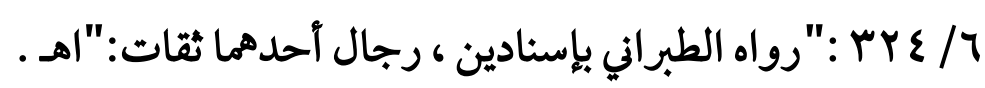

(Y) انظر فتح الباري شرح صحيح البخاري لابن حجر العسقلاني ^/ ه • . . .

و انظر تفصيل القول في مسألة آخر ما نزل من القرآن في البرهان في علوم القرآن

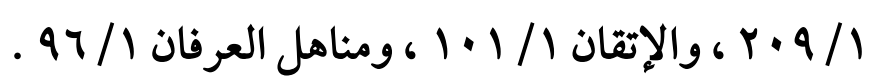


(719)

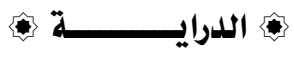

خلاصة القول أن سورة البقرة :"مدنيـة بإبمـاع الآراء ، وقـد ابتداً

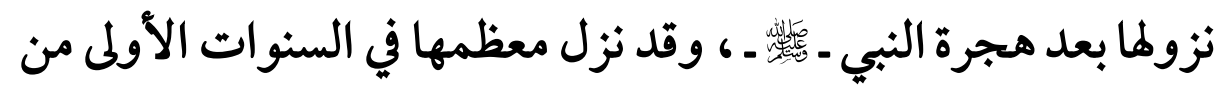

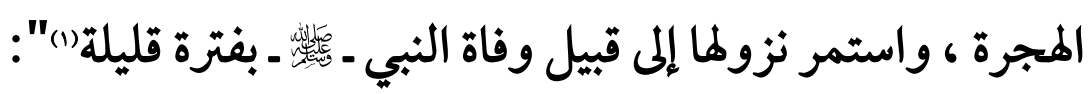

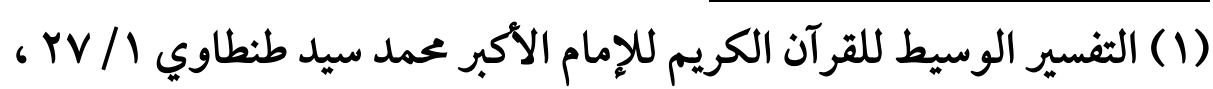

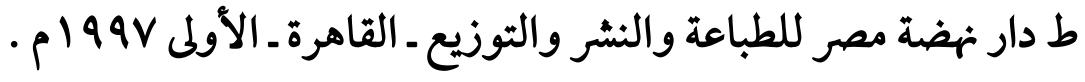




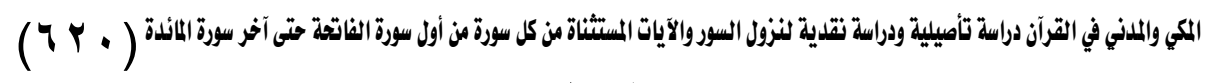

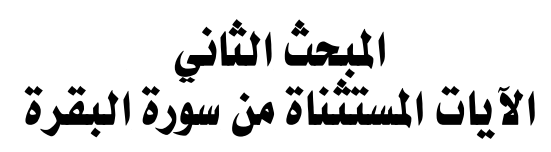

تقرر أن سورة البقرة مدنية ، لكن هناك ثلاث آيات اسُتُنْنِتَ منها ، ندرس كل آية منها في مطلب مستقل :

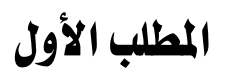

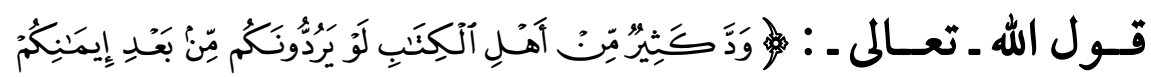

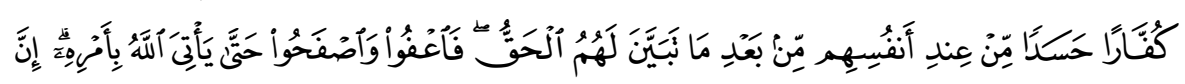

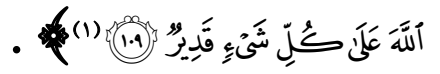

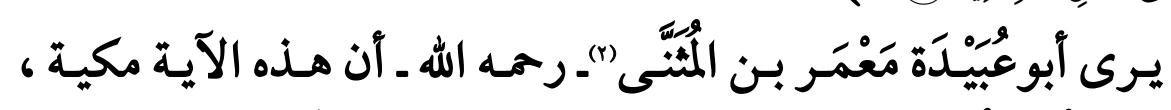

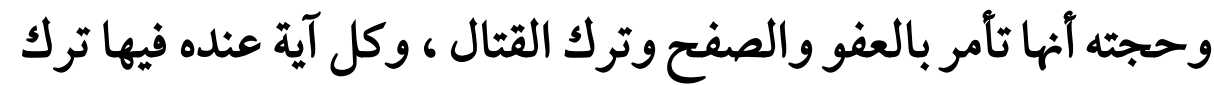

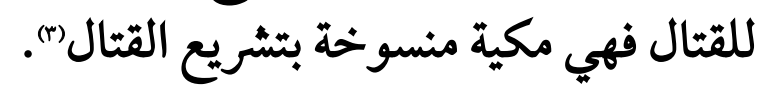

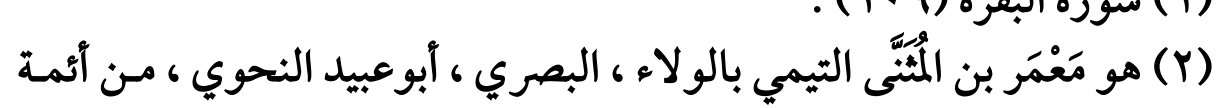

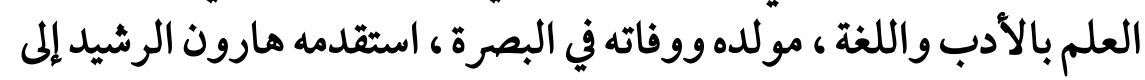

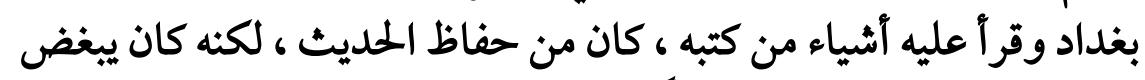

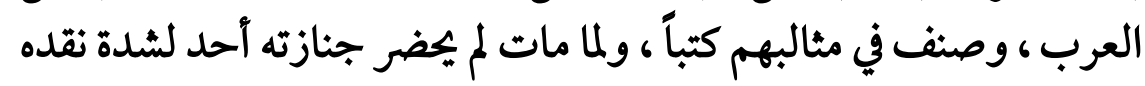

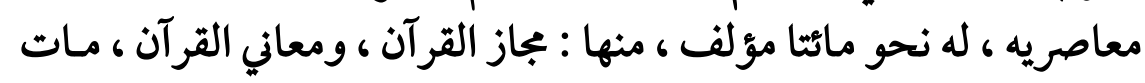

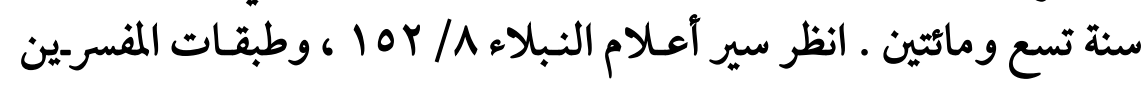

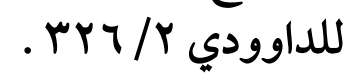

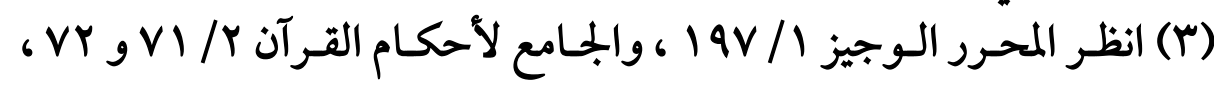

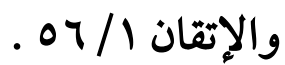


(4T)

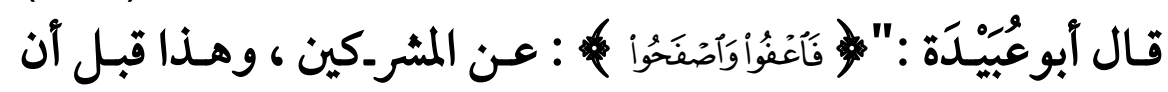

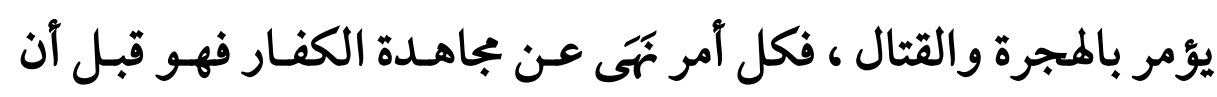

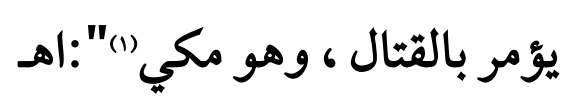

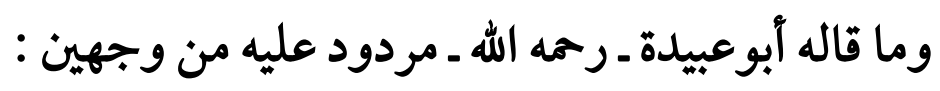

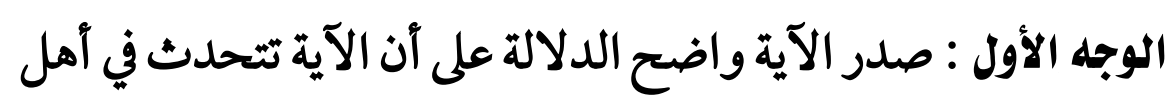

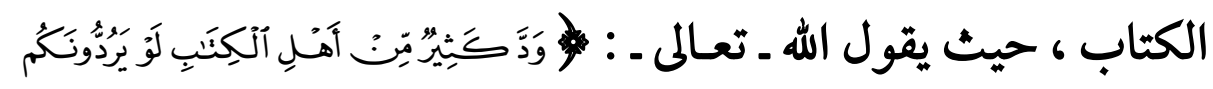

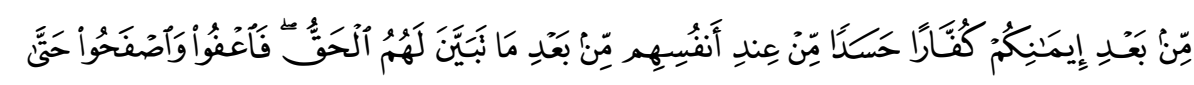

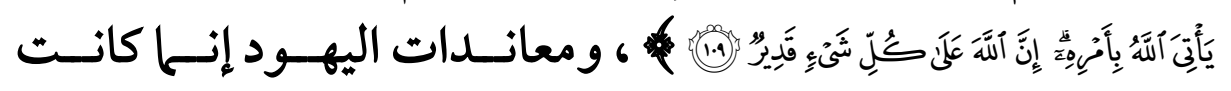
بالمدينة). الوجه الثاني : ـالأسباب التي نزلت فيها الآية كلها حوادث حدثت

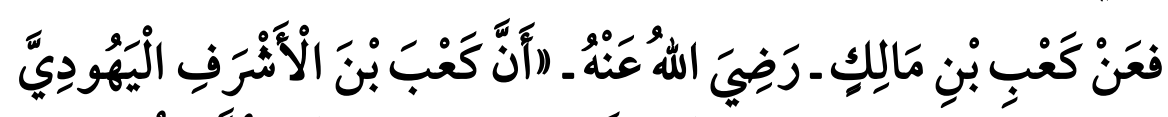

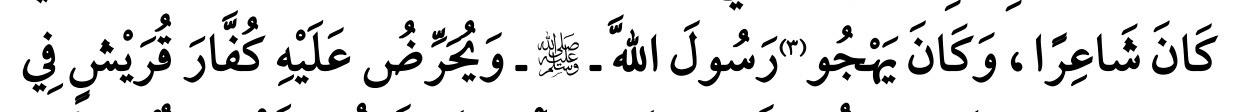

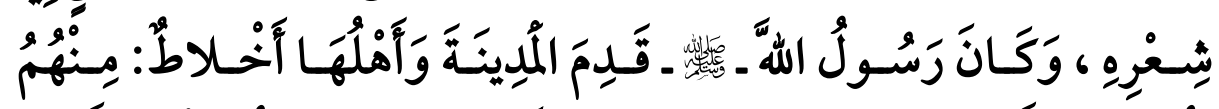

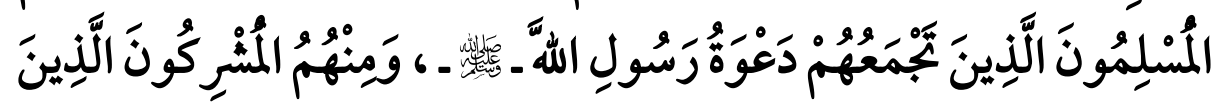

(1) جاز القرآن لأبي عبيدة معمر بن المثى التيمى البصري / / 0 ، ط مكتبة

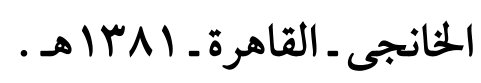

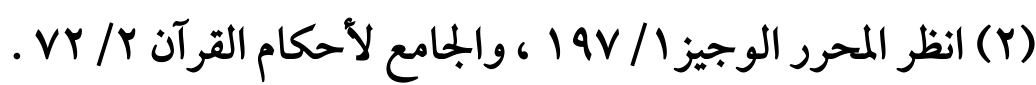

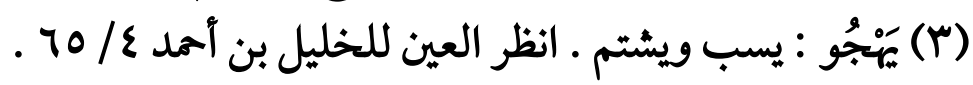




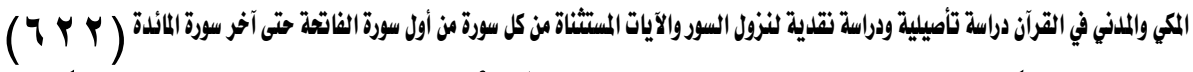

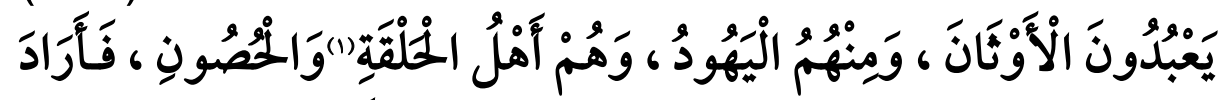

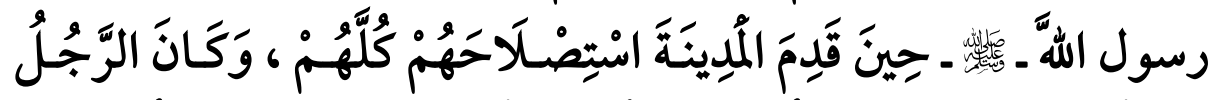

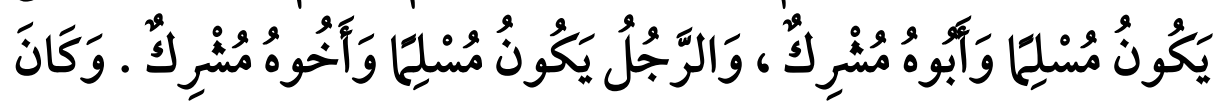

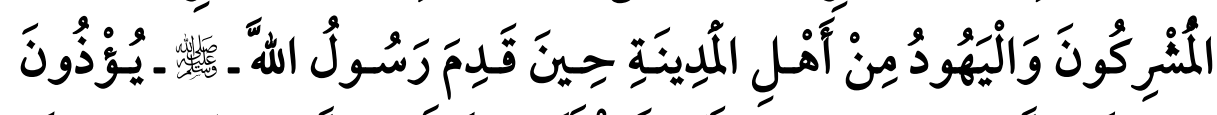

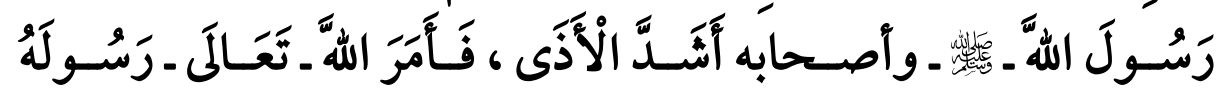

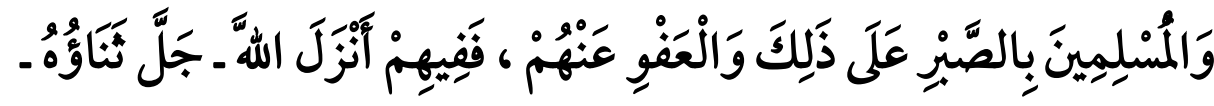

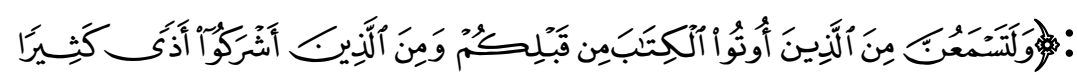

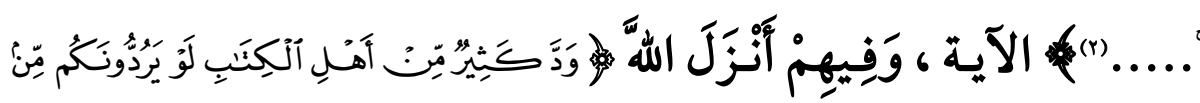

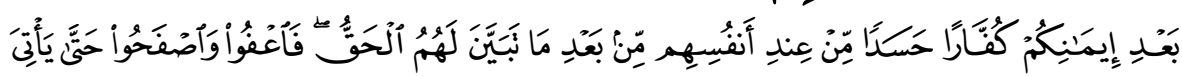

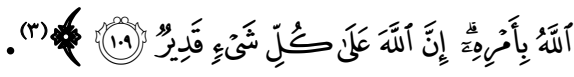

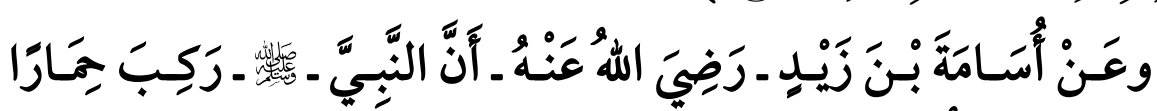

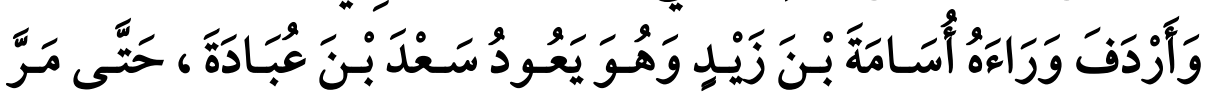

(1) الخلْفة : اسم لجملة السلاح والدروع وما أشبهها ـ انظر لسان العرب

$$
\text { . . }
$$

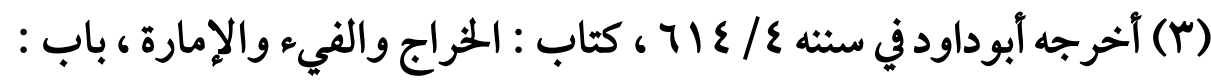

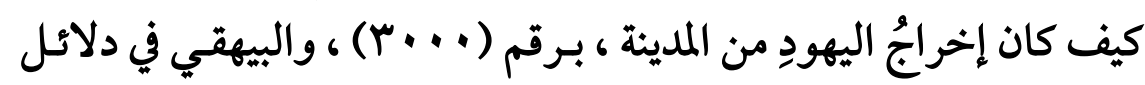

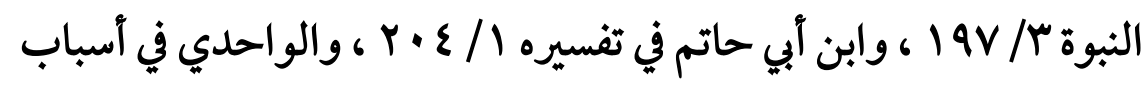

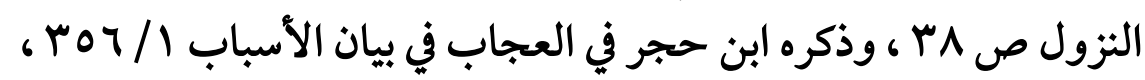

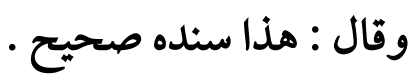


$(4 T H)$

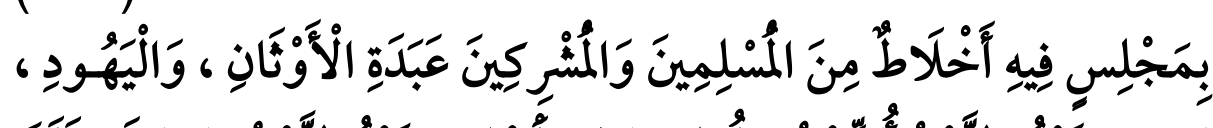

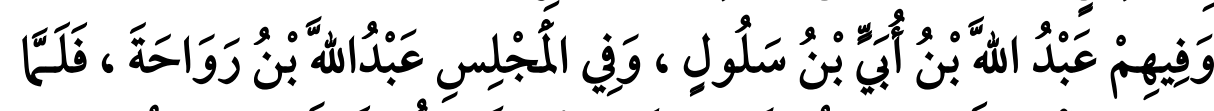

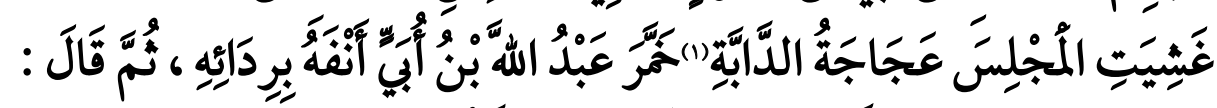

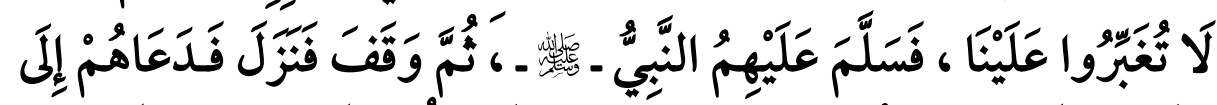

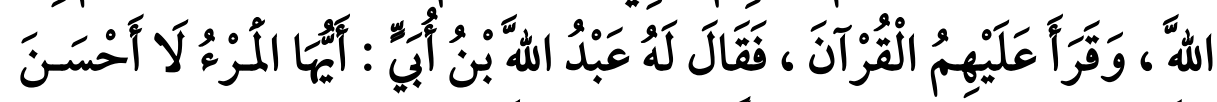

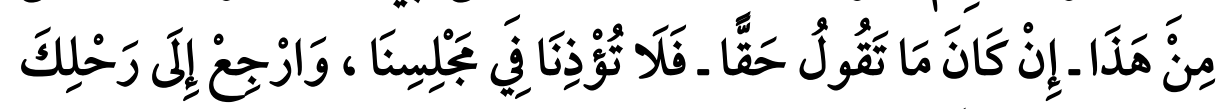

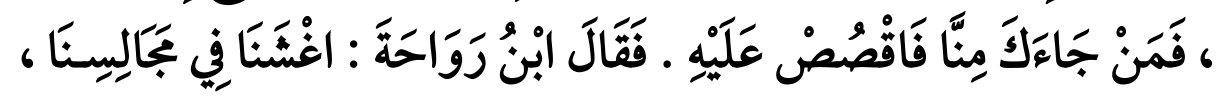

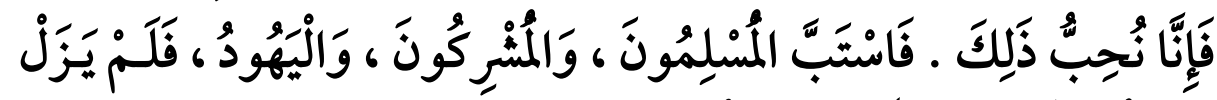

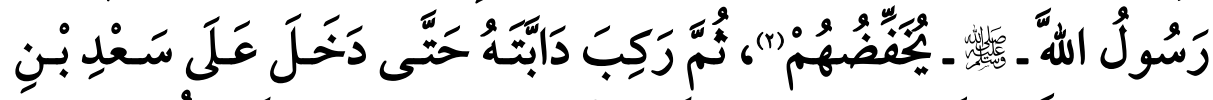

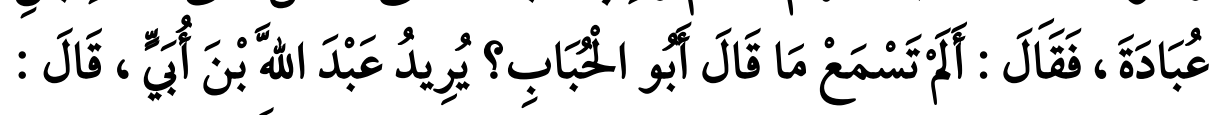

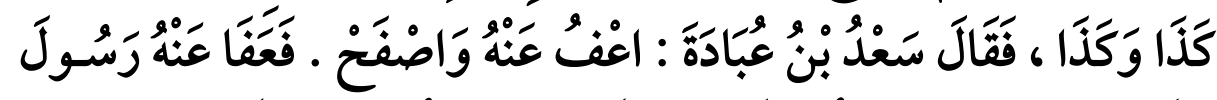

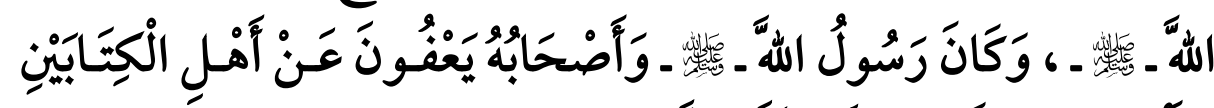

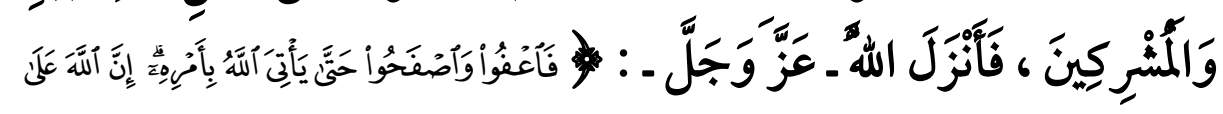

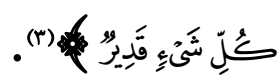

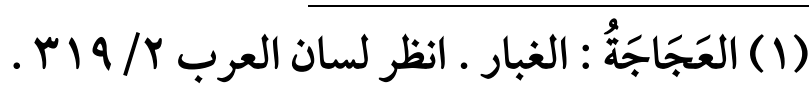

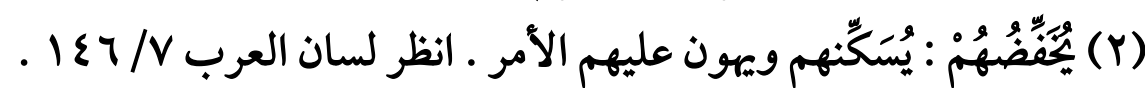

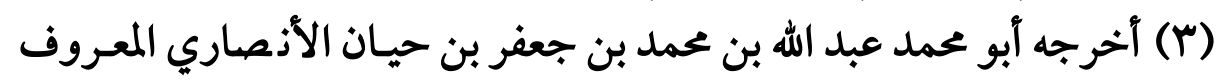

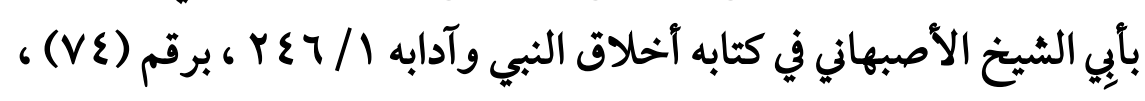

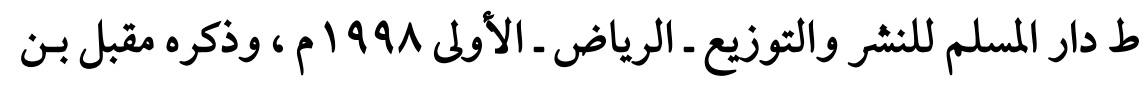




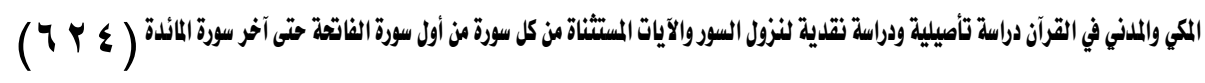
فقد دل هذان الحديثان على آن الآية مدنية .

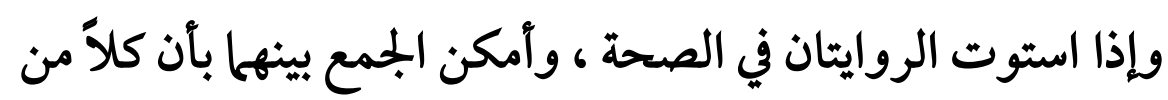

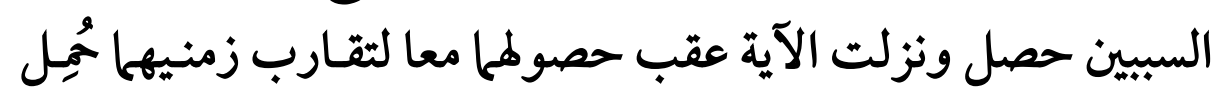

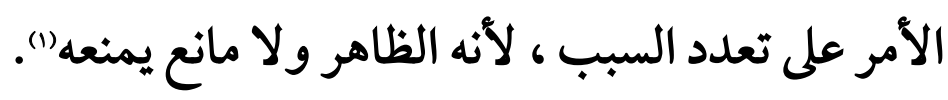

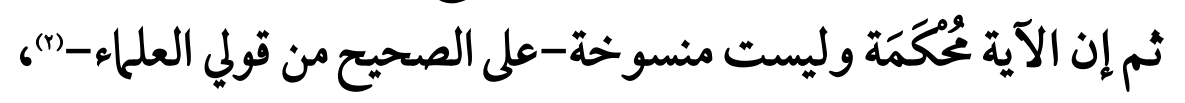

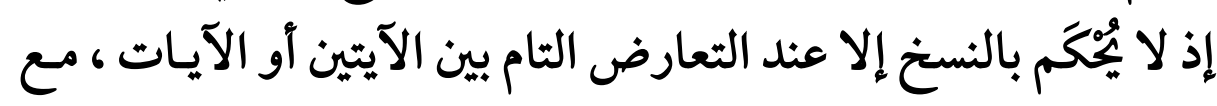

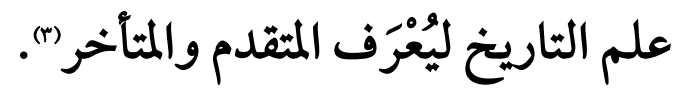

هادي الوادعي في كتابه الصحيح المسند من أسباب النزول ص 19 ( ، وحكم

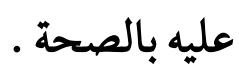

والحديث له أصل في الصحيحين ولكن بـدون التصريح بـأن هذه الحادثة هي

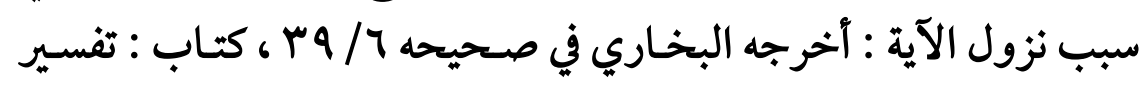

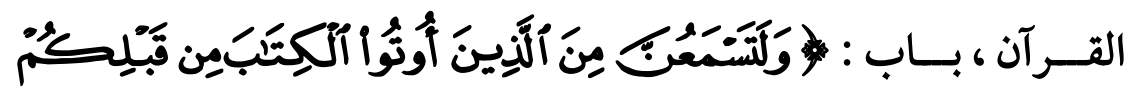

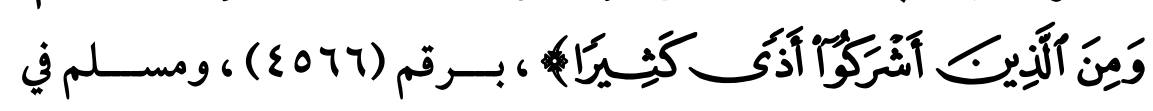

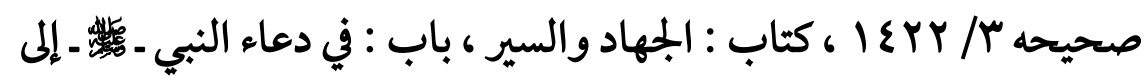

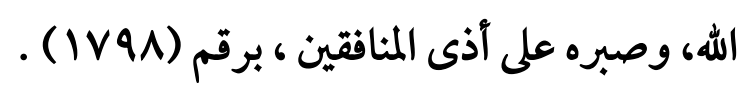

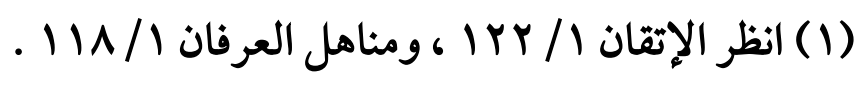

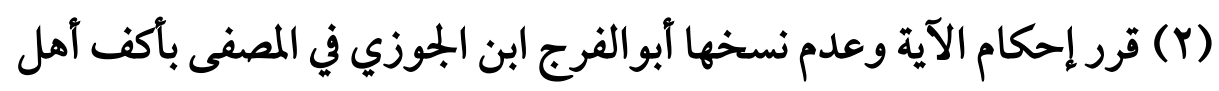

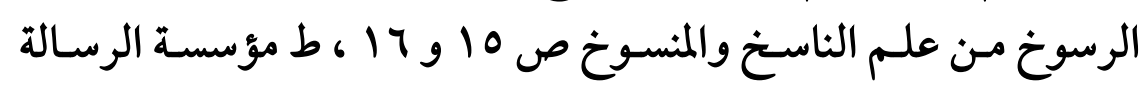

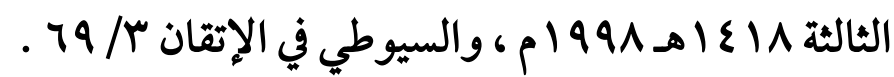

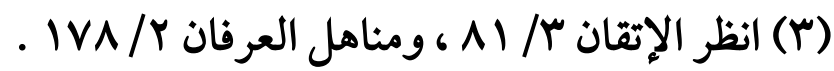


(4ro)

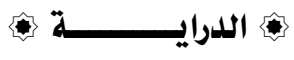

قال السَّخَاوي" (1) رحمه الله ـ :"متى كان للخطاب طريق في الحكم بأنه

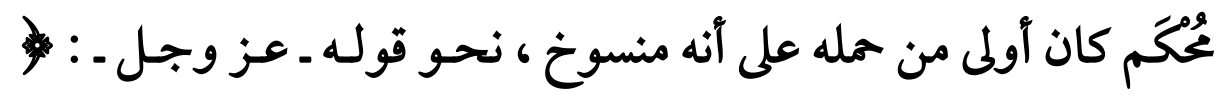

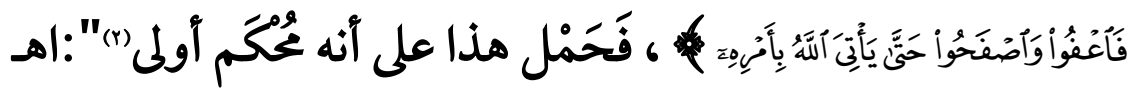

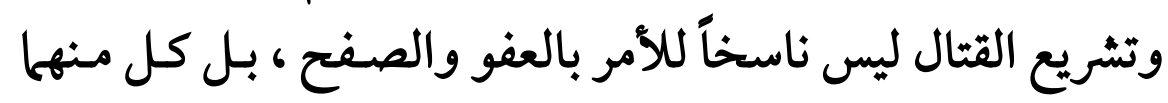
يجب امتثاله في وقته (r). فالآيـات التي تـأمر بـالعفو والصفتح إنـا هـي في حـق كـل مـؤمن

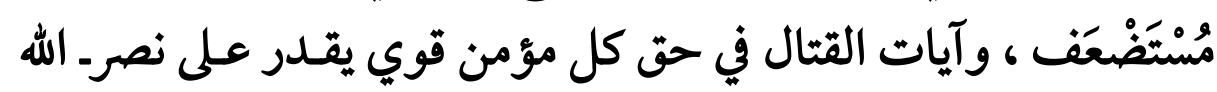

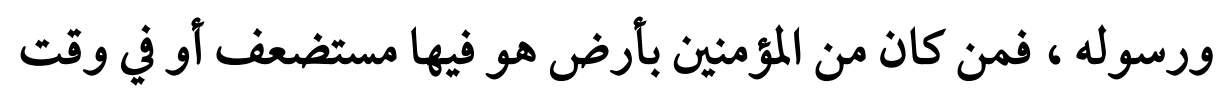

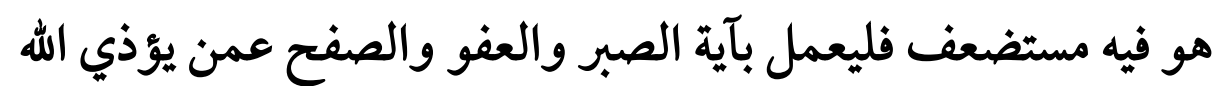

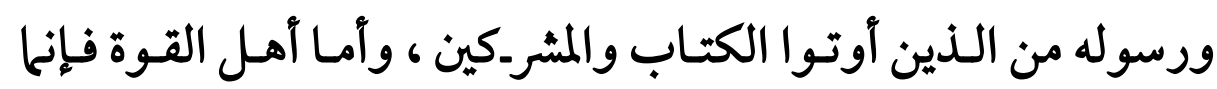

(1) هو علي بن محمد بن عبد الصمد الممداني المصري السخاوي الشافعي ، أبو الحسن ، عالم بالقراءات والأصـول واللغة والتفسير، آصله مـن (صَخَّا) بمصر، سكن دمشق ، وتوفي فيها سنة ثلاث وأربعين وستتائة ـ مـن كتبه : جمال القراء وكحال الإقراء ، وشرح الشاطبية ، وهو أول من شرحها ، وكان سبب شهرتها ـ انظر وفيات الأعيان س/ • ع ؟ ، وطبقات المفسرين للسيوطي ص

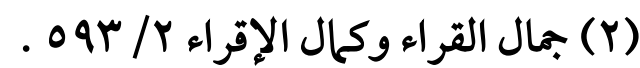

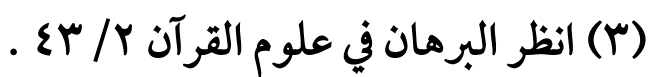




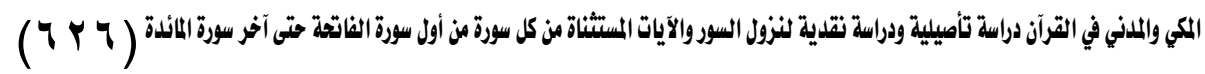
يعملون بآية قتال أثمة الكفر الذين يطعنون في الدين ويآية قتال الذين

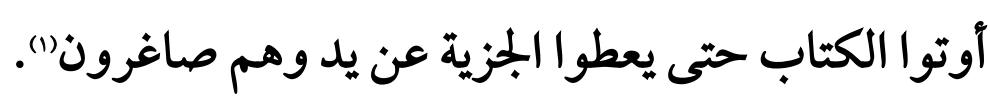

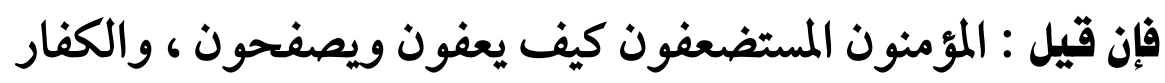
كانوا أصحاب الشوكة والقوة ، والصفح لا يكون إلا عن قدرة؟

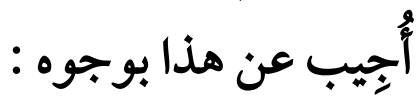

الوجه الأول : ـ أن الرجل من من الموه : المسلمين كان يُنَال بـالأذى ، فيقدر في

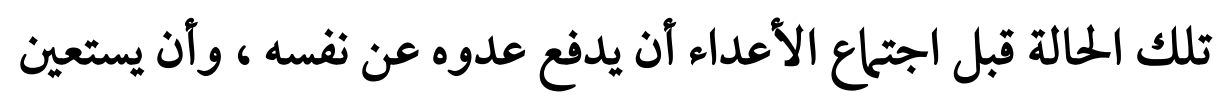

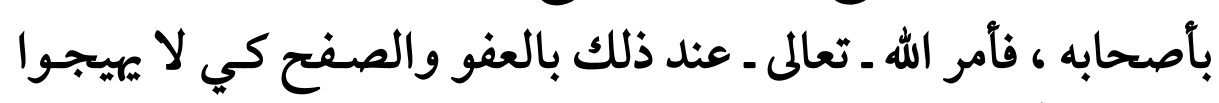

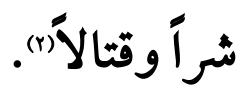

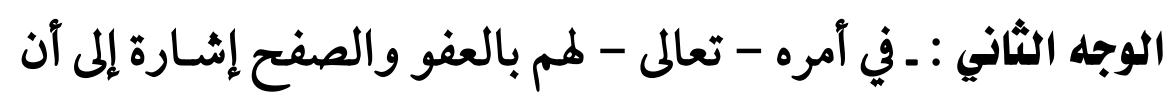

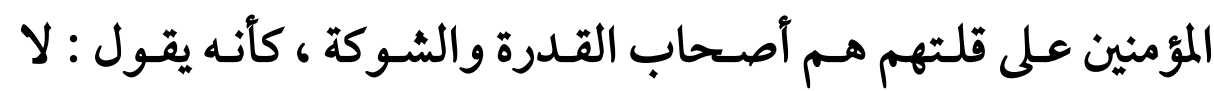

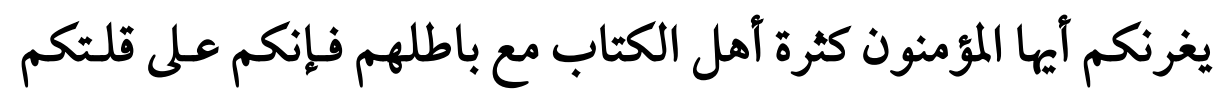

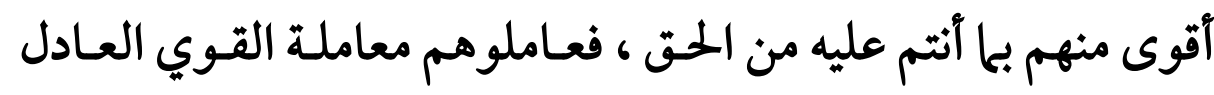

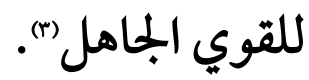

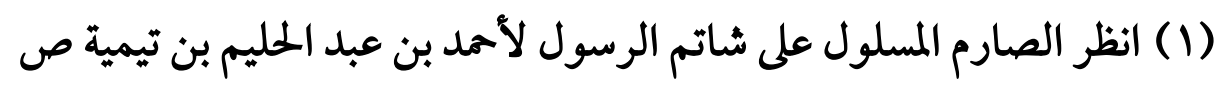

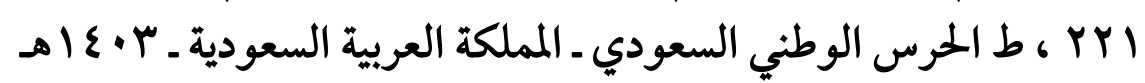

$$
\begin{aligned}
& \text { - }
\end{aligned}
$$

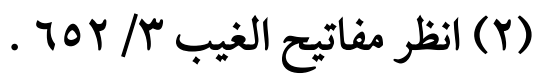

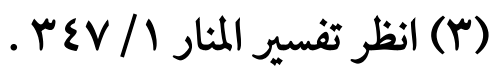


(TrV)

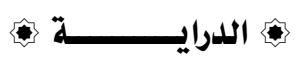

والوجه الثالث : ـ أُمِر المسلمون بالعفو والصفح عنهم في هذا الموضع

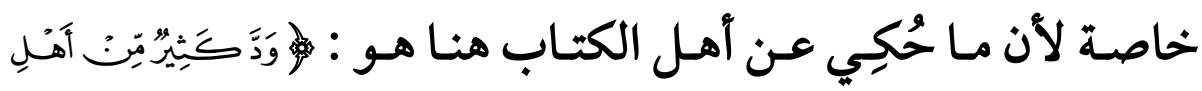

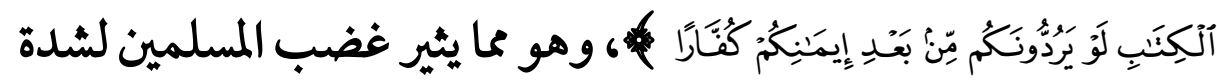

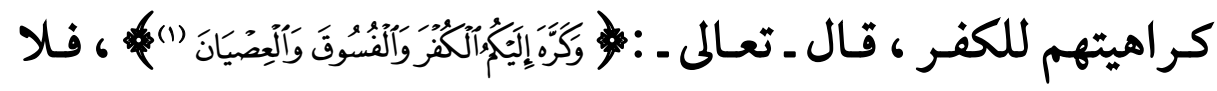

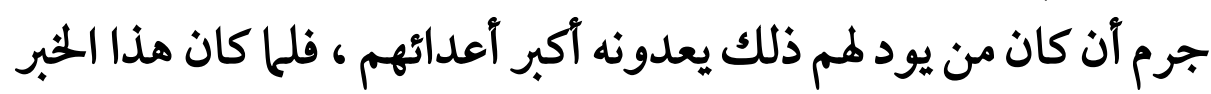

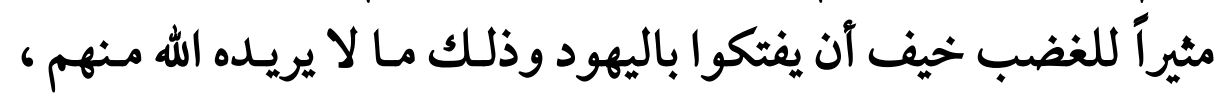

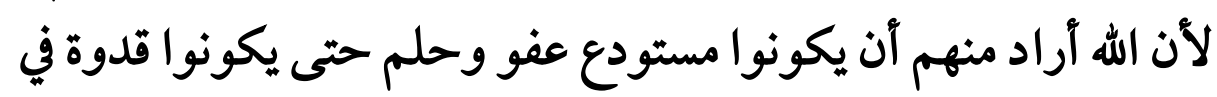
الفضائل (r) خلاصة القول أن الآية محل البحث مدنيـة كسورتها ، دل على هـذا

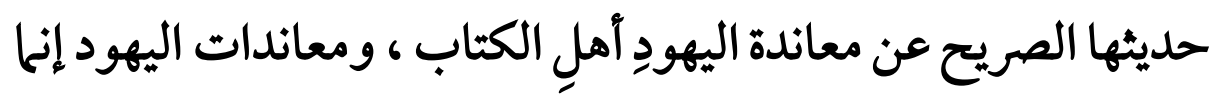

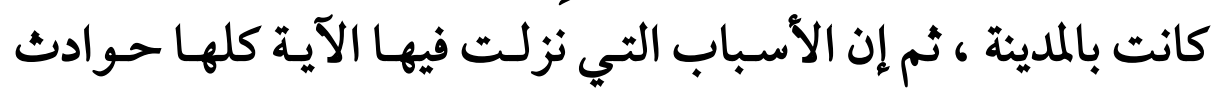
حدثت في المدينة . ودعوى مكية الآية مبنية على توهم آن العفو والصفح لم يكونا إلا في

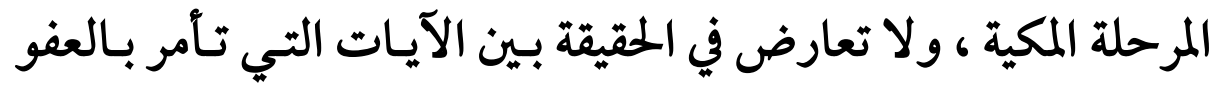

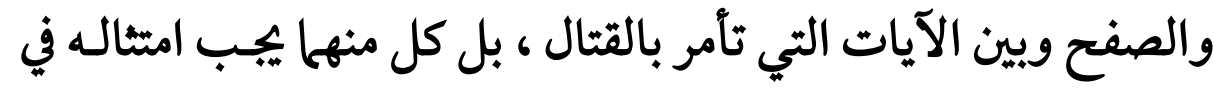

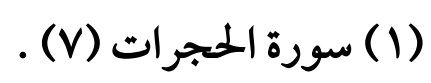

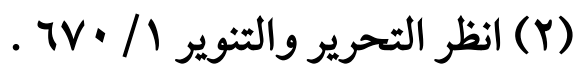




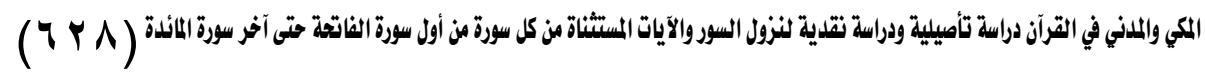

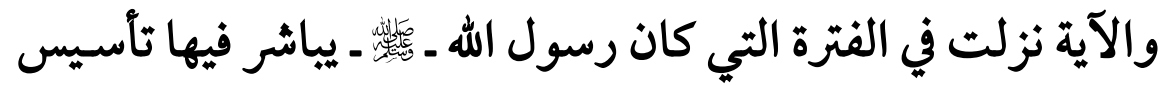

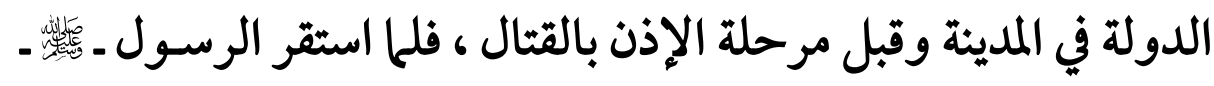

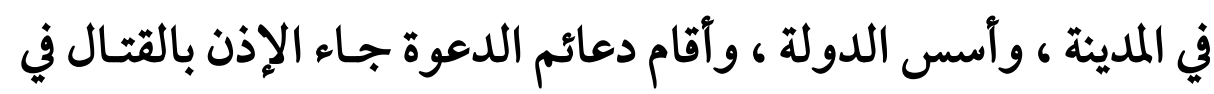

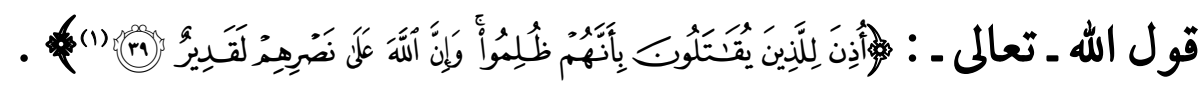

$$
\text { (1) سورة الحجج (q) ) (1) }
$$


(rrq)

\section{المطلب الثاني}

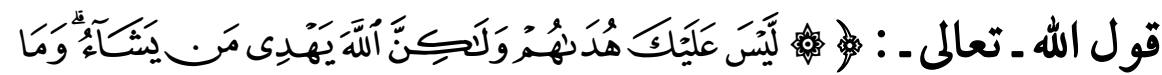

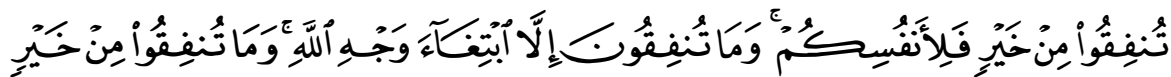

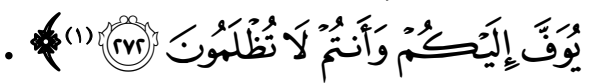

في معرض ذكر المكي والمدني من السور ، وذكر الآيات المستثناة من

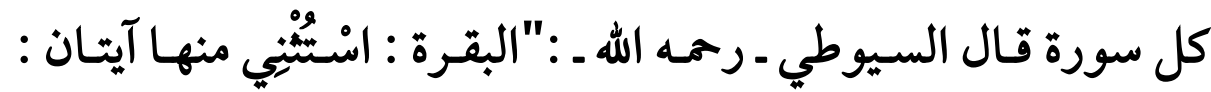

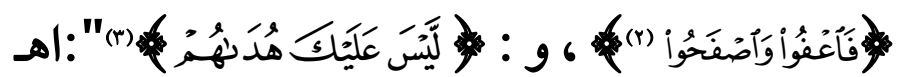

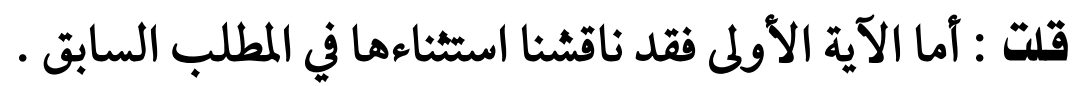

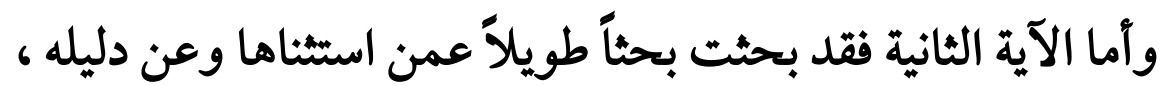

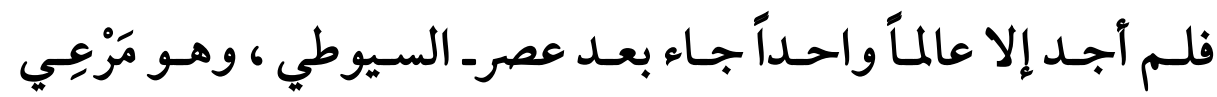

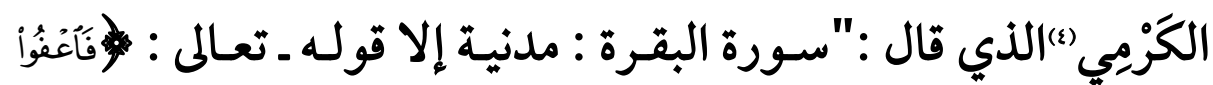

$$
\begin{aligned}
& \text { (1) سورة البقرة (YVY) . } \\
& \text { (Y) سورة البقرة (9 ( ) ) . }
\end{aligned}
$$

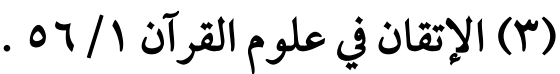

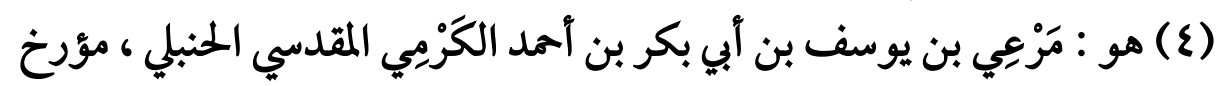

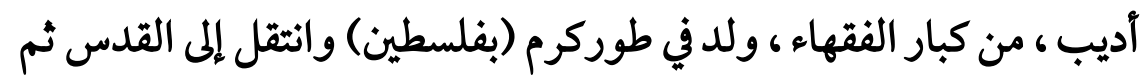

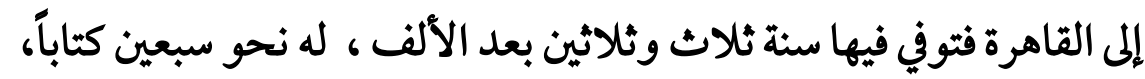

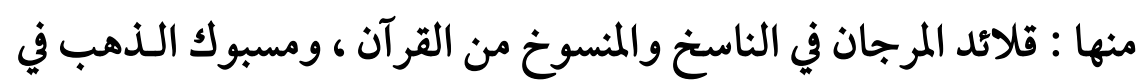

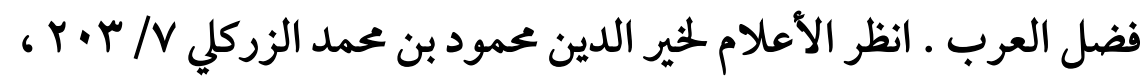

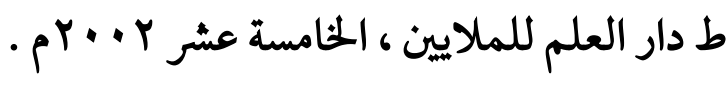




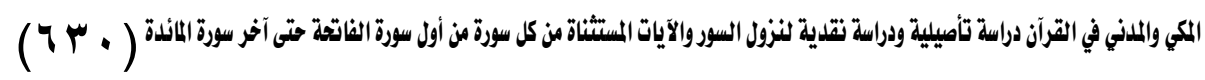

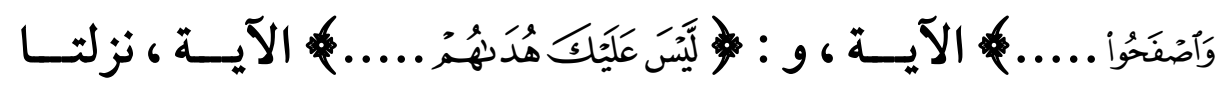

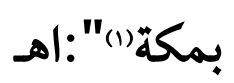

ولم أجد ـ مع طول البحث ـ أي دليل يدل على هذا الاستئاء ، اللهم

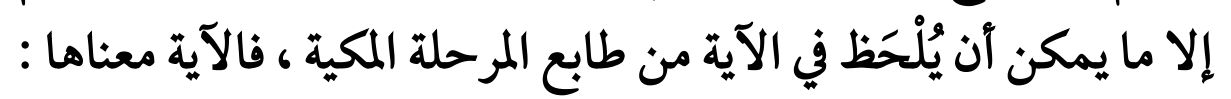

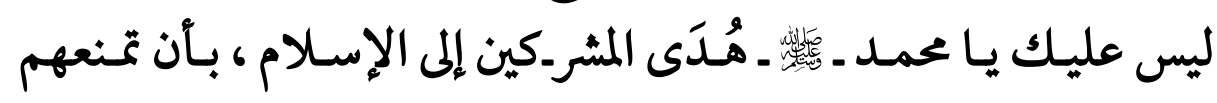

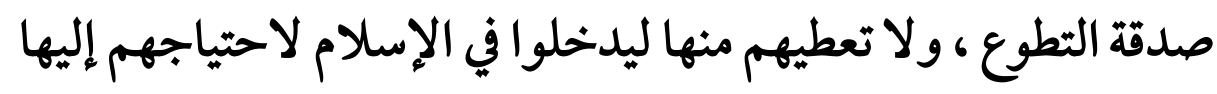

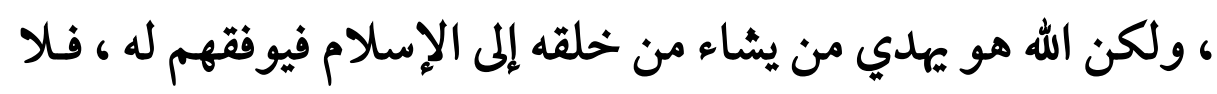
تمنعهم الصدقة (r).

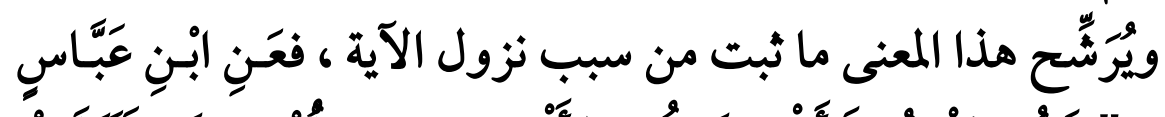

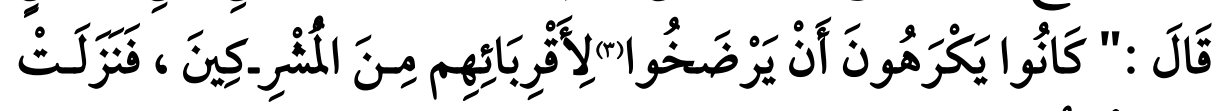

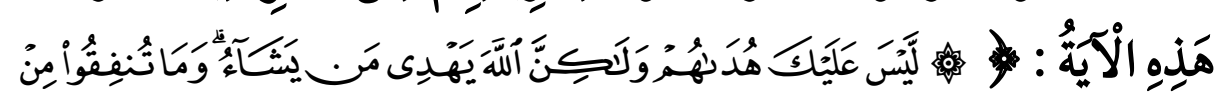

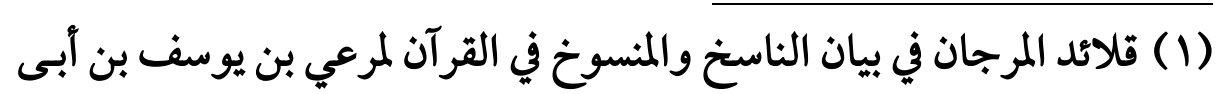

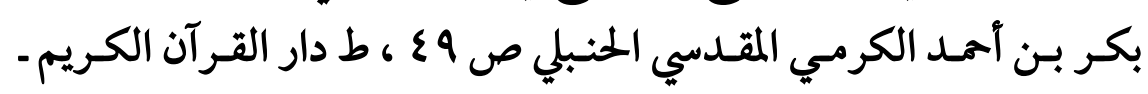

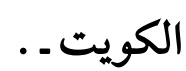

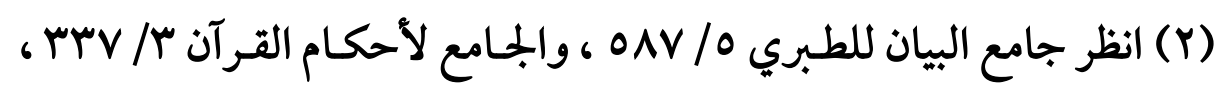

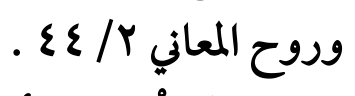

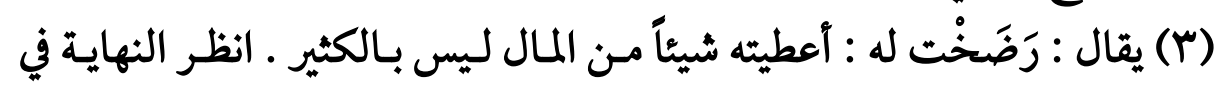

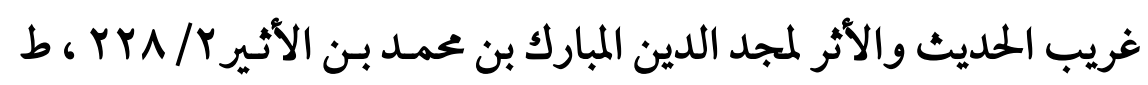

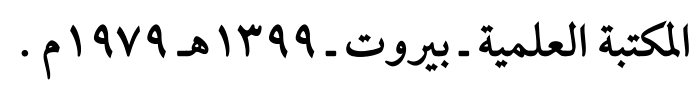


(Tr)

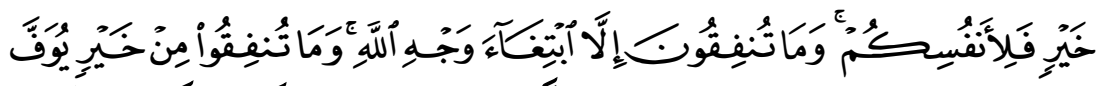

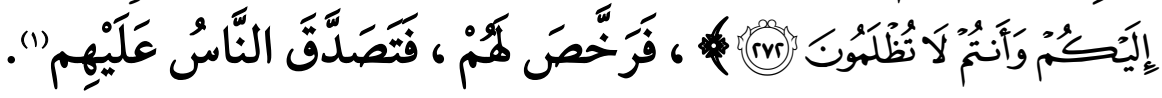

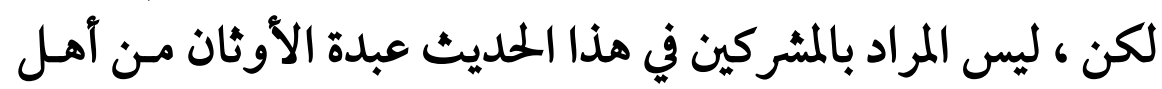

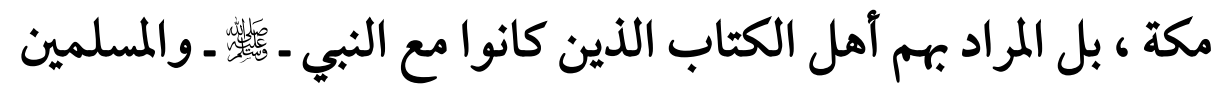

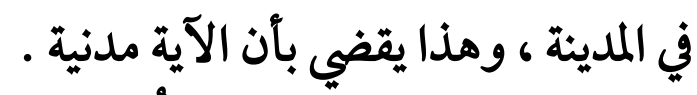

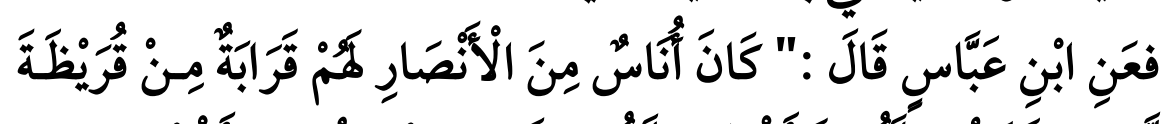

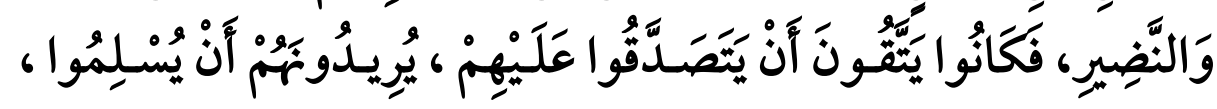

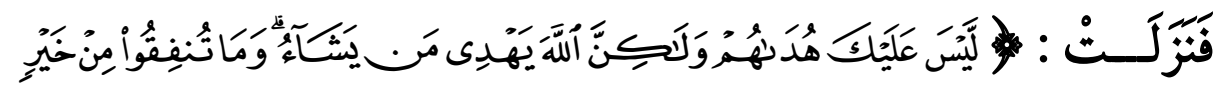

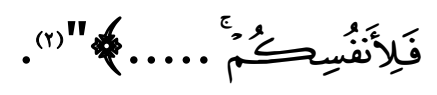

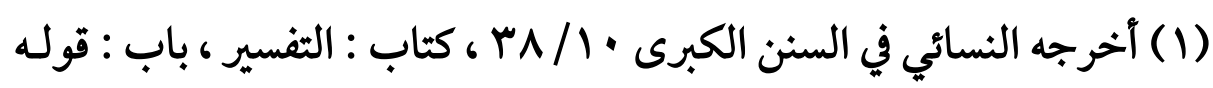

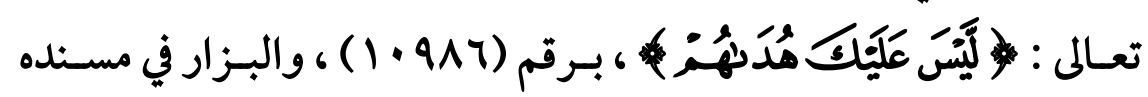

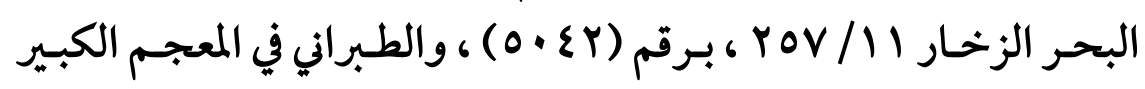

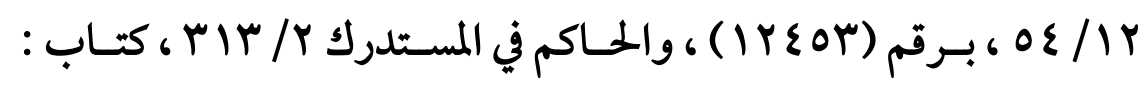

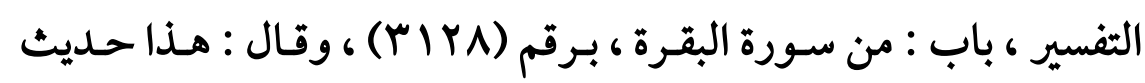

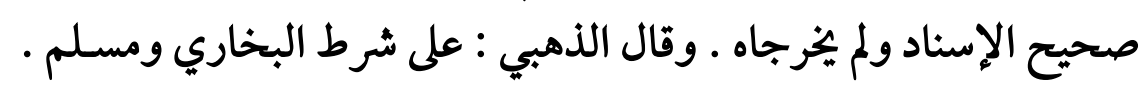

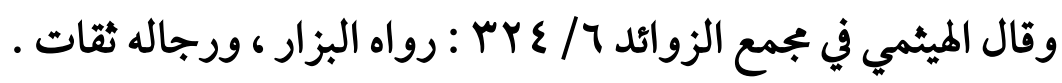

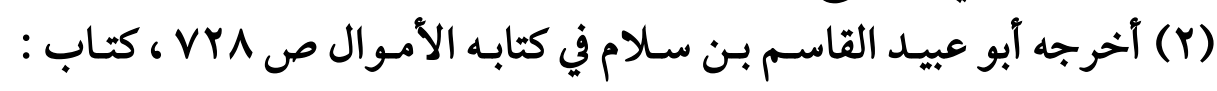

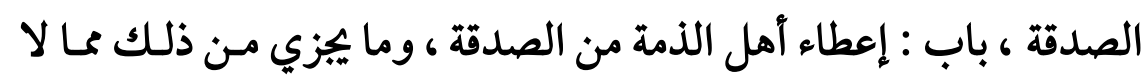

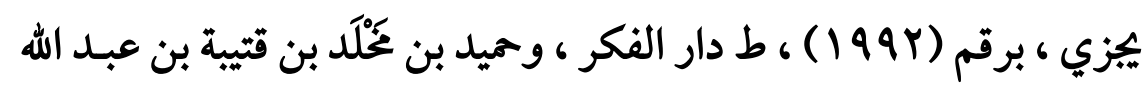

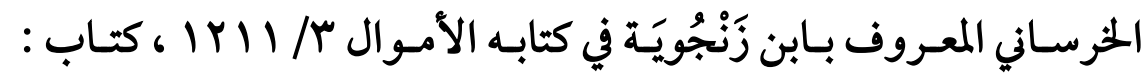




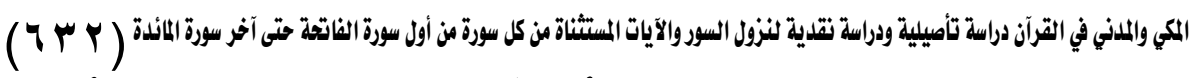

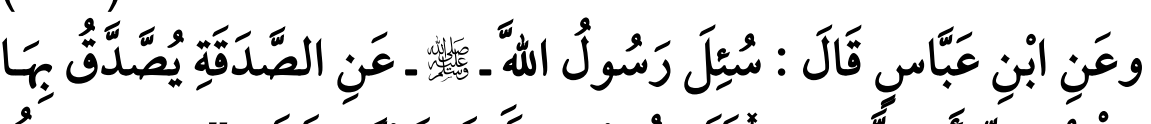

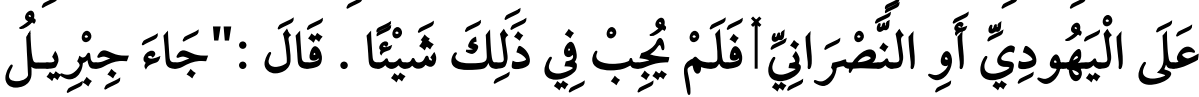

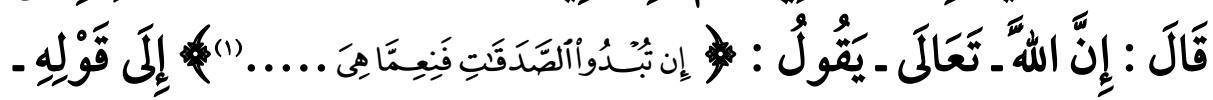

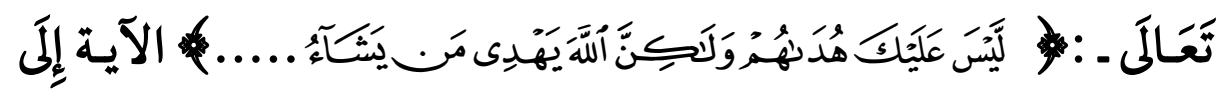

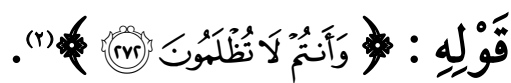
خلاصة القول أن الآية محل البحث مدنية كسورتها ، لأن رواية ابن

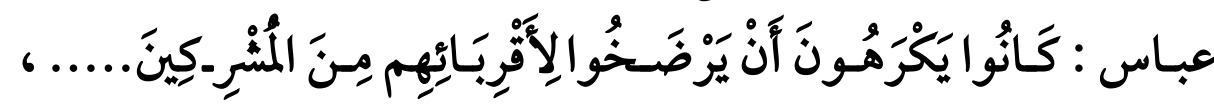

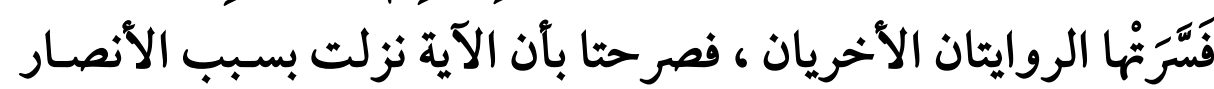
الذين كرهوا أن ينفقوا على أقربائهم من أهل الكتاب الذين كـانوا مـع

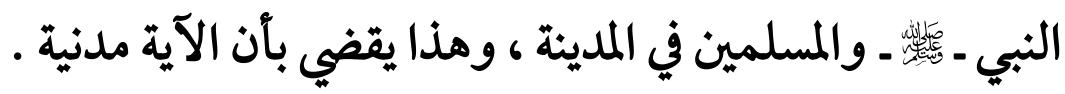

الصدقة وأحكامها وسننها ، باب : ما جاء في الصدقة على آهل الذمة ، برقم

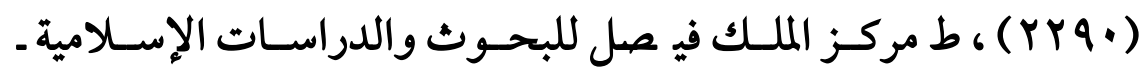

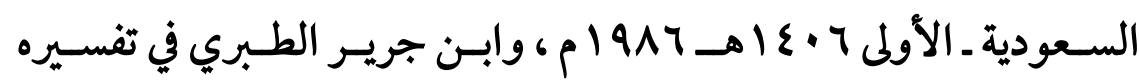

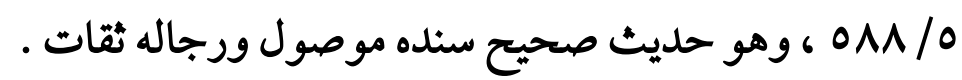

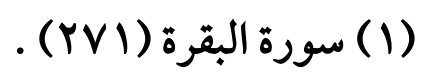

(Y) آخرجه عمر بن أحمد بـن عـثمان البغـدادي المعـروف بـابن شـاهين في كتابـه

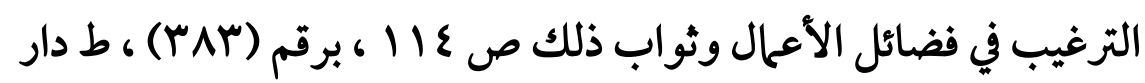

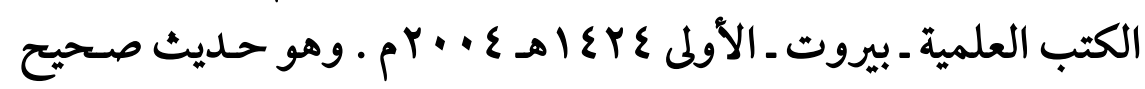
سنده موصول ورجاله ثقات . 
$(4 M T)$

\section{المطلب الثالث}

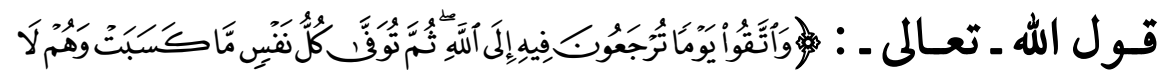

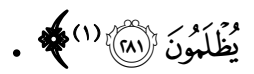

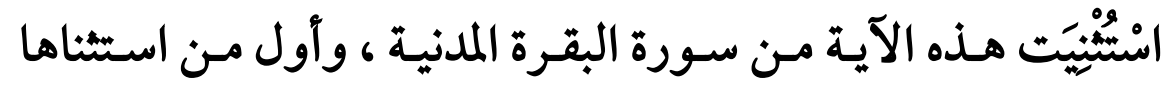

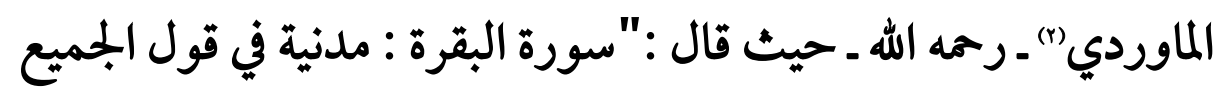

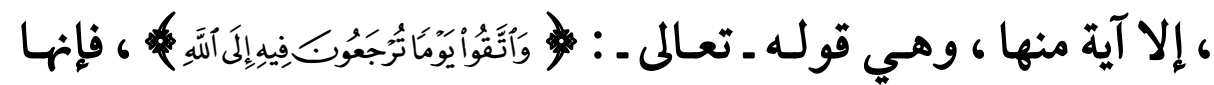

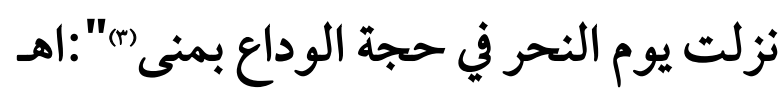

ونقل غير واحد من العلم)ء قول الماوردي هذا ، وسكت الودئ عنه (8).

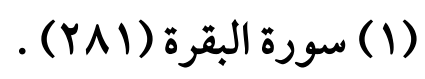

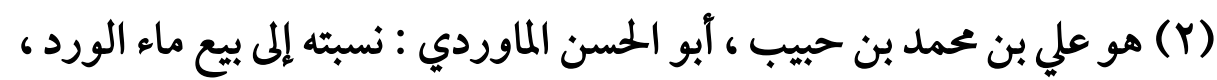

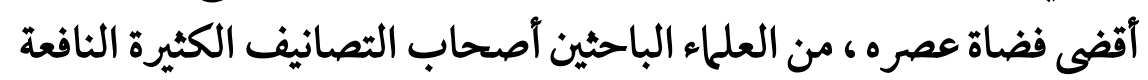

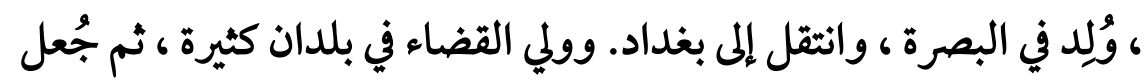

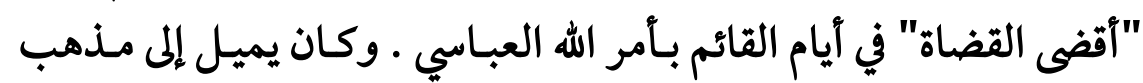

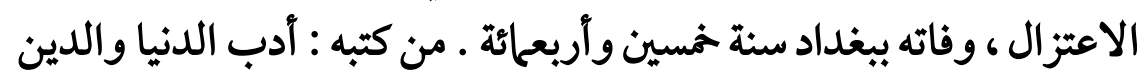

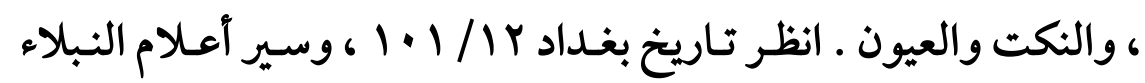
r

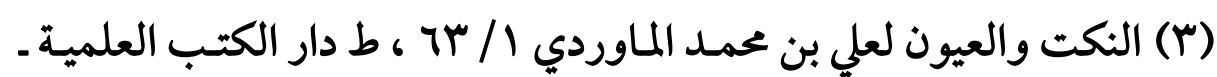
بيروت .

(ع) انظر زاد المسير / / ع ، ، وتفسير القرآن لعز الدين عبدالعزيز بن عبدالسلام

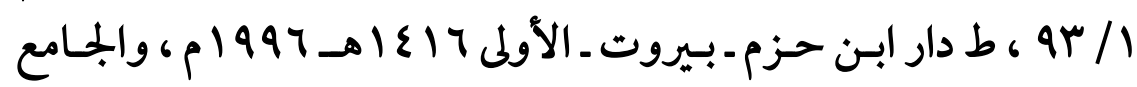

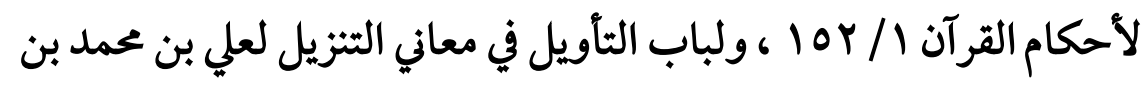




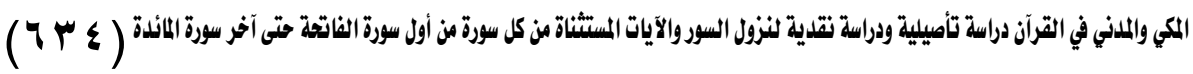

والماوردي ومن نقل عنه ذكروا أن الحجـة لمذا الاسـتثناء أن الآيـة

نزلت يوم النحر في حجة الوداع بمنى ، ويمكن مناقشتهم من وجهين :

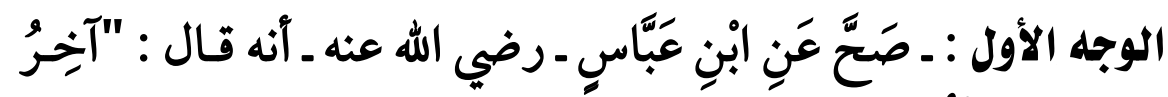

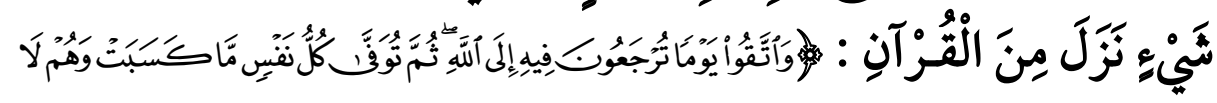

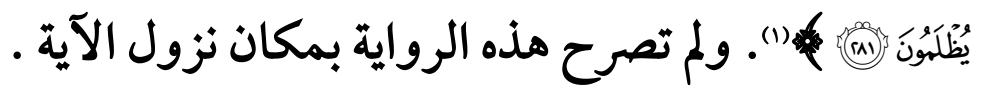

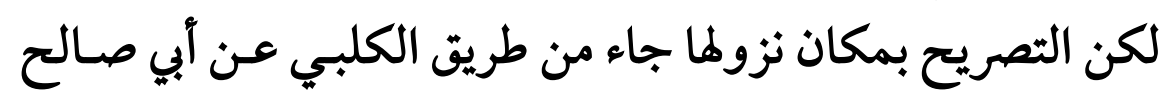

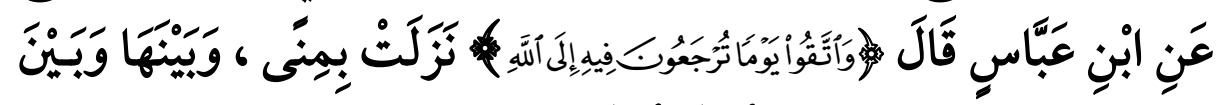

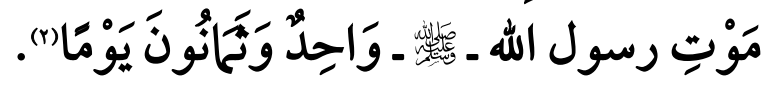

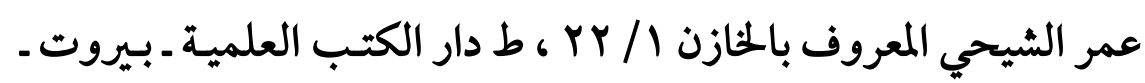

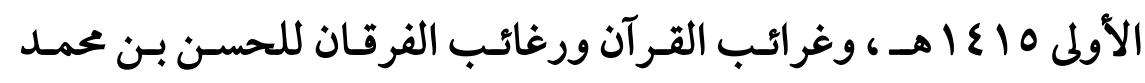

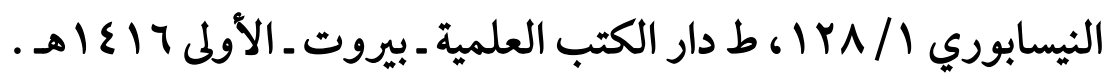

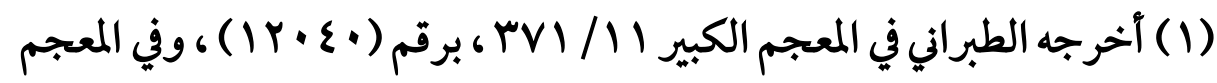

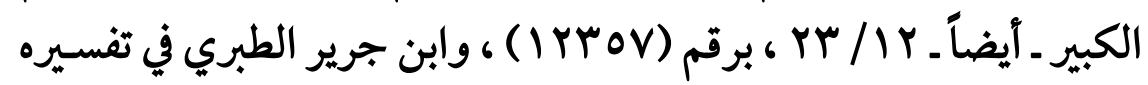

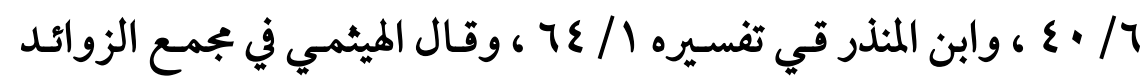

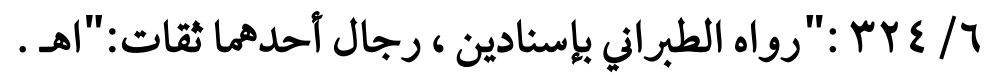

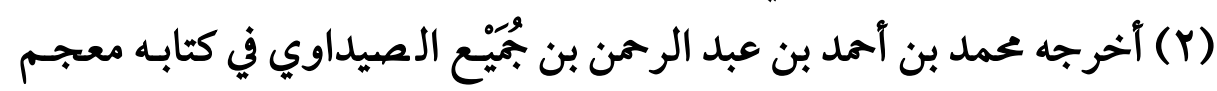

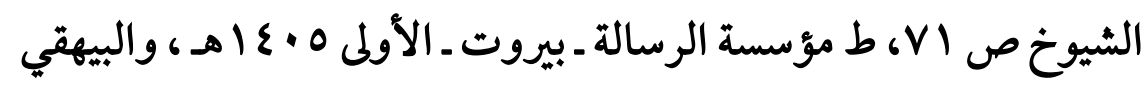

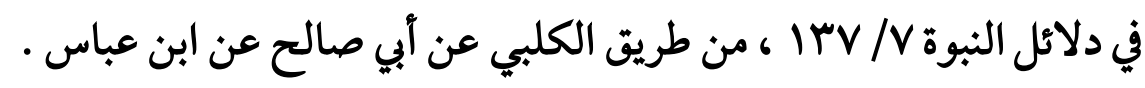
وهذا سند مهلهل ومسلسل بالعلل :

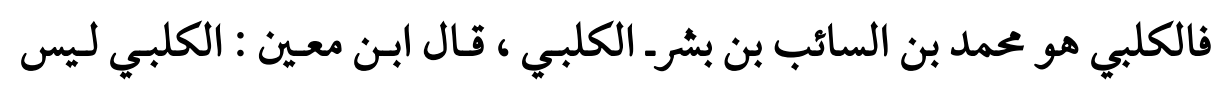

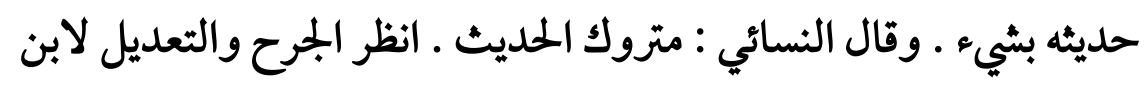




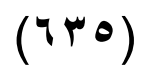

$$
\text { وهذا حديث بالطل ولا يصح الاحتجاج به . }
$$

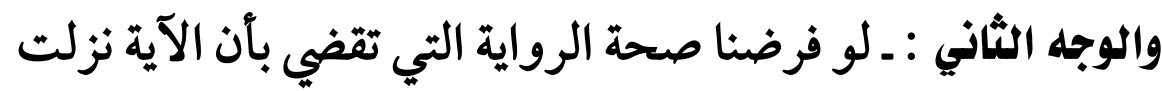

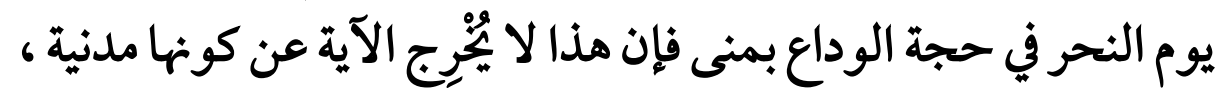

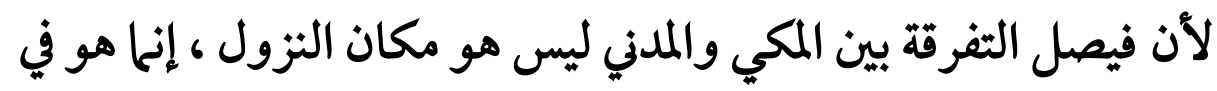

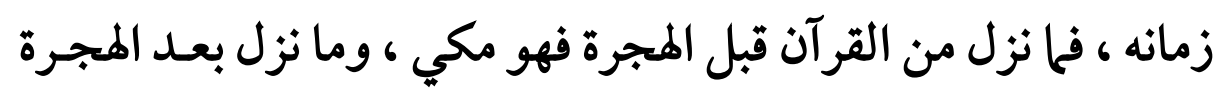

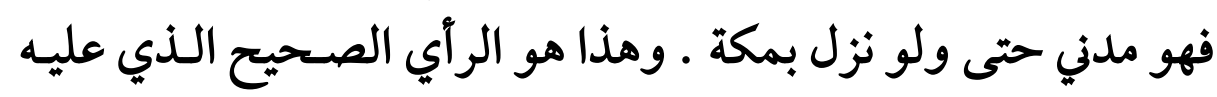
جمهور العلماء والسالم من كل انتقاد.

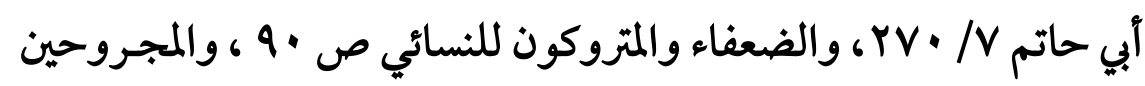

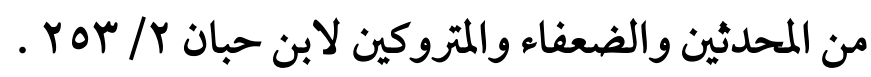

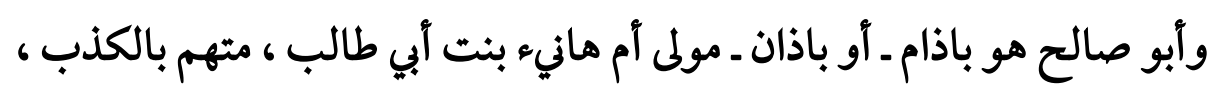

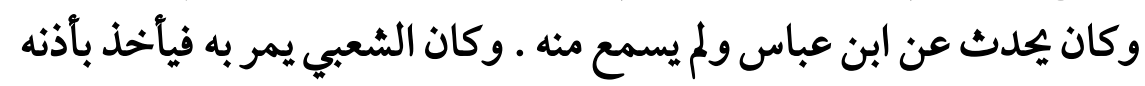

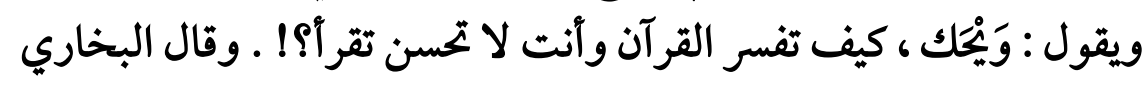

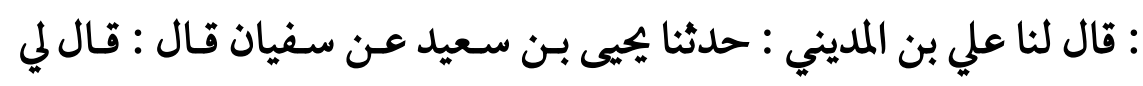

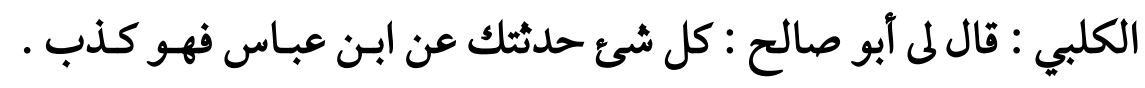

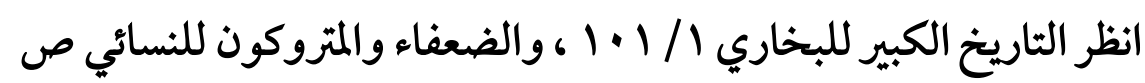

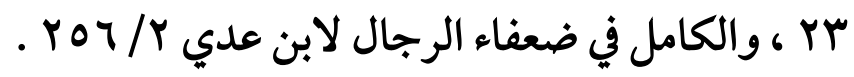




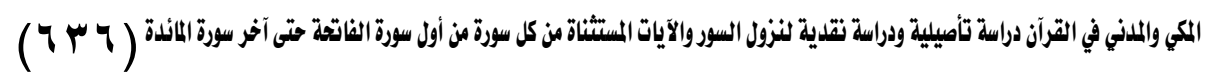
وهذا ما قرره غير واحد من العلماء في الرد على مكية هذه الآية'(1). خلاصة القول أن الآية محل البحث مدنية كسورتها ، ودعوى مكيتها استندت على حديث باطل ، وانطلقت من منظور مكاني ، ولو انطلقت من منظور زماني ـ كما هو رأي الجمهور ـ لما ترددت في إقرار مدنيتها ، إذ الآية آخر ما نزل من القرآن الكريم • وفي الجملة فالأصل في السورة المدنية أن تكون كل آياتها مدنية ، ولا يُقْبَل القول بمكية بعض آياتها إلا بدليل صحيح ·

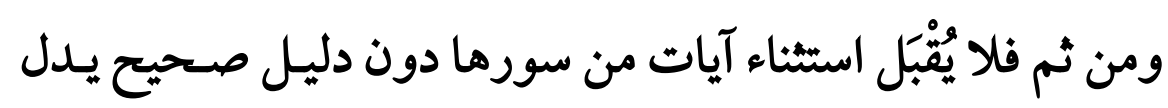
على ذلك الاستثناء ، لأن الاستثناء خحلاف الأصل ، ولما كان وجـود آيات مدنية في سورة مكية أو آيات مكية في سورة مدنية خلاف الأصل فالمختار عدم قبول القول به إلا إذا ثبت برواية صحيحة السند صريحة المتن سالمة من المعارضة والاحتمال .

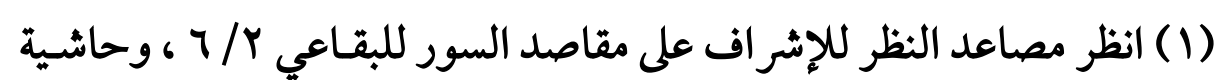

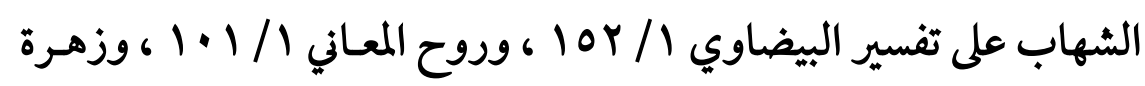

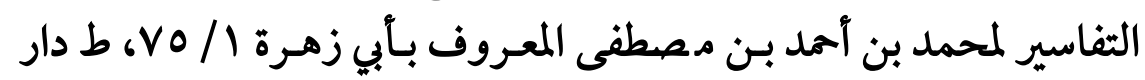

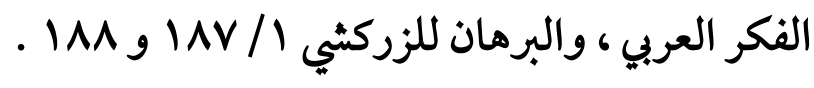


$(T r v)$

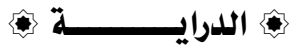

الثصل الثالث

سورة آل عمران النقان

لأن سورة آل عمران لمُ يُستَّْنْ من آياتها شيء فسأدرسها مـن خهلال

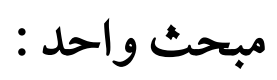

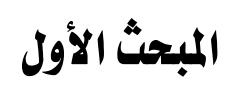

نزول سورة آل عمران

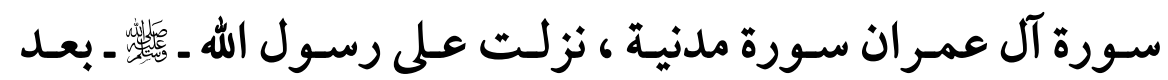

$$
\text { المجرةة(1). }
$$

والروايات التسع التي ذكرتها في مبحـث "الروايـات التي عددت

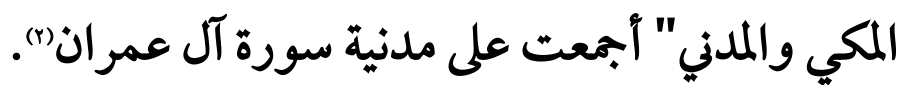

ويمكن أن نستدل على مدنية سورة آل عمر ان بأربعة أدلة :

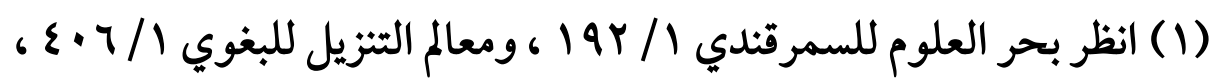

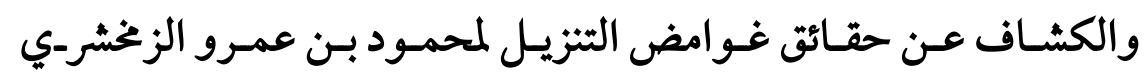

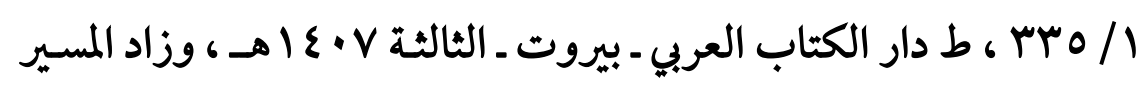

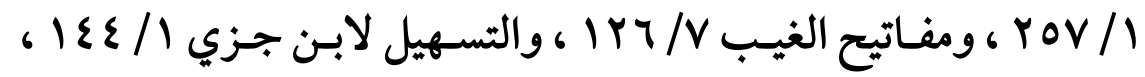

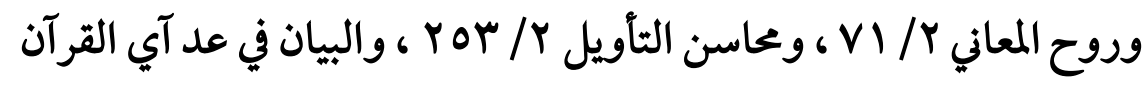

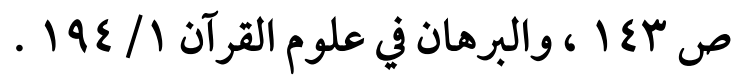

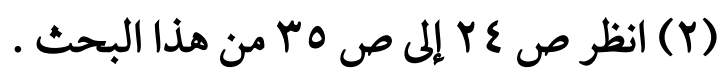




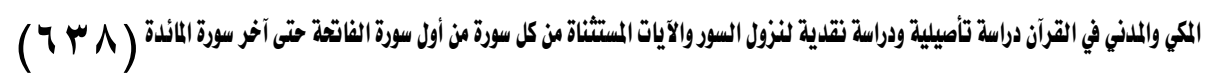
اللدليل الأول : ـ ما صح من أسباب نزول كثير مـن آيـات سورة آل

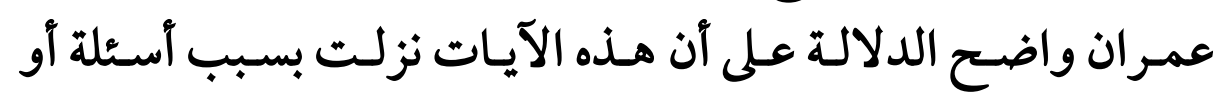

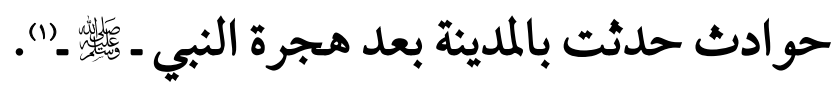

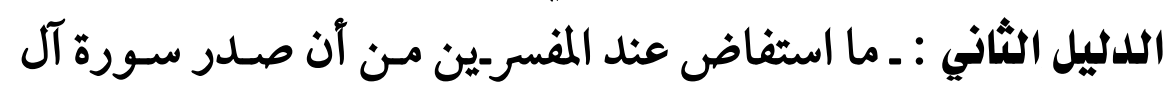

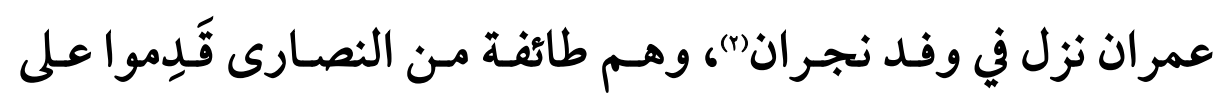

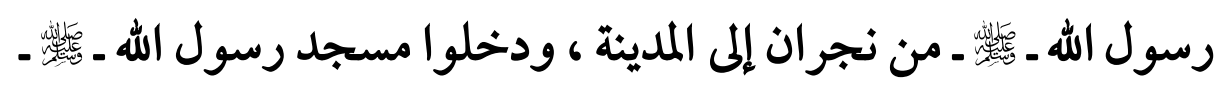

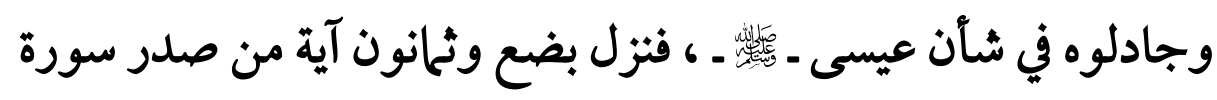

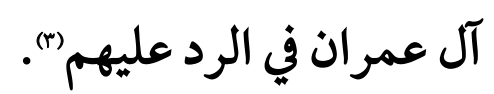

(1) انظر أسباب نزول كثير مـن آيـات سـورة آل عمـران في أسباب النزول

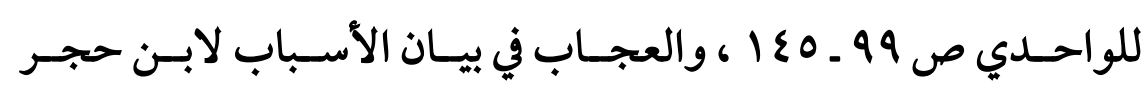

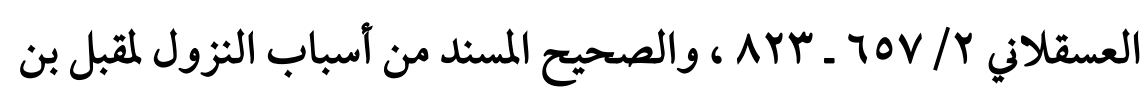

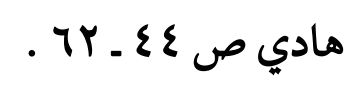

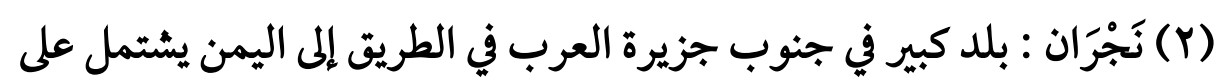

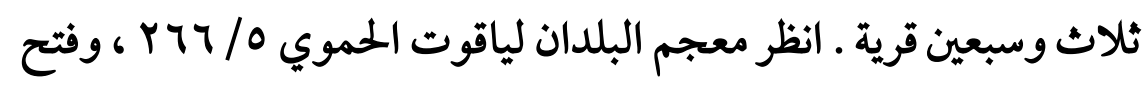

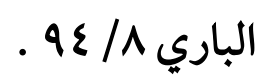

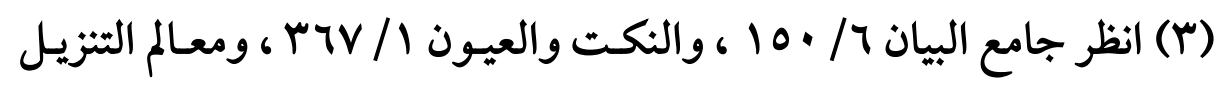

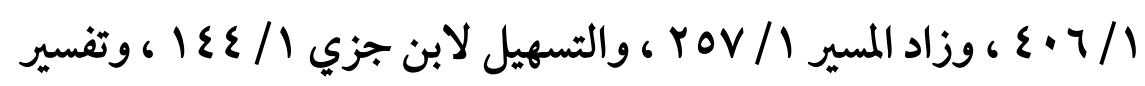

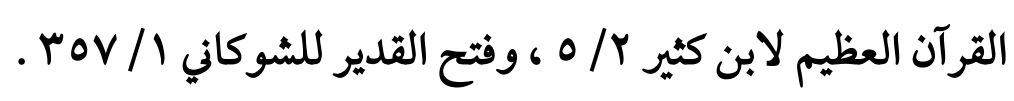




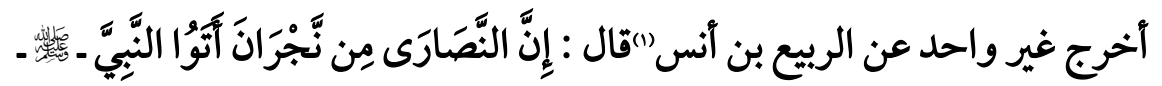

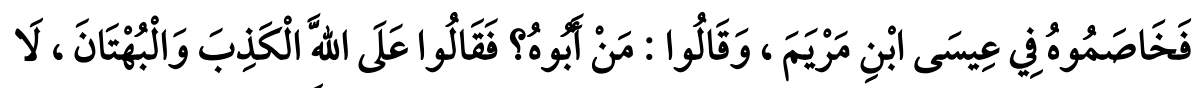

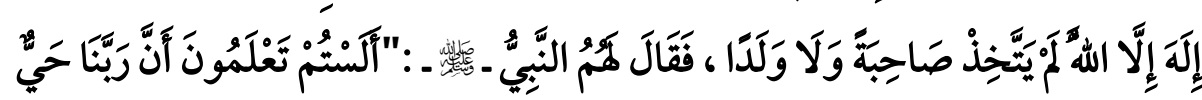

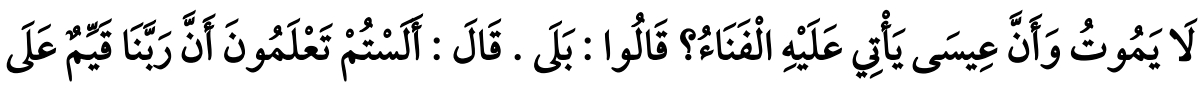

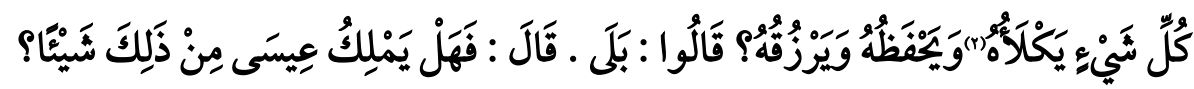

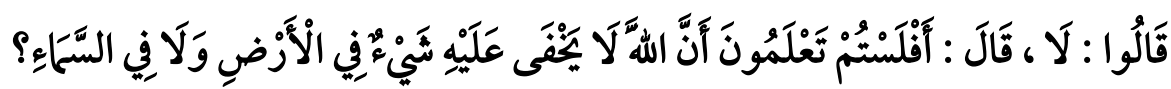

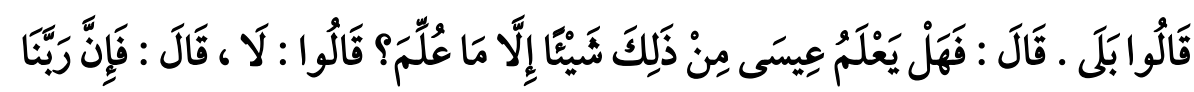

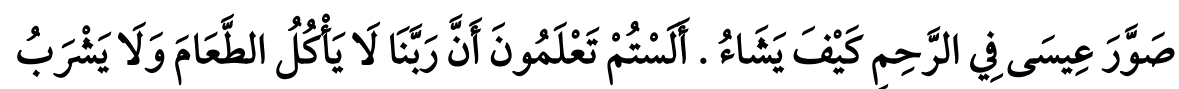

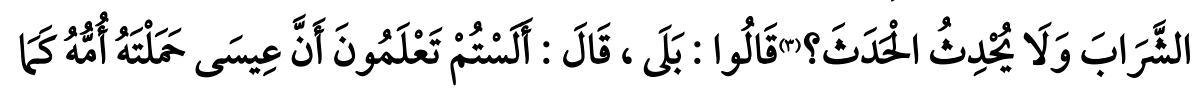

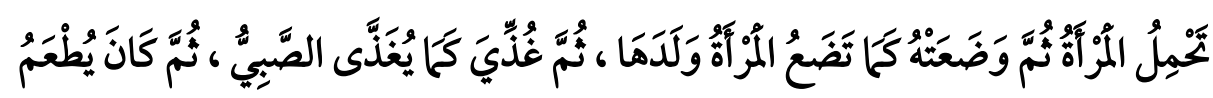

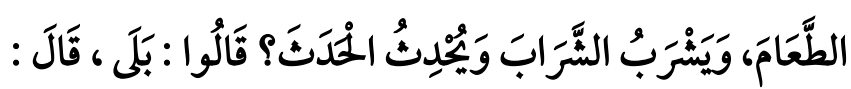

(1) هو الربيع بن أنس بن زياد البكري الخراساني المروزي ، أخذ العلم عن أنس

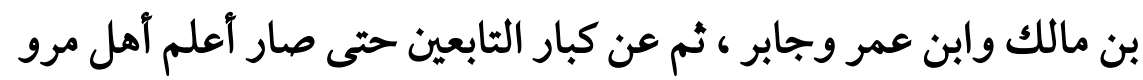

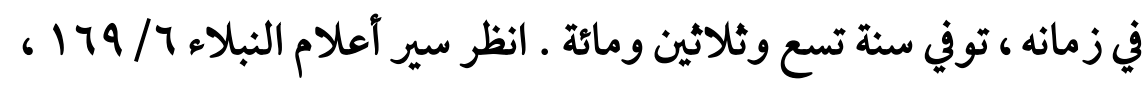

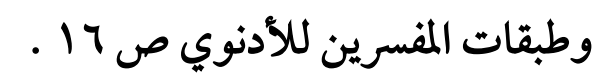

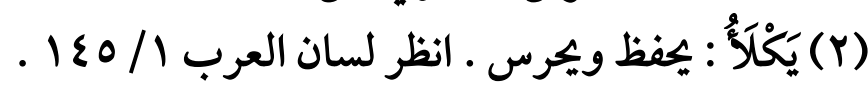

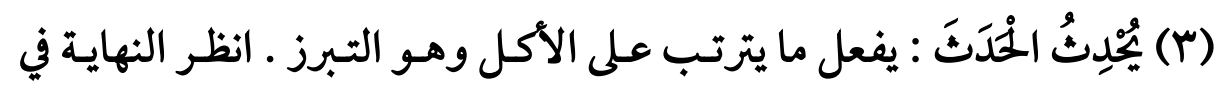

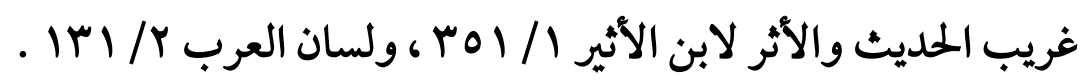




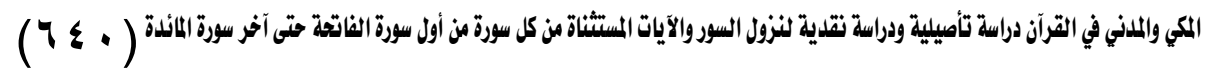

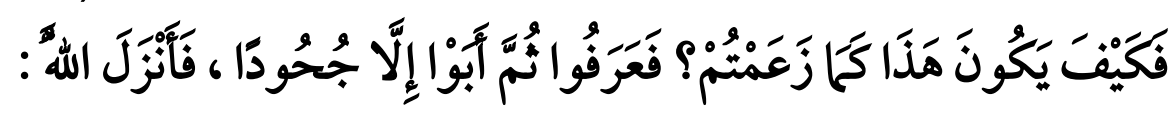

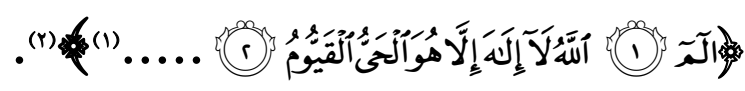

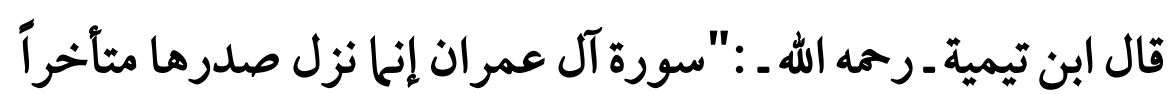
لما قدم وفد نجران بالنقل المتفيض المتواتر تهب":اهـ

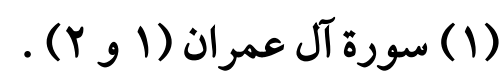

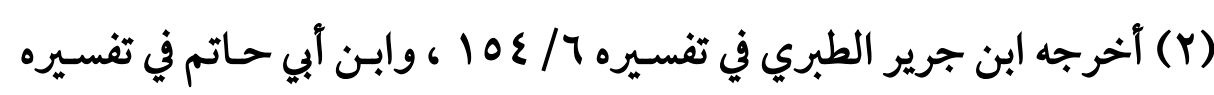

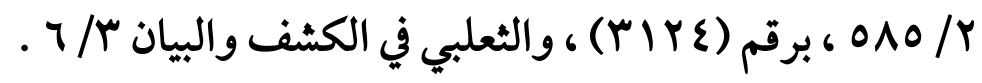

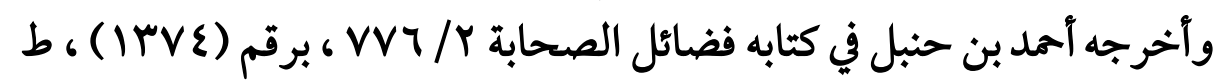

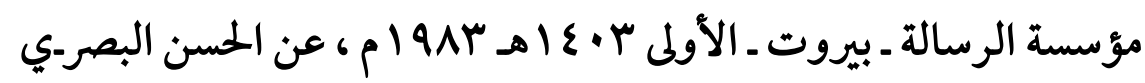
مرسلاً.

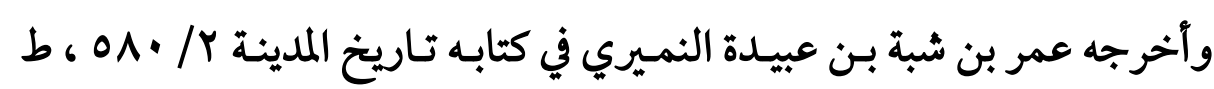

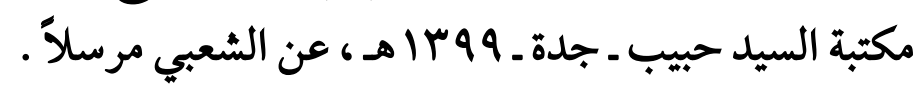

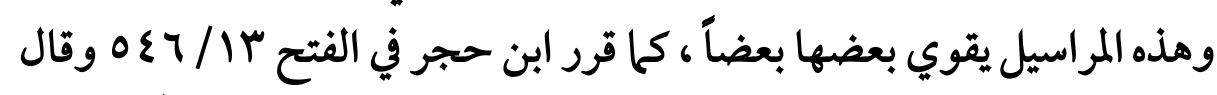

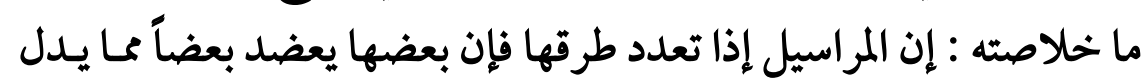
على آن للحديث أصلاً.

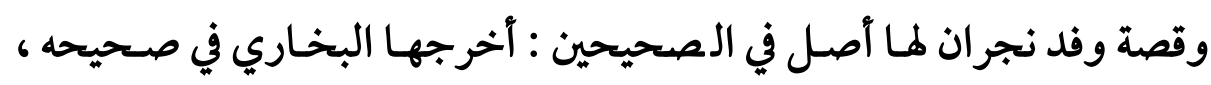

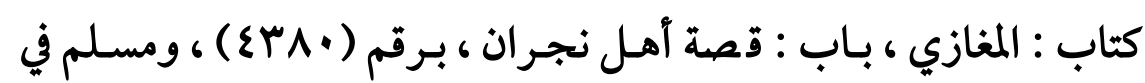

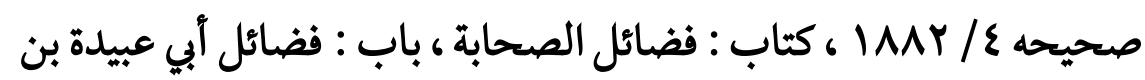

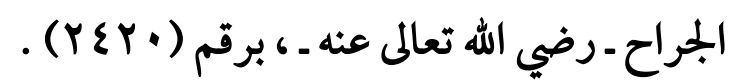

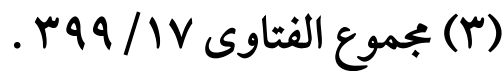


(T\&1)

الدليل الثالث : إجماع العلماء على آن سورة آل عمران مدنية نزلت

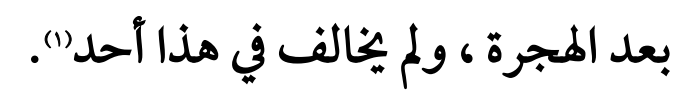

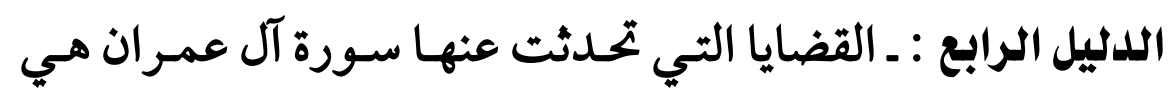

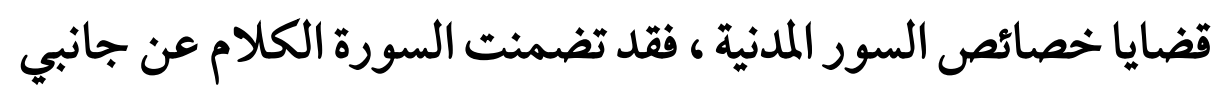

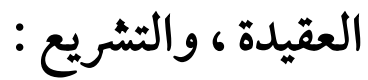

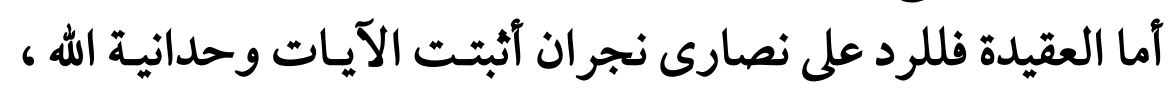

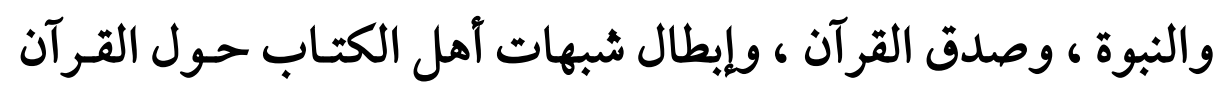

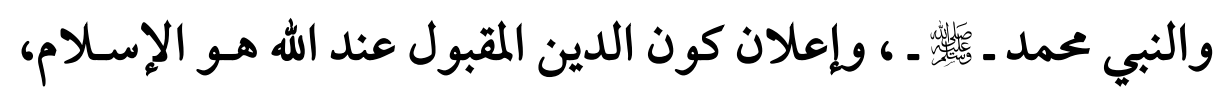

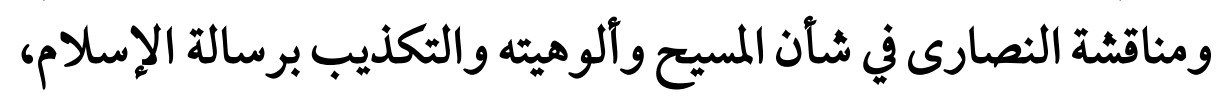
واستغرقت المناقشة قرابة نصف السورة").

(1) انظر تَقْلَ هذا الإجماع في المحرر الوجيز / / وه ، و وتفسير القرآن لعز الدين

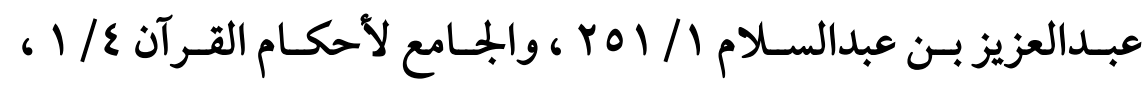

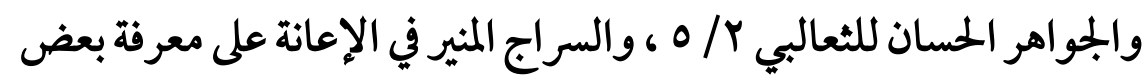

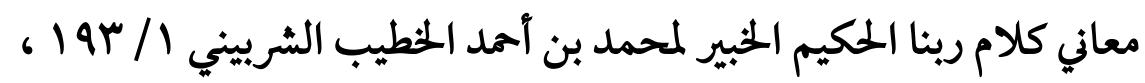

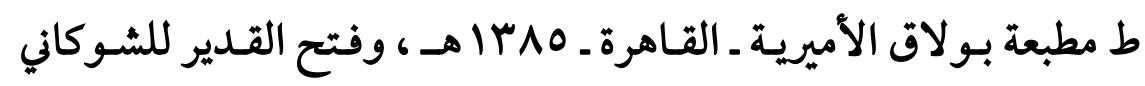

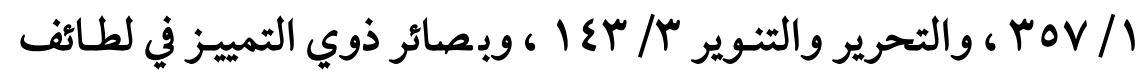

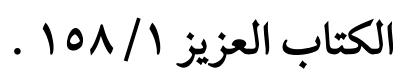

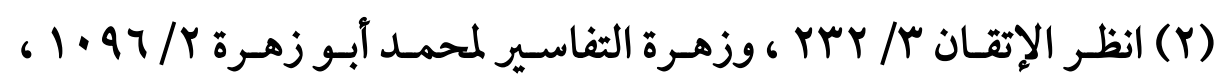

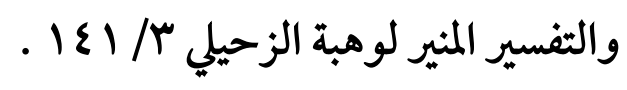




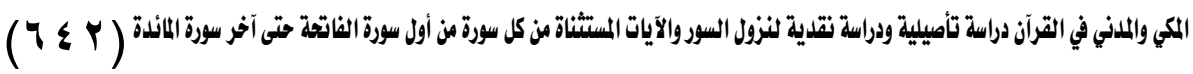
وأما التشريع فقد أبانت الآيات بعض أحكام الشر-ع مثل فرضـية

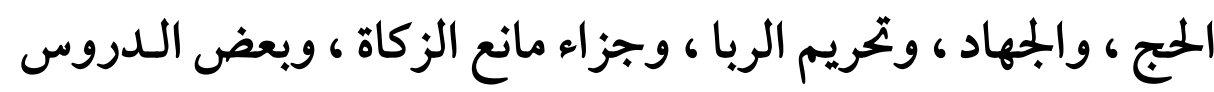

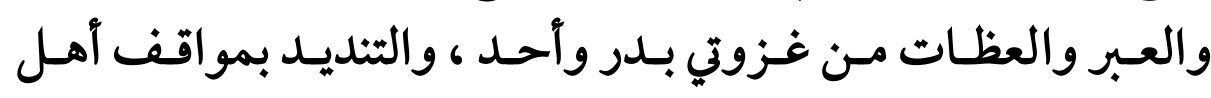

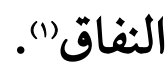

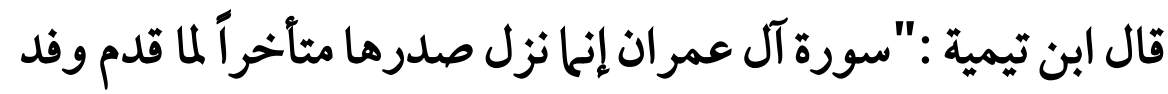

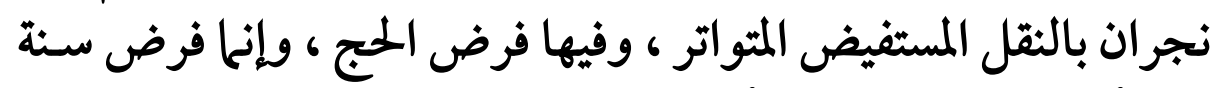

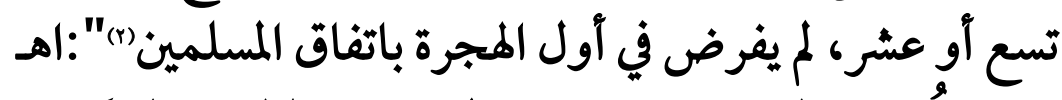

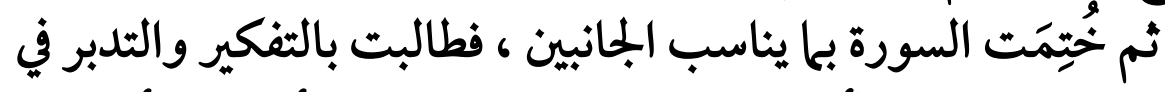

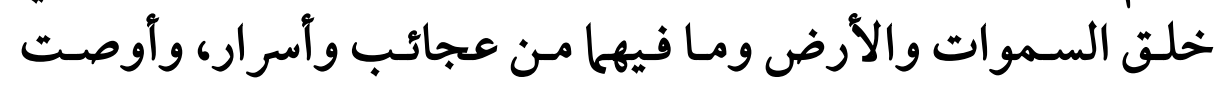

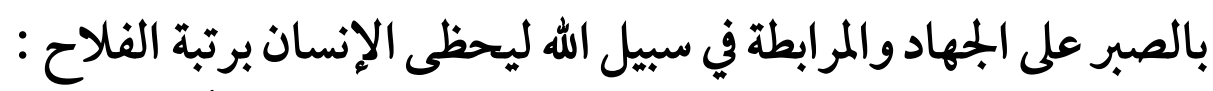

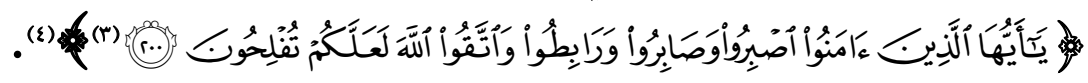

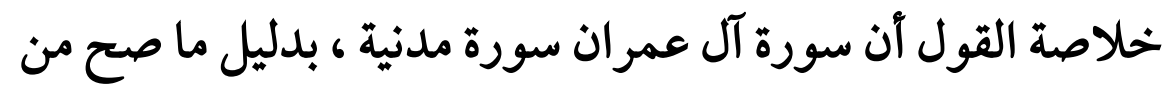

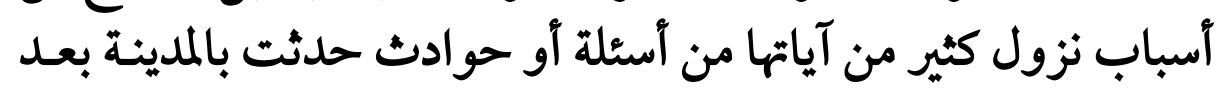

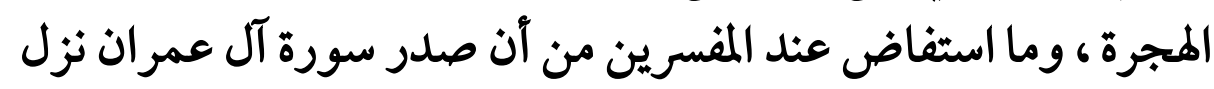

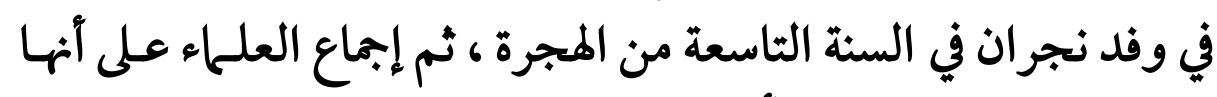
مدنية ، ولم يخالف في هذا في الحد المد ، والقضايا التي تحدثت من عنها هي قضايا خصائص السور المدنية .

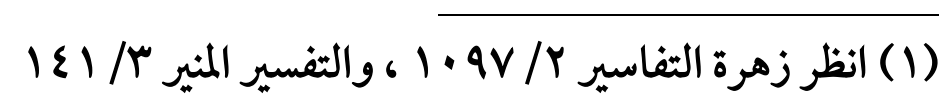

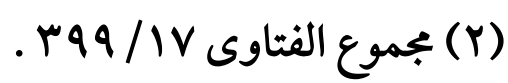

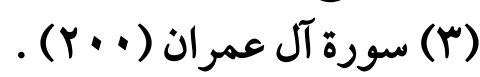

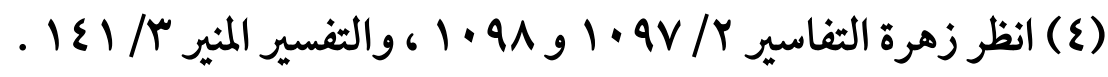




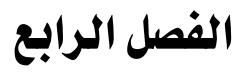

سورة النساs المعاي

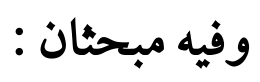

المبحث الأول

نزول سورة النساء

أبرزت كتب التفسير وعلوم القرآن آن سورة النساء فيها قورلان في

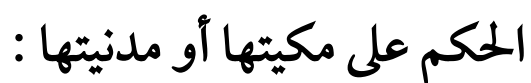

القول الأول : ـ أن سورة النساء سورة مدنية ، نزلت ملئه على رسول الله ـ

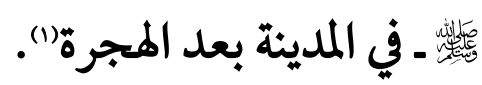

وبعض العلم|ء نسب هذا القول إلى الجمهور (r).

وبعضهم نقل الإجماع على مدنيتها (r).

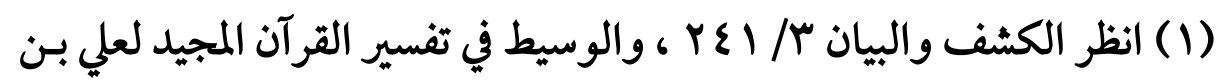

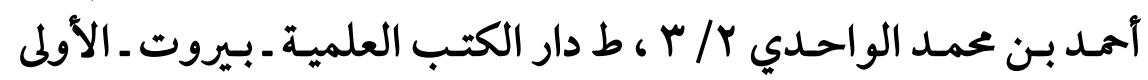

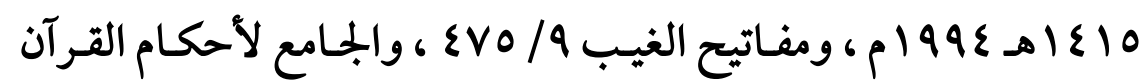

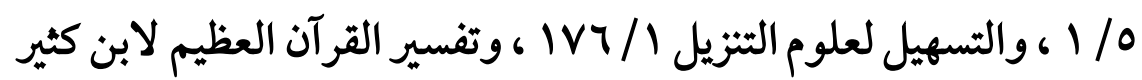

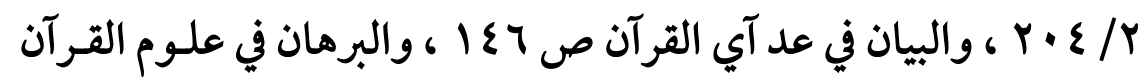

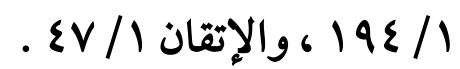

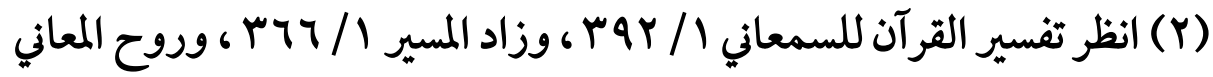

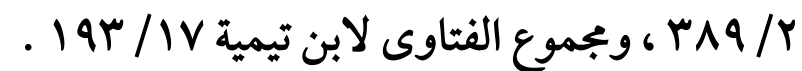

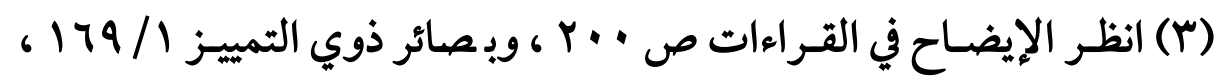

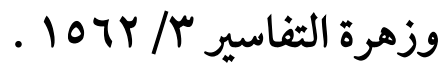




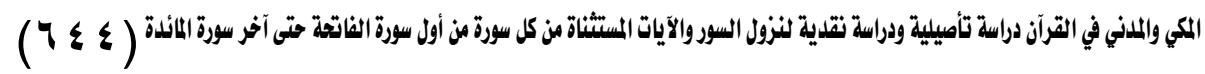
والروايات التسع التي ذكرتها في مبحـث "الروايـات التي عـددت

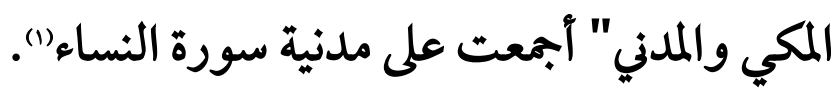
ويدل على مدنية سورة النساء ثلاثة أدلة :

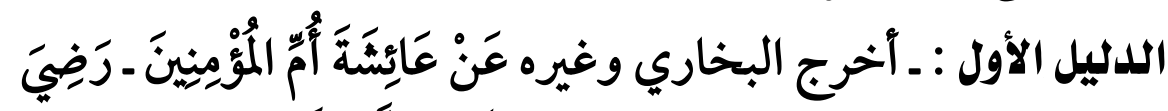

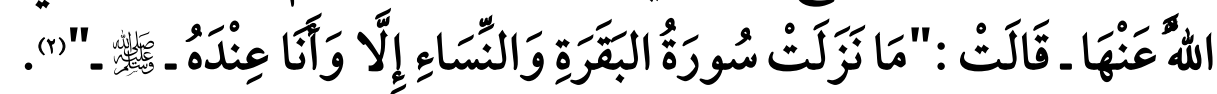

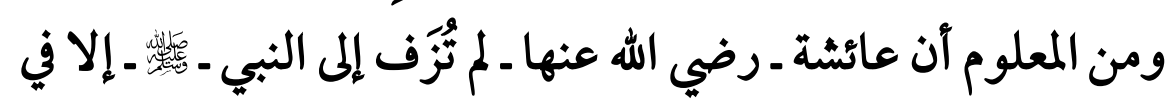

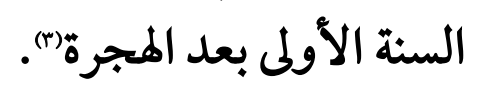
قال ابن حجر في الفتح :"أشارت بقولما : "وأنا عنده" أي : بالمدينة ، لأن دخولما عليه إنها كان بعد المجرة اتفاقاً ()": :اهـ

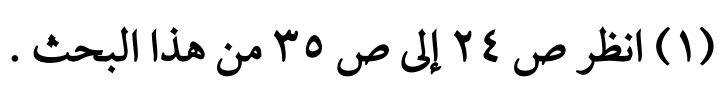

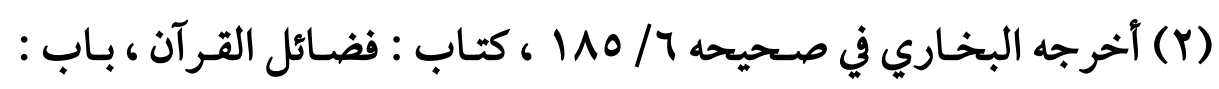

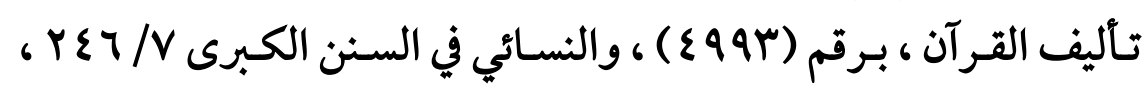

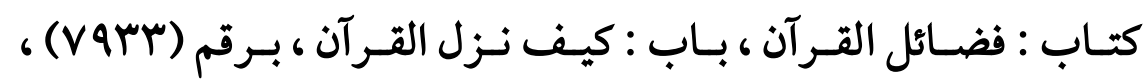

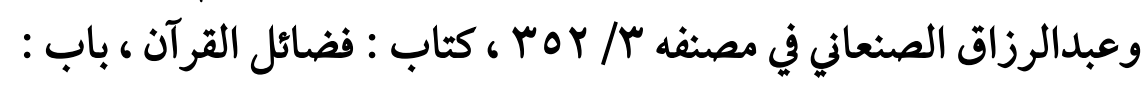

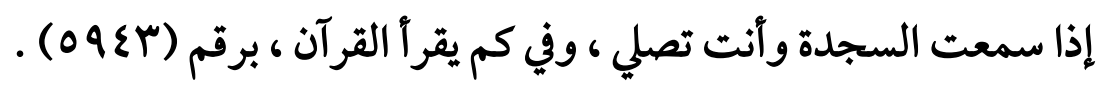

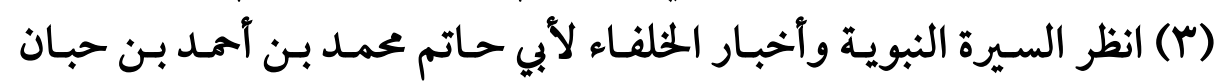

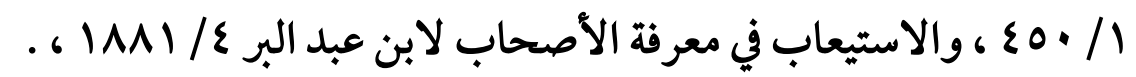

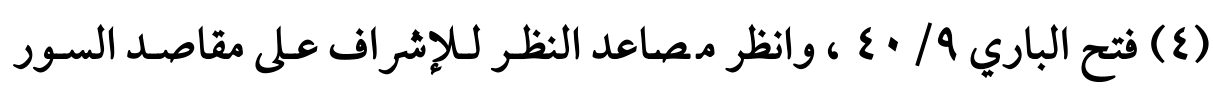

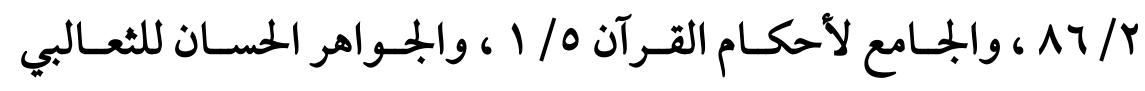


$(7 \leq 0)$

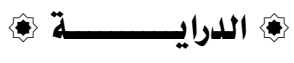

اللدليل الثاني : ـ ما صـح مـن أسباب نزول كثير مـن آيـات سـورة

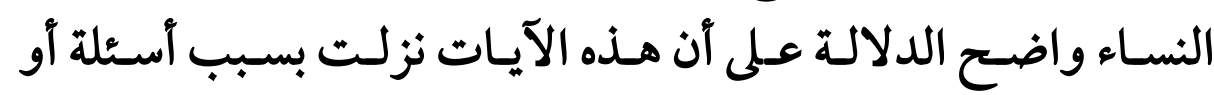

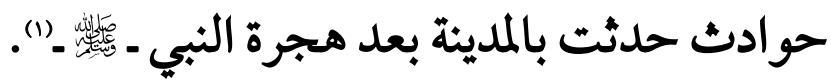

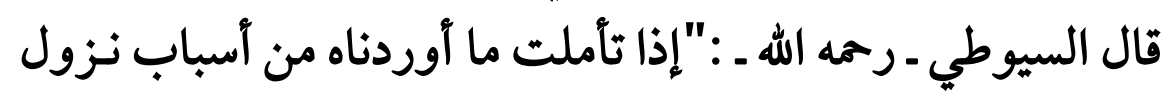
آيات هذه السورة ـ يعني سورة النساء ـ عرفت الرد على مـن قال بأنها

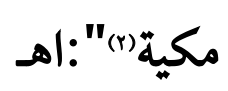

اللدليل الثالث : ـ القضايا التي تحدثت عنها سورة النساء هي قضـايا

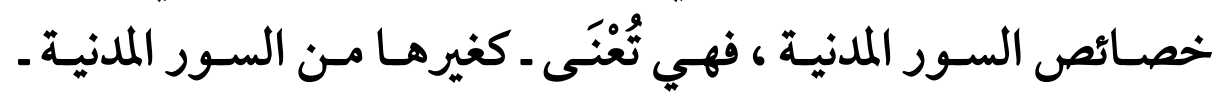

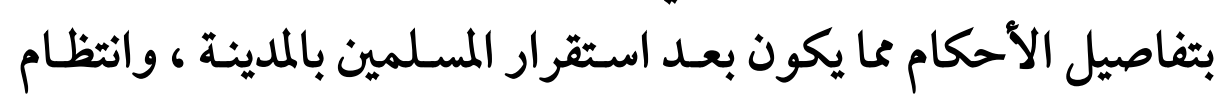

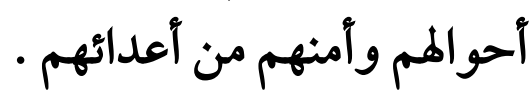

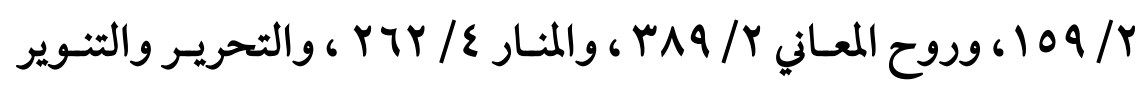

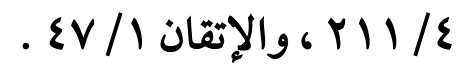

(1) انظر أسباب نزول كثير من آيات سورة النساء في أسباب النزول للواحدي

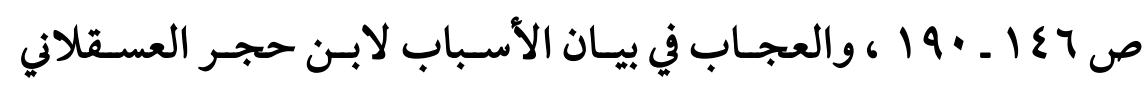

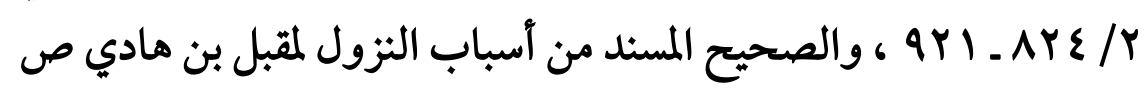
.

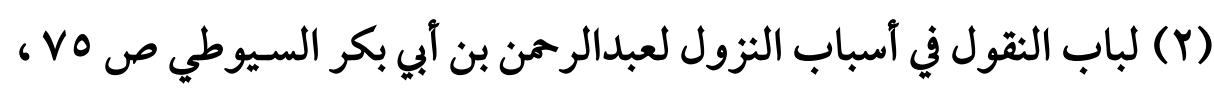

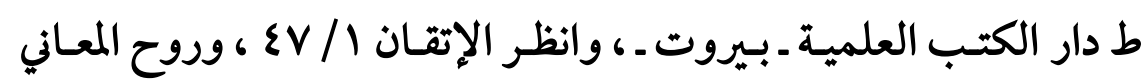
.r^q/r 


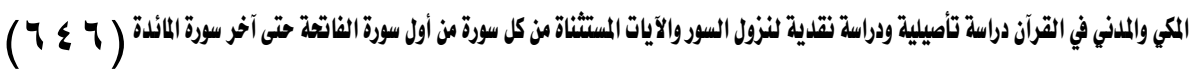
فافتحت ـ بعد الأمر بالتقوى ـ بأحكام اليتامى والبيوت ، و والأموال

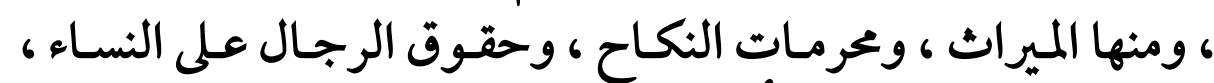

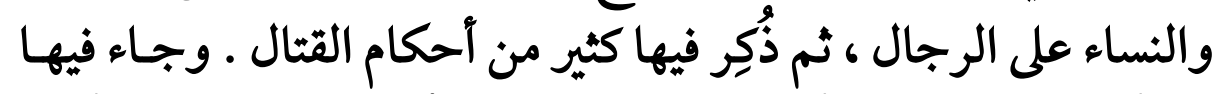

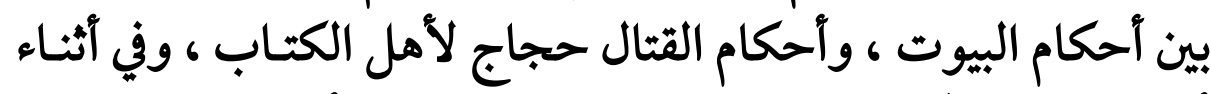

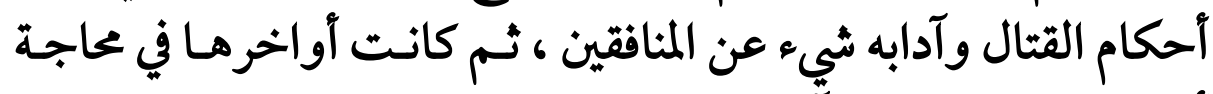

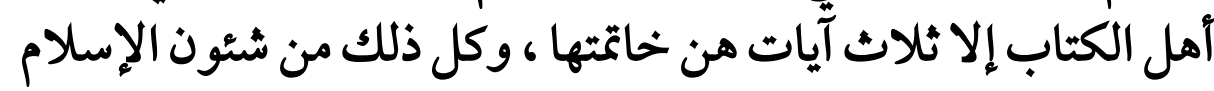
بعد المجرةة).

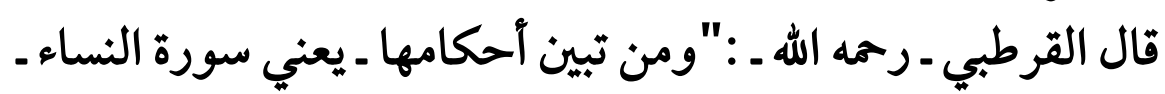

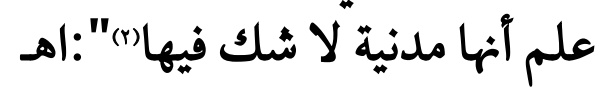

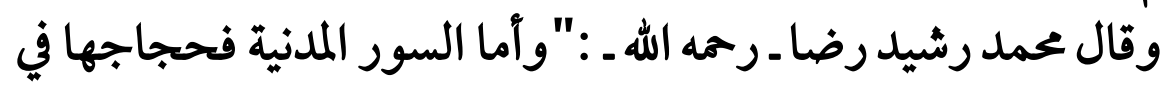

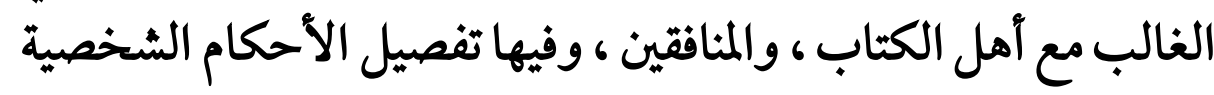

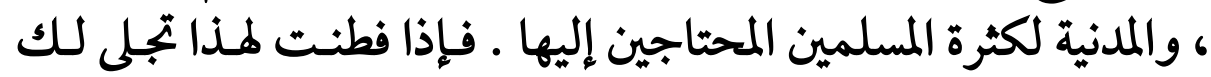

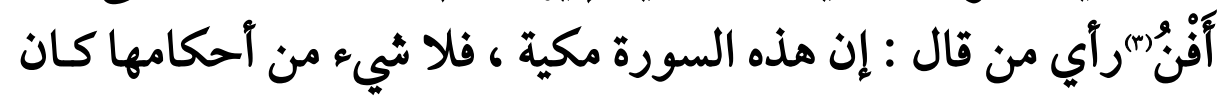

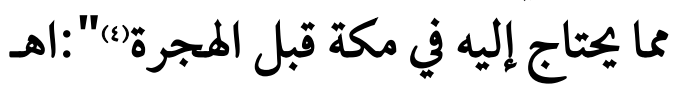

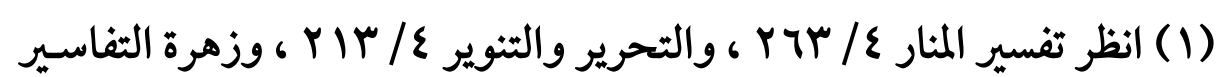

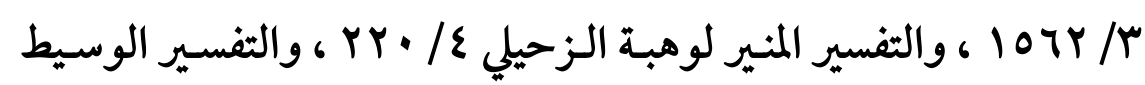
للطنطاوي

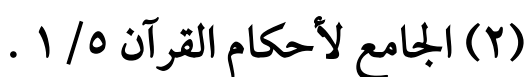

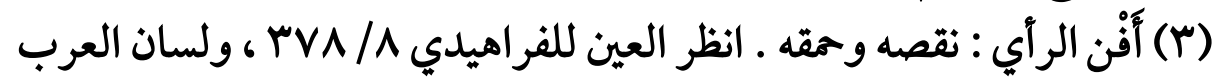

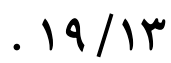

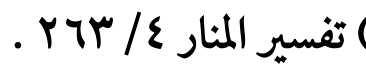


$(T \leq V)$

القول الثاني : ـ مـا ذهـب إليه النحـاس ـ رحمـه الله ـ في كتابـه معـاني

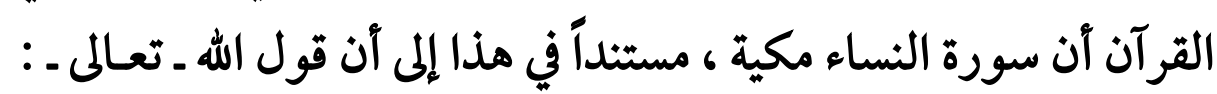

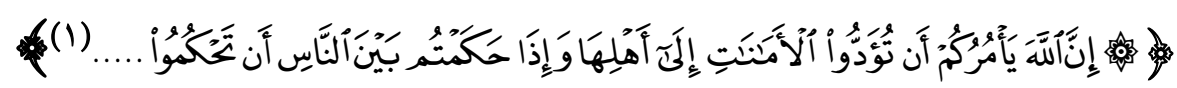

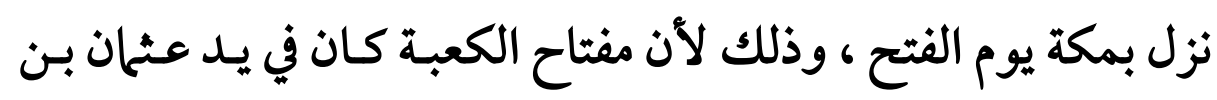

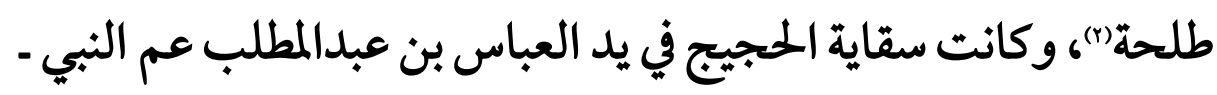

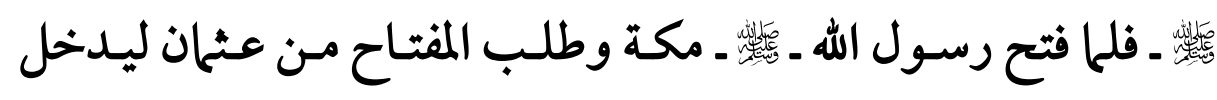

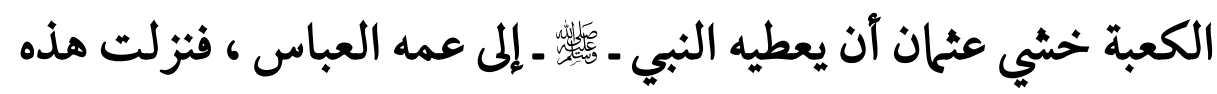

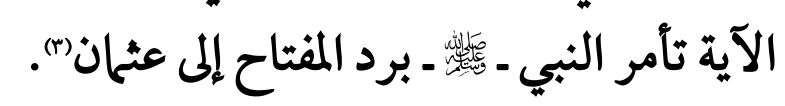

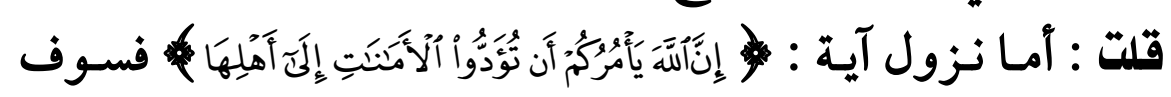
أناقشه في مبحث "الآيتان المستثناتان من سورة النساء" ـ إن شاء الله ـ

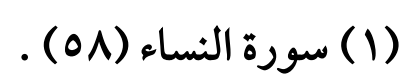

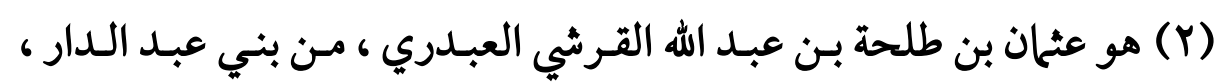

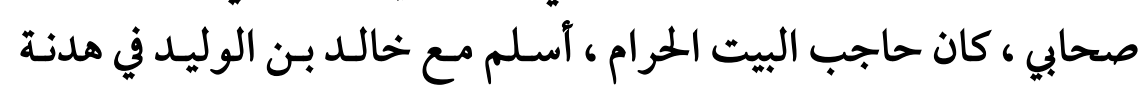

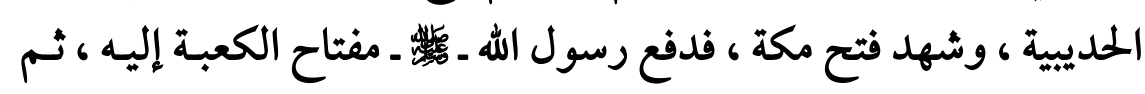

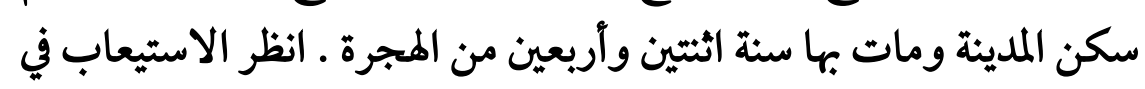

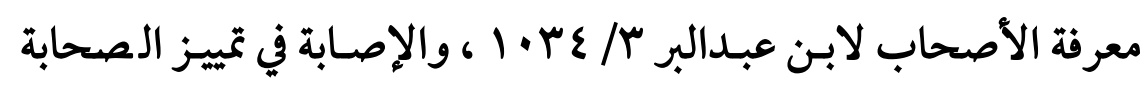

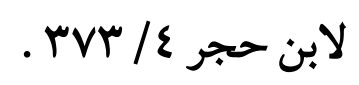

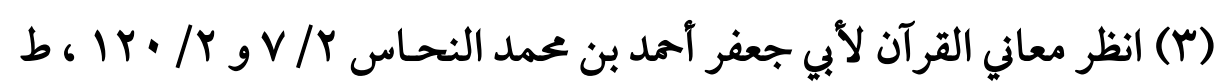

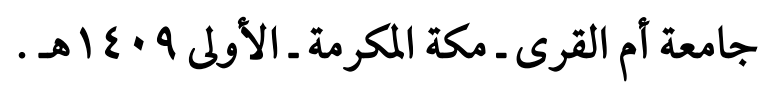




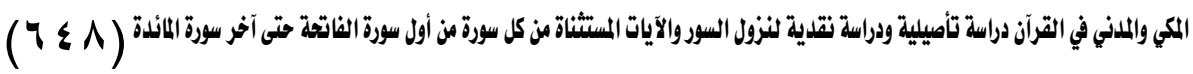

لكن العلماء قد عَلَت أصواتهم في الرد على النحاس في دعـواه مكيـة سورة النساء ، وكان ردهم عليه من وجهين :

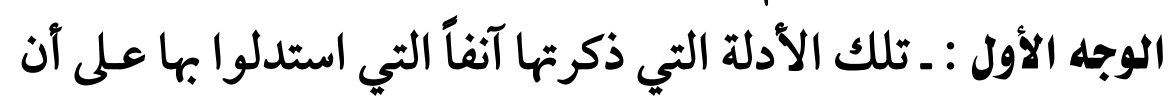
سورة النساء مدنية.

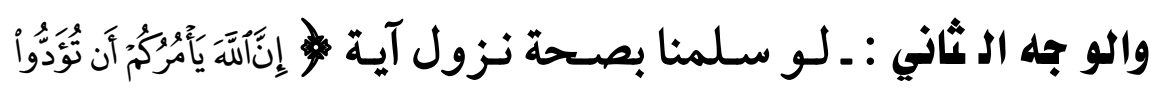

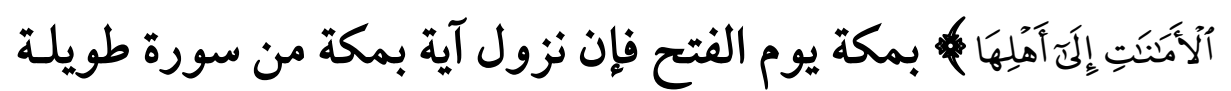

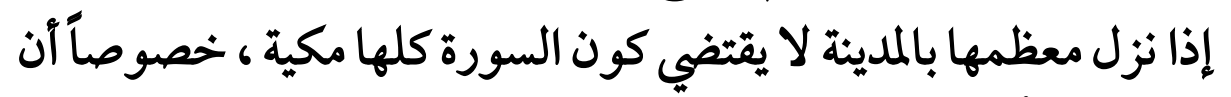

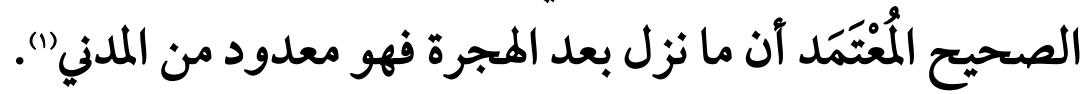

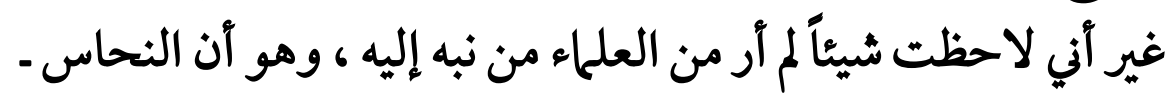

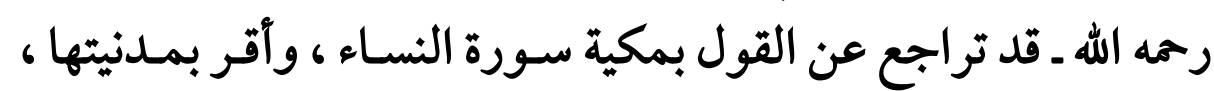

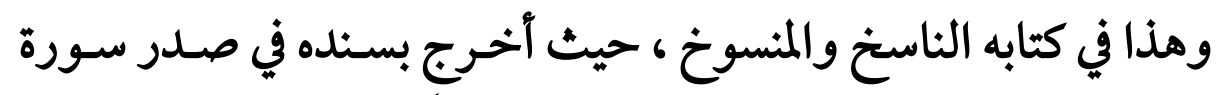

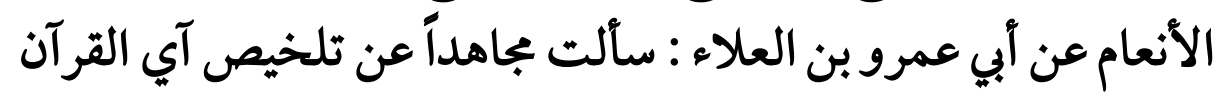

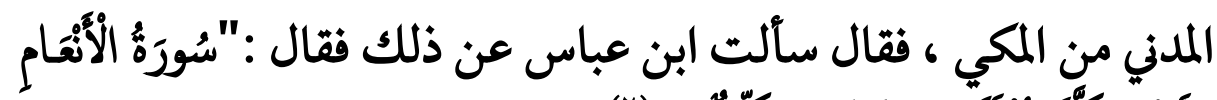

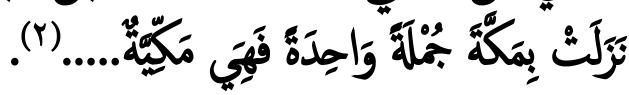

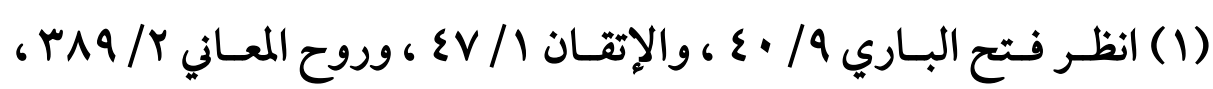

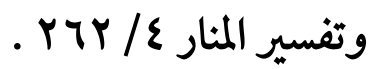

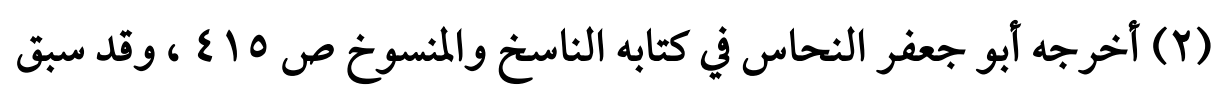
في مبحث "الروايات التي عددت المكي والمدني". 
$(7 \leq 9)$

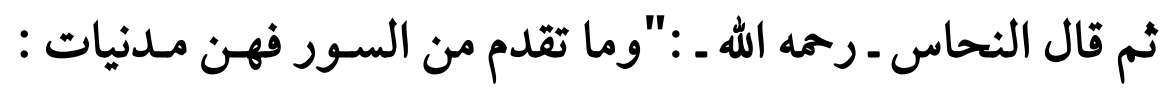

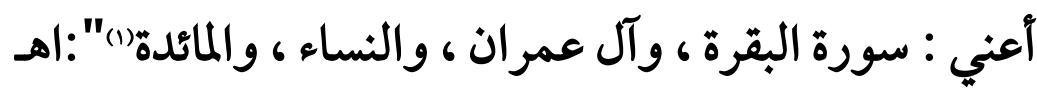
وكتاب "معاني القرآن" الذي قرر فيه النحاس مكية سورة النداء النساء

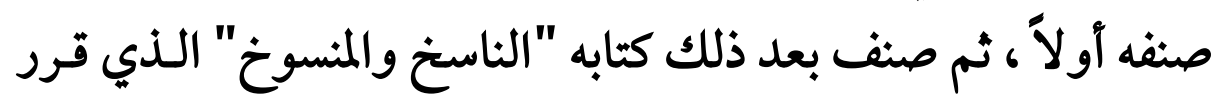

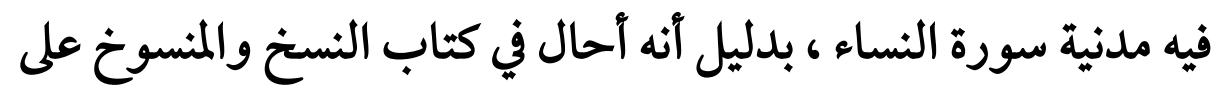
أشياء كان قد ذكرها في كتاب معاني القرآن (1).

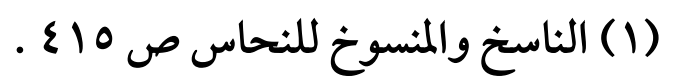

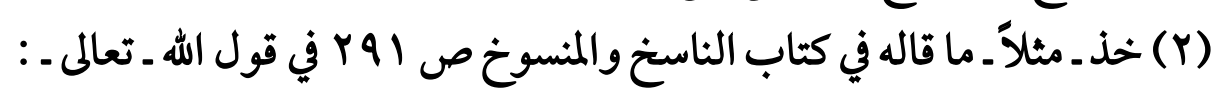

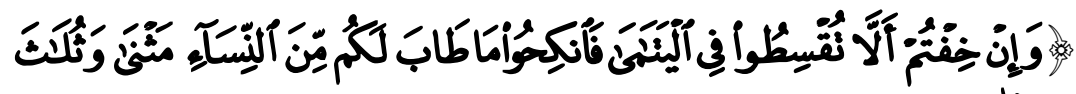

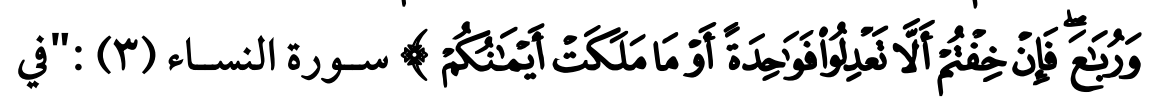

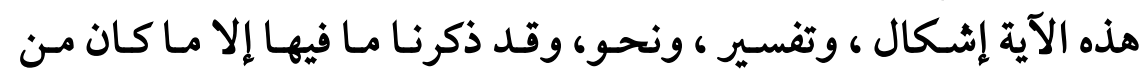

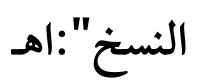
وما فيها من إشكال ، وتفسير ، ونحو قد ذكره في كتابه معاني القرآن r/ • 1 ـ .17

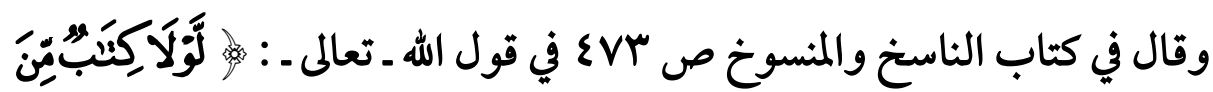

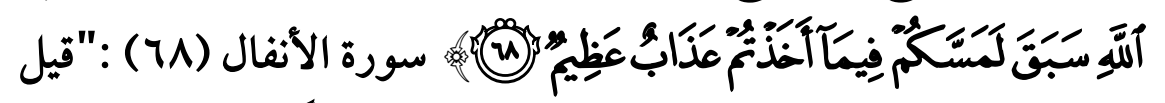

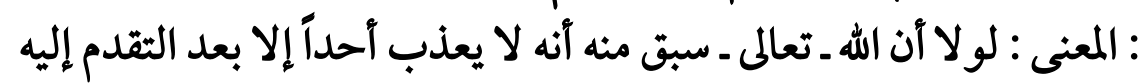

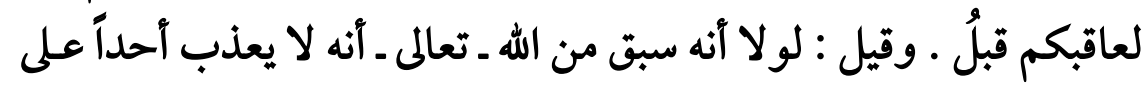

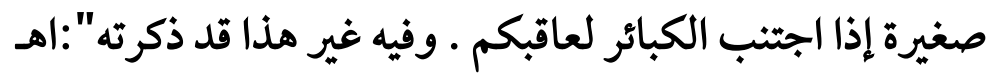




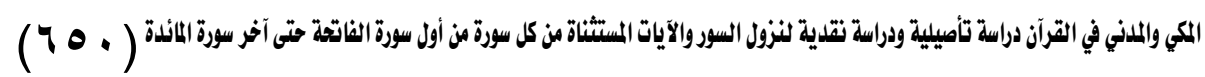

خلاصة القول أن سورة النساء سورة مدنية ، بـدليل قول عائشة ـ

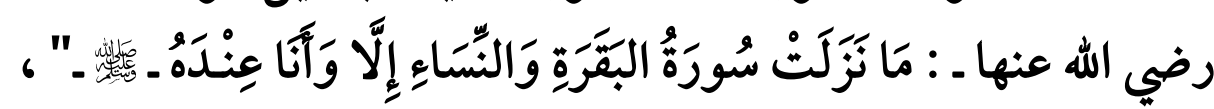

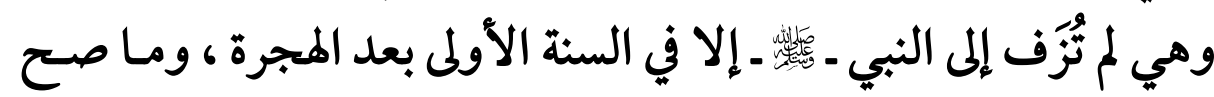

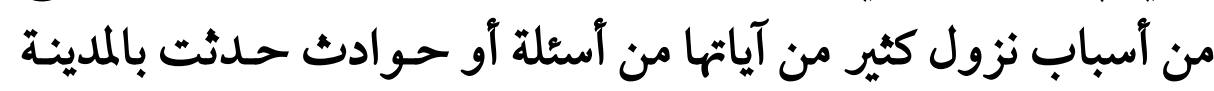

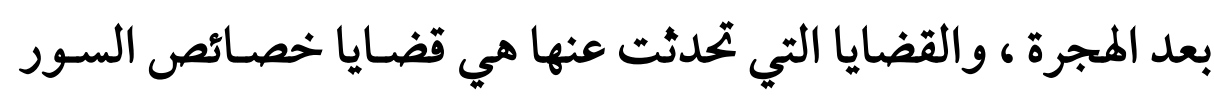

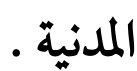

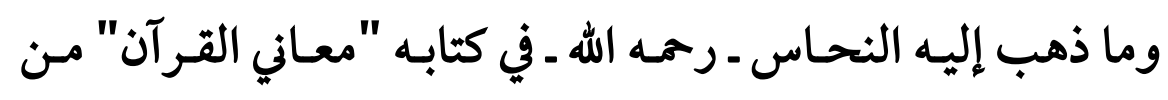

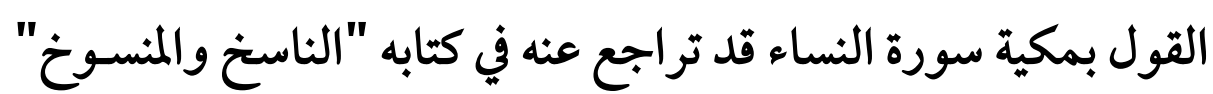

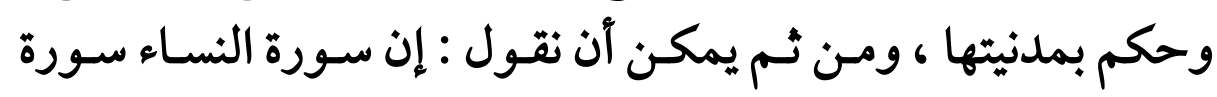

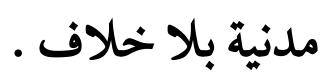

وغير هذا من الأقوال في تفسير الآية ذكرها النحاس رممه الله ـ في كتابه معاني

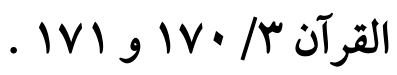


$(701)$

\section{المبحث الثاني}

\section{الآيتان المستثناتان من سورة النساء}

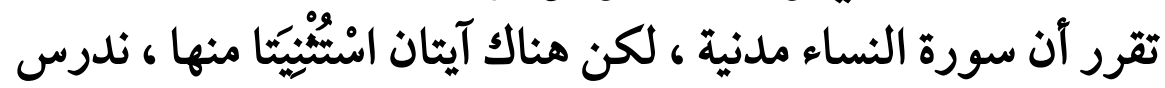

$$
\text { كل آية منها في مطلب مستقل : }
$$

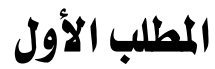

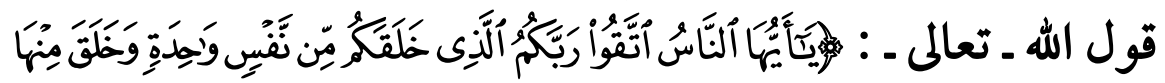

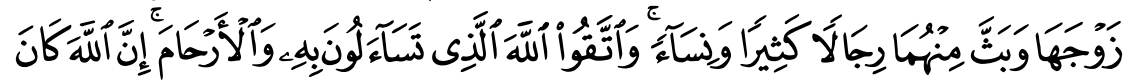

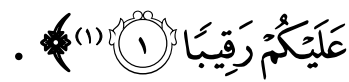

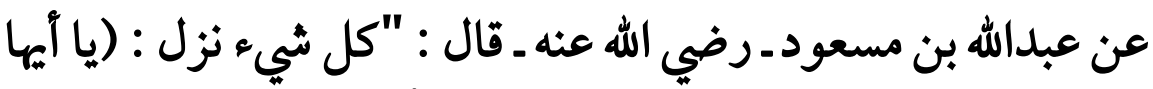

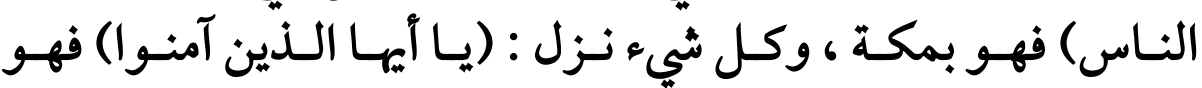

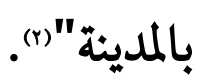

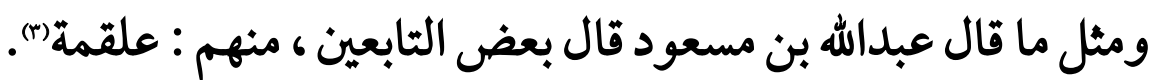

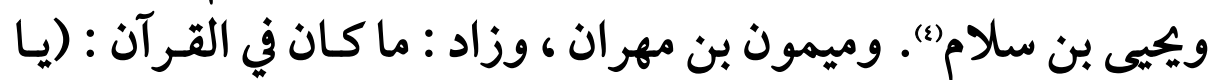

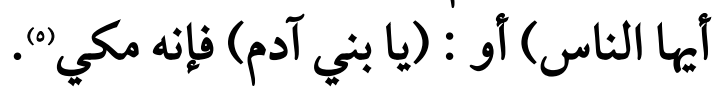

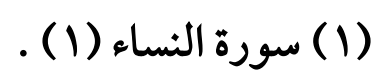

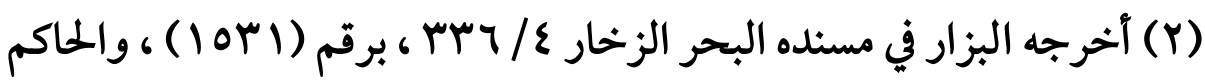

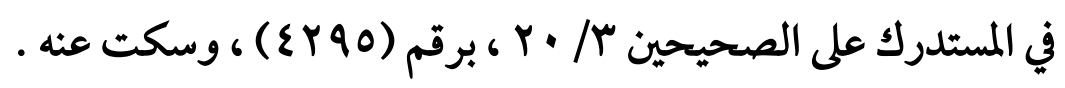

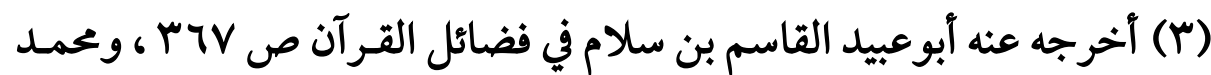

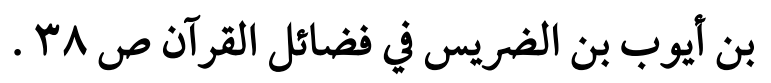

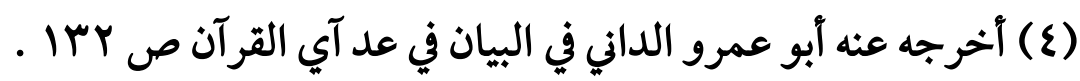

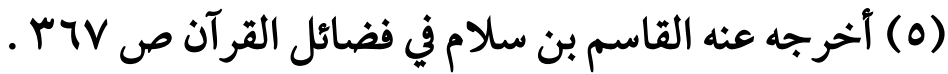




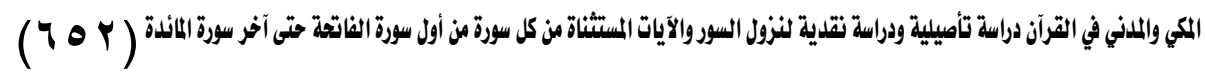

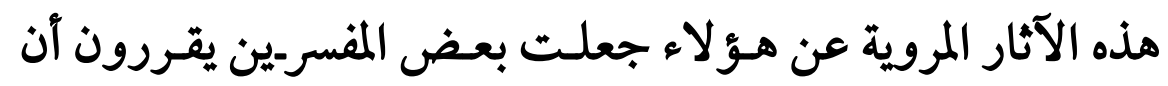

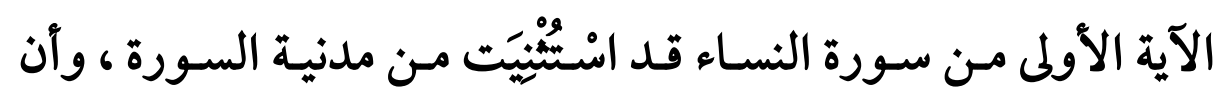
عبدالله بن مسعود ومن قال مثل قوله من التابعين يذهبون إلى آن الآيـة مكية)

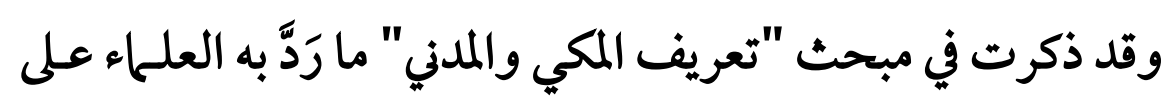
هذا القول ، وأزيد هنا من وجوه الرد المتعلقة بهذا الموضع آربعة وجوه :

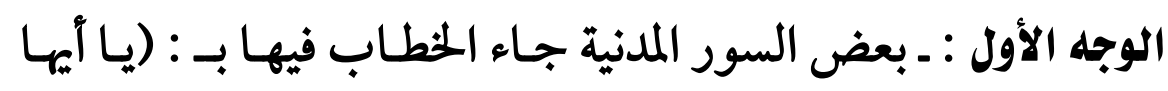

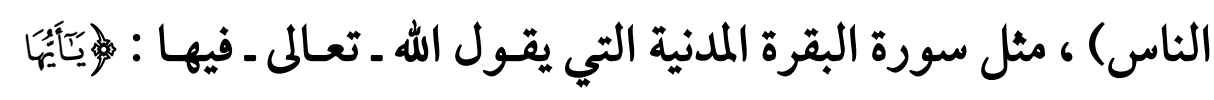

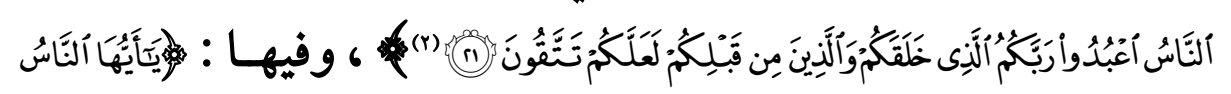

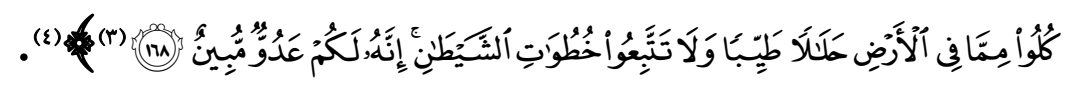

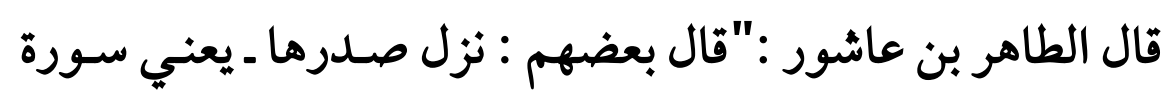

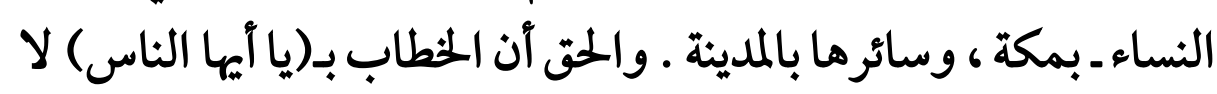

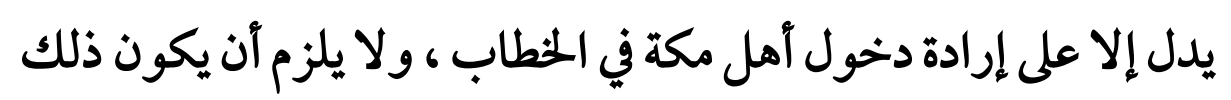

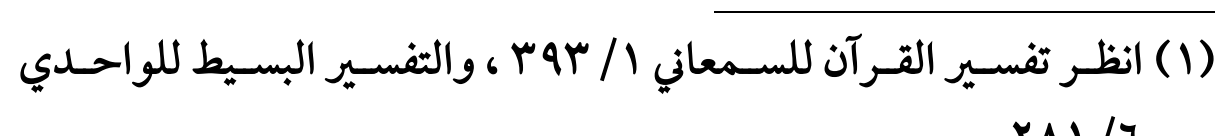

$$
\begin{aligned}
& \text {. r^I/7 }
\end{aligned}
$$

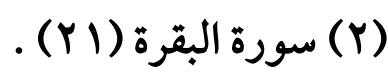

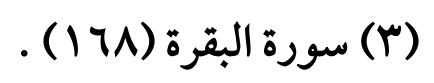

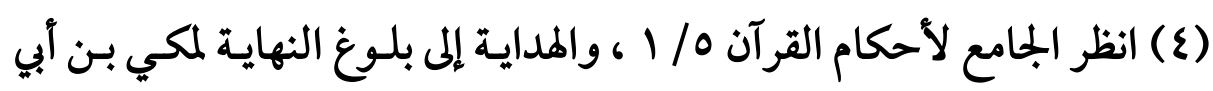

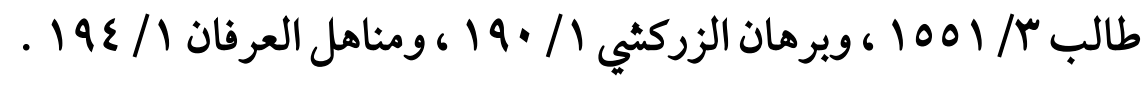


بمكـة ، ولا قبـل المجـرة ، فبإن كثيراً مـا فيـه : (يـا أيها النـاس) مـدني

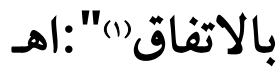

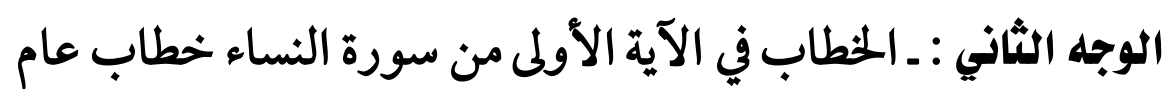

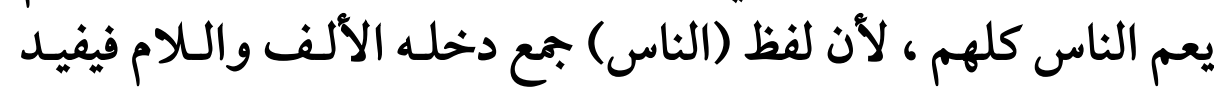

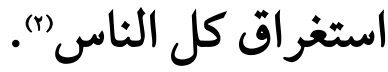
الوجه الثالث : ـ علل الله ـ تعالى ـ الأمر بالاتقاء بكونه ـ تعالى ـ خالقاً

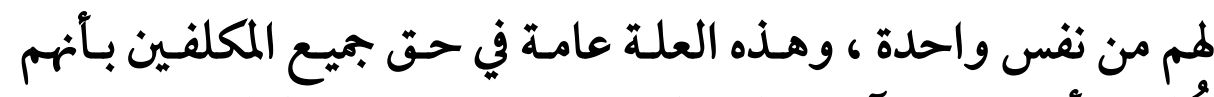

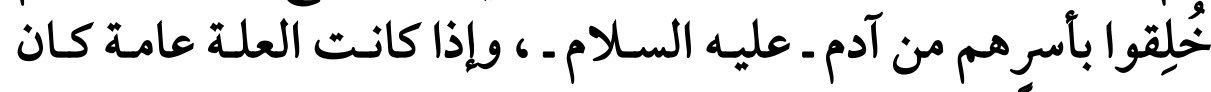

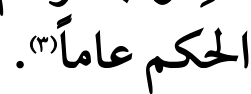
الوجه الرابع : ـ التكليف بالتقوى غير مختص بأهل مكة ، بل هو عام

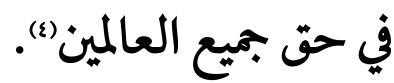
وإذا كان لفظ (الناس) عاماً في الكل ، وكان المان الأمر بالتقوى عامـاً في

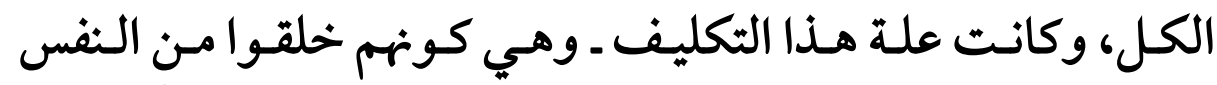

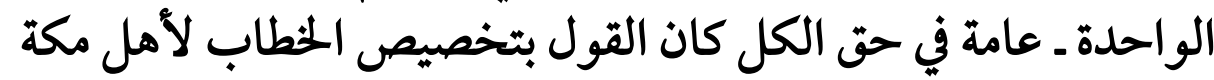

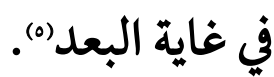
خلاصة القول أن الآية الأولى من سورة النساء مدنية كسورتها ، ولا يصح استثناؤها اعتهاداً على ضابط غير مطرد في سور القرآن وآياته .

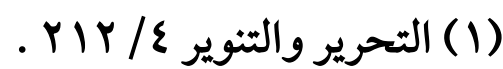

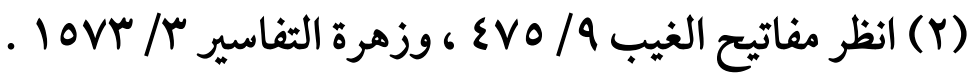

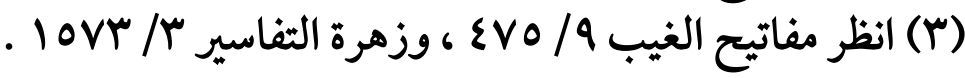

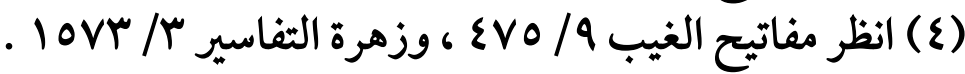

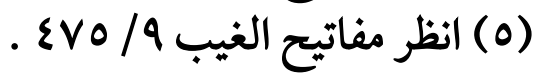




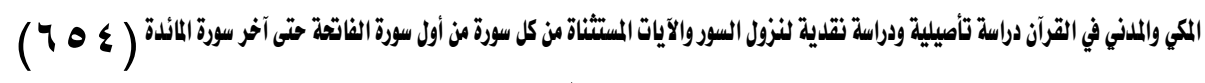
المطلب الثاني

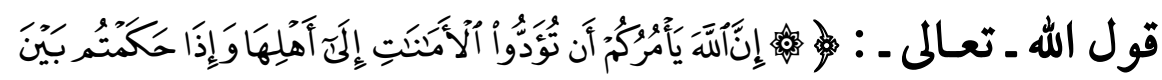

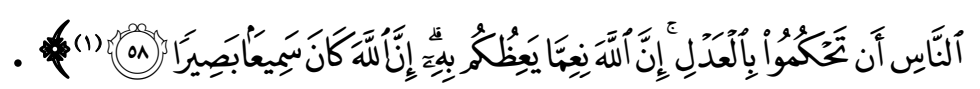

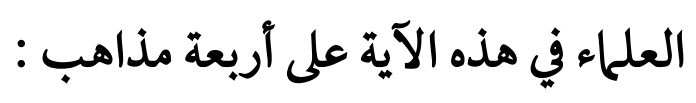

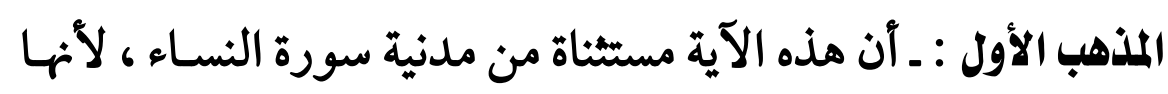

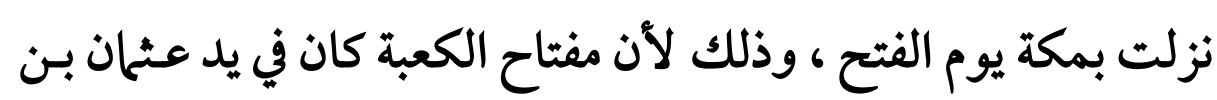

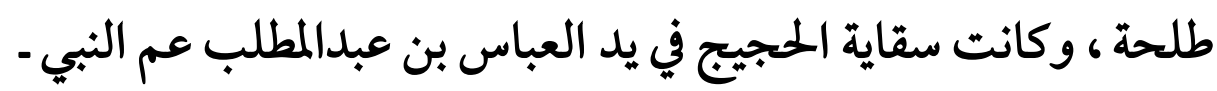

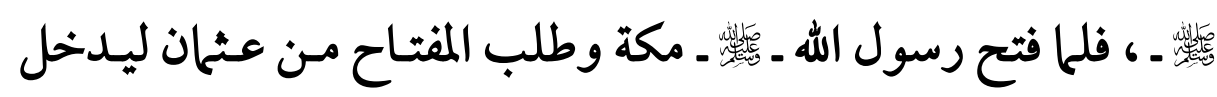
الكعبة خشي عثهان أن يعطيه إلى عمه العباس ، فنزلت هذه الآيـة تأمر

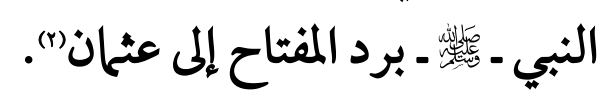

قلت : قصة نزول هذه الآية بسبب مفتـاح الكعبـة جـاءت مـن آربـع

$$
\text { روايات : }
$$

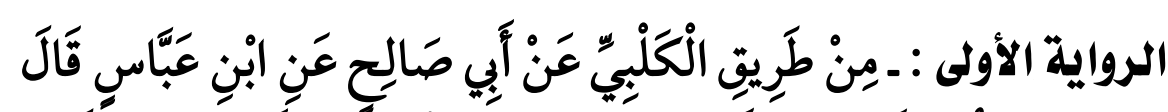

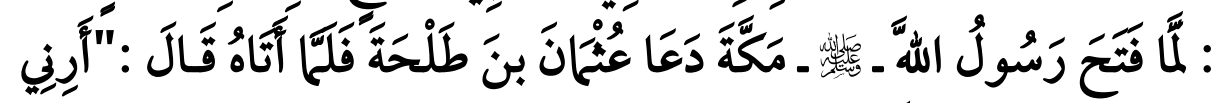

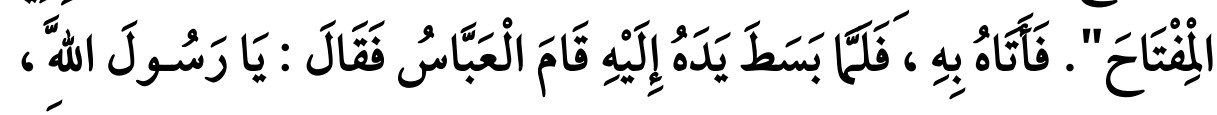

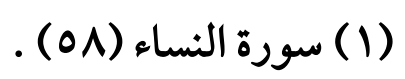

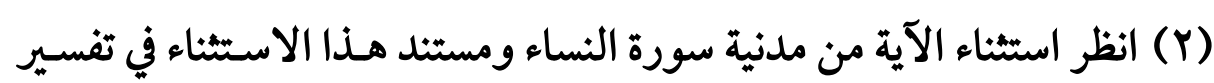

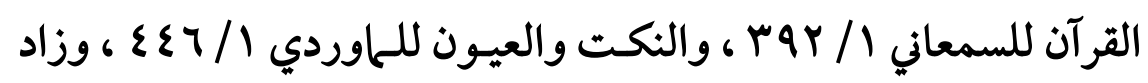

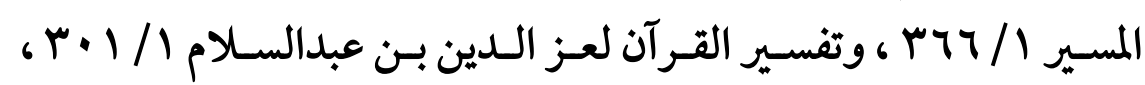

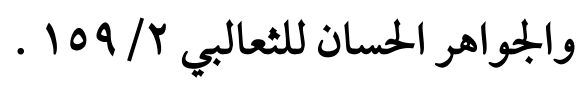




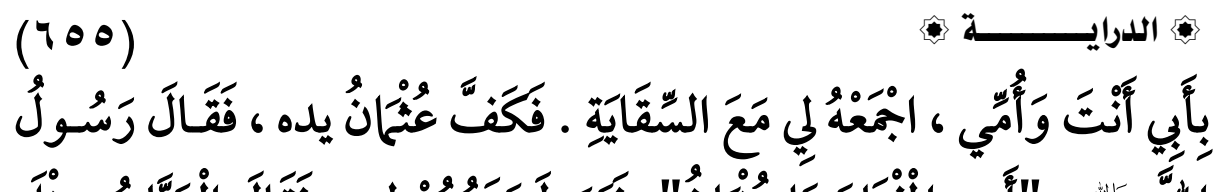

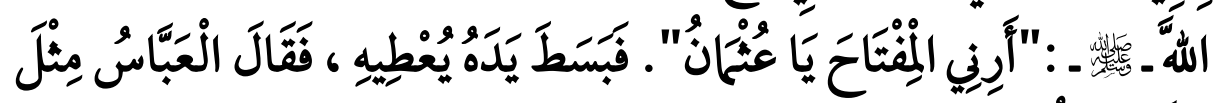

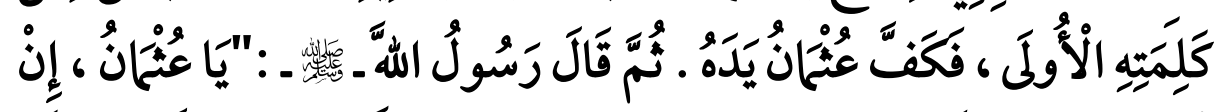

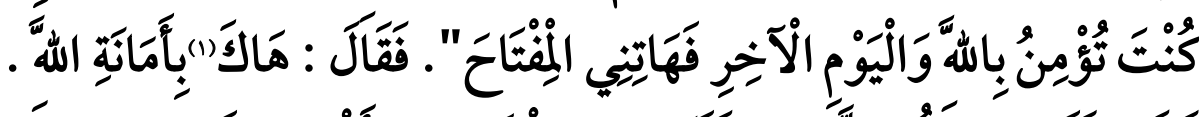

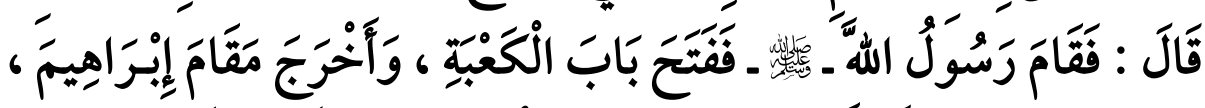

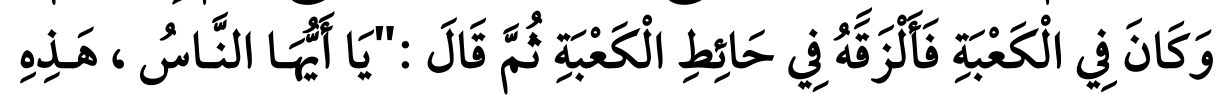

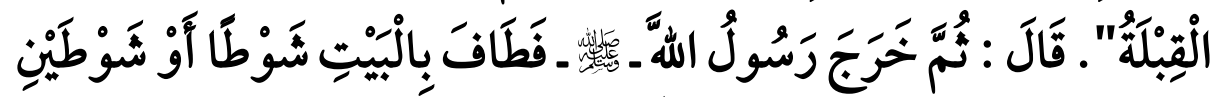

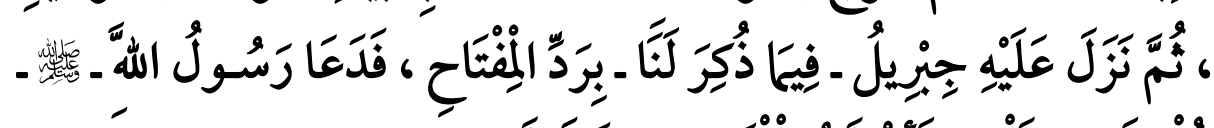

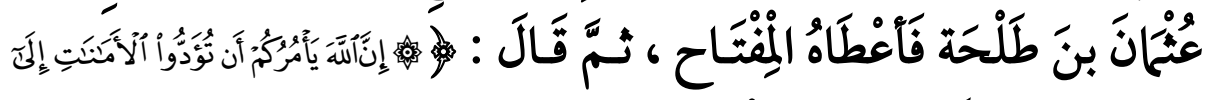

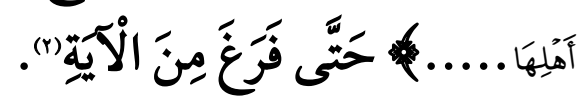

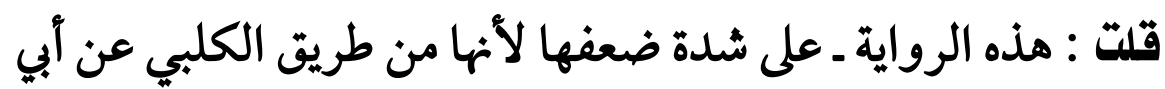

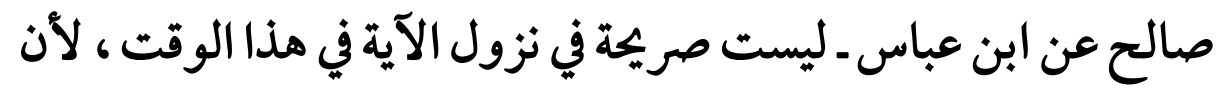

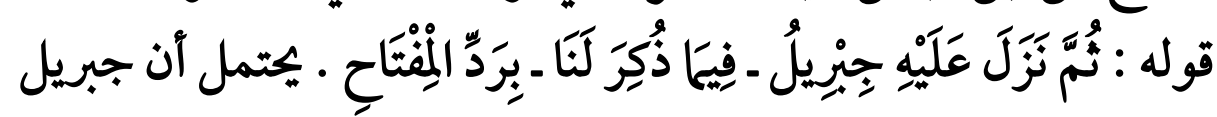

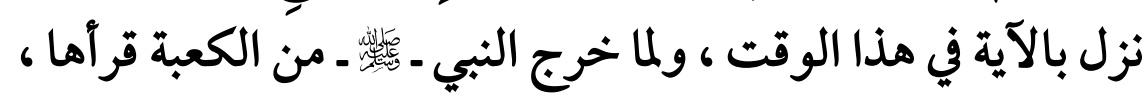

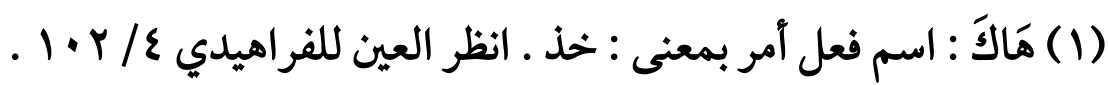

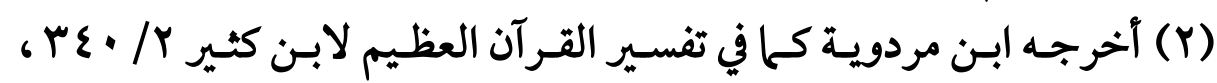

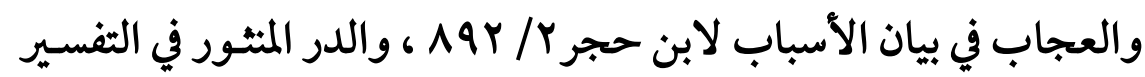

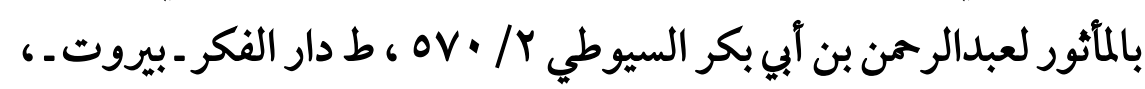

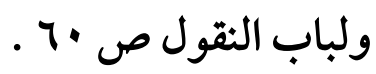




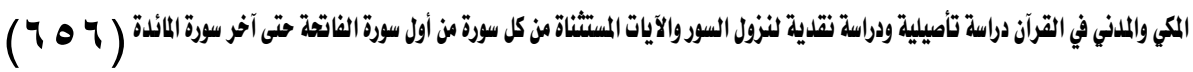

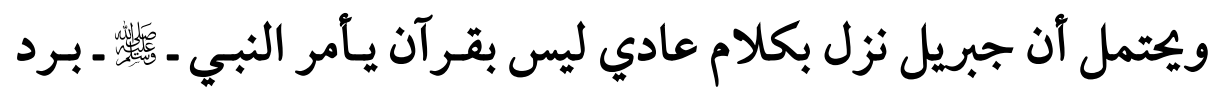

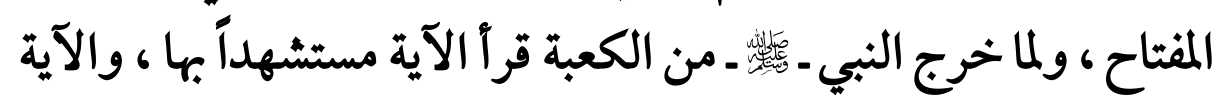
كانت قد نزلت قبل هذا اليوم •

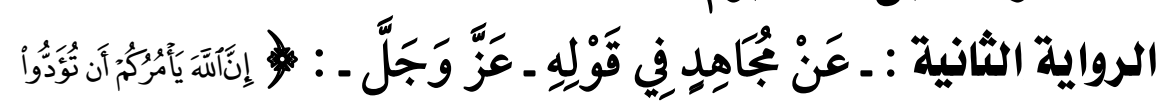

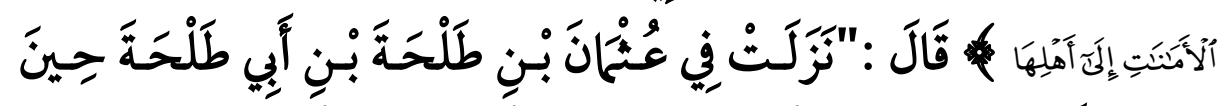

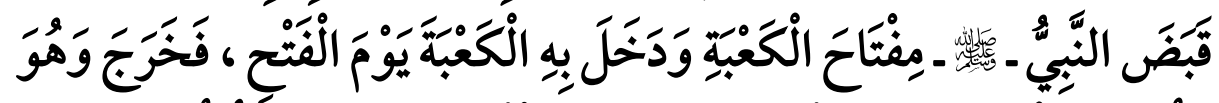

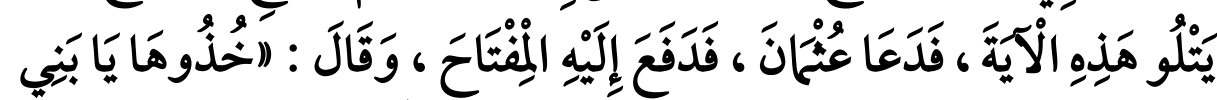

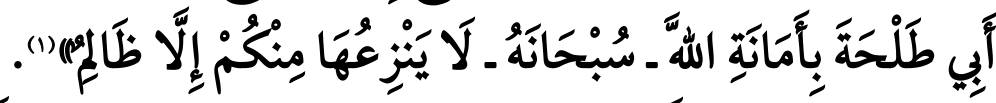

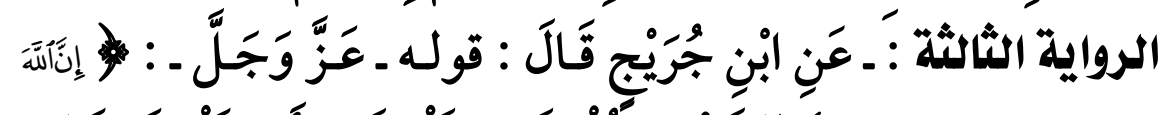

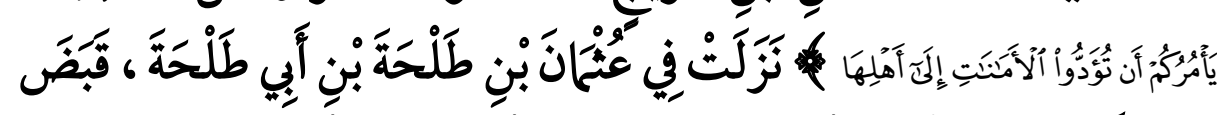

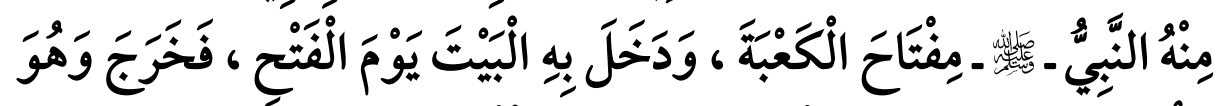

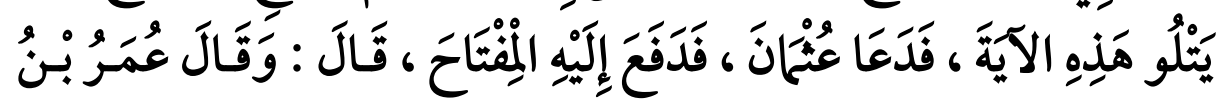

(1) أخرجه محمد بن عبد الله بن آحمد بن محمد بـن الوليد بـن عقبة بـن الأزرق

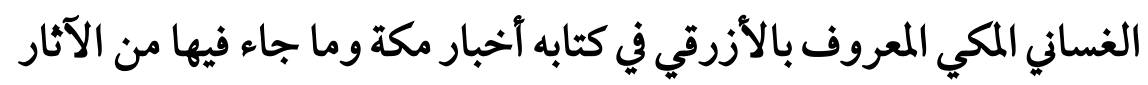

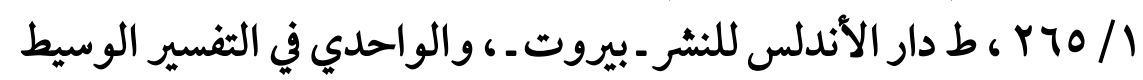

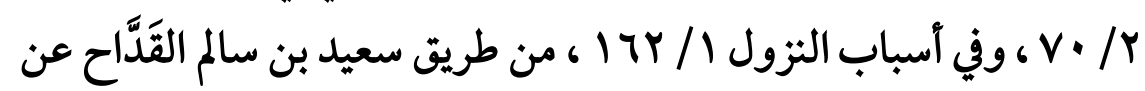

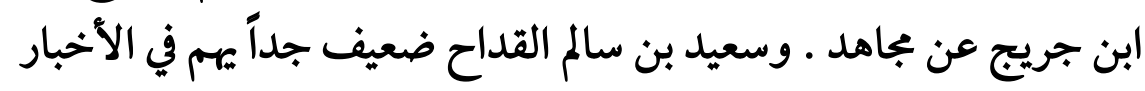

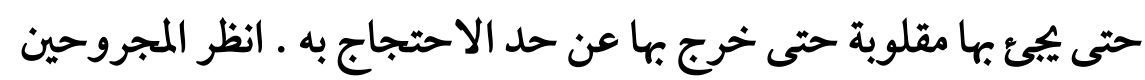

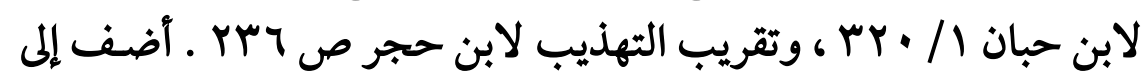

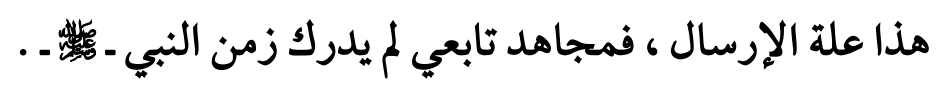


(rov)

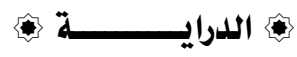

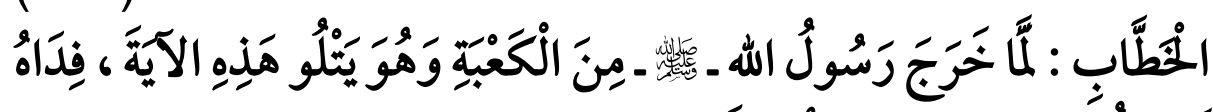

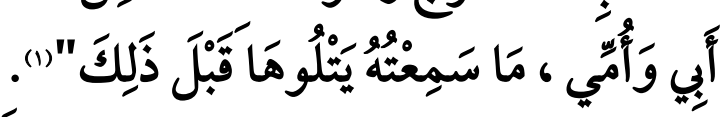

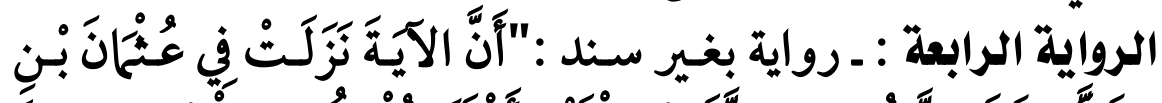

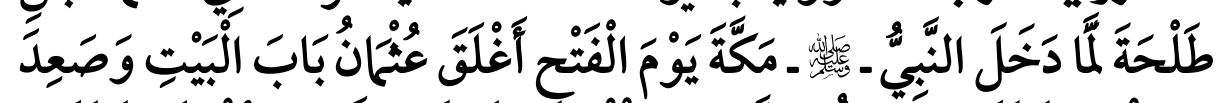

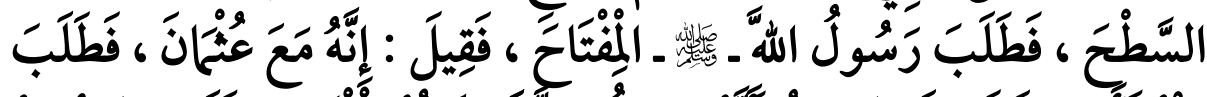

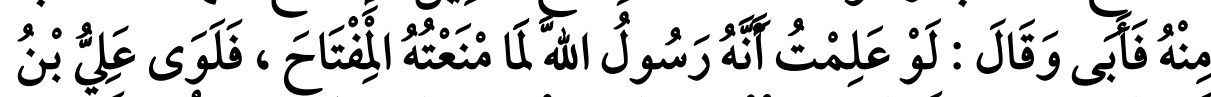

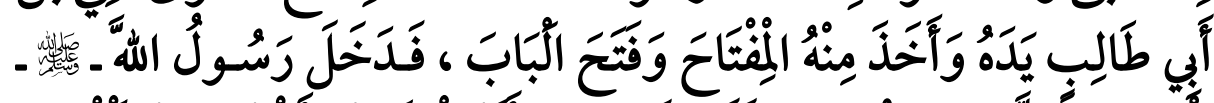

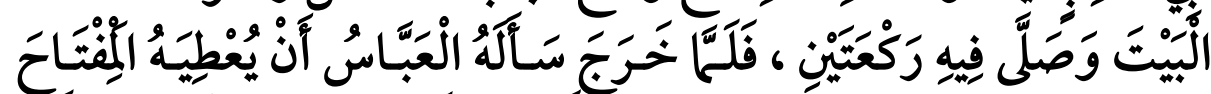

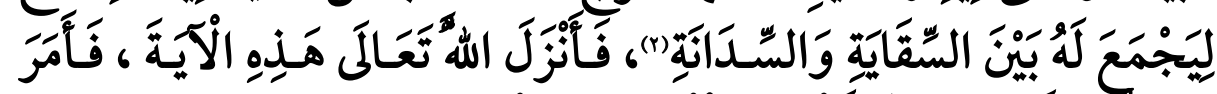

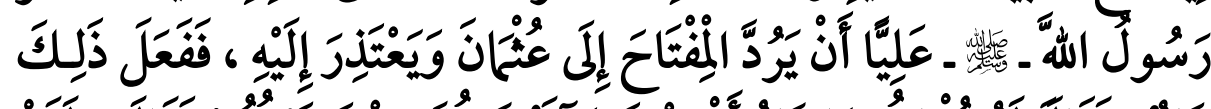

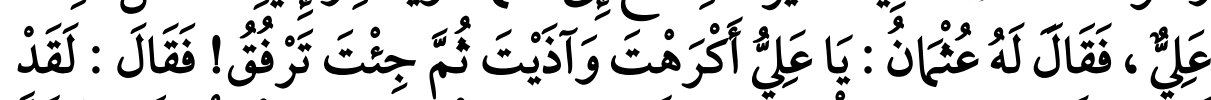

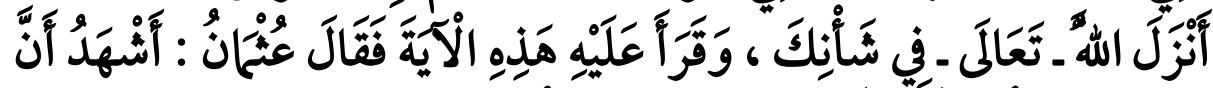

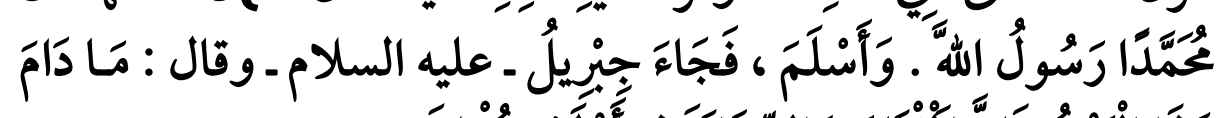

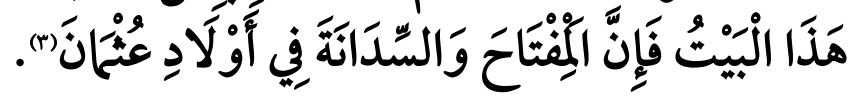

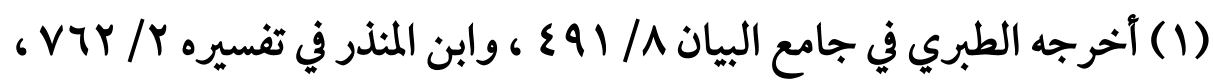

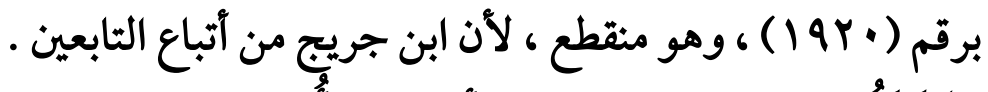

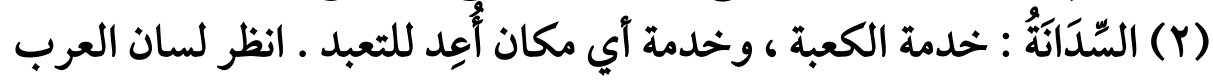

$$
r \cdot r / I r
$$

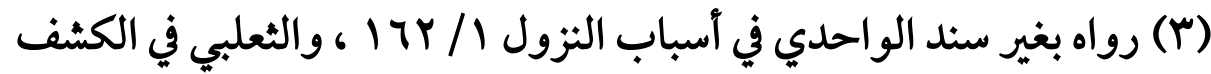

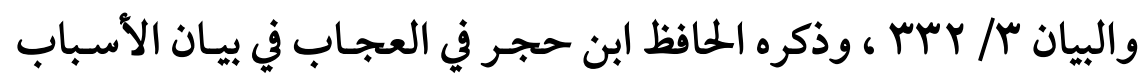

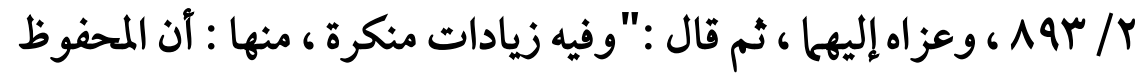




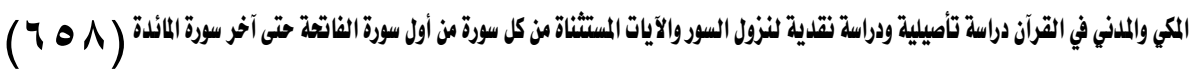

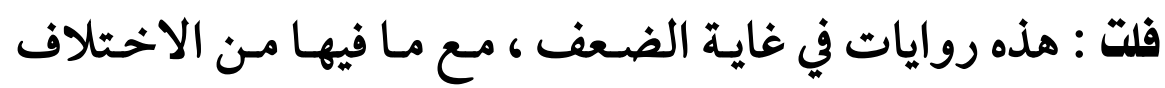

والاضطراب ، وقد اتفقت في شيء ، وانفردت كل رواية بشيء .

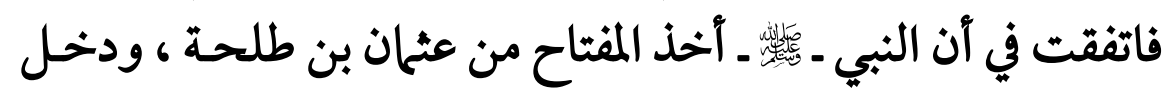

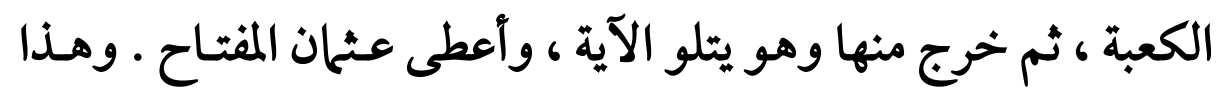

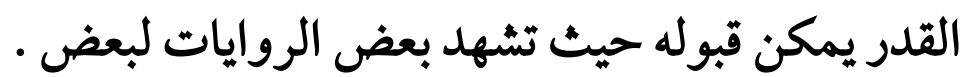

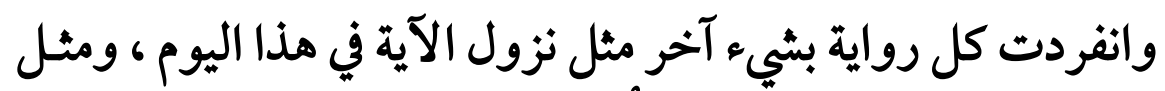

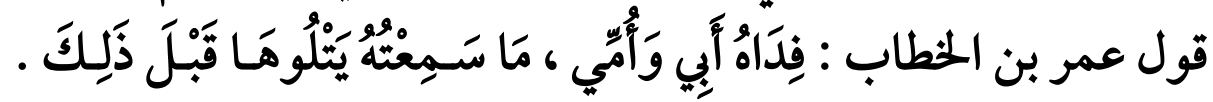

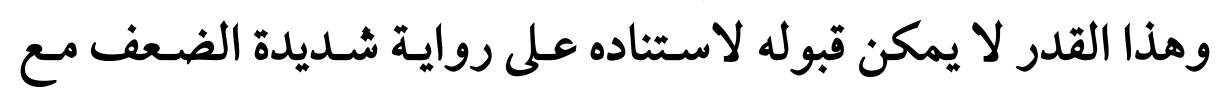

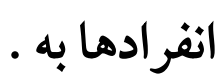

المذهب الثاني : ـ لو سلمنا بنزول الآية في مكة يوم الفتح فإن هـذا لا

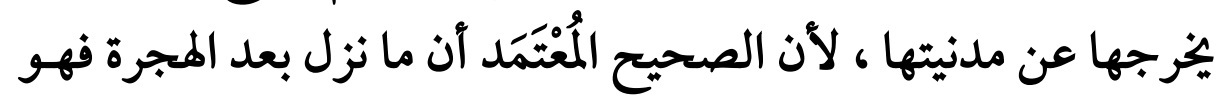

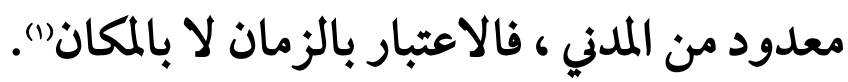

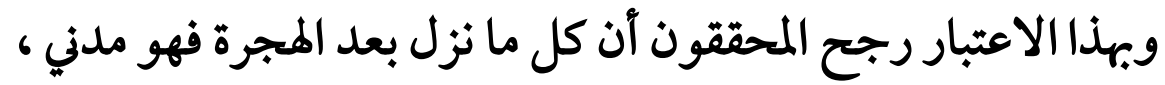

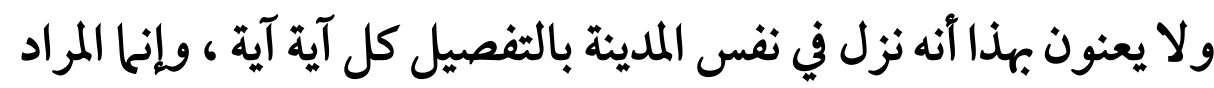

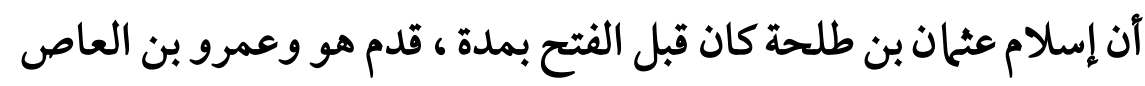

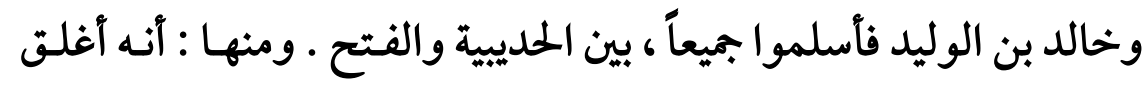

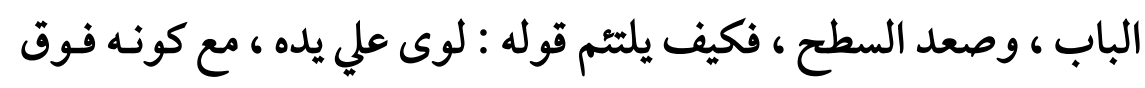

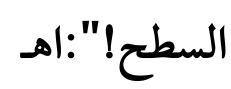

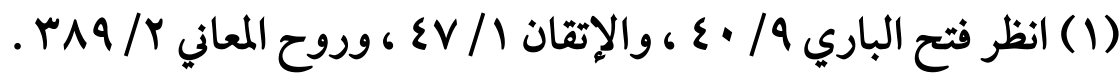


(709)

أنه نزل في الزمن الذي كانت المدينة فيه هي عاصـمة الإسـلام ، وكـان

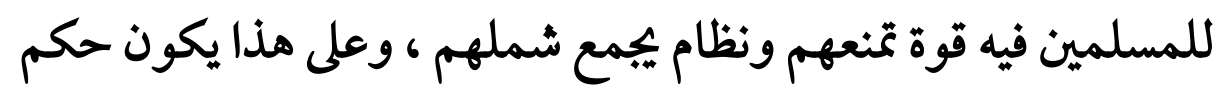

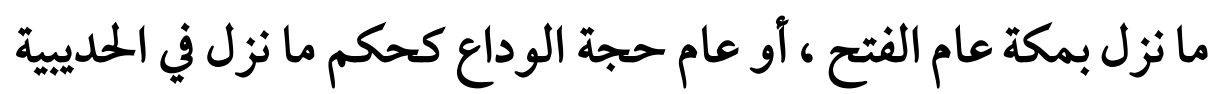

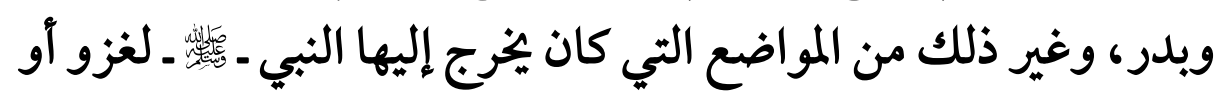

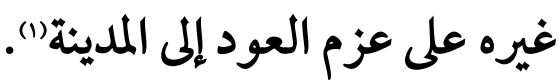

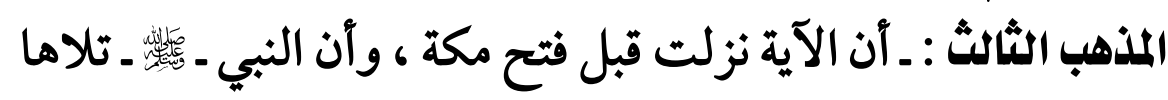

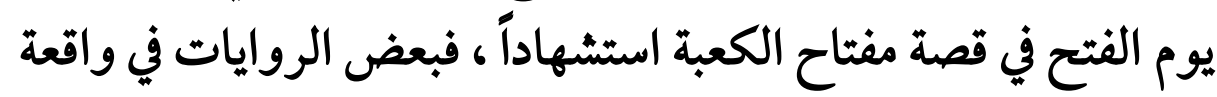

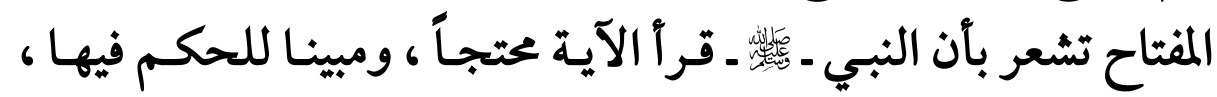
فالتبس الأمر مع بعض الرواة فظنوا آن الآية نزلت حينئذ (r).

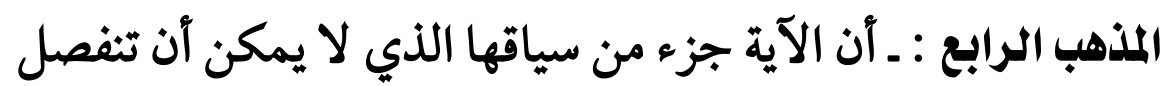

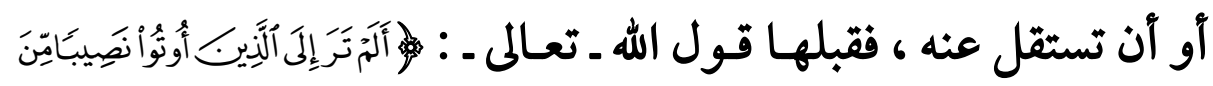

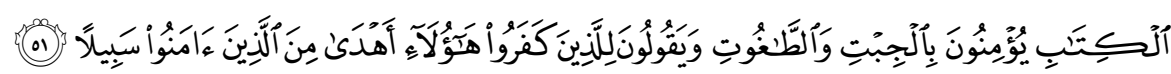
قال

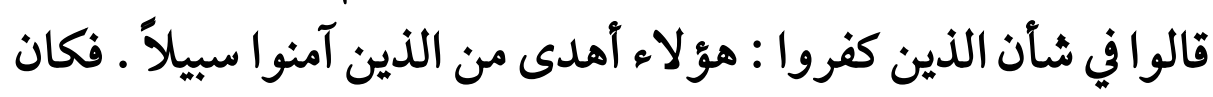

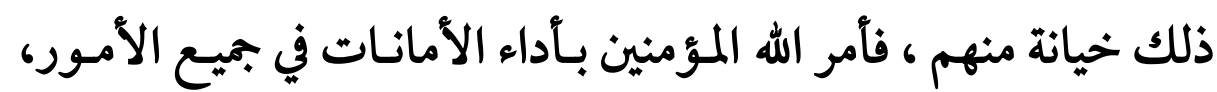

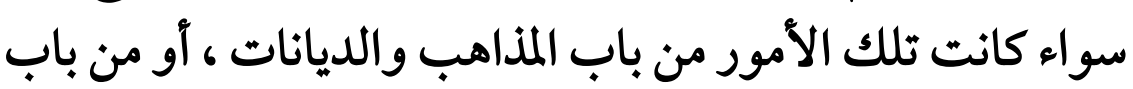

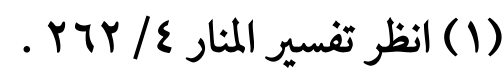

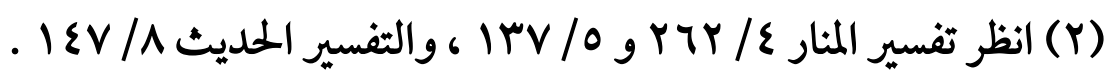

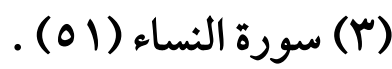




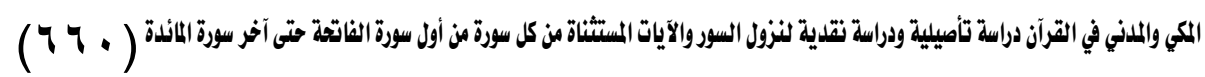

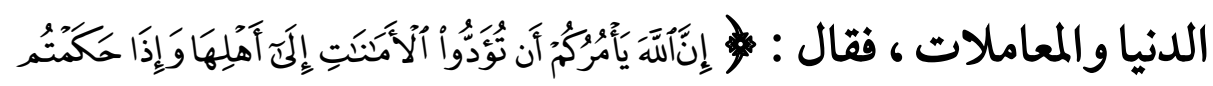

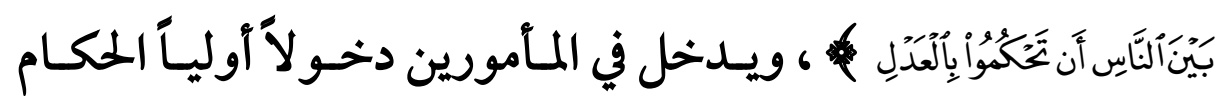

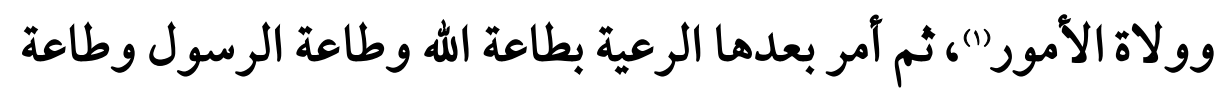

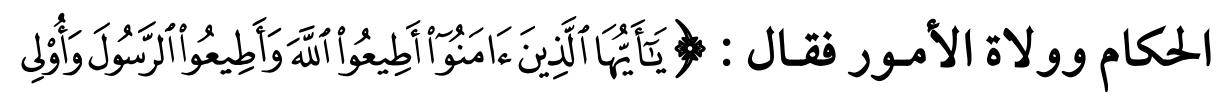

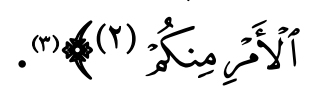

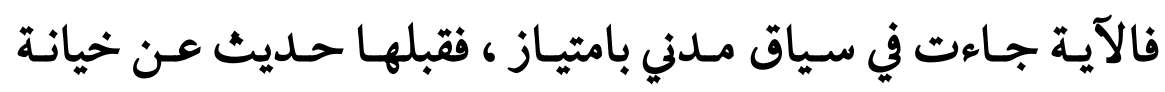

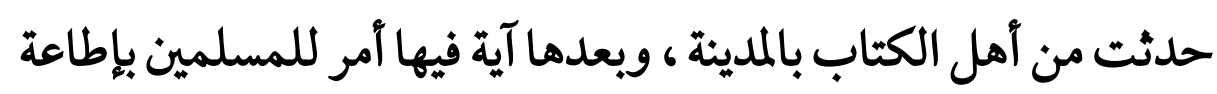

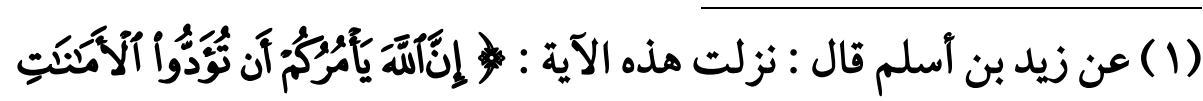

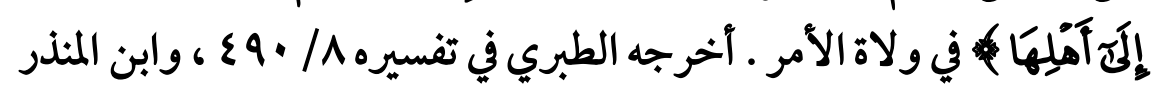

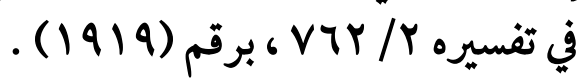

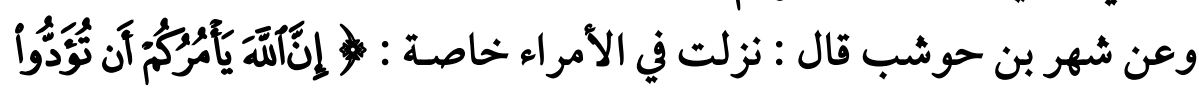

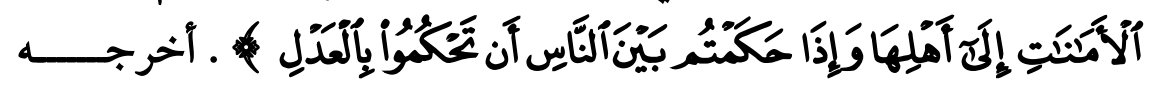

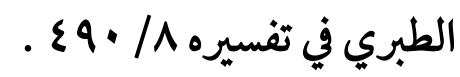

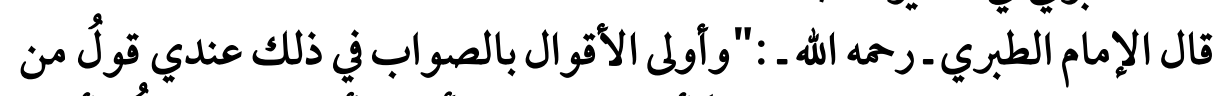

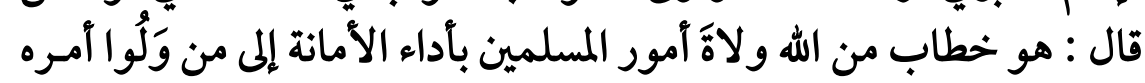

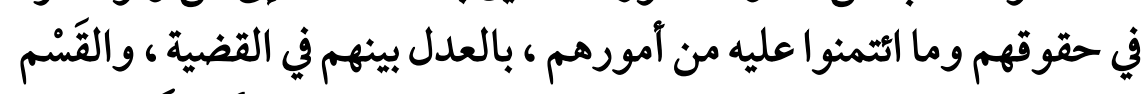

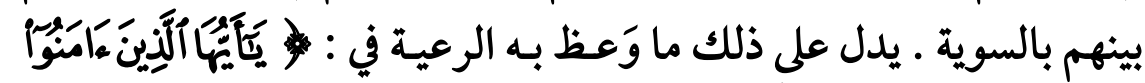

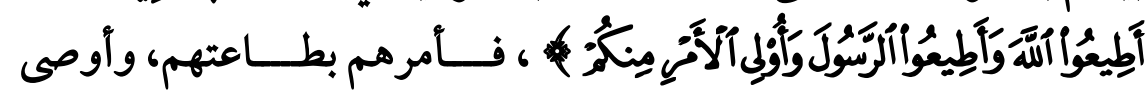

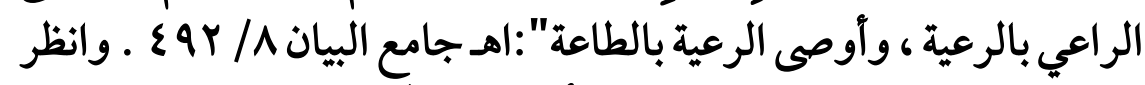

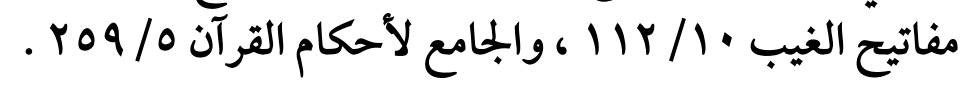

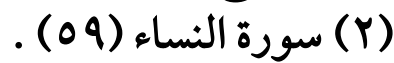

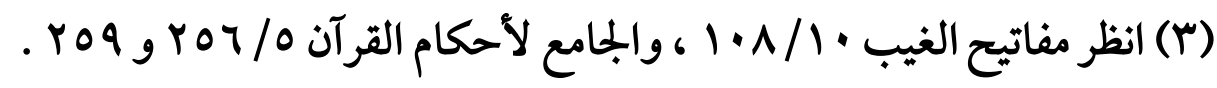


(74)

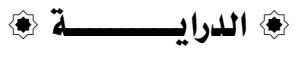

الله ورسوله وأولي الأمر ورَدّ ما يتنازعون فيـه إلى الله ورسـوله ، حيـث هالث

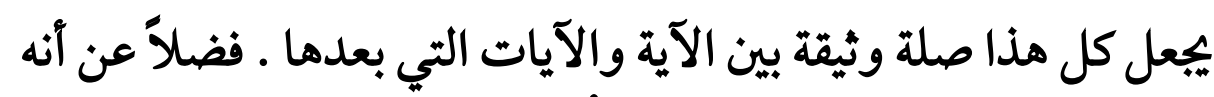

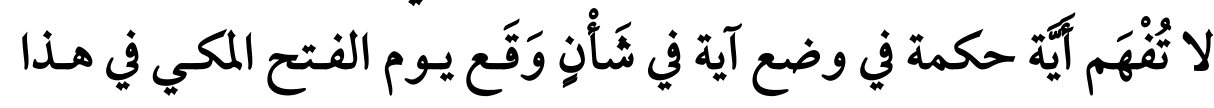

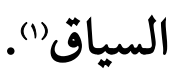

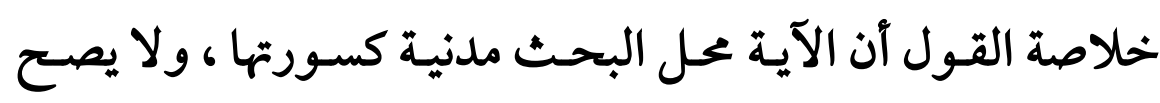

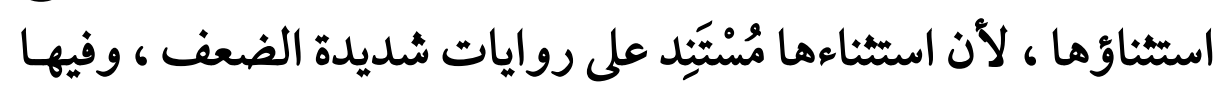
الكثير من الاختلاف والاضطراب ، يفيد بعضها آنها نزلت في مكة يوم الفتح

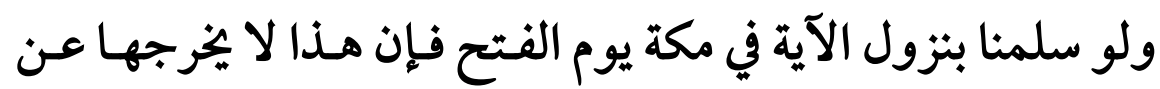

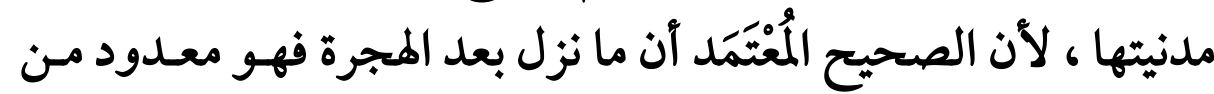

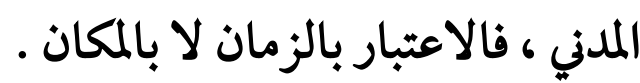

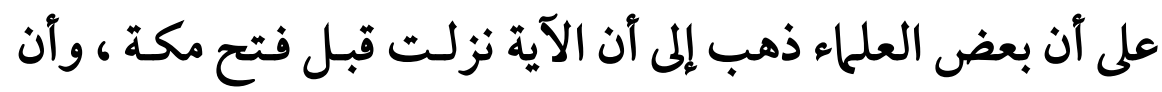

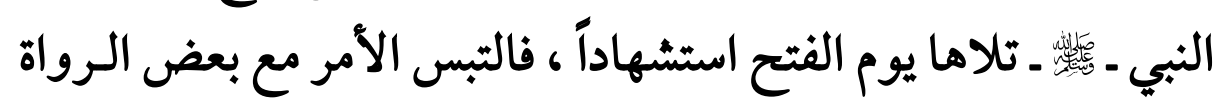

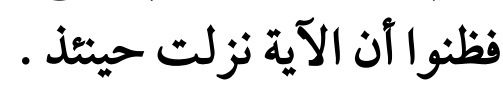

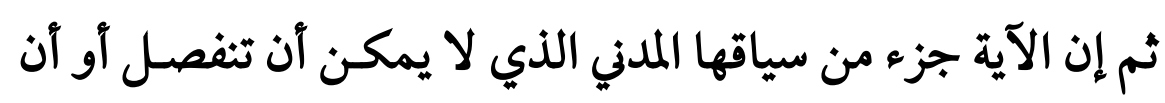

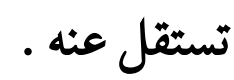

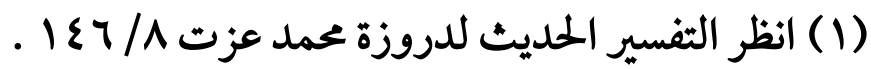




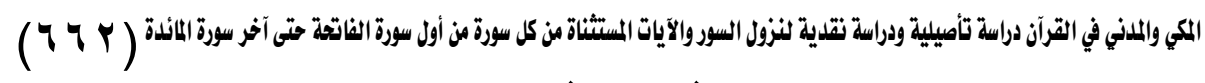
سورة المائدة الخامس

\section{المبحث الأول \\ نزول سورة المائدة}

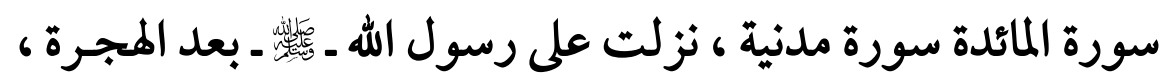

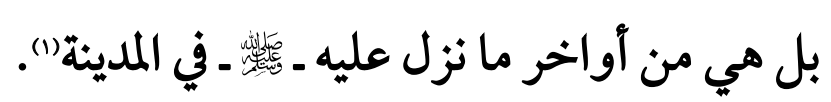

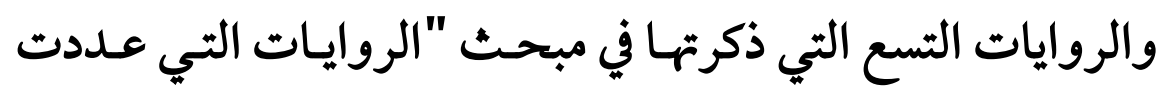

$$
\text { المكي والمدني" أجمعت على مدنية سورة المائدة"(). }
$$

ويمكن آن نستدل على مدنية سورة المائدة بخمسة أدلة :

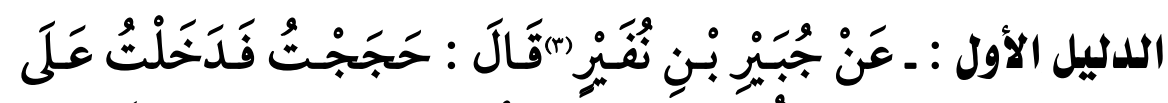

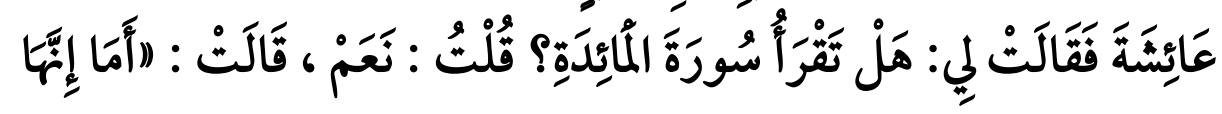

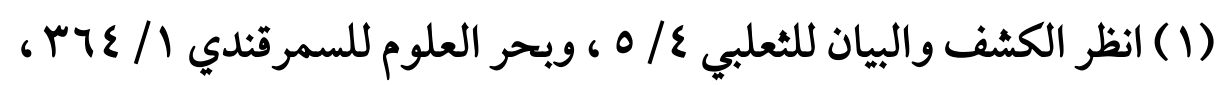

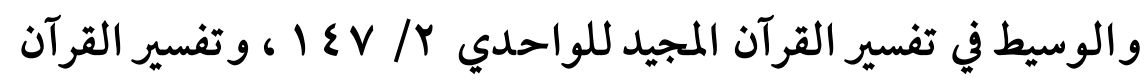

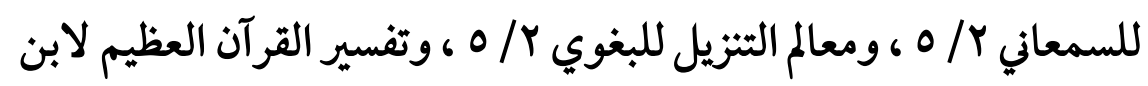

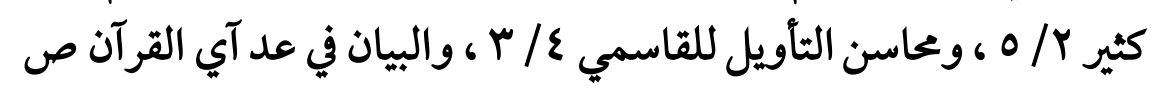

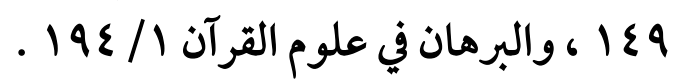

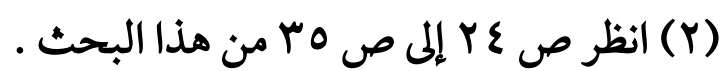

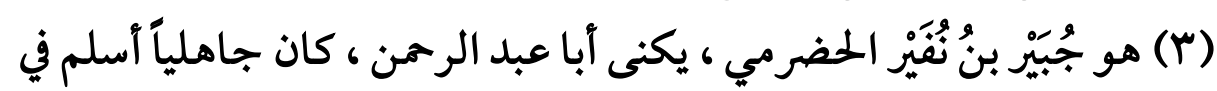

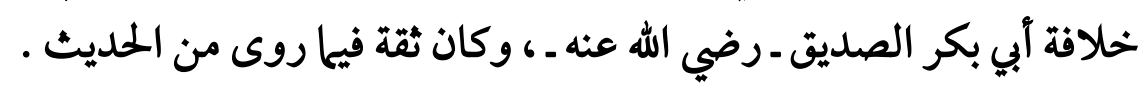


$(74 \%)$

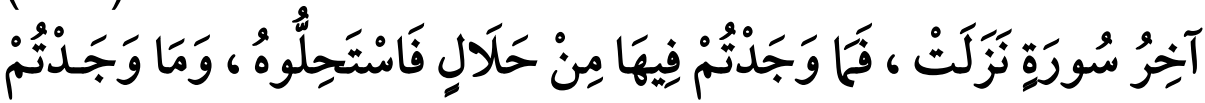

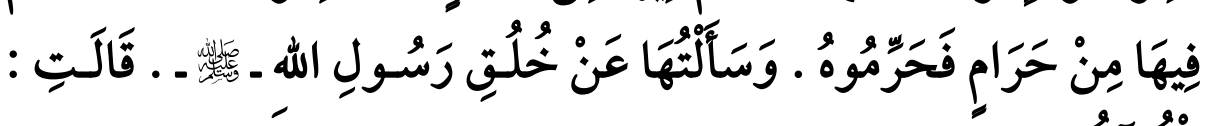

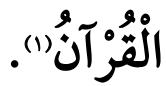

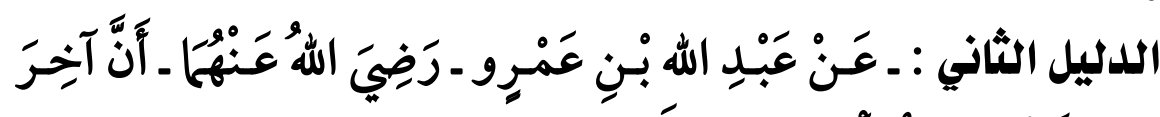

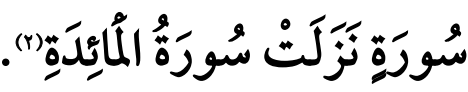

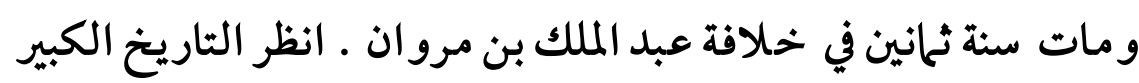

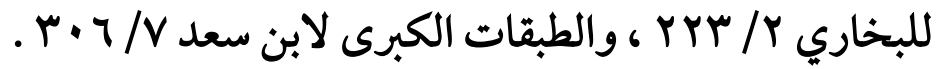

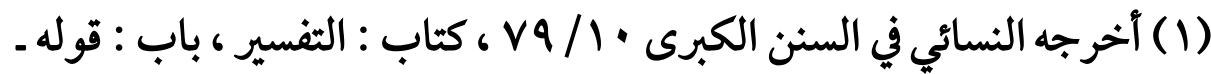

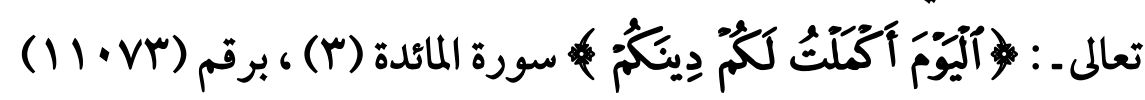

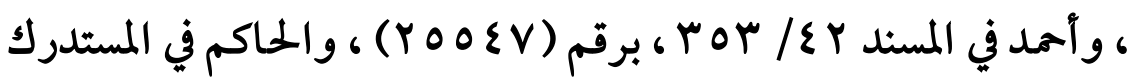

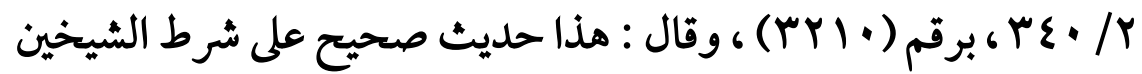

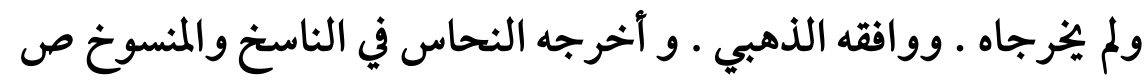

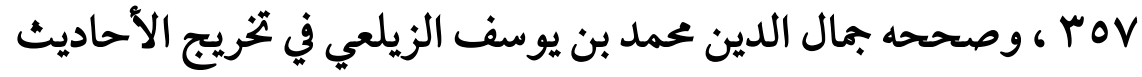

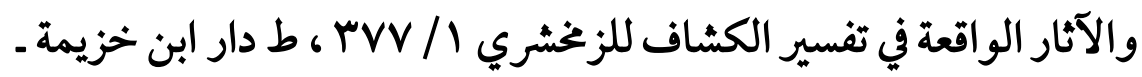

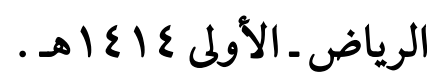

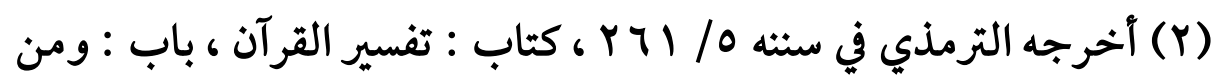

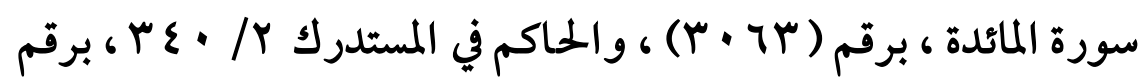

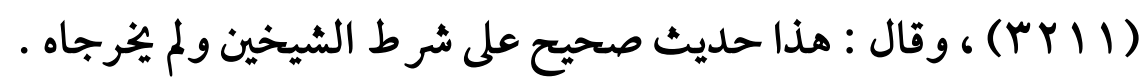

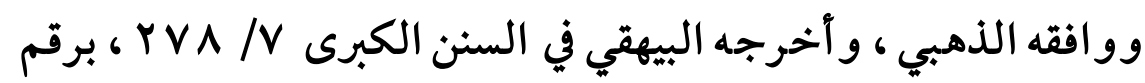




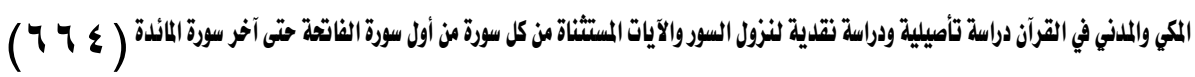

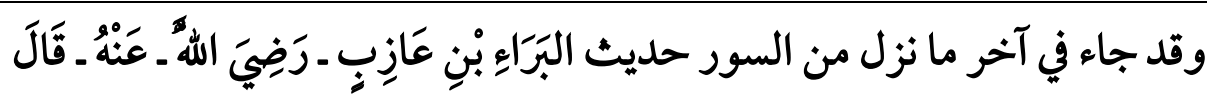
"آَخِرُ سُورَةِ نَزَزَتَتْ بَرَاءَة .

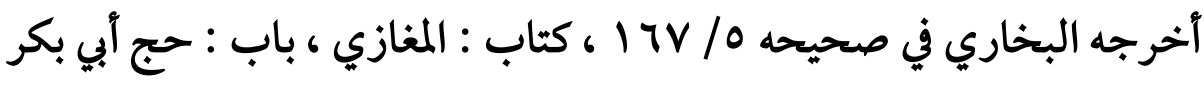

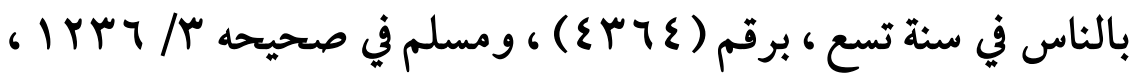

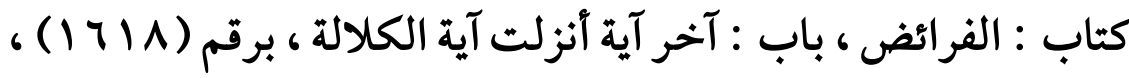

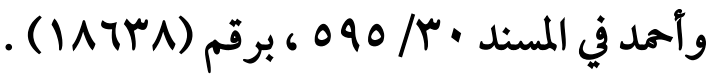

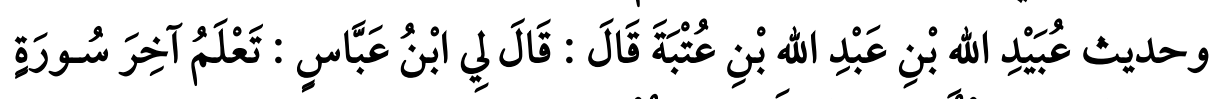

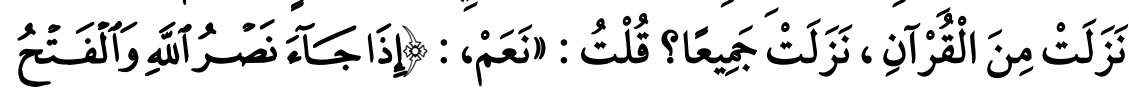

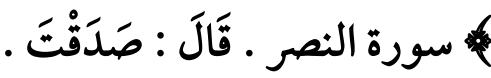

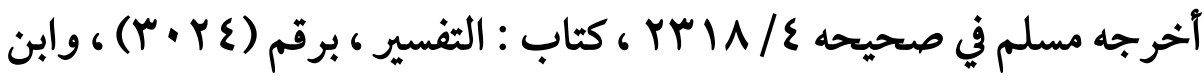

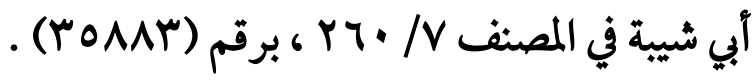

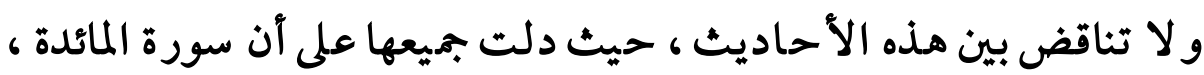
والتوبة، والنصر آخر ما نزل من السور . لادئ

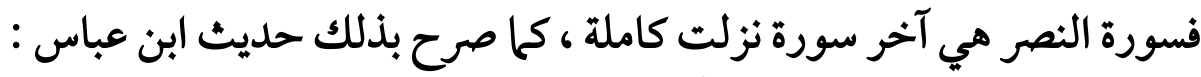

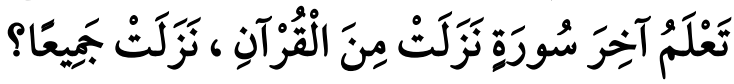

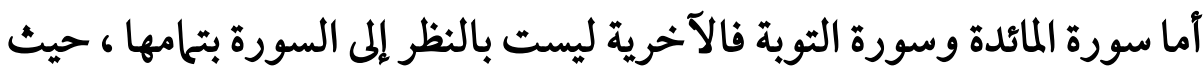

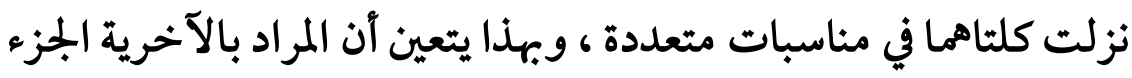

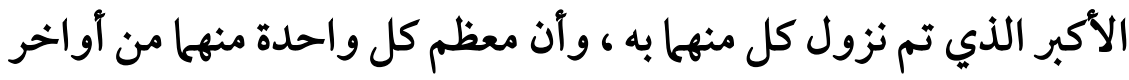

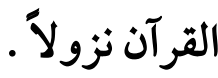

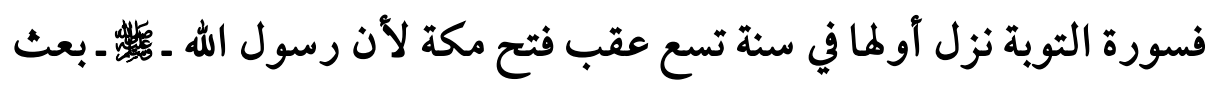

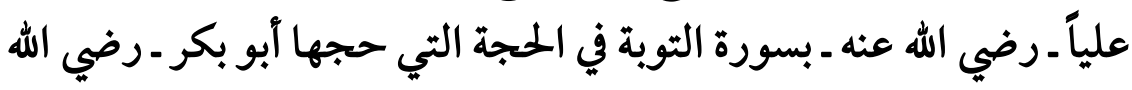


(7ro)

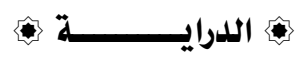

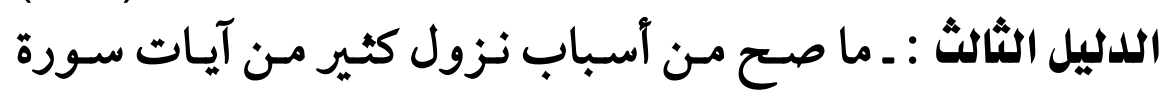

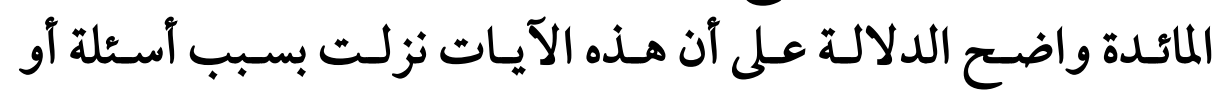

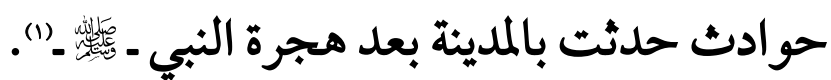

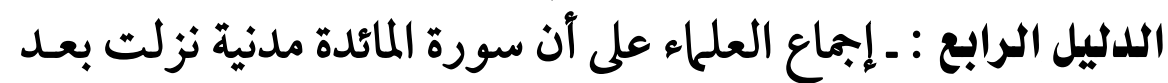
المجرة ، ولم يخالف في هذا أحد (r).

عنه ـ بالناس قبل حجة الوداع ، فقرأها على الناس حتى ختمها ، ونزل كثير

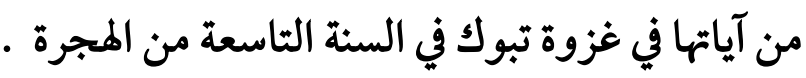

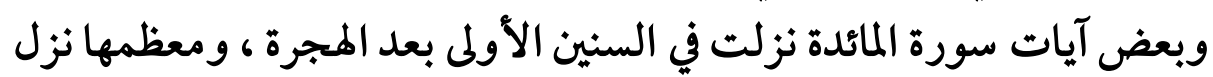

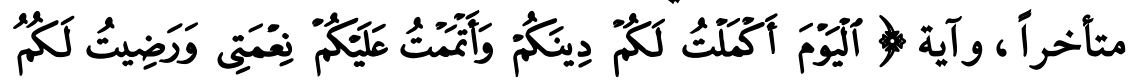

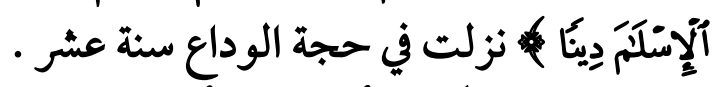

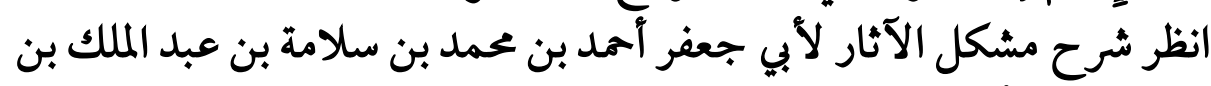

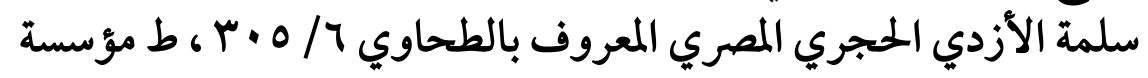

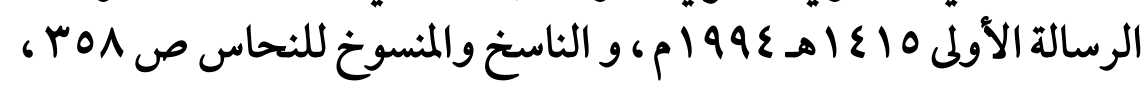

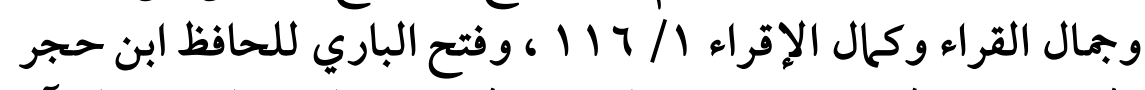

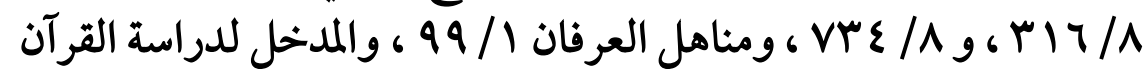

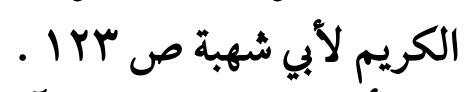

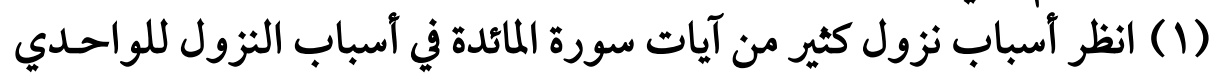

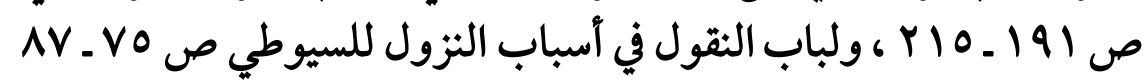

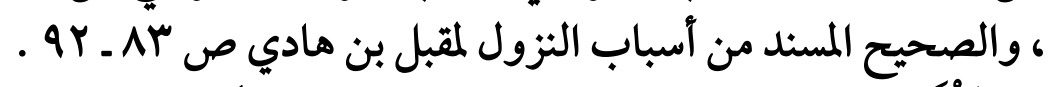

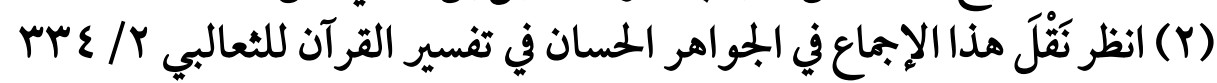

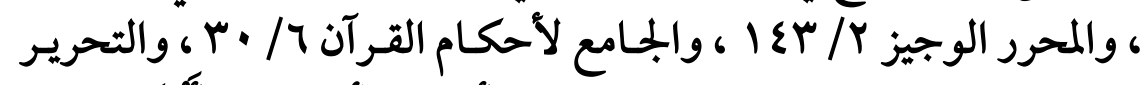

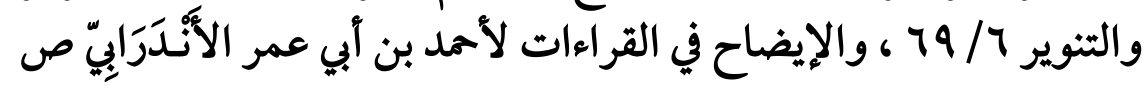




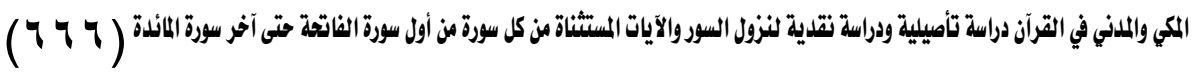
الدليل الخامس : ـ القضايا التي تحدثت عنها سورة المائدة هي قضايا

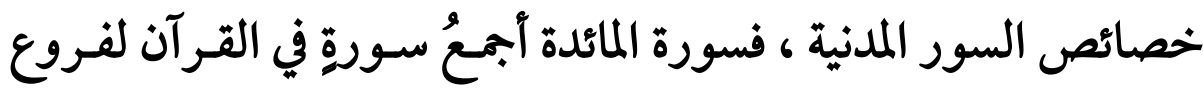

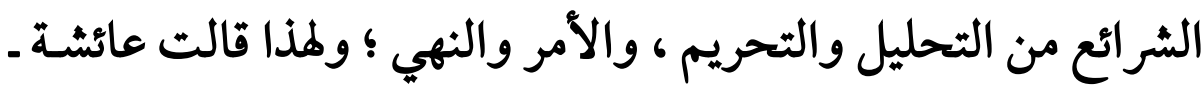

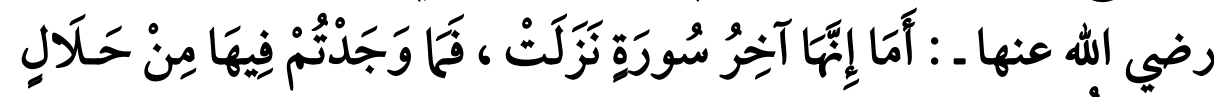

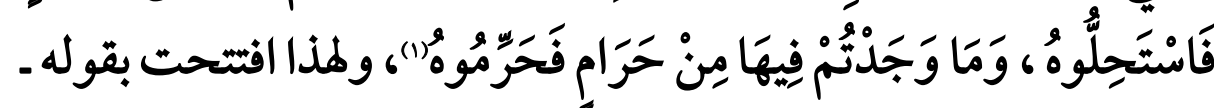

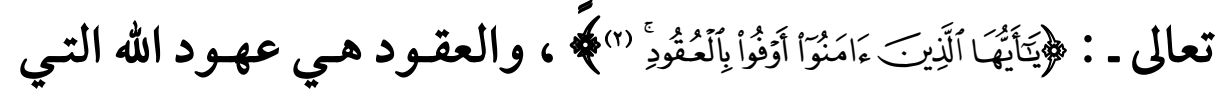

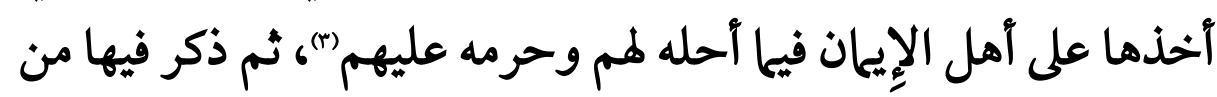

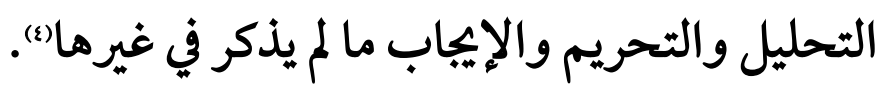

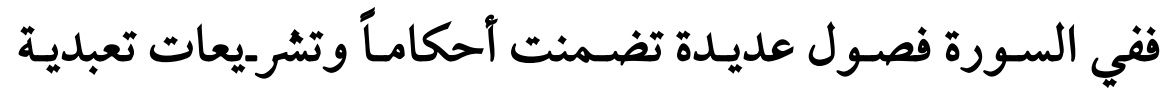

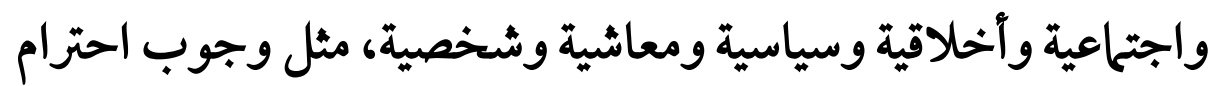

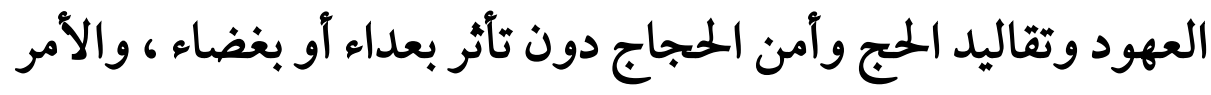
بالتعاون على البر والتقوى وعدم التعاون على الإثم والعـدوان بسـبب دون وليب

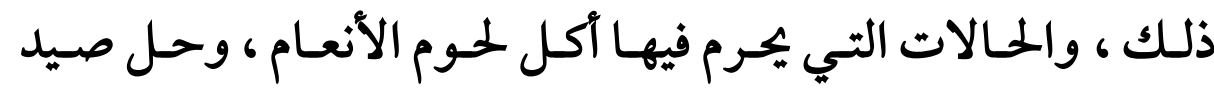

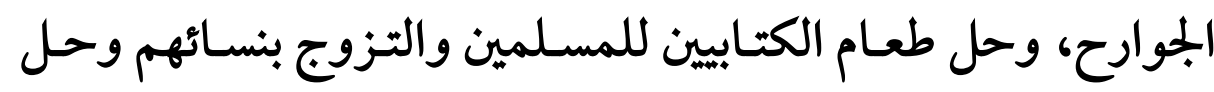

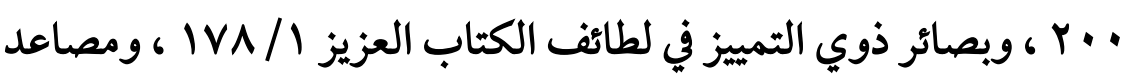

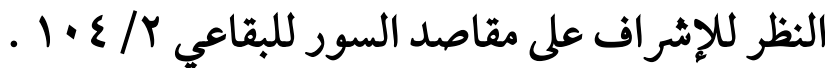

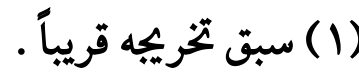

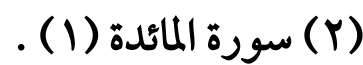

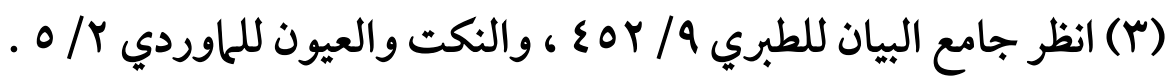

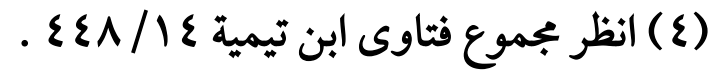




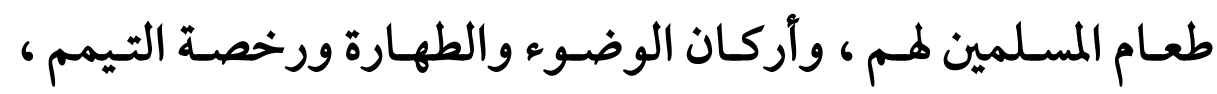

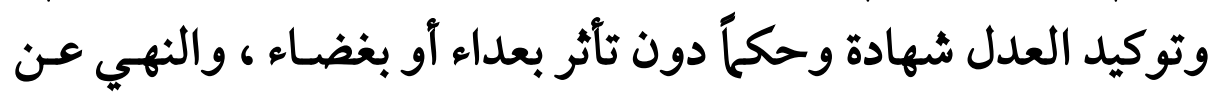

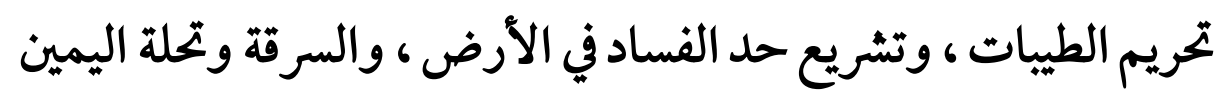

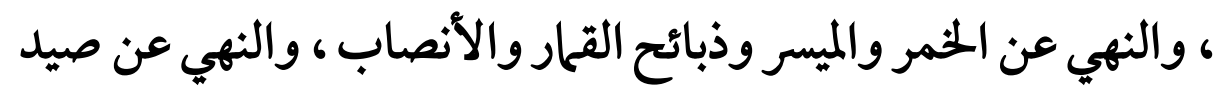

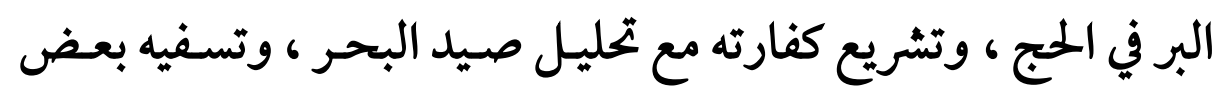

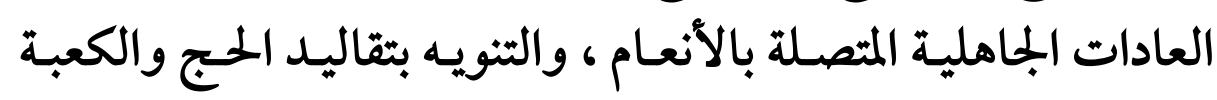
ومنافعها ، وتشريع الإشهاد على التركات وتحقيق صحة الشهادة .

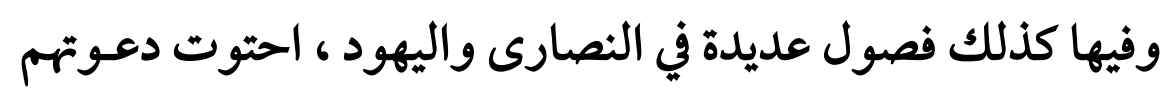

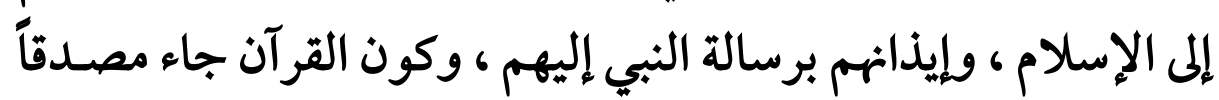

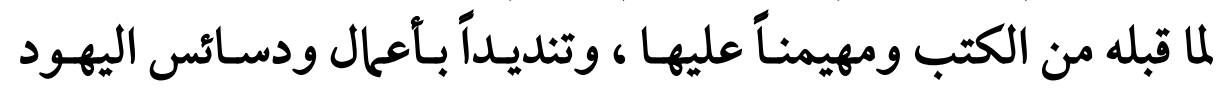

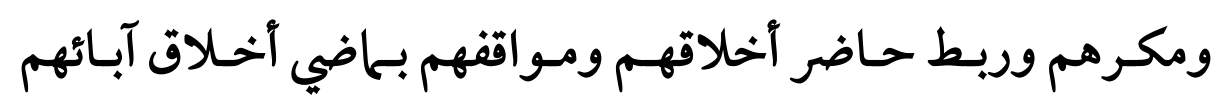

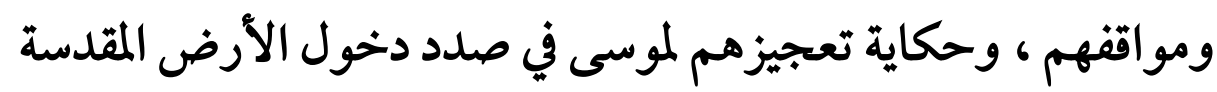

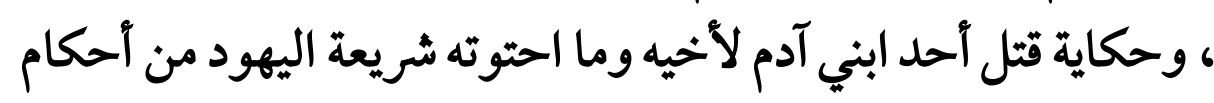

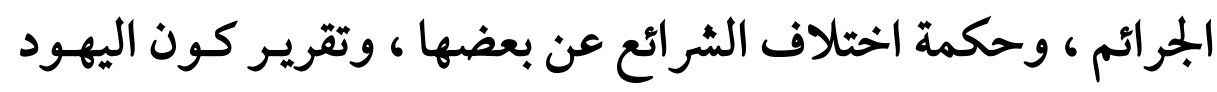

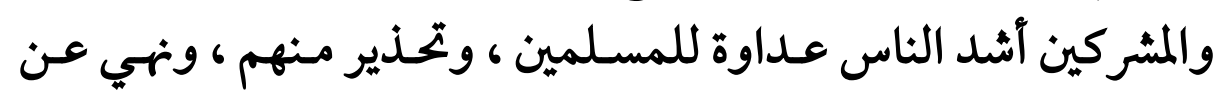
موالاة اليهود والنصارى الذين يعادون المسلمين ويسخرون من دينهم

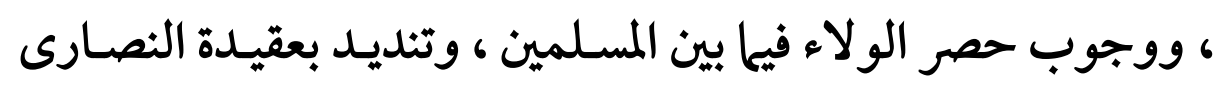
بالمسيح وأمه وتقرير ببطلانها لذاتها وعلى لسان السيد المسيح ، ومشهد المسديد من مشاهد إيهان بعض النصارى الذين منهم قسيسون ورهبان بها أنزل 


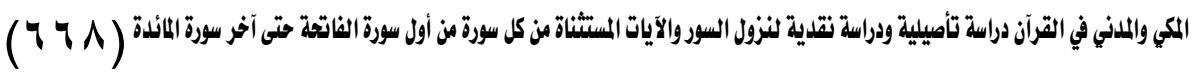

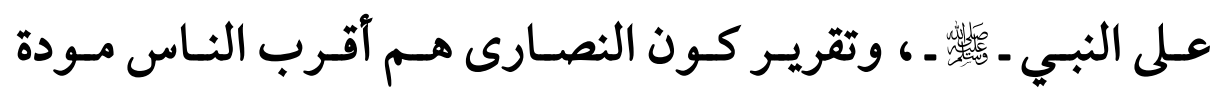

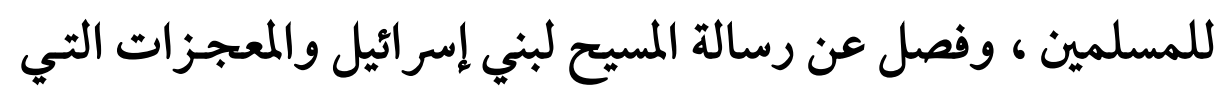

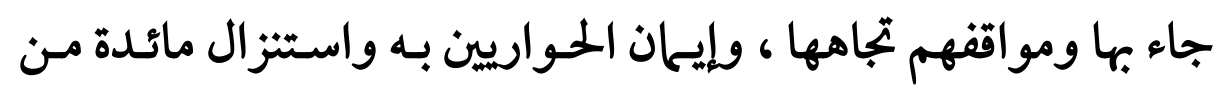
السماء بناء على طلبهم ، وقد سميت السورة باسمها بسبب ذلك ولك (1).

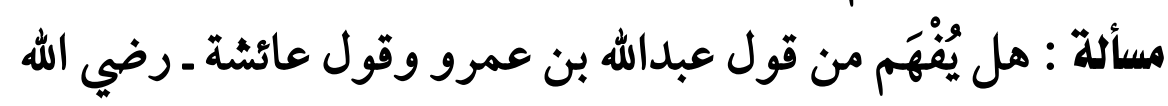

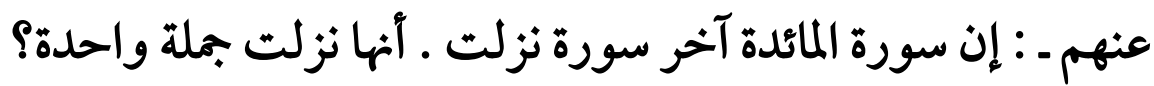

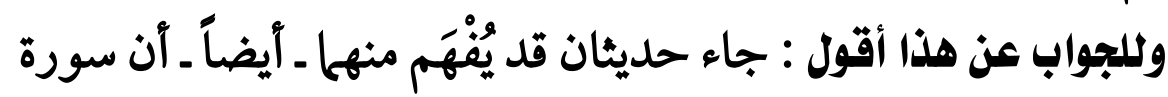

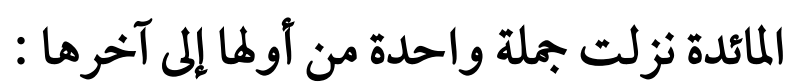

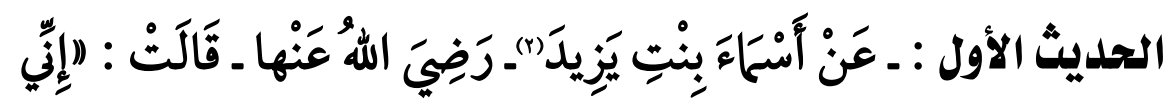

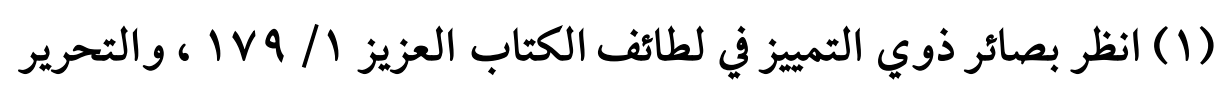

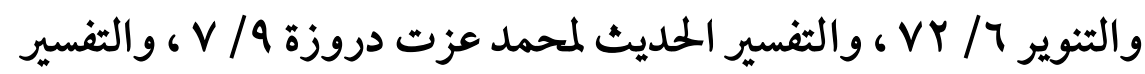

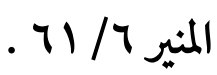

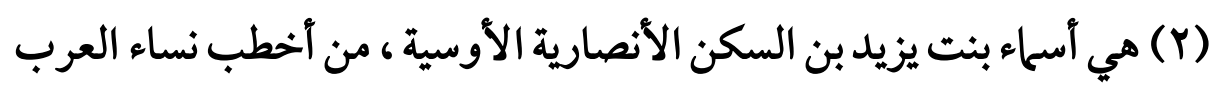

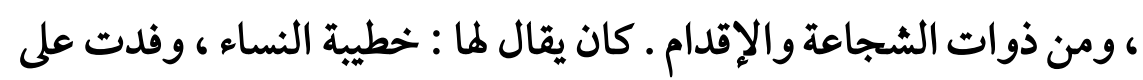

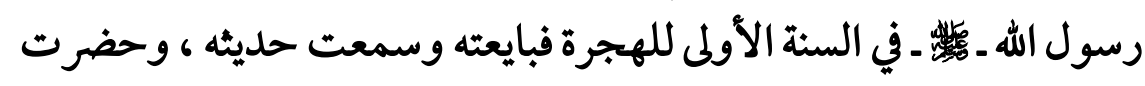

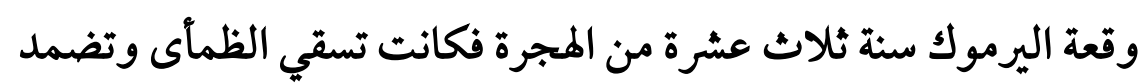

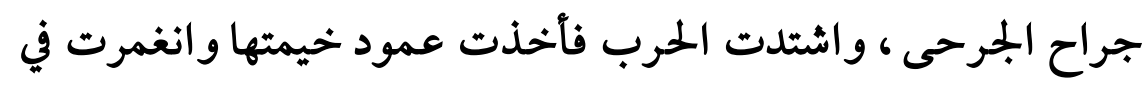

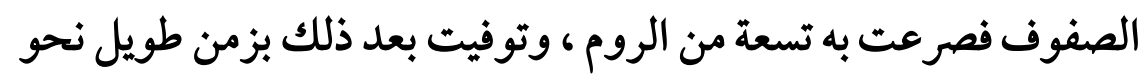

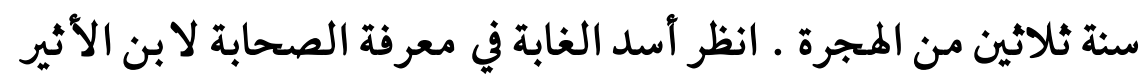

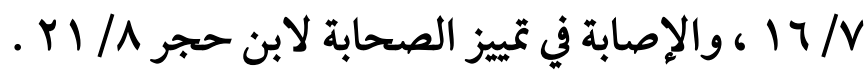




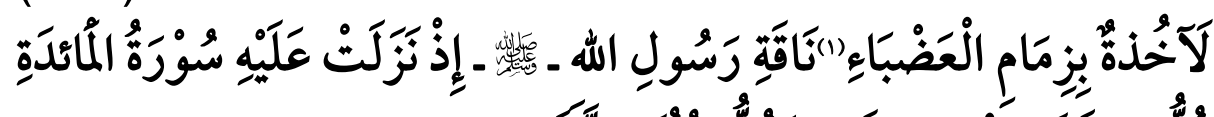

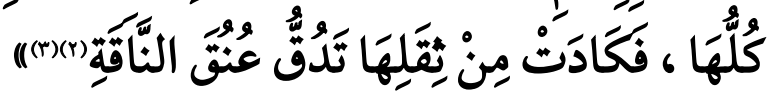

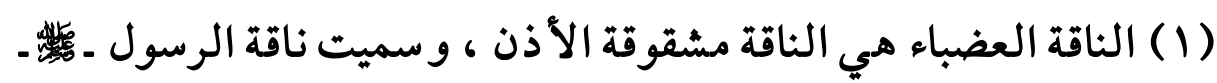

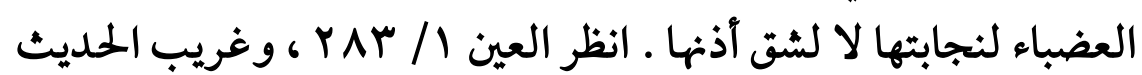

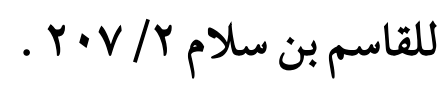

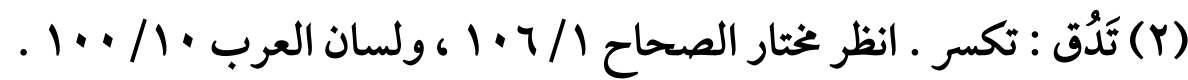

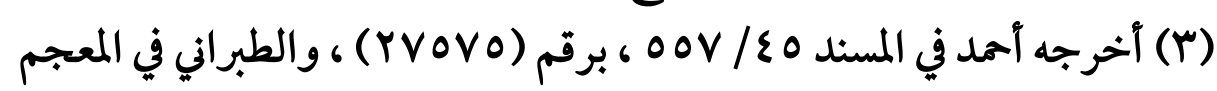

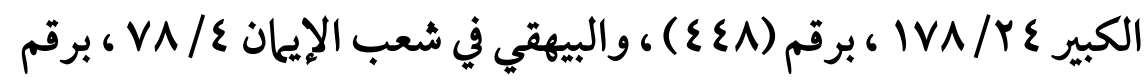

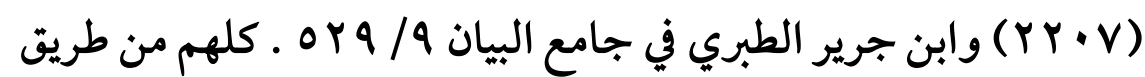

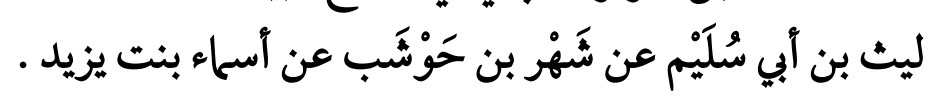

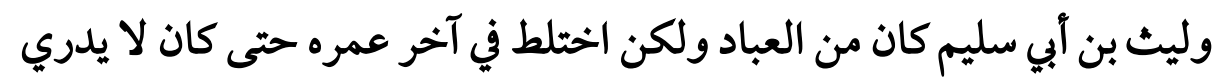

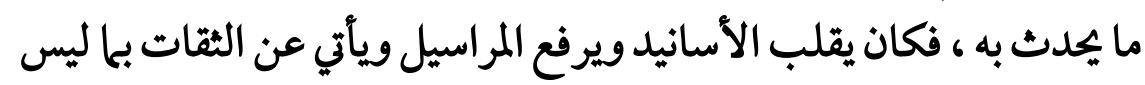

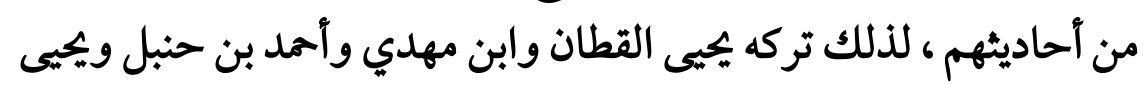

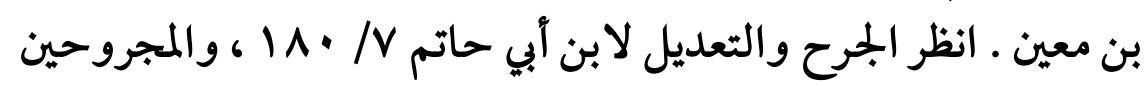

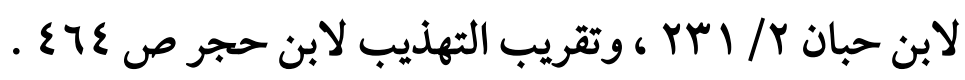

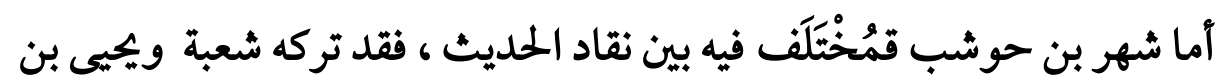

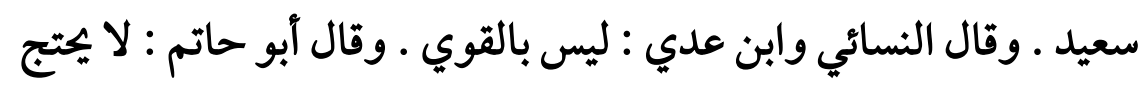

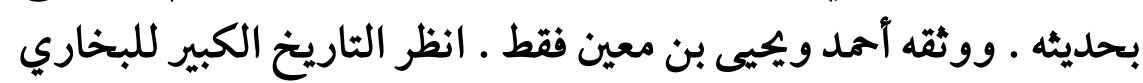

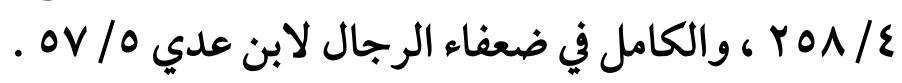

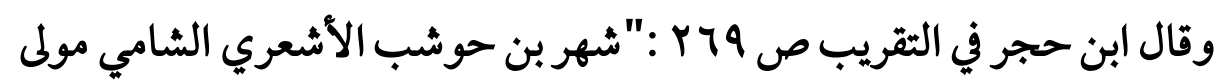

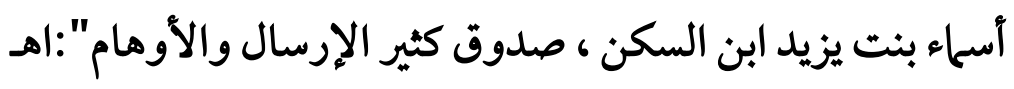




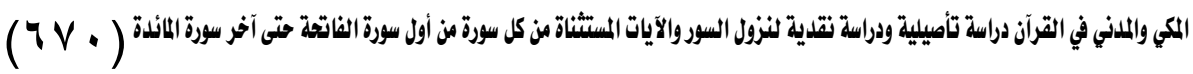

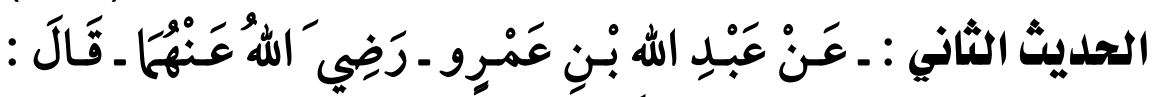

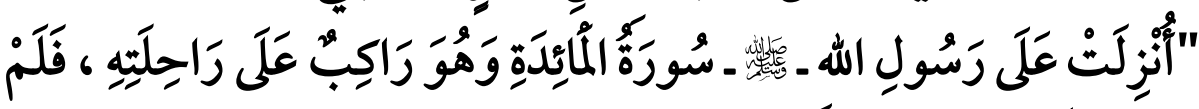

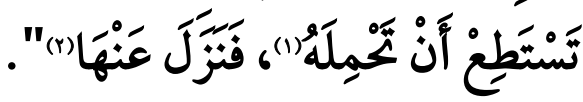

والحديث ذكره الميثمي في بجمع الزوائد / / ا وقال :"رواه أحمد والطبراني ،

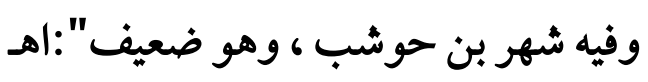

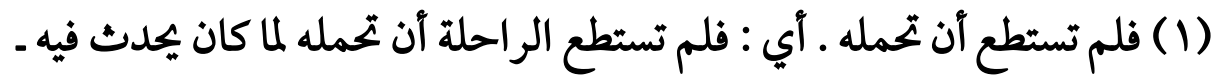

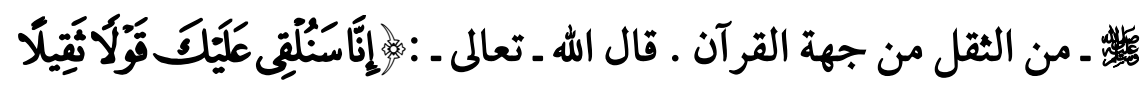

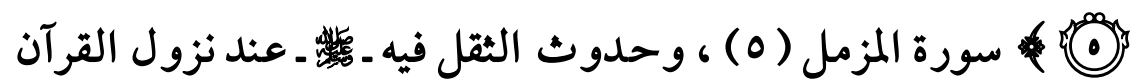

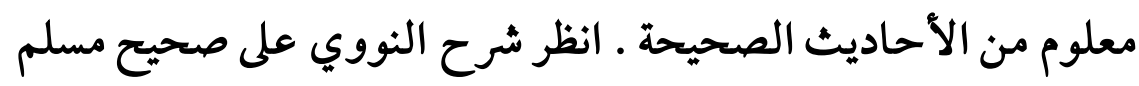

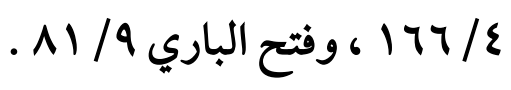

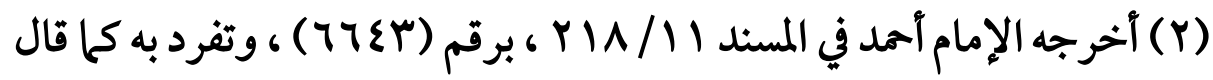

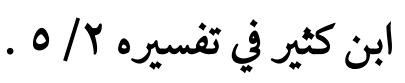

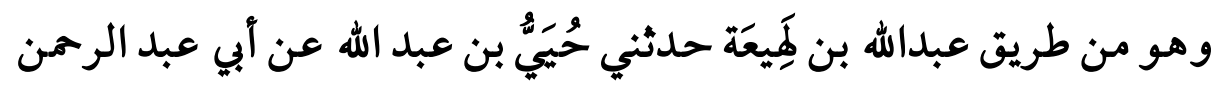

$$
\text { الحبُّلي عن عبد الله بن عمرو........... }
$$

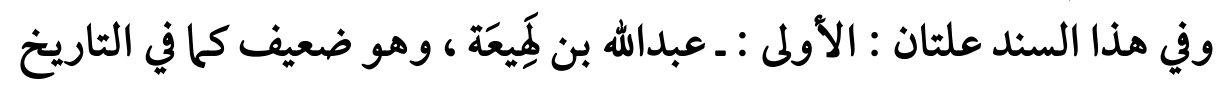

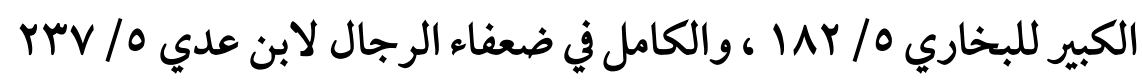

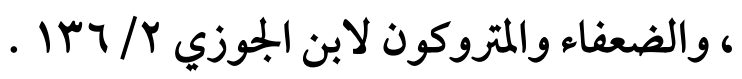

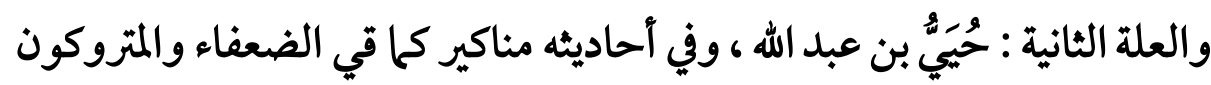

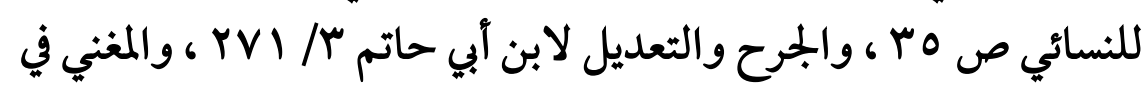

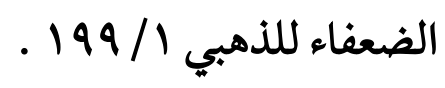


(TVI)

والحديثان ضعيفان ، ولعل الخطاً فيها من الرواة خفيفي الضبط ، فلعل

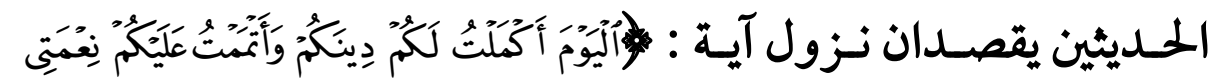

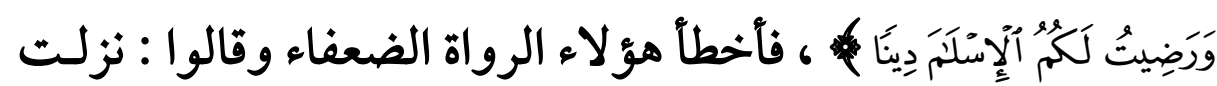

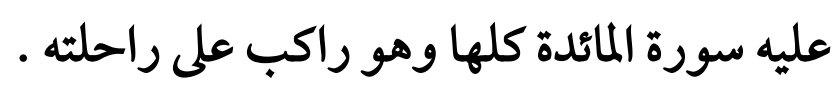

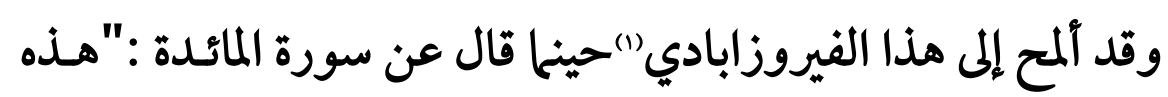

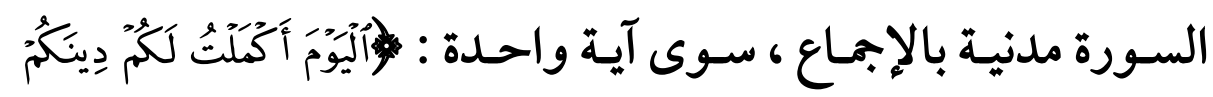

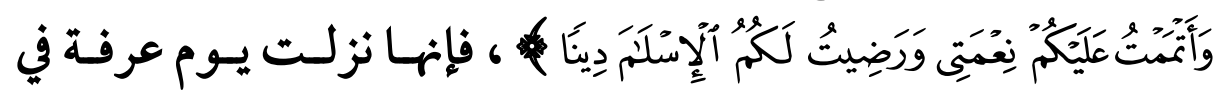

وقد ذكر الحديث وضعفه بهاتين العلتين الحافظ ابن حجر في كتابه المطالب العالية

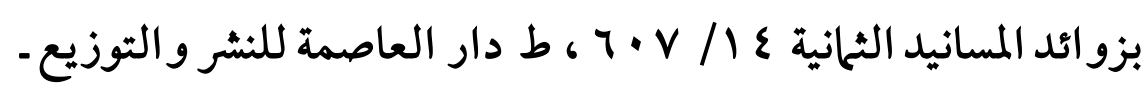

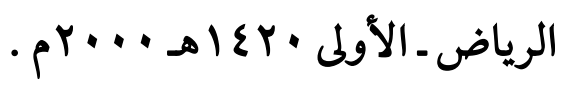

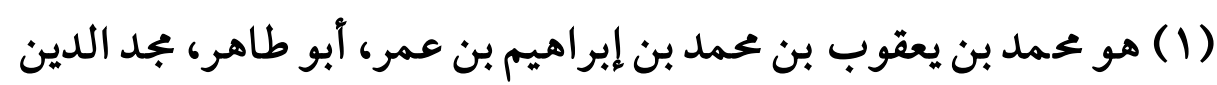

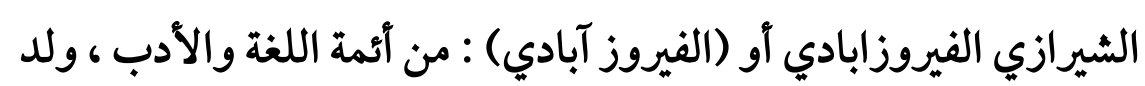

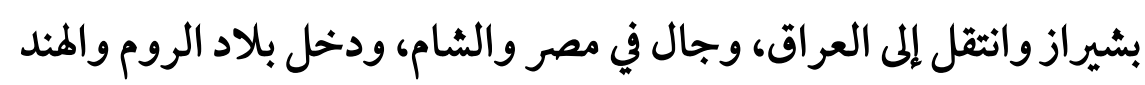

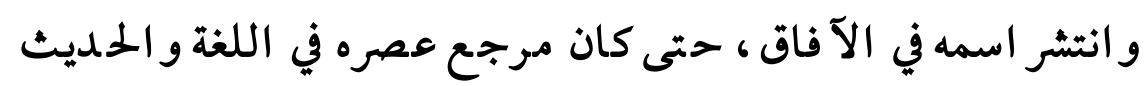

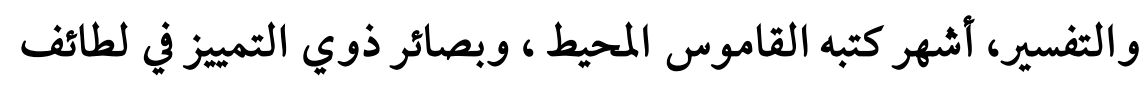

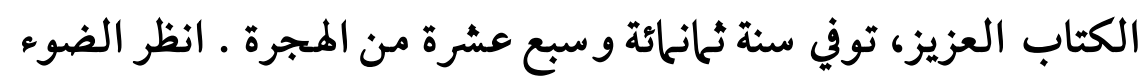

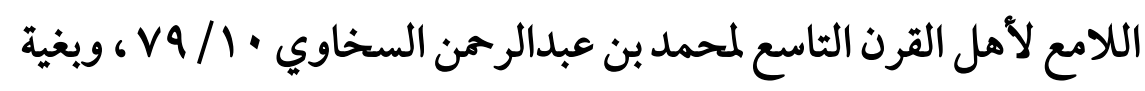

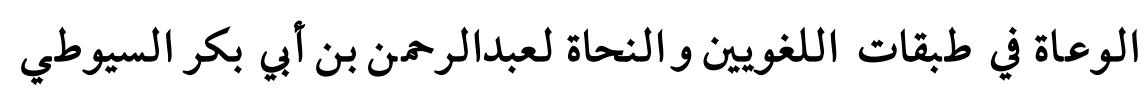
ا 


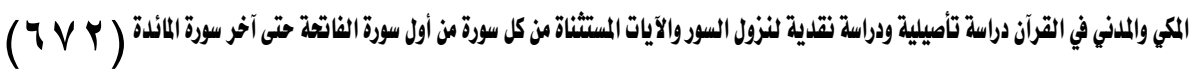

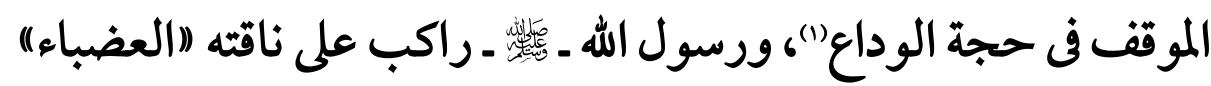
فسقطت الناقة على ركبتها من ثقل الوحي وشرف الآية (r)":اهـ

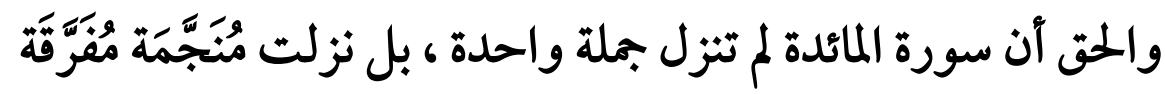

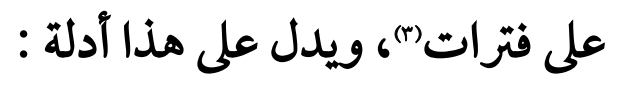

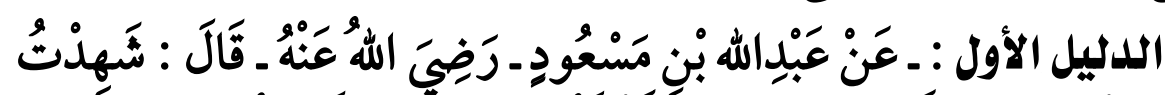

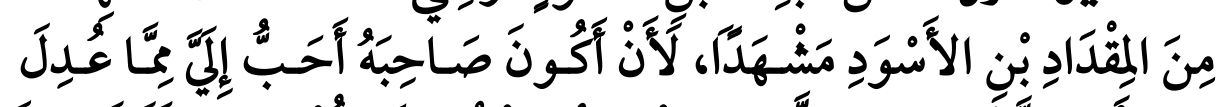

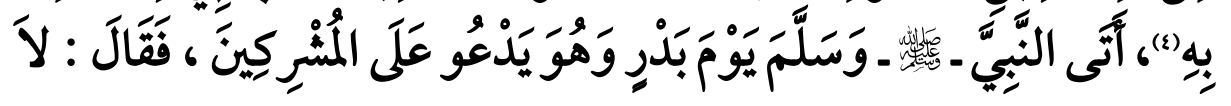

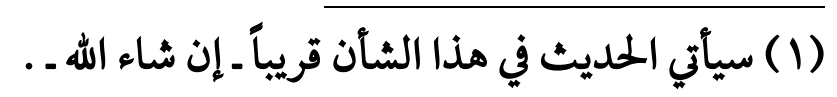

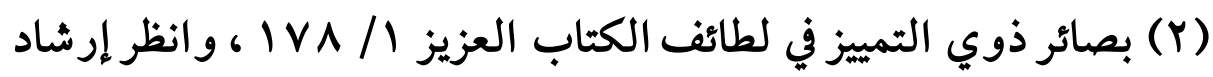

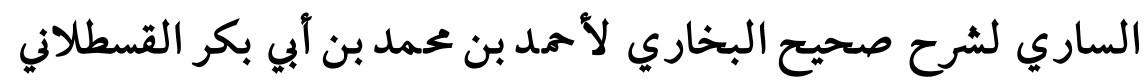

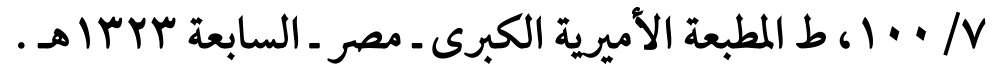

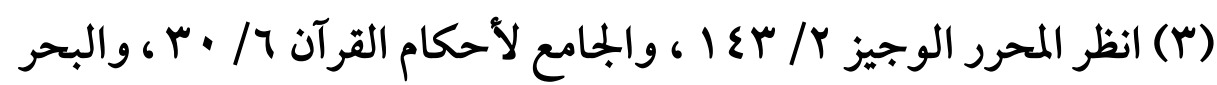

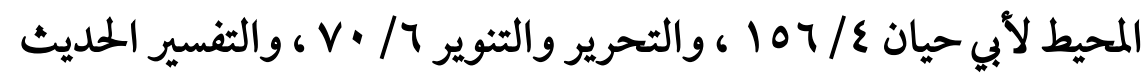

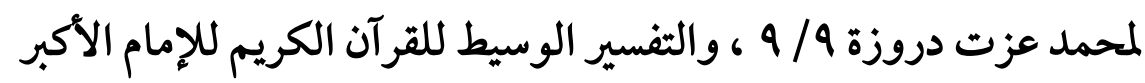

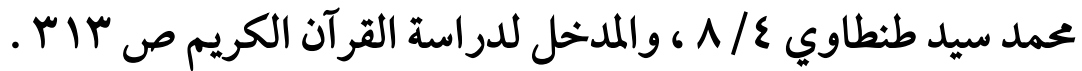

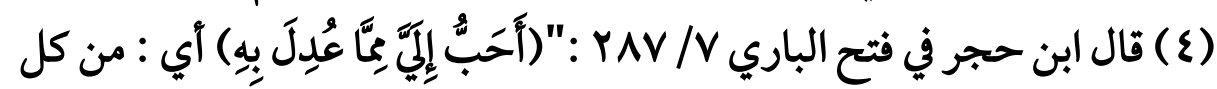

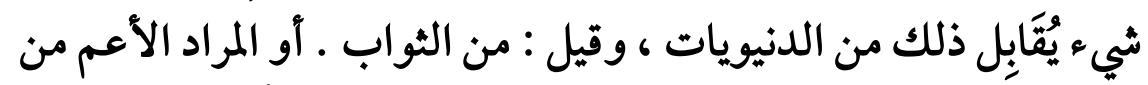

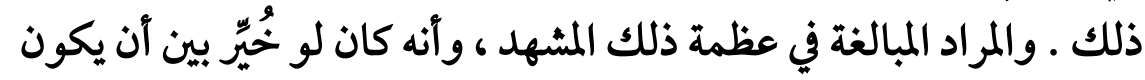

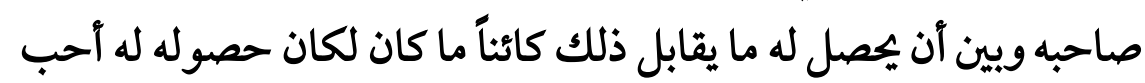
إليه":اهـ . 


\section{(TVT)}

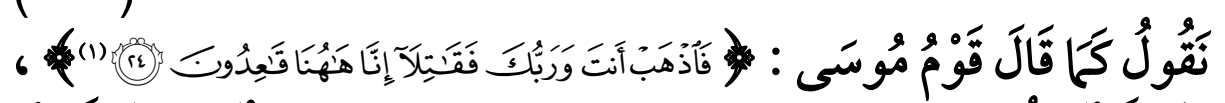

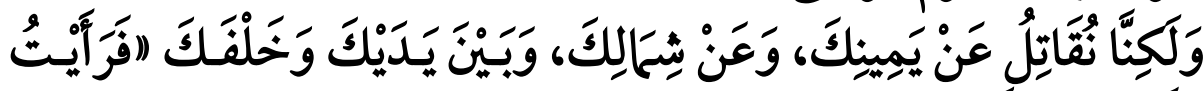

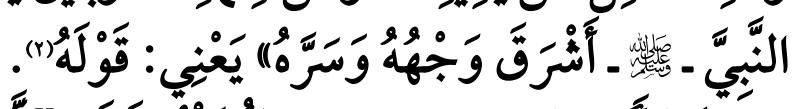

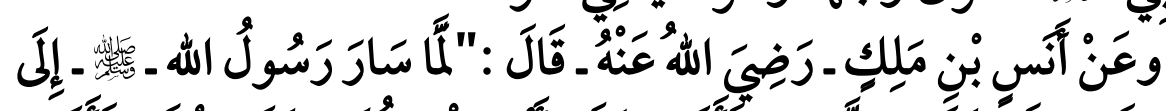

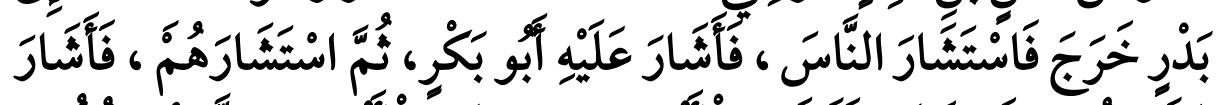

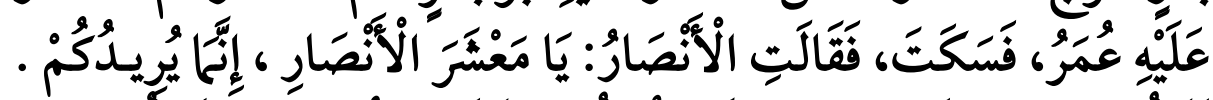

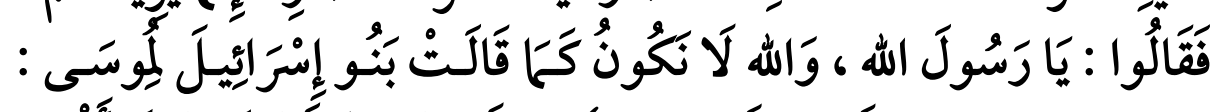

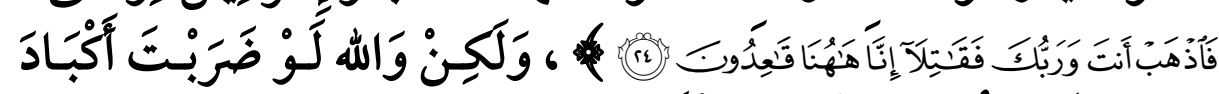

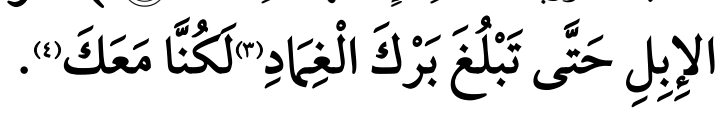

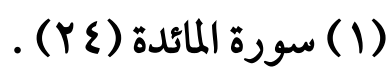

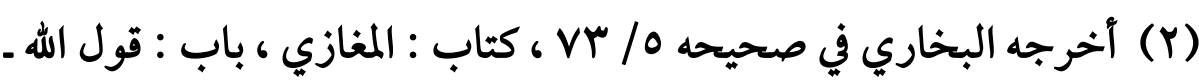

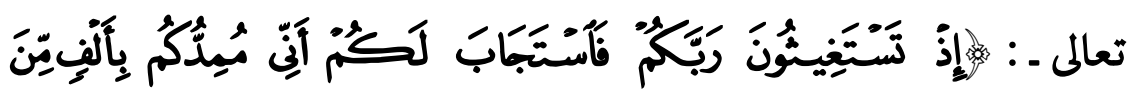

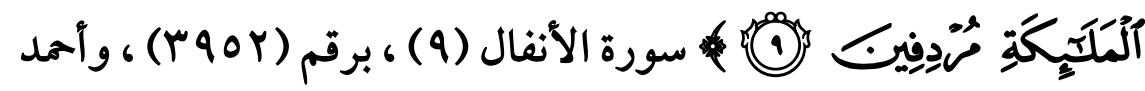

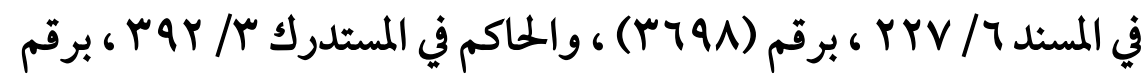
. (0\&A7)

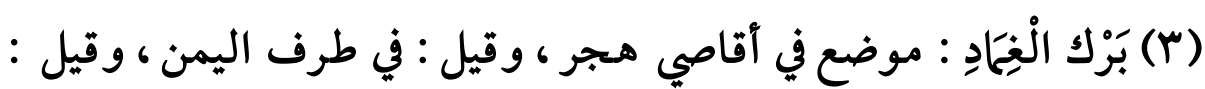

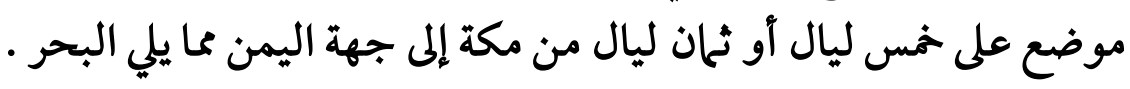

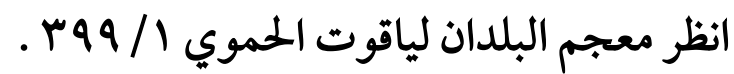

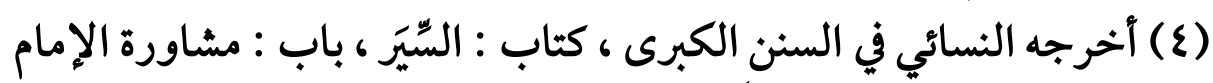

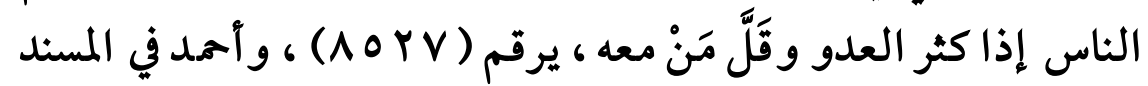

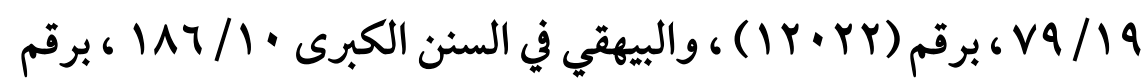




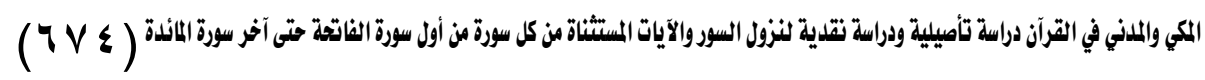
فهذان الحديثان يفيدان أن الصحابة كانوا على علم قبـل غزوة بـدر

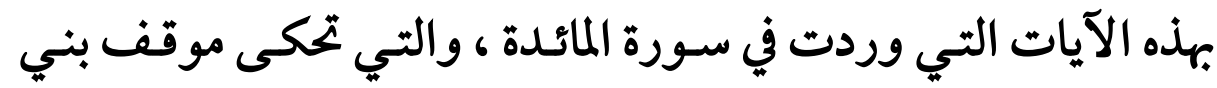

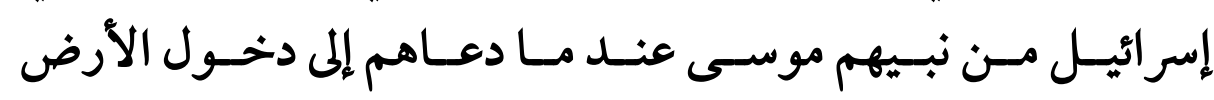

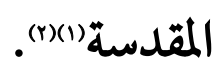

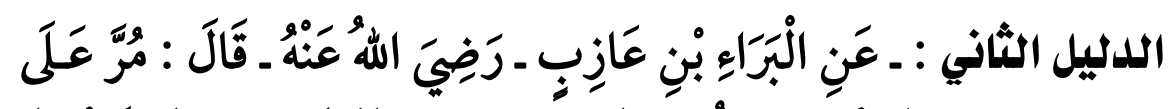

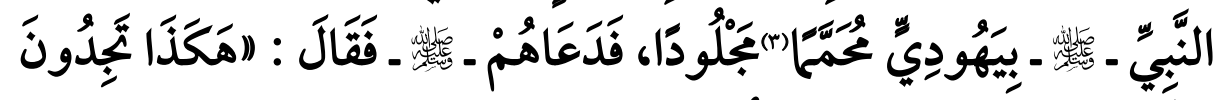

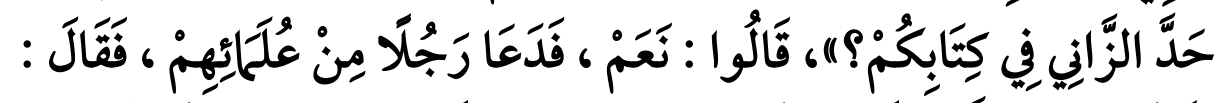

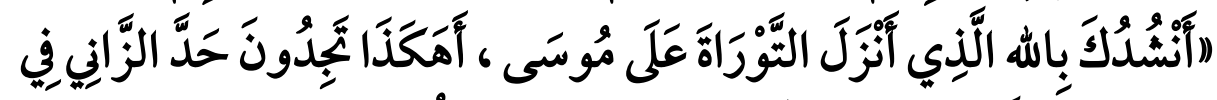

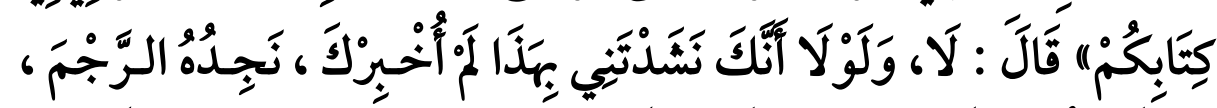

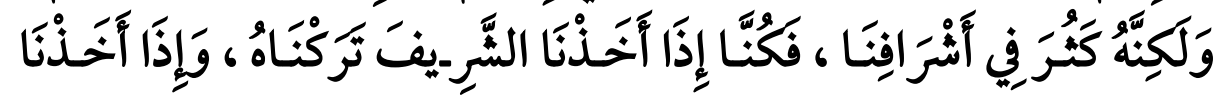

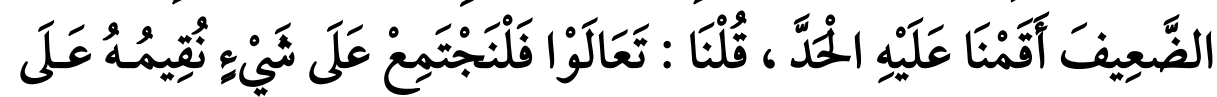

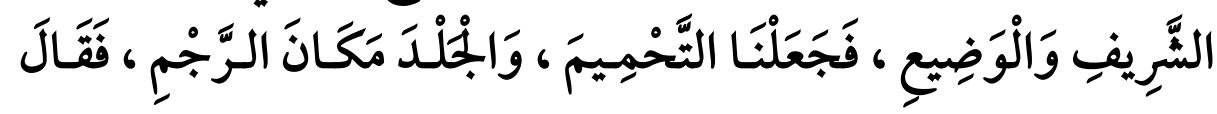

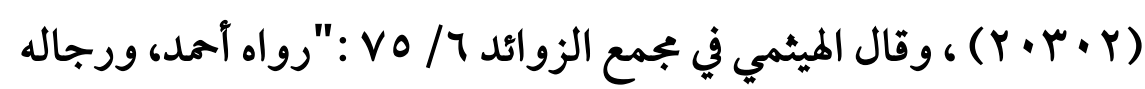

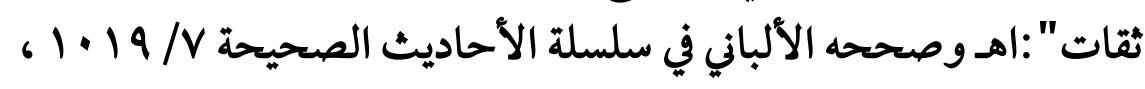

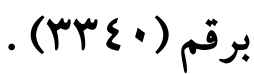

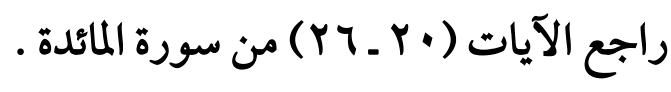

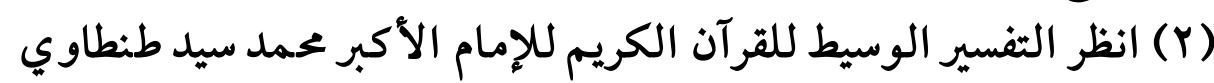

$$
9 / \varepsilon
$$

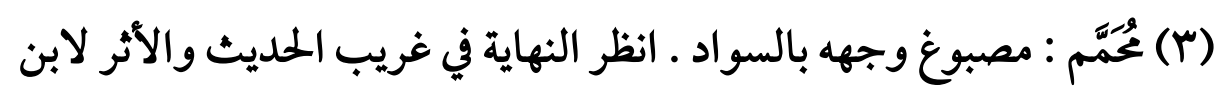

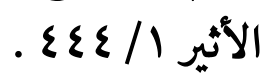


(ivo)

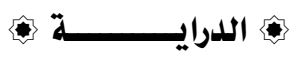

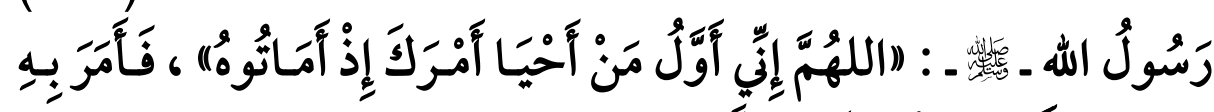

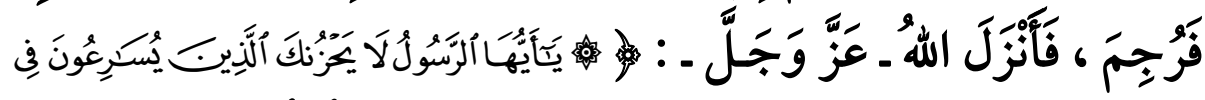

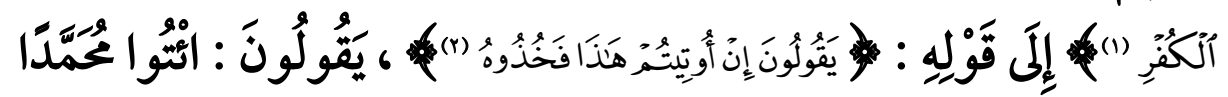
ـ ـأس

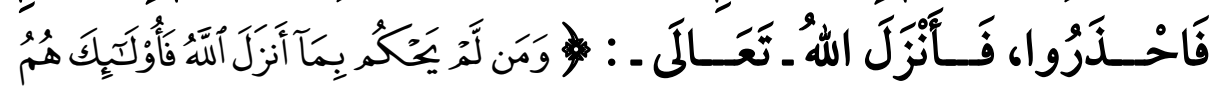

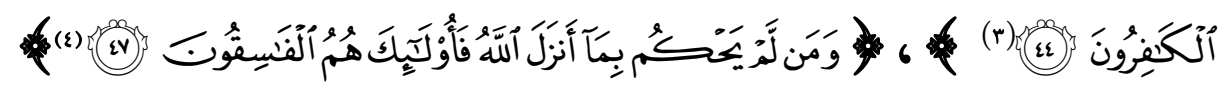
، فِي الْكُفَّارِ كُلْلَّاَ).

فهذه الآيات من سورة المائدة تحكى آلواناً من تعنت اليهود مع النبي ـ ـ إس

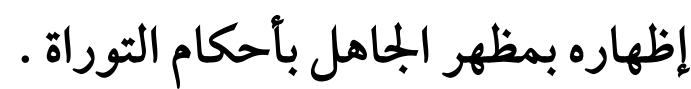

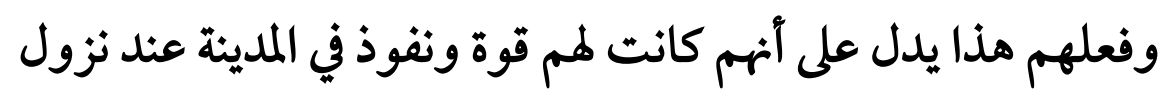

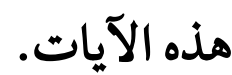

\begin{tabular}{|c|}
\hline (1) سورة المائدة (1) . \\
\hline (Y) سورة المائدة (1) . \\
\hline (Y) سورة المائدة (0) ) . \\
\hline (ع) سورة المائدة (عV) . \\
\hline
\end{tabular}

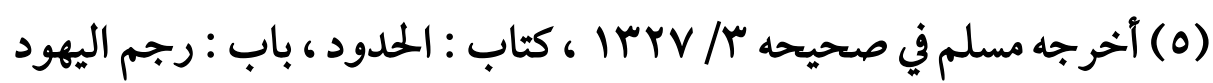

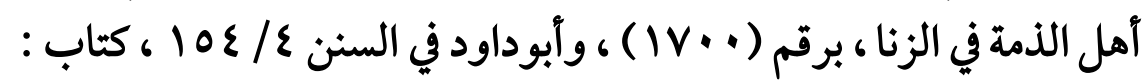

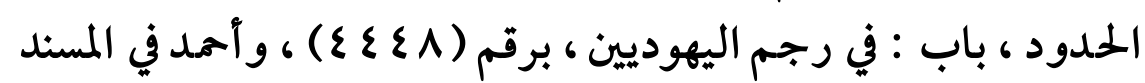

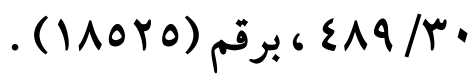




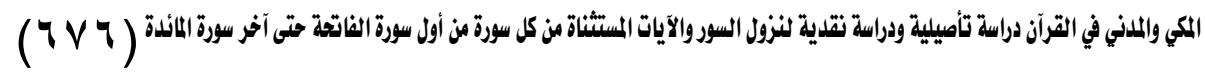
ومن المعروف أن نفوذ اليهود بالمدينة قد تلاشى بعد غزوة بني قريظة في السنة الخامسة من المجرة ـ وأن قوتهم قـد زالت بعـد فتح خيبر في أوائل السنة السابعة من الهجرة ، مما يدل على آن هذه الآيات نزلت قبل السنة الخامسة من المجرة").

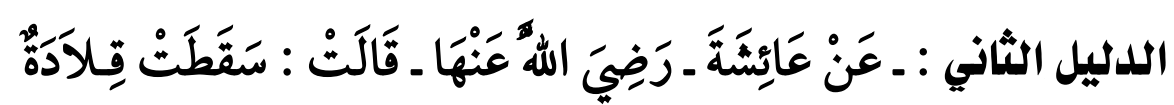

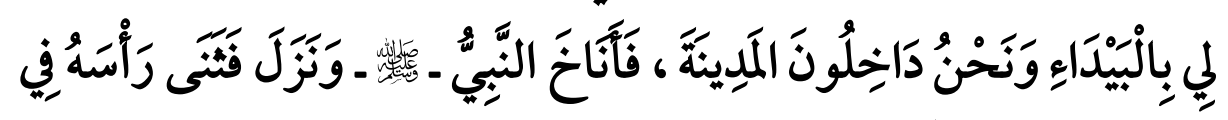

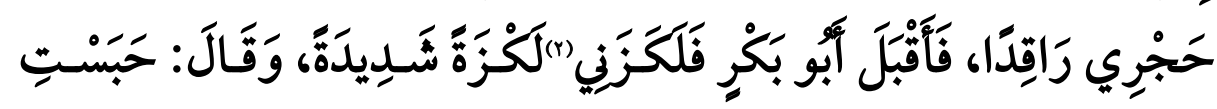

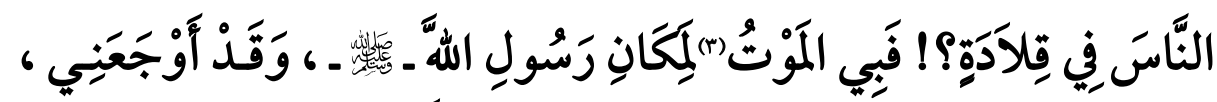

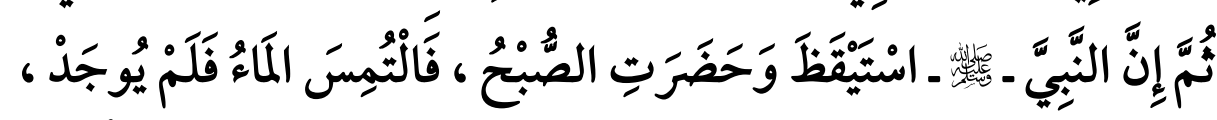

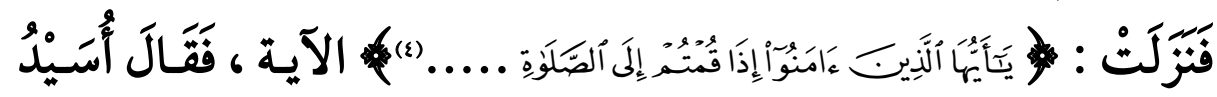

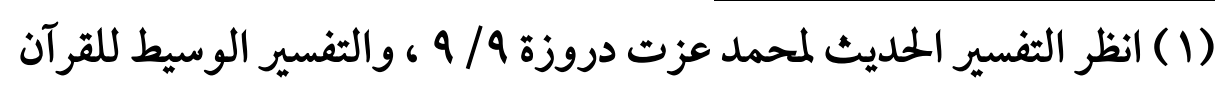

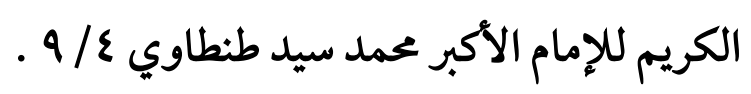

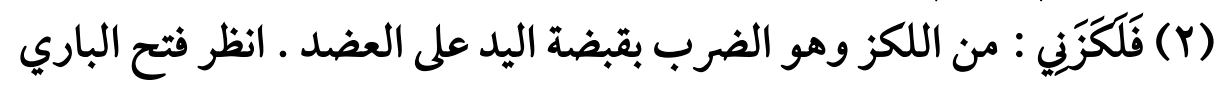

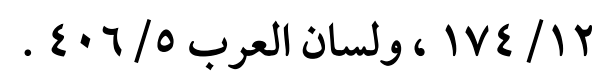

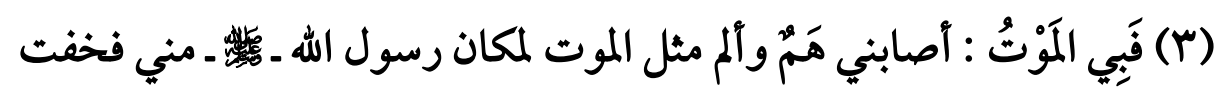

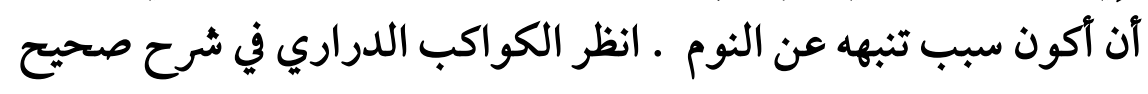

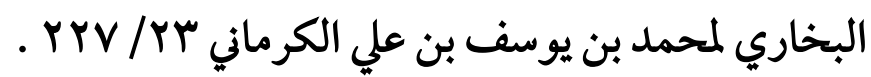

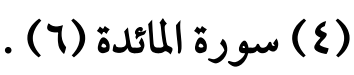


(TVV)

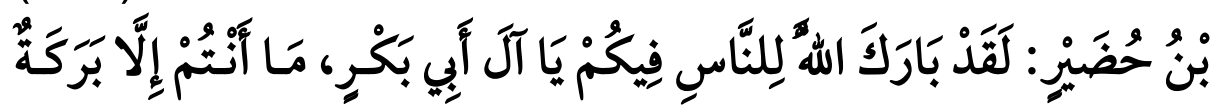

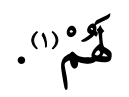

(1) أخرجه البخاري في صحيحه // / 0 ، كتاب : تنسير القرآن ، باب : قوله :

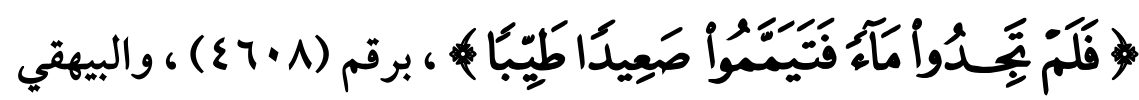

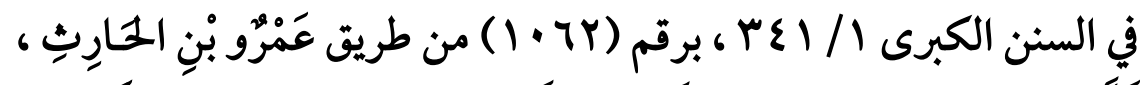

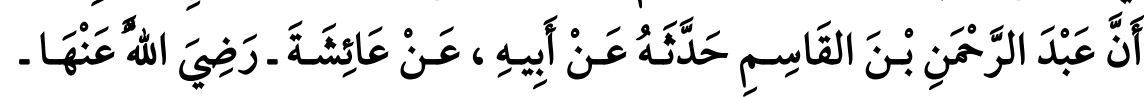

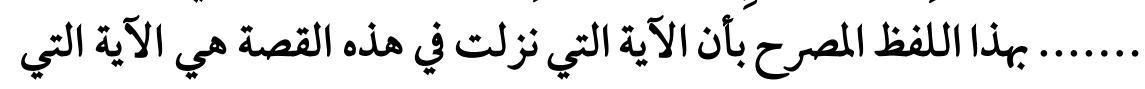

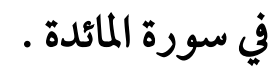

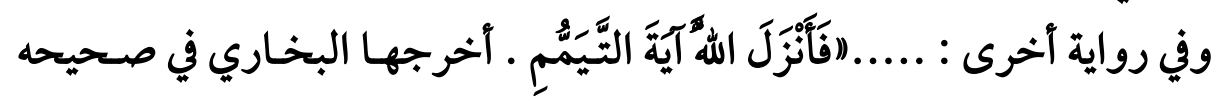

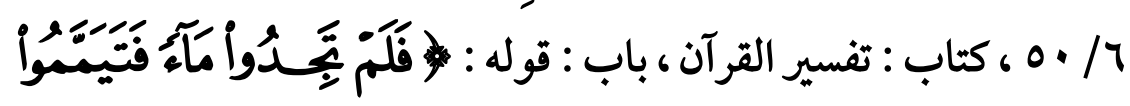

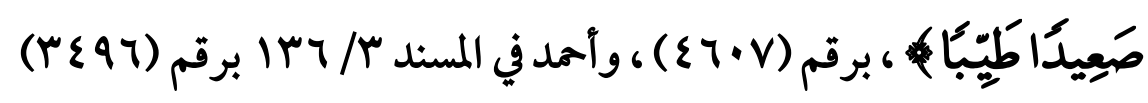
ومن ثم فكون آية التيم في هذا المديث مي آية المائدة ليس عل اتفاق بين العلاء

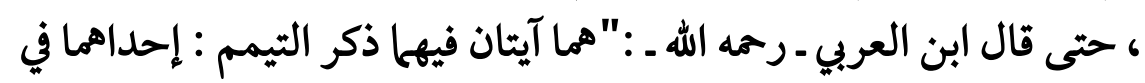

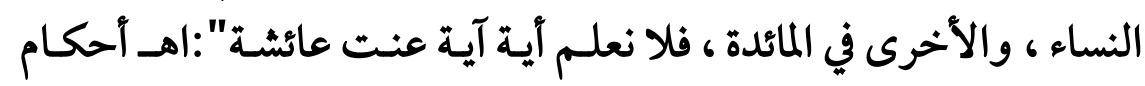

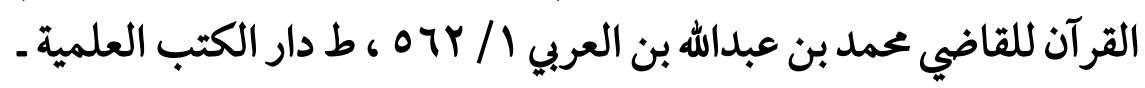

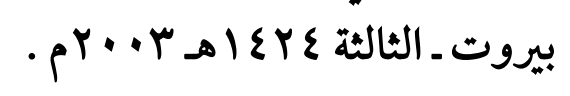

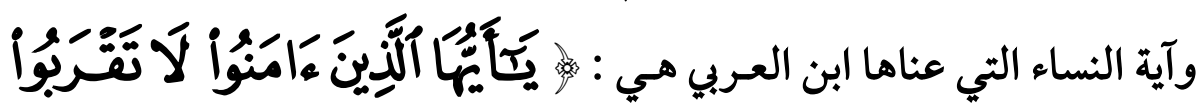

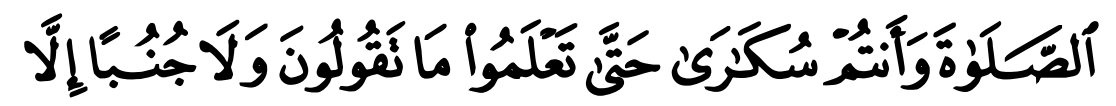




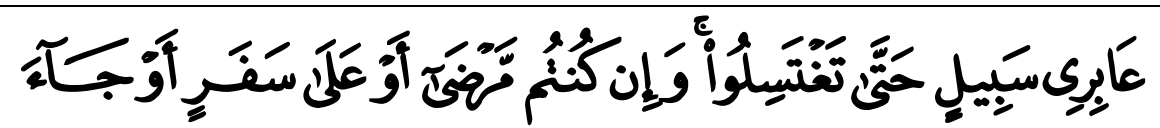

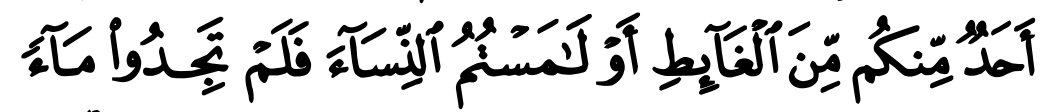

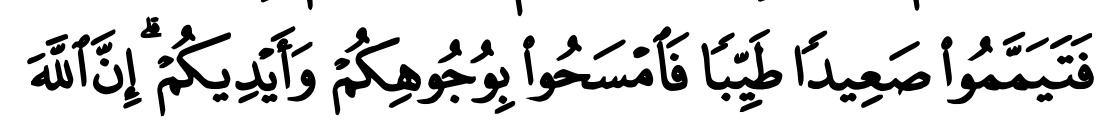

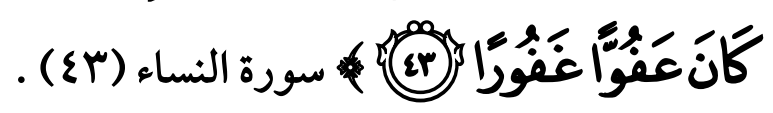

وفي تفسير آية النساء هذه ذكر القرطبي توقف ابن العرات العربي في تعيين أي الآيتين

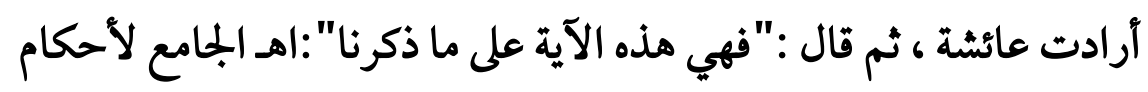

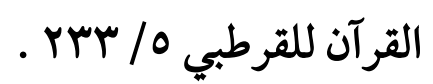

قال ابن حجر :"قال القرطبي : هي آية النساء ، ووجهه بأن آية المائدة تسمى آية

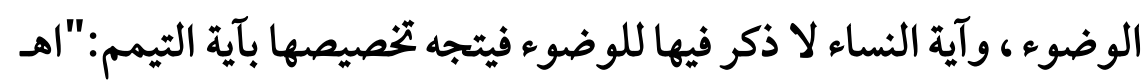

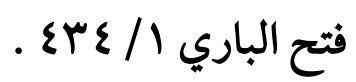

والصحيح آن عائثة ـ رضي الله عنها ـ عنت بآية الثيمم آية سورة المائدة ، والأدلة

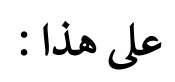

أولاً : صرحت رواية البخاري والبيهقي من طريق عمرو بن الحارث أن آية

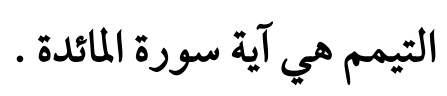

قال ابن حجر :"خفي على الجميع ما ظهر للبخاري من أن المراد بها آية المائدة

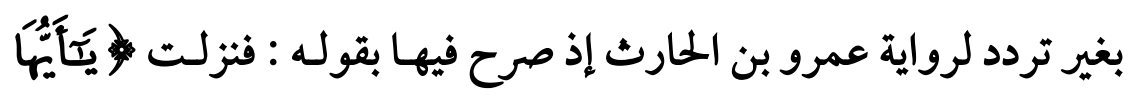

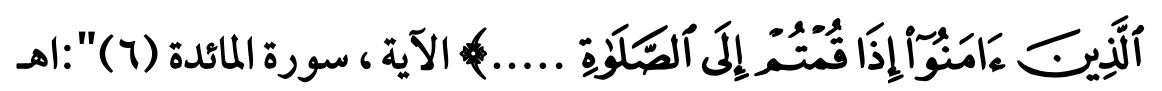

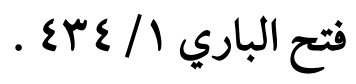


(7v9)

وهذا السفر المذكور في هذا الحديث كان في غزوة المَُيْيسيع إلى بني

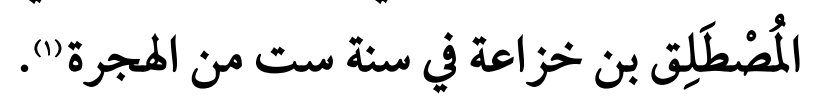

وقال السيوطي :" لا شك أن الذي مـال إليه البخـاري مـن أنها أيـة المائدة هـو

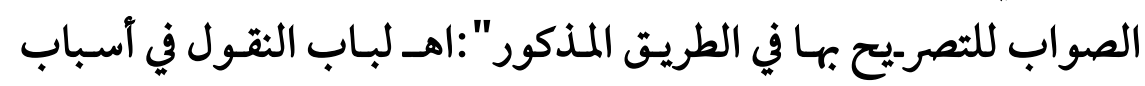

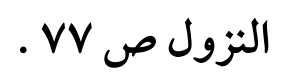

ثانياً : ـ ترجم الإمام البخاري ـ رممه الله ـ في صحيحه لحديث عائشة فقال : كتاب

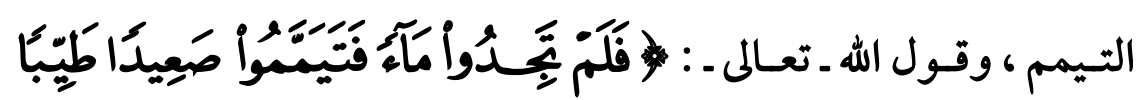

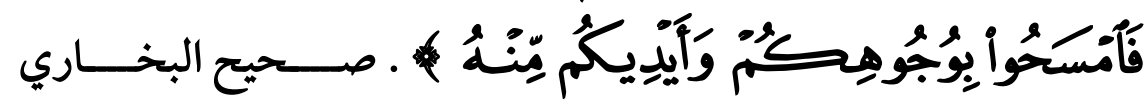
. V $\varepsilon$ و وهذا واضح الدلالة على أن المرادبآية التيمم هي آية سورة المائدة ، لآن آية سورة

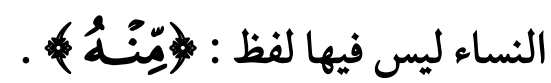
(1) انظر الاستذكار في شرح مذاهب علم)ء الأمصار مما رسمه مالك في موطئه

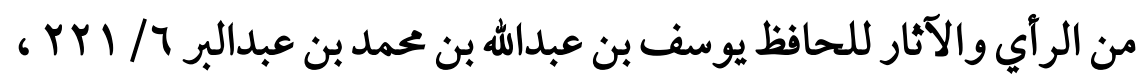

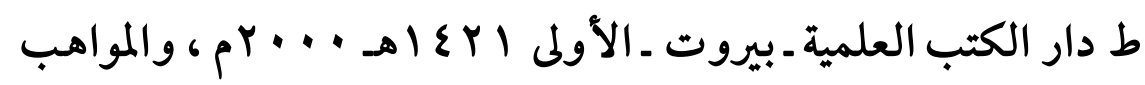

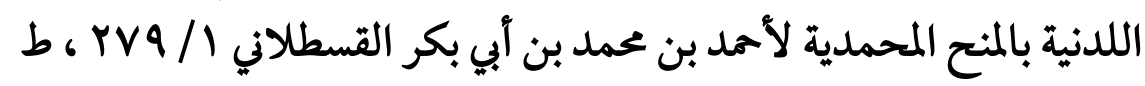

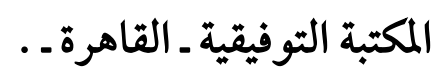

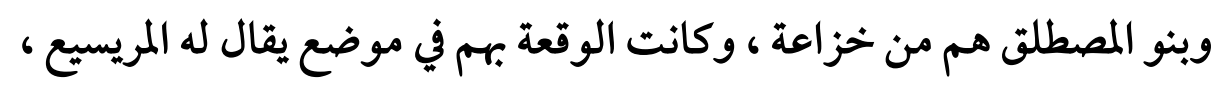

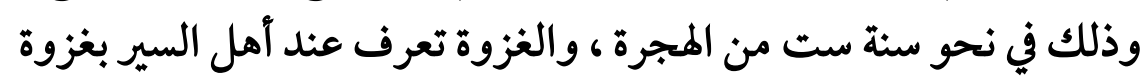

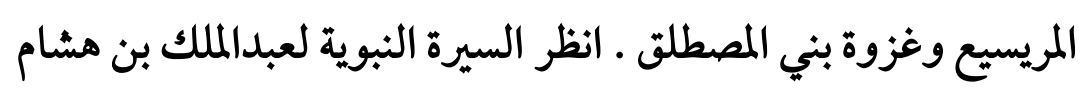




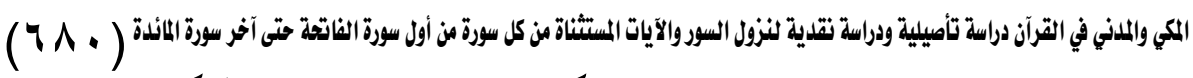

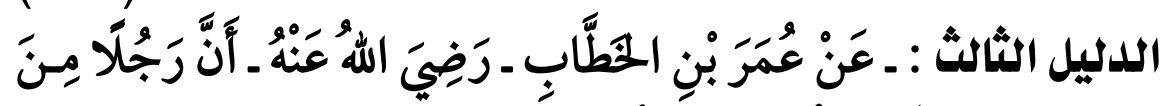

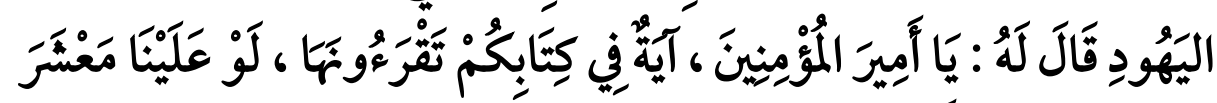

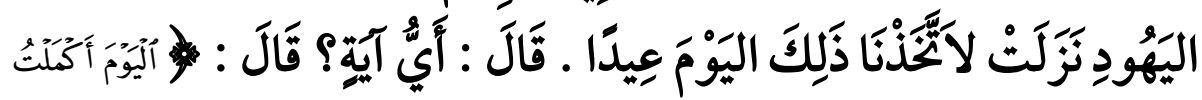

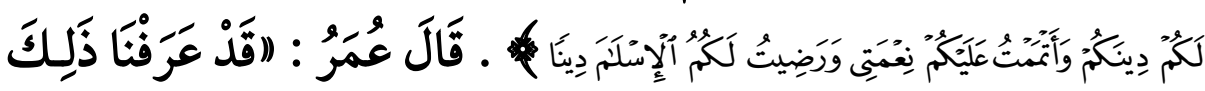

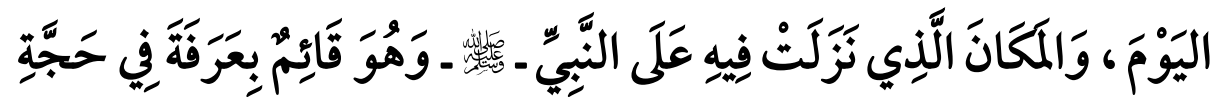

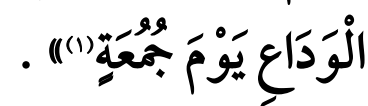
فدلَّ السنة الصحيحة على آن بعضى آيات سورة المائدة قد نـزل في حجة الوداع ، وبعضهها قـد نزل بعـد غـزوة المريسـيع ، وبعضسها كـان

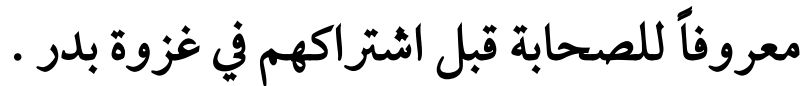
وبعض آيات هذه السورة تحكى آحداثاً وبجادلات قد حصلت بـت بـن

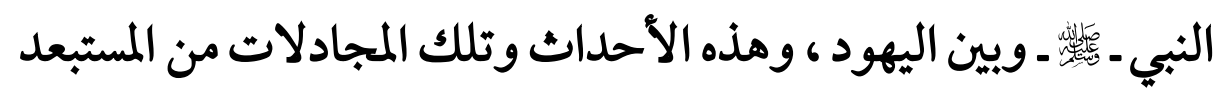
أن تكون قد حدثت بعد غزوة بني قريظة في السنة اللخامسة من المجرة ،

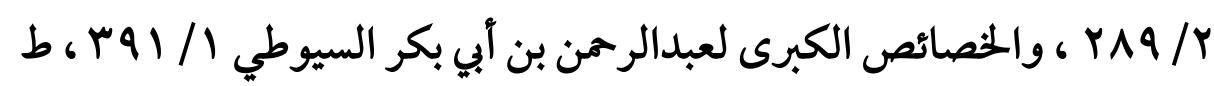

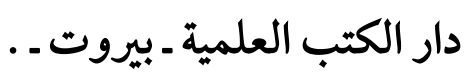

(1) أخرجه البخاري في صحيحه 7/ / 1 ، كتاب : تفسير القرآن ، باب : قوله :

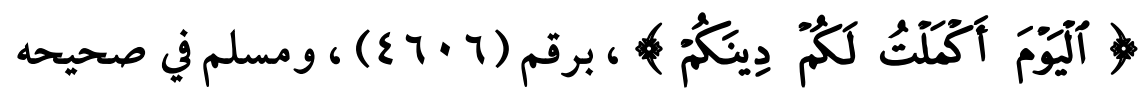

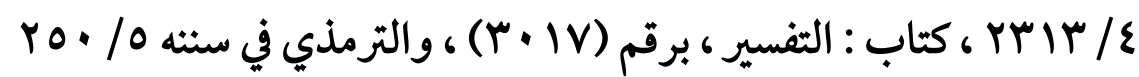

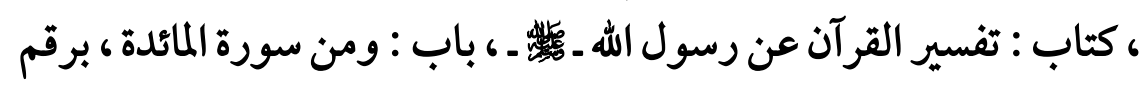


(4N1)

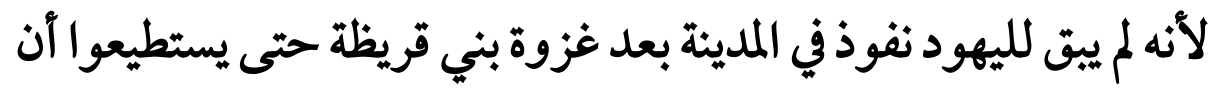

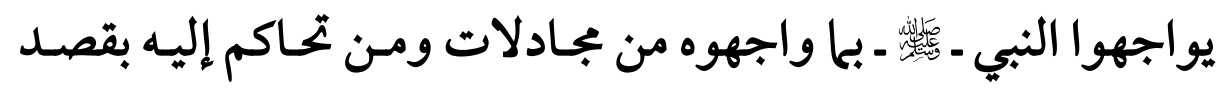
إحراجه.

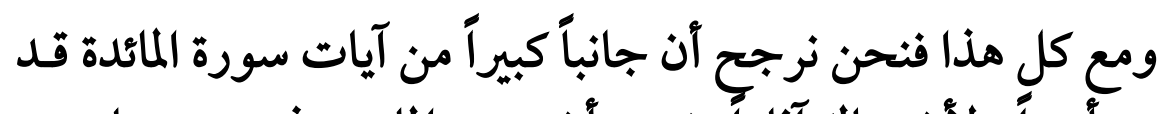

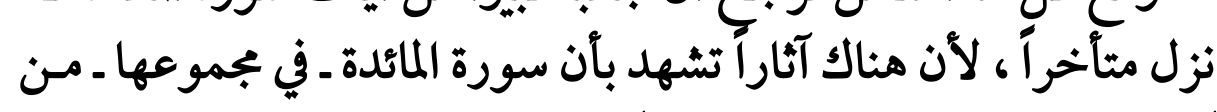

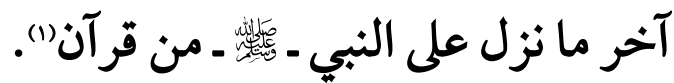

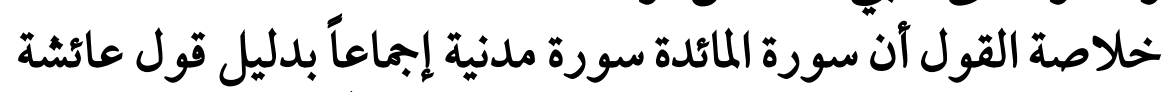

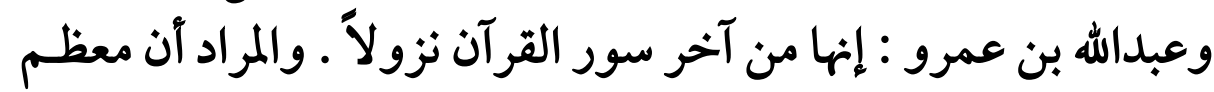

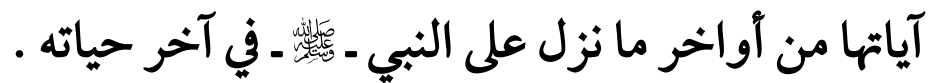

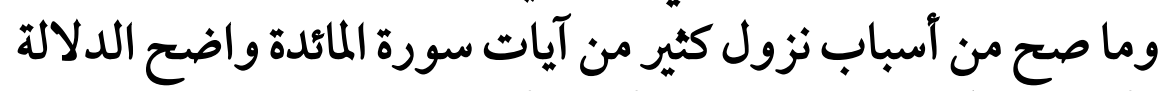

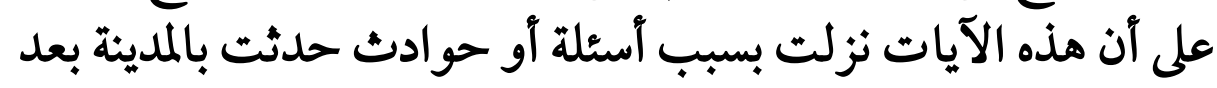

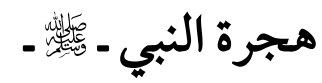
والقضايّا التي تحدثت عنها سورة المائدة هي قضايا خصائص السور المدنية . - المغايا ولم تنزل سورة المائدة دفعة واحدة بدليل أسباب نزول بعض آياتها ،

$$
\text { وهي حوادث حدثت في أزمنة متباعدة . }
$$

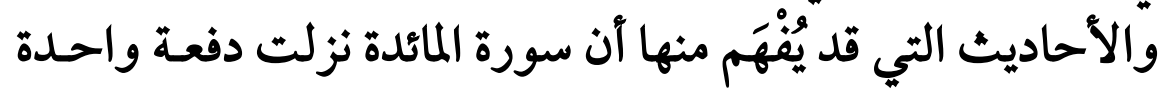

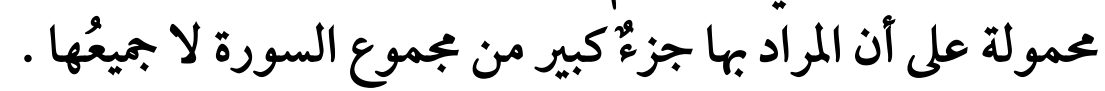

(1) انظر التفسير الوسيط للقرآن الكريم للإمام الأكبر محمد سيد طنطاوي $.1 \cdot / \varepsilon$ 


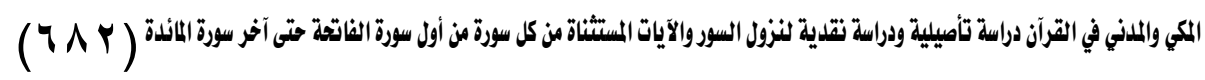

$$
\text { المبحث الثاني }
$$

\section{الآيتان المستثناتان من سورة المائدة الماندي}

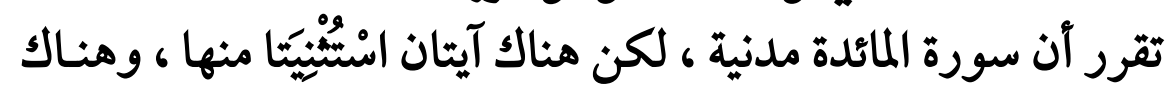

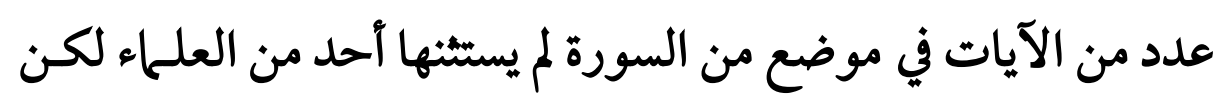

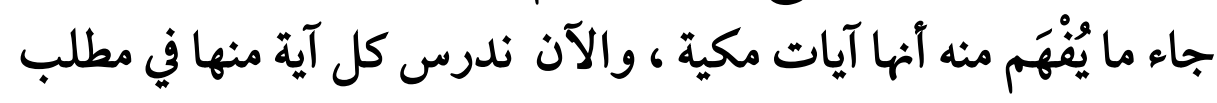

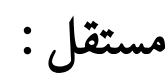

\section{المطلب الأول}

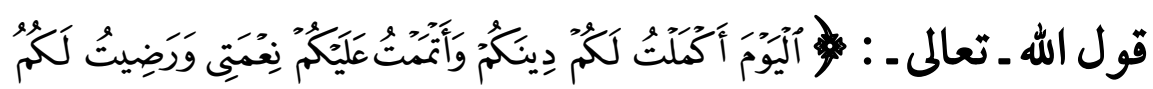

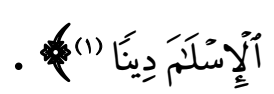

تقرر في المبحث السابق أن هذه الآية نزلت في مكة يوم عرفة في حجة الآنة

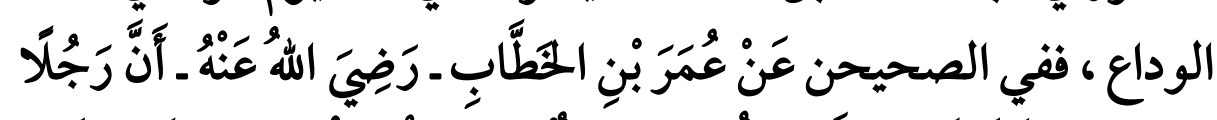

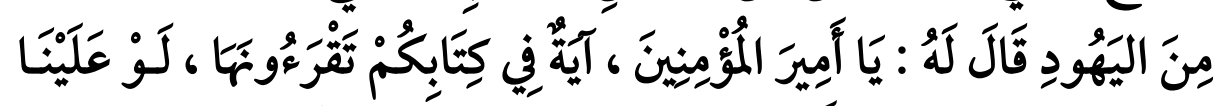

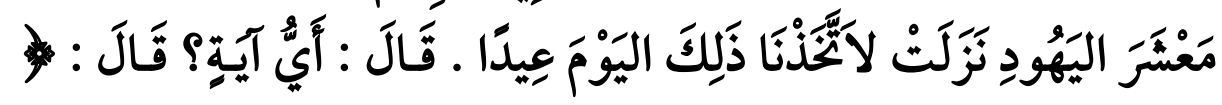

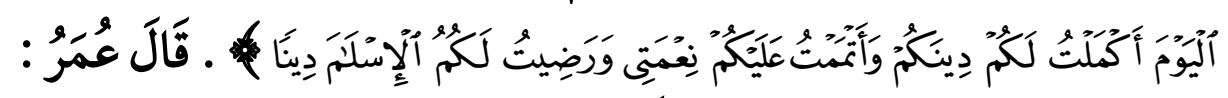

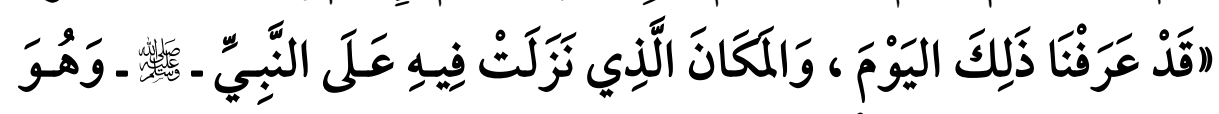

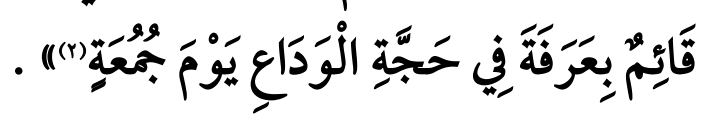

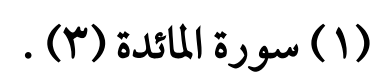

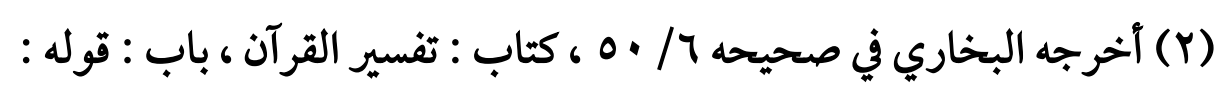

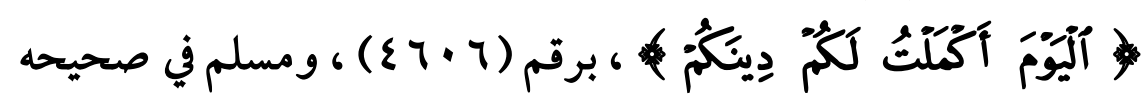

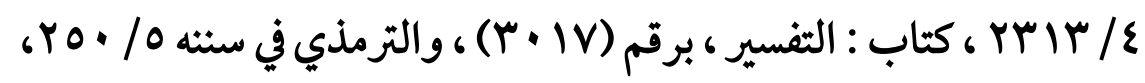


$(\neg \wedge r)$

وللعلماء في شأن هذه الآية ثلاثة اتجاهات :

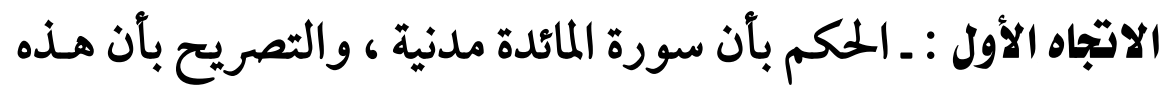

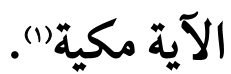

الاتجاه الثاني : ـ الحكم بأن سورة المائدة مدنية باستثئناء آيـة واحـدة

هي هذه الآية ، ولكن من غير تصريح بأن حكمها مكي (r).

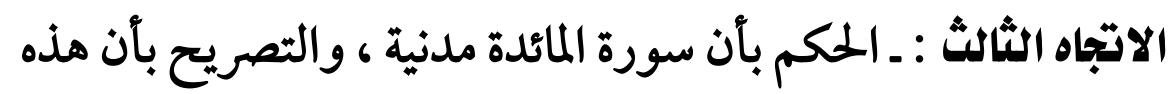

الآية مدنية ـ أيضاً ـ مع أنها نزلت في مكة يوم عرفة في حجة الوداع لمان.

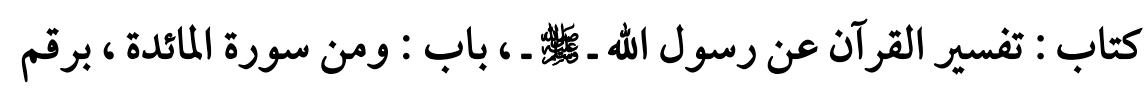
(r. $(r)$

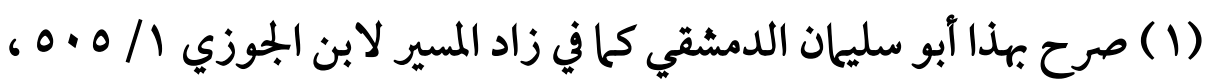

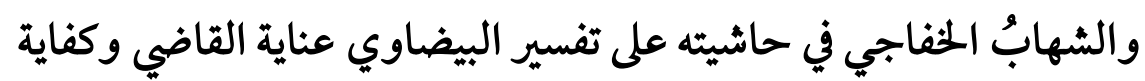

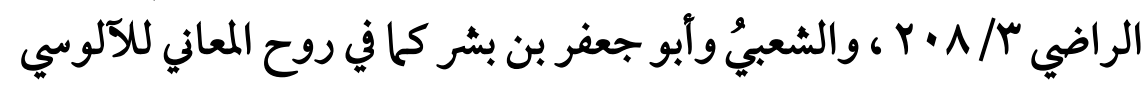
. Tr

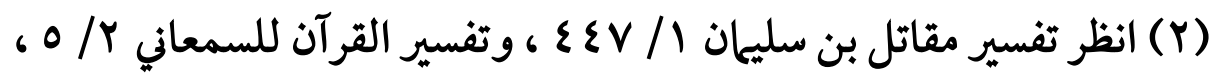

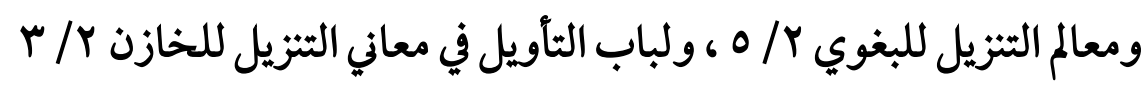

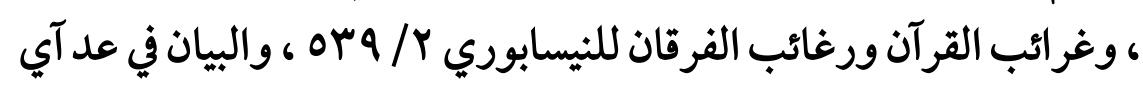

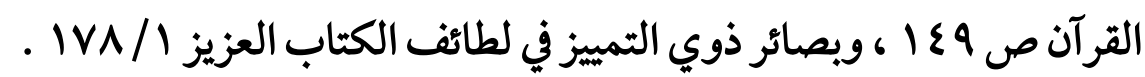

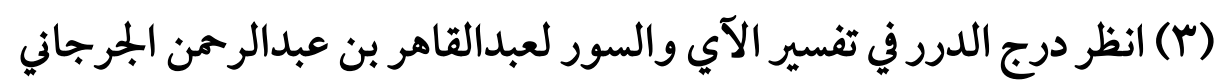

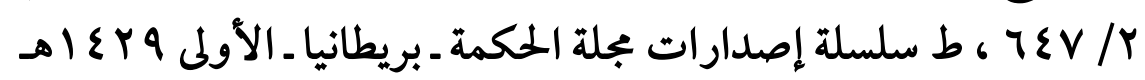

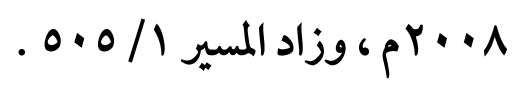




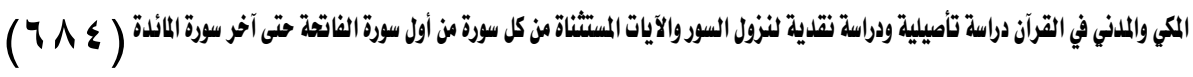
وهذا القول هو الصواب الذي عليه جمهور العلمله ، لآن كل مانزل

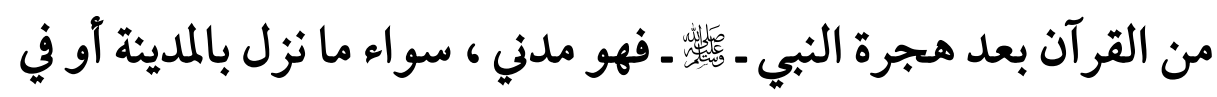

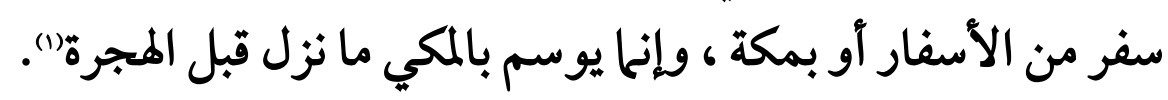

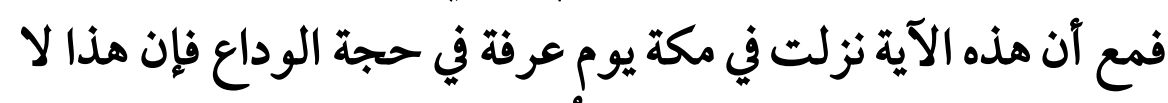

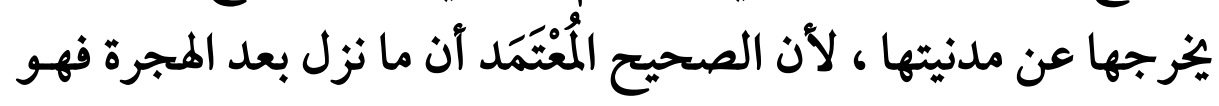

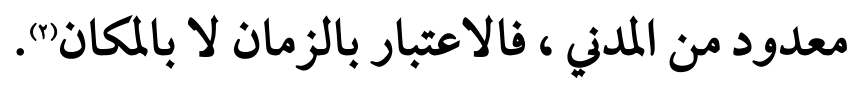

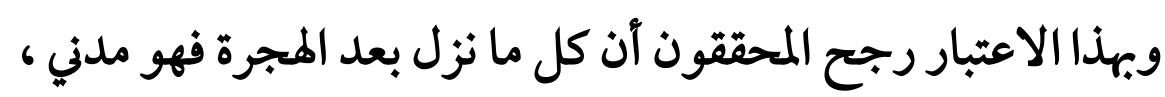

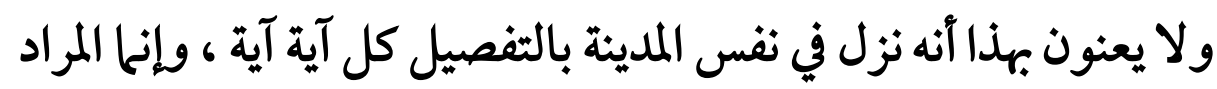

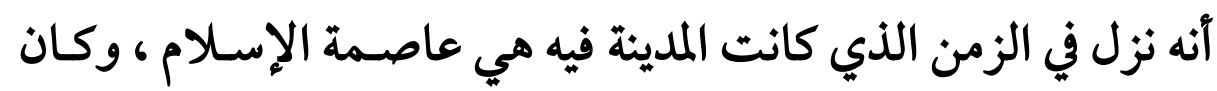

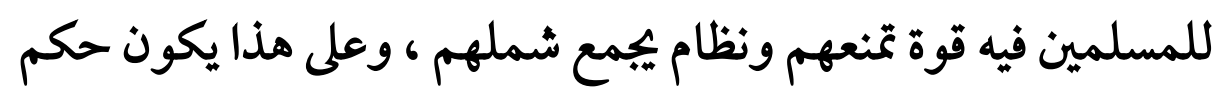
ما نزل بمكة عام الفتح ، أو عام حجة الوداع كحكم ما نزل فئم في الحديبية

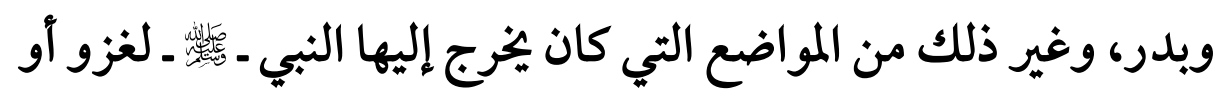
غيره على عزم العود إلى المدينة).

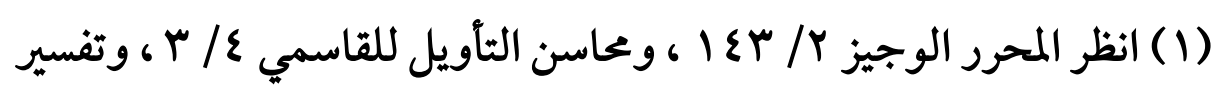

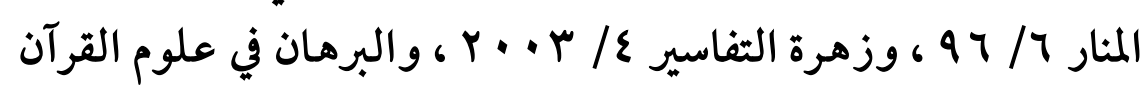

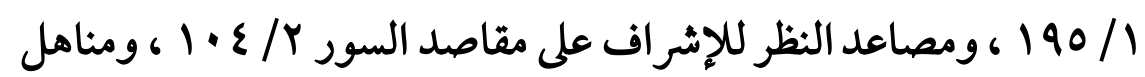

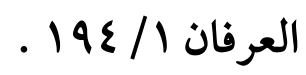

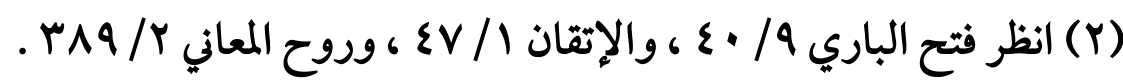

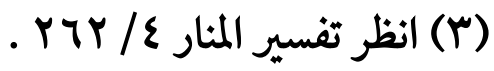


$(7 \wedge 0)$

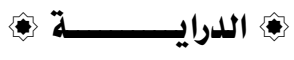

خلاصة القول أن الآية محل البحث نزلت في مكة يوم عرفة في حجة

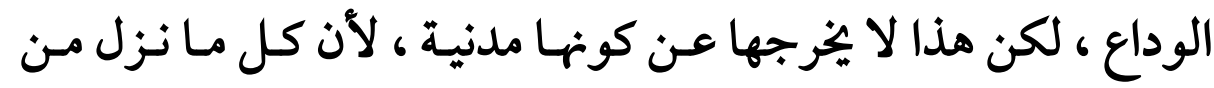

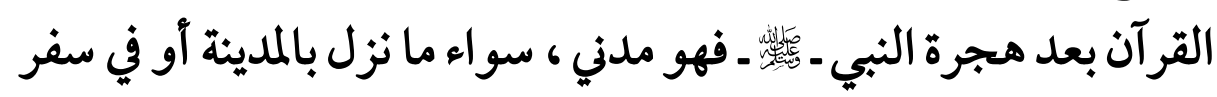
من الأسفار أو بمكة ، وإنحا يوسم بالمكي ما نزل قبل فيل الهجرة. 


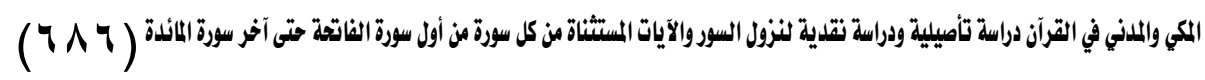

\section{المطاب الثاني}

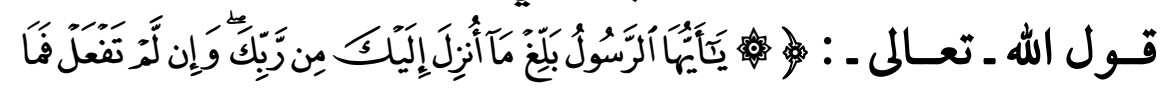

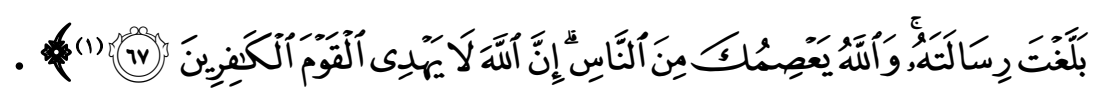

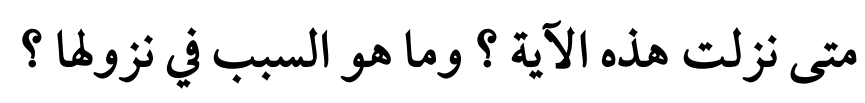

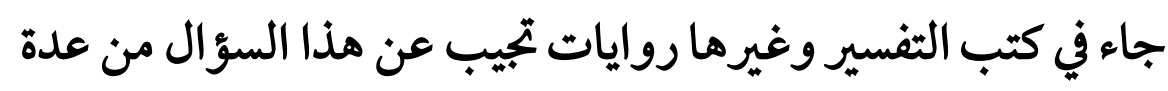

$$
\text { وجوه : }
$$

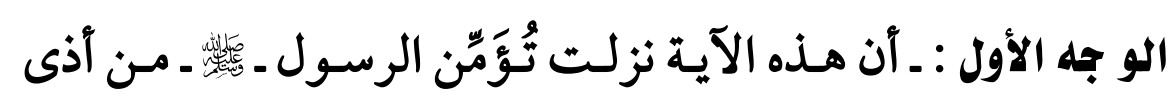

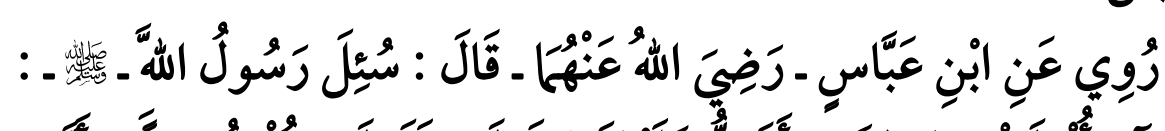

$$
\text { قريش • }
$$

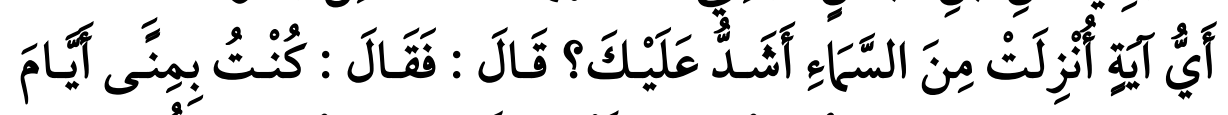

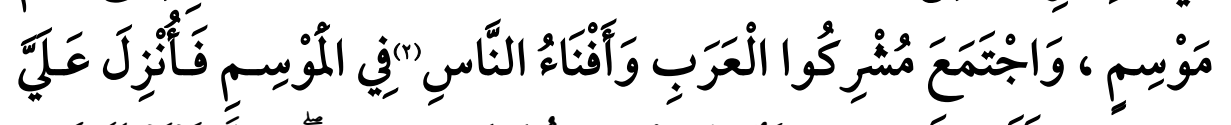

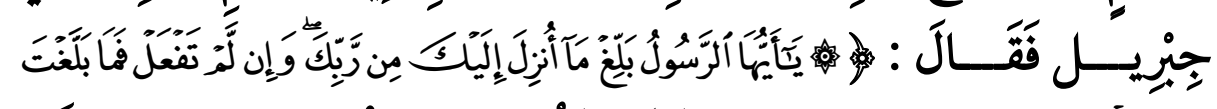

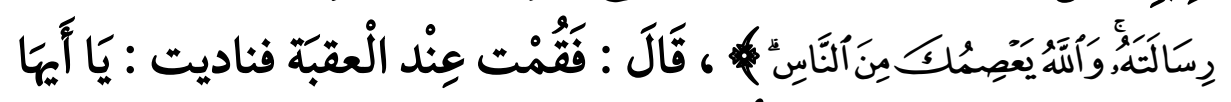

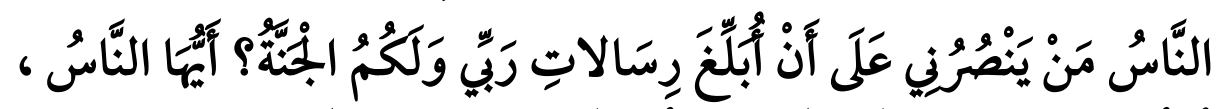

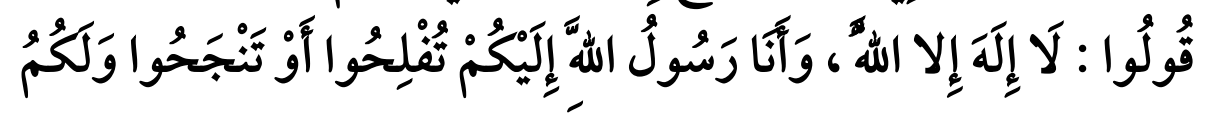

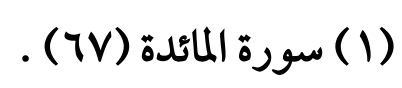

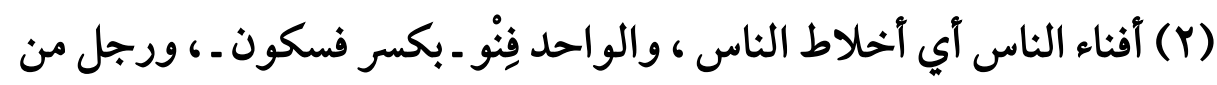

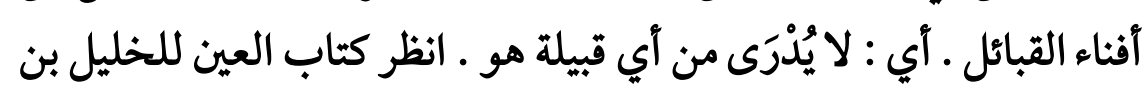

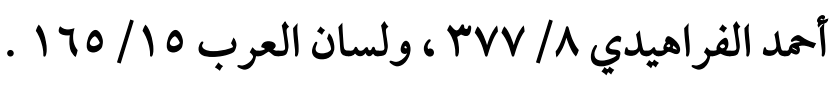


("^v)

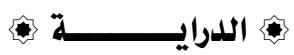

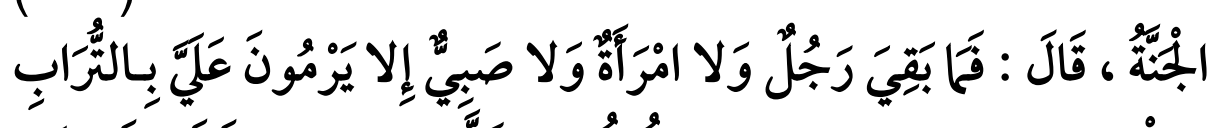

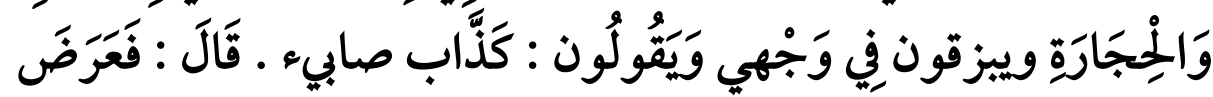

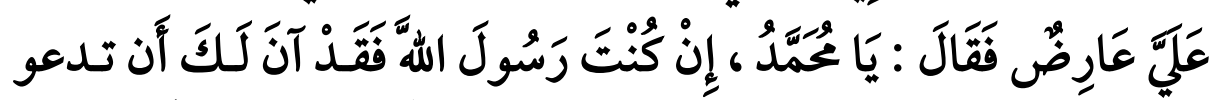

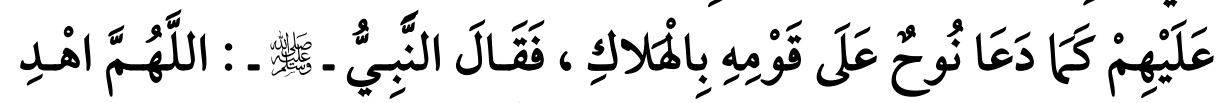

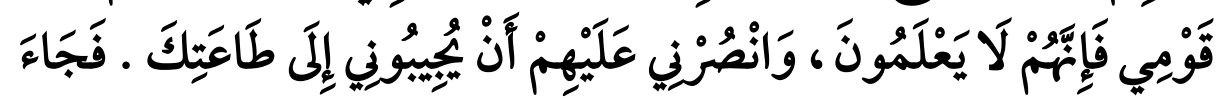

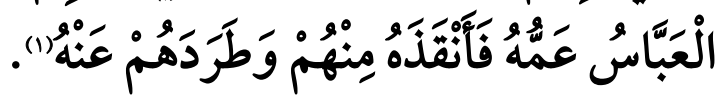

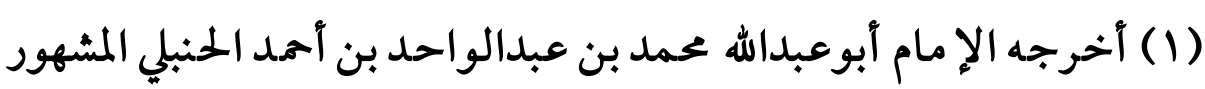

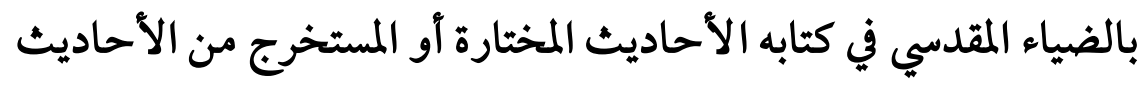

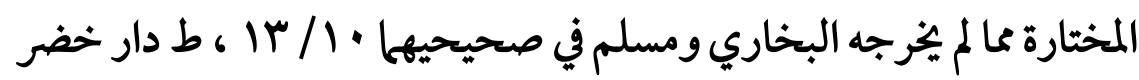

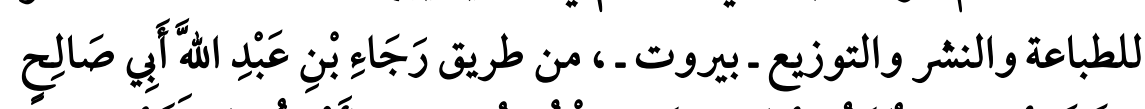

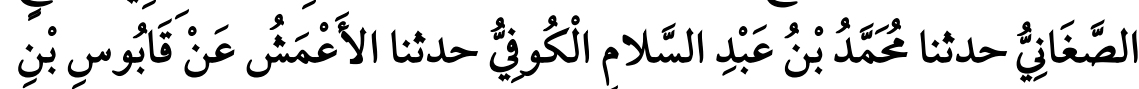

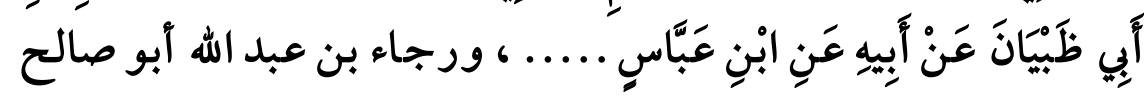

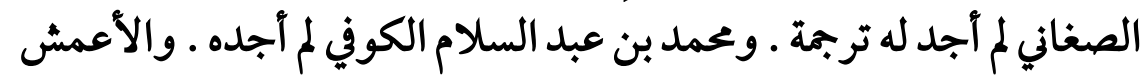

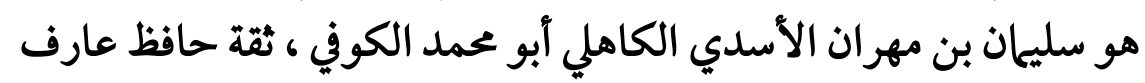

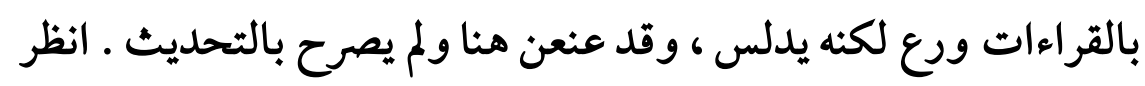

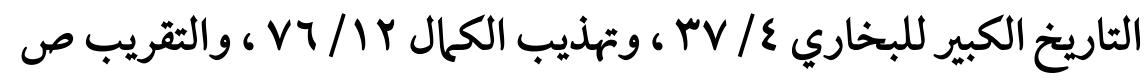

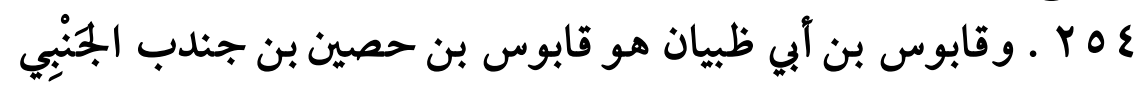

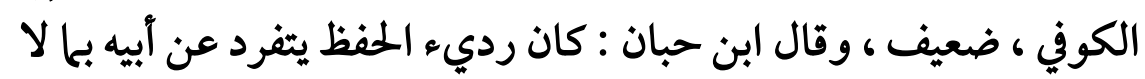

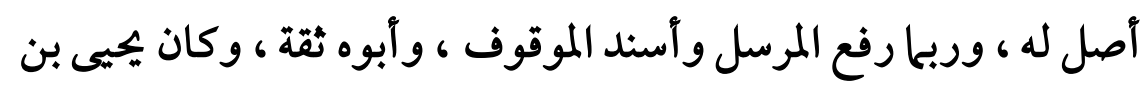

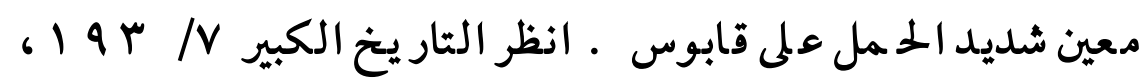

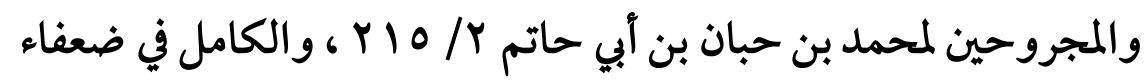




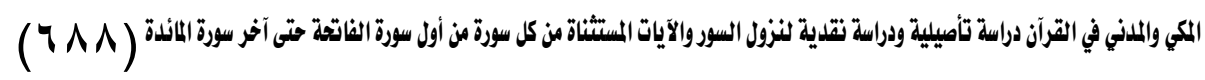

$$
\text { وهذا يقضي أن الآية مكية نزلت قبل المجرة . }
$$

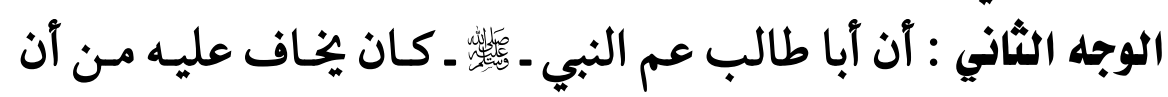

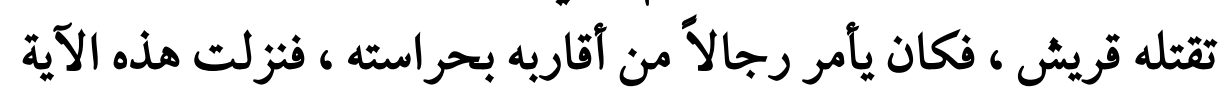

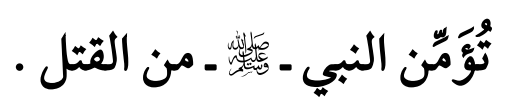

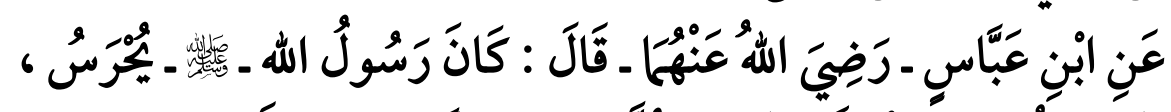

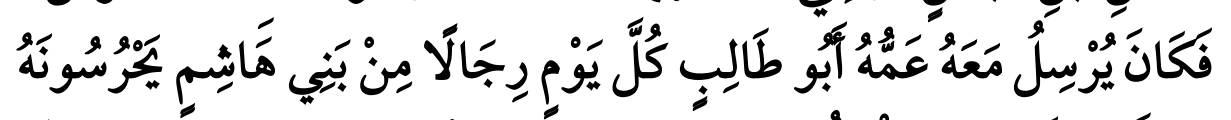

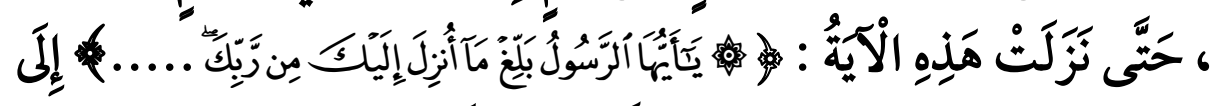

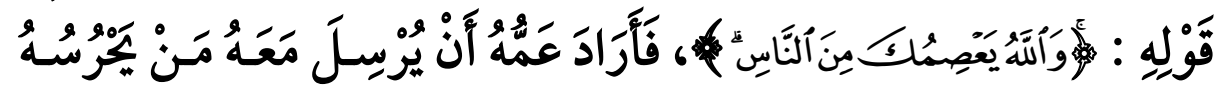

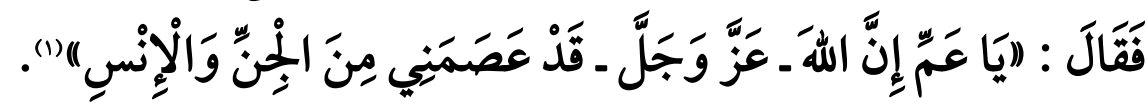

الرجال لابن عدي 1/ / ـ ـ ـ ومن ثم فالحديث مسلسل بالعلل فهو ضعيف

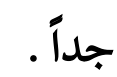

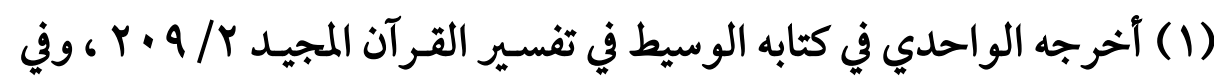

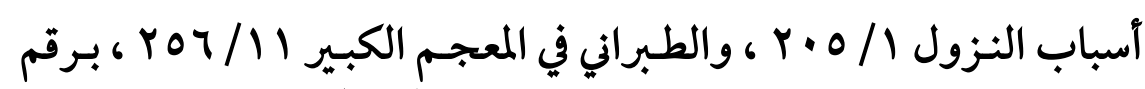

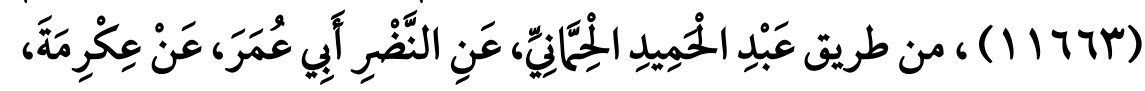

وعبد الحميد بن عبدالرممن الحماني قال عنه علماء الجرح والتعديل : ضعيف ليس

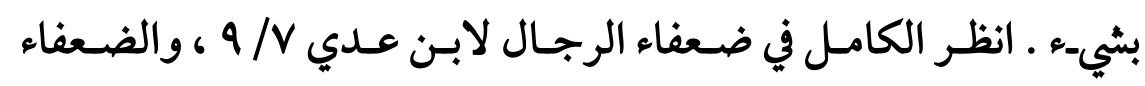

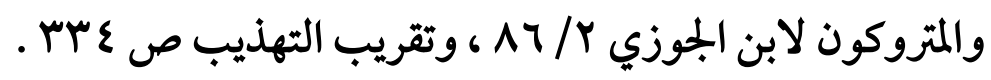

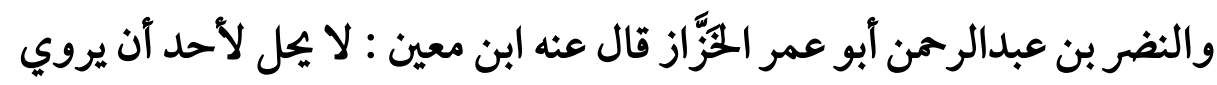

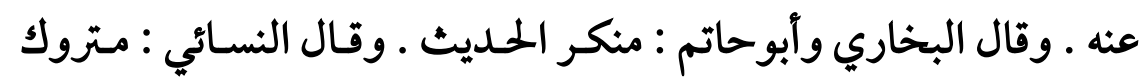


$(7 \wedge 9)$

وهذا ـ أيضاً ـ يقضي أن الآية مكية نزلت قبل المجرة . . هال

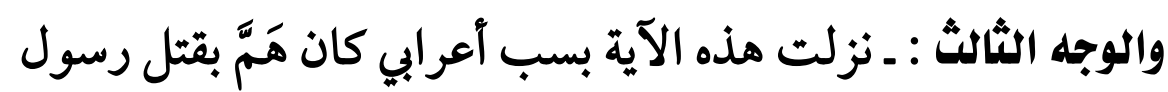

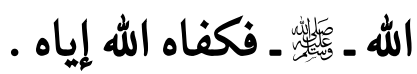

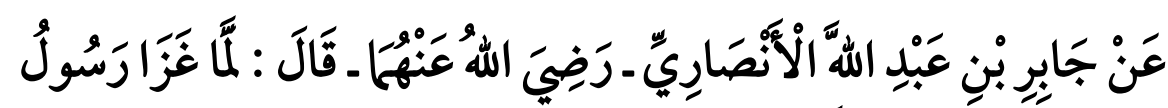

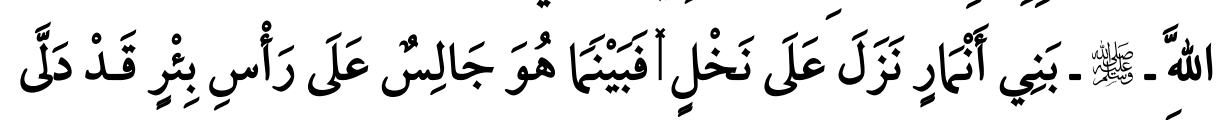

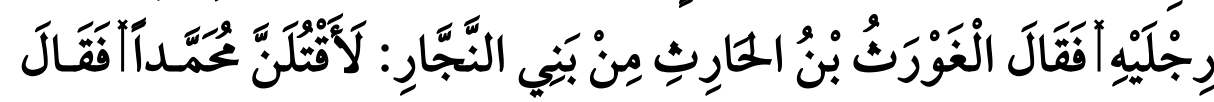

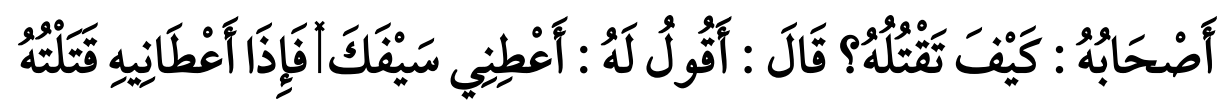

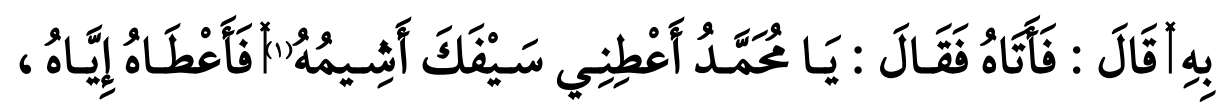

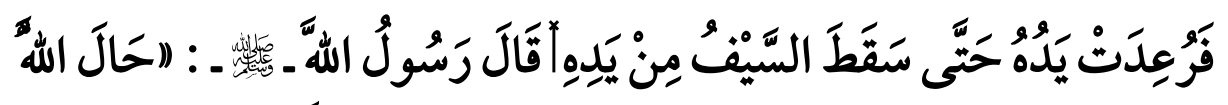

الحديث ـ وسُئيل أبونعيم الفضل بن دكين عن النضر بن عبد الرحمن الحزاز

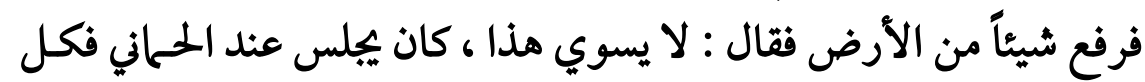

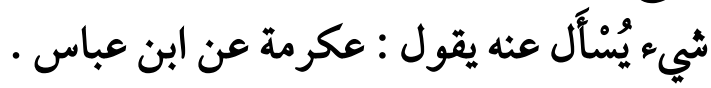

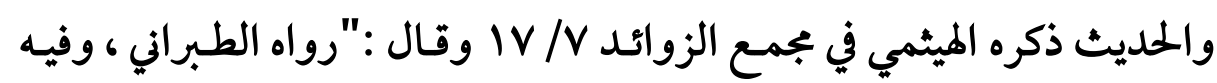
النضر بن عبد الرحمن وهو ضعيف":اهـ

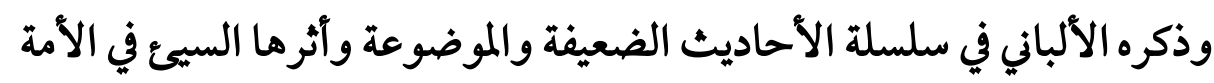

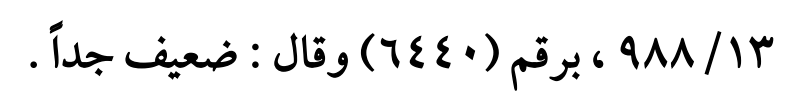

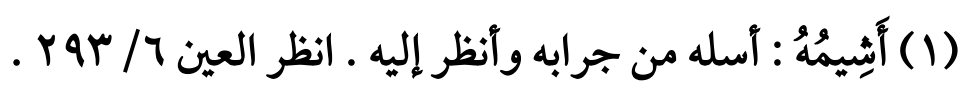




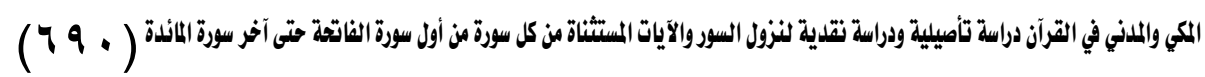

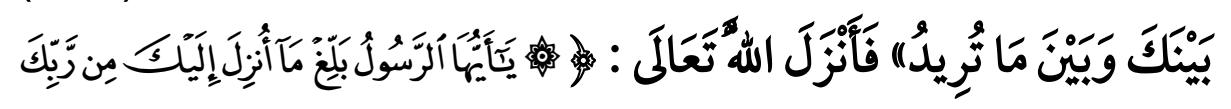

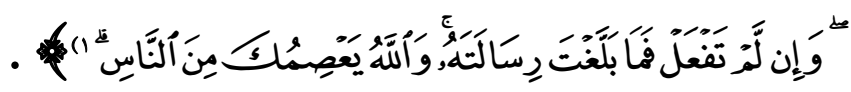

وكانت غزوة أنهار بناحية نجـد لثنتي عشرـة ليلة مضست مـن ربيـع الأول على رأس خمسة وعشرين شهراً من المجرة"(r).

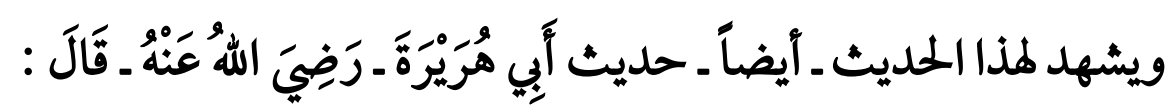

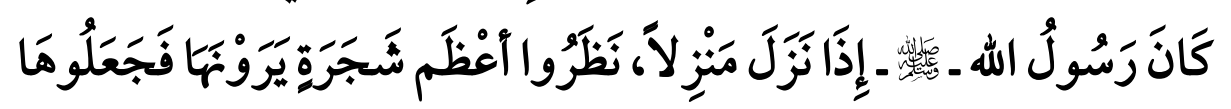

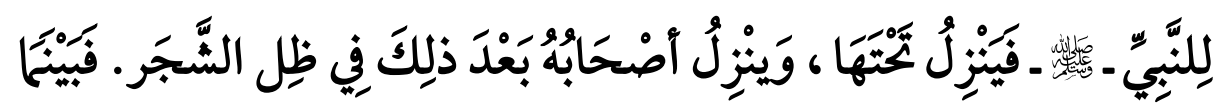

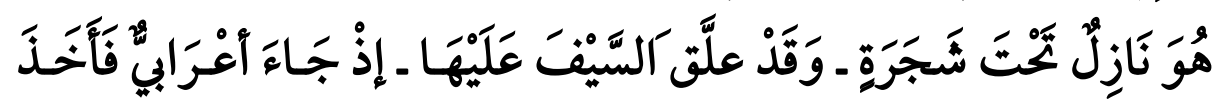

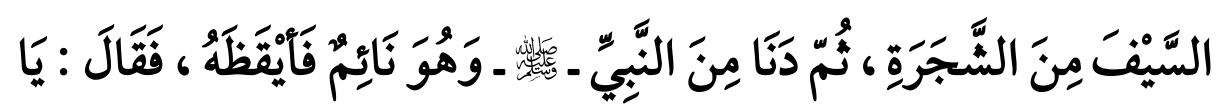

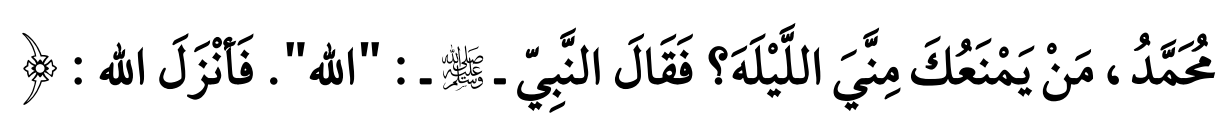

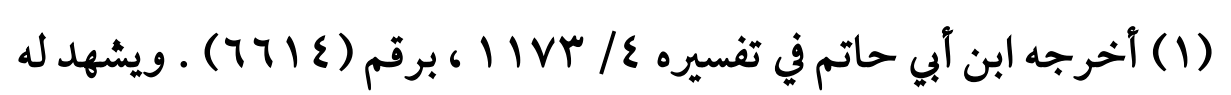

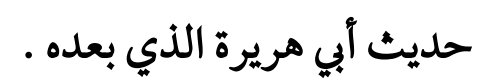

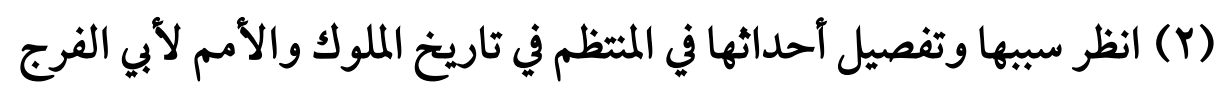

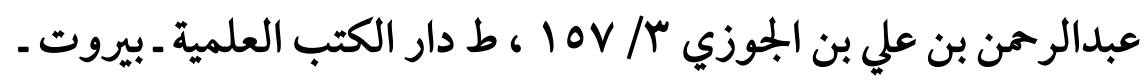

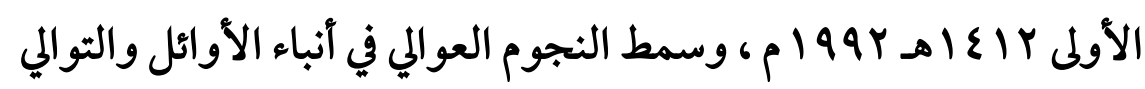

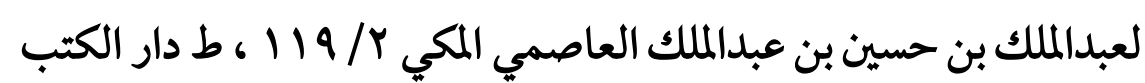

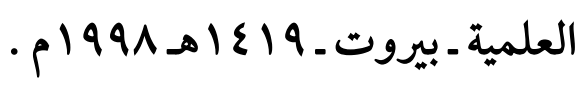




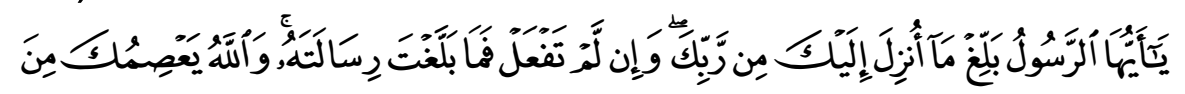
أَنَّاسِ (1)

وهذان الحديثان يقضيان أن الآية مدنية نزلت بعد المجرة . ومن أجل اختلاف هذه الروايات فإن للعلماء في شأن هذه الآية ثلاثة

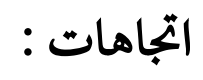

$$
\text { الاتجاه الأول : أن هذه الآية مكية . }
$$

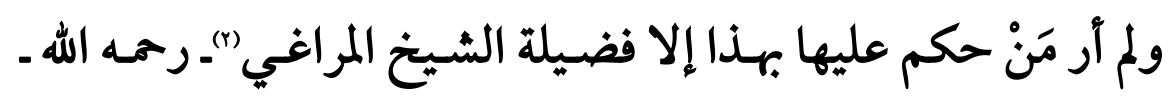
حينها قال :"وقد وُضِعَت هذه الآية ـ وهى مكية ـ في سياق تبلين أهـل

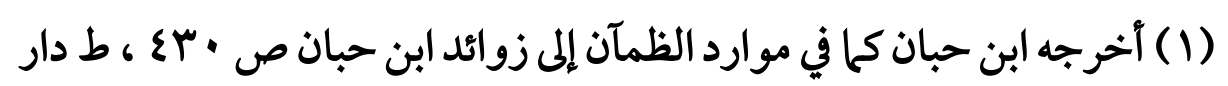

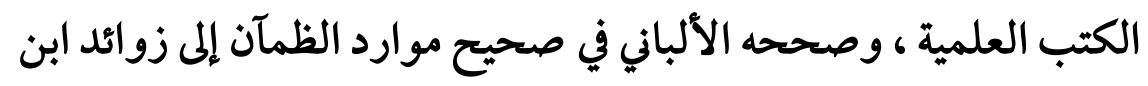

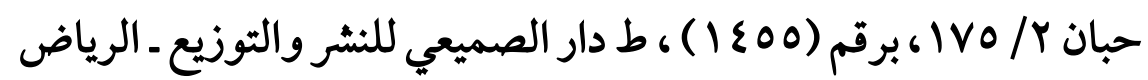

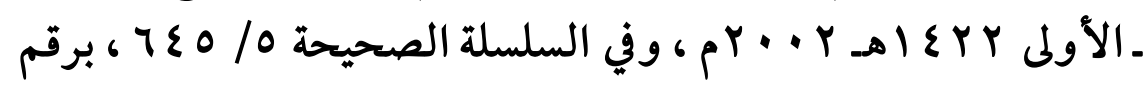

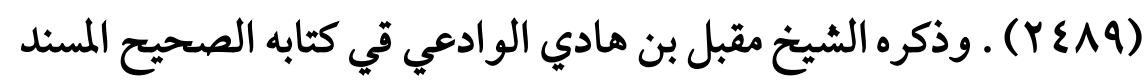

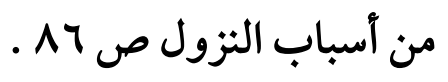

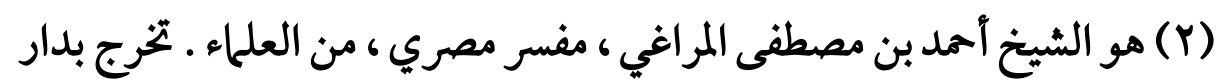

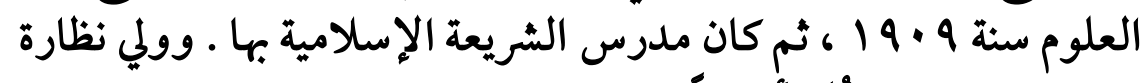

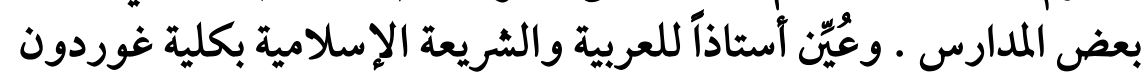

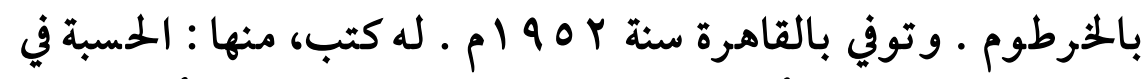

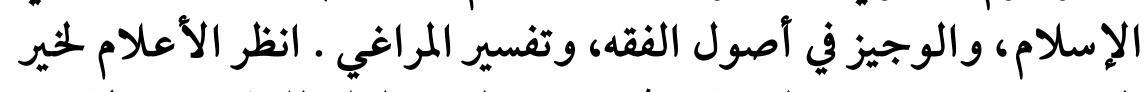

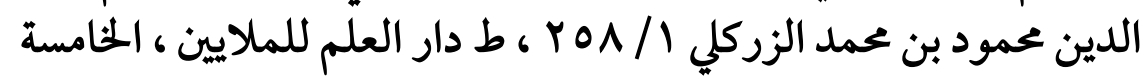




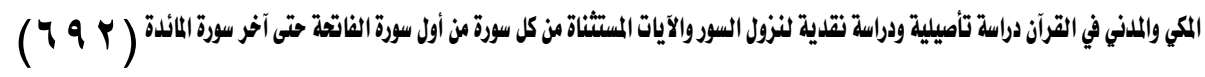

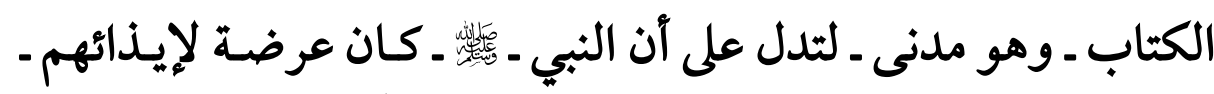

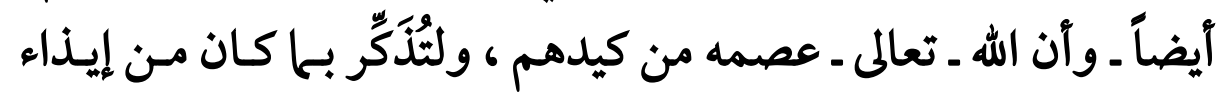
مشركي قومه من قبلهم" (1)":اهـ

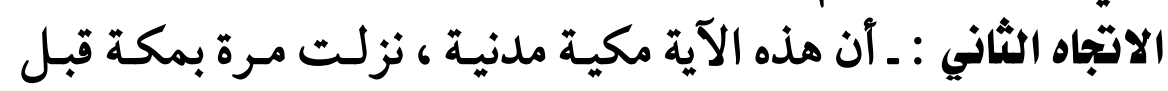

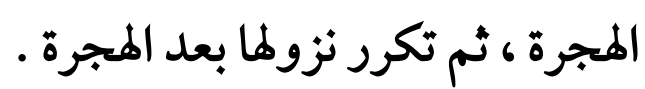

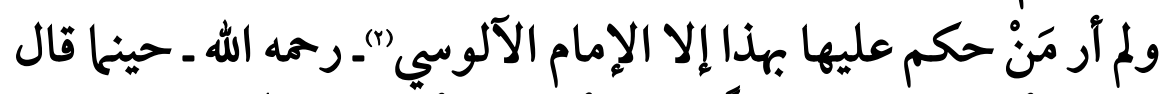

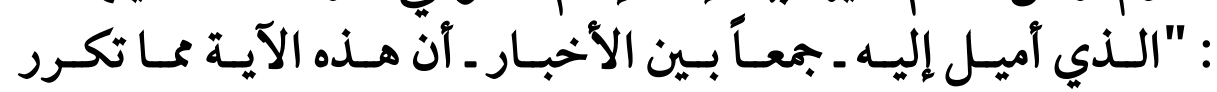

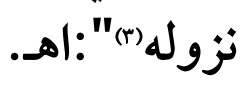

(1) تفسير المراغي للشيخ أحمد مصطفى المراغي 1 / ج 1 ، ط شر كة مكتبة

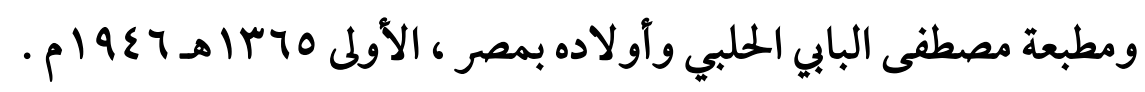

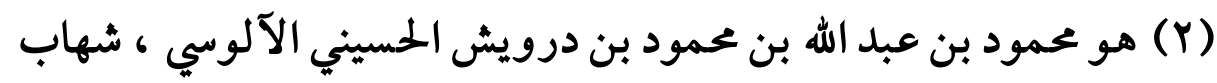

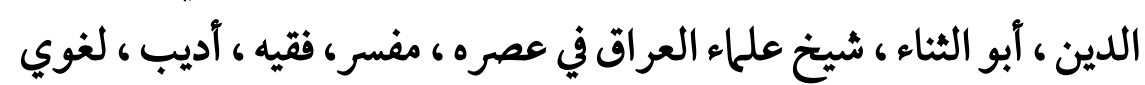

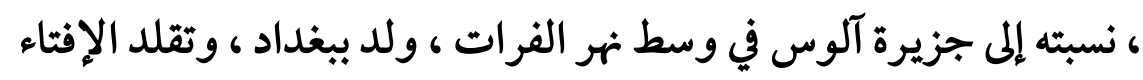

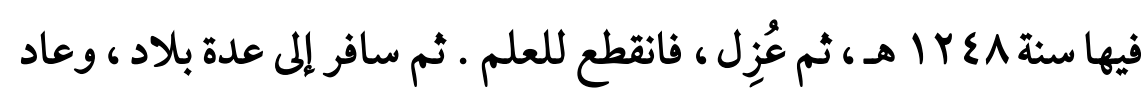

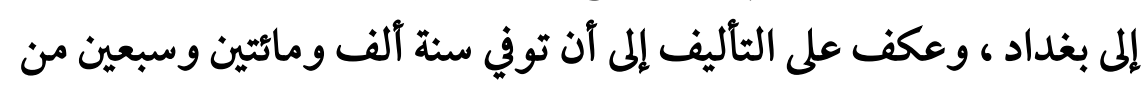

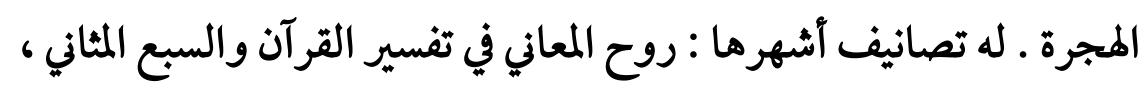

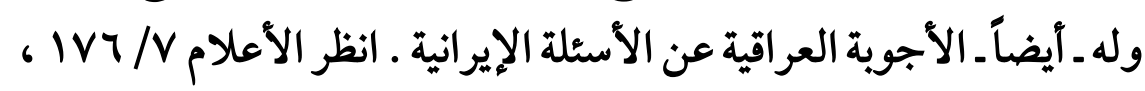

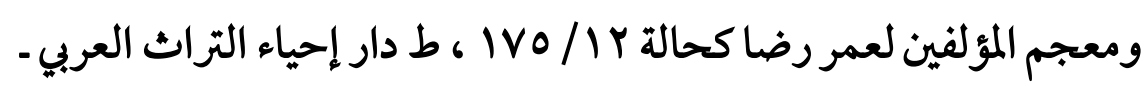
بيروت . .

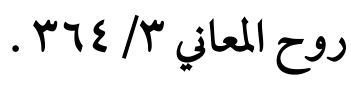


$(794)$

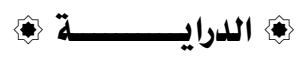

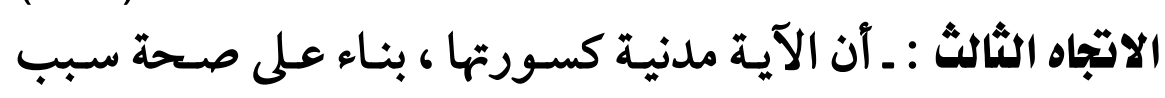

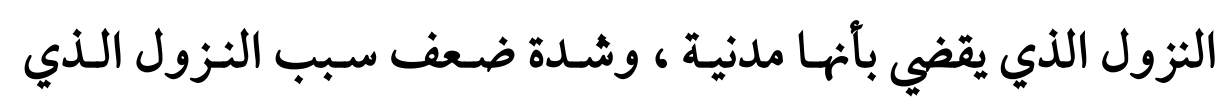
يقضي بأنها مكية .

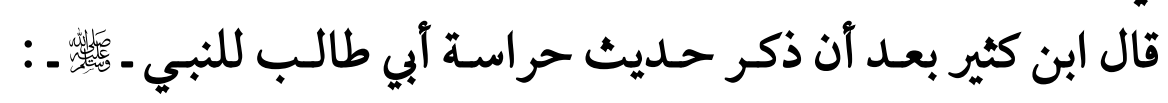

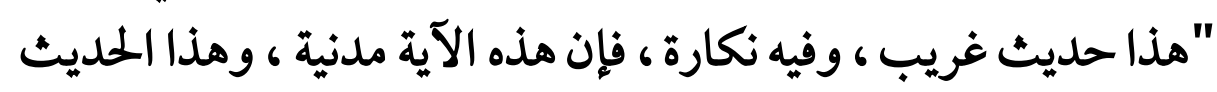

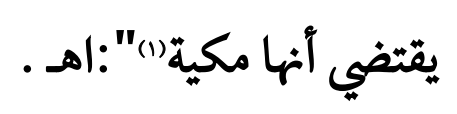
قلت : هذا الاتجاه هو الصحيح ، فالآية مدنية ، نزلت آول أول ما نزلت

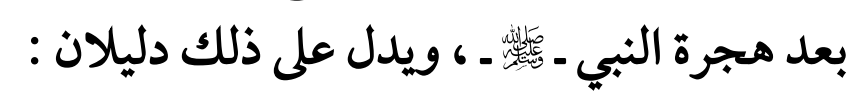

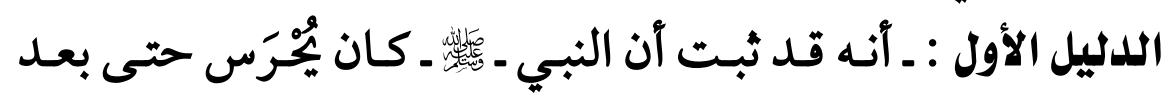

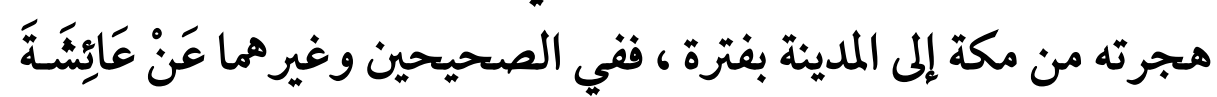

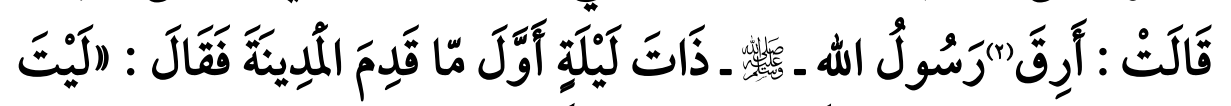

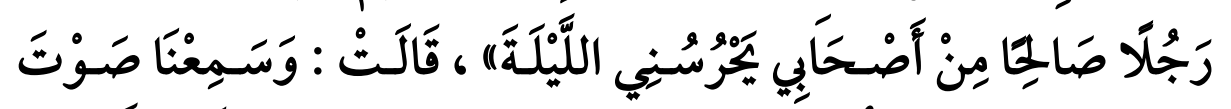

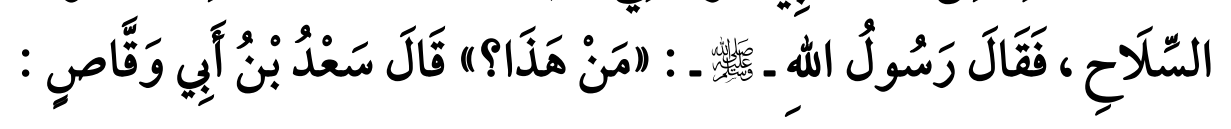

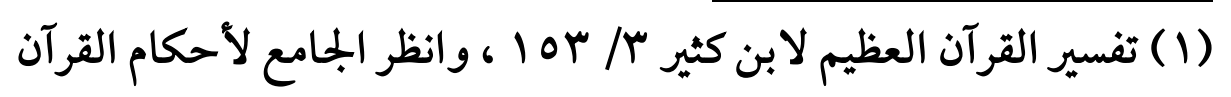

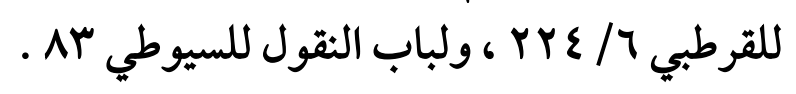

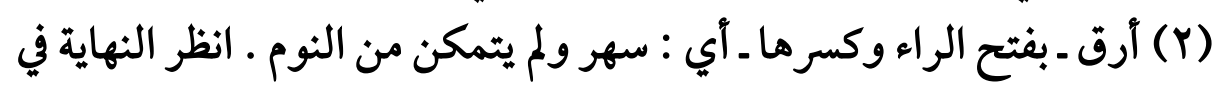

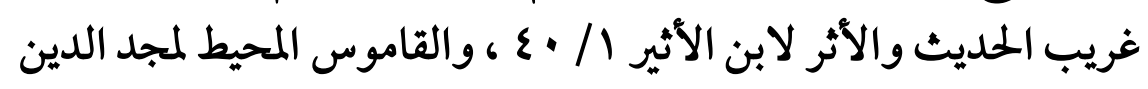

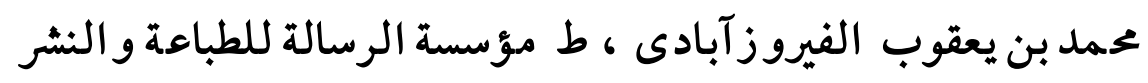

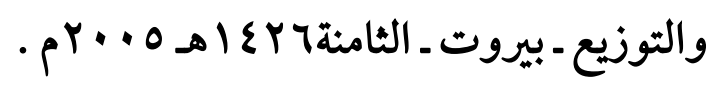




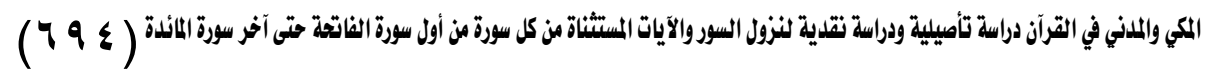

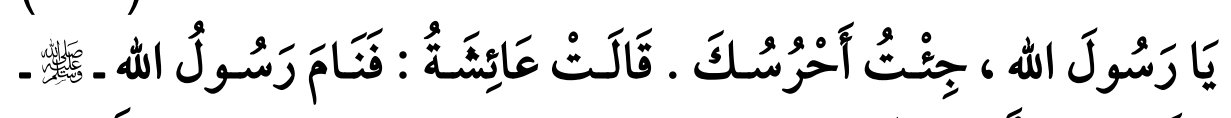

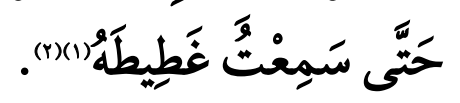
قال الإمام النووي في شرح هذا الحديث : ق"قال العلمهاء : وكان هـذا

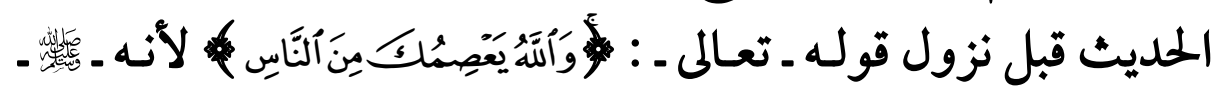

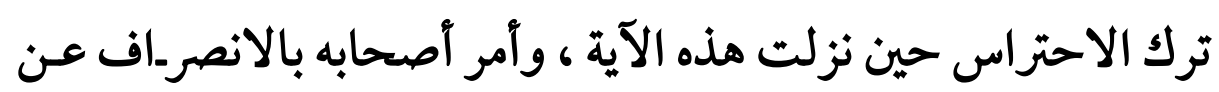

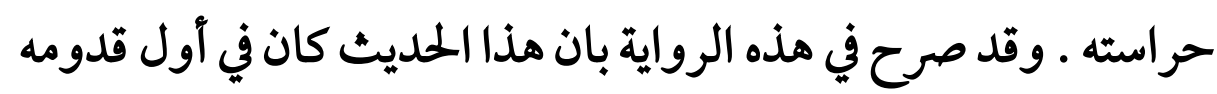

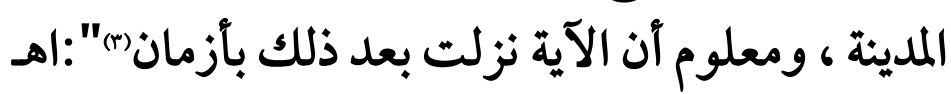

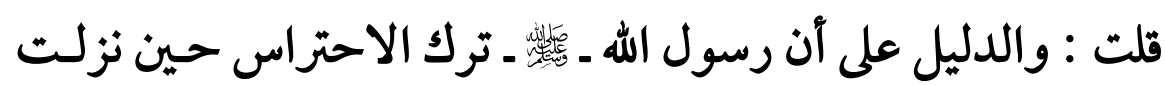

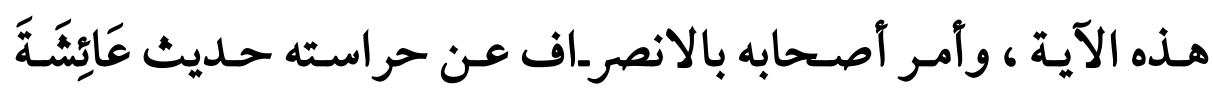

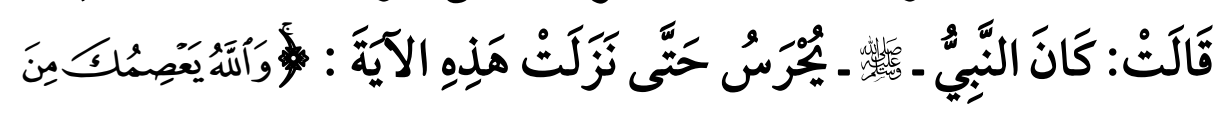

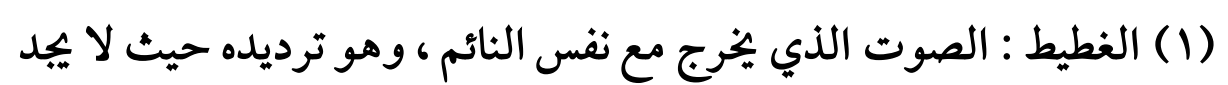

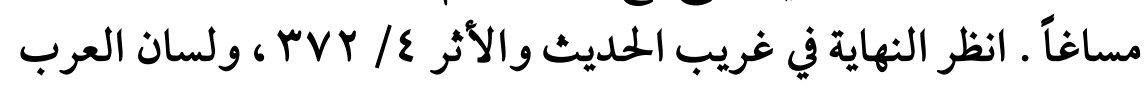
r r r / R

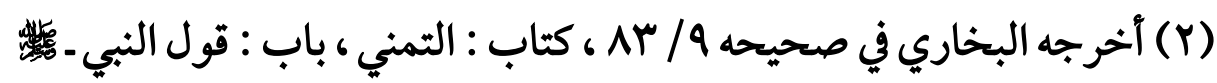

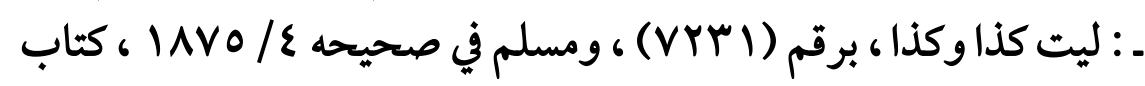

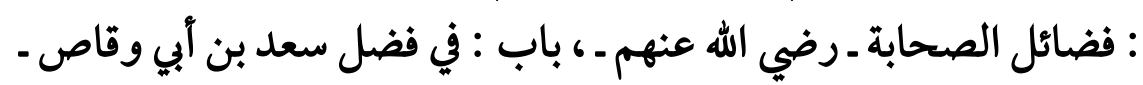

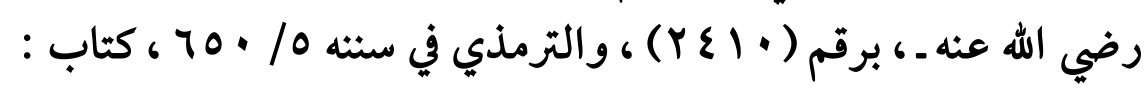

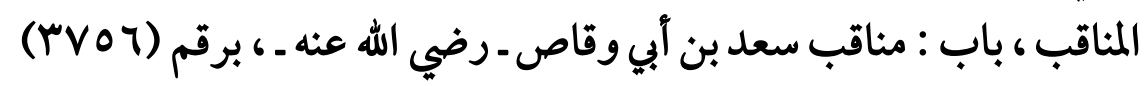

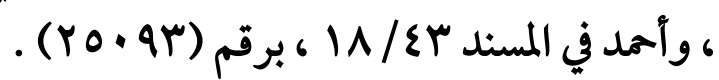

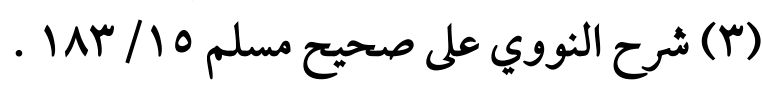


( 1900$)$

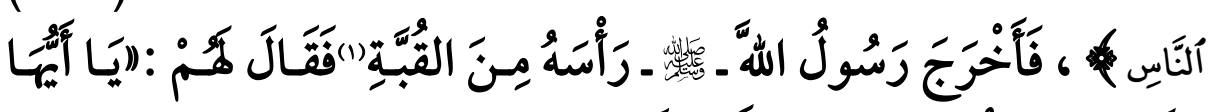

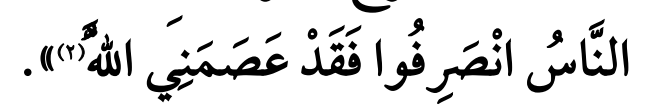

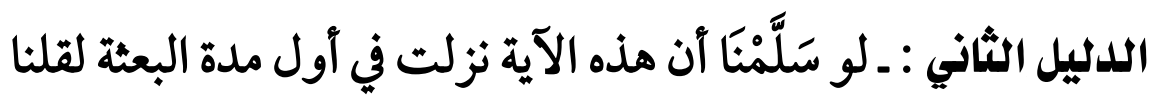

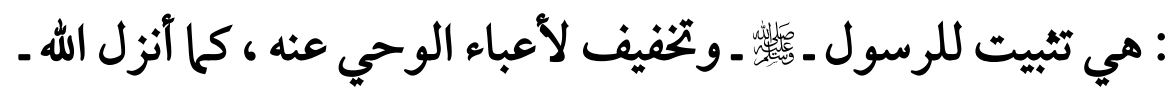

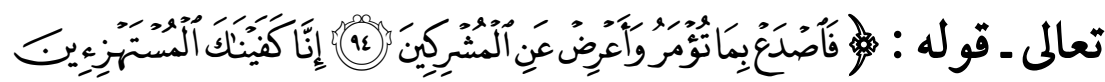

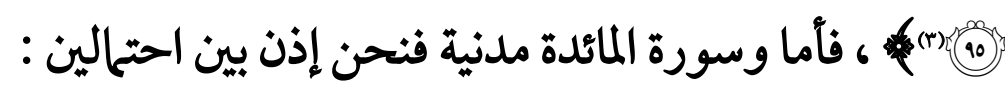

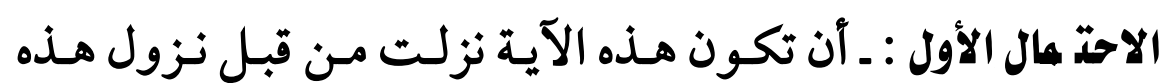

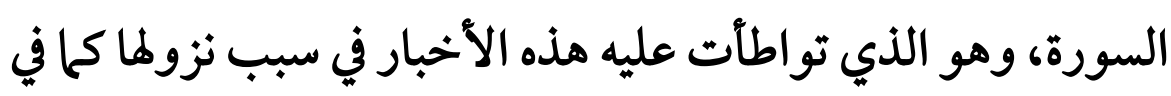

(1) القبة من الحيام : بيت صغير مستدير ، وهو من بيوت العرب يصنع من الصوف

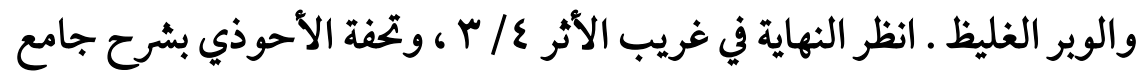

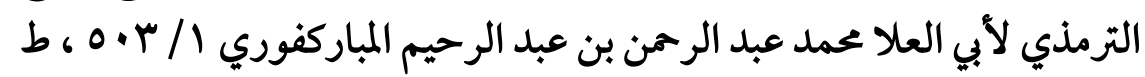

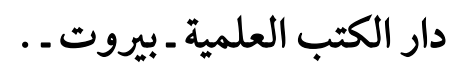

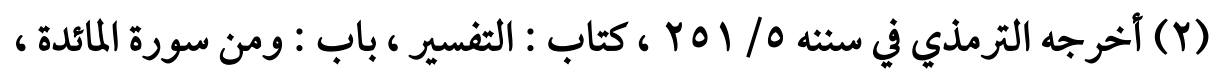

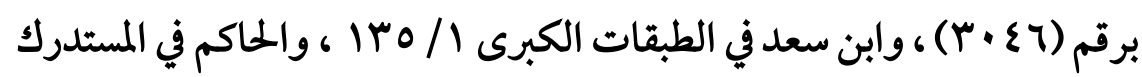

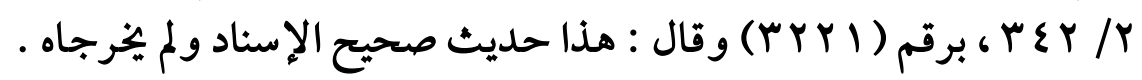

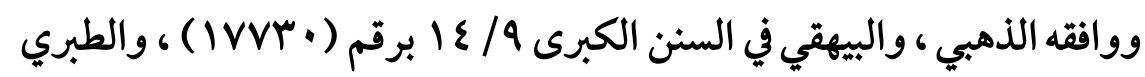

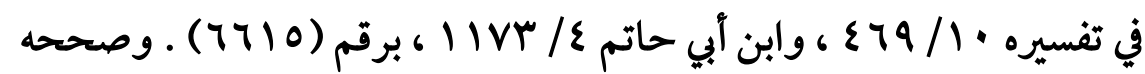

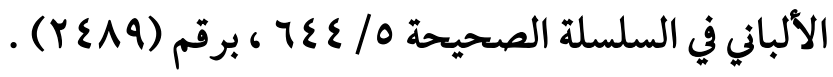

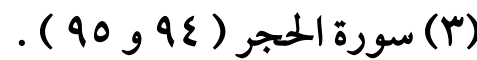




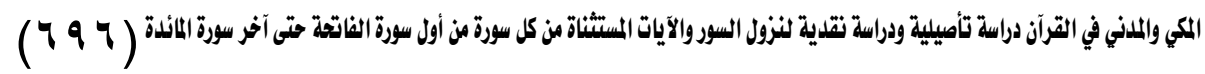

الوجهين الأولين ـ وهذا الاحتتال لا ينبغي اعتباره لاقتضائه أن تكون

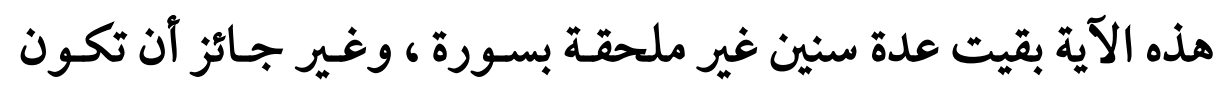
مقروءة بمفردها ، وبذلك تندحض جميع الأخبار الواردة في آسباب

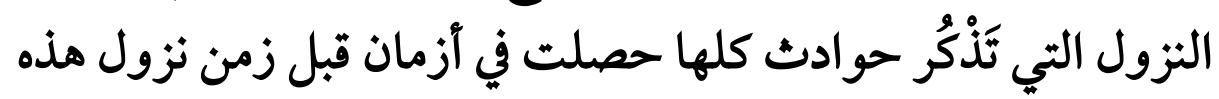
السورة . النزون التي

والاحتمال الثاني : ـ أن تكون هذه الآية سيقت لسبب خاص اقتضى.

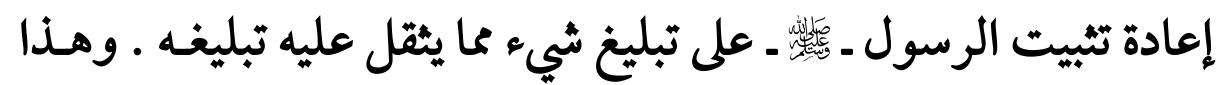

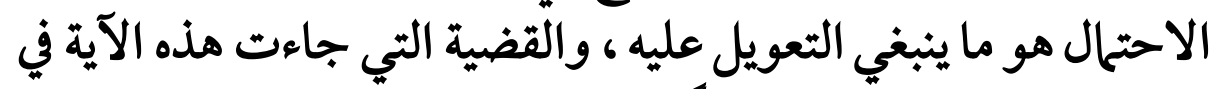

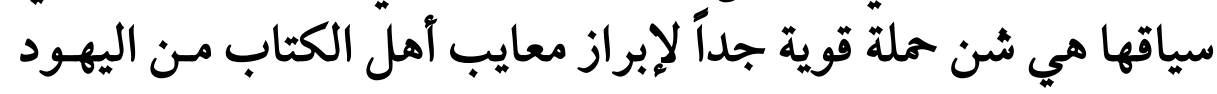

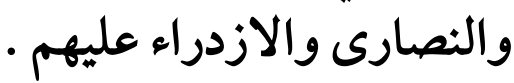

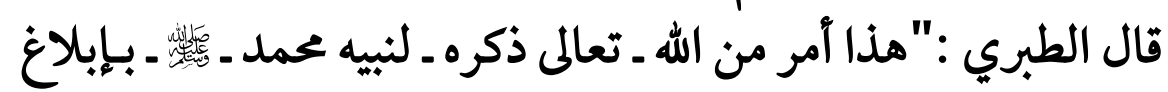

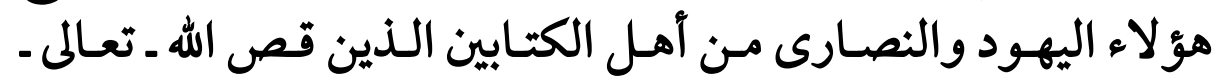

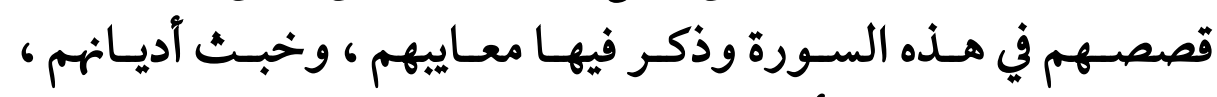

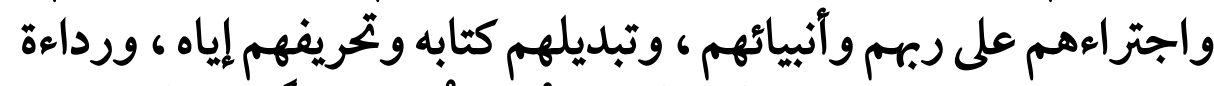

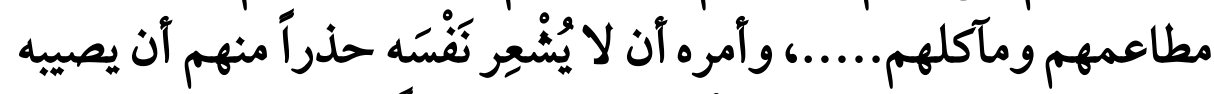

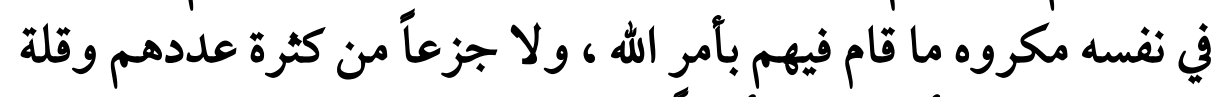

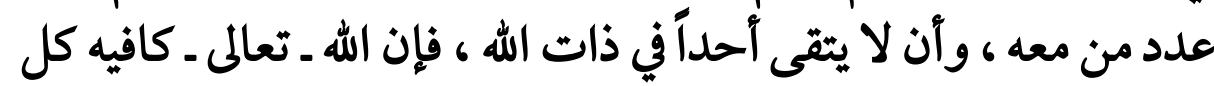

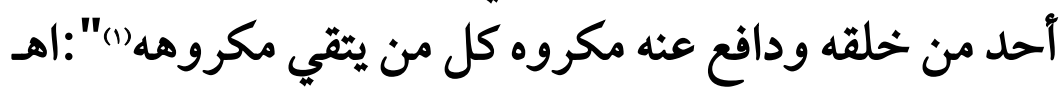

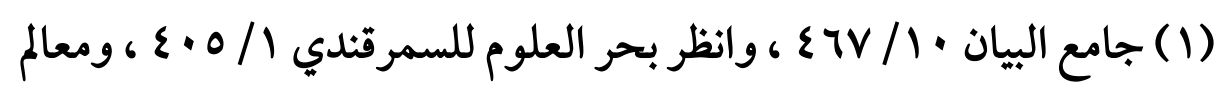

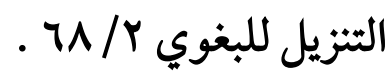


(79v)

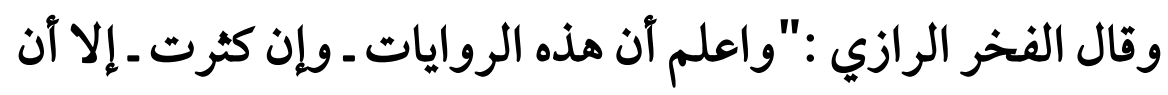

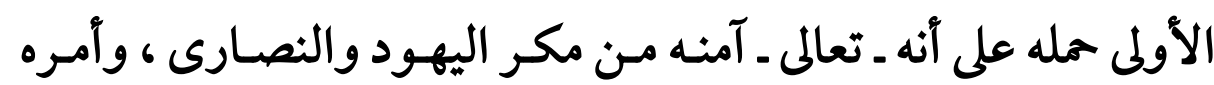

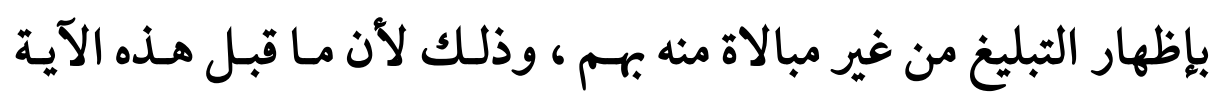

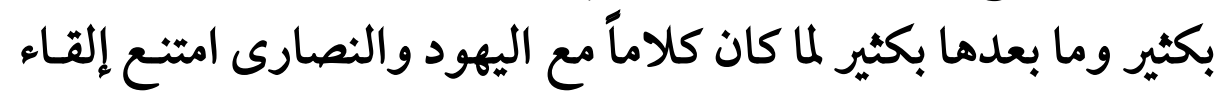

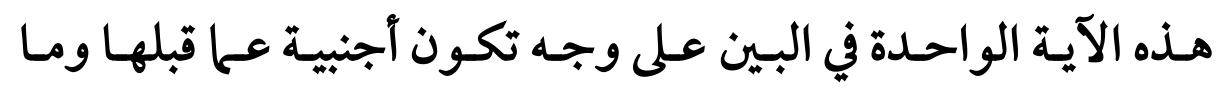

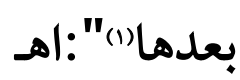

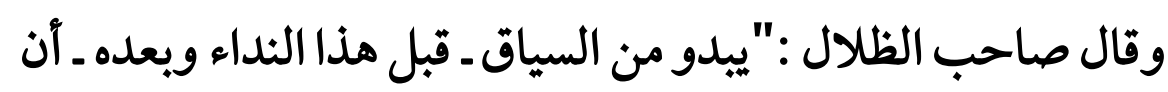

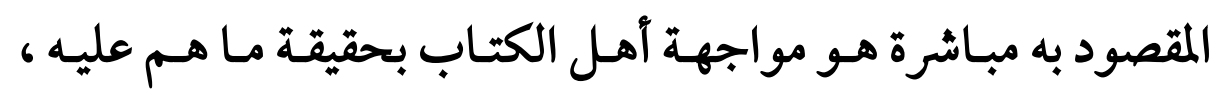

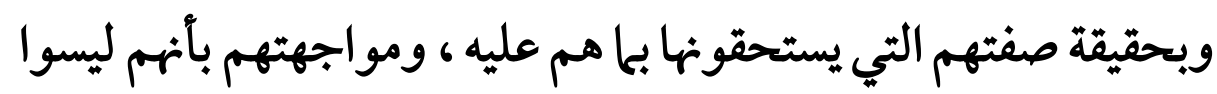

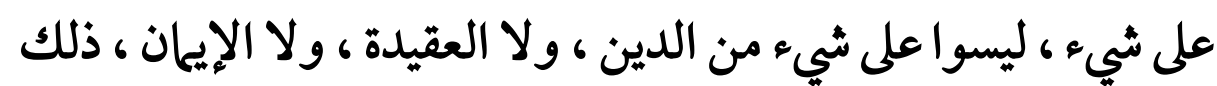

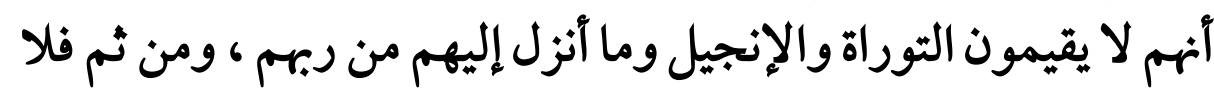

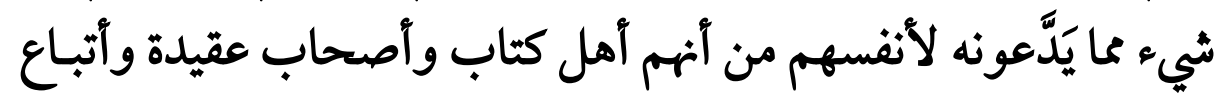
دين (")":اهـ

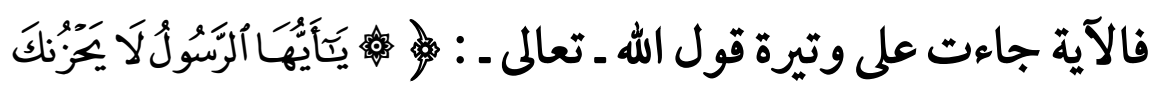

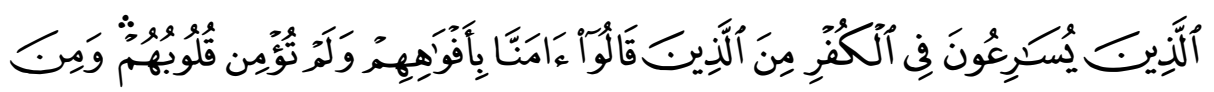

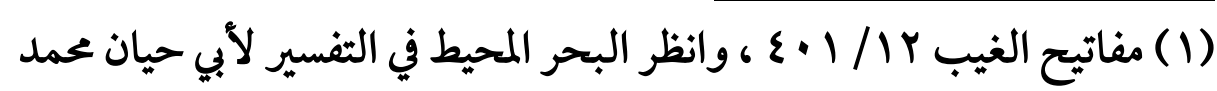

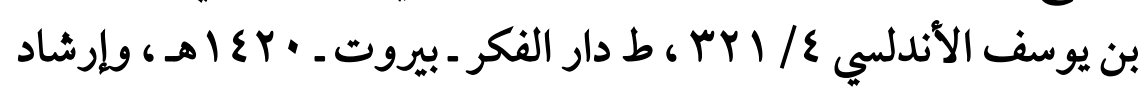

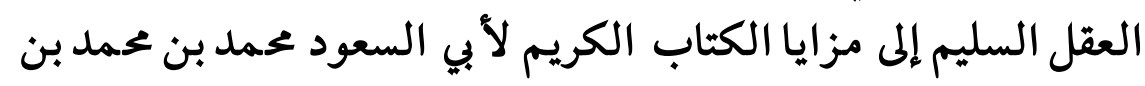

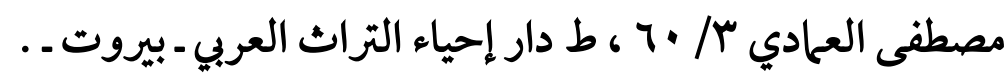

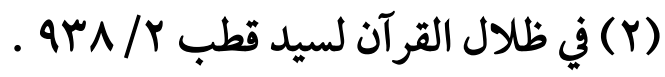




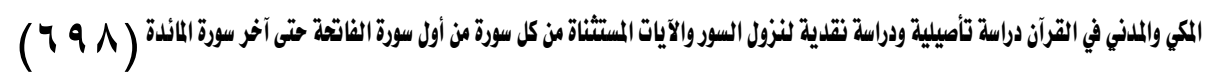

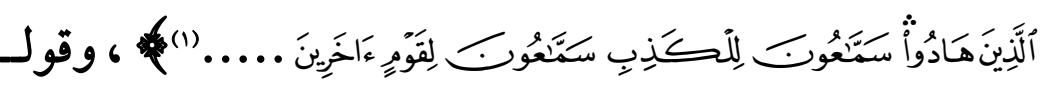

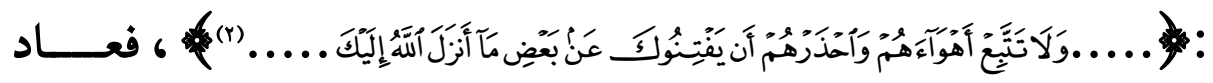

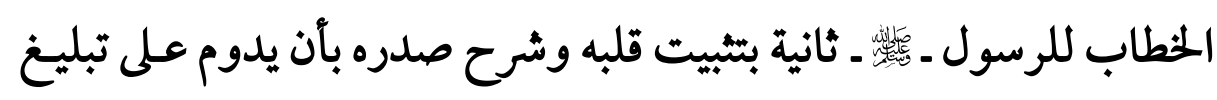

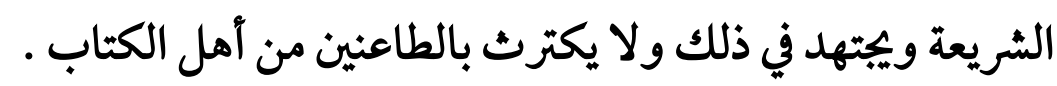

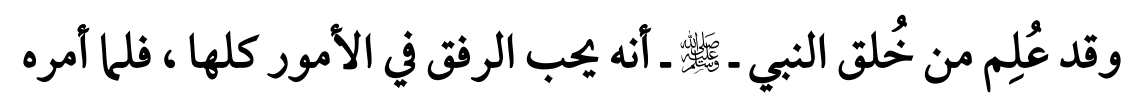

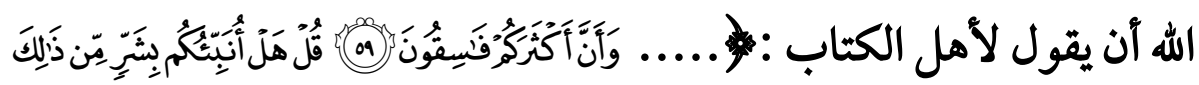

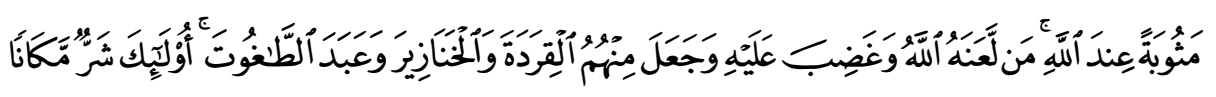

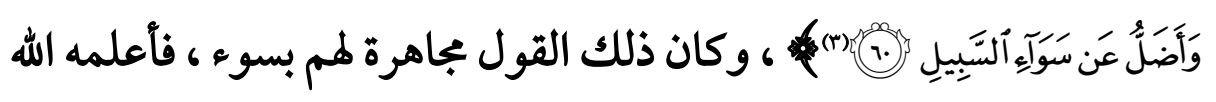
بأن هذا لا رفق فيه فلا يدخل فيا كان يعاملهم به من المجادلة بالتي هي

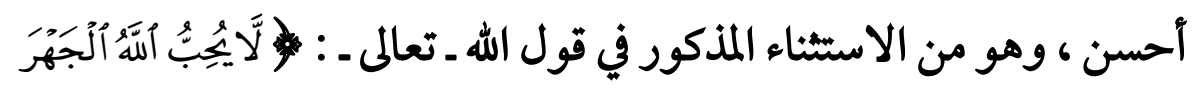

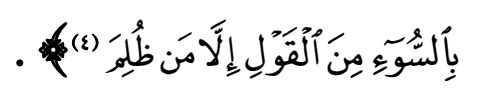

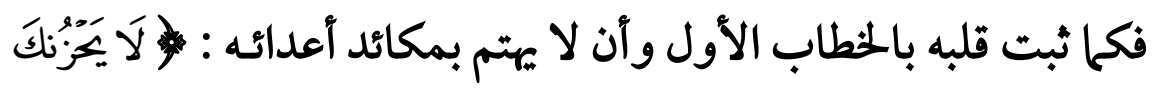

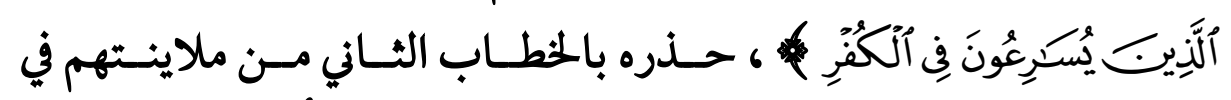

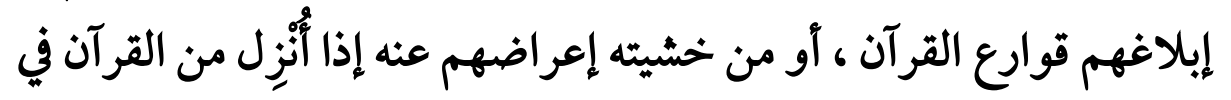

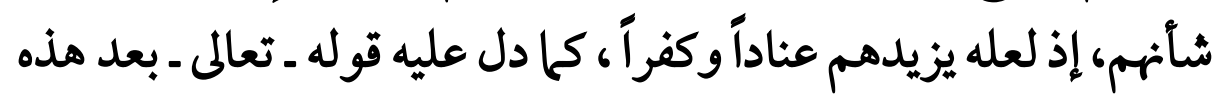

$$
\begin{aligned}
& \text { (1) سورة المائدة ( (ع) ). }
\end{aligned}
$$

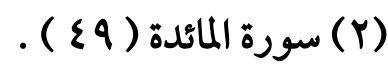

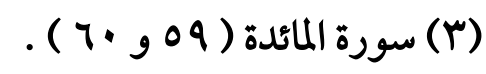

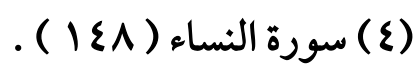




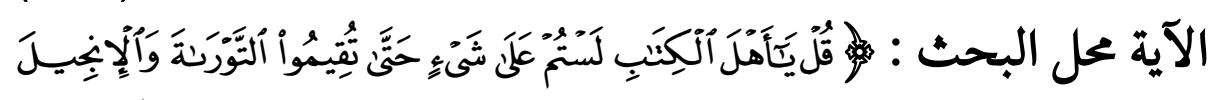

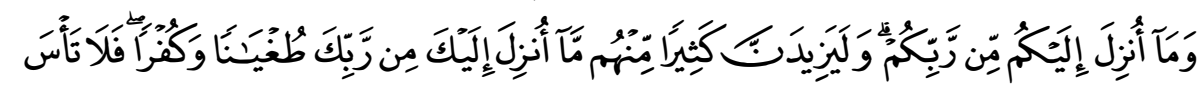

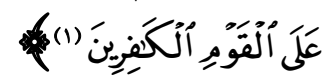

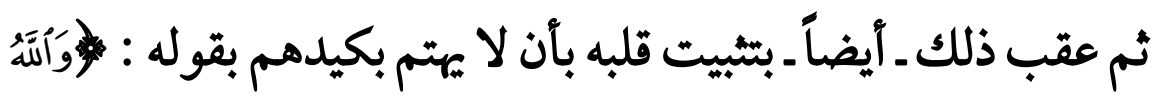

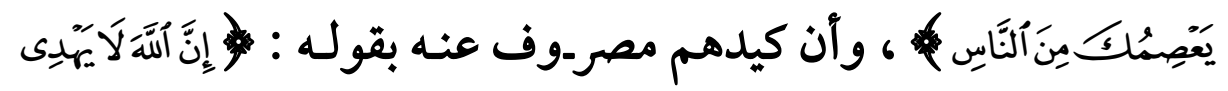

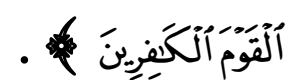

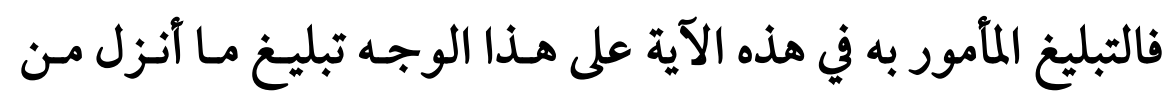

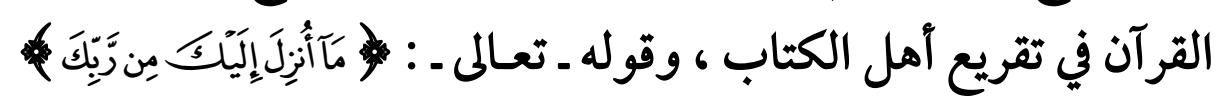

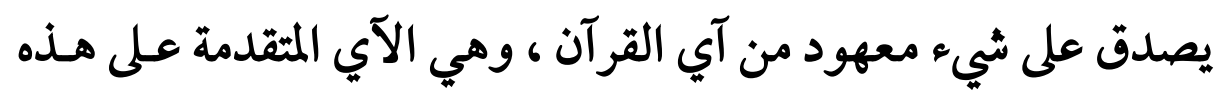
الآية بصفة خاصة ، ويصدق على كلى كل ما نزل من القرآ آن قبل ذلك اليوم الئل بصفة عامة").

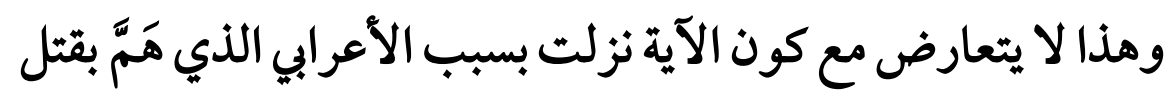

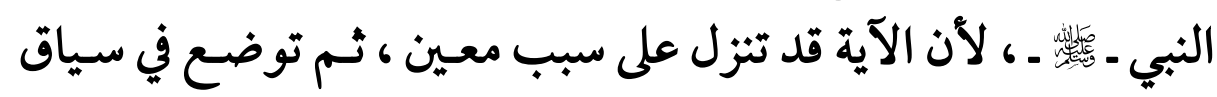

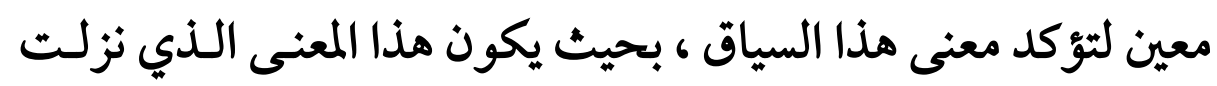

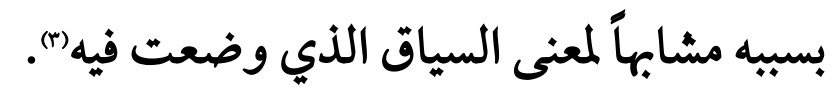

$$
\text { (1) (1) سورة المائدة ( (T) ). }
$$

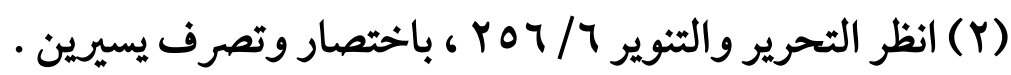

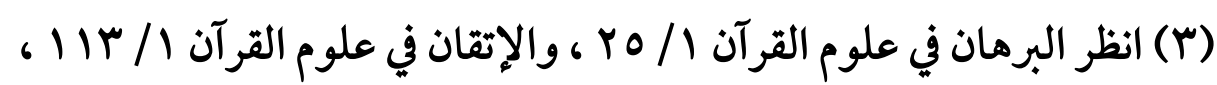

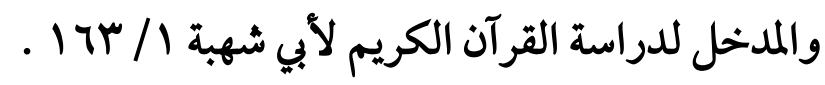




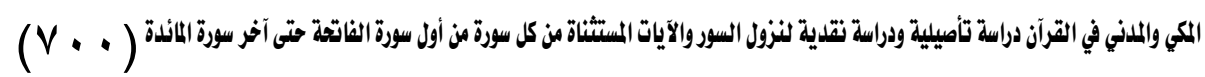

خلاصـة القـول أن الآيـة محل البحـث مدنيـة كسورتها ، ولم يمكـم

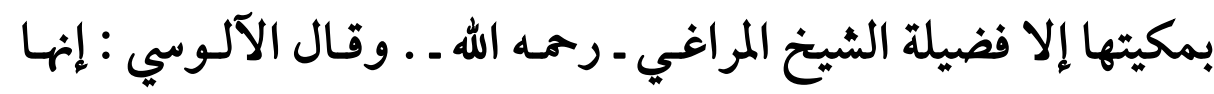

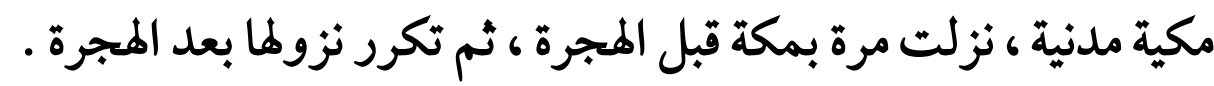

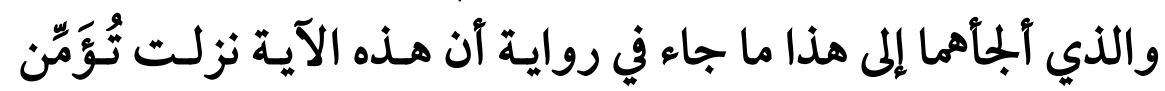

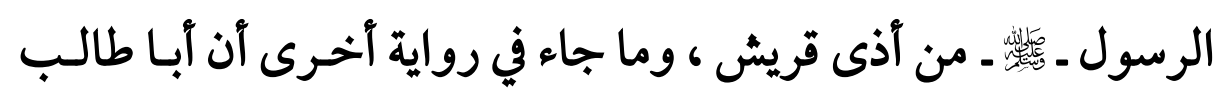

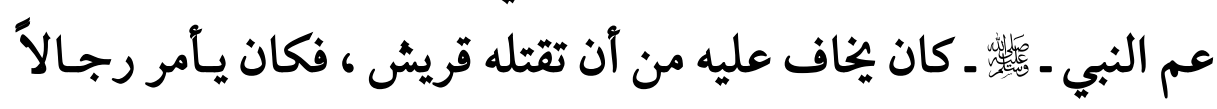

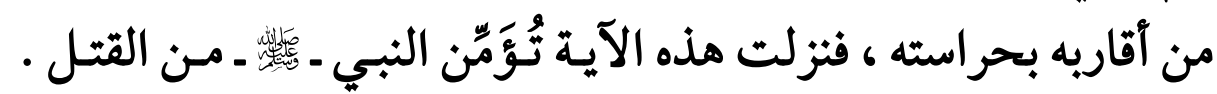
وهذه روايات ضعيفة جداً لا تقوم بها حجة .

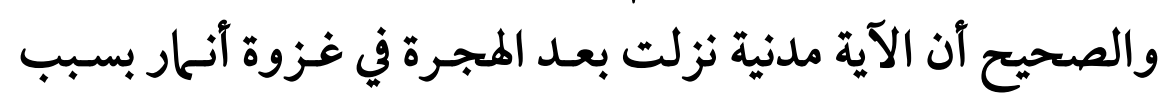

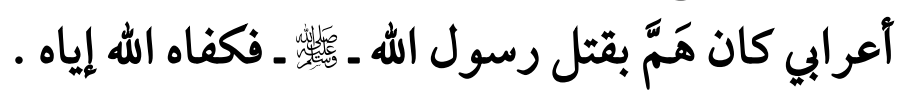




\section{المطلب الثالث}

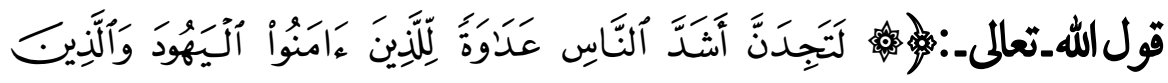

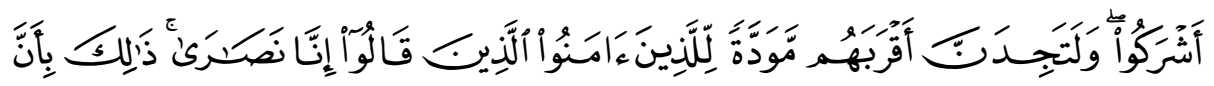

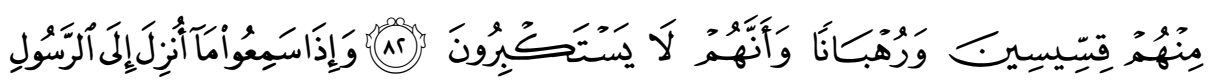

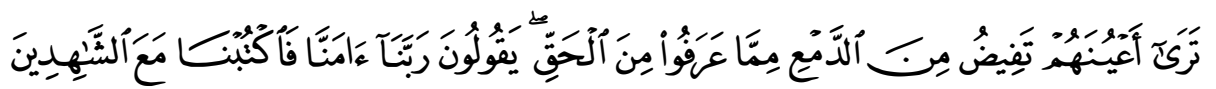

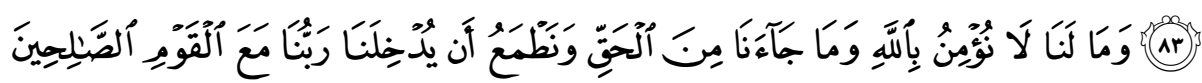

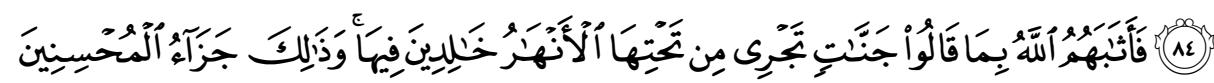

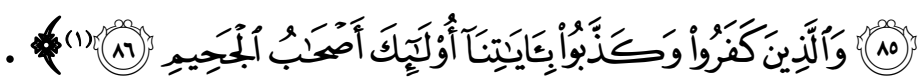

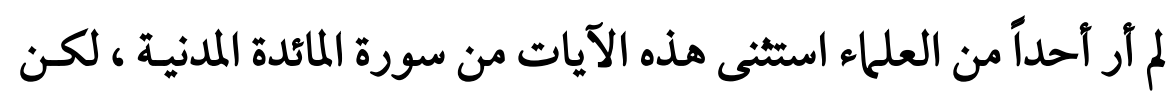

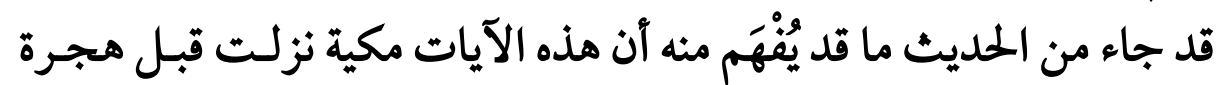

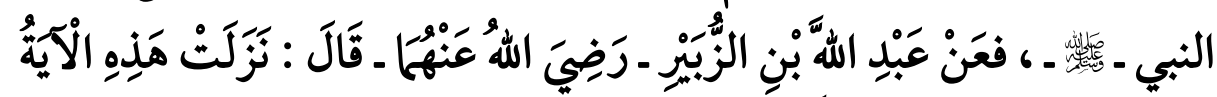

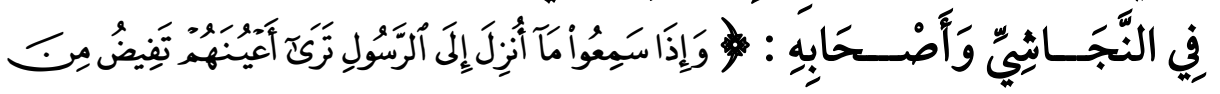

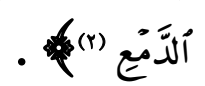

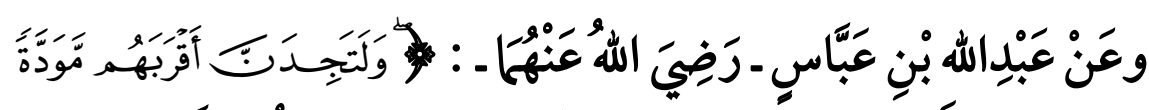

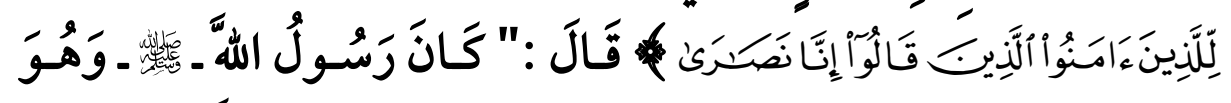

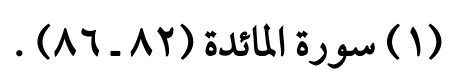

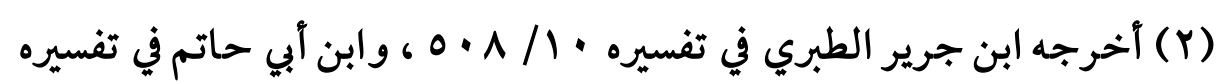

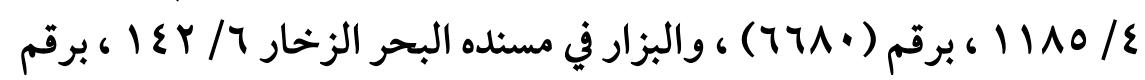

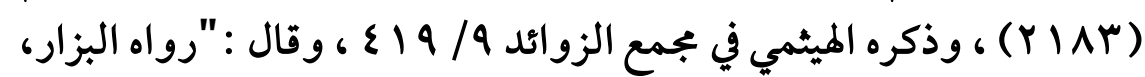

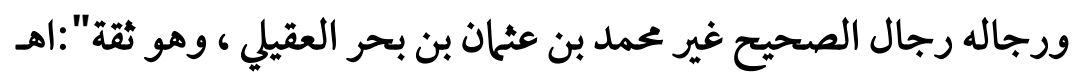




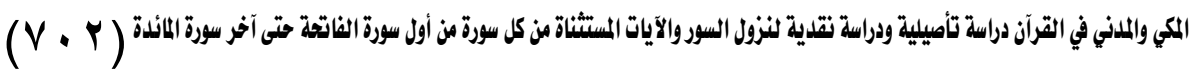

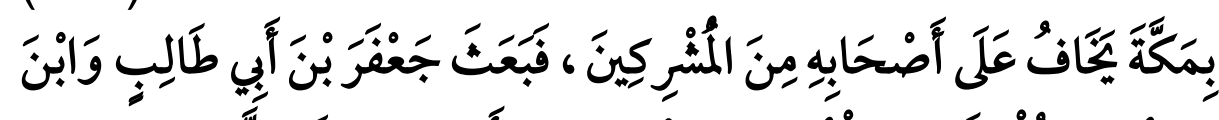

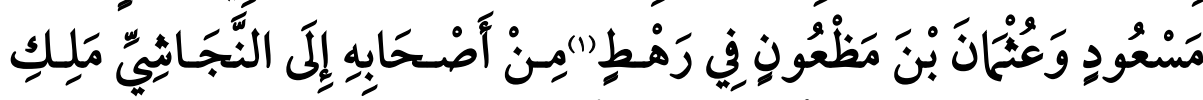

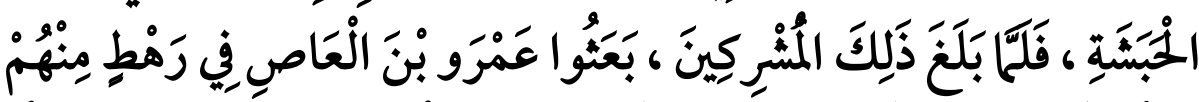

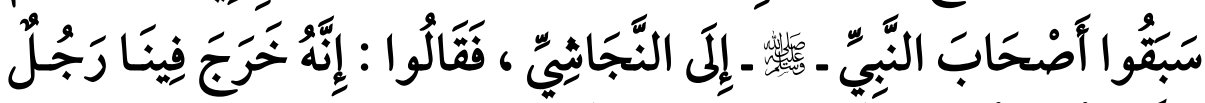

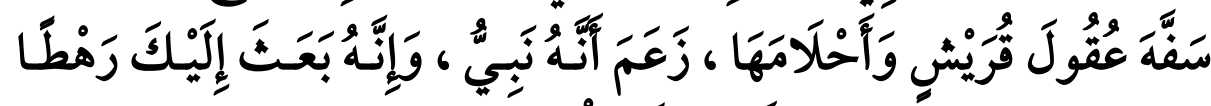

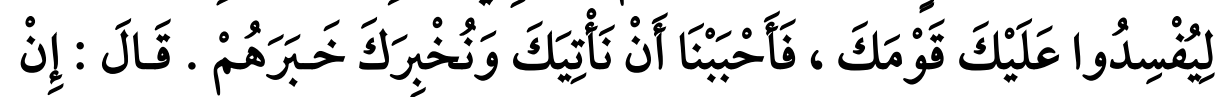

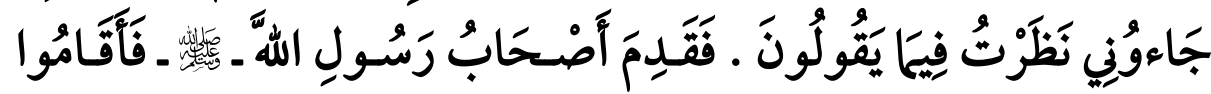

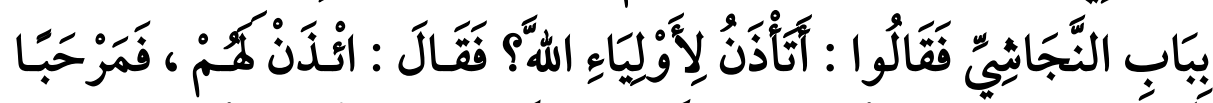

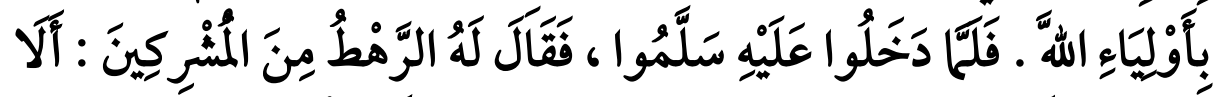

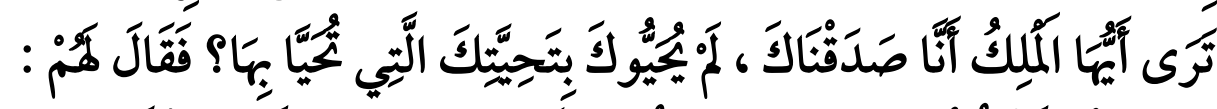

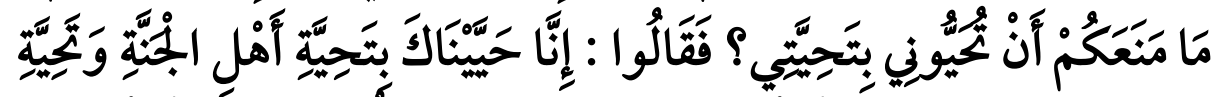

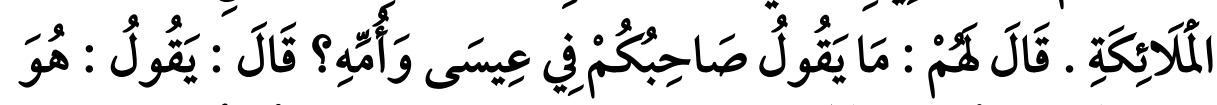

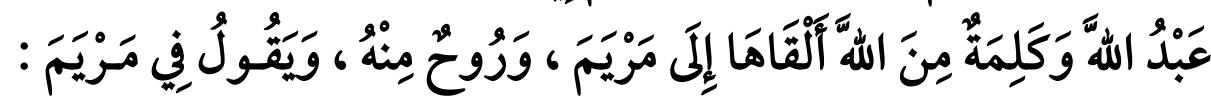

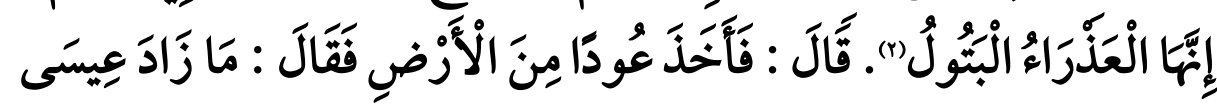

(1) الَّهُطُ : عدد يجمع من ثلائة إلى عشرة ، ويقال : من سبعة إلى عشرة ، وما

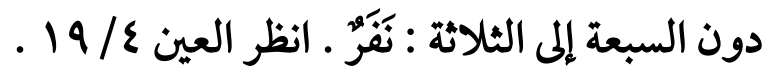

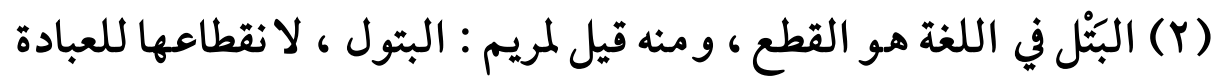

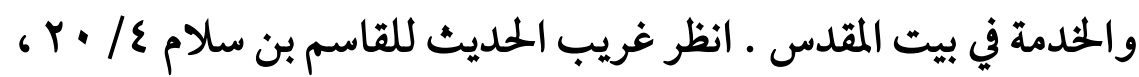

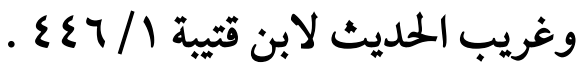


$(V \cdot r)$

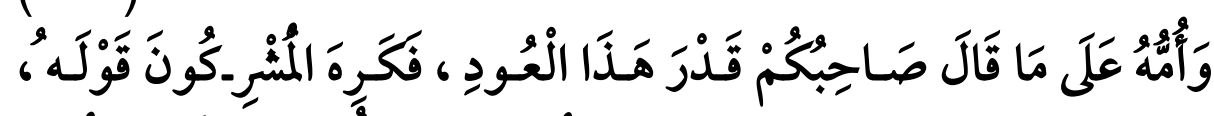

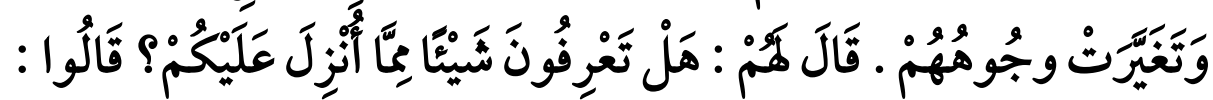

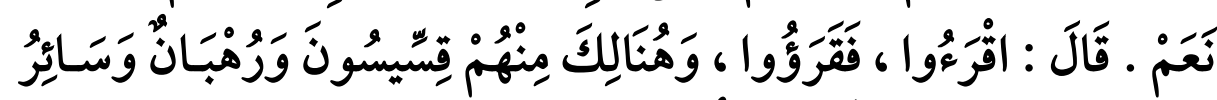

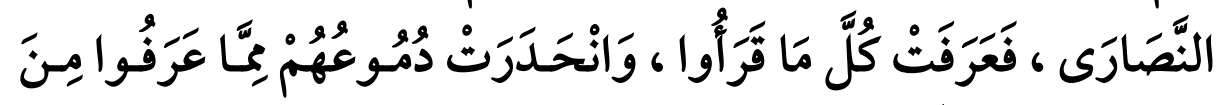

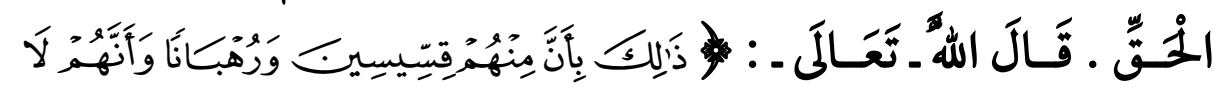

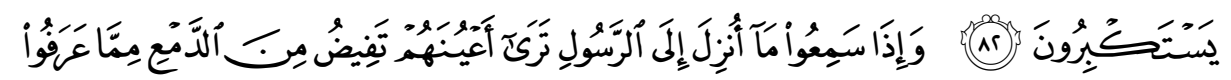

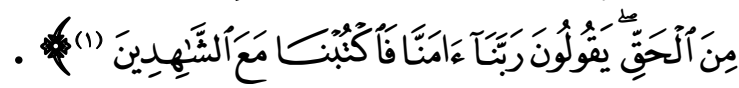

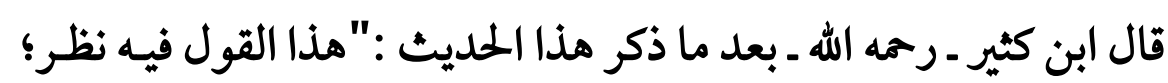

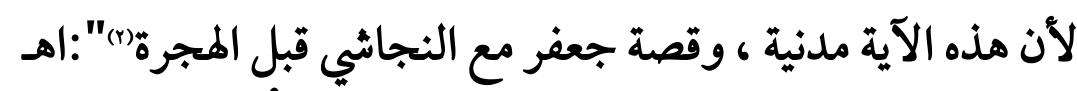

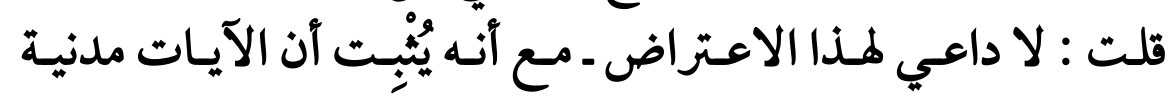

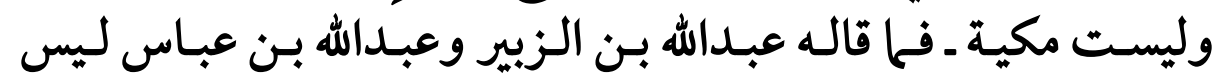

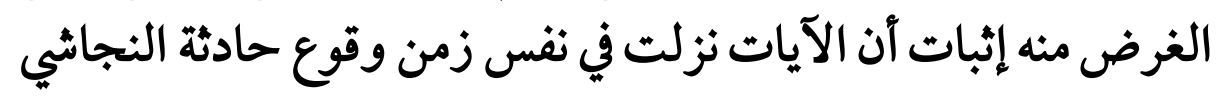

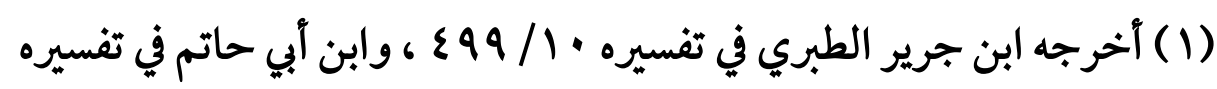

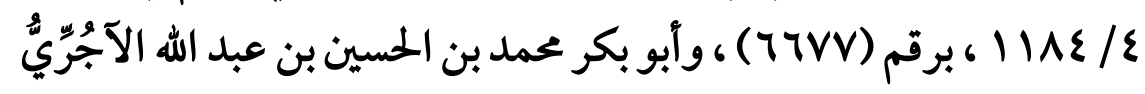

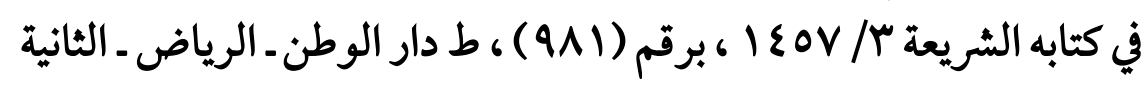

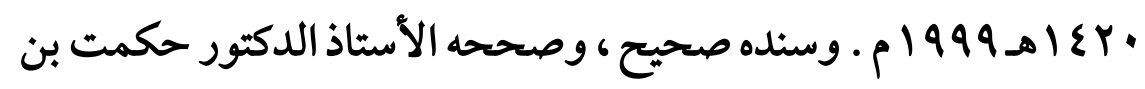

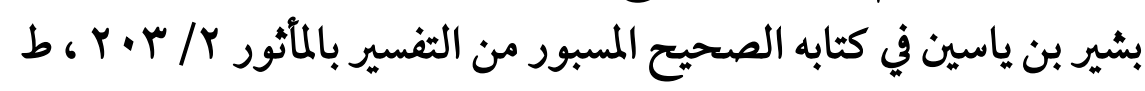

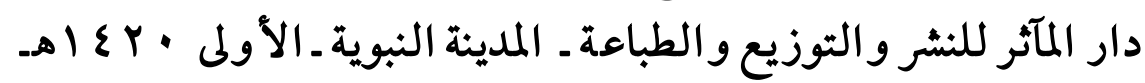




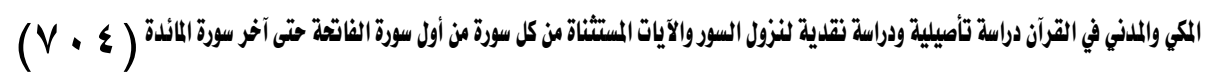

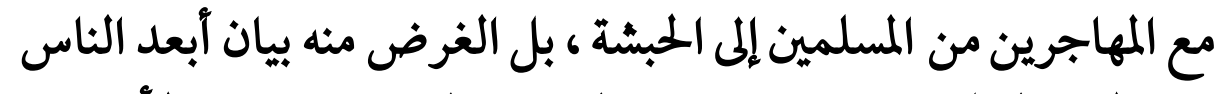

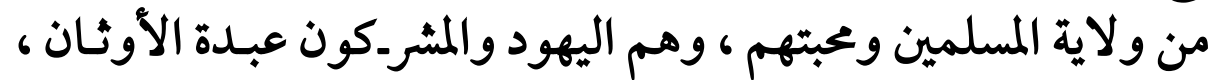

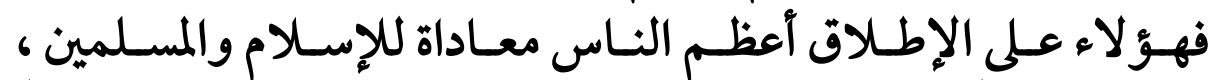

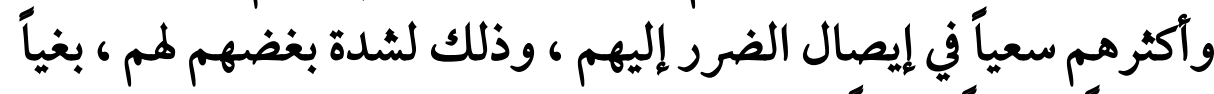

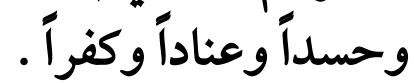

لكن آقرب الناس ولاية وعحبة للمسلمين هم النصارى ، وذكر تعالى

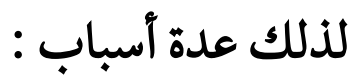

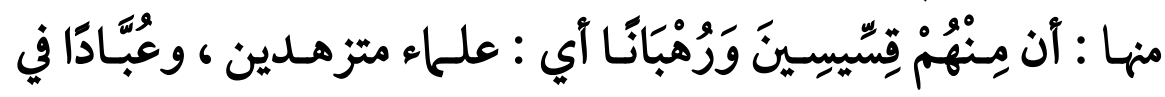

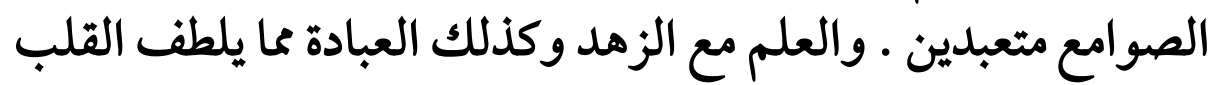

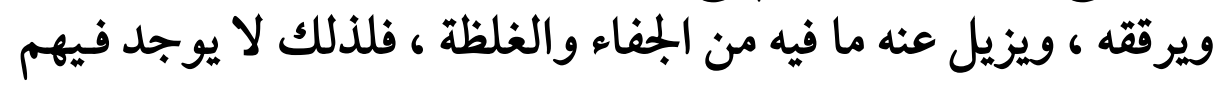

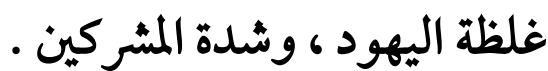

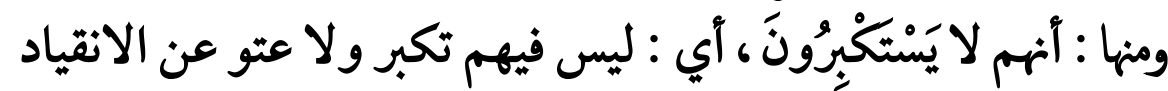

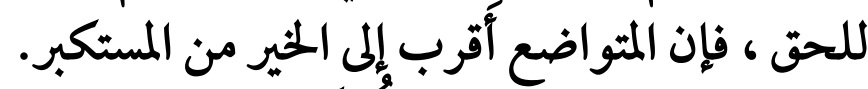

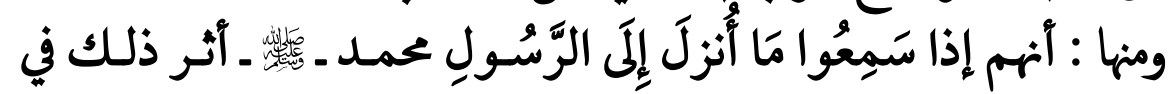

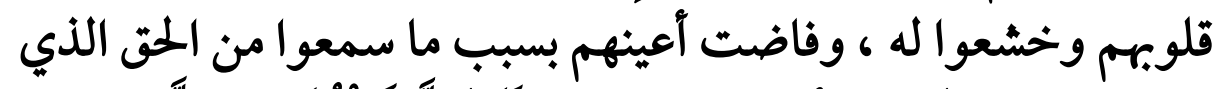

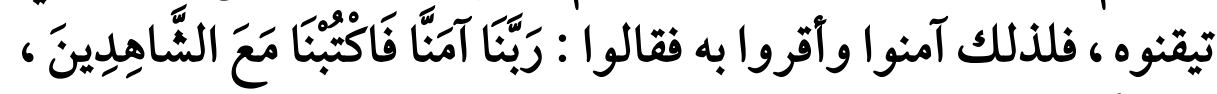

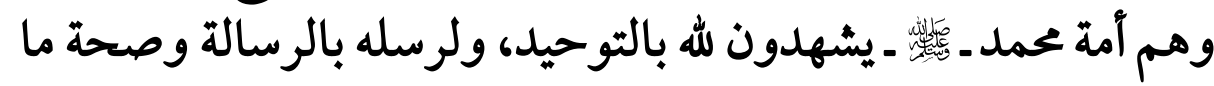

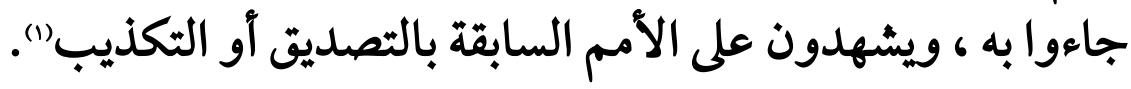

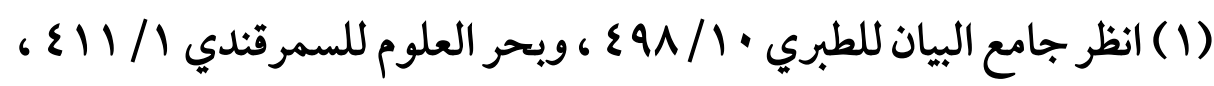

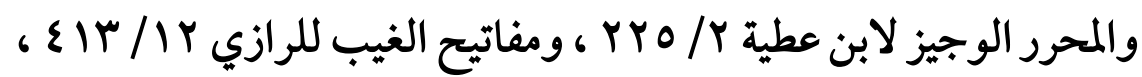

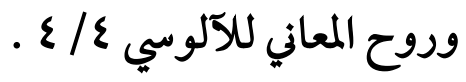


$(\mathrm{V} \cdot 0)$

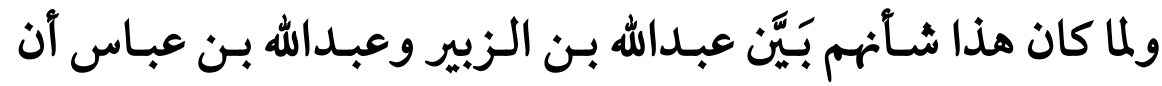

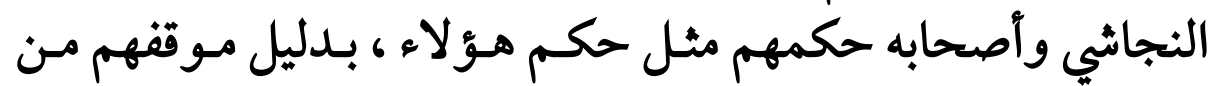

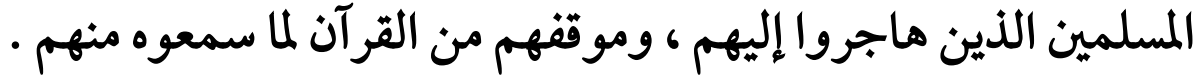

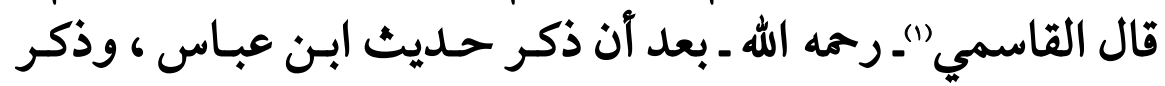

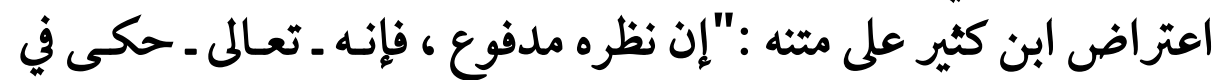

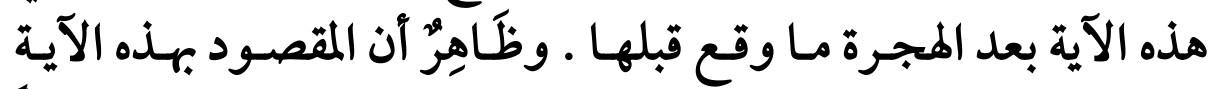

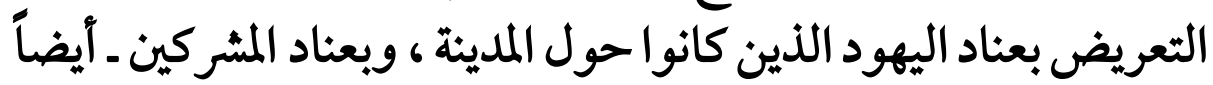

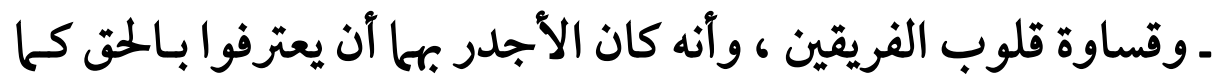
اعترف به النجاثي وأصحابه(r)":اهـ

(1) هو جمال الدين (أو محمد جمال الدين) بن محمد سعيد بن قاسم الحلاق ، من المال

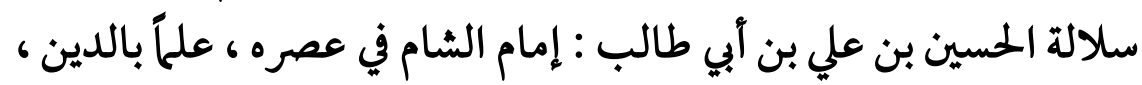

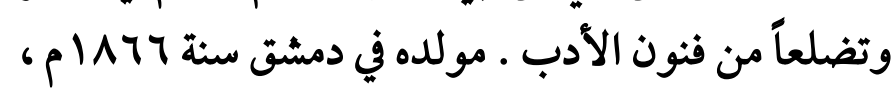

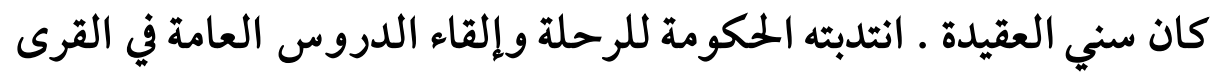

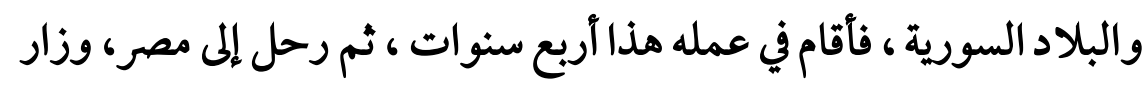

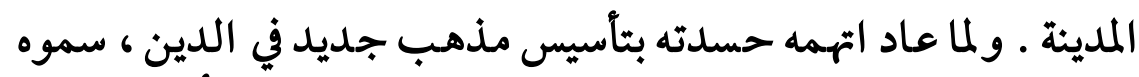

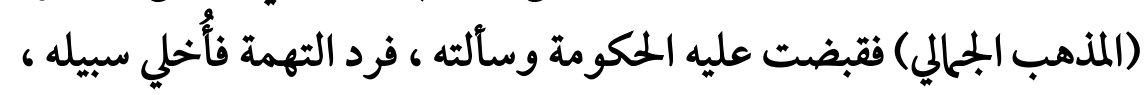

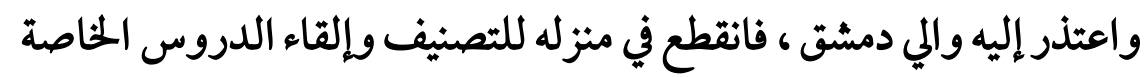

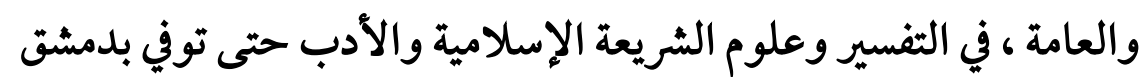

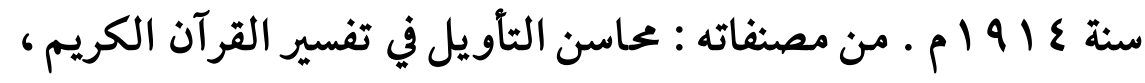

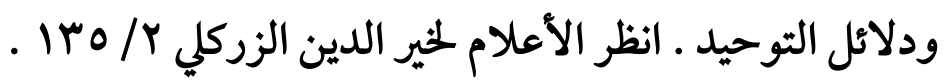

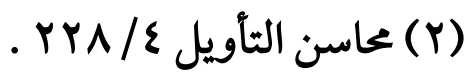




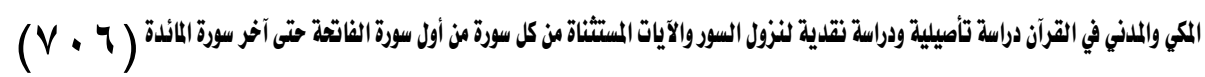

وأصـل هـذا أن العلـاء ـ رحمهـم الله ـ يفرقـون بـين صـيغة النزول

الصريحة، وصيغة النزول غير الصريحة .

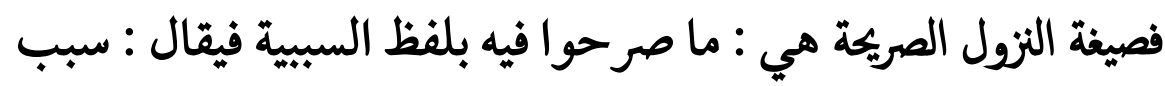

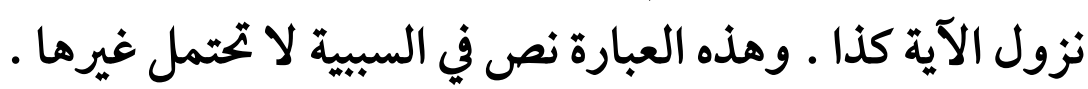

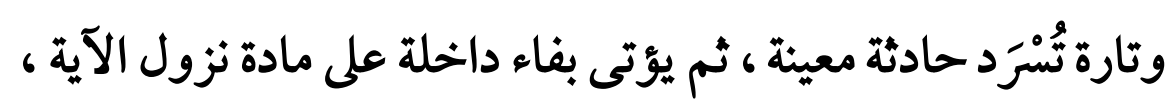
فيقال : حـدث كذا وكذا ، فنزل كذا ـ وهذه العبارة مثل الأولى في فئي

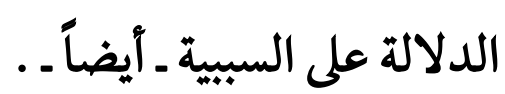

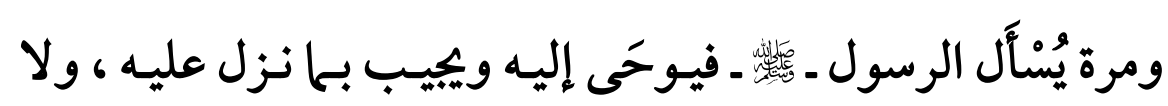
يكون تعبير بلفظ سبب النزول ولا تعبير بتلك الفاء ولكن السببية تفهم قطعاً من المقام ـ وفي كل هذه الحالات يكون نزول الآية في نفس زمن وقوع الحادثة أو السؤال . وصيغة النزول غير الصريحة هي : ما لا يُصََّّح فيها بلفظ السبب ، ولا الا يؤتى بتلك الفاء ، ولا بذلك الجواب المبني على السؤال ـ بـل يقـال :

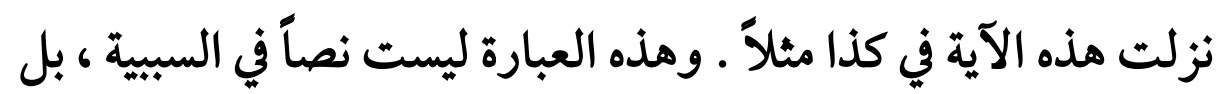
تحتملها ، وتحتمل أمرآ آخر هو بيان ما تضمنته الآية من الأحكام" (1).

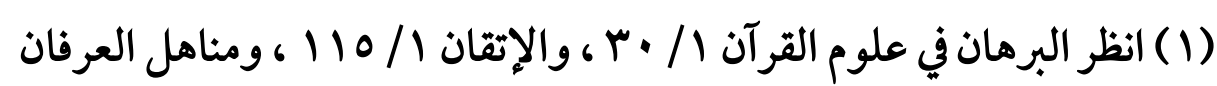

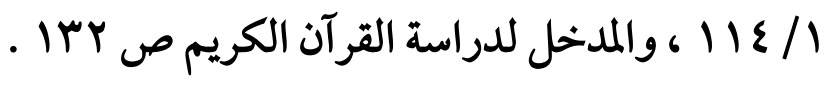


$(V \cdot V)$

قال ابن تيمية ـ رحمه الله ـ :"قولهم : نزلت هذه الآية في كذا ، يراد به

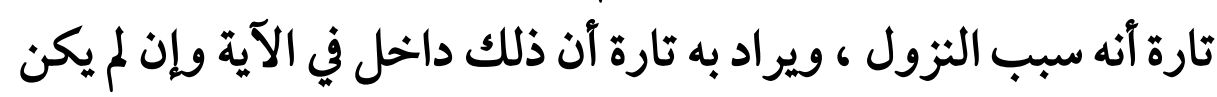

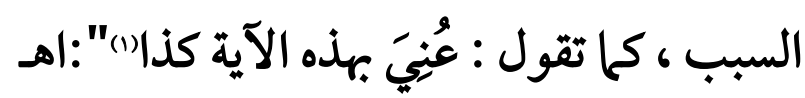

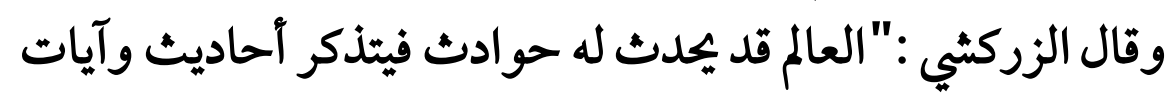

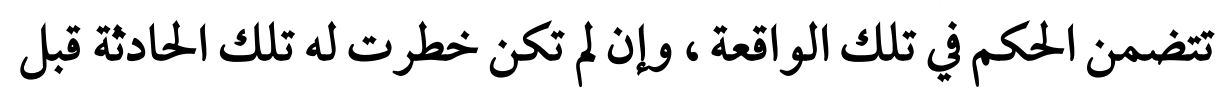
مع حفظه لذلك النص .

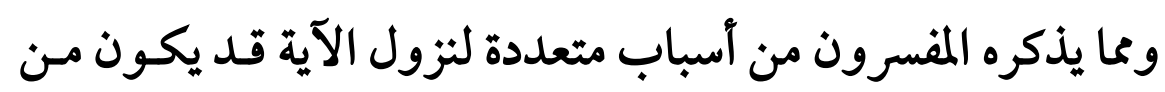

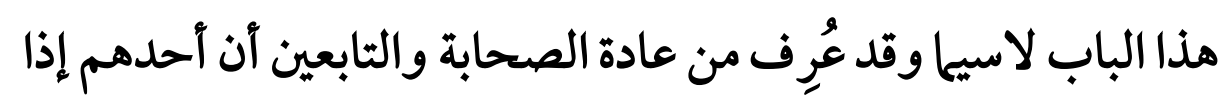

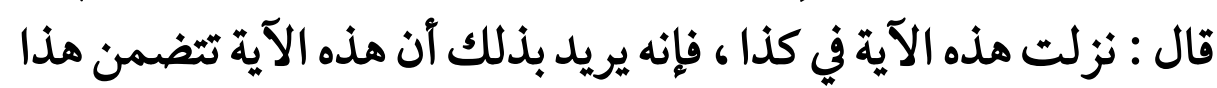

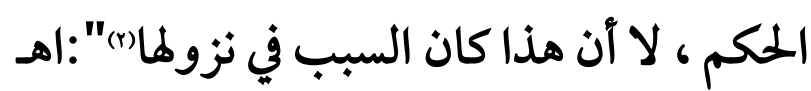

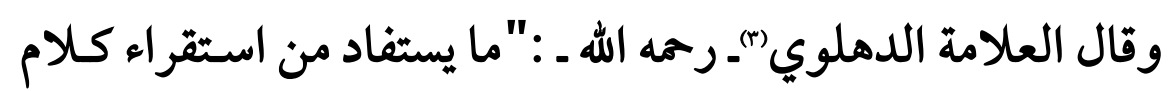

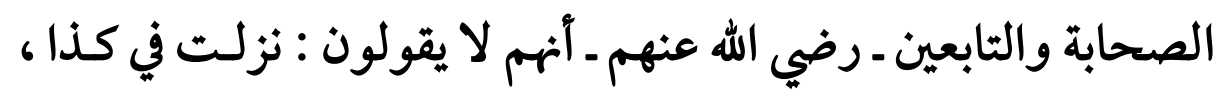

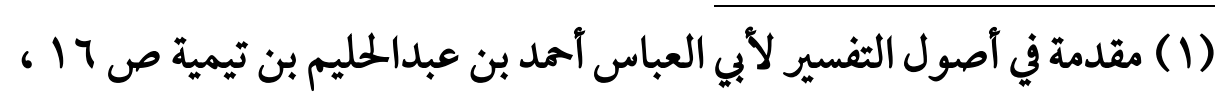

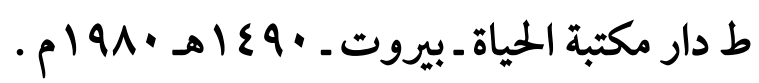

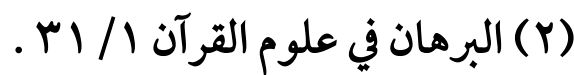

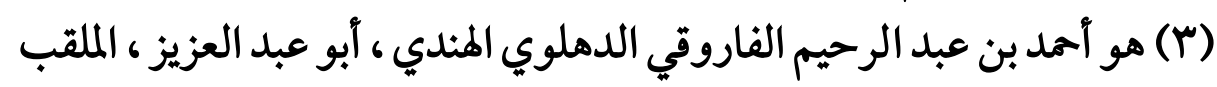

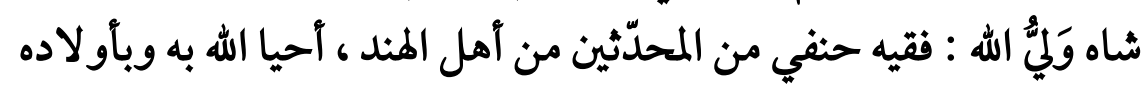

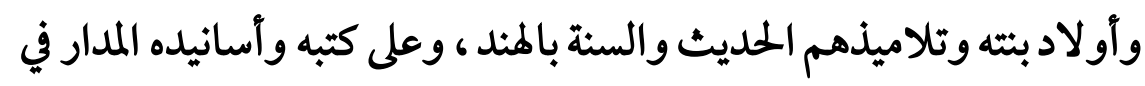

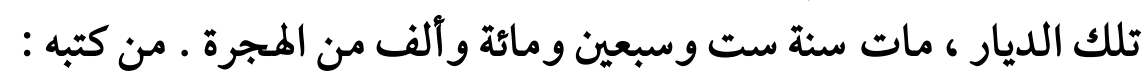

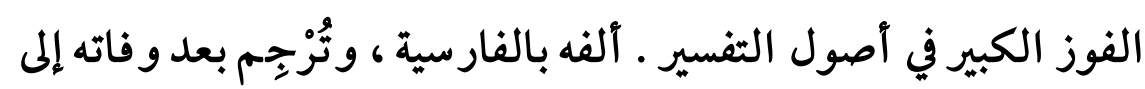




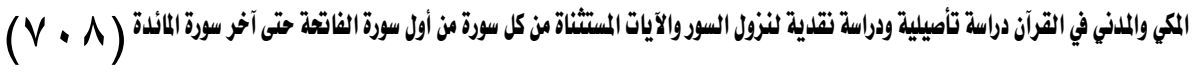

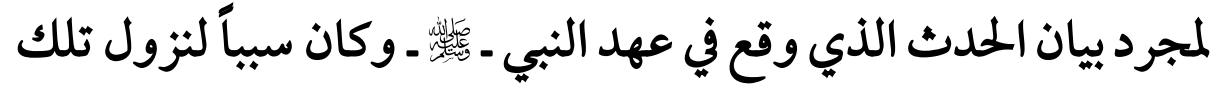

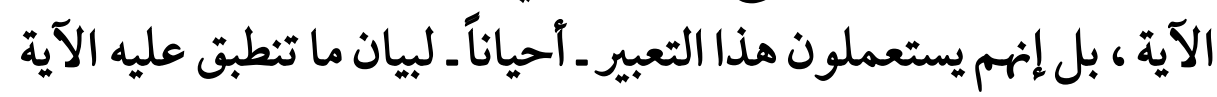

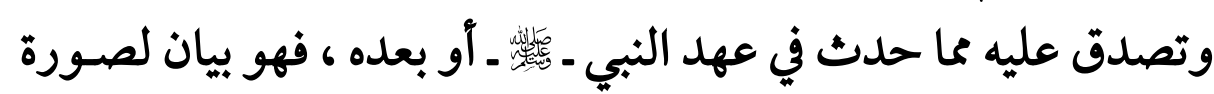

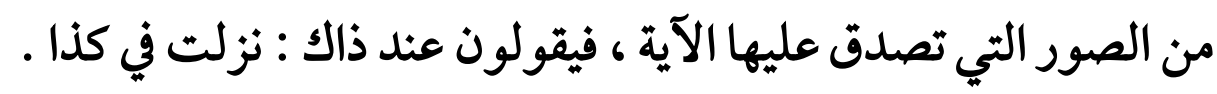

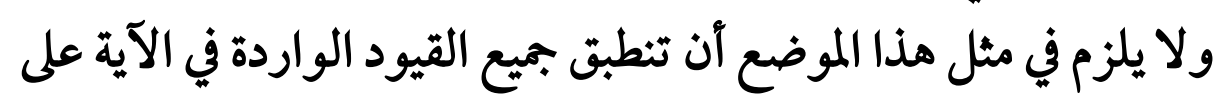

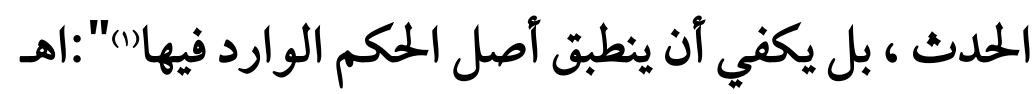

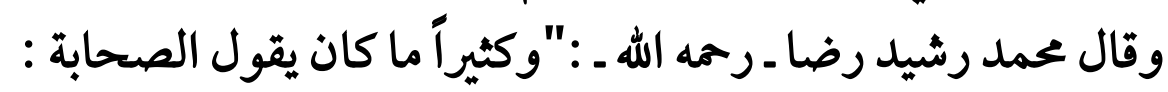

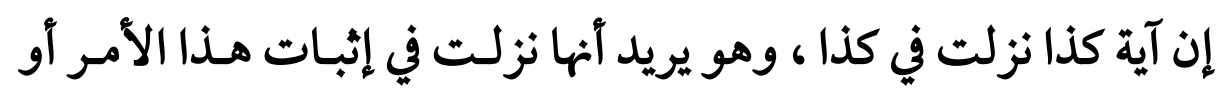

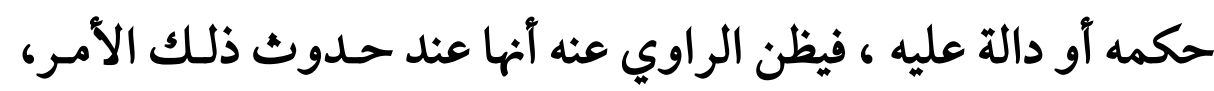

$$
\text { والصحابي لا يريد ذلك (r).":اهـ }
$$

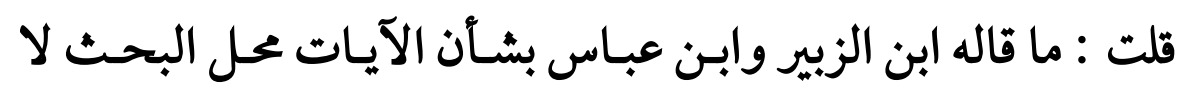

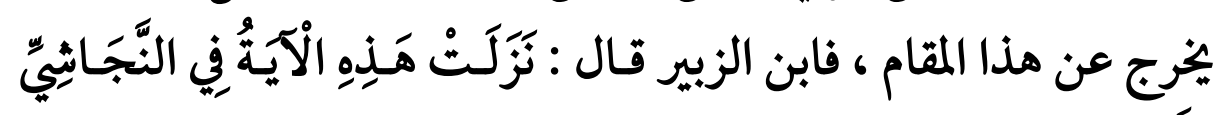

العربية والأُزدِيَّة ونُشِر بها ، وحجة الله البالغة ـ انظر فهرس الفهارس

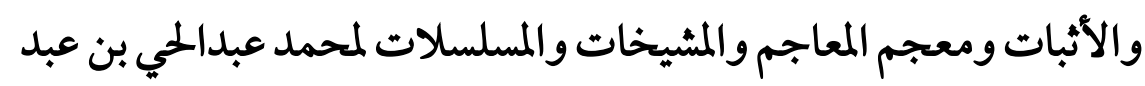

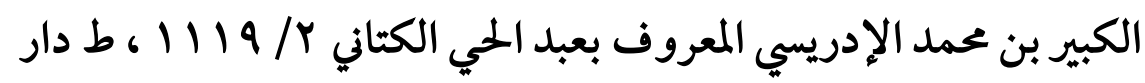

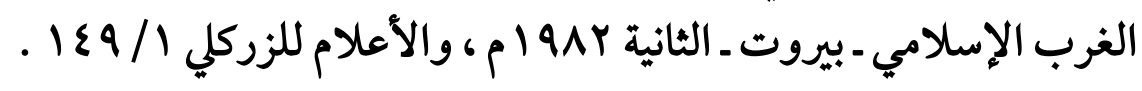

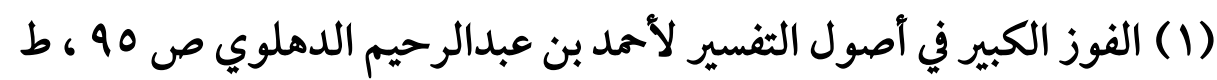

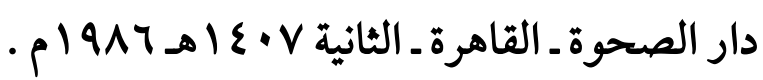

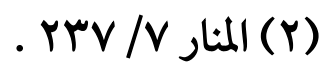


$(V \cdot 9)$

وابن عباس قرأ الآية ، ثم حكى موقف النجاشي وأصحابه ، ثم قال

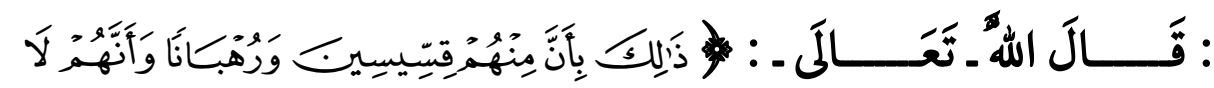

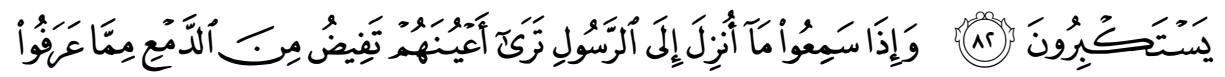

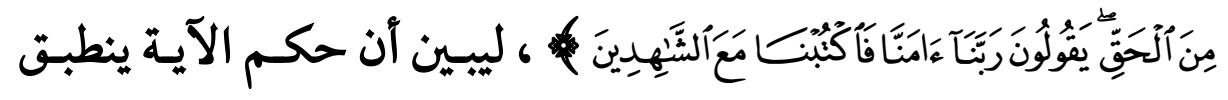
على النجاثي وأصحابه بسبب مـوقفهم مـن الصسحابة الذين هـاجروا إليهم ، وموقفهم من القرآن لما سمعوه منهم •

ومعنى هذا آن قصة النجاشي وبكائه ليست سبباً لنزول الآية لما بينها

$$
\text { من الزمن الطويل والأمد البعيد") }
$$

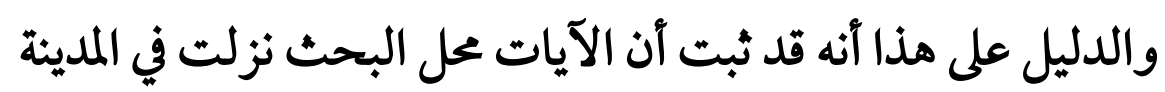

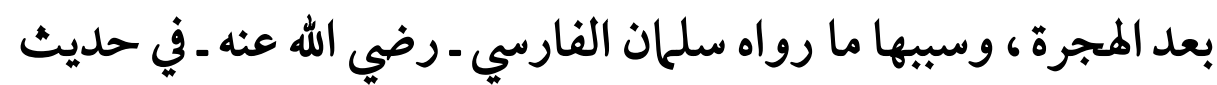
طويل جداً ذكر فيه قصة إسلامه ، وكيف أثه كان بجوسياً ثم تنصر على أنى

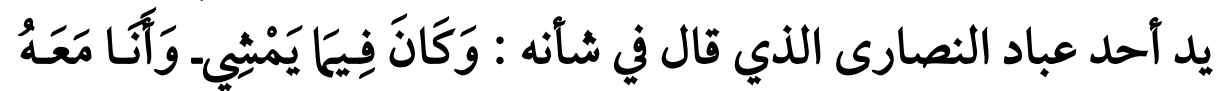

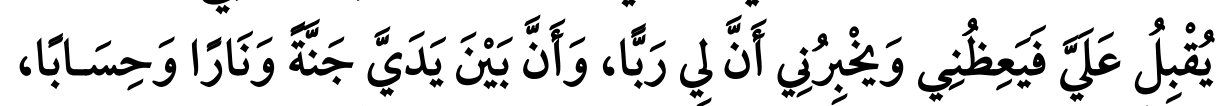

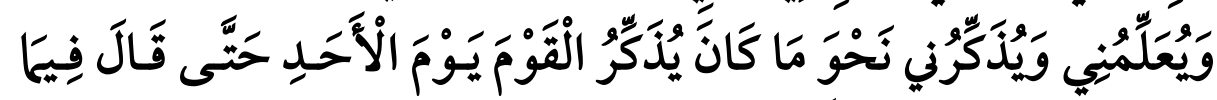

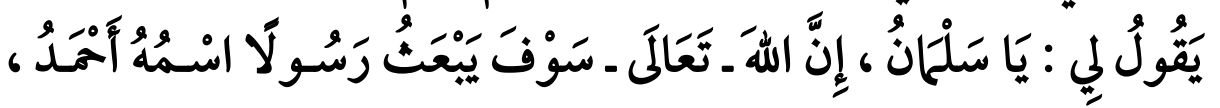

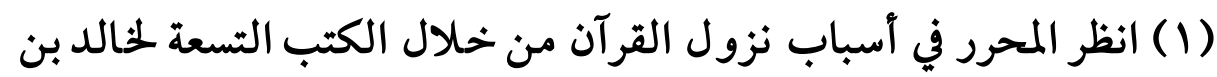

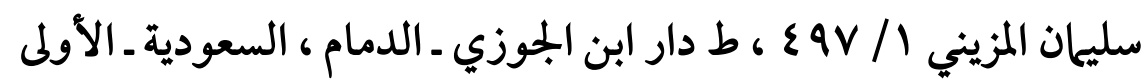




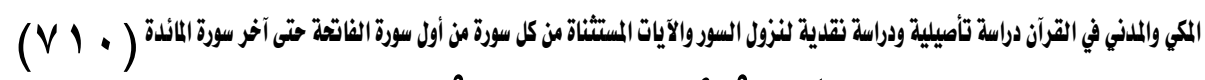

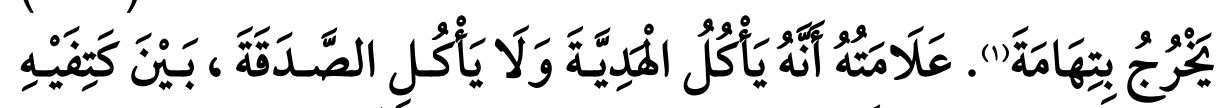

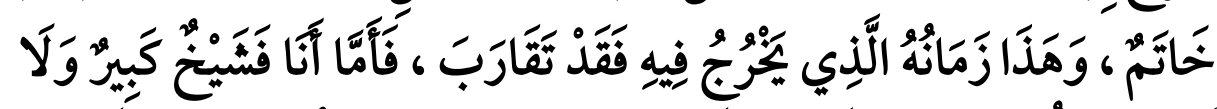

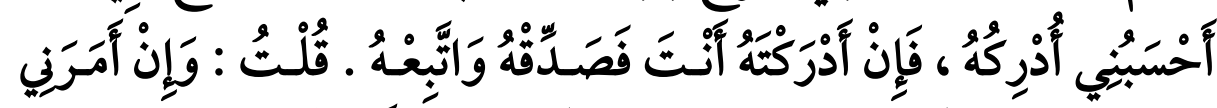

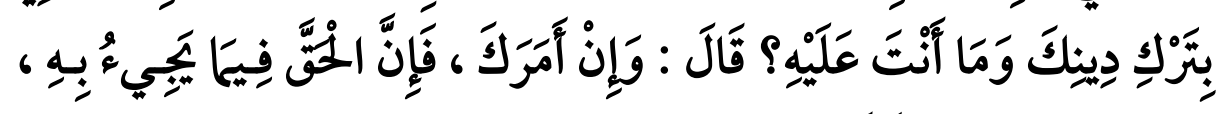

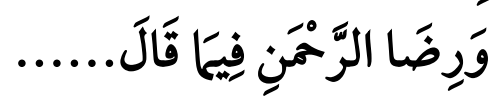

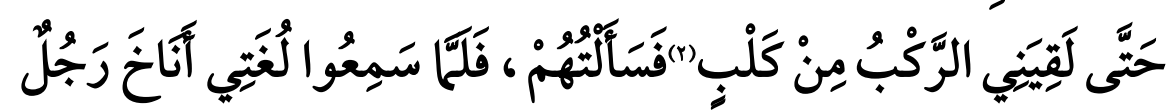

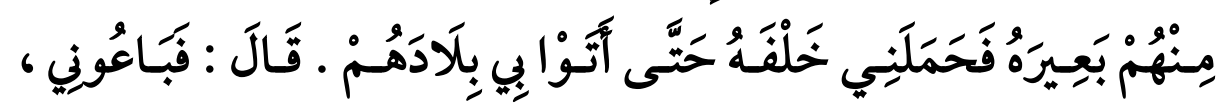

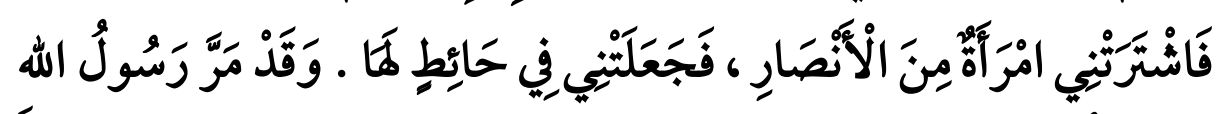

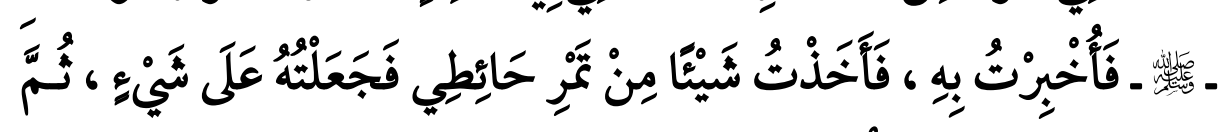

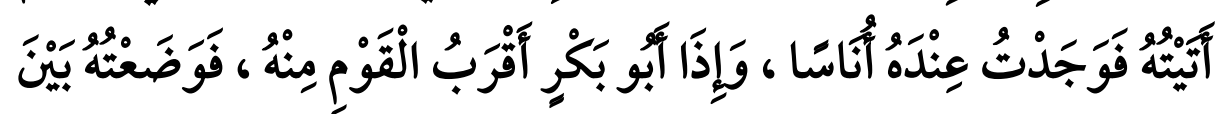

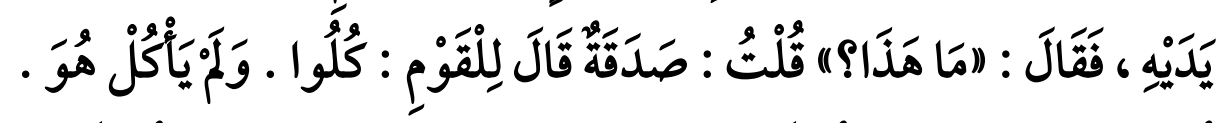

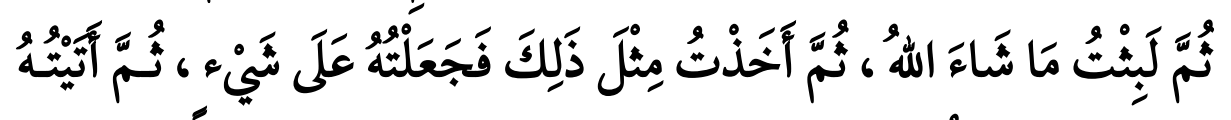

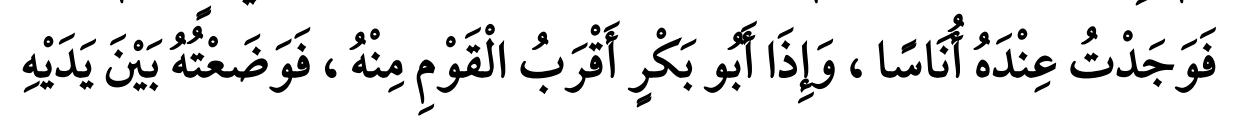

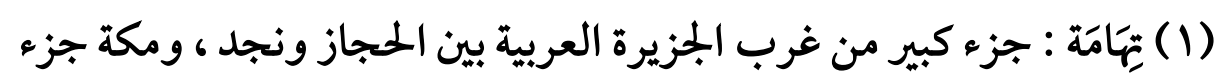

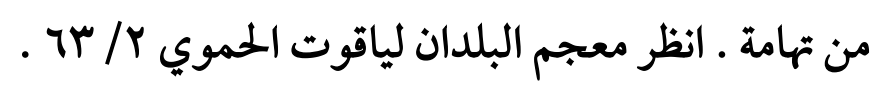

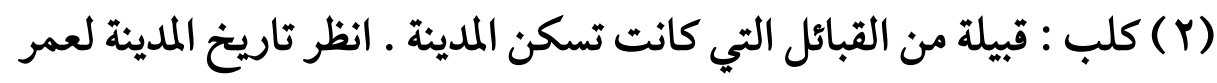

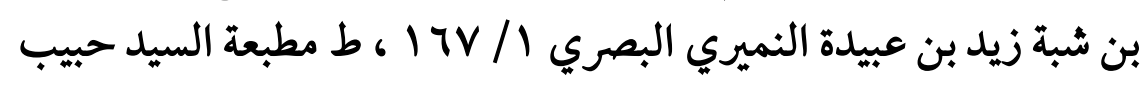

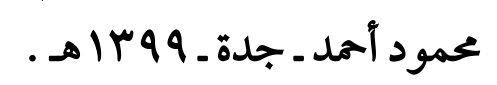


(VII)

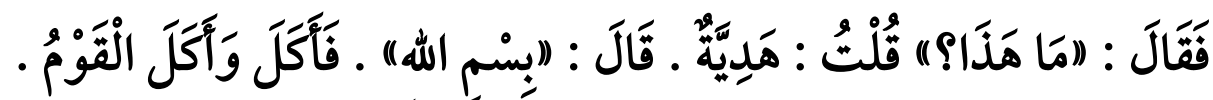

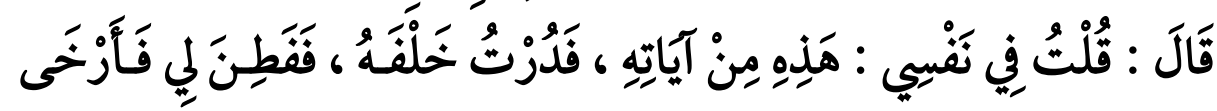

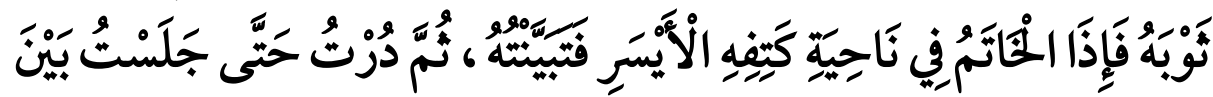

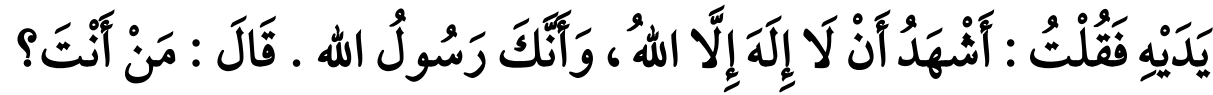

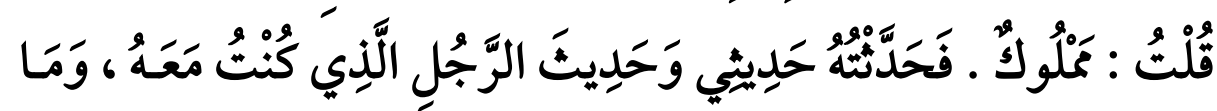

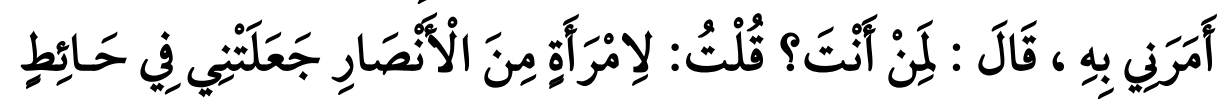

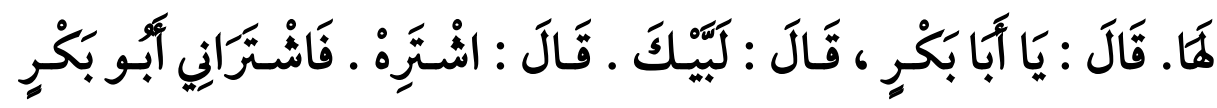

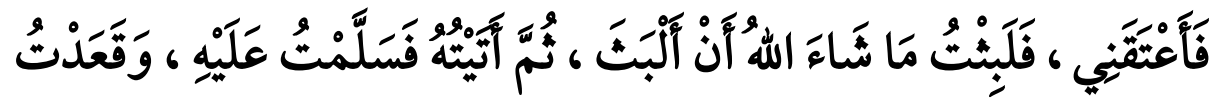

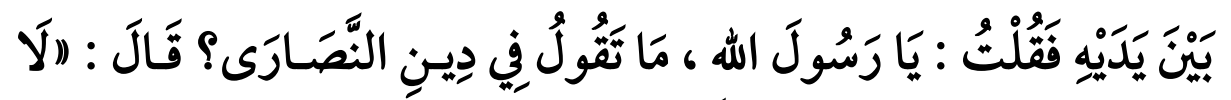

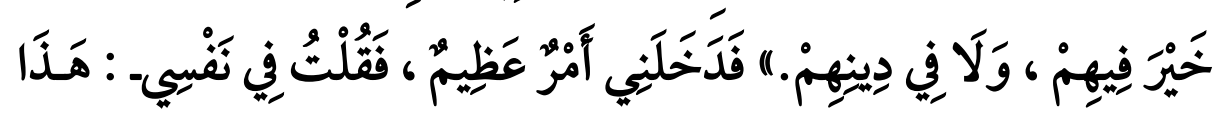

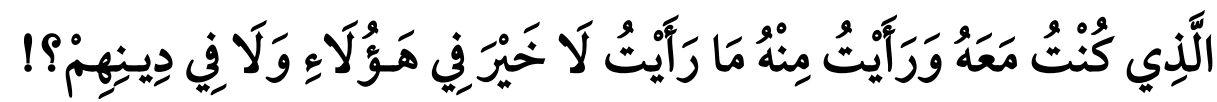

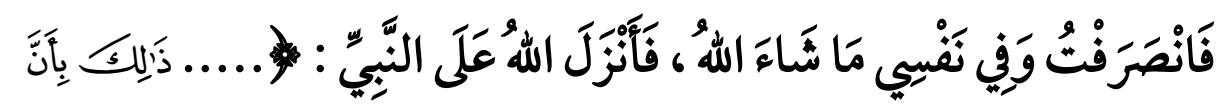

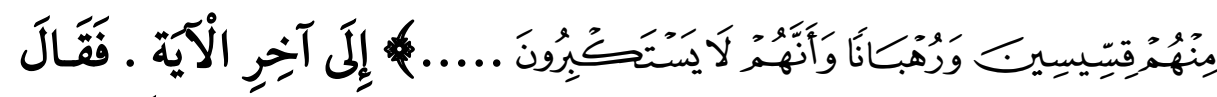

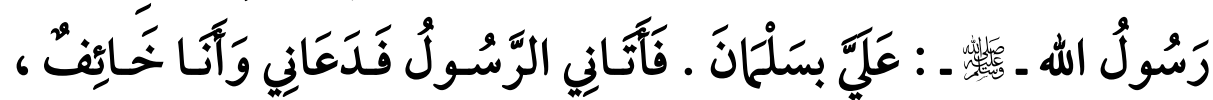

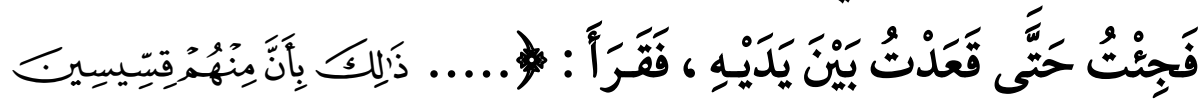

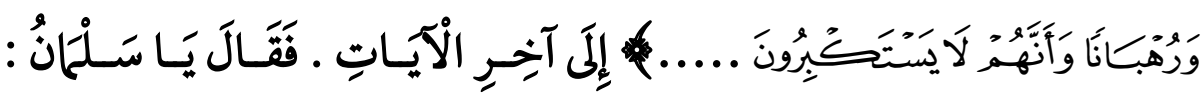

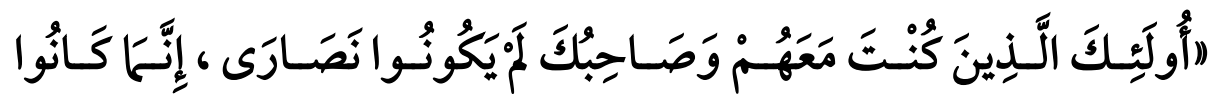




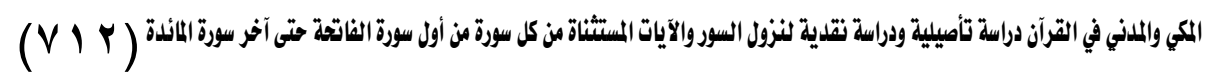

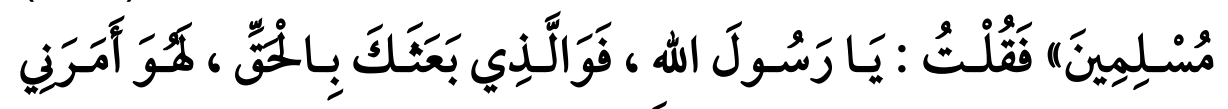

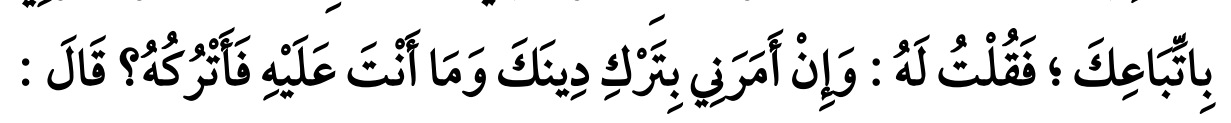

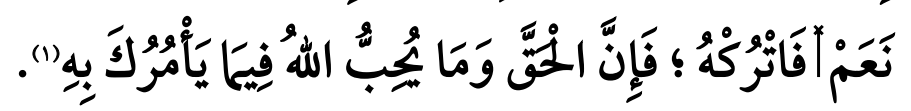

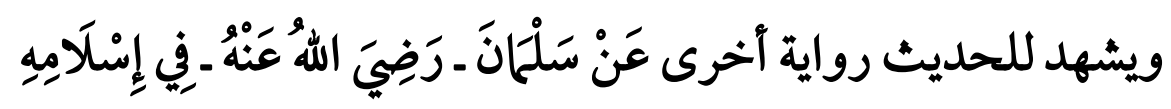

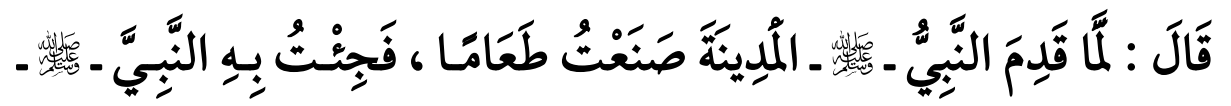

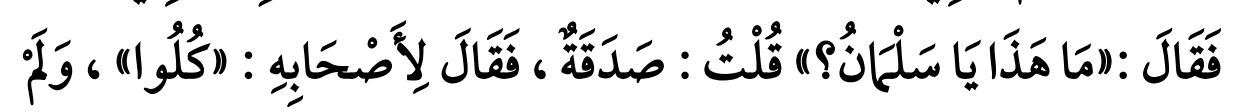

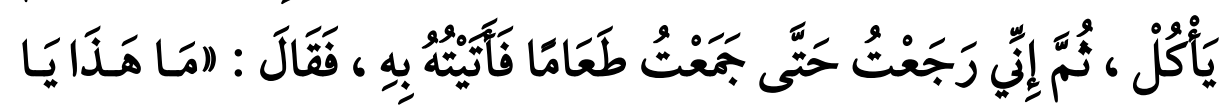

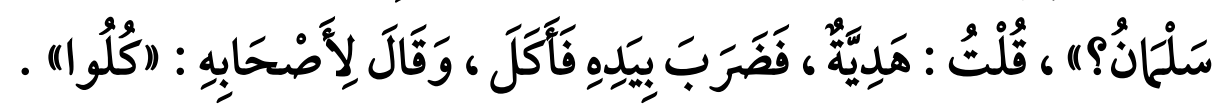

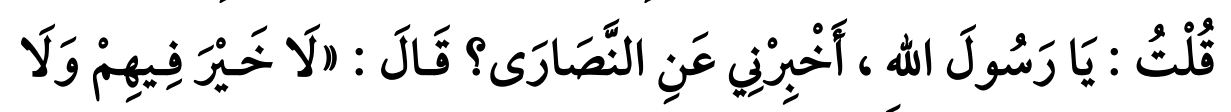

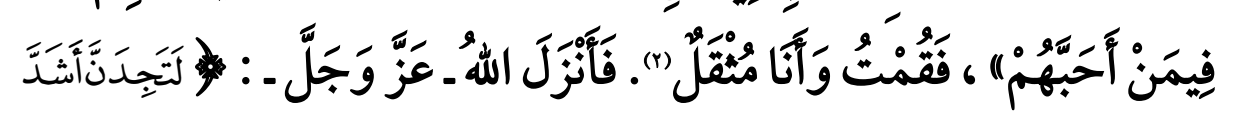

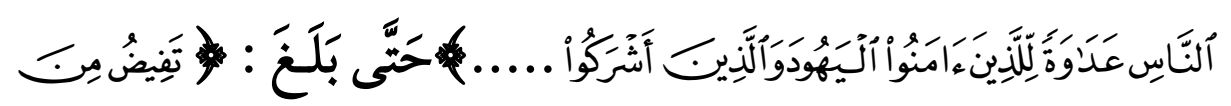

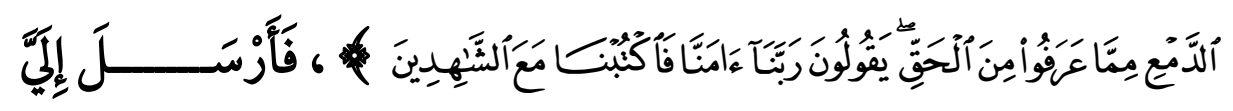

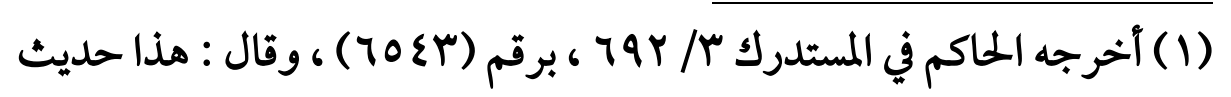

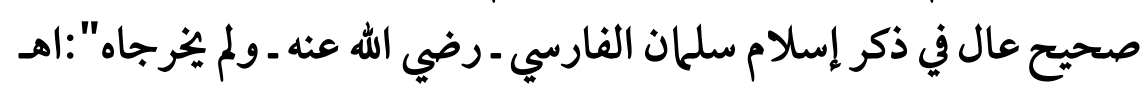

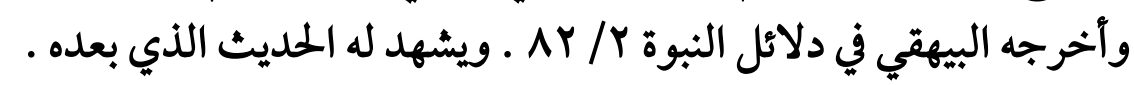

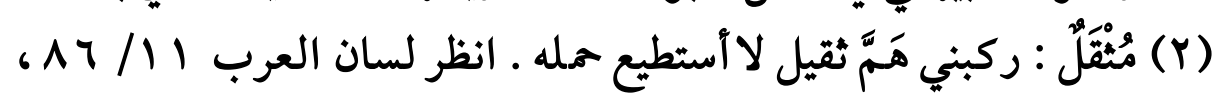

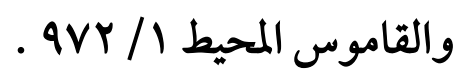


(VIT)

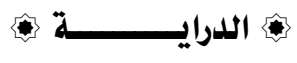

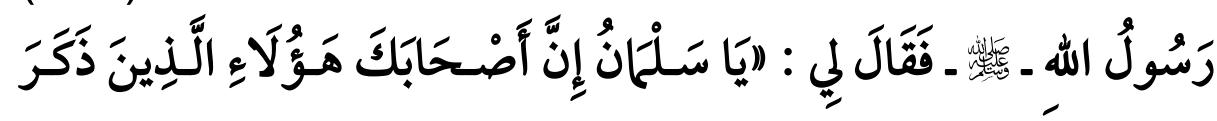

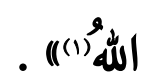

خلاصة القول : أن الآيات محل البحث مدنيات كسورتها ، ولم يستنها أحد من مدنية سورة المائدة .

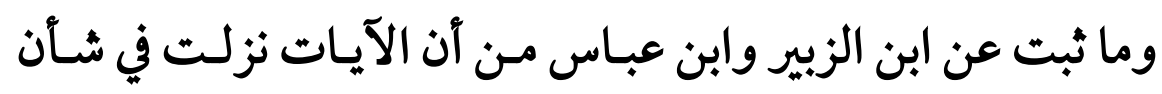

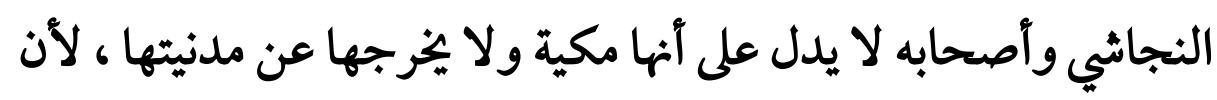

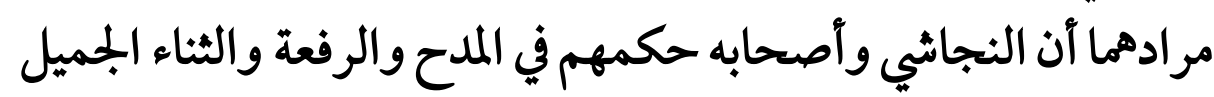

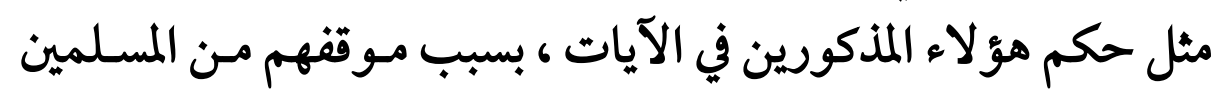

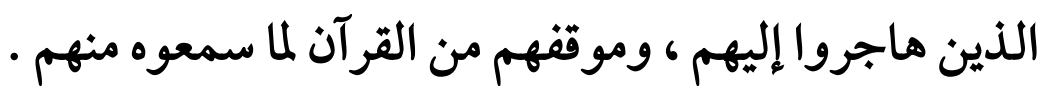

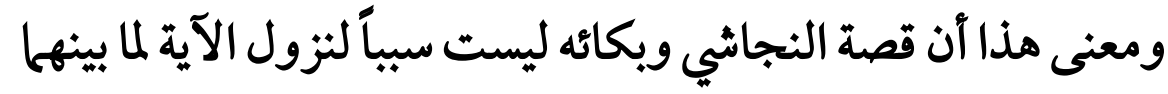

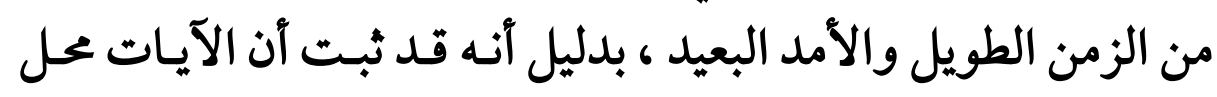

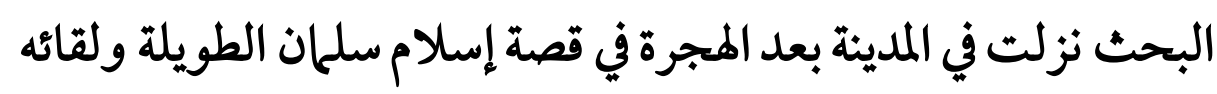

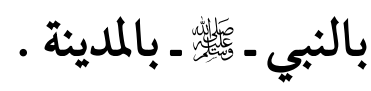

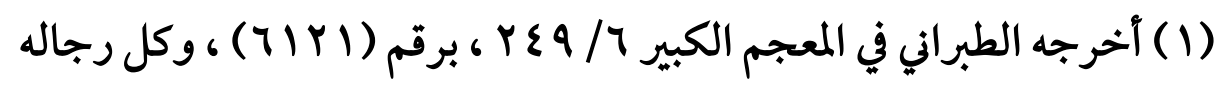

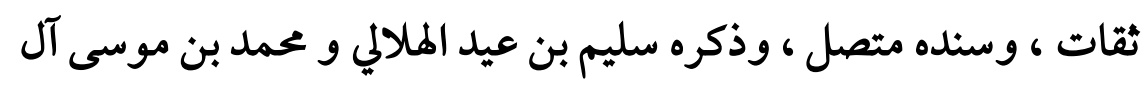

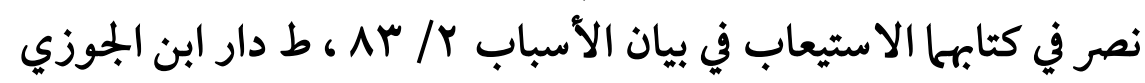

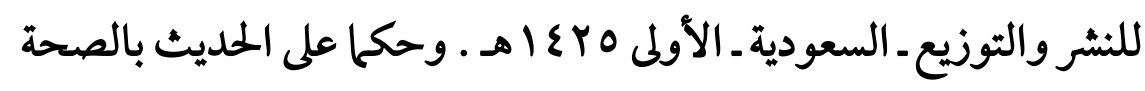




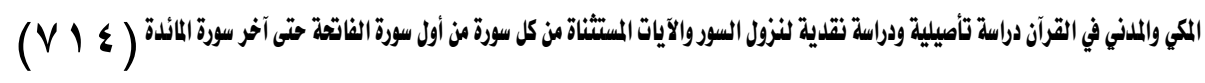

\section{الخاتثة}

الحمد لله رب العالمين ، والصلاة والسلام على أثرف المرسلين سيدنا

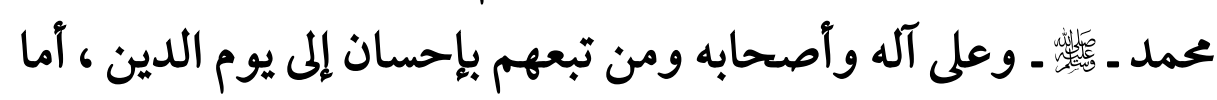
بعد... n n

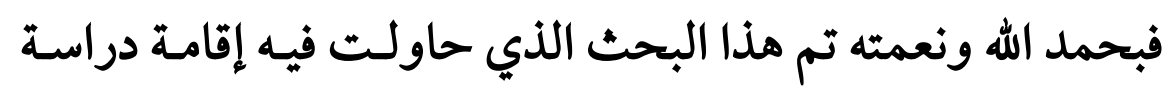

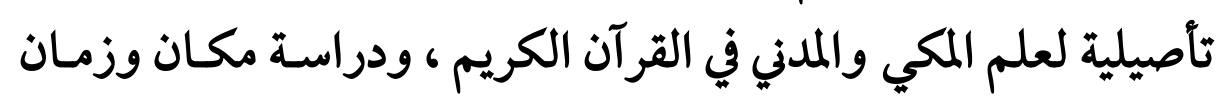

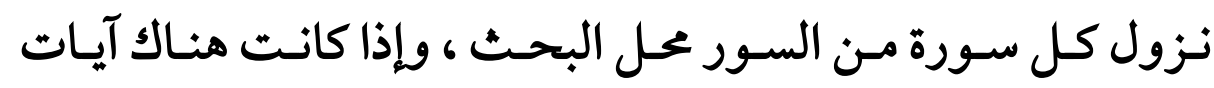

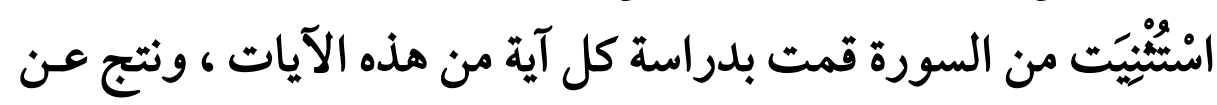

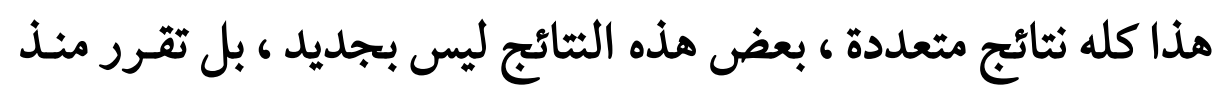

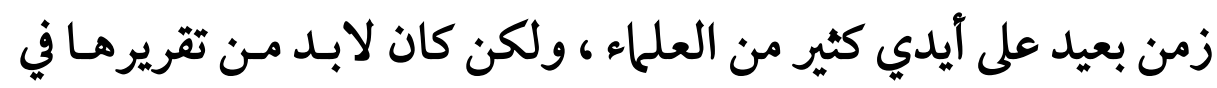

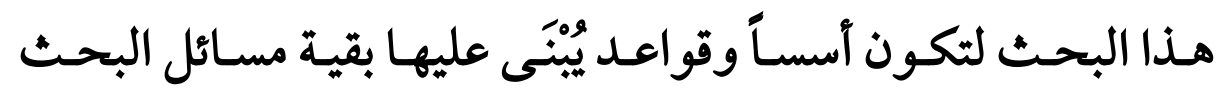

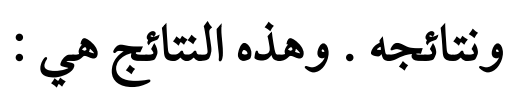

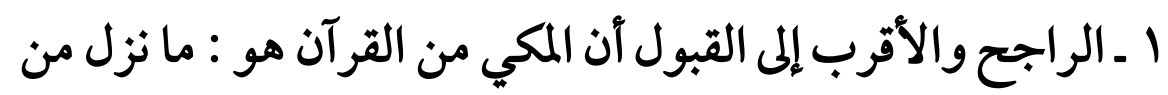

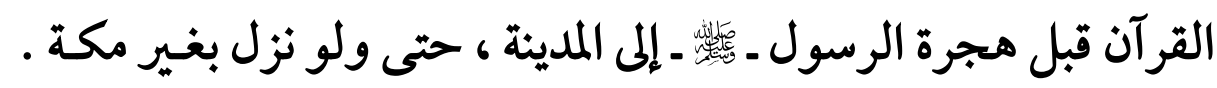

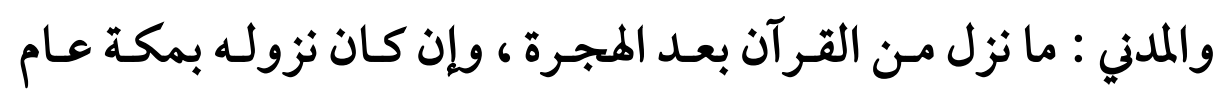
الفتح، أو عام حجة الوداع ، أو بسفر من الأسفار.

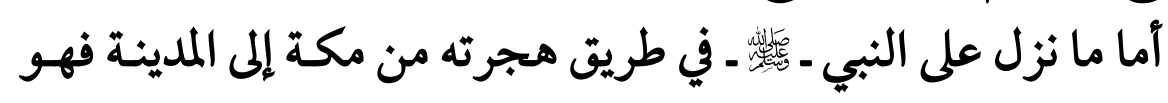

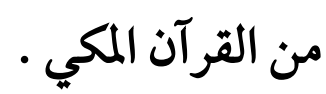


( $(10)$

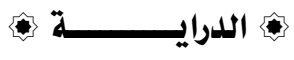

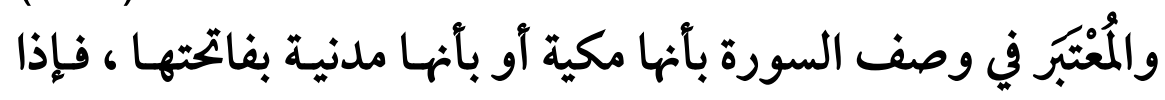
نزلت فاتحة سورة قبل المجرة فهي مكية ، وإذا نزلت فاتحة سـورة بعـد فئد

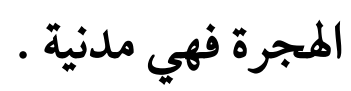

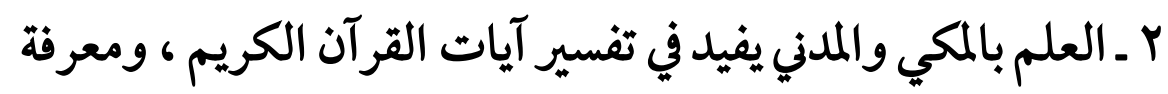

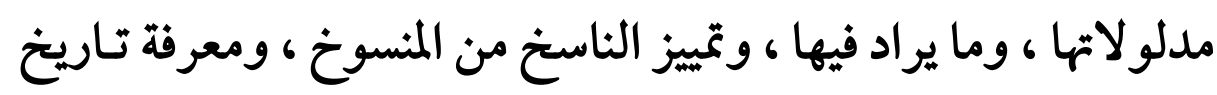

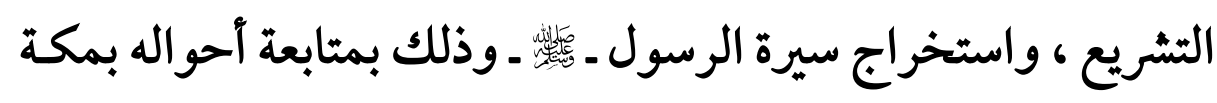
ومواقفه في الدعوة ، ثم أحواله في المدينة وسيرته في الدعوة إلى الله فيها

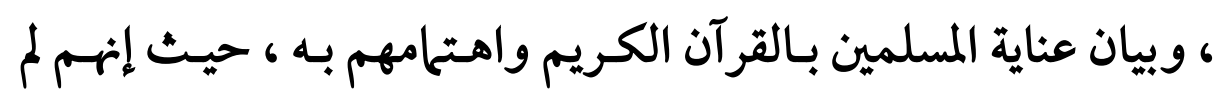

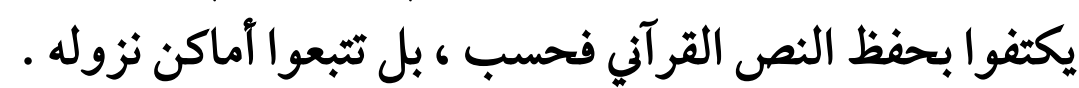

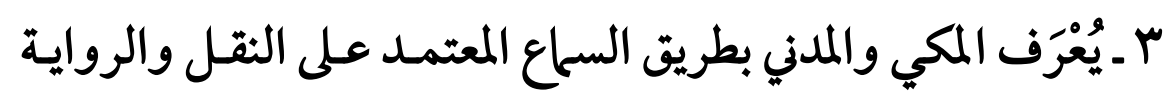

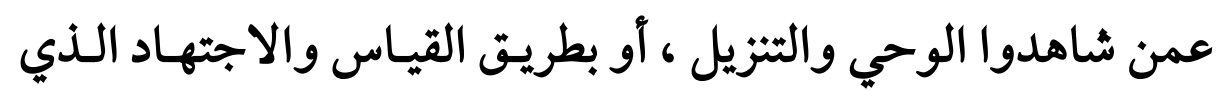
يستند إلى خصائص المكي وخصائص المدني . ع ـ وردت تسع روايات عن الصحابة والتابعين حددت السور المكية المبنية والمدنية ، اتفقت هذه الروايات في مجموعها على عشرين سورة أنها سور

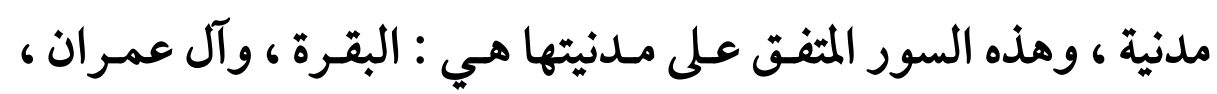

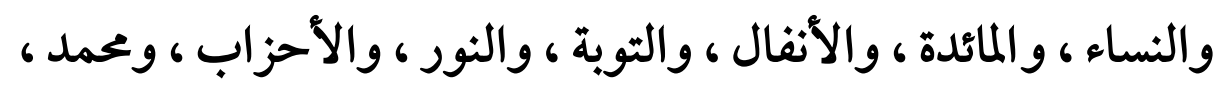

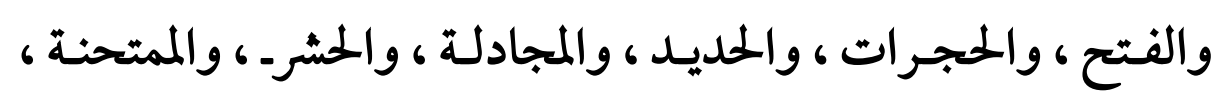

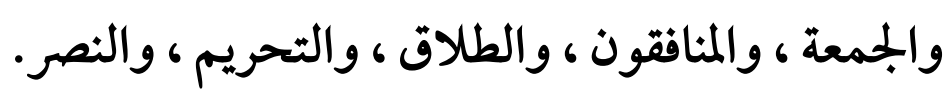




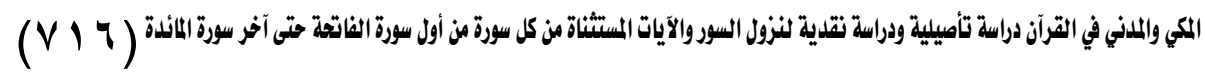
واختلفت هذه الروايات في سبع عشرة سورة وهي : الرعد ، والنحل،

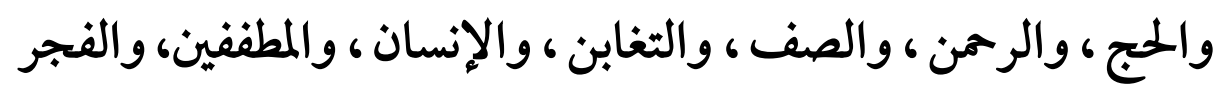

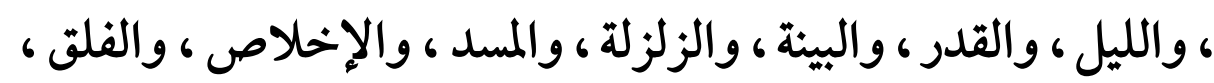
والناس •

واتفقت الروايات التسع في بجموعها على سبع وسبعين سورة أنها

$$
\text { سور مكية وهي ما تبقى من سور القرآن . }
$$

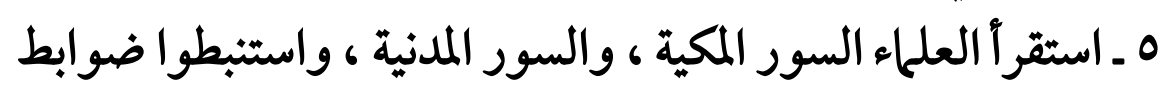

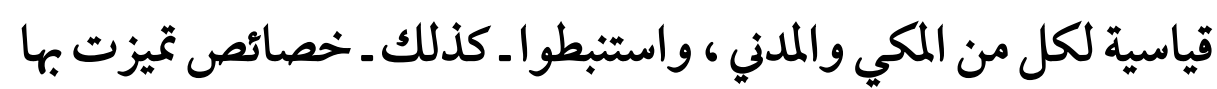
السور المكية ، وخصائص تميزت بها السور المدنية .

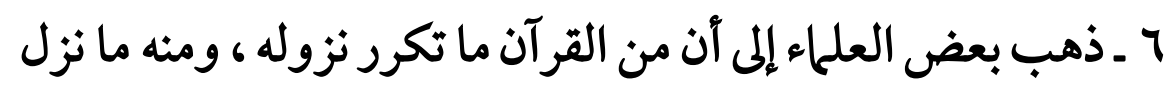
مرة بمكة قبل المجرة ثم نزل مرة أخرى بالمدينة بعد المجرة .

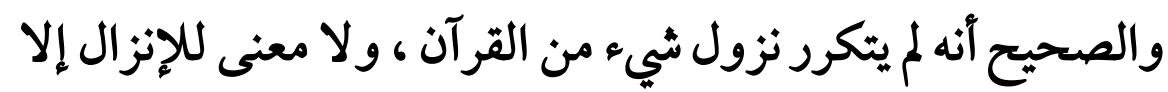

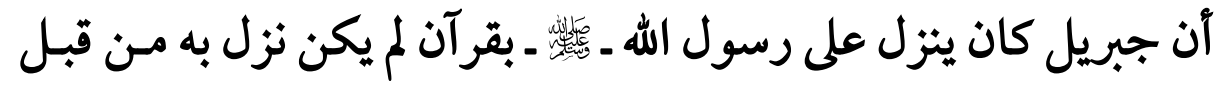

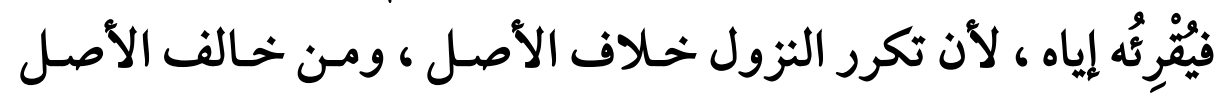

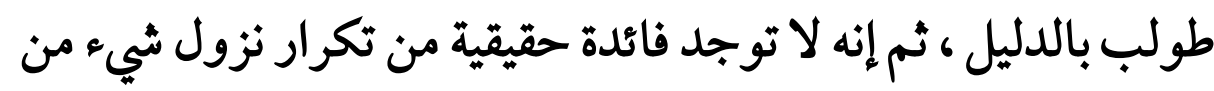

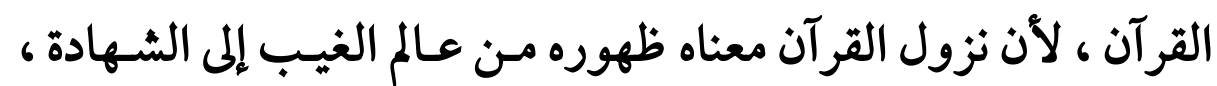

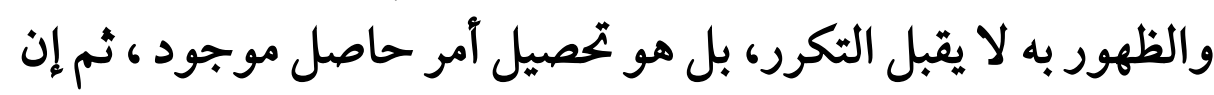

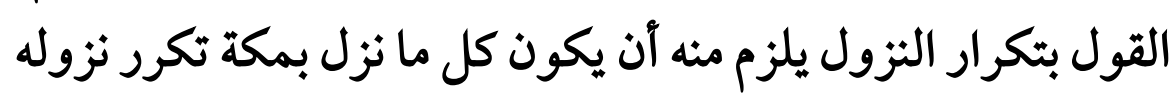


(VIV)

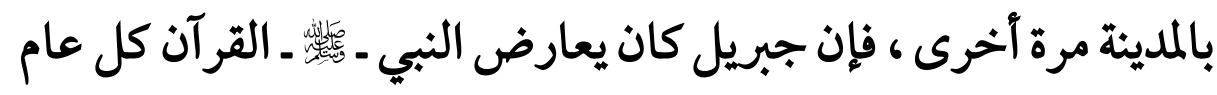

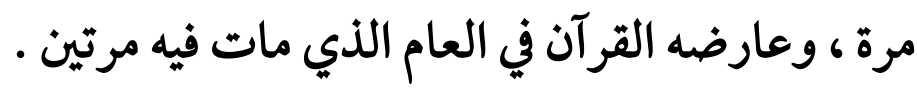

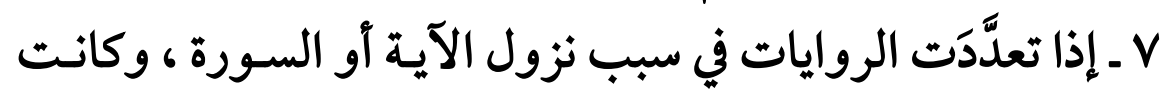

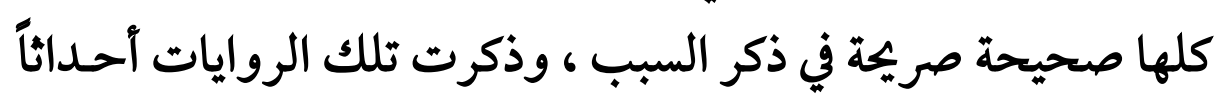

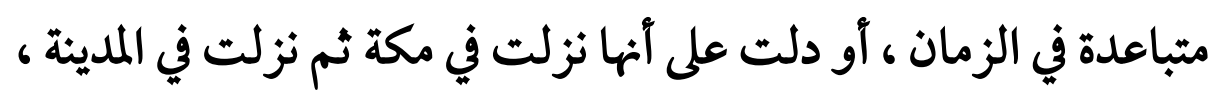

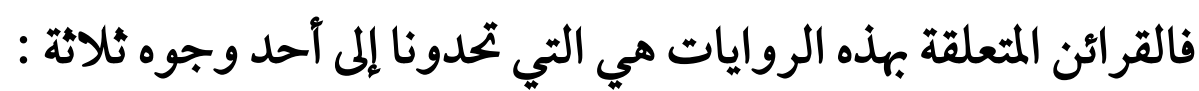

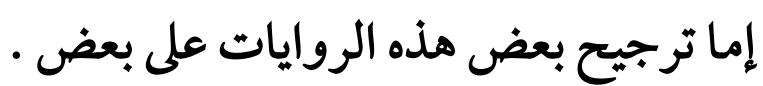

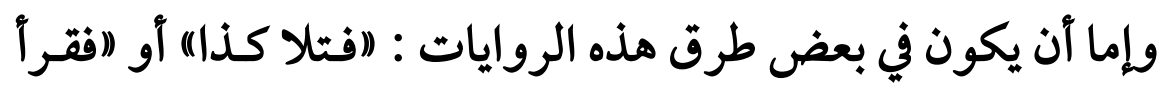

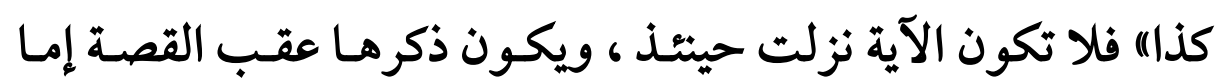

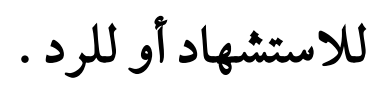

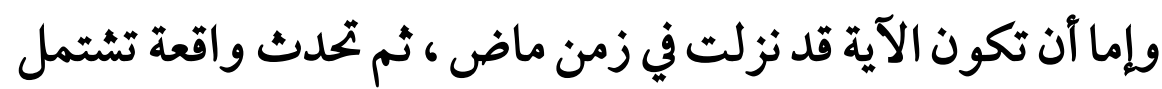

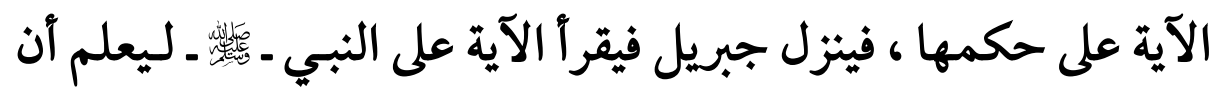
الآية تدل على حكم هذه الواقعة .

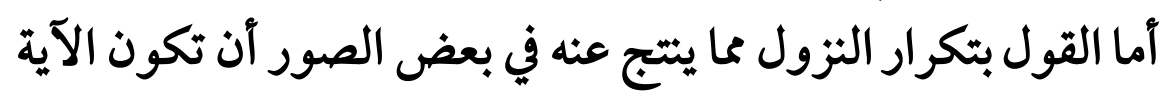

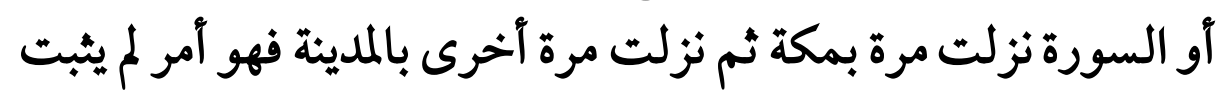

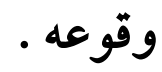

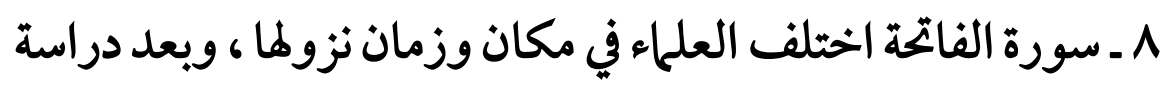

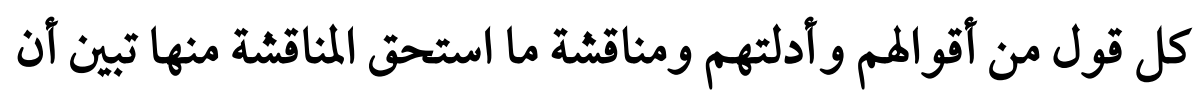




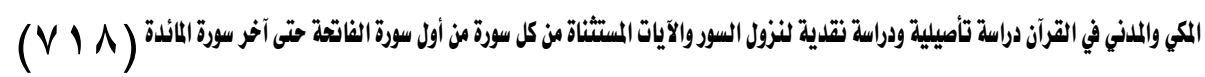

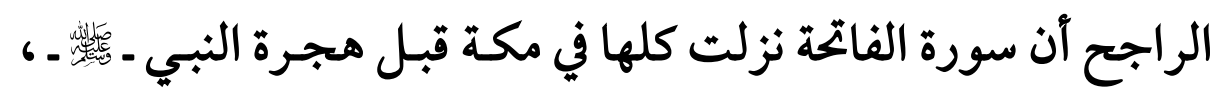

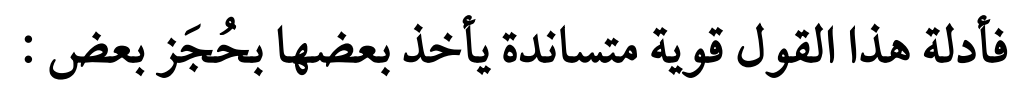

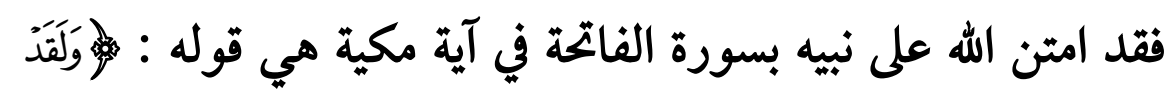

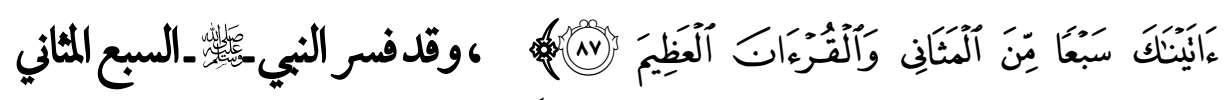
بالفاتحة ، وكفى بتفسير رسول الله تفسيراً . وثبت أن ولد عمرو بن الجموح قد تعلم الفاتحة قبل المجرة ، وقئ وقرأها على أبيه قبل إسلامه ، والثابت أن عمرو بن الجموح أسلم قبل هجرة تعرة

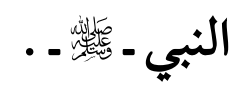

وشهد علي بن أبي طالب ـ رضي الله عنه ـ أنها نزلت بمكة .

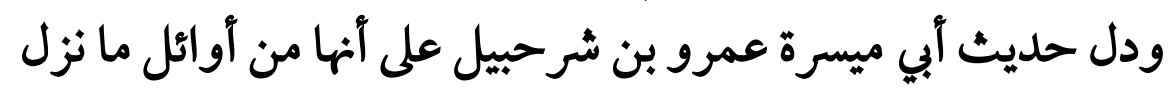

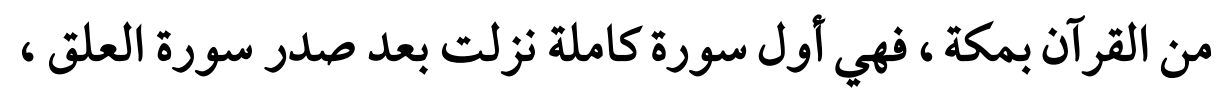

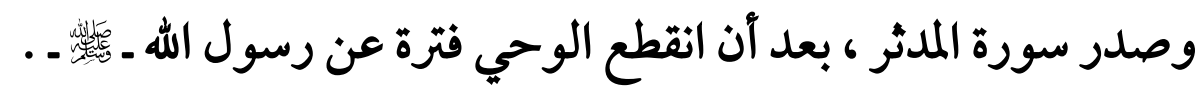

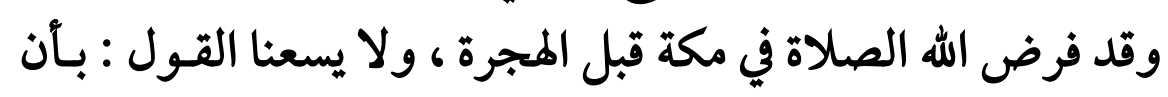

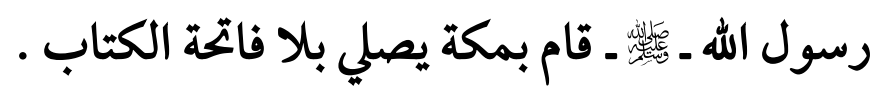

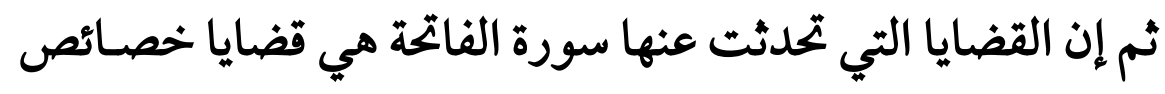
السور المكية . أما الأقوال الأخرى فأدلتها لم تسلم من المناقشة والرد . 
$(\vee 19)$

9 ـ سورة البقرة مدنية بإجماع الآراء ، وقد ابتـدأ نزولها بعـد هجرة

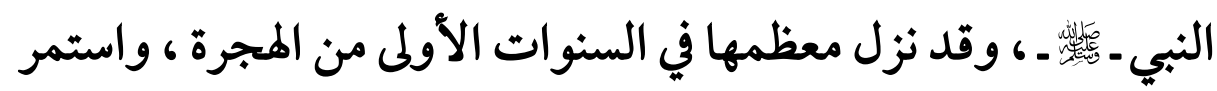

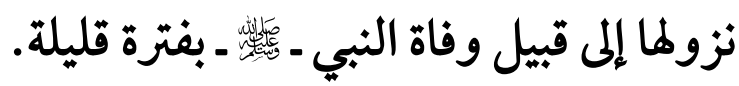

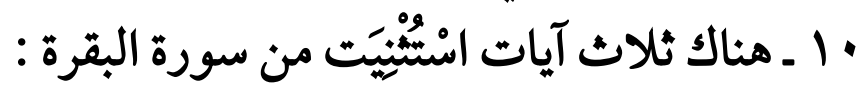

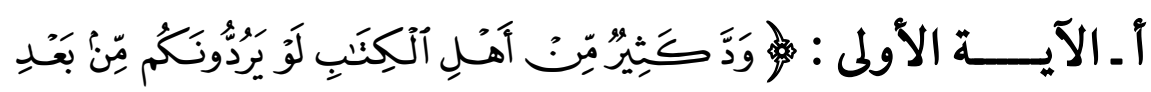

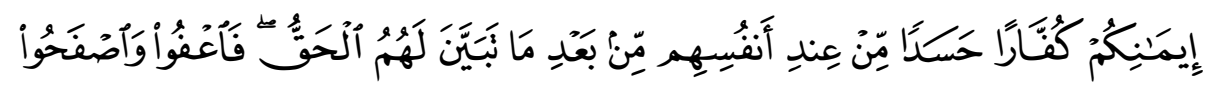

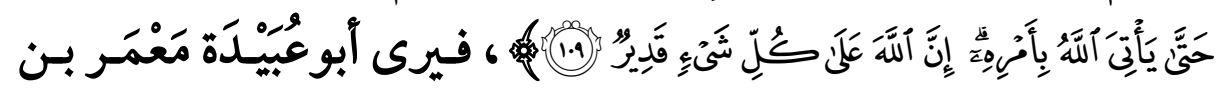

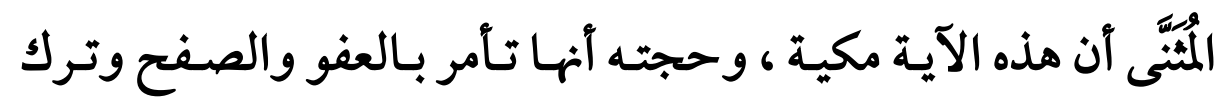

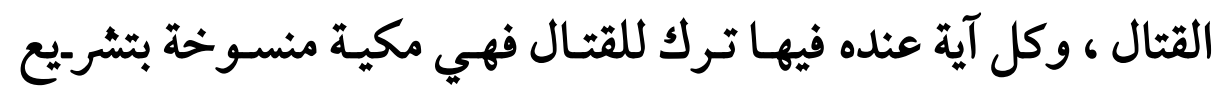
القتال .

والصحيح آن الآية مدنية كسورتها ، دل على هـذا حـديثها الصر-يح

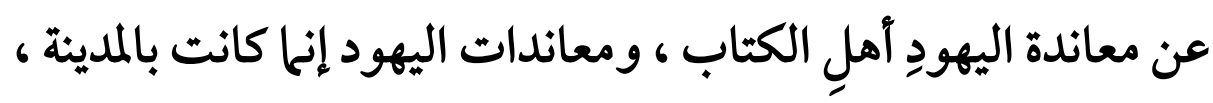

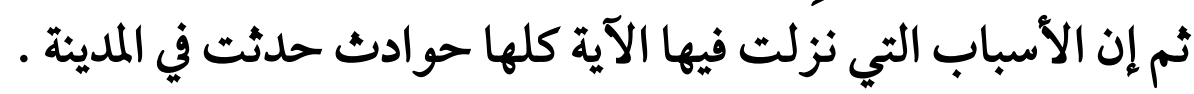

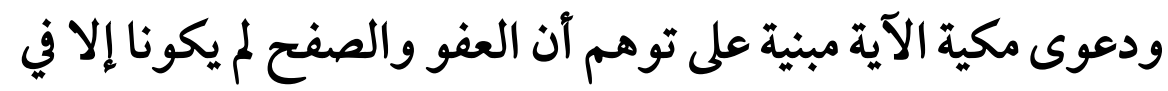

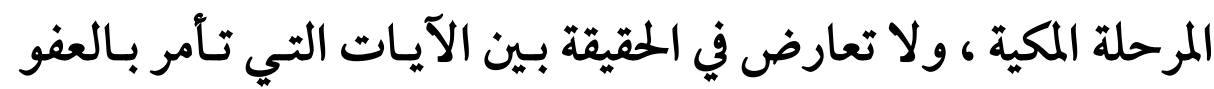

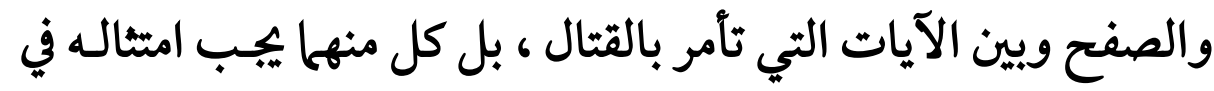
وقته .

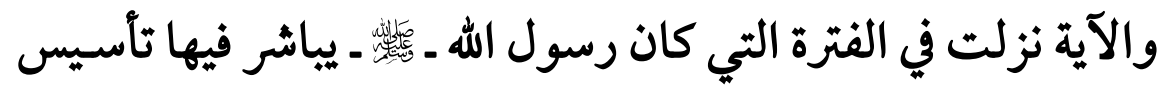

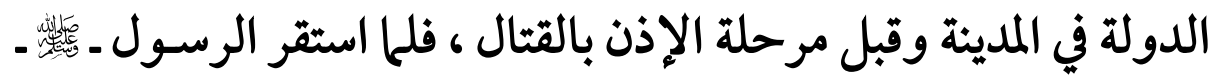

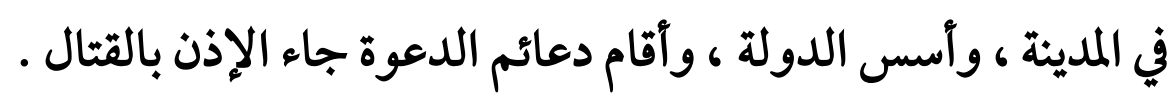




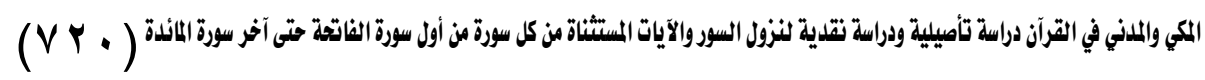

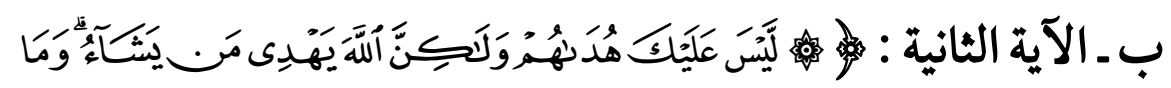

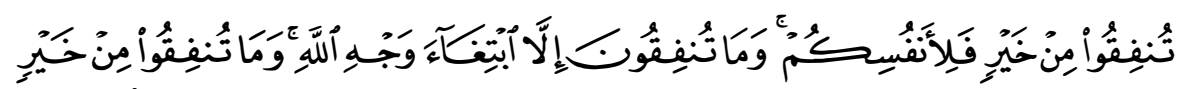

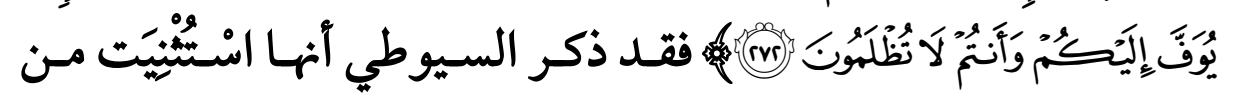
مدنية سورة البقرة .

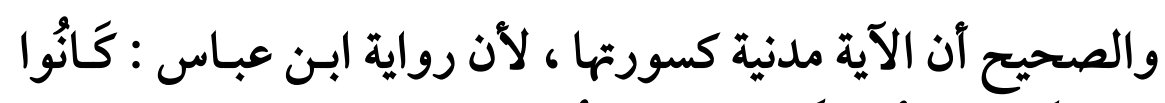

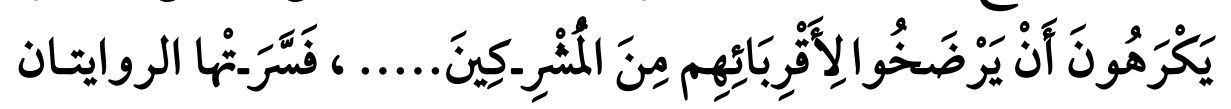

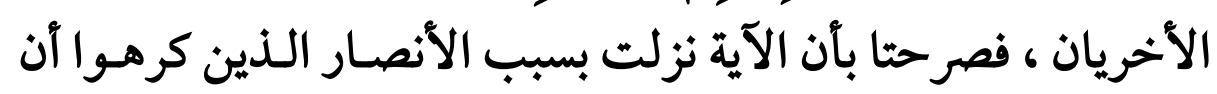

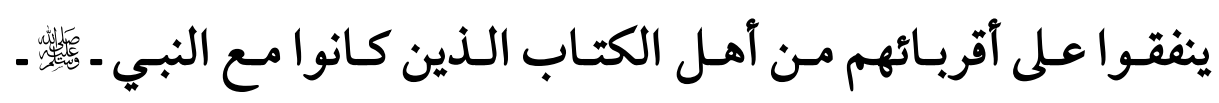

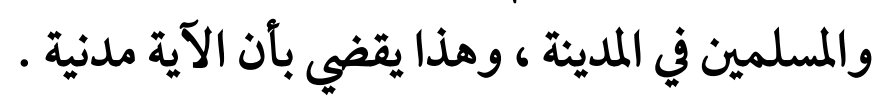

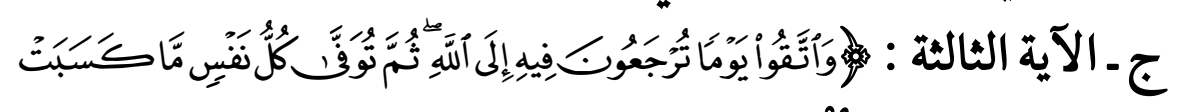

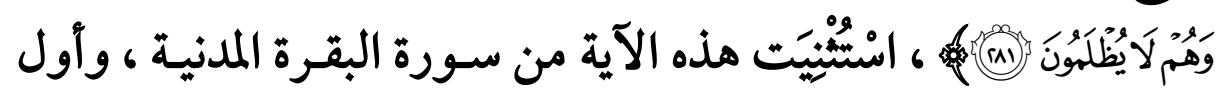

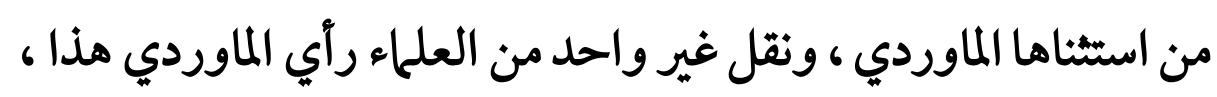

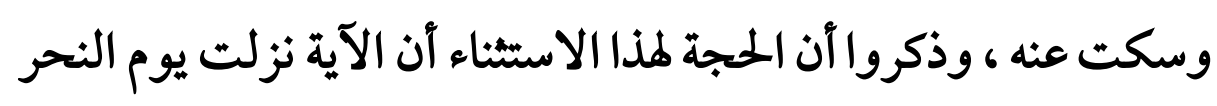

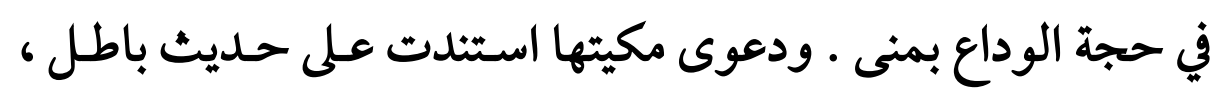

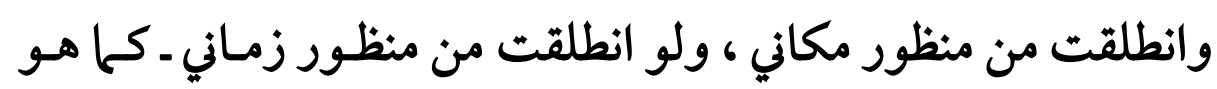

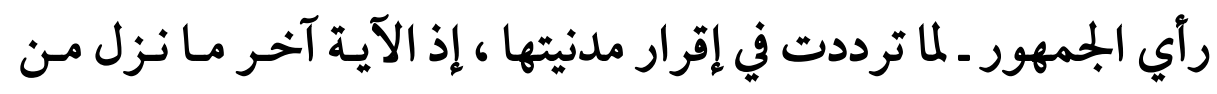

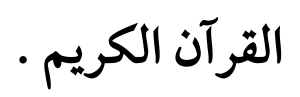
11 ـ سورة آل عمران سورة مدنية ، بدليل ما صح من أسباب نزول

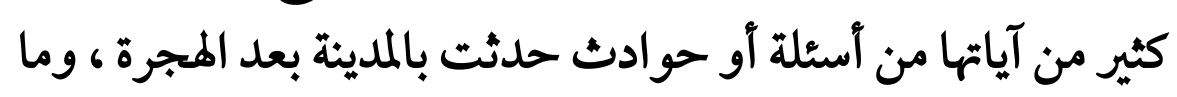




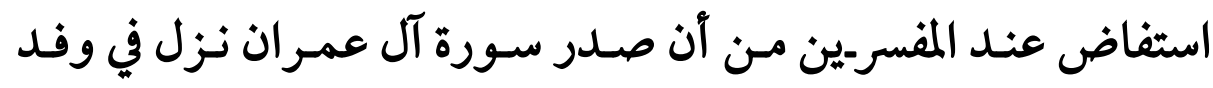

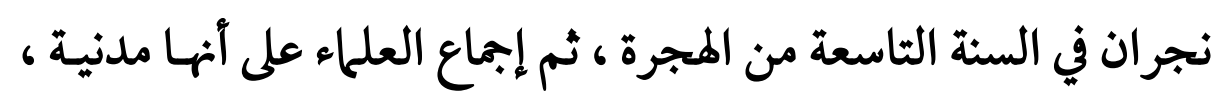

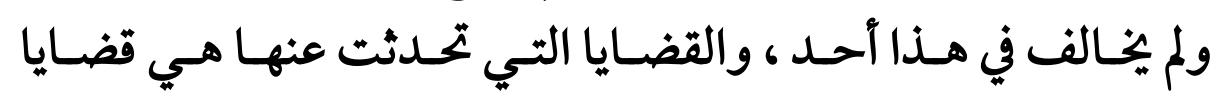

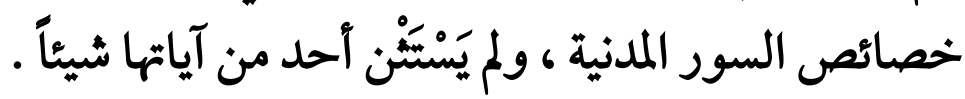

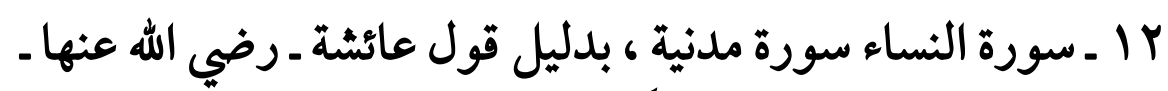

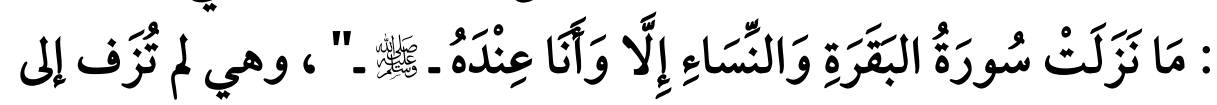

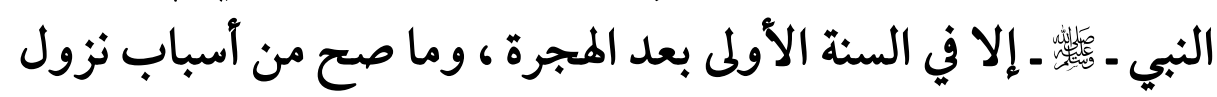

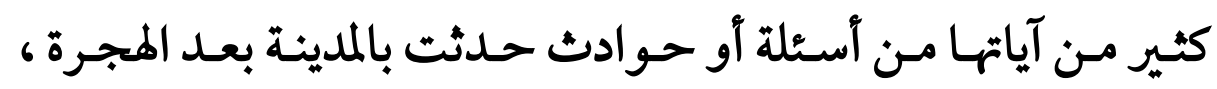

والقضايا التي تحدثت عنها هي قضايا خصائص السور المدنية .

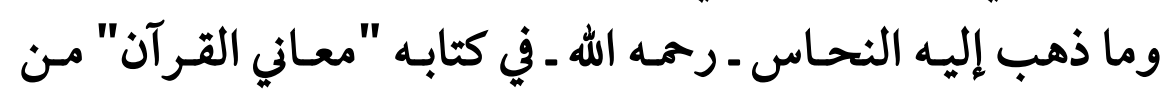

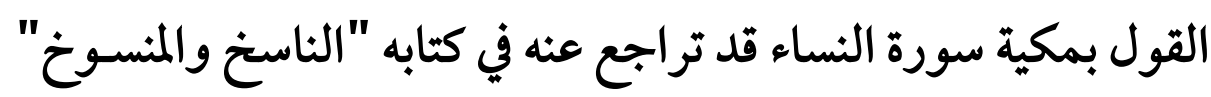

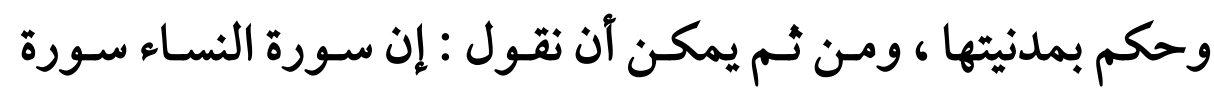

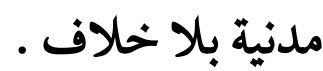

$$
10 \text { ـ اسْتُنيَيَ من مدنية سورة النساء آيتان : }
$$

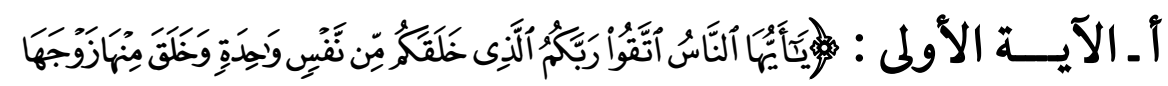

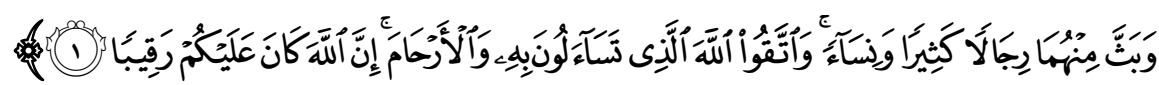

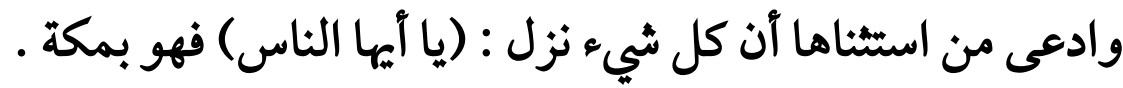




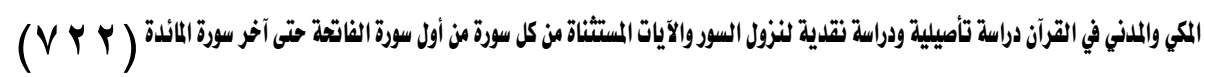
والصحيح أن هذا ضابط غير مضطرد في سور القرآن وآياته ، فبعض

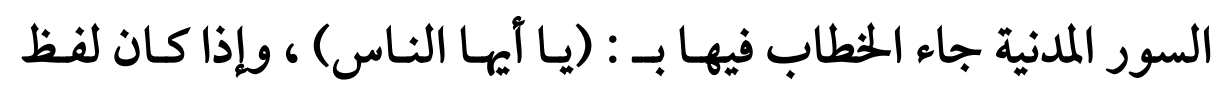

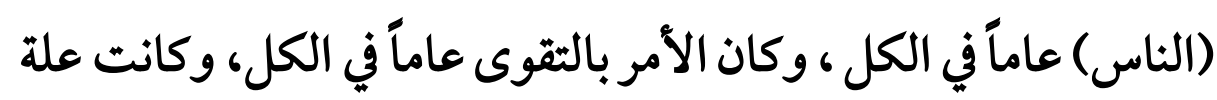

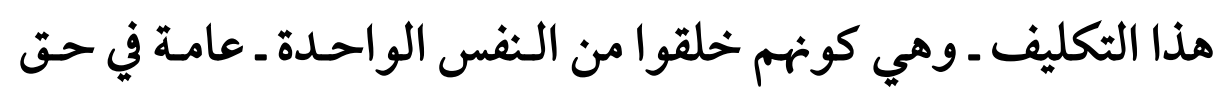

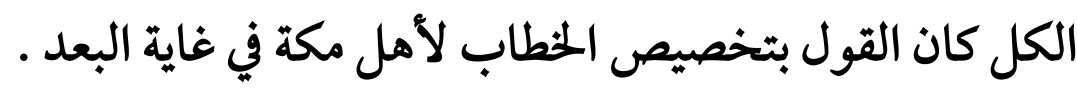

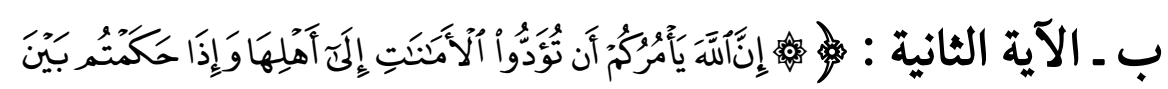

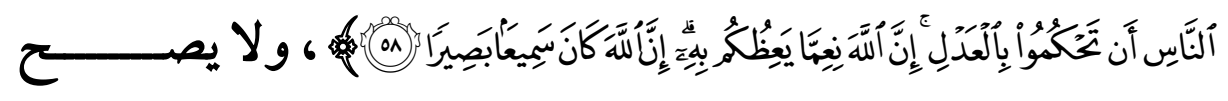

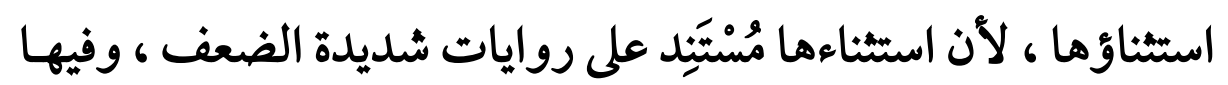
الكثير من الاختلاف والاضطراب ، يفيد بعضها أنها نزلت في مكة يوم • الفتح

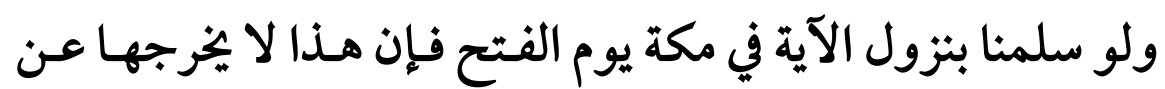

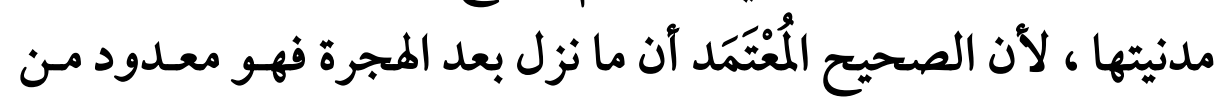

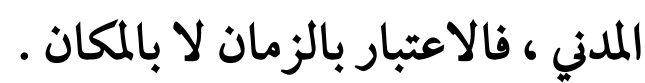

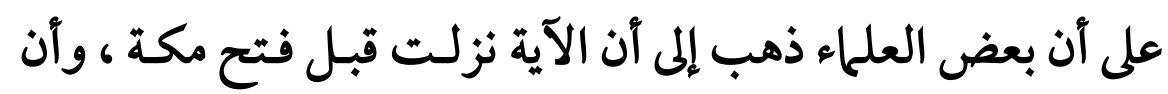

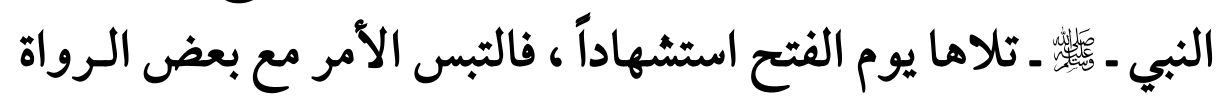

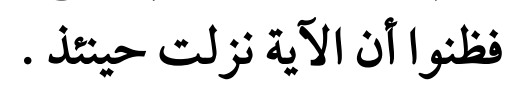

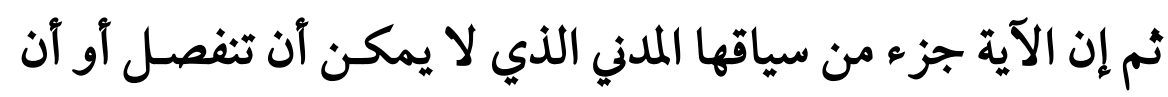

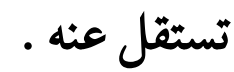


(VYr)

17 ـ سورة المائدة سورة مدنية إجماعاً بدليل قول عائشة وعبدالله بن

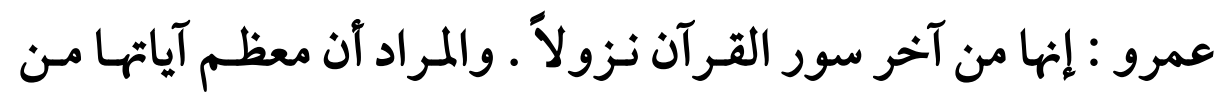

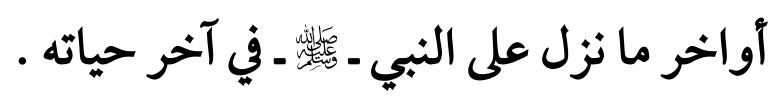

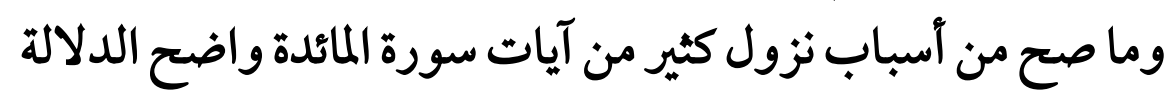

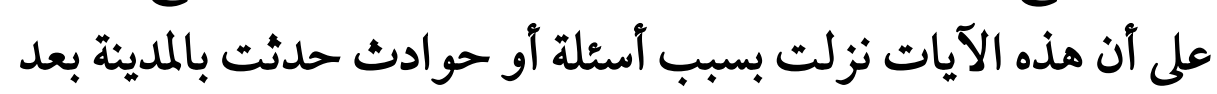

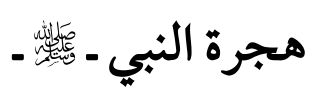

والقضايا التي تحدثت عنها سورة المائدة هي قضايا خصائص السور المدنية .

ولم تنزل سورة المائدة دفعة واحدة بدليل أسباب نزول بعض آياتها ،

$$
\text { وهي حوادث حدثت في أزمنة متباعدة . }
$$

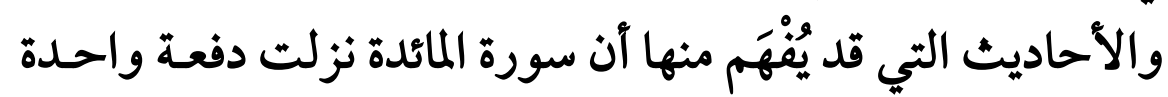

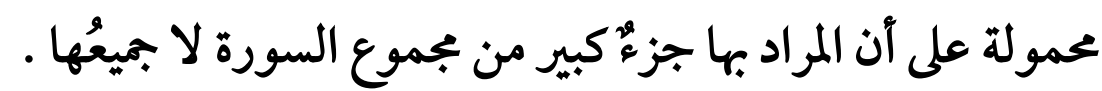

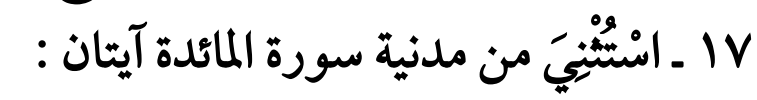

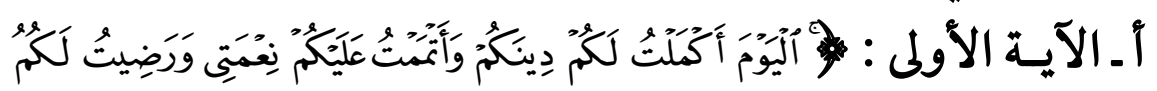

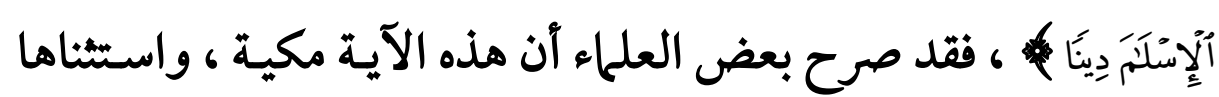

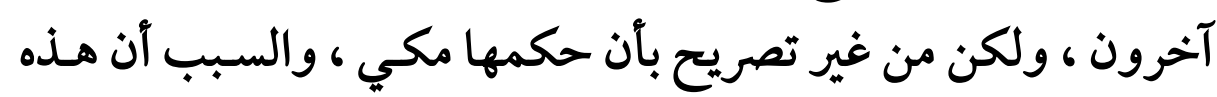

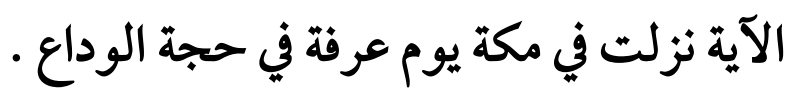




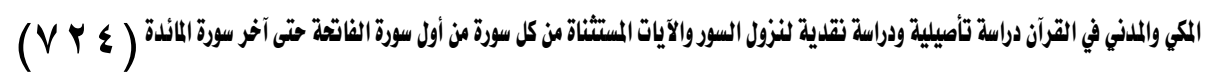

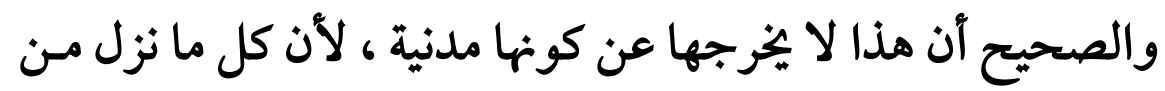

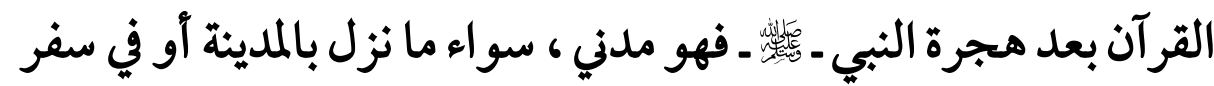

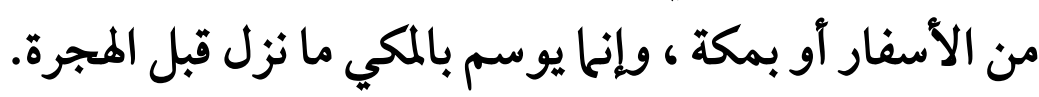

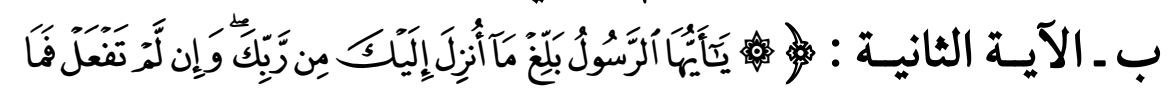

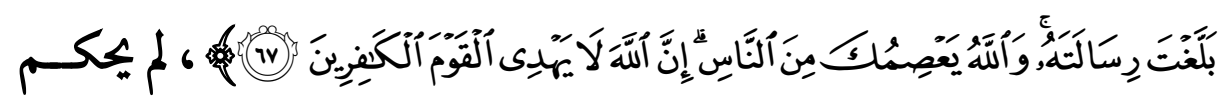

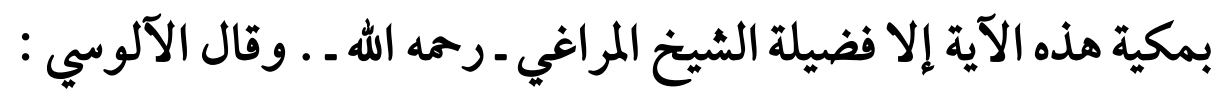

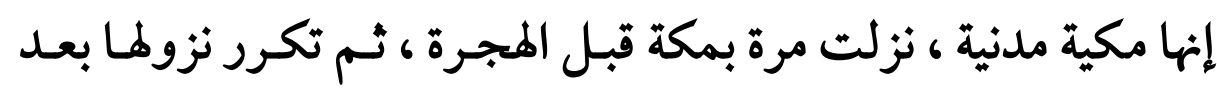
المجرة . والذي ألجأهما إلى هذا ما جاء في رواية أن هذه الآية نزلت تُوَّمَّن الرسول

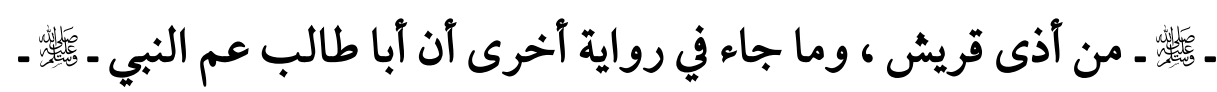

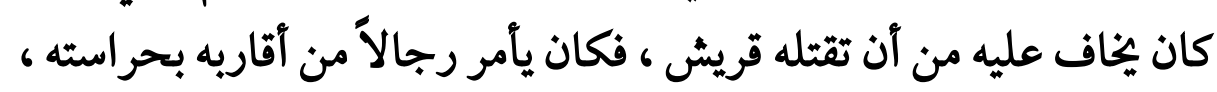

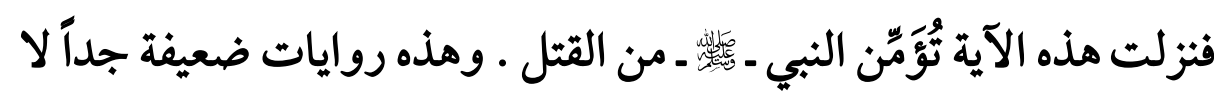
تقوم بها حجة . والصحيح آن الآية مدنية نزلت بعد الهجرة في غزوة أنهار بسبب أعرابي

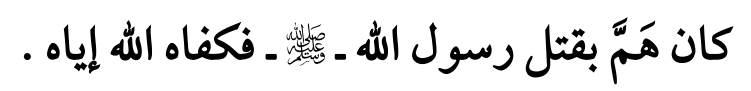

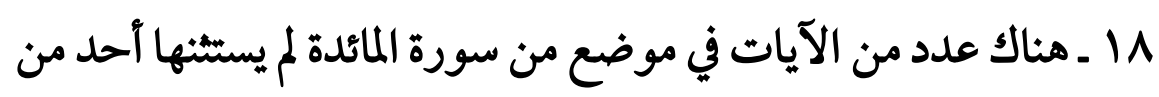

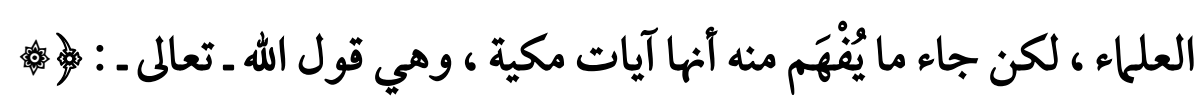

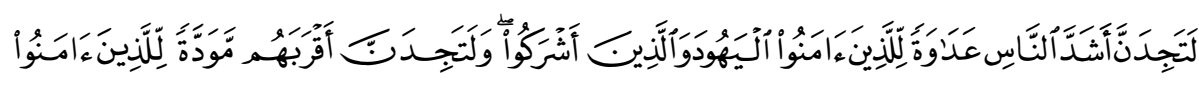

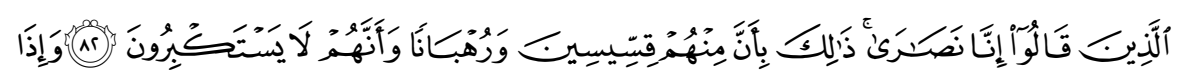

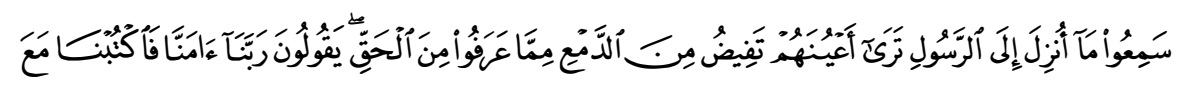




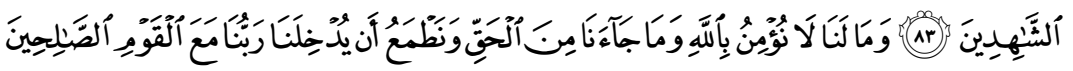

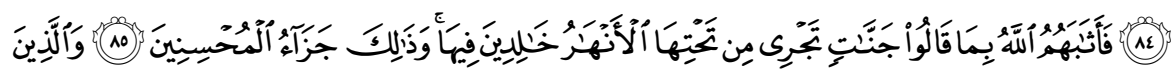

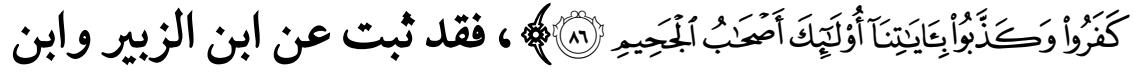
عباس آن هذه الآيات نزلت في شأن النجاشي وآصحابه .

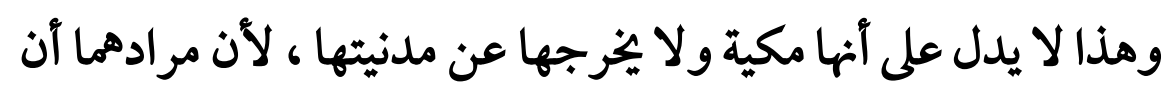

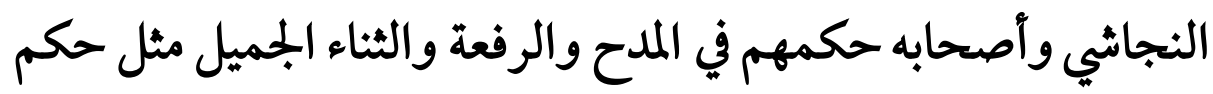

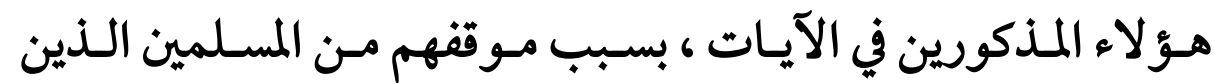

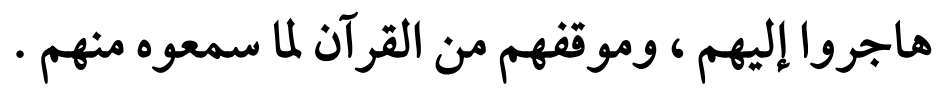

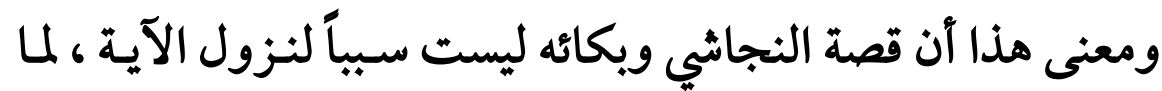

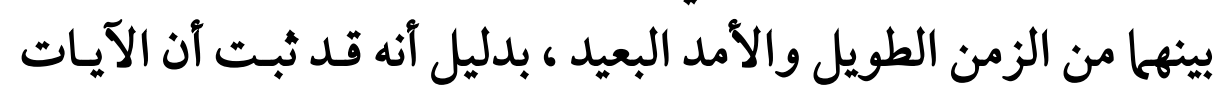

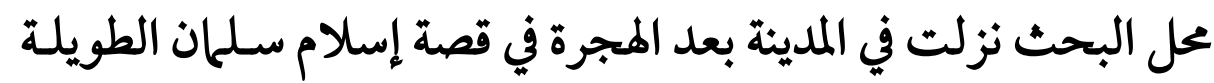

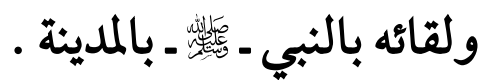
19 ـ الأصل في السورة المكية أن تكون كل آياتها مكية ، والأصل في ـ الماني

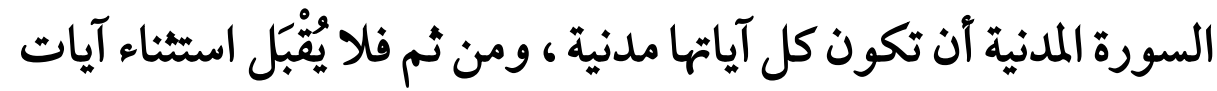
من سورها دون دليل صحيح يدل على ذلك الاستثناء ، لأن الاستشئاء

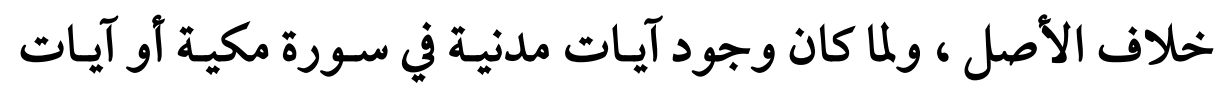
مكية في سورة مدنية خلاف الأصل فالمختار عدم قبول القول به إلا إذا ثبت برواية صحيحة السند صريحة المتن سالمة من المعارضة والاحتحال . 


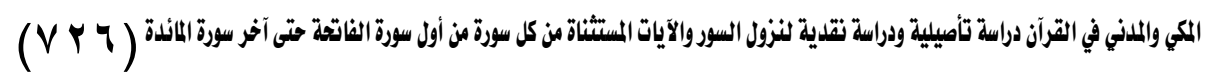
المراجع والمصادر

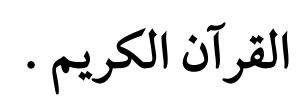

\section{كتب التفسير وعلوم القرآن}

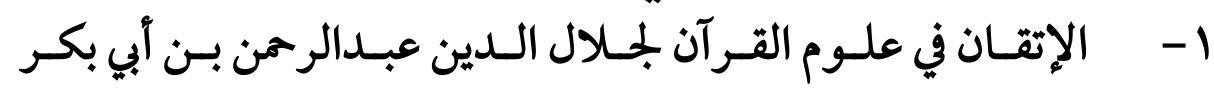

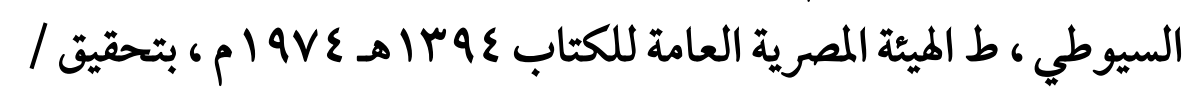

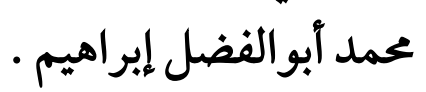

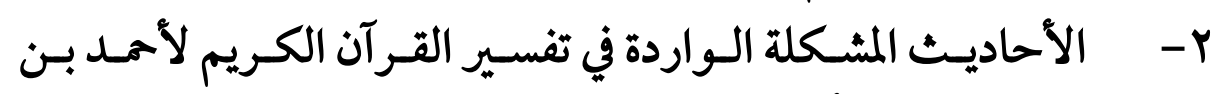

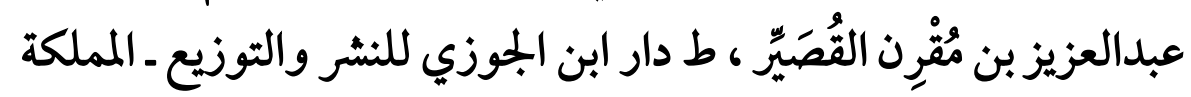

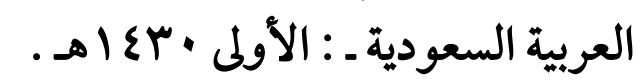

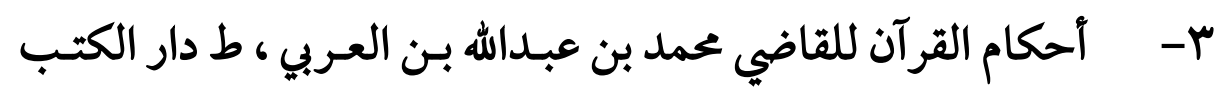

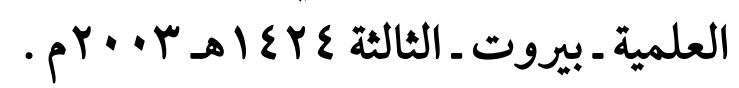

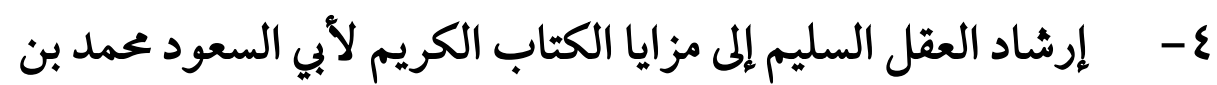

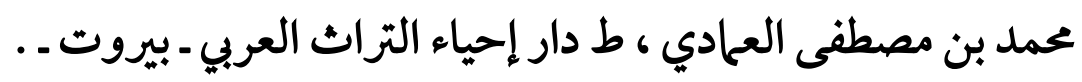

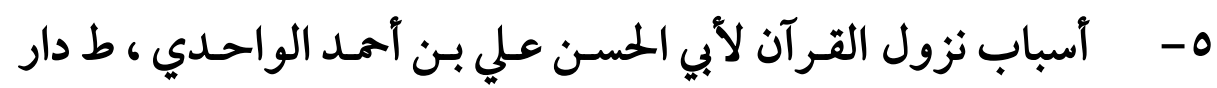

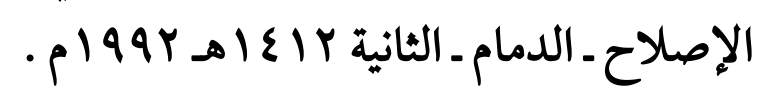

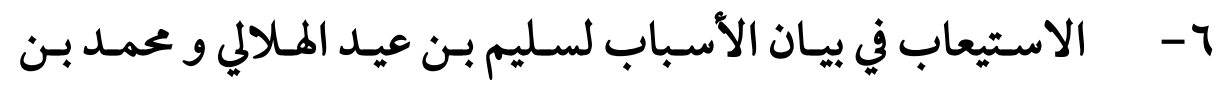

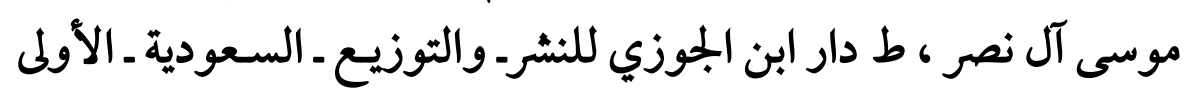

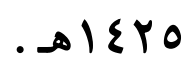

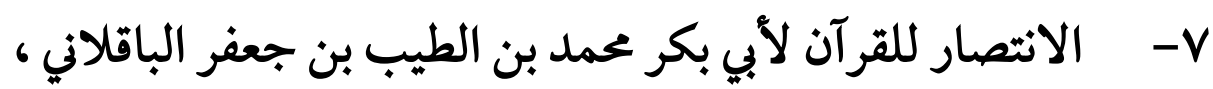

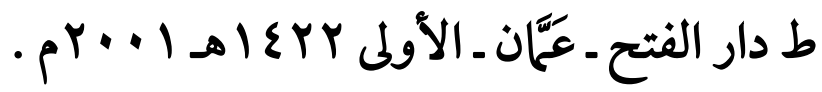


$(V Y V)$

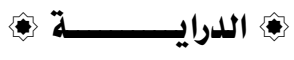

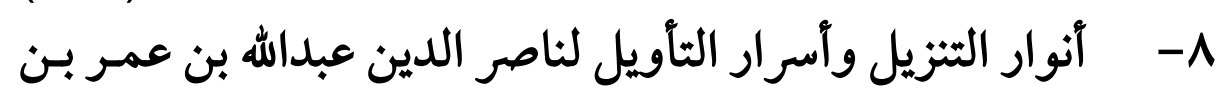

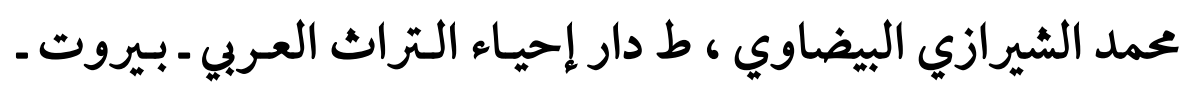

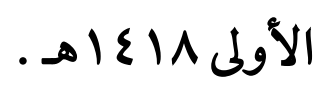

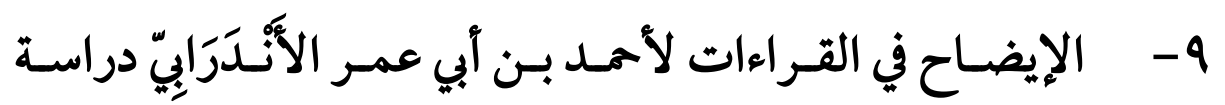

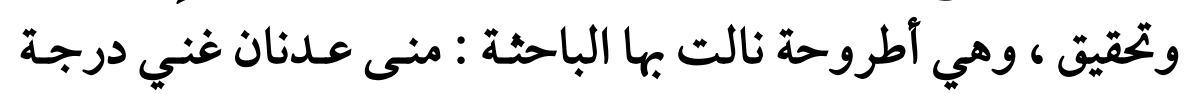

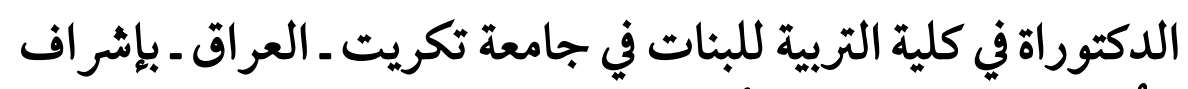

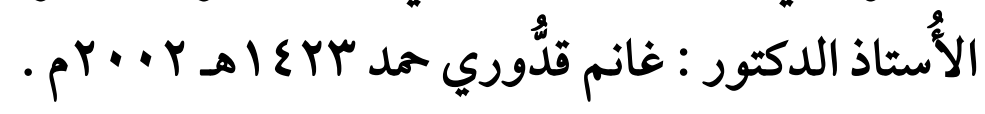

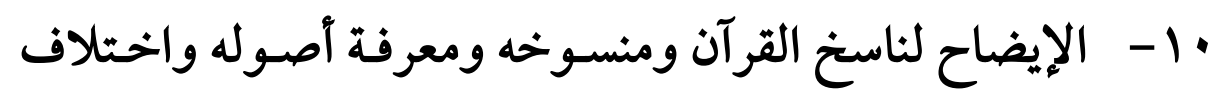

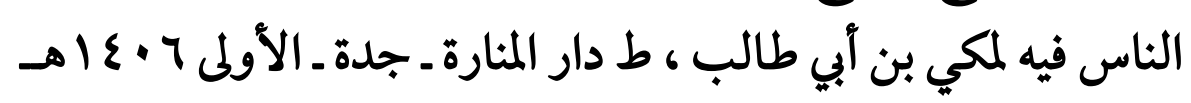
- 1917

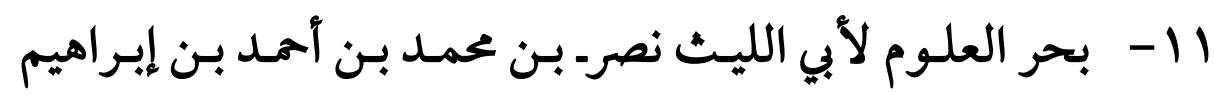

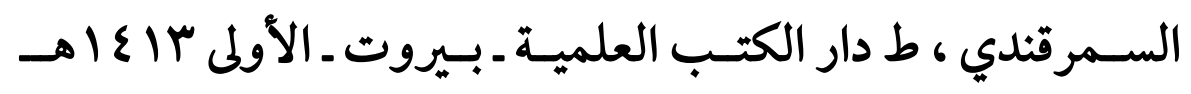
- p 1994

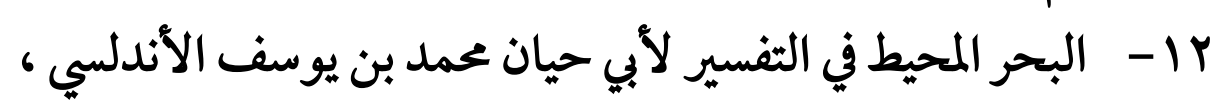

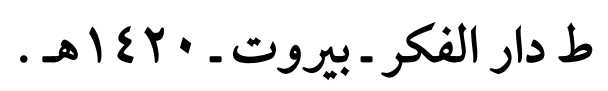

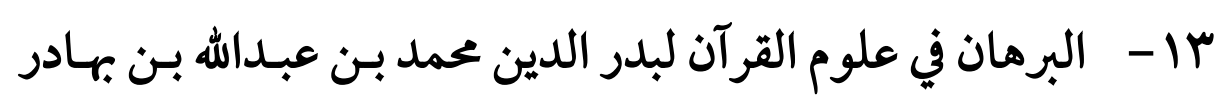
الز ركثي ، ط دار إحياء الكتب العربية عيسى البابي الحلبي وشركائه

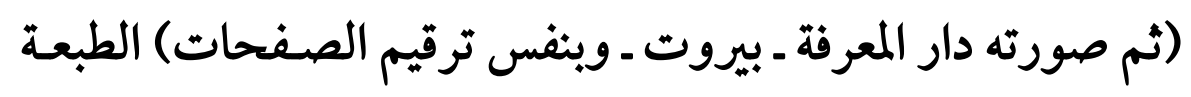

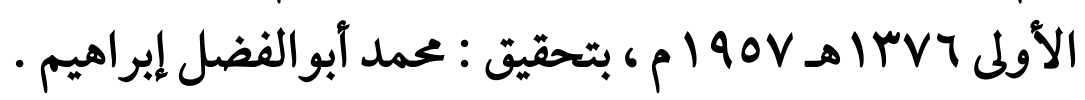




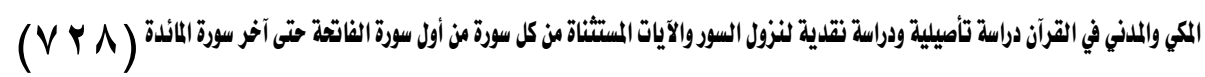

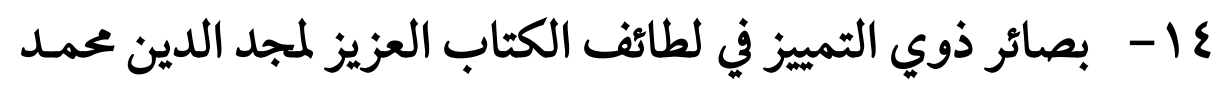

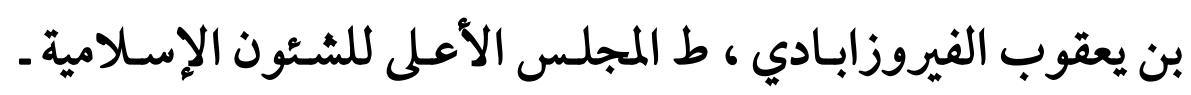

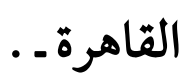

10 - بيان المعاني وهو تفسير مرتب على حسب ترتيب النزول تأليف :

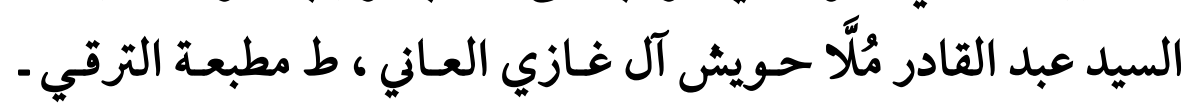

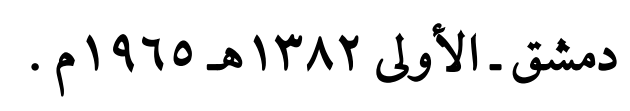

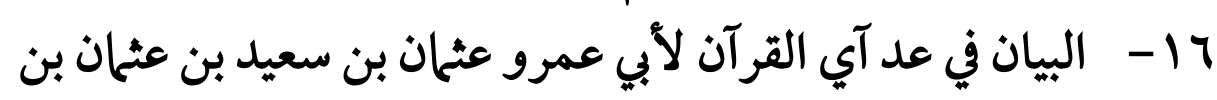

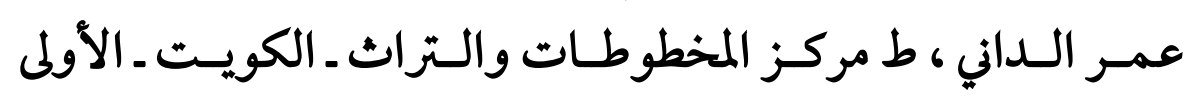

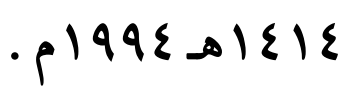

IV - اريخ نزول القرآن لمحمد رأفت سعيد ، ط دار الوفاء (المنصورة

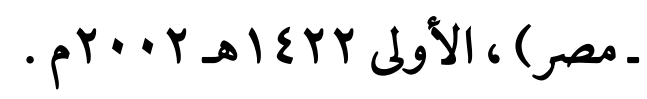

11 - تأويلات أهل السنة للإمام أبي منصور محمد بن محمد بن محمود

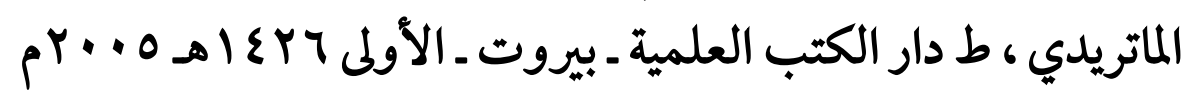

19 - التبيان لبعض المباحث المتعلقة بالقرآن على طريق الإتقان لطاهر

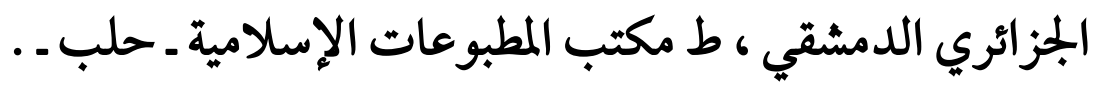

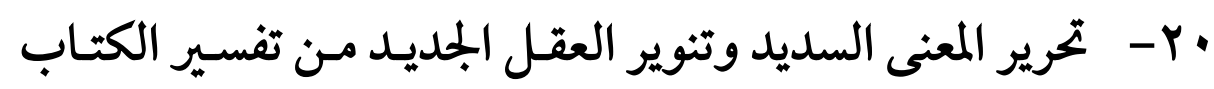

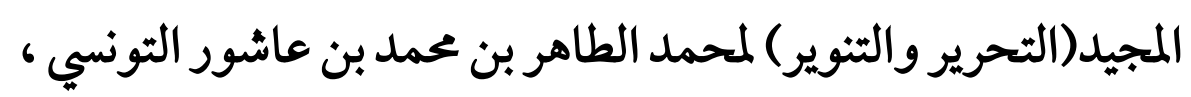

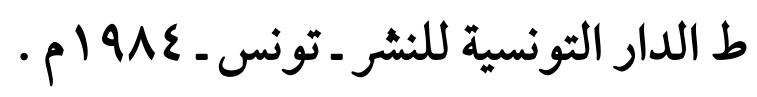


$($ rra)

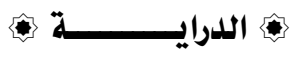

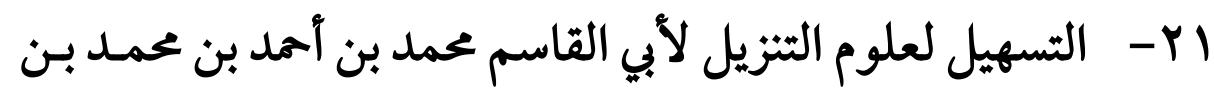

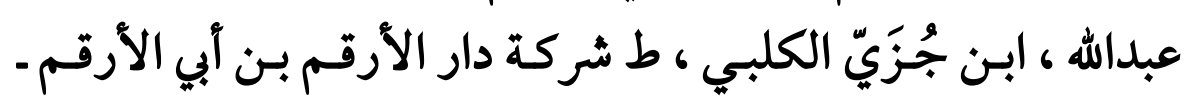

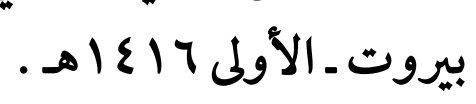

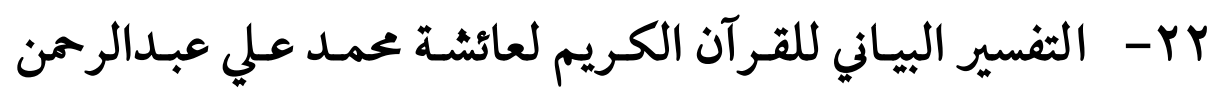

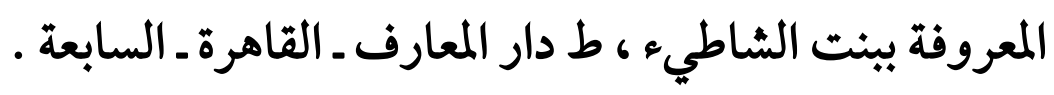

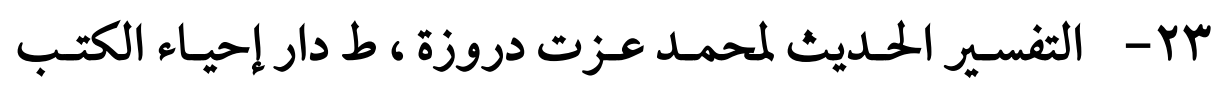

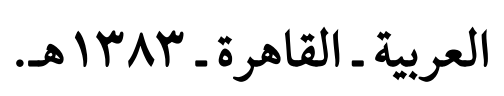

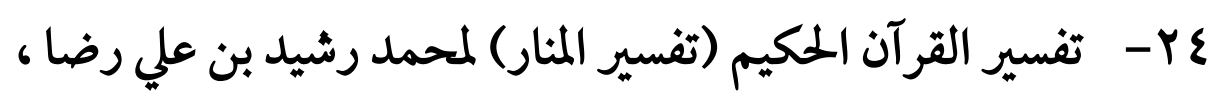

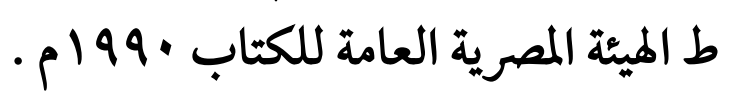

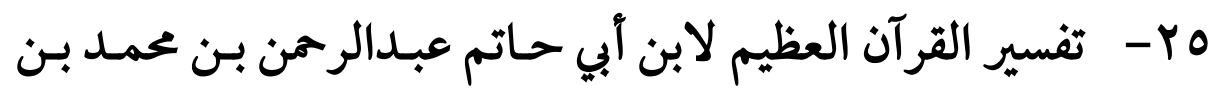
إدريس الرازي ، ط مكتبة نزار مصطفى الباز ـ السعودية ـ الثالثة

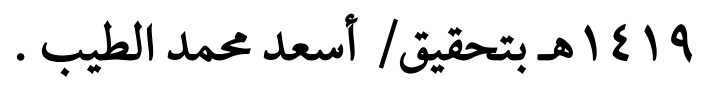

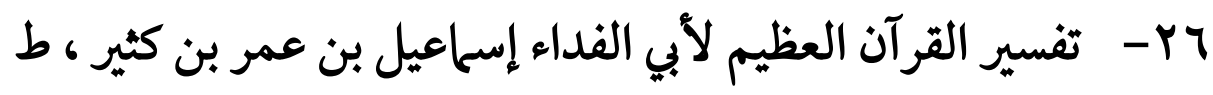

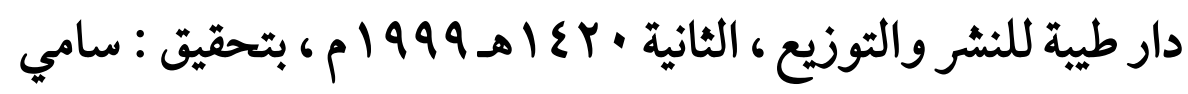

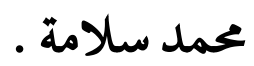

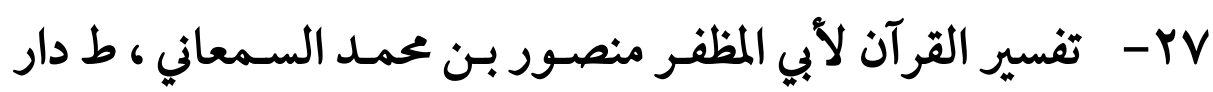

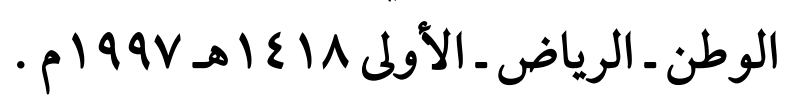




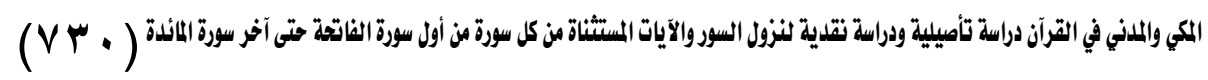

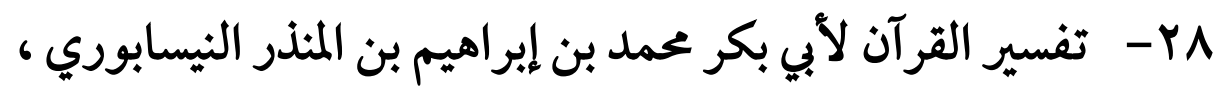

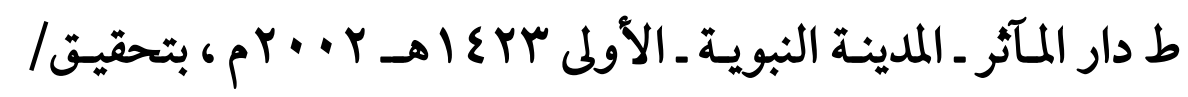

$$
\text { الدكتور: سعد بن محمد السعد . }
$$

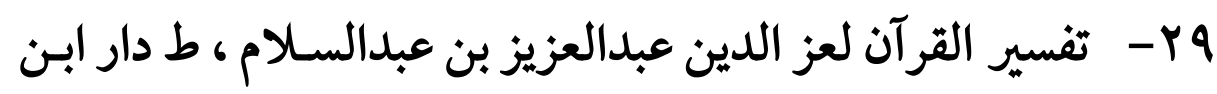

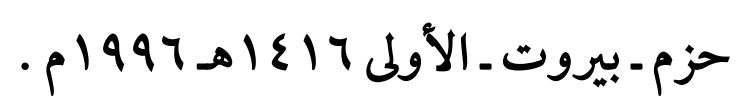

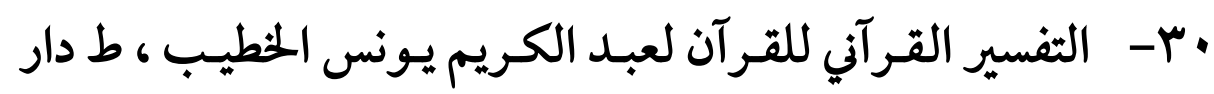

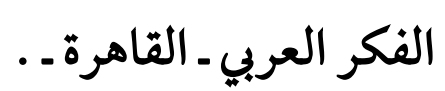

اب- تفسير المراغي للشيخ أحمد مصطفى المراغي ، ط شركة مكتبـة

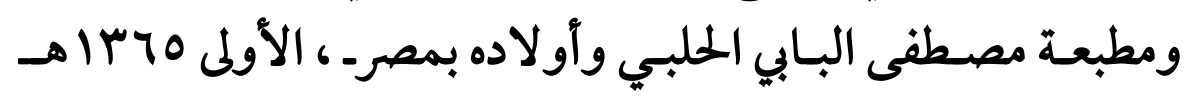
- p $19 \varepsilon 7$

r r- التفسـير المنـير في العقيـدة والشر-يعة والمنهج للـدكتور : وهبـة

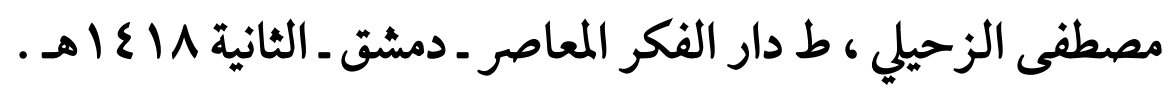

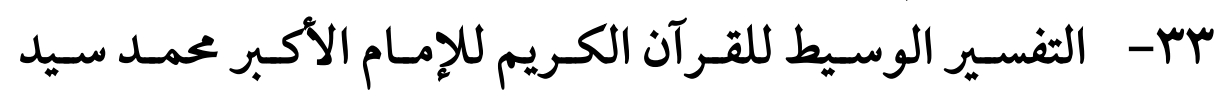

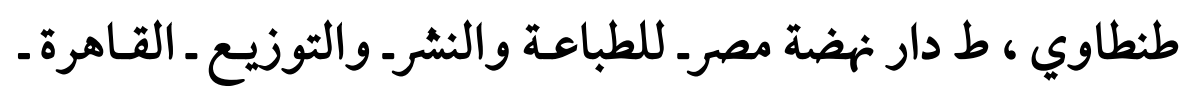

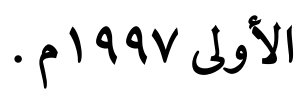

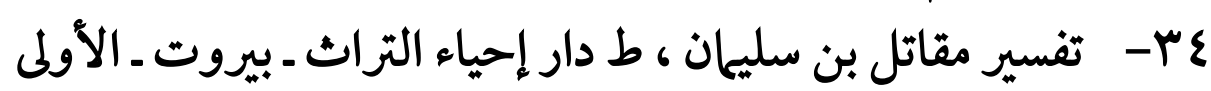


(VTI)

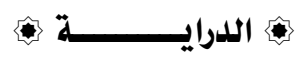

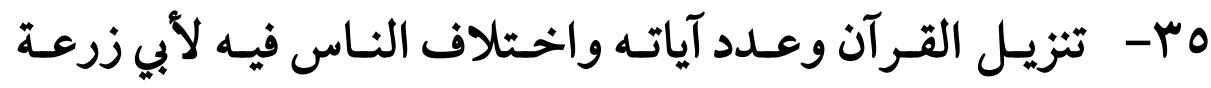

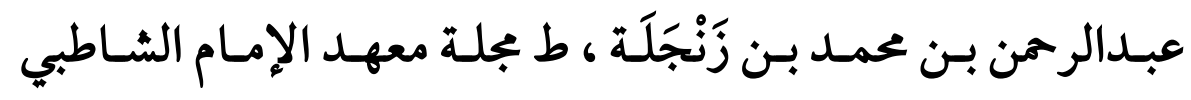

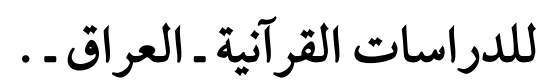

جr- جامع البيان في تأويل القرآن لأبي جعفر محمد بن جرير بن يزيد

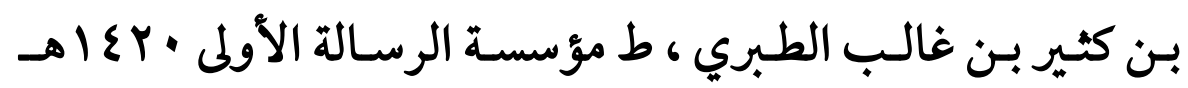

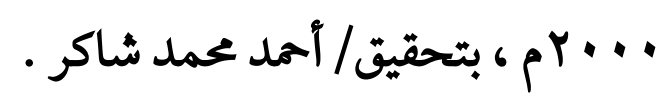

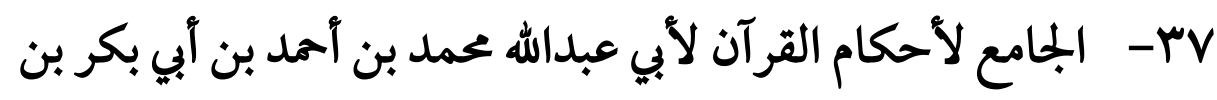

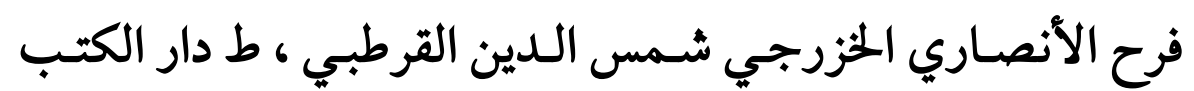

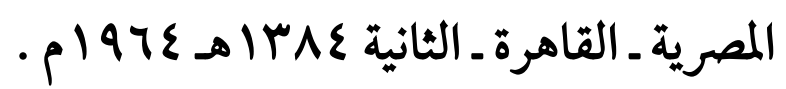

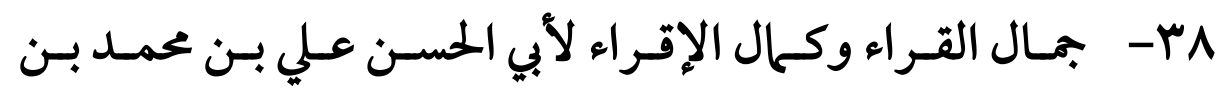

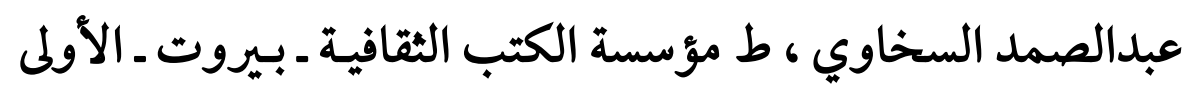

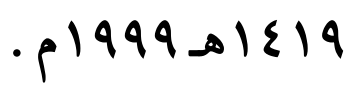

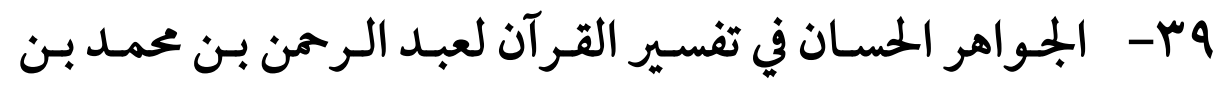

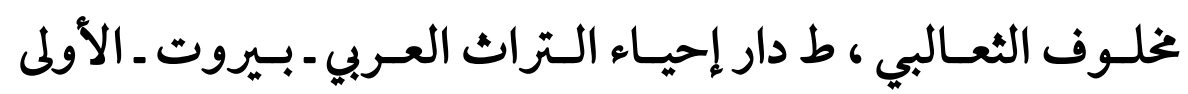
|| • ع-الحجة في القراءات السبع للحسين بن أحمد بن خحالويه ، ط دار

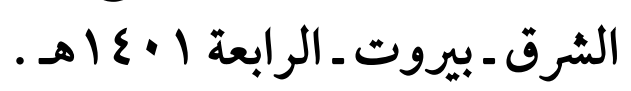

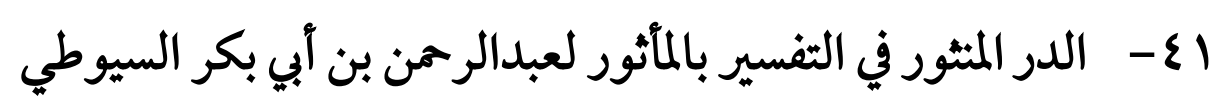

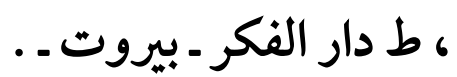




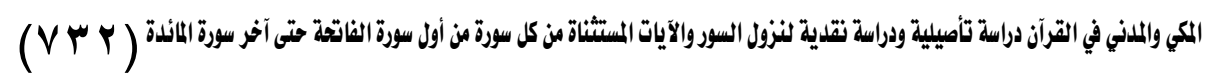
Y ع - دراسات في علوم القرآن الكريم لفهد بن عبدالرحمن بن سليمان

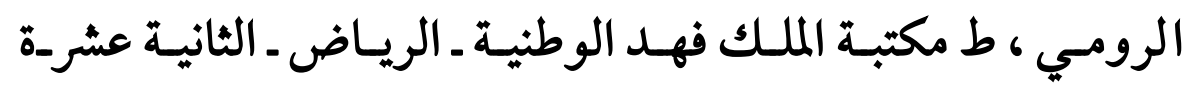

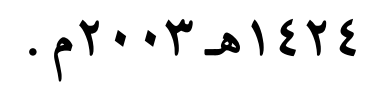

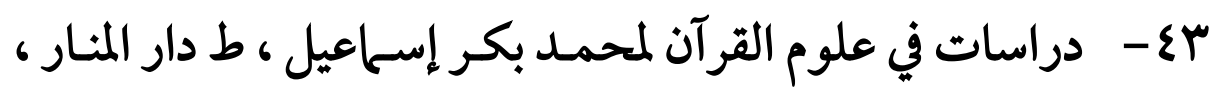

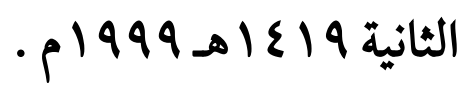

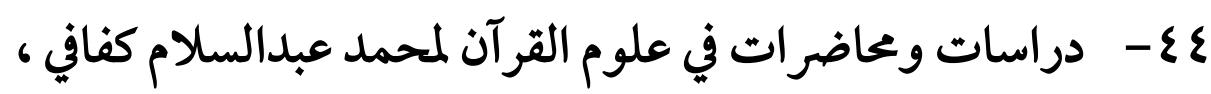

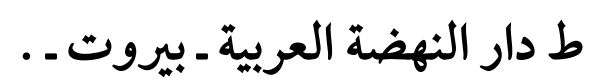

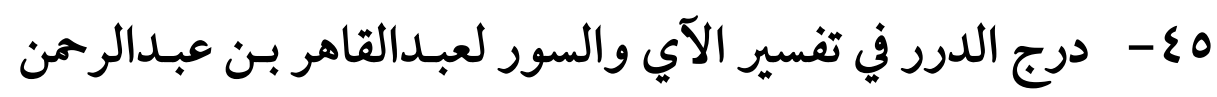

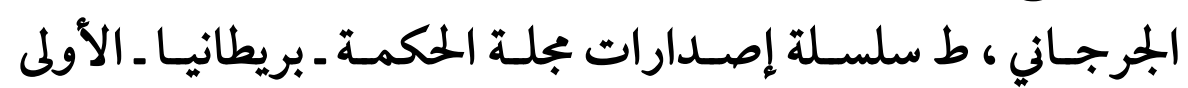

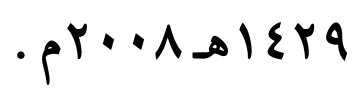
ح؟ - روح المعـاني في تفسـير القـرآن العظيم والسـبع المثاني لشـهاب

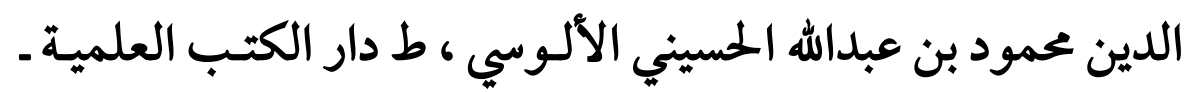

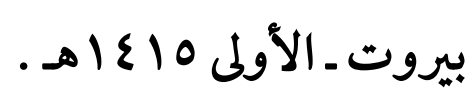

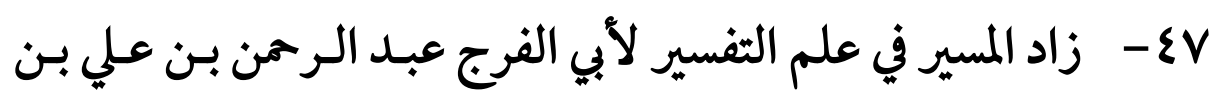

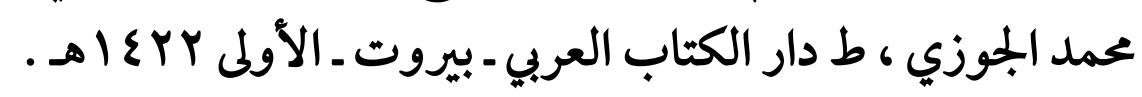

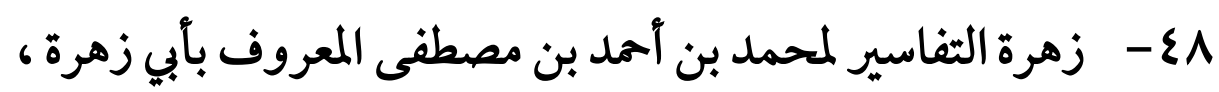

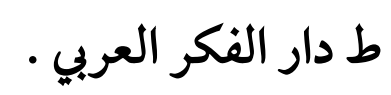

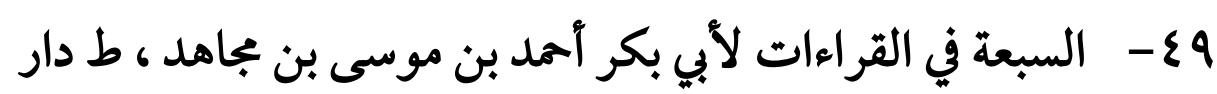

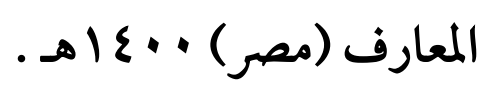


$(V T r)$

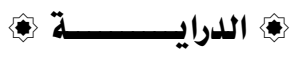

• - - السراج المنير في الإعانة على معرفة بعض معاني كلام ربنا الحكيم

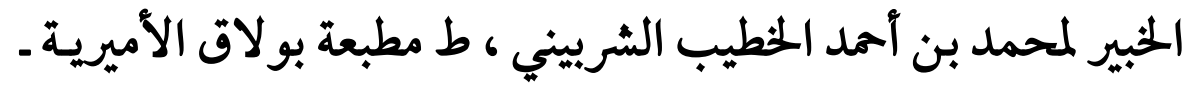

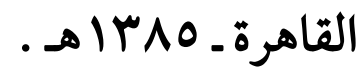

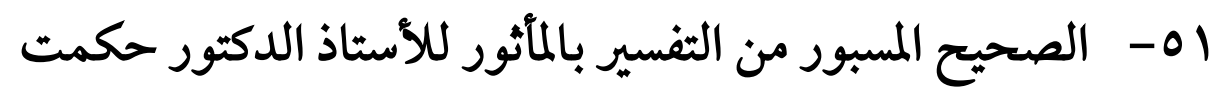

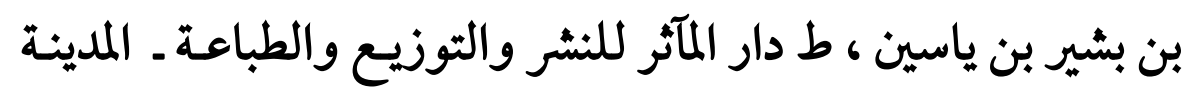

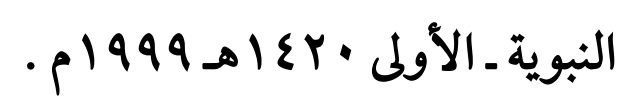

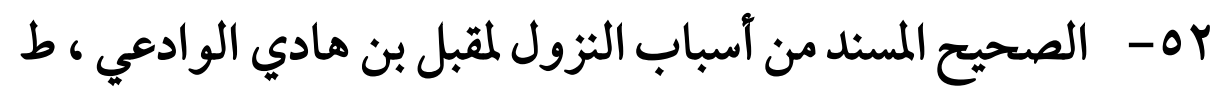

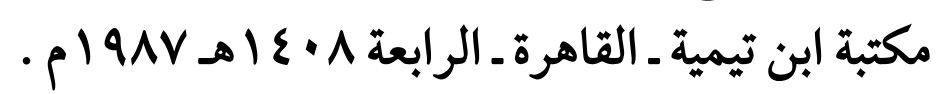

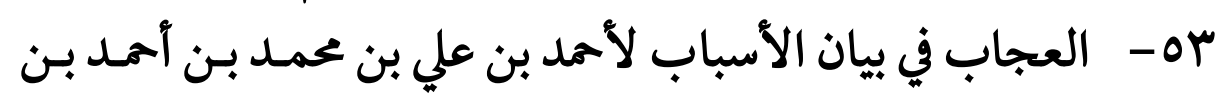

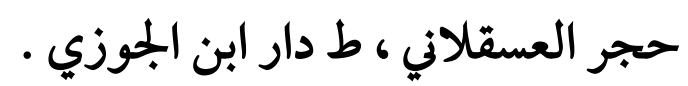

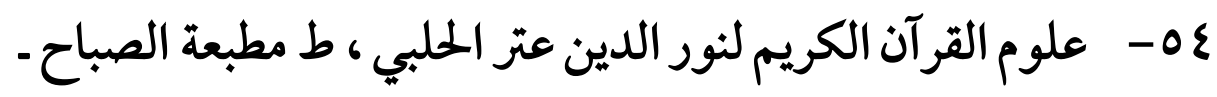

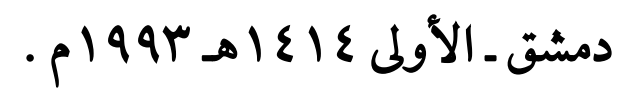

0 - عناية القاضي وكفاية الراضي وهي حاشية الشهاب على تفسير

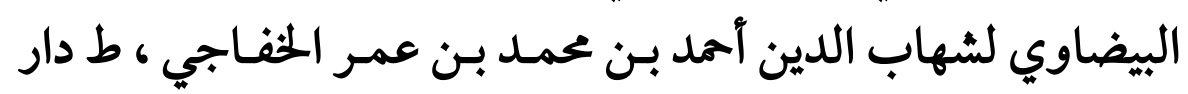

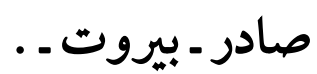

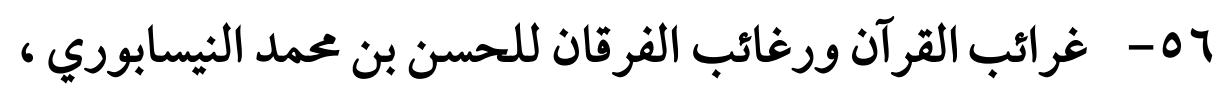

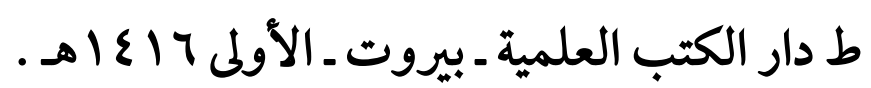




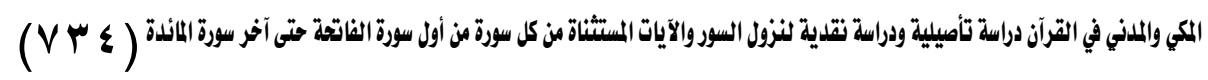

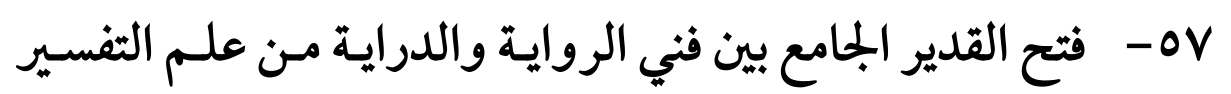

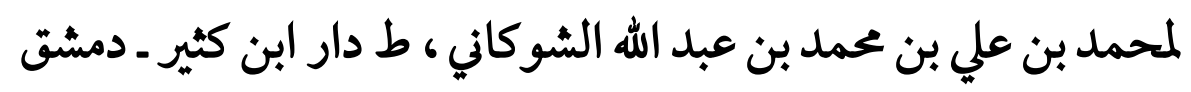

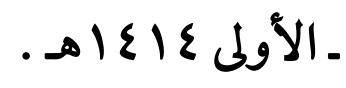

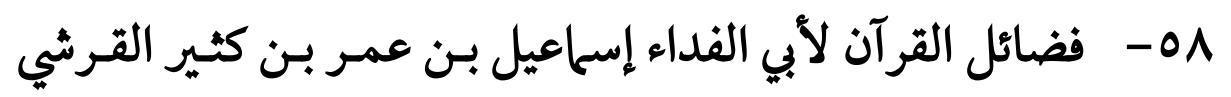

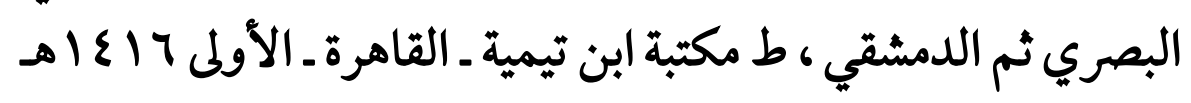

هـ- فضائل القرآن لأبي عبيد القاسـم بـن سلام ، ط دار ابن كثير

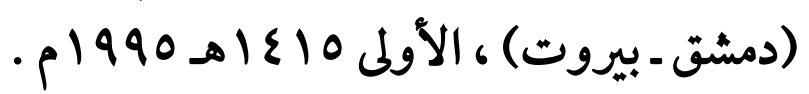

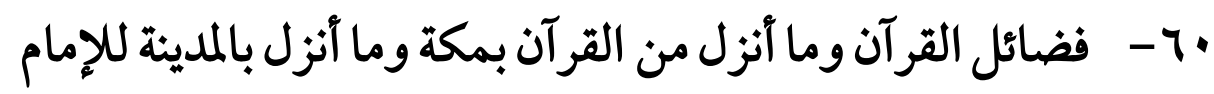

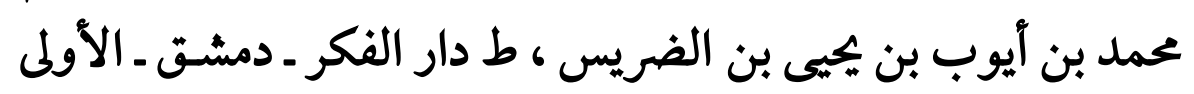

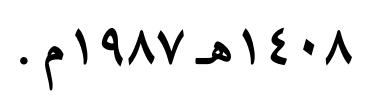

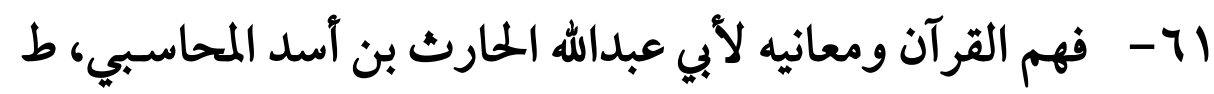

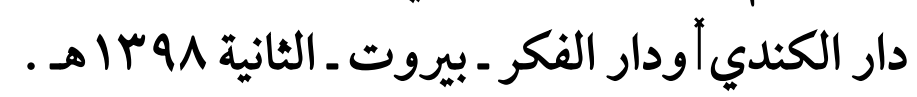

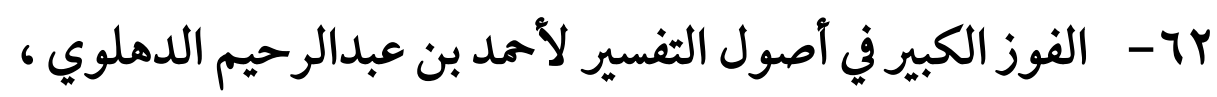

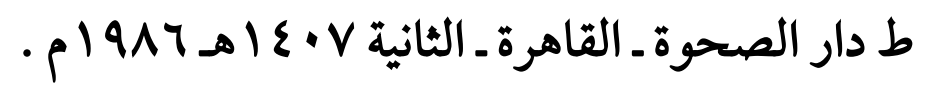

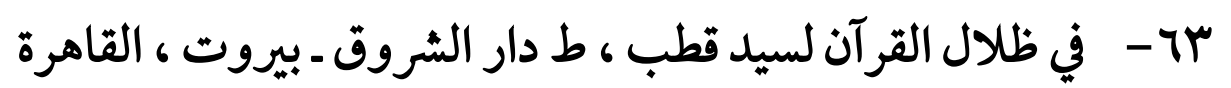

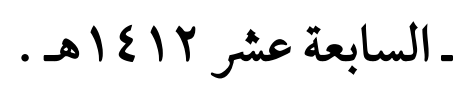

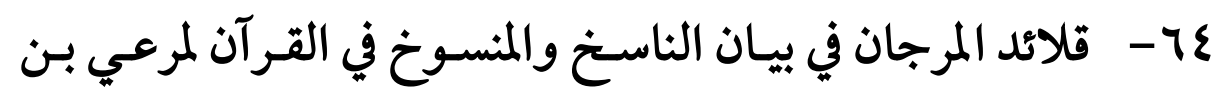

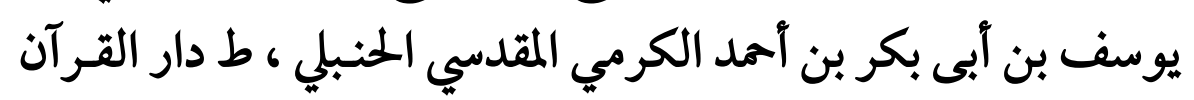

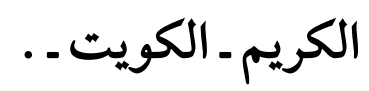




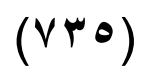

70- الكشـاف عـن حقــائق غـوامض التنزيـل لمحمـود بـن عمــرو

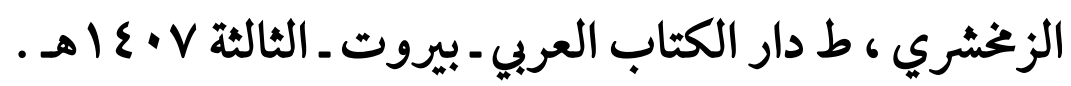
77 - الكشف والبيان عن تفسير القرآن لأحمد بن محمـد بـن إبـراهيم

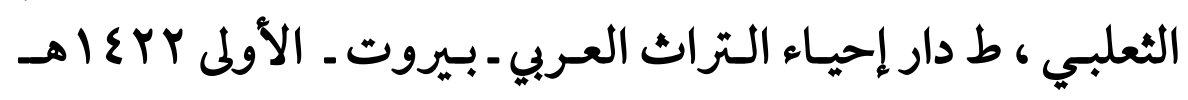
•

-TV

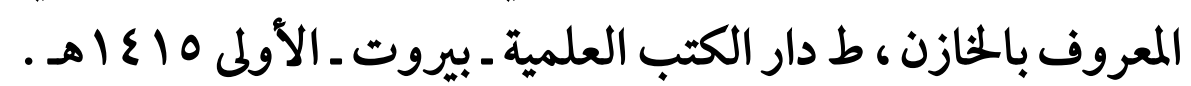

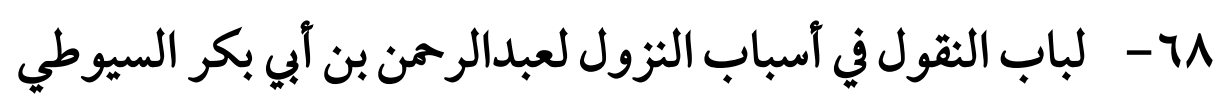

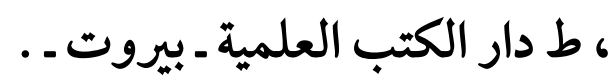

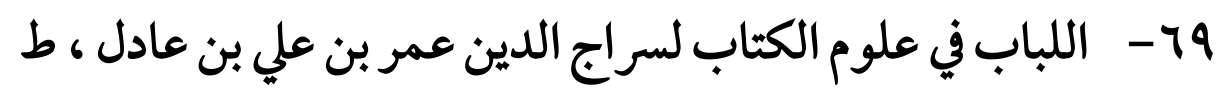

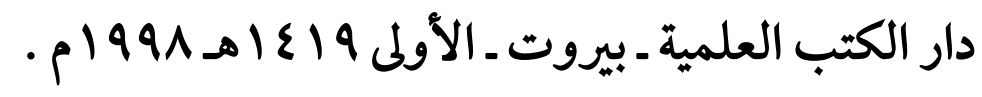
، · - مباحث في علوم القرآن لصبحي الصالح، ط دار العلم للملايين

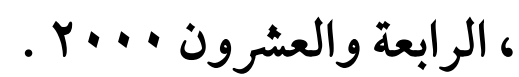

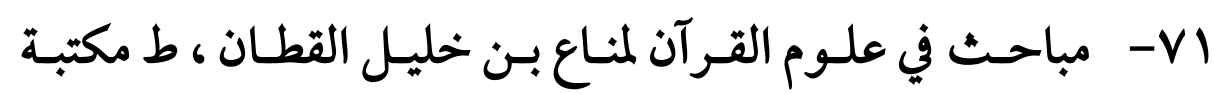

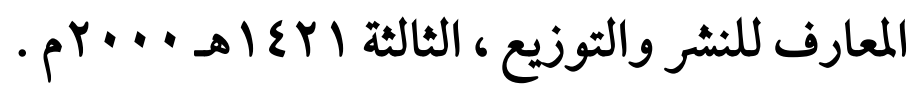
المان -VY

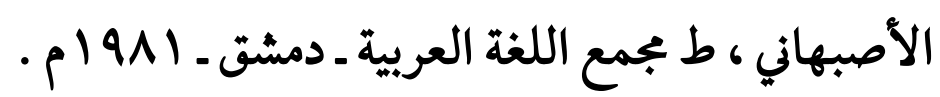

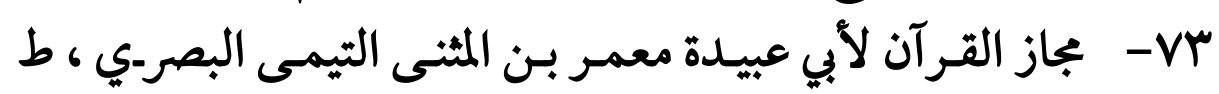

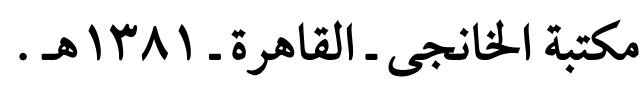




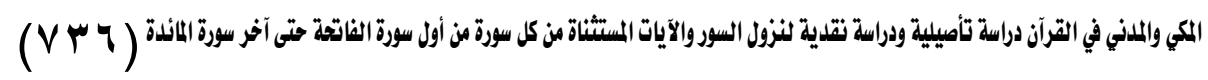

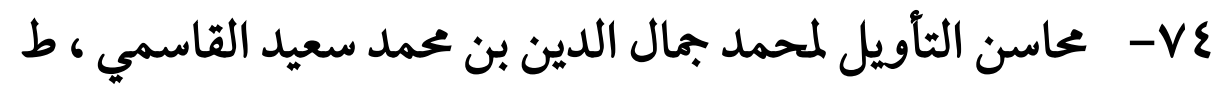

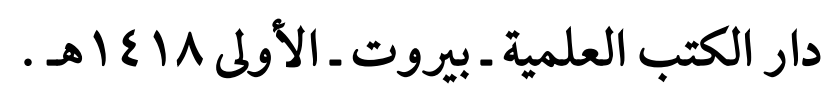

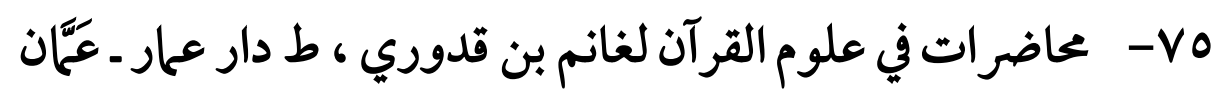

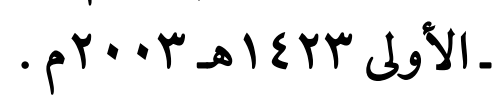

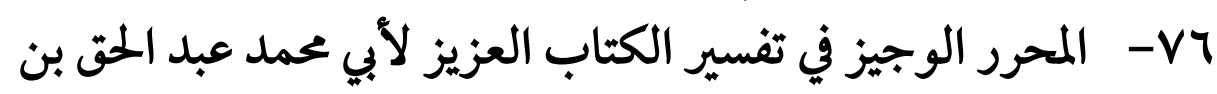

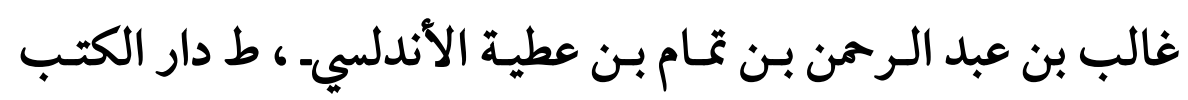

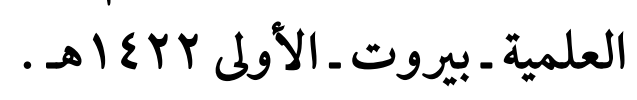

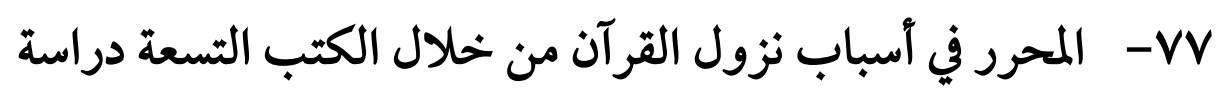

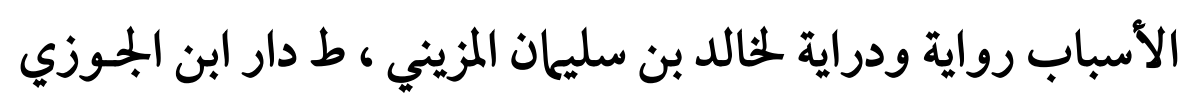

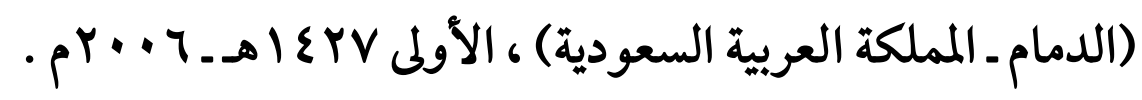

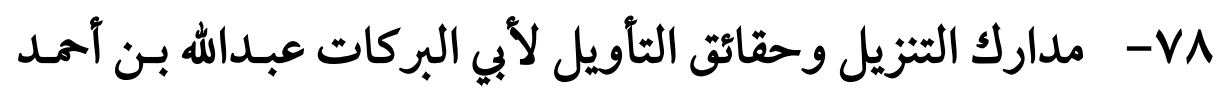

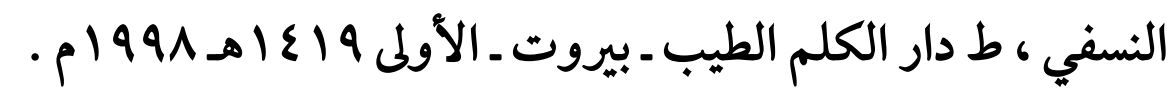

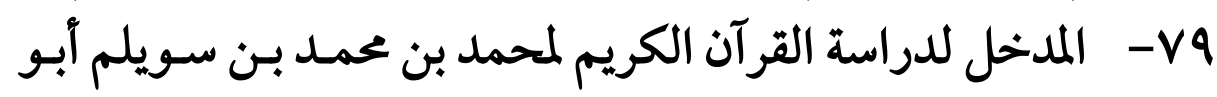

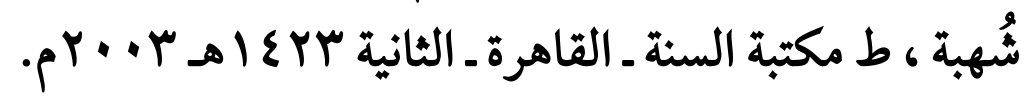

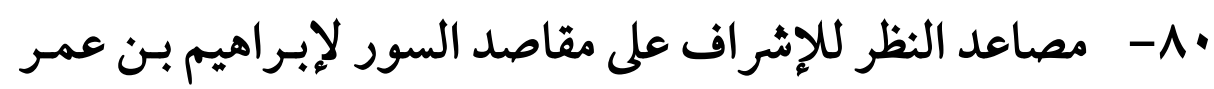

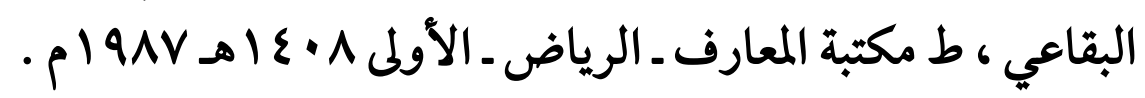

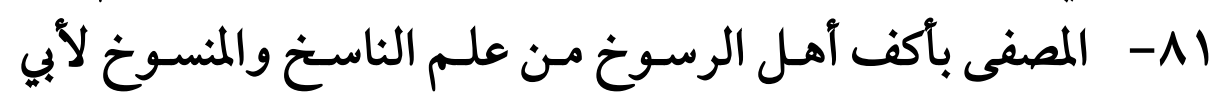

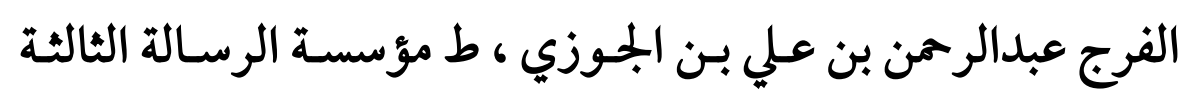


$(V \Psi V)$

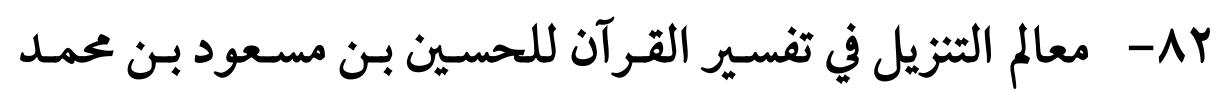

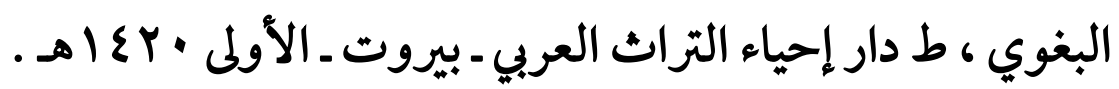

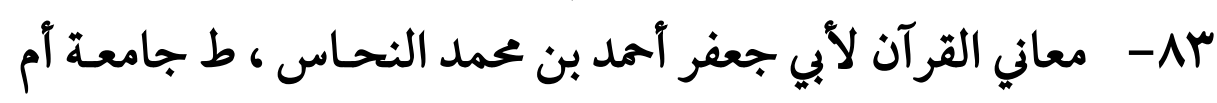

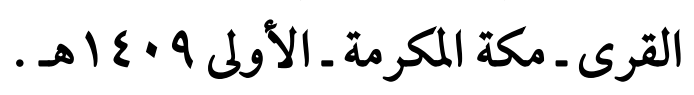

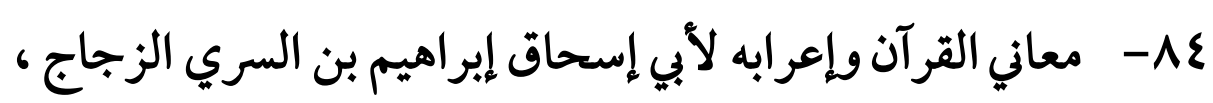

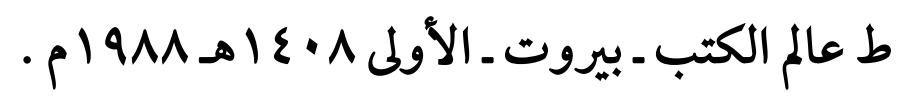

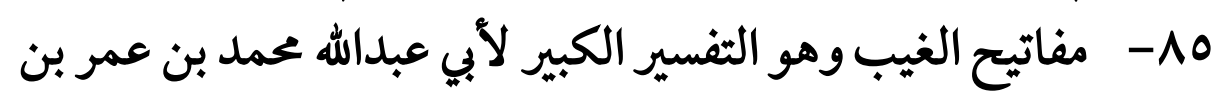

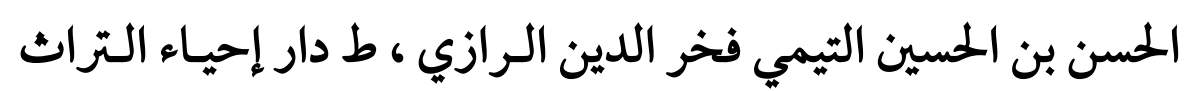

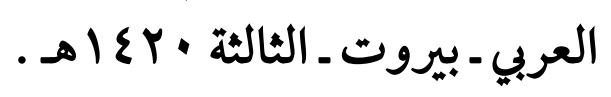

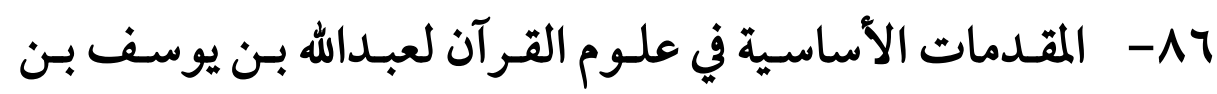

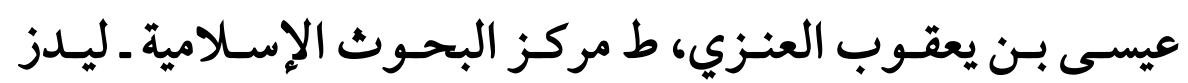

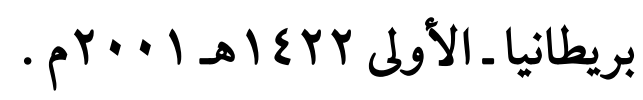

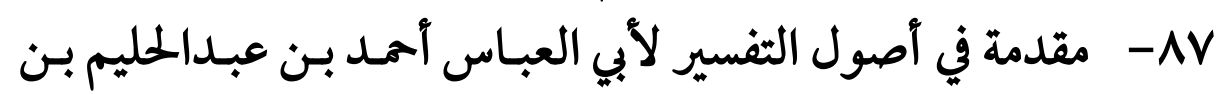

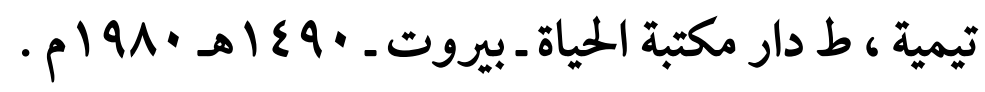

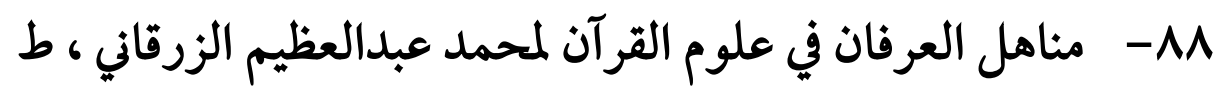
مطبعة عيسى البابي الحلبي وشركاه ، الطبعة الثالثة .

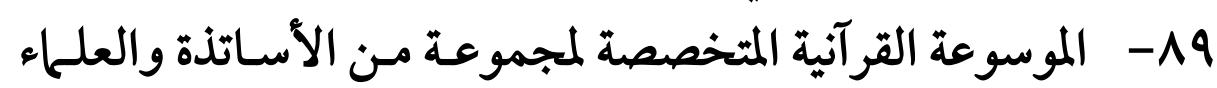
المتخصصين ، ط وزارة الأوقاف المصرية ـ القاهرة ـ . 


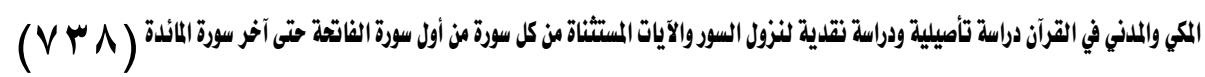

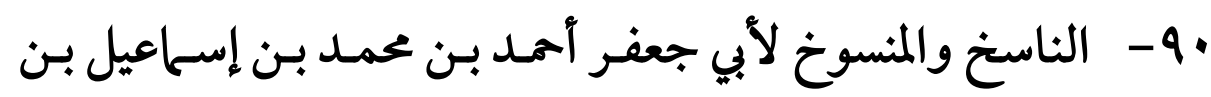

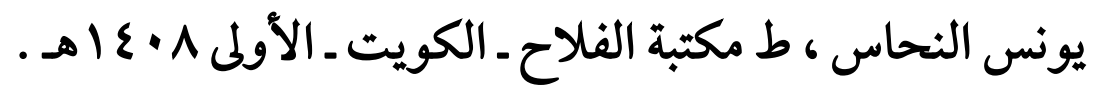

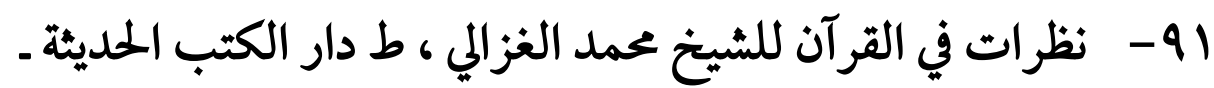

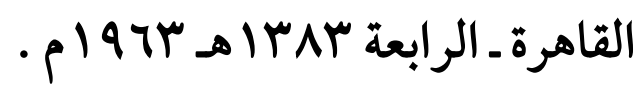

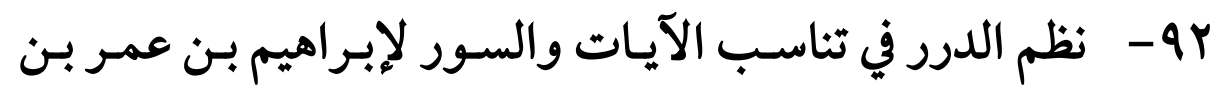
حسن البقاعي ، ط دار الكتاب الإسلامي ـ القاهرة ـ . .

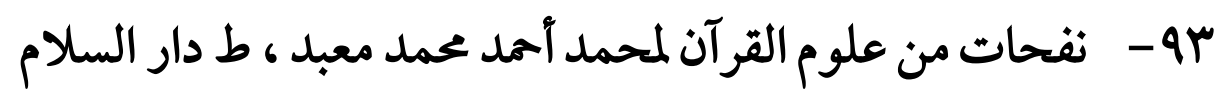

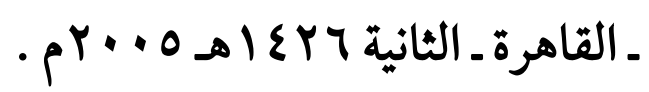

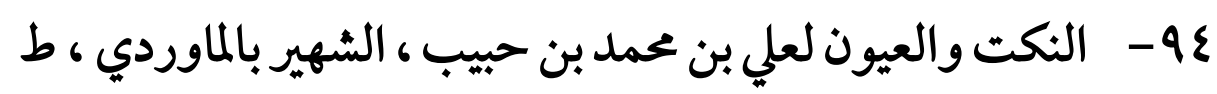
دار الكتب العلمية ـ بيروت ـ.

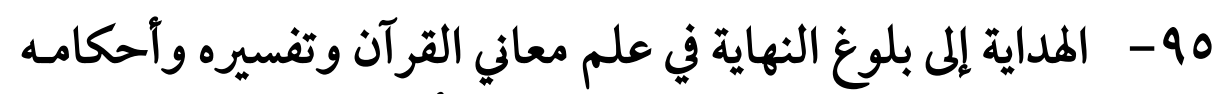

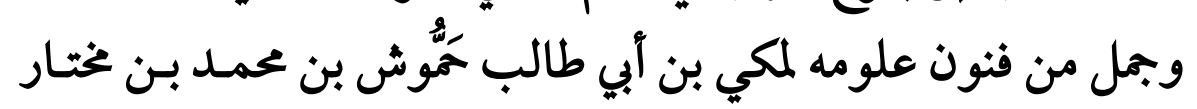

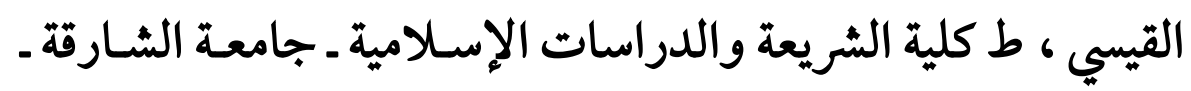

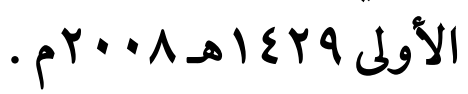

97- الوسيط في تفسير القرآن المجيد لعلي بن أحمد بن محمد بـن علي

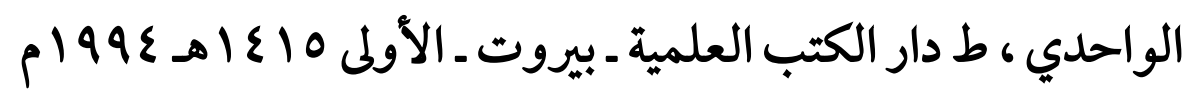

كتب الحلديث وعلومه

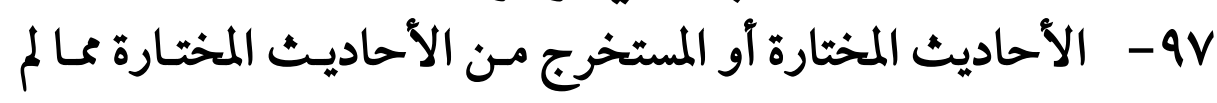

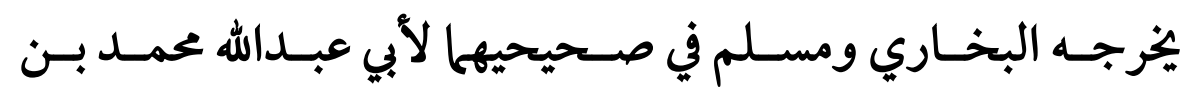


عبدالواحد بن أمد الحنبلي المشهور بالضياء المقـدسي ، ط دار خضر-

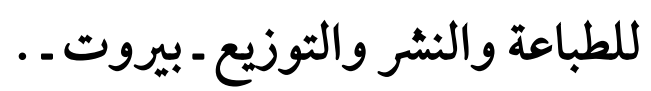

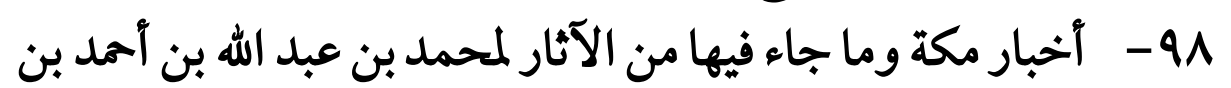

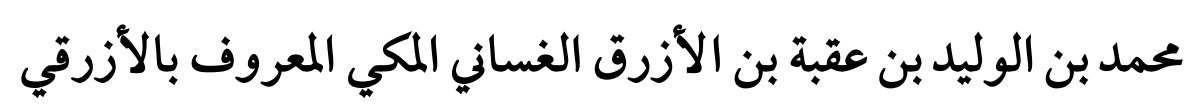

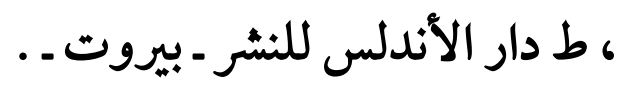

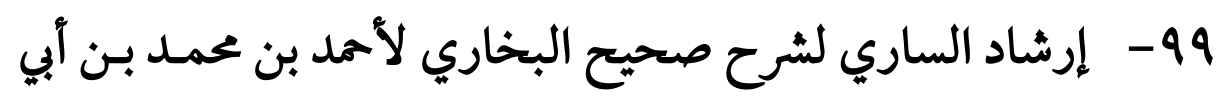

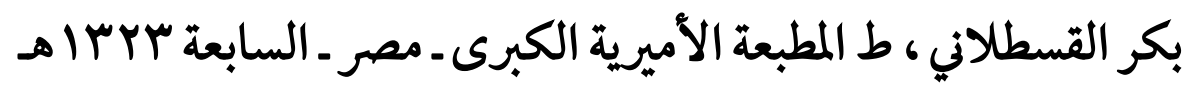

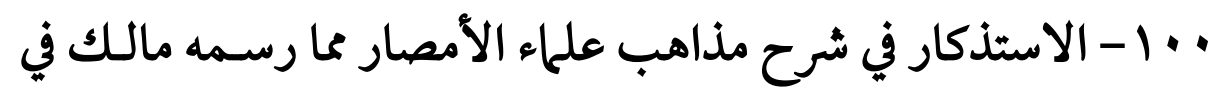

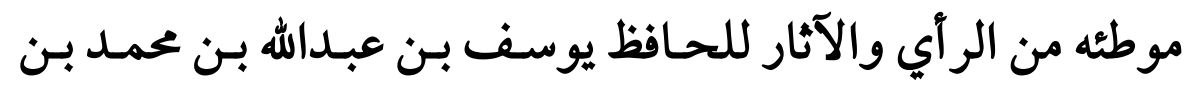

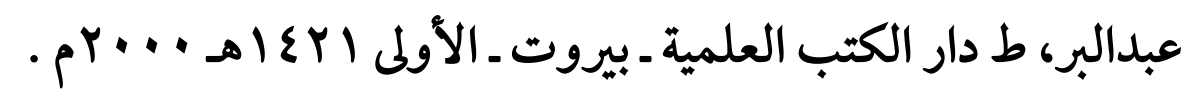

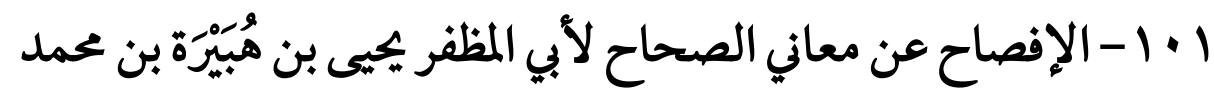

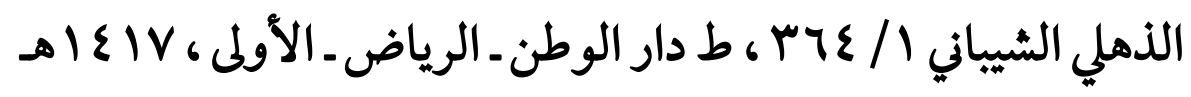

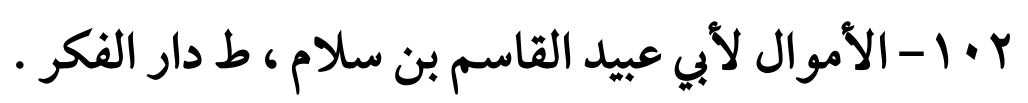

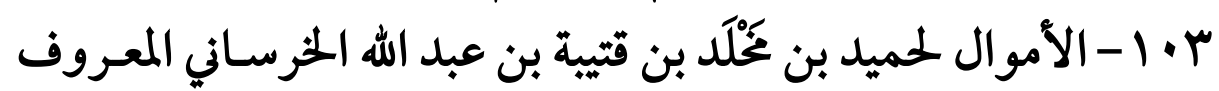
بابن زَنْجُويَة ، ط مركز الملك فيصل للبحوث والِ والدراسات الإسلامية

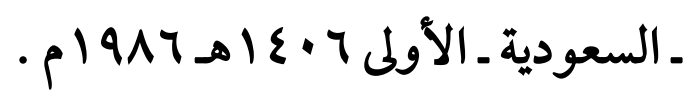




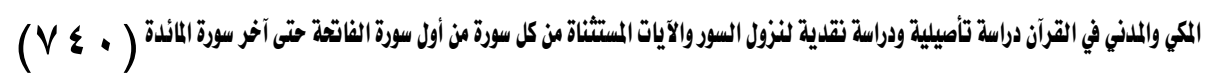

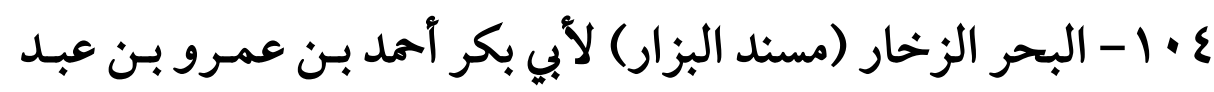

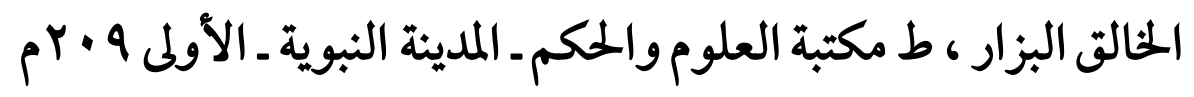

0 • 1 - البدر التحام شرح بلوغ المرام للحسين بن محمد المغربي ، ط دار

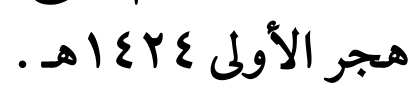

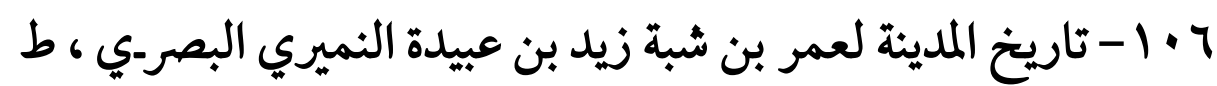

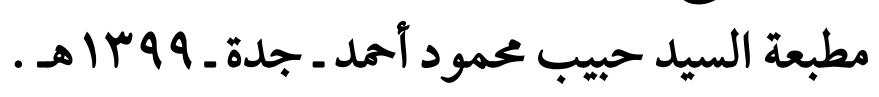

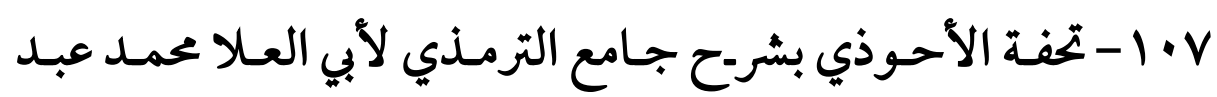

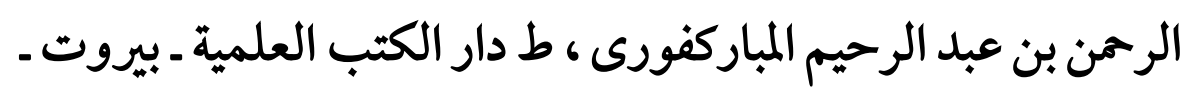

^• 1 - تخريج الأحاديث والآثار الواقعة في تفسير الكشاف للزخششري

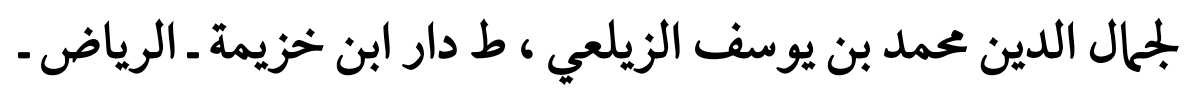

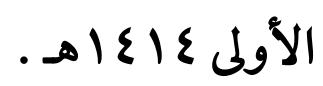

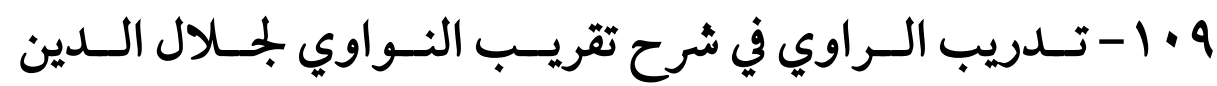

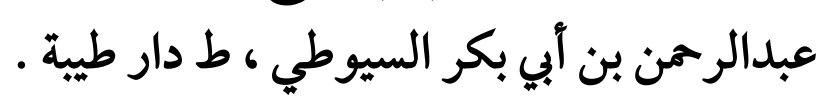

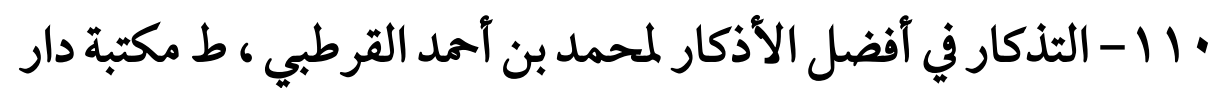

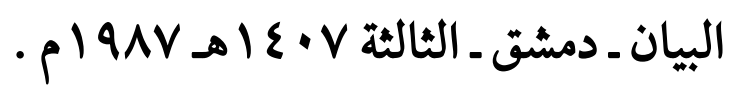

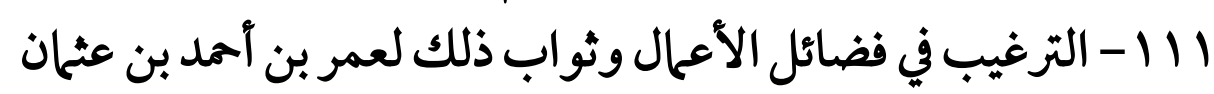

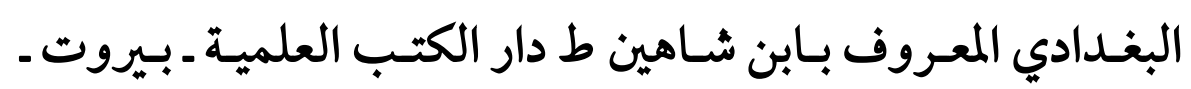

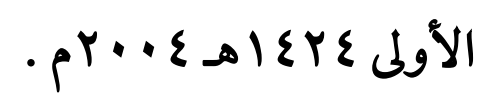


$(V \leq 1)$

Y)

r II - تغليق التعليق على صحيح البخاري لأحمد بن علي بن محمد بـن

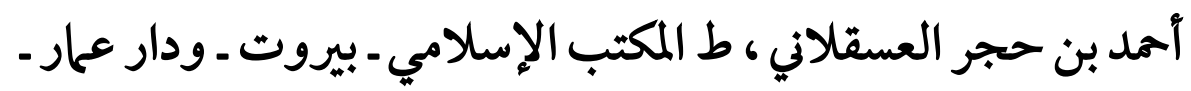

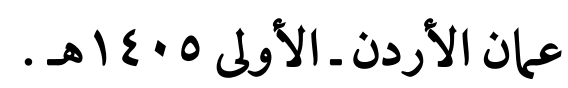

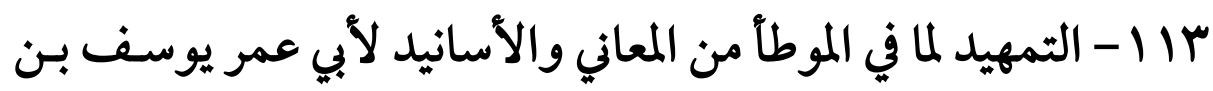

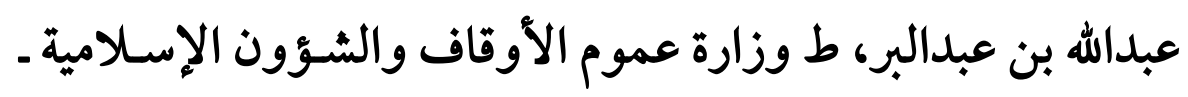

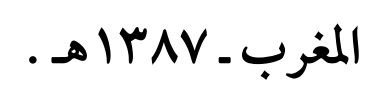

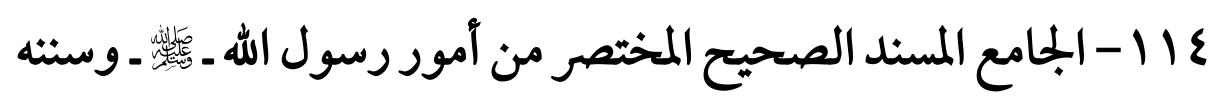

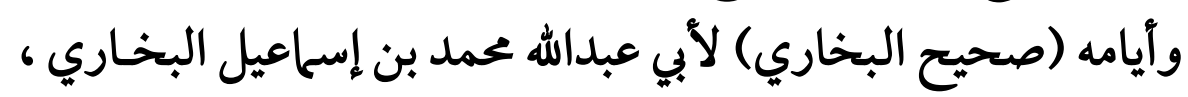

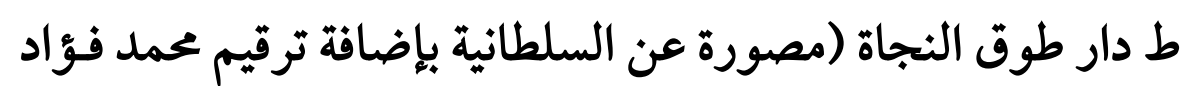

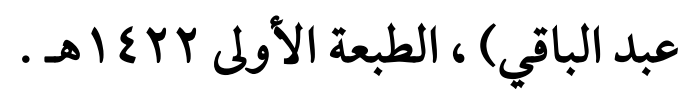

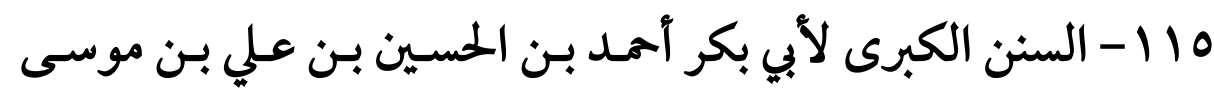

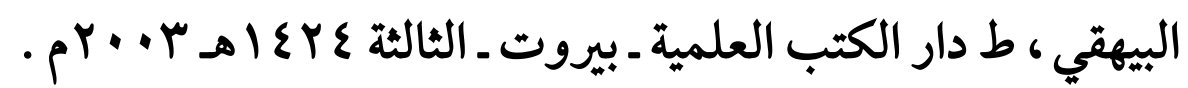

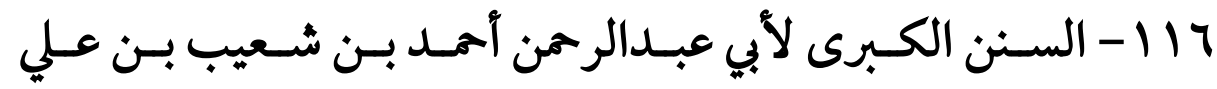

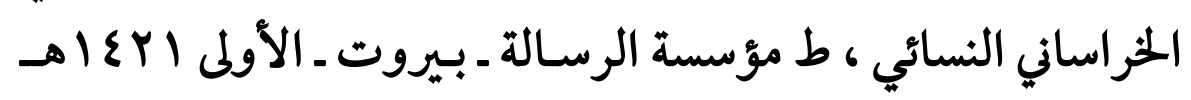
$\cdot p^{r \cdot \cdot 1}$ IIV

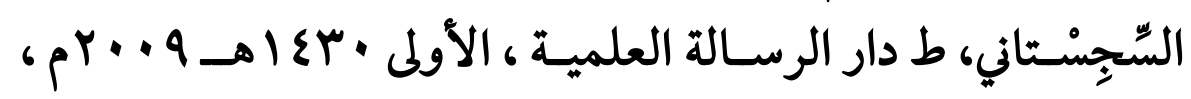

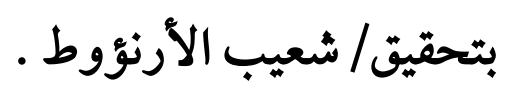

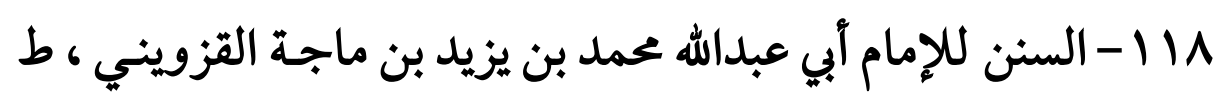
دار إحياء الكتب العربية (فيصل عيسى البابي الحلبي) . 


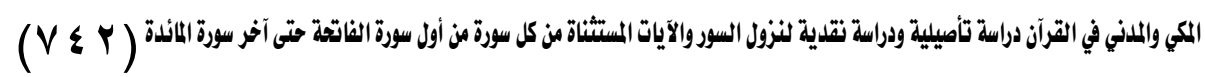

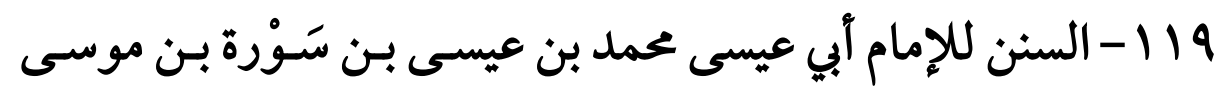

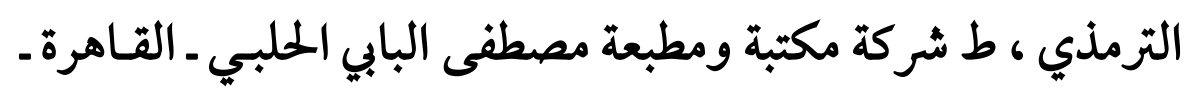

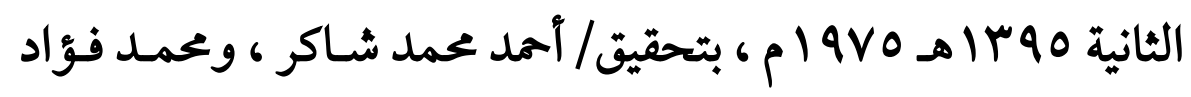

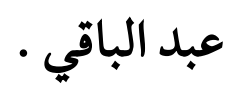
• r ا - شرح السنة لأبي محمد الحسين بن مسعود بـن محمد بـن الفراء

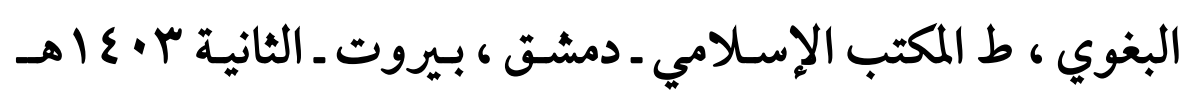
- مير | | ا - شرح مشكل الآثار لأبي جعفر أحمد بن محمد بن سلامة بن عبد

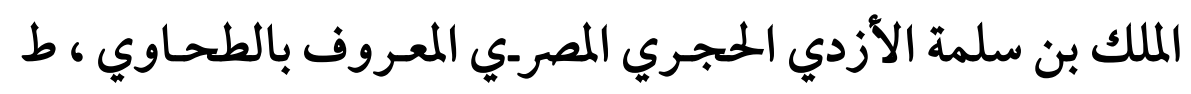

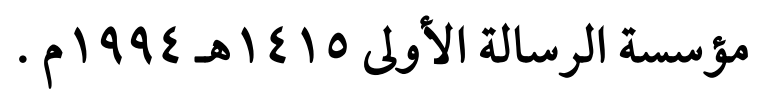

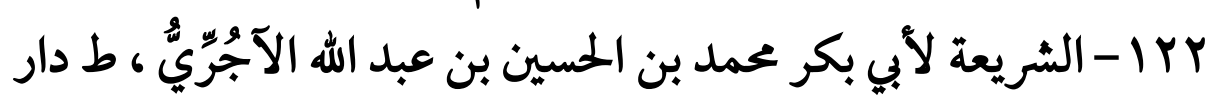

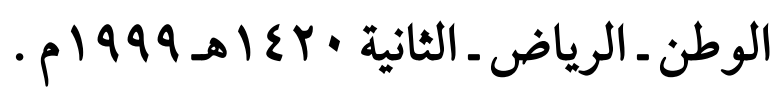

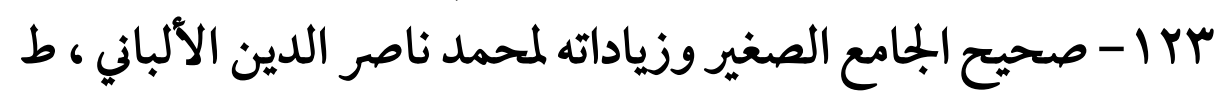

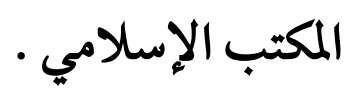
ع ا ا - صحيح موارد الظمآن إلى زوائد ابن حبان لمحمد نـاصر الدين

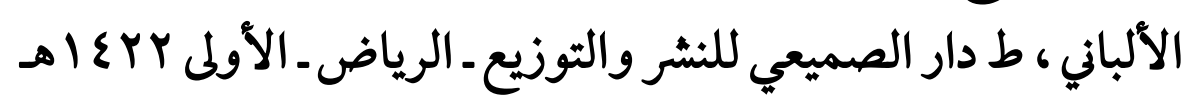
• r..r r

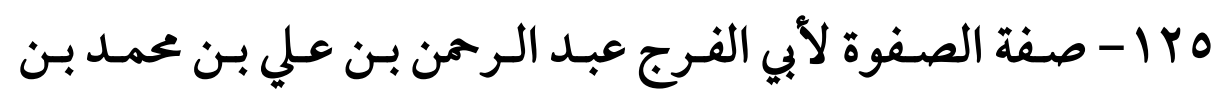

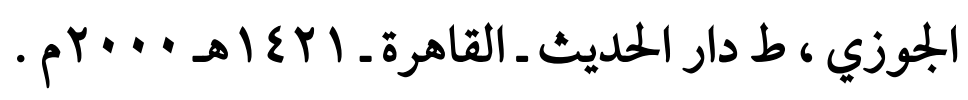


$(V \leq r)$

TY I - فتح الباري شرح صحيح البخاري لأبي الفضل أمد بن علي بن

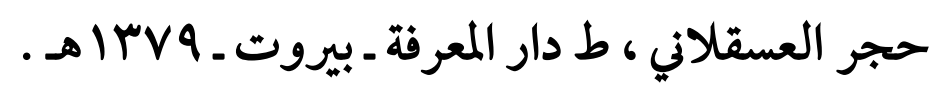

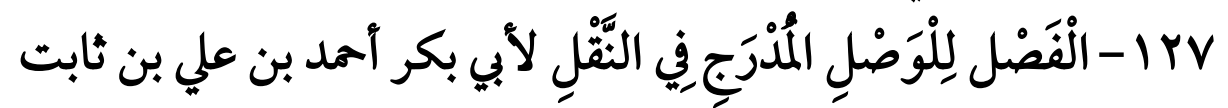

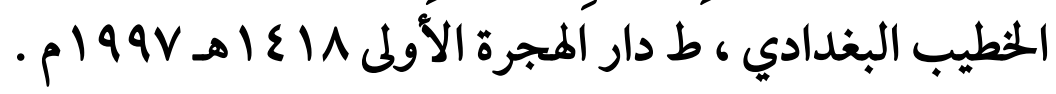

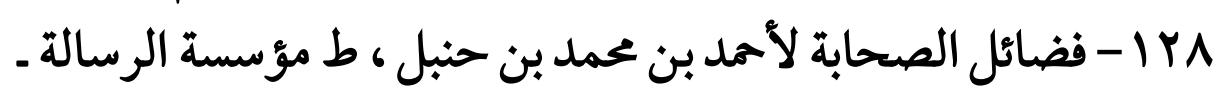

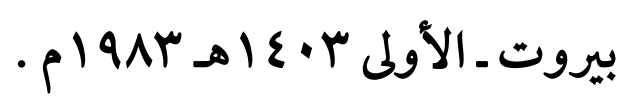

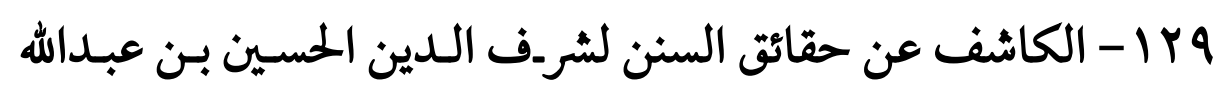

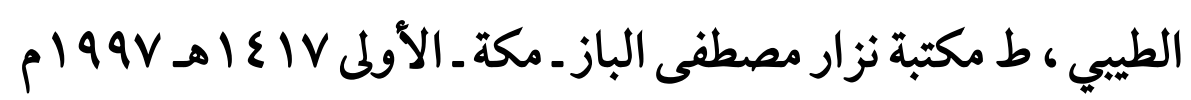

• با - كفايـة الحاجـة في شرح سـنن ابـن ماجـة لنور الـدين محمـد بـن

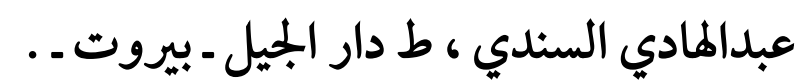

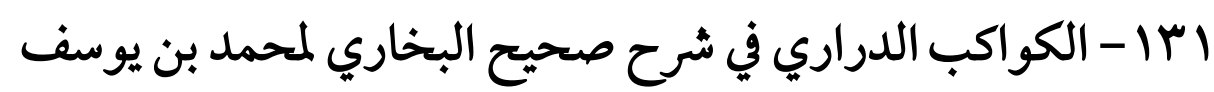

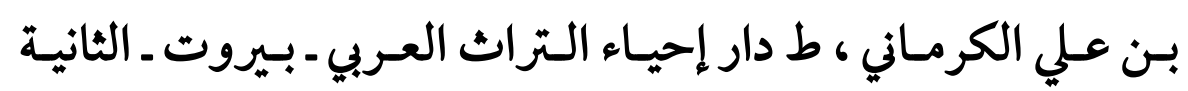

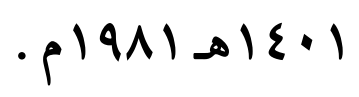

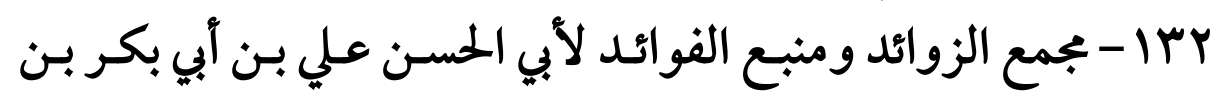

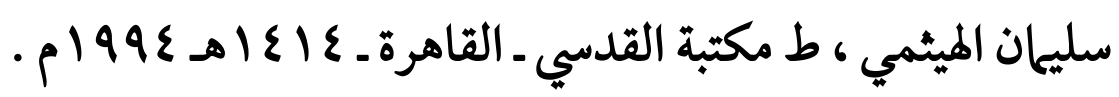

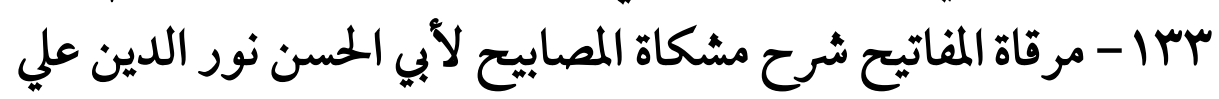

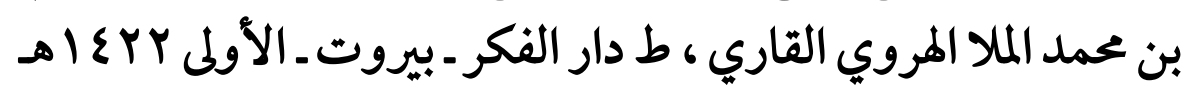




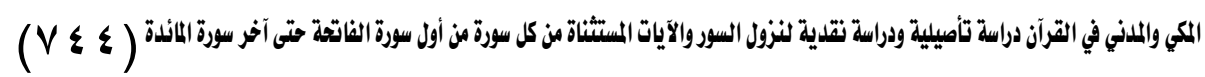
ع با - المستدرك على الصحيحين لأبي عبدالله الحاكم محمد بن عبداله

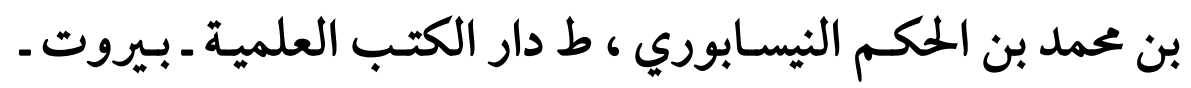

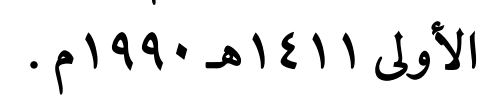

هrl - المسند الصحيح المختصر بنقل العدل عن العدل إلى رسول الله ـ

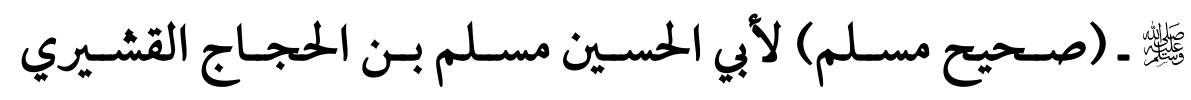
النيسابوري ، ط دار إحياء التراث العربي ـ بيروت -.

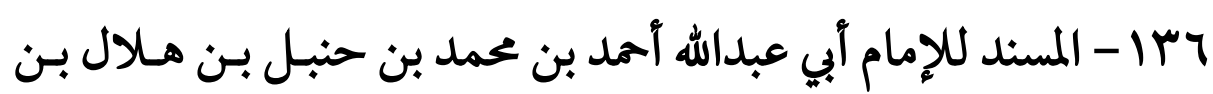

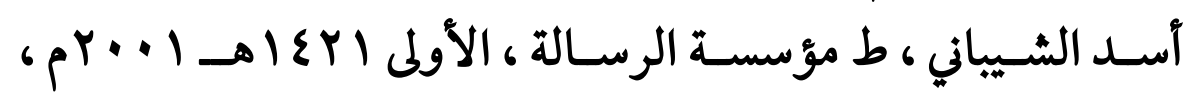

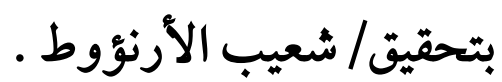

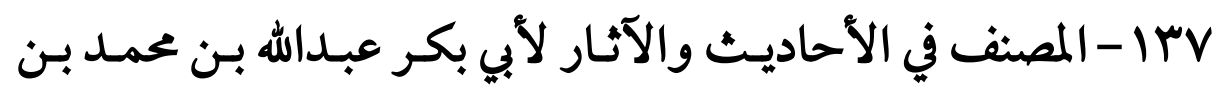

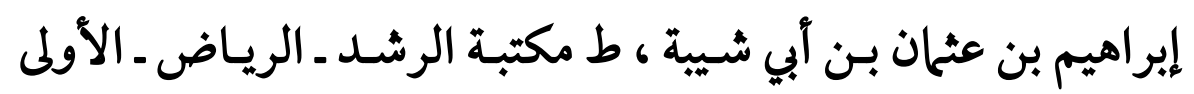
9

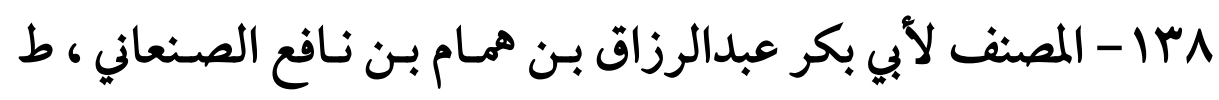

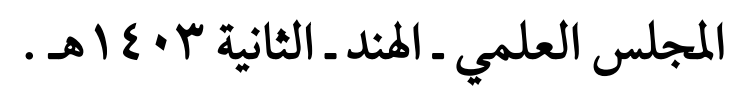

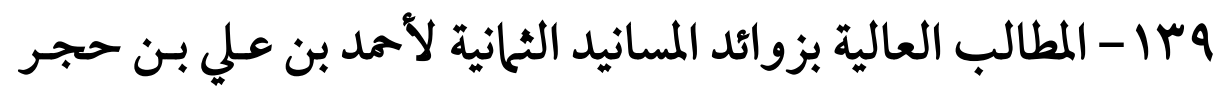

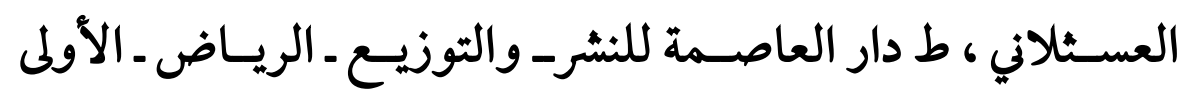

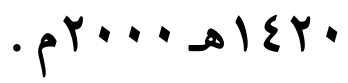
• ع ا - المعجم الأوسط لأبي القاسم سليمان بن أحمد بن آيوب الطبراني

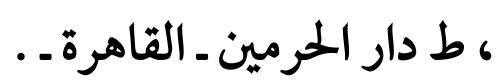


$(V \leq 0)$

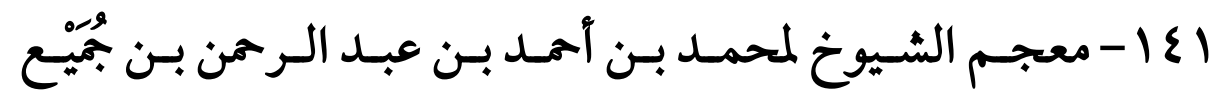

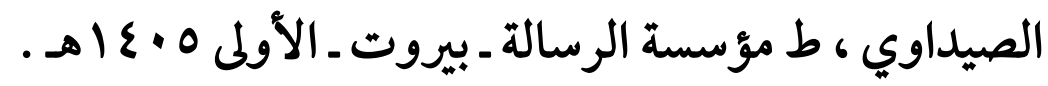

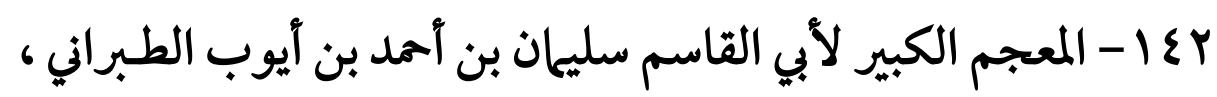
ط مكتبة ابن تيمية ـ القاهرة ـ الثانية .

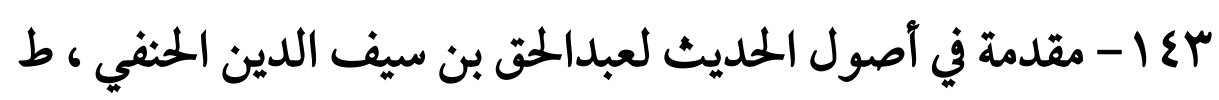

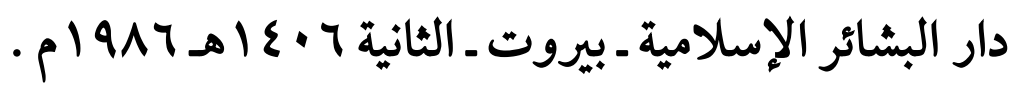

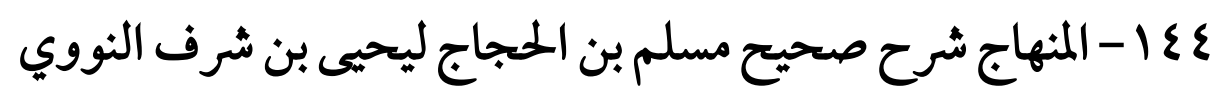

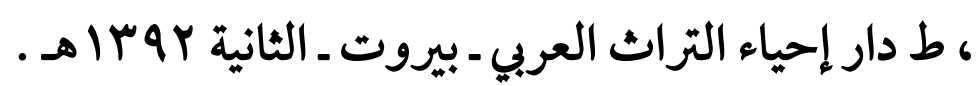

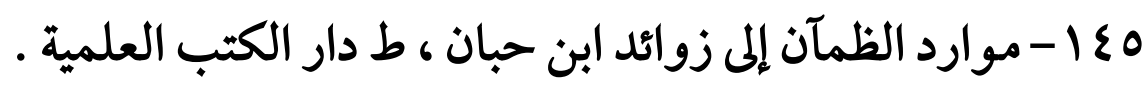
ح ا - نزهة النظر في توضيح نخبة الفكر في مصطلح أهل الأثر لأمدا

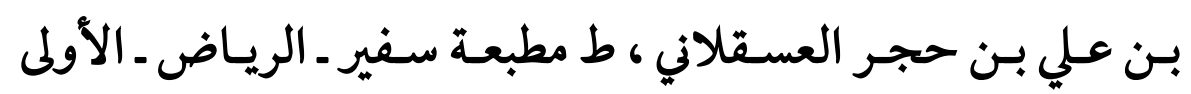
. هـ

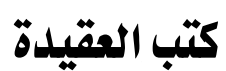

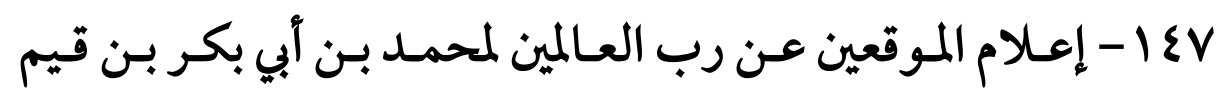

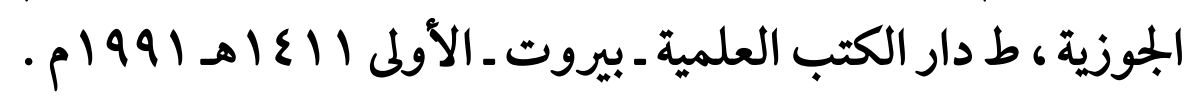

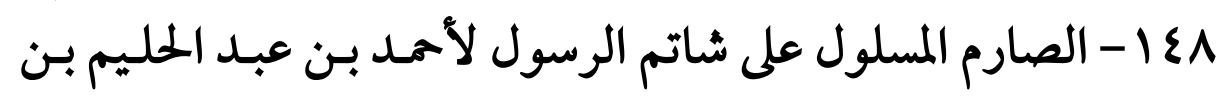

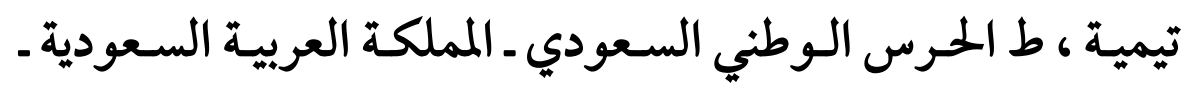

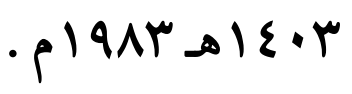




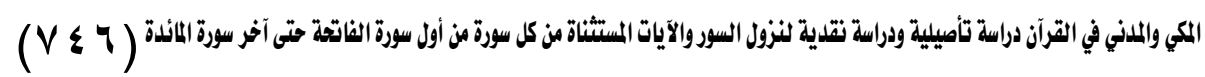

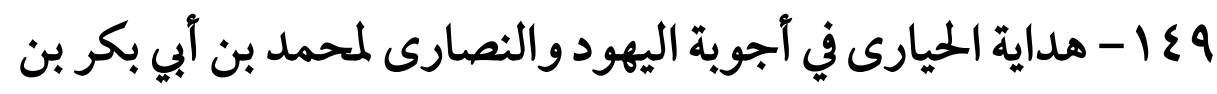

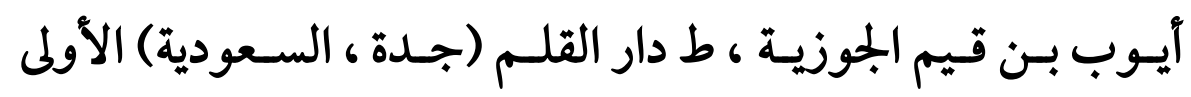

\section{كتب الققه وأصوله}

. 1997ـ 1817

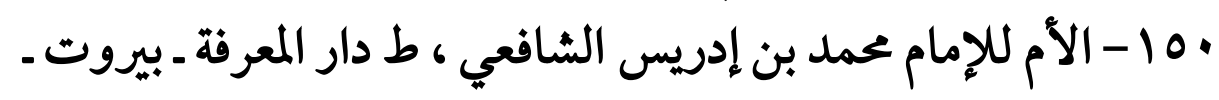

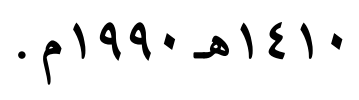

101 - البرهان في أصول الفقه لعبدالملك بـن عبدالله بـن يوسف آبي

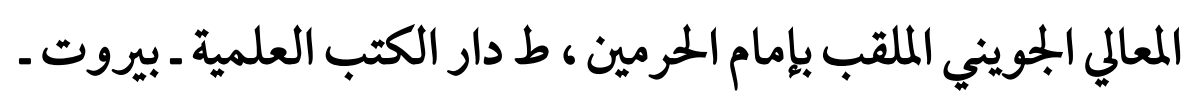

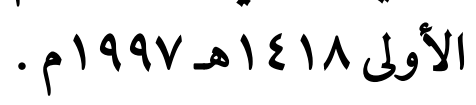

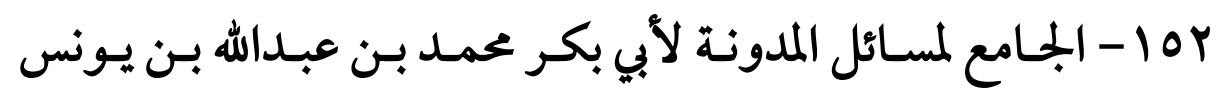

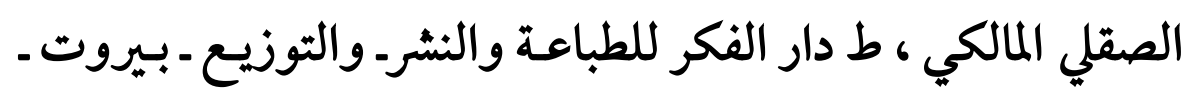

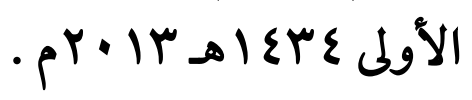

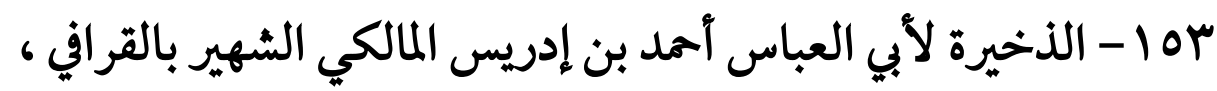

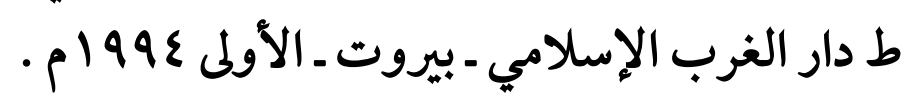

ع 10 - فتاوى ابن الصلاح عـثمان بـن عبـد الرحمن ، ط مكتبـة العلدوم

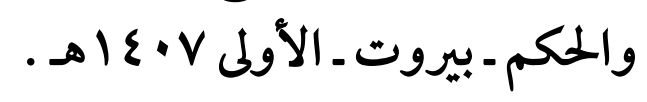

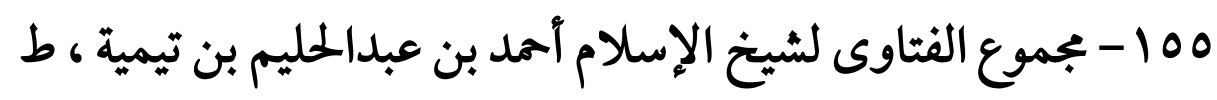

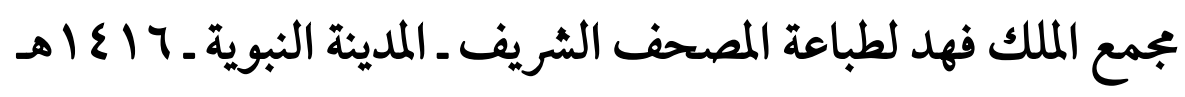


$(v \leq v)$

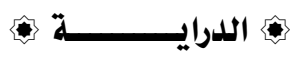

07 - المعونة على مذهب عالم المدينة (الإمام مالك بن أنس") لأبي محمد

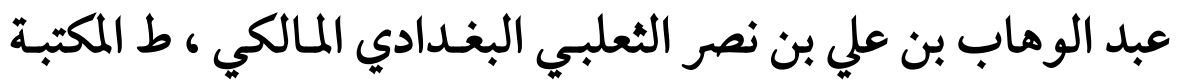

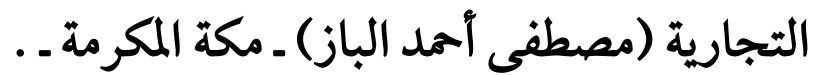

loV

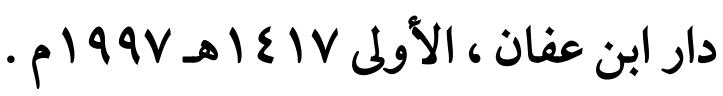

كتب السيرة والتاريخ

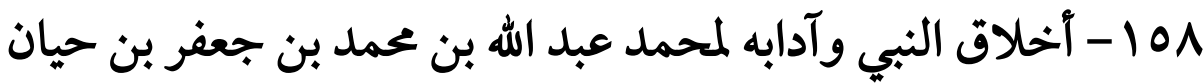

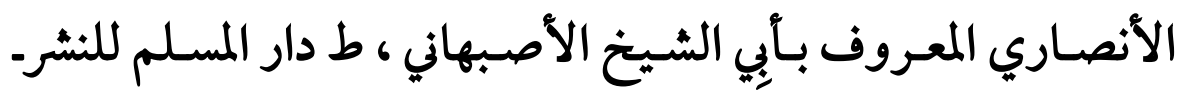

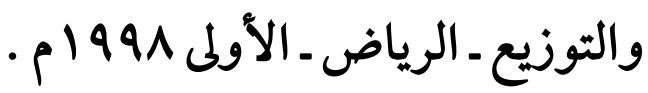

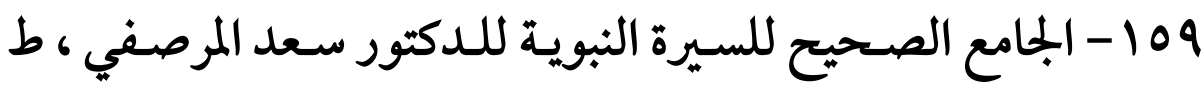

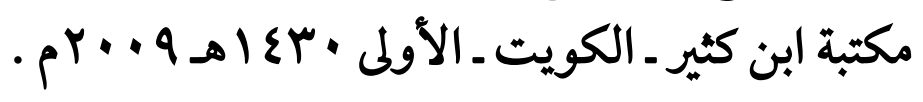

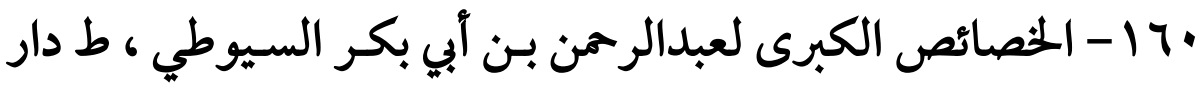

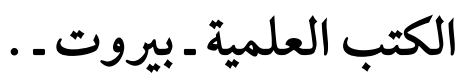

| 17 - دلائل النبوة لأبي بكر أحمد بن الحسين بن علي بن موسى البيهقي

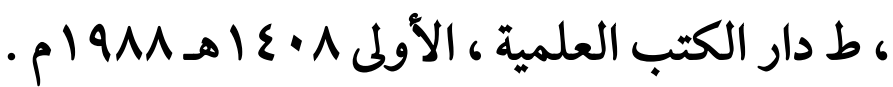

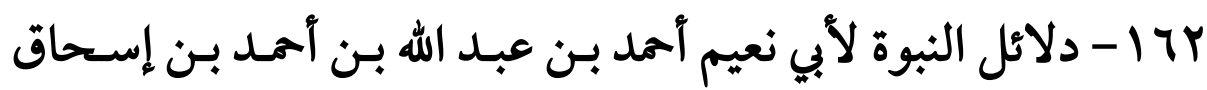

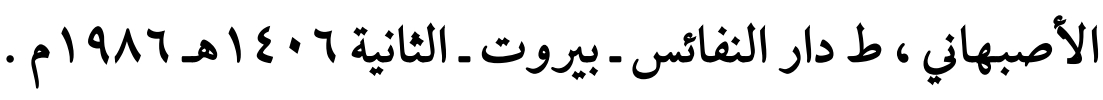

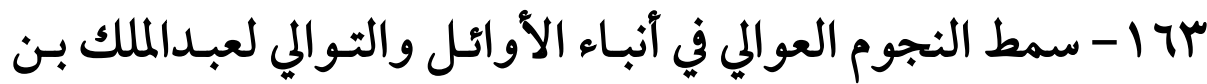

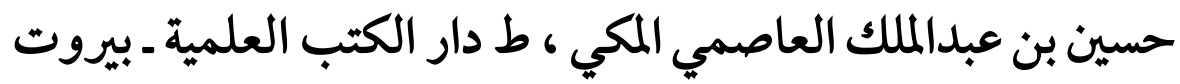

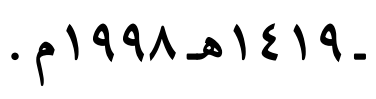




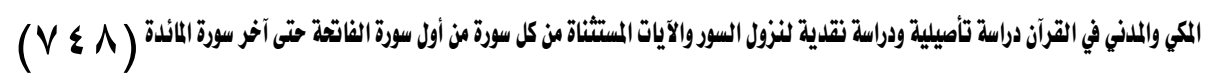
ع 1 - السيرة النبوية الصحيحة للدكتور أكرم ضياء العمري ، ط مكتبة

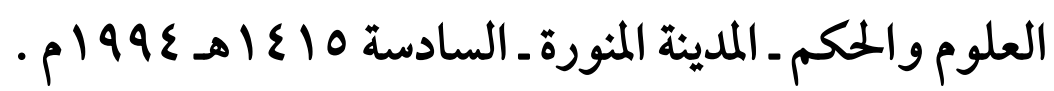

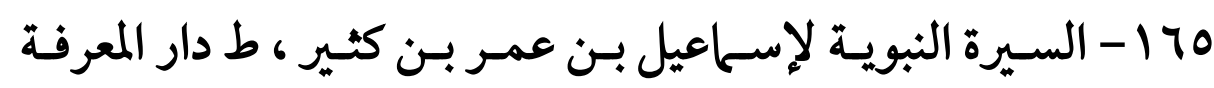

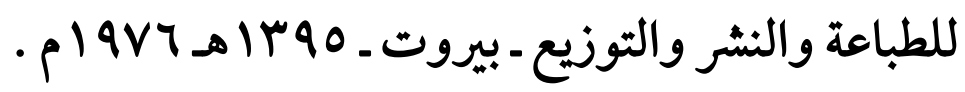

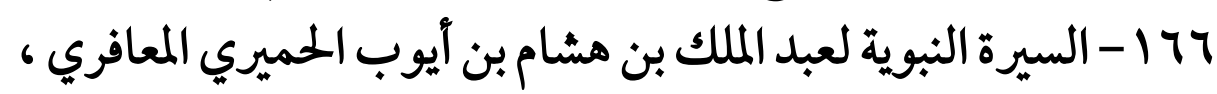
ط شركة مكتبة ومطبعة مصطفى البابي الحلبي وأولاده بمصر ، الثانية • ، ا IV - السيرة النبوية وأخبار الخلفاء لأبي حاتم محمد بن أحمد بن حبان

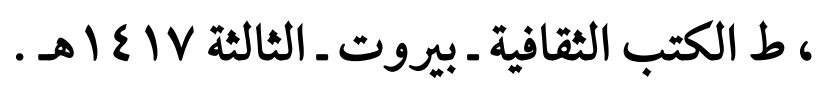

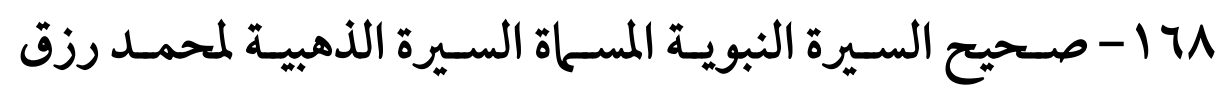

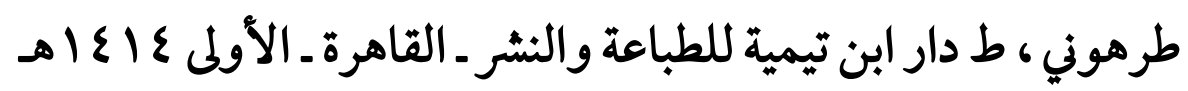

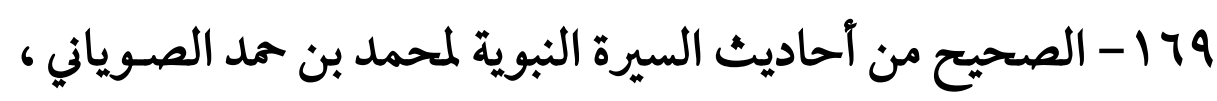

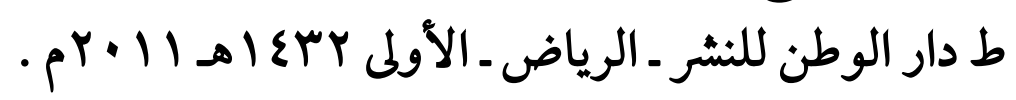

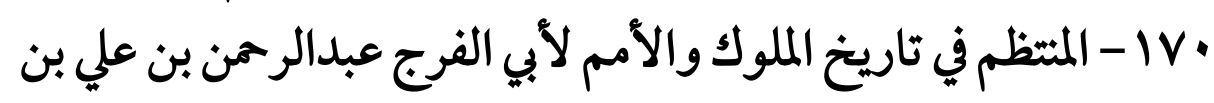

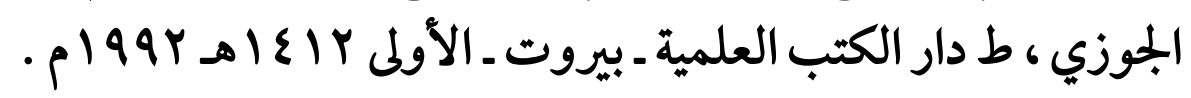

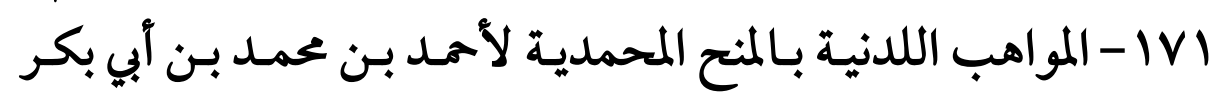

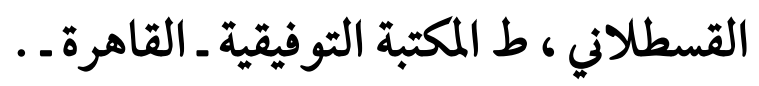


$(\vee \leq 9)$

\section{كتب المعاجم والفريب}

IVY والفنون لإسهاعيل بن محمد أمين بن مير سليم الباباني ، ط دار إحياء

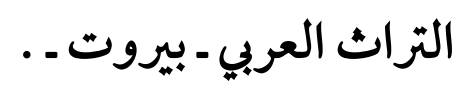

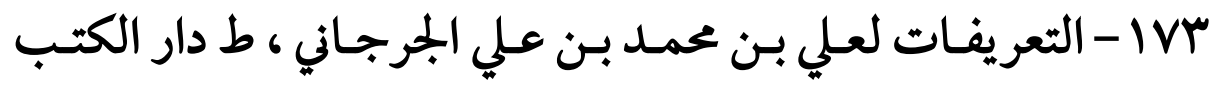

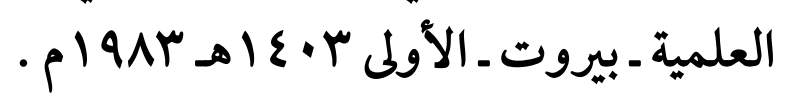

IV ع - التوقيف على مهات التعاريف لعبدالرؤوف بن تاج العارفين بن

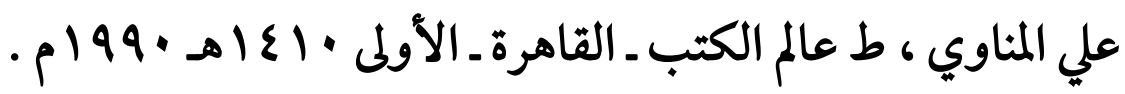

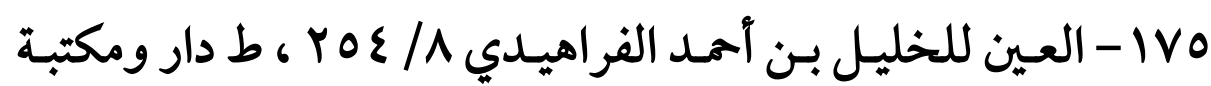

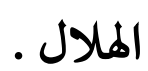

ا IV7 - غريب الحديث لأبي الفرج عبدالرحمن بن علي بن محمد الجموزي

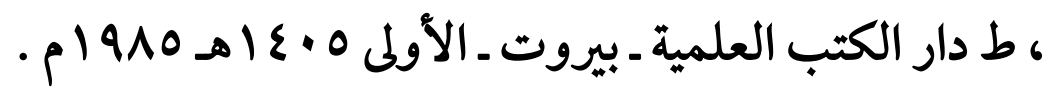

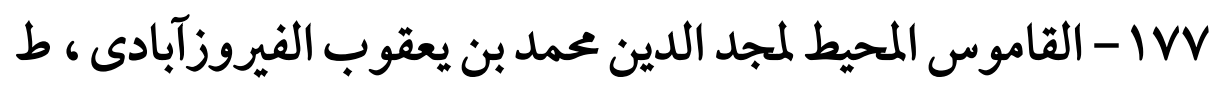

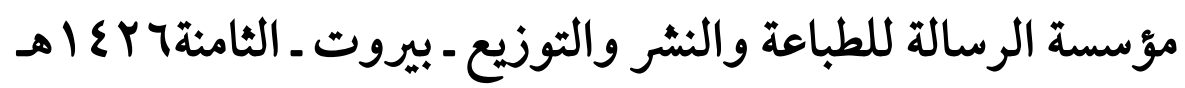
$\cdot{ }^{\prime} \cdot 0$

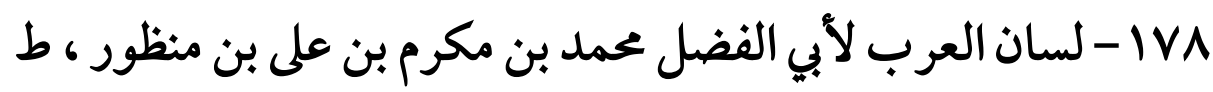

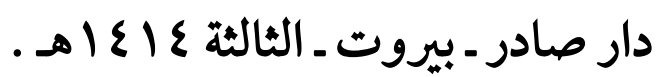

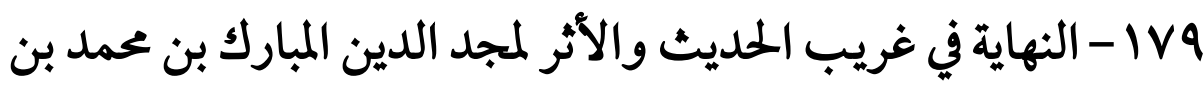

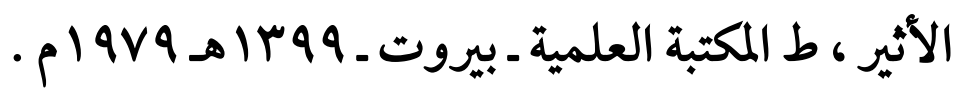




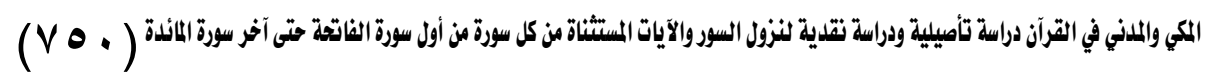
كتب تراجم الأعلام ورجال الحديث

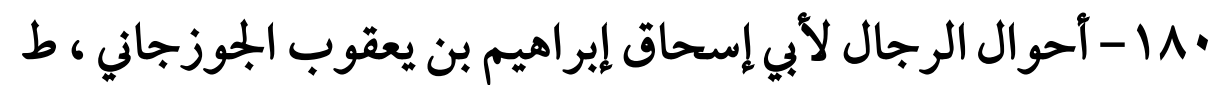

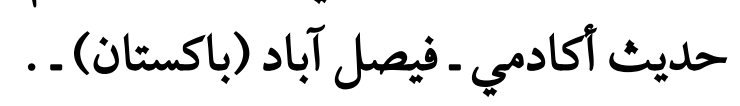

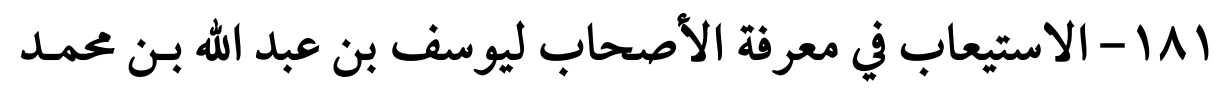

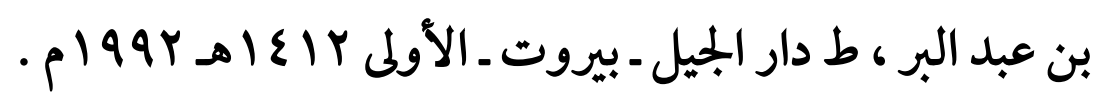

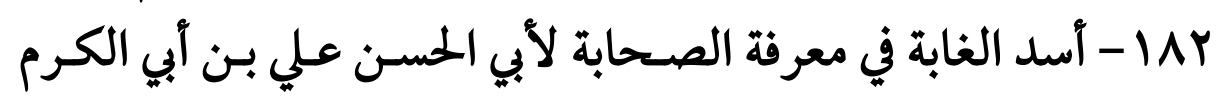

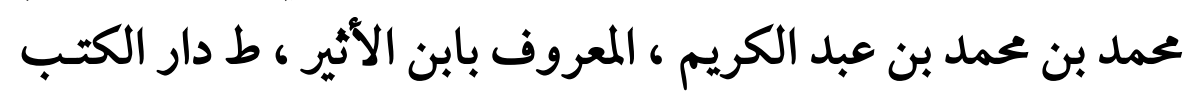

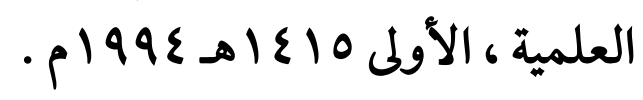

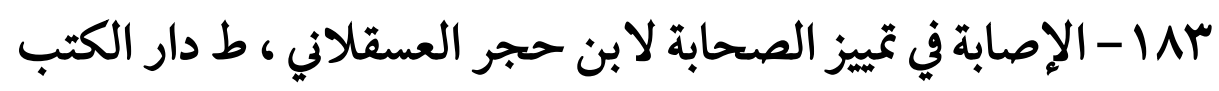

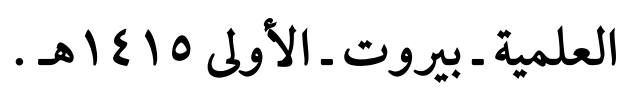

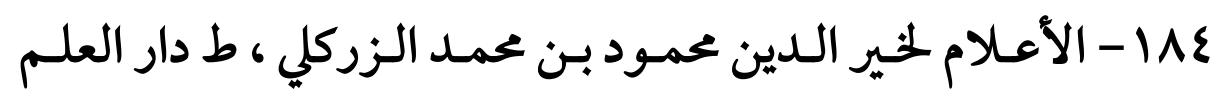

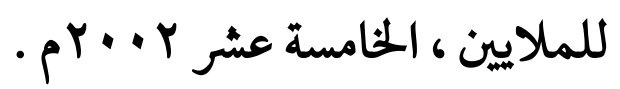

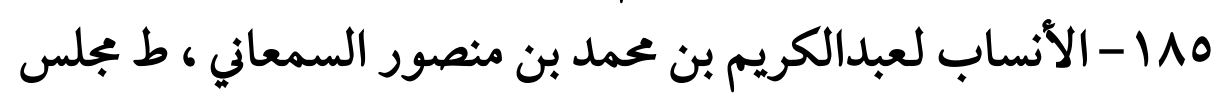

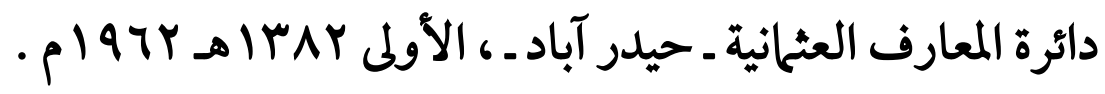

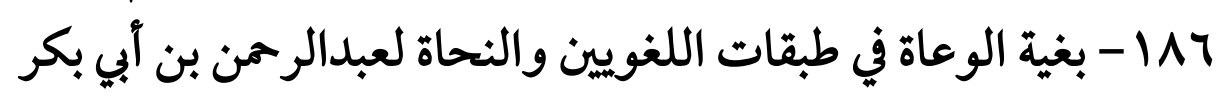

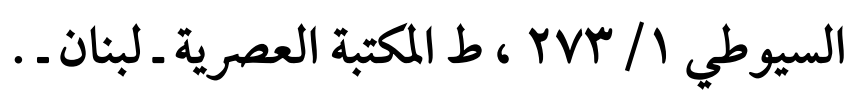

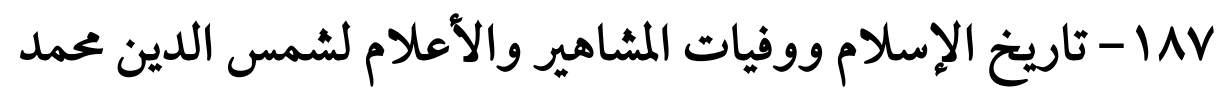

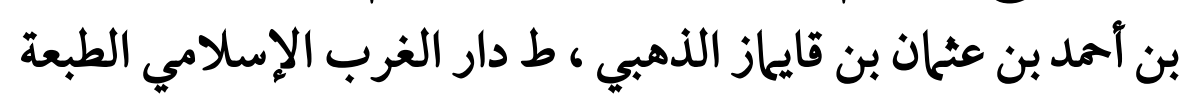

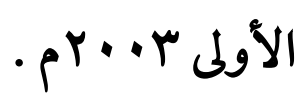


(vol)

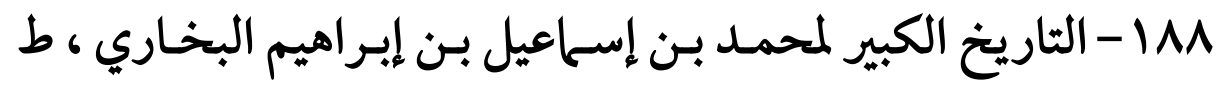

$$
\text { دائرة المعارف العثمانية ـ حيدر آباد (الهند) .. }
$$

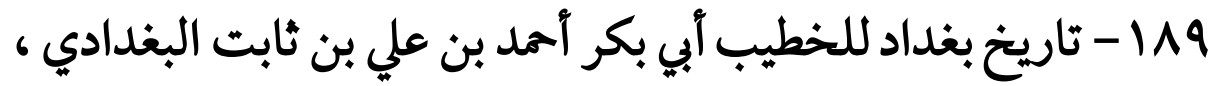

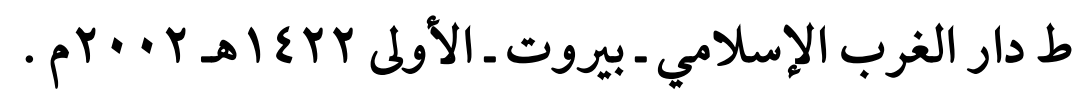

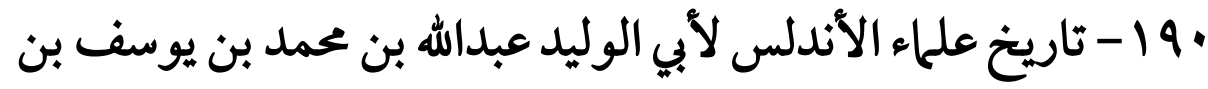

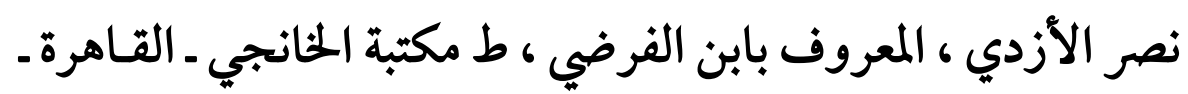

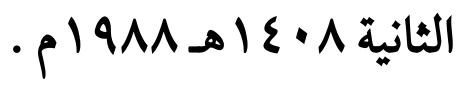

191 - تذكرة الحفاظ لشمس الدين محمد بن أحمد بن عثمان بن قَائياز

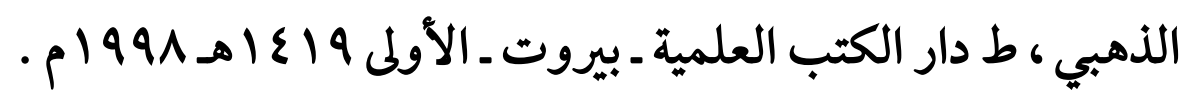

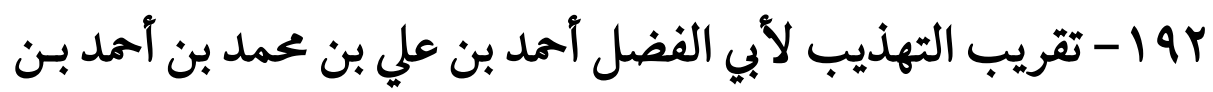

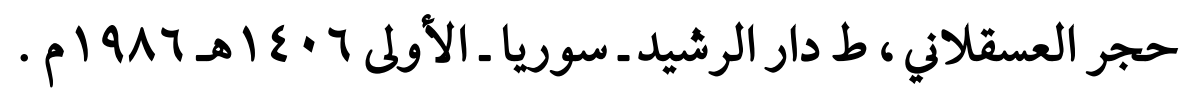

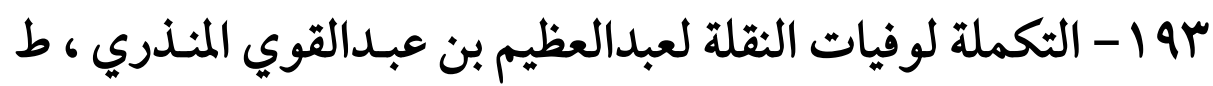

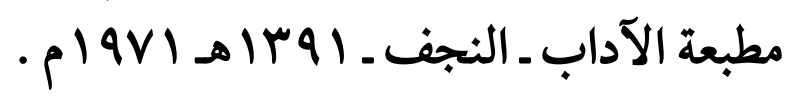

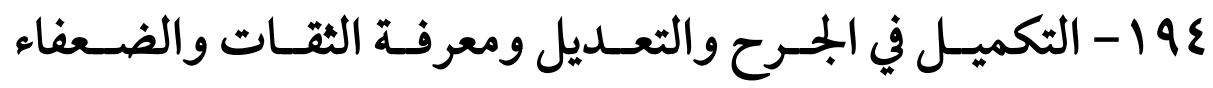

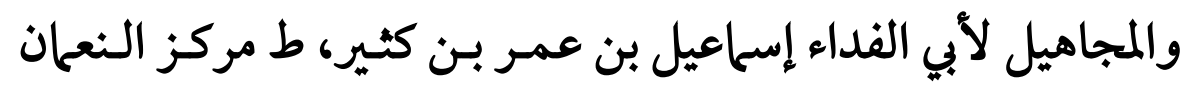
للبحوث والدراسات الإسلامية وتحقيق التراث والترجمة ـ اليمن -

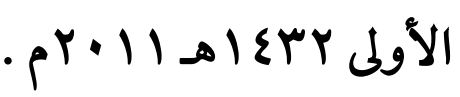




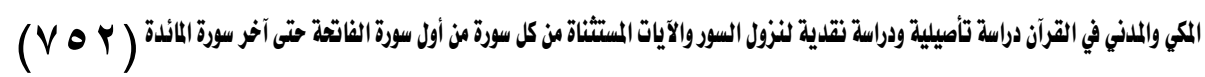
190 - تهذيب الكهال في أسهاء الرجـال ليوسف بـن عبـدالرحمن بـن

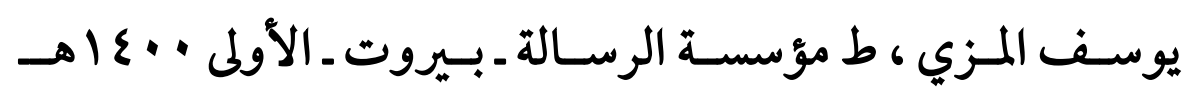
- 191 .

97 19 - الثقات لأبي حاتم محمد بن حبان بن أحمد بن حبان البستي ، ط ألمان

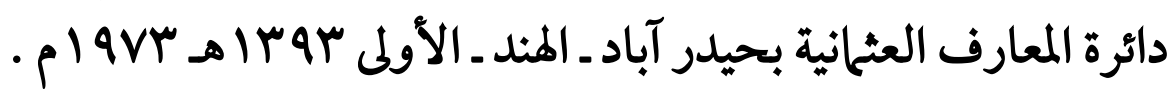

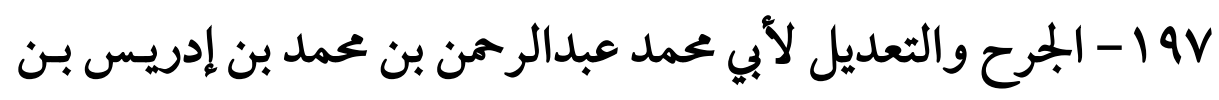

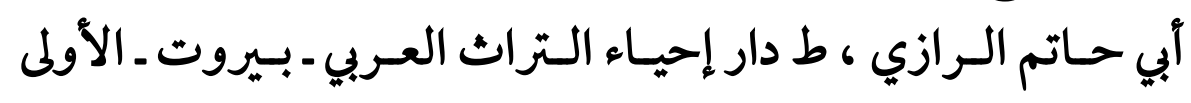

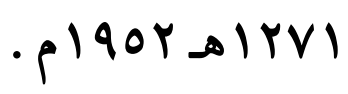

19 1 - الدرر الكامنة في أعيان المائة الثامنة لأبي الفضل آحمد بن علي بن محمد بن أحمد بن حجر العسقلاني ، ط بجلس دائرة المعارف العثلانية ـ

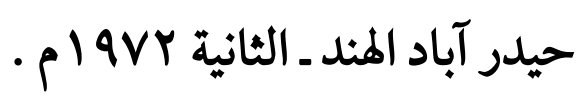

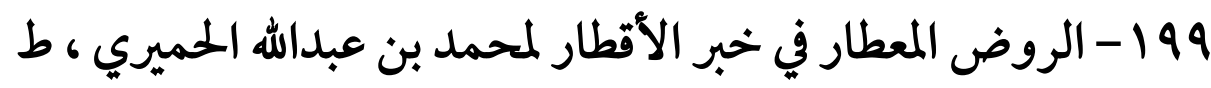

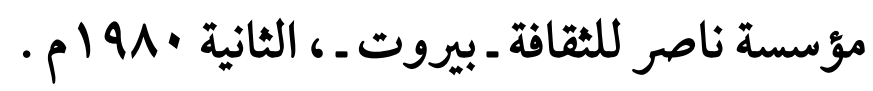

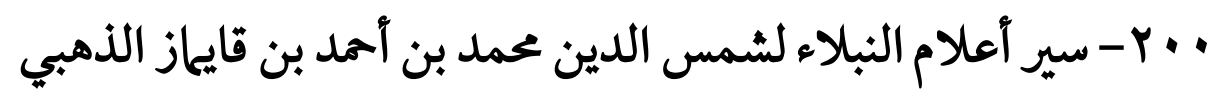

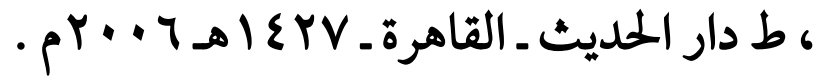

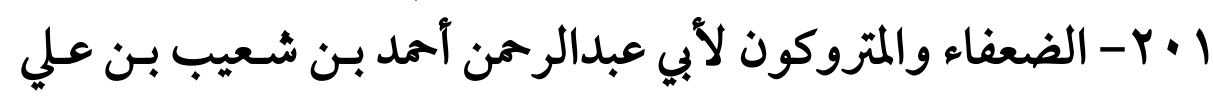

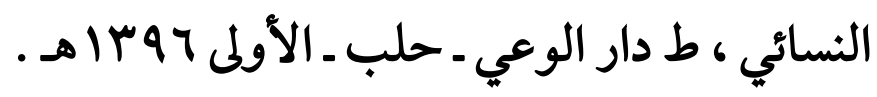

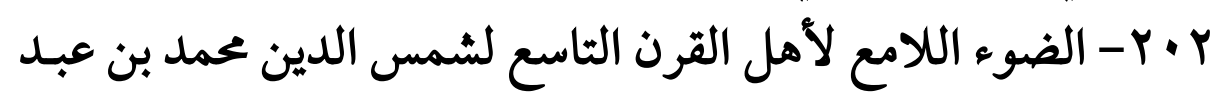

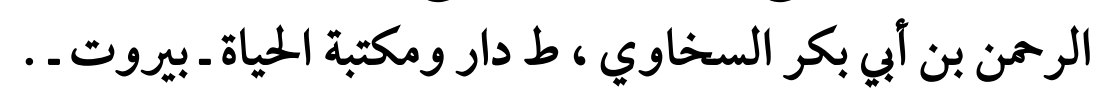


$(V \circ r)$

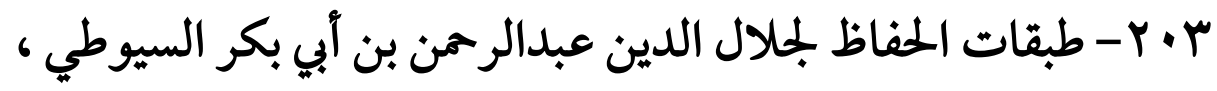

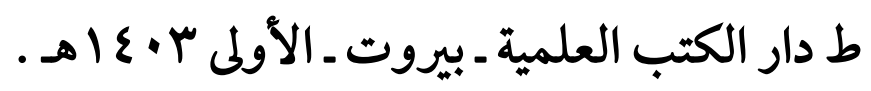

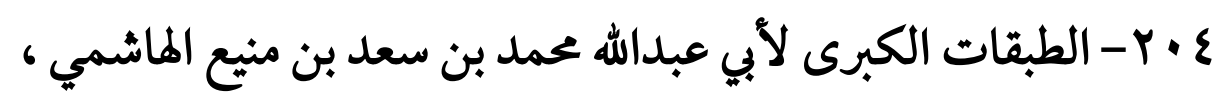

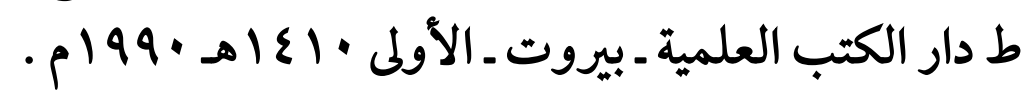

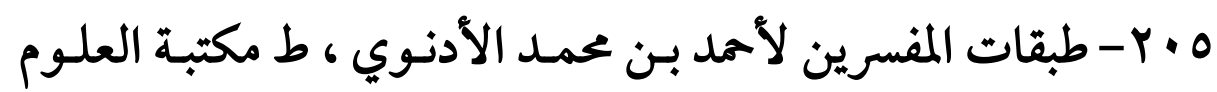

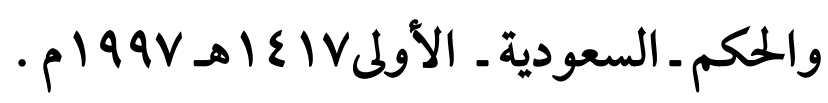

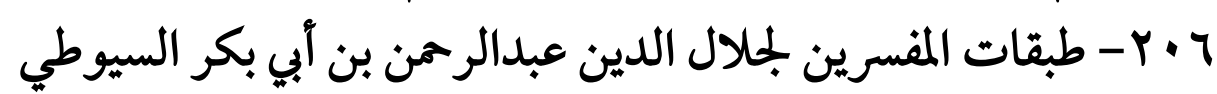

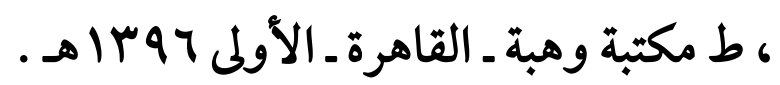

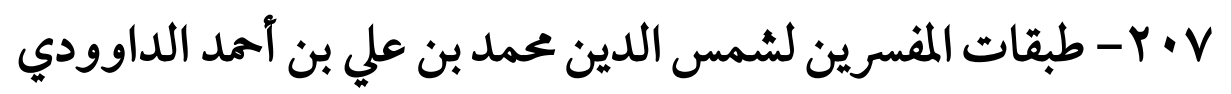

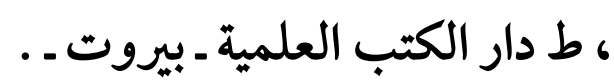

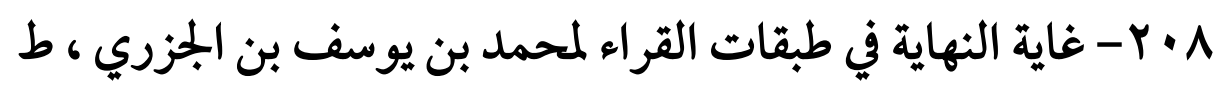

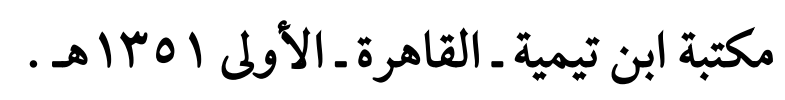

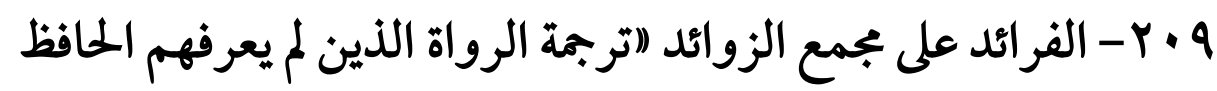

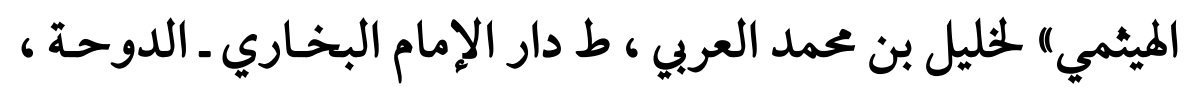

قطر - -

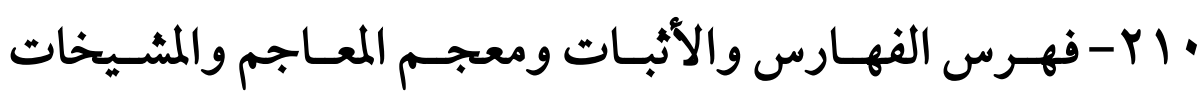

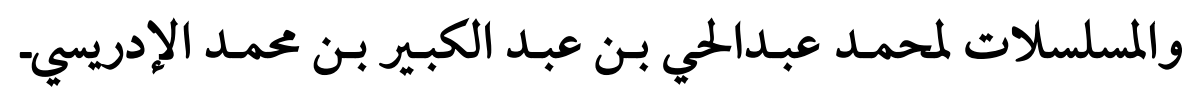

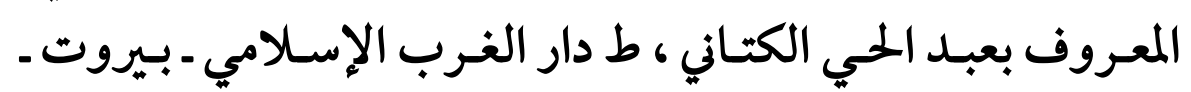

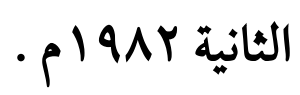




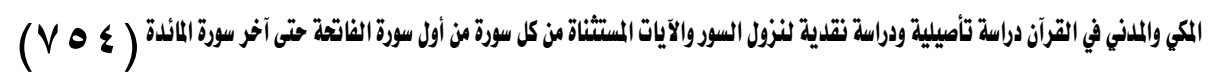

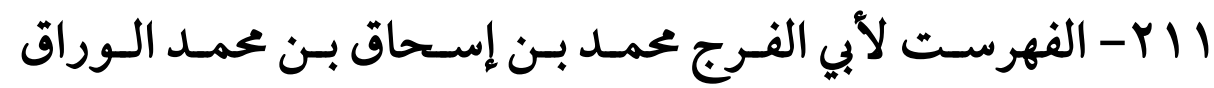

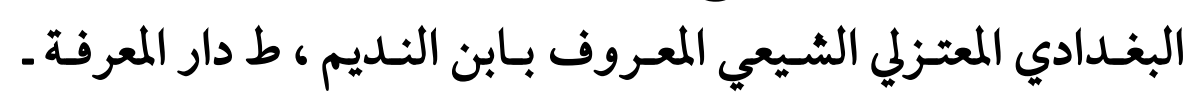

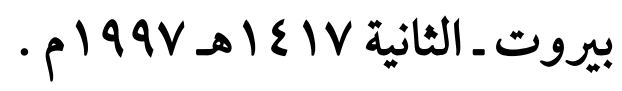

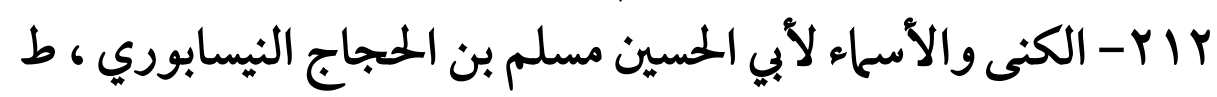

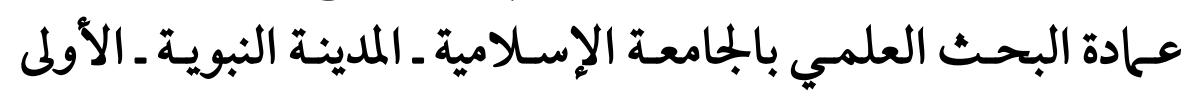

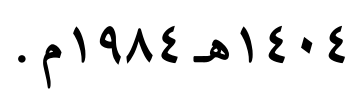

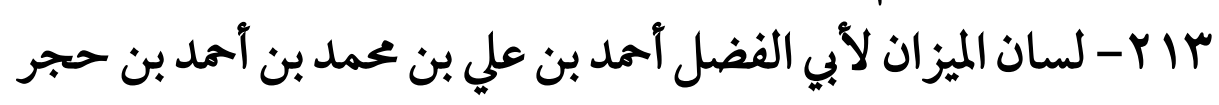

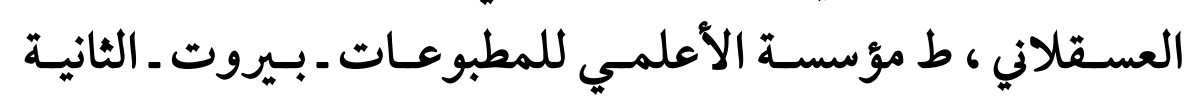

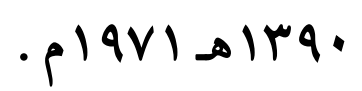

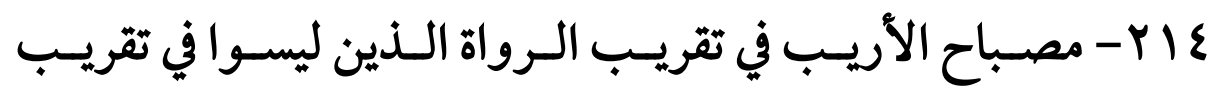

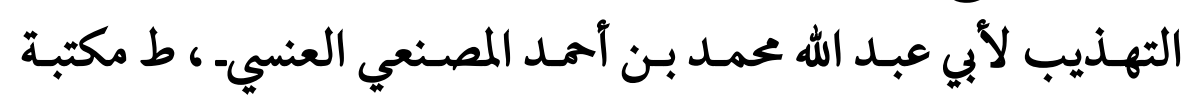

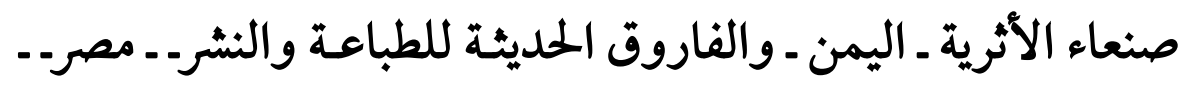

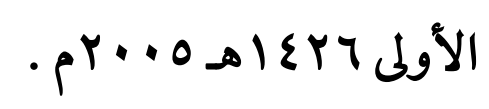

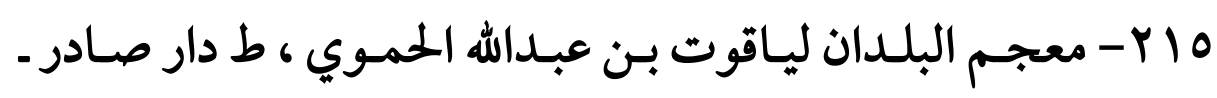

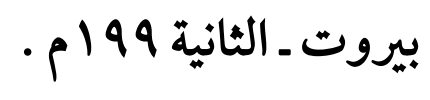

Y Y Y - معجم المؤلفين لعمر رضا كحالة ، ط دار إحياء التراث العربي - 


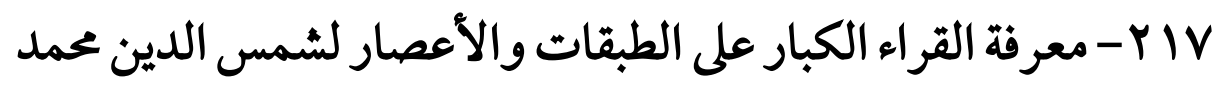

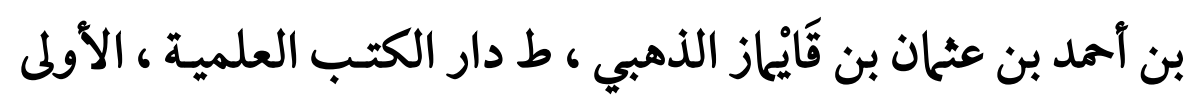

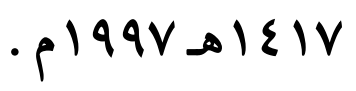
1 ، ا Y - المغني في الضعفاء لشمس الدين محمد بن أحمد بن عثمان الذهبي

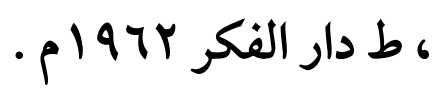

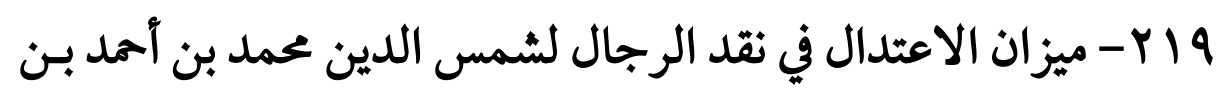

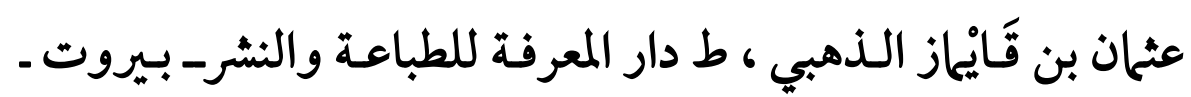

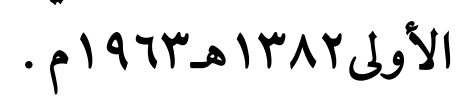

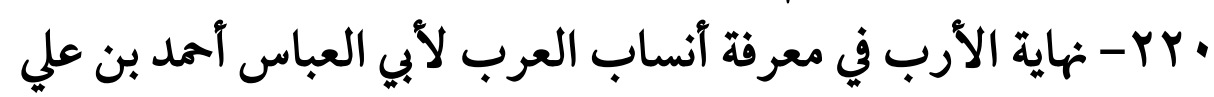

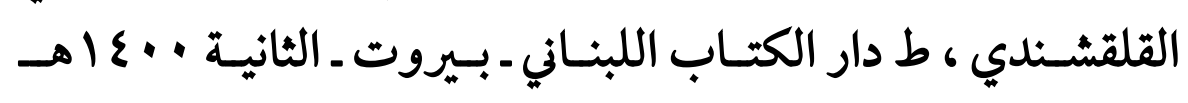
- 191. ا Y Y - وفيات الأعيان وأنباء أبناء الزمان لشمس الدين أحمد بن محمد

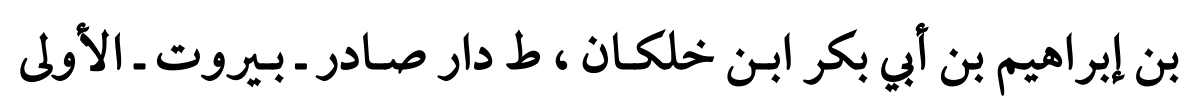




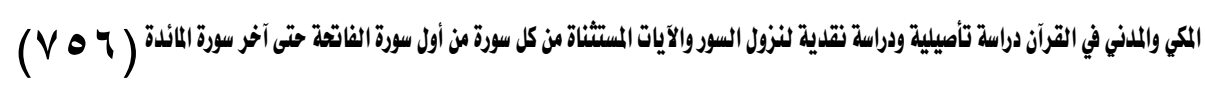
محتويات البحث

\begin{tabular}{|c|c|}
\hline رقّم الصفحة & الموضوع \\
\hline$\varepsilon \wedge q$ & المقدمة \\
\hline$\{9\}$ & المكي والمدني في القرآن الكريم دراسة تأصيلية \\
\hline$\varepsilon q V$ & الفصل الأول : ـ تعريف المكي والمدني وفوائد معرفته \\
\hline$\varepsilon 9 V$ & المبحث الأول : ـ تعريف المكي والمدني \\
\hline $01 \varepsilon$ & المبحث الثاني : ـ فوائد معرفة المكي والمدني \\
\hline 019 & الفصل الثاني : ـ طرق معرفة المكي والمدني \\
\hline OrY & المبحث الأول : ـ الروايات التي عددت المكي والمدني \\
\hline $0 \leqslant V$ & 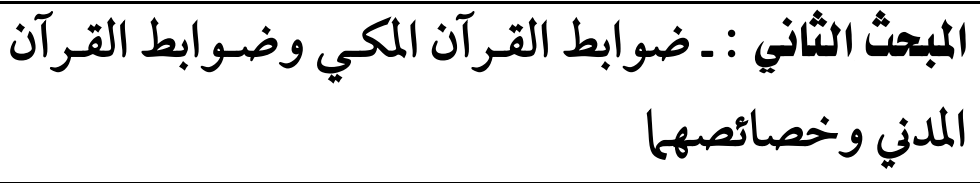 \\
\hline oTr & 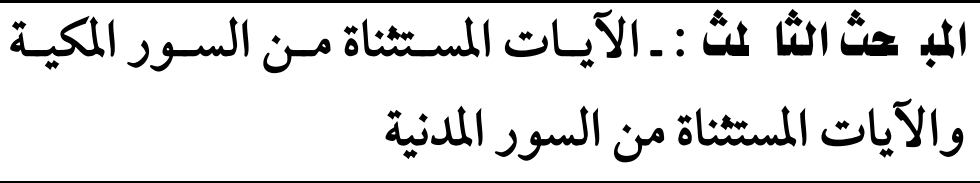 \\
\hline OTV & المبحث الرابع : ـ مل تكرر نزول شيء من القرآن؟ \\
\hline $0 \wedge 0$ & نزول السوروالآيات من أول سورة الثاتئية الثاني حتى آخر سورة \\
\hline $0 \wedge 7$ & الفصل الأول : ـ سورة الفاتحة \\
\hline $0 \wedge 7$ & وفيه مبحث واحد وهو : نزول سورة الفاتحة \\
\hline 711 & الفصل الثاني : ـ سورة البقرة \\
\hline
\end{tabular}




\begin{tabular}{|c|c|}
\hline$(V \bullet V)$ & 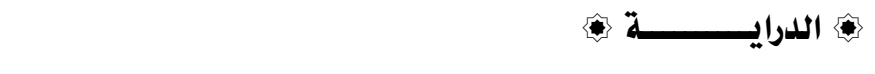 \\
\hline رقم الصفحة & الموضوع \\
\hline 711 & المبحث الأول : ـ نزول سورة البقرة \\
\hline $7 r \cdot$ & المبحث الثاني : الآيات المستثناة من سورة البقرة \\
\hline Trv & الفصل الثالث : ـ سورة آل عمران \\
\hline Trv & وفيه مبحث واحد وهو : نزول سورة آل عمران \\
\hline $7 \varepsilon r$ & الفصل الرابع : ـ سورة النساء \\
\hline $7 \varepsilon \mu$ & المبحث الأول : ـ نزول سورة النساء \\
\hline 701 & المبحثُ الثاني : ـ الآيتان المستثناتان من سورة النساء \\
\hline $77 r$ & الفصل الخامس : ـ سورة المائدة \\
\hline $77 r$ & المبحث الأول : ـ نزول سورة المائدة \\
\hline TAY & المبحث الثاني : ـ الآيتان المستثناتان من سورة المائدة \\
\hline $\operatorname{Vi\varepsilon }$ & الخايتمة \\
\hline VYT & المراجع والمصادر \\
\hline Voo & محتويات البحث \\
\hline
\end{tabular}

